\title{
vzgoja in izobraževanje predšolskih otrok prvega starostnega obdobja
}

Early Childhood Education and Care of Children under the Age of Three 
Knjižnica Ludus · 19 · ISSN 2630-3809

Urednica zbirke · Silva Bratož

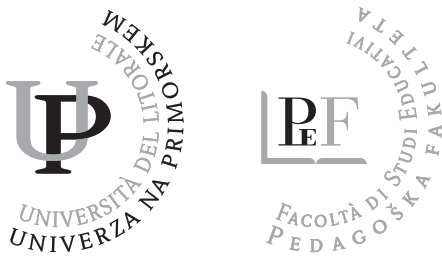




\section{Vzgoja in izobraževanje predšolskih otrok prvega starostnega obdobja Early Childhood Education and Care of Children under the Age of Three}

Uredile Sonja Čotar Konrad Bodgana Borota Sonja Rutar Karmen Drljić Giuliana Jelovčan

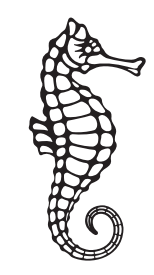


Vzgoja in izobraževanje predšolskih otrok prvega starostnega obdobja

Early Childhood Education and Care of Children under the Age of Three

Uredile · Sonja Čotar Konrad, Bodgana Borota, Sonja Rutar,

Karmen Drljić in Giuliana Jelovčan

Recenzenta · Marina Diković in Karin Bakračevič

Lektor · Davorin Dukić

Oblikovanje naslovnice · Tina Cotič

Risbe, oblikovanje in tehnična ureditev · Alen Ježovnik

Knjižnica Ludus $\cdot 19 \cdot$ ISSN 2630-3809

Urednica zbirke · Silva Bratož

Izdala in založila · Založba Univerze na Primorskem

Titov trg 4, 6000 Koper

www.hippocampus.si

Glavni urednik · Jonatan Vinkler

Vodja založbe A Alen Ježovnik

Koper $\cdot 2022$

(c) 2022 Avtorji

Brezplačna elektronska izdaja

https://www.hippocampus.si//SBN/978-961-293-134-6.pdf

https://www.hippocampus.si/ISBN/978-961-293-135-3/index.html

https://doi.org/10.26493/978-961-293-134-6

(c) Br-SA

Kataložni zapis o publikaciji (CIP) pripravili

v Narodni in univerzitetni knjižnici v Ljubljani

COBISS.SI-ID 91924995

ISBN 978-961-293-134-6 (PDF)

ISBN 978-961-293-135-3 (HTML) 


\section{Kazalo}

Predgovor

Sonja Čotar Konrad, Bodgana Borota, Sonja Rutar, Karmen Drljić in Giuliana Jelovčan · 7

Celovit in enovit sistem predšolske vzgoje z integracijo vzgojno-izobraževalne, zdravstvene in socialne dimenzije

Sonja Rutar $\cdot 9$

Nekateri vidiki raziskovanja zgodnjega učenja in poučevanja

Tina Štemberger $\cdot 25$

Akciono istraživanje i predškolska vaspitna praksa

Jelena Stamatović i Lidija Zlatić · 45

Nekateri vidiki udeležbe otrok v raziskavah

Martina Kovačič Kuzmić in Jurka Lepičnik Vodopivec · 55

Video Recording as a Research Method for Investigating Children

under Three Years of Age

Tuulikki Ukkonen-Mikkola and Juliene Madureira Ferreira $\cdot 67$

Perspektive vaspitanja djece jasličke dobi u Bosni i Hercegovini

Aleksandra Šindić $\cdot 77$

Izgorelost in samoučinkovitost strokovnih delavk v vrtcu

Sonja Čotar Konrad in Maja Lebeničnik · 91

The Importance of Preschool Teacher-Child Attachment for Healthy Childhood

Development

Petra Dolenc $\cdot 113$

Nega in vzgoja mlajšega otroka kot pomembna temelja razvoja

Janja Perko, Zlatka Cugmas in Mateja Pšunder · 125

Uporaba dobrih praks za spodbujanje socialno-emocionalnega razvoja pri otrocih prvega starostnega obdobja $\mathrm{v}$ vrtcu

Marta Licardo in Metka Purgaj 139

Mnenja strokovnih delavcev $v$ vrtcu o medpodročnem povezovanju

v prvem starostnem obdobju

Barbara Baloh, Petra Furlan, Giuliana Jelovčan in Bojana Kralj · 153

Izzivi zgodnje obravnave predšolskih otrok

Karmen Drljić $\cdot 169$ 
Pripomočki za vzgojitelje za detekcijo otrok z avtizmom v prvem starostnem obdobju (1-3)

Vanja Riccarda Kiswarday in Maja Rejc $\cdot 189$

Quality of Life of Families of Early Aged Children with Disabilities

Špela Golubović, Jasna Maksimović, Jovana Uzelac, and Sandra Glamočak · 211

Sensory Integration as the Path for Nurturing Toddlers' Wellbeing

Sanja Tatalović Vorkapić and Lana Osojnak $\cdot 223$

Slikanice v prvem starostnem obdobju

Janja Batič in Dragica Haramija $\cdot 245$

Acquisizione linguistica precoce e ruolo dell'adulto: la formazione in servizio come occasione di crescita professionale

Sergio Crasnich $\cdot 263$

Kako otroci prvega starostnega obdobja zaznavajo različne jezike?

Anita Sila in Silva Bratož $\cdot 277$

Learning Mathematics and Language through an Integrated Approach in Preschool Education

Sanja M. Maričić and Mirjana M. Stakić $\cdot 295$

Vključevanje staršev v zgodnje učenje matematike

Nataša Živkovič in Sanela Mešinović · 311

The Significance of the Constructivist Approach in Preschool Science Education Janja Plazar $\cdot 325$

Raziskovanje glasbenega razvoja in pomen glasbenega okolja za dojenčka Bogdana Borota 339

Značilno vedenje otrok prvega starostnega obdobja $v$ igralnicah z različno glasbo Barbara Kopačin $\cdot 353$

Stališča do pomena uspavanke v zgodnjem otroštvu nekoč in danes

Bogdana Borota in Bojana Kralj 369

Z merilnikom pospeška izmerjena gibalna aktivnost in gibalna neaktivnost otrok med prvim in tretjim letom starosti

Tadeja Volmut $\cdot 383$

Gibalna/športna (ne)aktivnost vzgojiteljic in njihova kompetentnost za razvoj gibanja predšolskih otrok v prvem starostnem obdobju

Matej Plevnik in Tanja Peternelj · 399

Delež prostega gibanja in spontane igre otrok v prvem starostnem obdobju Maja Cerar $\cdot 411$ 


\section{Predgovor}

\section{Sonja Čotar Konrad}

Univerza na Primorskem

sonja.cotarkonrad@pef.upr.si

\section{Bodgana Borota}

Univerza na Primorskem

bogdana.borota@pef.upr.si

\section{Sonja Rutar}

Univerza na Primorskem

sonja.rutar@pef.upr.si

\section{Karmen Drljić}

Univerza na Primorskem

karmen.drljic@pef.upr.si

\section{Giuliana Jelovčan}

Univerza na Primorskem

giuliana.jelovcan@pef.upr.si

Nekoliko nenavadno je monografijo, ki obravnava različne vidike vzgoje najmlajših otrok, nasloviti Vzgoja in izobraževanje predšolskih otrok prvega starostnega obdobja. Vendar odločitev temelji na dejstvu, da predšolska vzgoja na Slovenskem že od svojega nastanka dalje povezuje skrb/varstvo, vzgojo in izobraževanje, kar lahko le redko zasledimo v tujini. Pregled stanja na področju predšolske vzgoje in izobraževanja v Evropi kaže (Key Data on Early Childhood Education and Care in Europe 2019), da si v večini evropskih držav šele prizadevajo za enovito organizacijo predšolske vzgoje in profesionalizacijo predšolske vzgoje prvega starostnega obdobja.

V Sloveniji so vrtci organizirani celovito, enovito, od leta 1993 pa je celotna organizirana predšolska vzgoja v pristojnosti resornega ministrstva za vzgojo in izobraževanje. Organizacija predšolske vzgoje v Sloveniji tako izhaja iz tradicionalne, načrtne in sistemske skrbi za vzgojo in izobraževanje otrok v najzgodnejšem obdobju. Menimo, da je za ohranjanje dosežene ravni kakovosti predšolske vzgoje pri nas potrebno zagotoviti načrtno refleksijo obstoječe prakse, v katero je smiselno vključiti vse deležnike, vključene v organizacijo vzgoje in izobraževanja. Predvsem zato, ker so družine - in posledično otroci - v zgodnjem razvojnem obdobju najranljivejše in podvržene vplivom 
družbenega ter naravnega okolja. In zato, ker to pomeni temeljno poslanstvo vrtca, ki s tem ne zagotavlja zgolj podpore otroku, temveč tudi njegovi družini.

Znanstvena monografija izpostavlja potenciale otrok in vplive okolja na otrokov razvoj ter učenje. Vključuje predstavitev pristopov in strategij, ki lahko pomembno prispevajo k zagotavljanju integrirane, celovite in enovite vzgoje in izobraževanja, ter opozarja na nekatera pomembna vprašanja pri strokovnem delu in profesionalnem razvoju strokovnih delavk vrtca. Odpira tudi vprašanja raziskovanja zgodnjega obdobja, razvoja in učenja otrok. Poudarja pomen vloge družin in vrtca v otrokovem najzgodnejšem obdobju. Osredotoča se tudi na pomen zgodnje intervencije in obravnave otrok s posebnostmi v razvoju ter razlaga razvojna stanja in potenciale otrok z refleksijo družbenega konteksta. Monografija pa se odpira tudi v mednarodni prostor, saj predstavlja vzgojno-izobraževalne prakse tudi drugih držav.

Ugotavljamo, da sta vzgoja in izobraževanje v zgodnjem otroštvu redko celostno preučevana. Zato smo si prizadevali, da bi v monografiji predstavili raznolika sistemska, teoretična in empirična spoznanja. Mnoga odsevajo dolgoletna sistematična opazovanja in ugotovitve ter opozorila, ki jih bodo lahko smiselno upoštevali oblikovalci politik, drugi raziskovalci zgodnjega otroštva, vodstveni in strokovni delavci v vrtcih ter študentje, ko bodo iskali rešitve in odgovore na razpotjih svojih lastnih presoj, odločitev in ravnanj.

Z monografijo zato odpiramo pot razpravam, ki so in ostajajo ključne ob dejstvu, da otroci v najzgodnejšem obdobju smiselno in povedno interpretirajo vse, kar in kogar srečujejo na svojih poteh.

In zahvaljujemo se vsem, ki so kakorkoli pripomogli, da so spoznanja, predstavljena v monografiji, dobila pot do bralcev. 


\title{
Celovit in enovit sistem predšolske vzgoje z integracijo vzgojno-izobraževalne, zdravstvene in socialne dimenzije
}

\author{
Sonja Rutar \\ Univerza na Primorskem \\ sonja.rutar@pef.upr.si
}

\begin{abstract}
Sistem in organiziranost predšolske vzgoje v slovenskih vrtcih je celovit in enovit - zagotavlja povezanost skrbi/varstva, vzgoje in izobraževanja v prvem in drugem starostnem obdobju. Med prvim in drugim starostnim obdobjem so zagotovljene razvojna, pedagoška in profesionalna kontinuiteta. Sedanja oblika enovitega sistema in kontinuitete je bila zagotovljena že z Vzgojnim programom za vzgojo in varstvo predšolskih otrok (1979), nadaljevala se je s Kurikulumom za vrtce (Ministrstvo za šolstvo in šport, 1999). Problem, ki ga želimo v prispevku nasloviti, je, kako zagotoviti, da bodo vrtci ohranili senzibilnost in integriran pristop do otrok in njihovih družin z vključevanjem vzgojnoizobraževalne, zdravstvene in socialne dimenzije, ob zavedanju, da so otrokovi razvojni potenciali, zmožnosti za razvoj in učenje ter zdravje v neposredni povezavi s socialno-ekonomskimi pogoji otrok in njihovih družin.
\end{abstract}

Ključne besede: predšolski otrok, družina, kurikulum, učenje, razvoj

\section{Uvod}

V organizirano predšolsko vzgojo v Sloveniji so v skladu z Zakonom o vrtcih (2005) vključeni otroci od enajstega meseca starosti do vstopa v šolo. Kljub formalni delitvi skupin otrok na prvo in drugo starostno obdobje so vrtci organizirani enovito in celovito, $z$ namenom zagotavljanja varstva in vzgoje $v$ izobraževalnem sistemu, kar ni značilno za vse države evropskega prostora.

Skupno stališče na ravni OECD je, da sta skrb/varovanje in izobraževanje koncepta, ki sta v kakovostnih vrtcih medsebojno povezana (OECD 2001, 14; 2006). Slovenija ima konceptualno prednost pri organizaciji vzgoje, saj epistemološko vzgoja v najširšem pomenu vključuje (1) vzgojo, ki predstavlja seznanjanje $z$ vrednotami, razvoj skrbi posameznika zase in za druge in razvoj odnosov z drugimi, ter (2) izobraževanje, ki vključuje pridobivanje znanj, spretnosti in $s$ tem tudi razvoj sposobnosti. Obenem pa je organizirana predšolska vzgoja že v času Pestalozzija (1746-1827) poleg učenja, pridobivanja spoznanj skozi najrazličnejše aktivnosti, vključevala tudi nego in skrb za otroke ter njihovo zdravje (Žlebnik 1978), kar je za predšolsko vzgojo 
značilno tudi v sodobnem času (Marjanovič Umek, Fekonja Peklaj, Hočevar in Lepičnik Vodopivec 2011). Predvidevamo, da bi morebiten prehod z integrirane vzgojno-izobraževalne, socialne in zdravstvene skrbi za otroke ter njihove družine ( $v$ okviru organizirane predšolske vzgoje) na izključno vzgojno-izobraževalno predstavljal izključevanje dimenzij, ki so medsebojno povezane, soodvisne in pri vzgoji, izobraževanju in skrbi za najmlajše otroke vedno prisotne. Zato verjamemo, da je mogoče zagotavljati ustrezno vzgojo in izobraževanje za otroke v njihovem najzgodnejšem obdobju zgolj z interdisciplinarno povezanostjo zdravstvenih, medicinskih, pedagoških, psiholoških, socialnih in kulturno informiranih spoznanj.

V prispevku izpostavljamo pomen (1) celovitega in enovitega sistema predšolske vzgoje $v$ pristojnosti resornega ministrstva za izobraževanje, $z$ integracijo (2) vzgojno-izobraževalnega, zdravstvenega in socialnega področja ter z zagotovljeno (3) profesionalno, pedagoško in razvojno kontinuiteto v pedagoških pristopih.

\section{Celovit in enovit sistem predšolske vzgoje v pristojnosti resornega ministrstva za izobraževanje}

Vpogled v organiziranost predšolske vzgoje v različnih državah kaže (Eurydice 2019), da je Slovenija ena izmed redkih držav, ki (1) celovito povezuje skrb, varstvo in izobraževanje ter (2) zagotavlja enovito organizacijo in financiranje vzgoje za otroke prvega ter drugega starostnega obdobja. V državah, $v$ katerih je skrb za otroke $v$ najzgodnejšem obdobju (do tretjega leta starosti) v pristojnosti socialnega varstva, za starejše otroke pa v pristojnosti resornega ministrstva za izobraževanje, sta dve starostni obdobji z vsebinskega in organizacijskega vidika ter načina financiranja ločeni, kar predstavlja težavo pri zagotavljanju celovitega in integriranega sistema vzgoje s povezanostjo zdravstvene, socialne in vzgojno-izobraževalne dimenzije. Enovit sistem vzgoje in izobraževanja je organiziran samo na Hrvaškem, v Latviji, Litvi, na Finskem, Švedskem, v Bosni in Hercegovini, na Islandiji, v Črni Gori, Severni Makedoniji, na Norveškem, v Srbiji in Sloveniji (Eurydice 2019). Posledično imajo programe in smernice za pedagoško delo zgolj z otroki drugega starostnega obdobja v Belgiji (flamska skupnost), Bolgariji, na Češkem, v Italiji, Franciji, Cipru, Luksemburgu, Avstriji, na Poljskem, Portugalskem, Slovaškem, v Lihtenštajnu in Švici (Eurydice in Eurostat 2014). V navedenih državah za skupine mlajših otrok ni predpisanega pedagoškega programa, kar kaže na diskurz, ki ob odsotnosti pedagoških vodil oziroma načel lahko vodi v manj strukturirane in načrtovane vzgojno-izobraževalne spodbude ter ravnanja v času otrokovega bivanja v vrtcih. 
Prvotna skrb, vzgoja in zaščita otrok v času odsotnosti staršev, je bila s prisotnostjo pedagoškega diskurza (ki verjame $v$ otrokove spoznavne zmožnosti in omogoča razvoj z zagotavljanjem pogojev za učenje) $z$ izobraževalnimi elementi (cilji in nalogami) $v$ Sloveniji prisotna že $z$ državnim načrtnim ustanavljanjem otroških vrtcev, osnovnošolskim zakonom, sprejetim 14. maja 1869. Povezanost igre in poučevanja v ciljih in dejavnostih je prisotna, skladno s Fröeblovim konceptom, že v učnih načrtih za vrtce, ki so ga pripravile uršulinke leta 1908 (Pavlič 2006).

Skrb, varstvo ter vzgoja in izobraževanje so bili povezani v celovito dejavnost tudi v prvem nacionalnem programu za vrtce, Vzgojnem programu za vzgojo in varstvo otrok, nastalem leta 1979. $V$ tem dokumentu so bili opredeljeni vsebine in program vzgojnega dela za otroke do tretjega leta starosti ter vzgojni program za otroke od tretjega leta do vstopa $v$ šolo. Vzgojni program za vzgojo in varstvo predšolskih otrok je določal, da se v vzgojnovarstveni zavod vključujejo otroci, stari od 8 mesecev do 7 let, in prebijejo v njem tudi do 10 ur dnevno (Vzgojni program za vzgojo in varstvo otrok 1979, 6). Že $v$ tem dokumentu je bilo poudarjeno preseganje izključno varstvene vloge vrtca v času materine odsotnosti otrok. Program je izhajal iz spoznanj o velikih spoznavnih zmožnostih otrok, poudarjal je vlogo vrtca oziroma ustrezne predšolske vzgoje za razvoj otrokovih dispozicij, sposobnosti ter vpliv socialnega, družinskega in družbenega okolja na razvoj otrok. Poudarjeni sta bili tudi nega in skrb za zdravje otrok. Od vzgojitelja se je pričakovalo, da sledi spoznanjem s področja psihologije, mentalne higiene, medicine in pedagogike. Zato je bila vzgojno-varstvena dejavnost pojmovana kot pomoč družini in dopolnitev vzgoje ter nadomestilo v času, ko sta bila starša zaposlena (Vzgojni program za vzgojo in varstvo otrok 1979). Tako današnja organiziranost predšolske vzgoje v Sloveniji izhaja iz tradicionalnega in načrtnega vertikalnega organiziranja ter povezovanja skupin otrok prvega in drugega starostnega obdobja.

Organizirana predšolska vzgoja v vrtcih je bila v Sloveniji po osamosvojitvi najprej v pristojnosti Republiškega komiteja za zdravstveno in socialno varstvo, od leta 1993 pa resornega ministrstva za izobraževanje. V Kurikulumu za vrtce (Ministrstvo za šolstvo in šport 1999), zdravstveni in socialni vidik nista eksplicitno izpostavljena, vendar je bilo v Zakonu o vrtcih leta 1996 opredeljeno, da so temeljne naloge vrtcev pomoč staršem pri celoviti skrbi za otroke, izboljšanje kvalitete življenja družin in otrok ter ustvarjanje pogojev za razvoj otrokovih telesnih in duševnih sposobnosti.

Utemeljen prenos organizirane predšolske vzgoje v pristojnost resornega ministrstva za izobraževanje je povezan predvsem s spoznanji o velikih raz- 
vojnih potencialih otrok, ključni vlogi najzgodnejših izkušenj v aktualnem in kasnejšem razvoju otrok (Phillips in Shonkoff 2000) ter vplivu vrste in kakovosti izkušenj, ki jim je otrok izpostavljen v različnih družinskih okoljih, na otrokov razvoj in učenje (Hart in Risley 1995).

Način organizacije in vsebinski vidik skrbi za predšolske otroke pa sta vedno manifestacija podobe o otroku (Malaguzzi 1994), razumevanj in interpretacije otrokovih potencialov, prepričanj in razlag vlog, ki jih ima otrok v družbi. Phillips in Shonkoff $(2000,2)$ sta v odmevni raziskavi skupaj s sodelavci povzela dotedanja spoznanja o razvoju in učenju otrok. Poudarjata:

- pomen zgodnjih izkušenj v življenju otrok ter centralno nalogo in vlogo zgodnjih odnosov z otroki kot virom pomoči, podpore v situacijah, ko otrok potrebuje podporo;

- vpliv interaktivnega delovanja genetskih in okoljskih vplivov na razvoj možganov in način otrokovega delovanja;

- velike razvojne zmožnosti otrok;

- zmožnost razvoja kompleksnega čustvovanja v zgodnjem otroštvu, kar predstavlja zmožnost za razvoj ključnih socialnih spretnosti v prvih letih otrokovega življenja;

- obstoj kapacitet za spreminjanje poti otrokovega razvoja skozi načrtovane aktivnosti.

Spoznanja implicirajo, da za otroka v najzgodnejšem obdobju ni dovolj zgolj skrb, ki se manifestira v oskrbi in varovanju, pač pa je pomembno zagotavljanje ustreznih, načrtovanih izkušenj, ki pomembno vplivajo na otrokovo učenje in razvoj, še posebno na učenje in razvoj otrok, ki prihajajo iz depriviligiranih okolij (Burger 2010).

Ob dejstvu, da obstajajo različne oblike organizirane predšolske vzgoje v mednarodnem okolju, Peter Moss in John Bennett (2006) poudarjata, da je v vseh državah potrebno zagotoviti integriran sistem varstva in izobraževanja. Za to, da bi države lahko zagotovile integriran sistem, menita, da je potrebno zadostiti naslednjim pogojem:

- Razširiti je potrebno vrednote in načela javnega izobraževalnega sistema na vse predšolske inštitucije/vrtce z zagotavljanjem dostopa do visokokakovostnih vrtcev za vse otroke, kar velja za univerzalno pravico; postati mora brezplačna ali javno subvencionirana storitev, ki se priznava kot javno dobro, financirano s strani države, in ne kot zasebna dejavnost, kot je organizirana v nekaterih državah. 
- Organizirati je potrebno enoten strukturni okvir, ki bo nadomestil paralelno strukturo, ločeno na varstvo in izobraževanje. To je mogoče zagotoviti z ustreznim financiranjem in novim poklicem predšolskega učitelja/vzgojitelja, ki dela z otroki do tretjega leta starosti in po tretjemu letu starosti.

- Razviti je potrebno integrativni koncept, ki zajema učenje, skrb in psihološko blagostanje najmlajših otrok, kar presega politiko in prakso "zgodnjega izobraževanja« in »varstva otrok« kot ločenih subjektov.

Kasneje so Kaga, Bennett in Moss (2010) preučevali situacijo ločenih in celovitih integriranih sistemov $v$ različnih državah. Ugotavljajo, da ni mogoče govoriti o absolutni prednosti integriranega sistema, če se integracija ne zgodi postopno in premišljeno, $z$ jasno konceptualizacijo namena sprememb. Sprememba z umeščenostjo predšolske vzgoje na področje izobraževanja ne zahteva zgolj formalnih sprememb na ravni prenosa pristojnosti na področje izobraževanja, pač pa soočanje z nevarnostmi »pošolanja« vrtcev, možnosti poslabšanja odnosov, nepovezanosti z drugimi področji (zdravje, sociala) in povečanja stroškov $z$ boljšo izobrazbeno strukturo zaposlenih in $s$ pripravo novega kurikuluma. Mednarodna spoznanja tako omogočajo refleksijo obstoječe strukture slovenske predšolske vzgoje in podobe o otroku. $\checkmark$ Sloveniji ima sedanja ureditev in organizacija vrtcev naslednje značilnosti:

- zagotovljen je organizacijsko enovit (organizacijsko povezana vzgoja in izobraževanje prvega in drugega starostnega obdobja) ter celovit (povezanost skrbi/varovanja, vzgoje in izobraževanja) sistem vzgoje in izobraževanja;

- strokovni delavci, zaposleni v vrtcih, so izobraženi za delo v prvem in drugem starostnem obdobju;

- kurikulum vsebuje cilje in dejavnosti za delo z otroki obeh starostnih obdobij;

- obstaja pa nevarnost nepovezanosti, neintegriranosti z drugimi področji - zdravstvom in socialnim varstvom.

Stanje v slovenskih vrtcih kaže na upoštevanje velikih razvojnih potencialov otrok, njihovih zmožnosti za učenje, kar se odraža pri vzpostavljanju profesionalne in pedagoške kontinuitete. Ob poudarjanju izobraževalne vloge predšolske vzgoje, pomembne predvsem za otroke, ki imajo manjše priložnosti za pridobivanje akademskih znanj in spretnosti v domačih okoljih, pa 
je potrebno upoštevati, da je otrok vpet v različna socialno-ekonomska okolja, ki pomembno vplivajo na njegove (z)možnosti za učenje in zdravje.

\section{Povezanost vzgojno-izobraževalnega, socialnega in zdravstvenega področja}

»Vsak otrok ima pravico do enakih možnosti za razvoj« je najpogostejši slogan vlad, ki v svojih odločitvah upoštevajo spoznanja o vplivih okolja na otrokov razvoj. Okolje in strukturni družbeni pogoji zato vplivajo tudi na (z)možnosti otrokovih družin za zagotavljanje optimalnega razvoja otrok. Ta spoznanja vlade vodijo k prizadevanjem za organizacijo dostopa do visokokakovostnih vrtcev za vse otroke. Študije namreč kažejo, da zgodnje intervencije in predvsem visokokakovostni predšolski programi vplivajo na otrokove kasnejše učne dosežke ter življenjske navade, odnose z drugimi, zdravstveno in socialno-ekonomsko stanje $v$ odrasli dobi (Vandenbroeck 2011; Woodhead, Grantham-McGregor in Klaus 2015).

Čeprav so sistematični zbrani dokazi o vplivih okolja na otrokovo učenje in razvoj na voljo šele v sodobnem času (Hart in Risley 1995), so vrtci od samega nastanka (Žlebnik 1978) povezovali vzgojno-izobraževalno, socialno in zdravstveno področje. Podobno je usposabljanje negovalk (1840) in kasneje vzgojiteljic (1950) vključevalo vsebine o higienskih pravilih. Kasneje, v drugi polovici 20. stoletja, so bile te vsebine zajete v zdravstveni vzgoji (Lepičnik Vodopivec in Hmelak 2018).

$\mathrm{V}$ normative in strukturne standarde slovenskih vrtcev je tudi danes zajet zdravstveni vidik; določeni so tehnični in zdravstveno higienski normativi, nadzorovana priprava prehrane, organizirani obiski zobozdravstvenih delavcev $v$ vrtcih in organizirana predavanja pediatrov za starše otrok. Pomembnost zdravja in sistemske skrbi za zdravje poudarja tudi M. RossinSlater (2015), ki je ugotovila, da so odrasli bolj zdravi, višje izobraženi in živijo tudi v boljših ekonomskih razmerah, če so bili zdravi v zgodnjem otroštvu. Vendar je $v$ svoji raziskavi ugotovila tudi, da je zdravje otrok $v$ neposredni povezavi s socialnimi razmerami, v katerih živijo otroci v družinskem okolju.

Socialno vlogo vrtcev in s tem upoštevanje družinskih/socialnih razmer opredeljuje 20. člen Zakona o vrtcih, ki določa, da ima v skladu z odločbo pristojnega organa pri sprejemu $v$ vrtec prednost otrok $s$ posebnimi potrebami. Prednost pri sprejemu v vrtec ima tudi otrok, za katerega starši predložijo mnenje centra za socialno delo o ogroženosti zaradi socialnega položaja družine. Mnenje o ogroženosti otroka zaradi socialnega položaja družine vsebuje navedbe, da je družina v skladu s predpisi, ki urejajo socialno varnost oziroma položaj družine, obravnavana kot socialno ogrožena družina s 
strani centra za socialno delo, kar je razvidno iz uradnih evidenc, ki jih vodijo centri za socialno delo. Ustanovitelj pa določa tudi druge kriterije pri vključevanju otrok v vrtec, če število prijavljenih otrok presega razpoložljivo število mest. Ti pogosto vključujejo število otrok v družini ter posebno skrb za enostarševske družine in družine, v katerih sta zaposlena oba starša oziroma sta starša študenta. Upoštevajo se tudi priporočila razvojne ambulante, dispanzerja za psihohigieno ali svetovalnega centra z navedbo razlogov za nujnost vključitve otroka v vrtec (Pravilnik o sprejemu otrok v vrtec 2012).

Poudarjeno vlogo vrtcev pri zagotavljanju ustreznih pogojev za otrokov razvoj v družinskih okoljih je mogoče prepoznati tudi v smernicah za svetovalno delo v vrtcih (Čačinovič 2008). Področja delovanja svetovalne službe v vrtcih so: (a) svetovalno delo z otroki, (b) svetovalno delo z vzgojitelji in pomočniki vzgojiteljev, (c) svetovalno delo s starši in družinami, (č) sodelovanje $z$ vodstvom vrtca, (d) sodelovanje z zunanjimi ustanovami. Pri svetovalnem delu s starši se od svetovalne službe pričakuje zagotavljanje pomoči staršem pri njihovem vključevanju v vzgojno-izobraževalno delo v oddelku, zagotavljanje pomoči staršem pri razumevanju in spodbujanju otrokovega razvoja ter učenja v predšolskem obdobju in pri opravljanju starševske vloge ter pomoč staršem, ko je zaradi njihovih različnih osebnostnih, socialnih, zdravstvenih ali materialno-ekonomskih stisk ogrožen otrokov normalni razvoj (Čačinovič 2008, 20).

Kljub dobro organizirani mreži javnih vrtcev M. Šebart Kovač in Štefanc $(2017,125)$ v slovenski študiji o položaju otrok v Sloveniji danes ugotavljata, da je treba povečati delež vključenosti otrok $v$ vrtce $v$ Sloveniji, predvsem v prvem starostnem obdobju, in zagotoviti sistemske ukrepe, ki »spodbujajo vključevanje otrok v vrtce, še posebno tiste, ki prihajajo iz manj spodbudnega okolja, robnih skupin, priseljencev in otrok s posebnimi potrebami«.

Ob spoznanjih, da ima organizirana predšolska vzgoja pozitiven vpliv na otrokov razvoj, še posebno otrok, ki prihajajo iz depriviligiranih okolij, Vandenbroeck (2011) opozarja, da izobraževalni sistem pogosto reproducira socialno neenakost z zanikanjem situacij in potreb staršev ter pogosto prezrtostjo stanj, s katerimi se soočajo starši in otroci iz depriviligiranih okolij. Sistemska predstava o vlogi predšolske vzgoje je namreč pogosto povezana s pričakovanjem ekonomskega učinka $v$ prihodnosti, zato lahko vzgojnoizobraževalna praksa spregleda otroštvo tukaj in zdaj ter s tem razvojne potrebe otrok v času otroštva. Spregleda in zanika lahko tudi partikularne posebnosti, zmožnosti otrok in staršev, aspiracije in načine vsakdanjega življenja ter dejstvo, da je lahko določen socialno-ekonomski vidik (npr. starši brez prevoznega sredstva, slabe bivanjske razmere družine ...) ključna ovira pri 
dostopu do organizirane predšolske vzgoje. Otrokovi pogoji za razvoj in učenje so namreč odvisni od kompleksnega zdravstvenega in socialnega stanja družin, kar tudi vpliva na funkcionalnost družin. Na mnoge družinske situacije starši nimajo neposrednega vpliva (npr. neustrezno plačano delo staršev in zato nizki družinski dohodki, neustrezni delovni čas staršev, kar onemogoča stalno skrb za otroke, nedostopnost vrtcev).

Ob dejstvu, da zgodnje otroštvo pomeni občutljivo obdobje $z$ vidika razvoja otrokovih zmožnosti, je potrebno v procesu izobraževanja za poklic vzgojitelja poleg poznavanja kurikularnih področij ter načinov učenja in poučevanja otrok zagotoviti ustrezno senzibilizacijo strokovnih delavcev za prepoznavanje situacij vseh otrok (za njihovo socialno in zdravstveno stanje) ter funkcionalne zmožnosti družin. Raziskave sicer spodbudno kažejo, da imajo slovenske vzgojiteljice predšolskih otrok pozitivna stališča do inkluzije, ki so jih imele možnost razvijati na različnih stopnjah izobraževanja, vključno v času študija (Štemberger in Kiswarday 2017). To je pomembno spoznanje, saj S. Čotar Konrad (2018) izpostavlja, da bi moralo biti temeljno poslanstvo vzgojiteljice pri delu z družinami, da s svojim strokovnim delom (opazovanjem, pogovorom, odprtostjo, afiliativno naravnanostjo) in refleksijo lastnega poklicnega poslanstva opolnomoči funkcionalnost družine predšolskega otroka in posledično krepi otrokov psihosocialni razvoj. Obenem pa ugotavlja, da v slovenskem prostoru ni zagotovljenega sistematičnega usposabljanja vzgojiteljic za poznavanje in razumevanje specifičnih razvojnih nalog ter delovanja družine predšolskega otroka. Ob tem resno oviro pri opolnomočenju staršev oziroma družin predstavlja tudi neoliberalni diskurz navideznih neskončnih možnosti izbir in odločitev (Rose 1997), ki starše vodi v prevzemanje osebne odgovornosti za njihove načine življenja in življenjske pogoje. To se povezuje $z$ občutki porazov in neuspešnosti ob morebitni nezmožnosti zagotavljanja ustreznih materialnih pogojev ter medsebojnih odnosov v družinah. Starši (in morda tudi strokovni delavci v vrtcih) lahko spregledajo dejstvo, da je človekovo bivanje družbeno in socialno soodvisno, življenjske zmožnosti pa sistemsko pogojene (Bronfenbrenner 1994) s faktorji, ki vplivajo na dostop posameznika do materialnih in drugih bivanjskih pogojev. Zato starši pogosto nimajo drugih možnosti oziroma izbir.

Ob zagotavljanju ustreznih zdravstvenih pogojev in skrbi za zdravje otrokv vrtcih ter poznavanju družinskih in socialnih razmer otrok ter njihovih družin je treba upoštevati tudi otrokove predhodne spoznavne vsebine, priložnosti in navade, ki so kulturno kontekstualizirane. S tem je mogoče zagotoviti smiselnost (razvojno in kulturno odzivnost) ter učinkovitost vzgoje (rezultate). Izhajajoč iz študije, ki je preučevala ključne profesionalne kompetence vzgo- 
jiteljev (Urban idr. 2012), izhaja, da mora družba otrokom in družinam zagotoviti dostop do visokokakovostnih predšolskih programov in rezultatov, ki se kažejo v razvojnih in spoznavnih dosežkih otrok. Prav ti so namreč ključnega pomena za otroke, družine, skupnosti in širšo družbo. Kakovost, ki vodi do omenjenih rezultatov, pa mora vključevati vrednote in subjektivne predstave vseh, ki so vključeni v proces vzgoje, socialno konstrukcijo, refleksijo različnih kultur ter stalno usklajevanje vseh, vključenih v proces vzgoje (Dahlberg, Moss in Pence 2008).

\section{Zagotavljanje profesionalne, pedagoške in razvojne kontinuitete}

Lally idr. $(1996,17)$ so mnenja, da se razvojno primerni programi pomembno razlikujejo od programov za starejše otroke zaradi značilnosti in specifičnih potreb otrok do tretjega leta starosti, ki so povezane s spoznanji, da:

- se razvojne spremembe $v$ tem obdobju dogajajo veliko hitreje kot $v$ kateremkoli obdobju kasneje v življenju;

- so v času zgodnjega otroštva, tako kot v vseh drugih starostnih obdobjih, vsa razvojna področja - kognitivni, socialni, emocionalni in fizični razvoj - medsebojno prepletena;

- so otroci v zgodnjem otroštvu pri zadovoljevanju svojih potreb v celoti odvisni od odraslih;

- so majhni otroci v stiski še posebej ranljivi, ker se ne zmorejo aktivno spopadati z neugodjem ali s stresom.

Raziskave, še posebno s področja nevroznanosti, poudarjajo, da so otroci kompetentni učenci že od prenatalnega obdobja naprej (Dalli idr. 2011), zato je potrebno zagotoviti dostojanstveno in spoštljivo ravnanje z njimi (Goldschmied in Jackson 1994). Način ravnanja pa je utemeljen v vzorcih kulturnega in družbenega okolja ter interpretacijah otroka bodisi kot »bitja potreb« bodisi kot »bitja pravic«, kajti otroštvo je bilo in je sociokulturni konstrukt v vseh zgodovinskih obdobjih in družbenih okoljih (James in Prout 2003). Empirična spoznanja, ki jih povzema National Council on the Developing Child pri Harvard University, so pokazala, da je zdrav psihofizični razvoj otroka odvisen od kakovosti in zanesljivosti odnosov s pomembnimi drugimi (referenčnimi osebami v družini in izven nje) (National Scientific Council on the Developing Child 2004), kajti »zgodnje izkušnje so vgrajene v naša telesa« kot notranji model navezanosti, torej odnosa otroka do sebe in do okolja (Center on the Developing Child 2010, 1).

Ob zgoraj nevedenem je vsebinska profesionalizacija poklica vzgojitelja 
odvisna predvsem od predstave, podobe, razumevanja in razlage, kdo je otrok in kaj potrebuje za učenje ter razvoj v zgodnjem otroštvu. Bertram in Pascal (2016) opozarjata, da obstajajo velike razlike $v$ zakonskih podlagah, oblikah in vrstah predšolske vzgoje, dostopnosti in deležu otrok, vključenih $v$ predšolsko vzgojo, ter $v$ pričakovanjih na ravni različnih držav glede pričakovanih rezultatov, dosežkov otrok $v$ tem obdobju. Moss (2006) tudi ugotavlja, da neenovit, deljen sistem vzgoje predšolskih otrok vodi v deprofesionalizacijo, k različnim pričakovanjem ter normativom glede pričakovane in zahtevane stopnje izobrazbe strokovnih delavcev, ki delajo z otroki v njihovem prvem oziroma drugem starostnem obdobju. Podatki kažejo (Moss 2006), da so strokovni delavci v prvem starostnem obdobju v večini držav manj izobraženi, slabše plačani, večinoma gre za ženske.

Pedagoško kontinuiteto ( $z$ enovitim in celovitim kurikulumom) z namenom zagotavljanja ustreznega spodbujanja učenja in $s$ tem razvoja je zato mogoče zagotavljati izključno s profesionalno kontinuiteto - enako stopnjo in vrsto izobrazbe strokovnih delavcev, zaposlenih v ustanovah z otroki prvega in drugega starostnega obdobja, ter $s$ tem njihovo profesionalizacijo. Slednje pa je mogoče zagotoviti takrat, ko se strokovni delavci, ki delajo z otroki obeh starostnih obdobij, izobražujejo v izobraževalnih programih z enotnimi teoretičnimi, političnimi in etičnimi izhodišči - vrednotami, stališči in ravnanji.

Na sliki 1 predstavljamo sistemski model interakcij za vzpostavljanje celovite (skrb, varstvo, vzgoja in izobraževanje) in enovite (vzgoja in izobraževanje otrok prvega in drugega starostnega obdobja) predšolske vzgoje za potrebe integrirane (zdravstvo, sociala, izobraževanje) vzgoje otrok v vrtcih, ki tradicionalno, implicitno že obstaja. Povezuje državno in lokalno raven vrtca. Skozi diskurz integracije različnih vsebinskih področij (vzgoje in izobraževanja, socialnega in zdravstvenega področja) pa zagotavlja vzpostavljanje ustreznih strukturnih standardov kakovosti ter pedagoško in razvojno kontinuiteto.

Ugotavljamo, da je za zagotavljanje rezultatov v predšolski vzgoji treba zagotoviti integracijo ter povezanost zdravstvene, socialne in izobraževalne dimenzije, kar mora odsevati tudi vsebina strukturnih standardov kakovosti in procesnih načel kakovosti. Ravno slednja, procesna načela kakovosti, v slovenskem prostoru niso definirana.

Urban idr. (2012) poudarjajo, da mora kakovost vključevati vse spodaj navedene dimenzije:

- izkušnje in rezultate otrok (pripadanje, vključenost, psihološko blagostanje, oblikovanje smisla in pomena ter dosežke); 


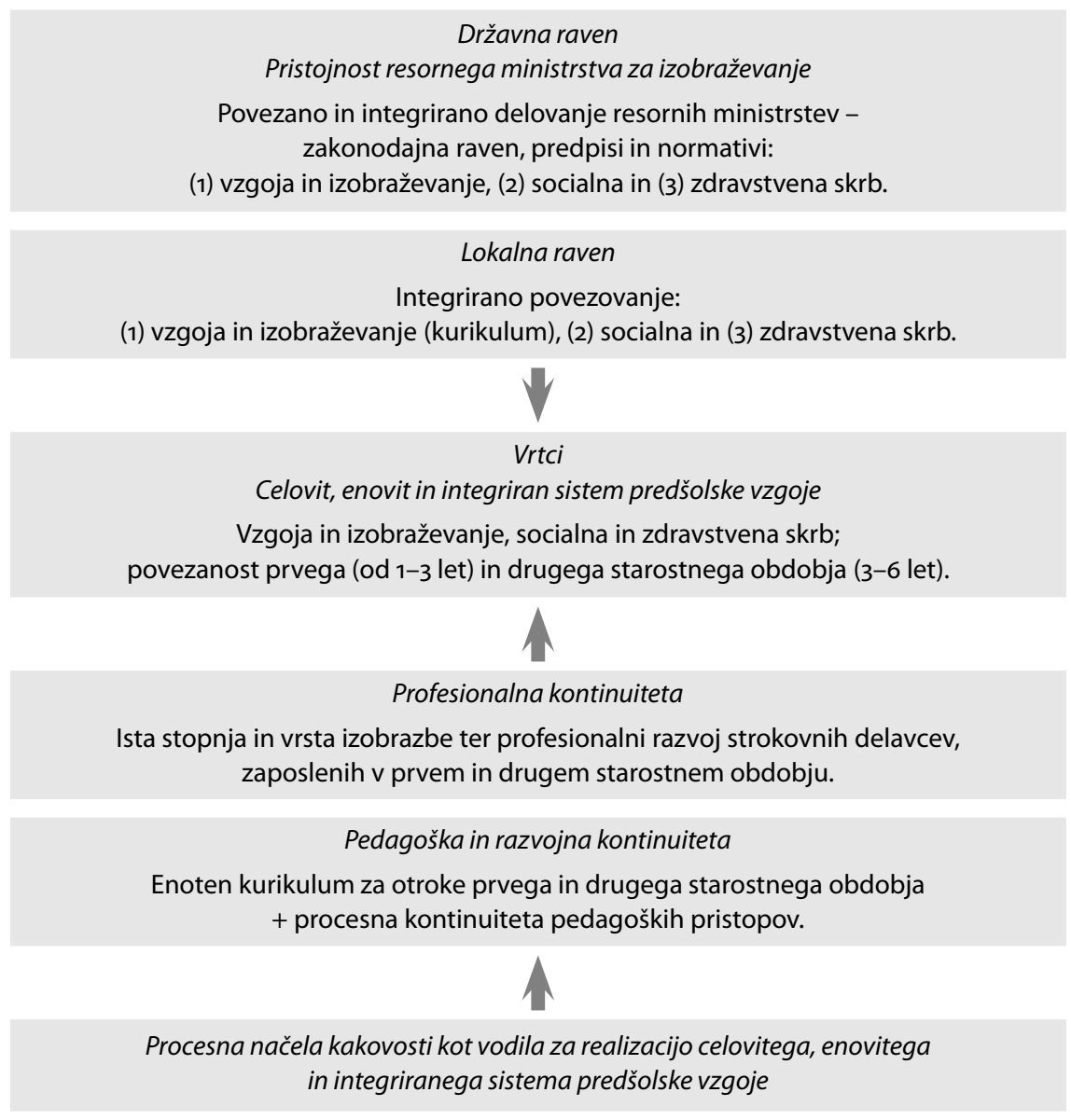

Slika 1 Organizacijski model celovitega, enovitega in integriranega sistema predšolske vzgoje

- izkušnje staršev in skrbnikov (pripadanje, vključenost, psihološko blagostanje, zagotavljanje dostopa do vrtcev);

- interakcije (med odraslimi in otroki, med otroki, med strokovnimi delavci in starši, med člani timov, med inštitucijami, med vrtcem in lokalno skupnostjo, med različnimi strokovnimi področji, med prakso in raziskovanjem, v okolju, kjer se izvaja pripravništvo, in na ravni vlade);

- strukturne pogoje (ustrezno razmerje med številom otrok in odraslih, ustrezno število otrok v skupini, velikost notranjih in zunanjih površin ter materialov za igro, plačane ure posrednega dela za otroke, zagotavljanje stalnega profesionalnega razvoja s podporo strokovnim delavcem pri raziskovanju lastne prakse in kritični refleksiji prakse); 
- sistem evalvacije, spremljanja in izboljševanja prakse (notranja in zunanja evalvacija z vključevanjem vseh deležnikov, na pobudo in s podporo izvajalcev predšolske vzgoje, ustanoviteljev oziroma lokalnih ali nacionalnih služb).

Kot primer ustreznih procesnih načel kakovosti navajamo vodila za profesionalno refleksijo, spremljanje in načrtovanje sprememb pedagoškega procesa v prvem starostnem obdobju, A Quality Framework for Early Childhood Practice in Services for Children under Three Years of Age (International Step by Step Association 2016). Ta vključujejo ravnanja, ki naj bi bila značilna za delo strokovnih delavcev $v$ pedagoškem procesu in so: (1) skrb za odnose, (2) spoštovanje družin in sodelovanje z njimi, vključevanje skupnosti, cenjenje raznolikosti in življenje vrednot demokracije; (3) skrb za zdravje, psihološko blagostanje in prehrano otrok; (4) skrb za spodbujanje celovitega razvoja in učenja otrok; (5) opazovanje, spremljanje razvoja, interesov, močnih strani in potreb otrok, dokumentiranje, refleksija in načrtovanje učenja; (6) zagotavljanje spodbudnega učnega okolja, ki otroku nudi varnost, psihološko blagostanje in priložnosti za učenje; (7) stalen profesionalni razvoj strokovnih delavcev; (8) medsektorsko povezovanje in sodelovanje z drugimi strokovnjaki, službami znotraj vrtca in med sektorji na način, ki zagotavlja zasebnost, zaupnost in dostojanstvo otrok ter družin. Verjamemo, da samo medresorska povezanost na državni in lokalni ravni, ki zagotavlja pogoje za integriran sistem delovanja na ravni vrtca, strokovnim delavcem omogoča senzibilizirano vzpostavljanje zdravstvene, socialne, vzgojne in izobraževalne skrbi ter odnosov z otroki, utemeljenih v procesnih vodilih zagotavljanja razvojne kontinuitete in prakse.

\section{Sklep}

Slovenija ima tradicionalo organiziran celovit in enovit sistem predšolske vzgoje, ki omogoča zagotavljanje profesionalne, pedagoške in razvojne kontinuitete. V prispevku nas je zanimalo, kako zagotoviti, da bodo vrtci ohranili senzibilnost in integriran pristop do otrok in njihovih družin, z vključevanjem vzgojno-izobraževalne, socialne in zdravstvene dimenzije.

S profesionalno kontinuiteto (za zaposlitev na delovnem mestu vzgojitelja $v$ prvem in drugem starostnem obdobju se zahtevata enaka stopnja in vrsta zaključenega programa) je zagotovljena oziroma omogočena razvojna kontinuiteta $v$ pedagoških pristopih in ravnanjih $v$ oddelkih prvega in drugega starostnega obdobja. Pomembno izhodišče integriranega delovanja je tudi enoten program, $z$ enakimi področji dejavnosti v kurikulumu za otroke pr- 
vega in drugega starostnega obdobja. S tem je zagotovljena pedagoška kontinuiteta. Enotna organizacijska in programska izhodišča so bila v Sloveniji vzpostavljena že z Vzgojnim programom za vzgojo in varstvo predšolskih otrok, izdanem leta 1979. Prenova izobraževanja leta 1996 in Kurikulum za vrtce (Ministrstvo za šolstvo in šport 1999) sta nadaljevala s to strokovno tradicijo.

Predvsem za otroke in družine otrok prvega starostnega obdobja je treba poleg razvojno primerne vzgoje in izobraževanja (z zagotavljanjem profesionalne in pedagoške kontinuitete) omogočiti tudi integriran sistem zdravstvene, socialne in kulturne senzibilnosti, ki smo ga predstavili v Organizacijskem modelu celovitega, enovitega in integriranega sistema predšolske vzgoje. Ta zagotavlja sinhronizirano povezanost strukturnih standardov in procesnih načel kakovosti.

V prispevku smo želeli izpostaviti potrebo po načrtno reflektirani sistemski strukturi organizacije predšolske vzgoje, ki v oddelku, na mikroravni, neposredno vpliva na vsebino in obliko vzgojno-izobraževalnih interakcij strokovnih delavcev z otroki. Verjamemo pa, da je ustrezna procesna načela kakovosti in pedagoška ravnanja $v$ prvem starostnem obdobju mogoče definirati ter realizirati izključno $s$ teoretično konceptualizacijo povezanosti vzgojnoizobraževalne, socialne in zdravstvene dimenzije.

In nenazadnje smo želeli opozoriti tudi na nevarnost prezrtosti razvojnih, socialnih, zdravstvenih, kulturnih raznolikosti, posebnosti in potreb otrok ter njihovih družin. Izhajamo iz prepričanja, da ranljivost staršev in otrok v zgodnjem obdobju še ne pomeni nekompetentnosti ali nezmožnosti. Zagotovo pa so za to obdobje značilni večja potreba po pomoči, navajanje staršev na novo vlogo, če gre za otroka prvorojenca, večja zdravstvena in socialna ranljivost, zato tudi večja potreba po zdravstveno in socialno senzibilnih/senzibiliziranih strokovnih delavcih, zaposlenih v vrtcih.

\section{Literatura}

Bertram, T., in C. Pascal. 2016. Early Childhood Policies and Systems in Eight Countries. Hamburg: International Association for the Evaluation of Educational Achievement.

Bronfenbrenner, U. 1994. »Ecological Models of Human Development.« V International Encyclopedia of Education, 3:1643-1647. 2. izd. Oxford: Elsevier.

Burger, K. 2010. »How Does Early Childhood Care and Education Affect Cognitive Development? An International Review of the Effects of Early Interventions for Children from Different Social Backgrounds. "Early Childhood Research Quarterly 25 (2): 140-165.

Center on the Developing Child. 2010. The Foundations of Lifelong Health Are Built in Early Childhood. Cambridge, MA: Harvard University. 
Čačinovič, G. 2008. Programske smernice: svetovalna služba v vrtcu. Ljubljana: Zavod Republike Slovenije za šolstvo.

Čotar Konrad, S. 2018. »Vloga vzgojiteljice pri opolnomočenju funkcionalnosti družine predšolskega otroka.«Pedagoška obzorja: časopis za didaktiko in metodiko 33 (1): 70-81.

Dahlberg, G., P. Moss in A. Pence. 2008. Beyond Quality in Early Childhood Education and Care: Languages of Evaluation. London in New York: Taylor \& Francis.

Dalli, C., E. J. White, J. Rockel, I. Duhn, E. Buchanan, S. Davidson, S. Ganly, L. Kus in B. Wang. 2011. Quality Early Childhood Education for Under-Two-YearOlds: What Should it Look Like? A Literature Review. Wellington: Ministry of Education.

Eurydice. 2019. Key Data on Early Childhood Education and Care in Europe: 2019 Edition; Eurydice Report. Luxembourg: Publications Office of the European Union.

Eurydice in Eurostat. 2014. Key Data on Early Childhood Education and Care in Europe: 2014 Edition; Eurydice and Eurostat Report. Luxembourg: Publications Office of the European Union.

Goldschmeid, E., in S. Jackson, S. 1994. People Under Three: Young Children in Day Care. London: Routledge.

Hart, B., in T. R. Risley. 1995. Meaningful Differences in the Everyday Experience of Young American Children. Baltimore, MD: Brookes.

International Step by Step Association. 2016. A Quality Framework for Early Childhood Practice in Services for Children under Three Years of Age. B. k.: International Step by Step Association.

James, A., in A. Prout. 2003. Constructing and Reconstructing Childhood:Contemporary Issues in the Sociological Study of Childhood. London: Routledge.

Kaga, Y., J. Bennett in P. Moss. 2010. Caring and Learning Together: A CrossNational Study on the Integration of Early Childhood Care and Education Within Education. Paris: Unesco.

Lally, R. J., S. Provence, E. Szanton in B. Weissbourd. 1996. »Developmentally Appropriate Care for Children From Birth to Age 3."V Developmentally Appropriate Practice in early Childhood Programs Serving Children From Birth Through Age 8, ur. S. Bredekamp, 17-33. Washington, DC: National Association for the Education of Young Children.

Lepičnik Vodopivec, J., in M. Hmelak. 2018. Vzgojitelji predšolskih otrok in skrb za lastni profesionalni razvoj. Koper: Založba Univerze na Primorskem.

Malaguzzi, L. 1994. "Your Image of the Child: Where Teaching Begins.» https://www.reggioalliance.org/downloads/malaguzzi:ccie:1994.pdf

Marjanovič Umek, L., U. Fekonja Peklaj, A. Hočevar in J. Lepičnik Vodopivec. 2011. Vrtci. V Bela knjiga o vzgoji in izobraževanju v Republiki Sloveniji, ur. J. Krek in M. Metljak, 63-105. Ljubljana: Pedagoški inštitut. 
Ministrstvo za šolstvo in šport. 1999. Kurikulum za vrtce: predšolska vzgoja v vrtcih. Ljubljana: Ministrstvo za šolstvo in šport.

Moss, P. 2006. "Structures, Understandings and Discourses: Possibilities for Re-Envisioning the Early Childhood Worker.« Contemporary Issues in Early Childhood 7 (1): 30-41.

Moss, P., in J. Bennett. 2006. »Toward a New Pedagogical Meeting Place? Bringing Early Childhood into the Education System."Predstavljeno na Nuffield Educational Seminar, London, 26 september. https://www .childcarecanada.org/sites/default/files/Bennett\%20and\%20Moss \%20(2006)\%20Towards\%20a\%2opedagogical\%2omeeting\%2oplace.pdf

National Scientific Council on the Developing Child. 2004. "Young Children Develop in an Environment of Relationships. " Working Paper 1, Harvard University, Cambridge, MA.

OECD. 2001. Starting Strong. Pariz: OECD. 2006. Starting Strong 2. Pariz: OECD.

Pavlič, S. 2006. Zgodovina idrijskega šolstva do leta 1945. Idrija: Bogataj.

Phillips, D. A., in J. P. Shonkoff, ur. 2000. From Neurons to Neighborhoods: The Science of Early Childhood Development. Washington, DC: National Academies Press.

Pravilnik o sprejemu otrok v vrtec. 2012. Uradni list Republike Slovenije, št. 28.

Rose, N. 1997. »Avtoriteta in genealogija subjektivnosti.« Časopis za kritiko znanosti 25 (183): 131-159.

Rossin-Slater, M. 2015. »Promoting Health in Early Childhood." The Future of Children 25 (1): 35-64.

Šebart Kovač, M., in M. Štefanc. 2017. »|zobraževanje otrok.« V Položaj otrok v Sloveniji danes: situacijska analiza, ur. A. Črnak Meglič in B. Kobal Tomc, 113139. Ljubljana: Inštitut Republike Slovenije za socialno varstvo.

Štemberger, T., in V. R. Kiswarday. 2018. »Attitude Towards Inclusive Education: The Perspective of Slovenian Preschool and Primary School Teachers. «European Journal of Special Needs Education 33 (1): 47-58.

Urban, M., M. Vandenbroeck, K. Van Laere, A. Lazzari in J. Peeters. 2012. »Towards Competent Systems in Early Childhood Education and Care: Implications for Policy and Practice.« European Journal of Education 47 (4): 508-526.

Vandenbroeck, M. 2011. »Diversity in Early Childhood Services." http://www .child-encyclopedia.com/sites/default/files/textes-experts/en/857/diversity -in-early-childhood-services.pdf

Vzgojni program za vzgojo in varstvo predšolskih otrok. 1979. Ljubljana: Zavod Socialistične Republike Slovenije za šolstvo.

Woodhead, M., S. Grantham-McGregor in S. Klaus. 2015. On Early Childhood Development. https://www.youtube.com/watch?v=1u97nDR3K3s

Zakon o vrtcih. 2005. Uradni list Republike Slovenije, št. 100.

Žlebnik, L. 1978. Obča zgodovina pedagogike. Ljubljana: DZS. 
A Comprehensive and Unitary System of Early Childhood Education and Care with the Integration of Educational, Health and Social Dimensions

The system and organization of early childhood education and care in Slovenia is unitary; ensures the connection of care, upbringing and education in the first and second age period. Developmental, pedagogical and professional continuity is ensured between the first and second age groups. The current form of system and continuity was already provided by the Educational program for education and care of preschool children (Vzgojni program za vzgojo in varstvo predšolskih otrok 1979) and later with the Kindergarten Curriculum (Kurikulum za vrtce 1999). The problem addressed in this paper is how to ensure sensibility and holistic approach to children and their families, including educational, social and health dimension, given the fact that child's development potentials, developmental and learning abilities and the health of children are directly related to the socio-economic conditions of children and their families.

Keywords: ICT, distance education, correspondence education, e-learning, higher education 


\title{
Nekateri vidiki raziskovanja zgodnjega učenja in poučevanja
}

\author{
Tina Štemberger \\ Univerza na Primorskem \\ tina.stemberger@pef.upr.si
}

\begin{abstract}
Področje pedagoške metodologije, ki se ukvarja z raziskovanjem vzgoje in izobraževanja, je zaradi specifike področja, ki ga obravnava, zelo široko in raznoliko. $V$ tem kontekstu se zato znotraj pedagoške metodologije pojavljajo tudi podpodročja, ki se osredotočajo na posamezna področja znotraj vzgoje in izobraževanja. Eno takih je področje raziskovanja otroštva, zgodnjega učenja in poučevanja, ki se v zadnjih desetletjih, zlasti pod vplivom anglosaksonske tradicije, nekoliko odmika od tradicionalne pozitivistične raziskovalne paradigme. $V$ prispevku se zato usmerjamo na specifike raziskovanja zgodnjega učenja in poučevanja, pri čemer posebej izpostavljamo vprašanje etičnosti ter naslavljamo različne pristope in načine zbiranja podatkov pri raziskovanju tega obdobja.
\end{abstract}

Ključne besede: pedagoško raziskovanje, zgodnje učenje in poučevanje, etika, tehnike zbiranja podatkov

\section{Uvod}

Pogledi na zgodnje otroštvo ter s tem na zgodnje učenje in poučevanje so se $\checkmark$ zadnjih desetletjih občutno spremenili, kar je narekovalo tudi potrebo po intenzivnejšem raziskovanju tega področja. Objavljene študije so temeljile na različnih metodoloških okvirih, nastale so tudi pod vplivom različnih družbenih, ekonomskih in političnih potreb. Raziskovanje zgodnjega otroštva se je razvijalo v različne smeri, pojavljale so se nove paradigme, v zadnjem času pa je posebno aktualno vprašanje raziskovanja s participacijo otrok (Langston idr. 2004; Rayna in Leavers 2011; Rutar 2014). V pričujočem prispevku se v kontekstu pedagoškega raziskovanja usmerjamo v etičnost pri raziskovanju zgodnjega otroštva ter $v$ nekatere vidike in posebnosti raziskovanja zgodnjega otroštva ter prikazujemo možne pristope $\mathrm{k}$ raziskovanju in tehniki zbiranja podatkov. Pri tem posebej izpostavljamo dejstvo, da so možni različni raziskovalni pristopi in tehnike zbiranja podatkov ter njihove kombinacije, o čemer se raziskovalec odloča na podlagi ciljev, ki jih v raziskavi zasleduje.

\section{Vprašanje etičnosti}

V raziskovanju se vse bolj poudarja etični vidik, v otroštvu pa je to vprašanje, zaradi starosti in ranljivosti (občutljivosti) otrok, še toliko bolj izpostavljeno 
(Mukherji in Albon 2010). Tudi H. L. Cameron (2015) poudarja, da se pri raziskavah, ki vključujejo otroke, vprašanje etičnosti pojavlja v vseh vidikih raziskovanja.

Med prvimi dilemami se poraja vprašanje kompetentnosti otrok za sodelovanje v raziskavi. A. Langston idr. (2004) izpostavljajo, da je med raziskovalci dolgo prevladovalo mnenje, da se $z$ otroki, mlajšimi od 3 let, ne more kaj veliko raziskovati. To gre po njihovem pripisati predvsem dejstvu, da se je kot znanstveno raziskovanje pojmovalo raziskovanje, ki je potekalo $v$ laboratorijih, medtem ko se je $v$ raziskovanje $v$ avtentičnih okoljih usmerjalo le nekaj raziskovalcev. $V$ povezavi z vprašanjem kompetentnosti otrok za sodelovanje $v$ raziskavi ter $\mathrm{s}$ samim sodelovanjem $v$ raziskavi je potrebno izpostaviti tudi t. i. informirano soglasje (Kodelja 2017), ki je pomemben element raziskav, v katere so vključeni ljudje. Informirano soglasje pomeni, da so se sodelujoči prostovoljno odločili za sodelovanje $v$ raziskavi, da je soglasje posledica svobodne volje in temelji na podlagi informaciji o naravi raziskave, njenemu namenu, uporabi izsledkov, o koristih in tveganjih ter obveznostih udeležencev. Pri tem Kodelja (2017) posebej opozarja na raziskave, v katere so vključeni otroci, ki takšnega soglasja sploh ne morejo dati. Po njegovem prepričanju informirano soglasje predpostavlja avtonomijo in odgovornost, otrok pa, predvsem mlajši, ni avtonomen, ne v moralnem pomenu besede ne formalnopravno odgovoren za svoja dejanja, zato informiranega soglasja za sodelovanje $v$ raziskavi ne more dati. Pri tem se sklicuje tudi na Konvencijo o otrokovih pravicah (1989), ki vsakemu otroku zagotavlja pravico do glasu oz. svobodnega izražanja lastnih mnenj takrat, ko je »sposoben oblikovati lastna mnenja«. Temu nasprotno je mnenje A. Langston idr. (2004), ki trdijo, da tudi zelo majhni otroci lahko izrazijo privolitev ali pa tudi nestrinjanje $z$ vključitvijo $v$ raziskavo. To lahko pokažejo na različne načine, in sicer: (i) ne želijo sodelovati z raziskovalcem; (ii) postanejo nenavadno tiho, (iii) obrnejo se stran in jočejo; (iv) ne želijo uporabljati pripomočkov, ki jih vključuje raziskava. Pri tem je smiselno upoštevati tudi, kot, denimo, izpostavlja koncept stotih jezikov Reggio Emilia, da se lahko otroci (četudi še ne znajo govoriti) izražajo na različne načine, npr. preko glasbe, oblikovanja, risanja, plesa ipd. (RobertsHolmes 2005). Raziskovalec naj bi bil torej občutljiv za otrokova sporočila ter pozoren na spremembe njegovega vedenja, pri čemer so opažanja staršev ali, denimo, vzgojiteljev v vrtcu, ki otroka dobro poznajo, zelo dragocena. Ob tem pa je vendarle potrebno opozoriti še na dvoje (Langston idr. 2004): (i) na možnost, da si otroci želijo ugoditi odraslim in je to razlog, da sledijo aktivnostim oz. sodelujejo v raziskavi, in (ii) na možnost, da otroci sicer sodelujejo, a, kot poudarja Kodelja (2017), ni možno z gotovostjo trditi, da njihovo sode- 
lovanje temelji na razumevanju narave raziskave, njenega namena, uporabe izsledkov, koristi in tveganj ter obveznosti udeležencev.

Formalnopravno so starši (oz. skrbniki) tisti, ki odločajo o vključitvi otroka v raziskavo, vendar pa se postavlja vprašanje, ali morajo pri svoji odločitvi upoštevati tudi otrokovo mnenje. Glede na Konvencijo o otrokovih pravicah (1989) morajo starši ravnati tako, da je odločitev v največjo korist otroka, ter pri tem upoštevati otrokovo starost in zrelost ter vpliv odločitve na otrokovo življenje. Kodelja (2017) zato predlaga, da bi bilo dobro, da bi tudi raziskovalci v prošnji staršem za soglasje zapisali, da naj pri svoji odločitvi upoštevajo tudi mnenje otrok. Ob tem pa H. L. Cameron (2015) opozarja tudi na možnost, da se starši dejansko ne strinjajo s sodelovanjem otrok v raziskavi, a vseeno pristanejo, saj se z moralnega vidika čutijo dolžni zagotoviti otrokovo sodelovanje $v$ raziskavi.

V zadnjem času (Robson 2006) se vse pogosteje pojavlja tudi zahteva po obravnavi in odobritvi raziskovalnega načrta na komisijah za etična vprašanja v raziskovanju, ki naj bi bile oblikovane na univerzah in drugih raziskovalnih institucijah.

\section{Pristopi k raziskovanju}

Z metodološkega vidika sta se na področju raziskovanja vzgoje in izobraževanja, izhajajoč iz različnih filozofskih paradigem, uveljavila dva pristopa (ali dve paradigmi): kvantitativni in kvalitativni. Kvantitativno raziskovanje temelji na pozitivistični in postpozitivistični paradigmi, kvalitativno raziskovanje pa na kritični teoriji in konstruktivizmu (Mažgon 2008). Za kvantitativno metodologijo je značilno, da se usmerja v merjenje, kvantifikacijo, definiranje spremenljivk, oblikovanje in preizkušanje hipotez s statističnimi postopki ter posploševanje rezultatov. Za kvalitativno metodologijo je značilna usmerjenost $v$ raziskovanje in razumevanje posameznikov ali skupin, temelji na prožnih raziskovalnih vprašanjih, podatki se običajno zbirajo preko tesnega sodelovanja $z$ udeleženci raziskave, analiza podatkov temelji na induktivnem sklepanju (Creswell 2014). V nadaljevanju prikazujemo nekatere glavne razlike med raziskovalnima pristopoma (paradigmama).

Mnogi raziskovalci (Aubrey idr. 2000; Mažgon 2008; Marentič Požarnik 1990; Creswell 2008), opozarjajo, da je potrebno narediti premik h kombiniranju pristopov (Creswell 2008) ali k sintezi paradigem pedagoškega raziskovanja (Mužić 1994), torej k uporabi obeh metodologij oz. k paradigmatskemu relativizmu (Mažgon 2008), ki upravičuje uporabo obeh paradigem, ki vodita do odgovorov na raziskovalna vprašanja (Mažgon 2006).

P. Mukherji in D. Albon (2010) ugotavljata, da se na področju raziskovanja 
Preglednica 1 Razlike med kvantitativno in kvalitativno paradigmo

\begin{tabular}{|c|c|c|}
\hline Postavka & Kvantitativna paradigma & Kvalitativna paradigma \\
\hline Cilj & $\begin{array}{l}\text { Pojasnjevanje: napoved in kontrola. } \\
\text { Iskanje vzročno-posledičnih zvez - } \\
\text { kavzalna paradigma. Potrjevanje hi- } \\
\text { potez, ki vodi k trditvam o dejstvih, } \\
\text { splošno veljavnih resnicah. }\end{array}$ & $\begin{array}{l}\text { Kritika, restitucija, emancipacija, re- } \\
\text { konstrukcija. Razumevanje razisko- } \\
\text { vanih pojavov - interpretativna pa- } \\
\text { radigma. Strukturni, zgodovinski } \\
\text { vpogled, posameznikova konstruk- } \\
\text { cija. }\end{array}$ \\
\hline $\begin{array}{l}\text { Metodološki } \\
\text { okvir }\end{array}$ & $\begin{array}{l}\text { Uporaba empirično-analitičnih po- } \\
\text { stopkov, uporaba določenih meto- } \\
\text { doloških instrumentov. }\end{array}$ & $\begin{array}{l}\text { Fenomenološki pristop: hermenev- } \\
\text { tična analiza, intuicija kot vir spozna- } \\
\text { nja. }\end{array}$ \\
\hline $\begin{array}{l}\text { Kriteriji } \\
\text { kakovosti }\end{array}$ & $\begin{array}{l}\text { Rigorozni: notranja in zunanja ve- } \\
\text { ljavnost, zanesljivost in objektivnost. }\end{array}$ & $\begin{array}{l}\text { Verodostojnostni kriterij nepristra- } \\
\text { nosti, ontološka verodostojnost, iz- } \\
\text { obraževalna verodostojnost, kata- } \\
\text { lična verodostojnost (vodi k akciji) in } \\
\text { taktična verodostojnost (omogoča } \\
\text { akcijo), pojavlja se tudi vprašanje o } \\
\text { ustreznosti kriterijev kvalitete. }\end{array}$ \\
\hline $\begin{array}{l}\text { Vloga } \\
\text { raziskovalcev }\end{array}$ & $\begin{array}{l}\text { „Nezainteresirani znanstvenik« kot } \\
\text { informator politike in tistih, ki imajo } \\
\text { moč odločanja. }\end{array}$ & $\begin{array}{l}\text { Odnos zaupanja med raziskovalcem } \\
\text { in raziskovancem, avtentičnost, raz- } \\
\text { iskovalec tudi kot udeleženec razis- } \\
\text { kave (npr. opazovanje z udeležbo.) }\end{array}$ \\
\hline $\begin{array}{l}\text { Učenje za } \\
\text { raziskovanje }\end{array}$ & $\begin{array}{l}\text { Tehnično, kvantitativno, kvalitativno, } \\
\text { vsebinske teorije. }\end{array}$ & $\begin{array}{l}\text { Resocializacija, kvantitativna in kva- } \\
\text { litativna, vrednote altruizma in opol- } \\
\text { nomočenja. }\end{array}$ \\
\hline
\end{tabular}

Opombe Povzeto po Lincoln in Guba $(2000,166)$, Mažgon $(2008,37)$ in Mužić $(1994,14)$.

zgodnjega otroštva povečuje število raziskav, ki so kvalitativne narave, torej temeljijo na interpretativni paradigmi, ki poudarja »naravno okolje«, se pravi raziskovanje v avtentični situaciji. Kot poudarja J. Dunn (2005), je namreč potrebno pri raziskovanju zgodnjega otroštva:

- upoštevati zakonitosti odraščanja in razvoja otrok;

- izvesti raziskavo v situaciji, ki ima za otroka čustven pomen;

- opazovati otroke v vsakdanjih situacijah njihovega vsakdanjega življenja.

\section{Raziskave v okviru zgodnjega učenja in poučevanja}

V nadaljevanju predstavljamo naslednje raziskave, za katere menimo, da bi preko njih lahko uresničevali raziskovalne cilje na področju zgodnjega učenja in poučevanja: pregledna raziskava, etnografska raziskava, študija primera, akcijska raziskava, pristop kritičnega dogodka, mozaični pristop. 


\section{Pregledna raziskava}

Pregledne raziskave so zelo pogost način raziskovanja zgodnjega otroštva. Poznamo t.i. longitudinalne raziskave, ki potekajo dalj časa, ter t.i prečne raziskave, za katere je značilno, da so časovno omejene. Longitudinalne raziskave spremljajo večjo skupino otrok skozi daljše časovno obdobje, npr. od rojstva naprej, in preučujejo vplive različnih okoliščin (npr. razlike v razvoju določenih lastnosti otrok glede na socialno-ekonomski status družin, $v$ katerih odraščajo). Ena takih raziskav je, denimo, raziskava The Millennium Cohort Study, ki je bila izvedena v Združenem kraljestvu in je vključevala 18.800 novorojenčkov, ki so bili rojeni leta 2000 , in je trajala do leta 2007. Rezultati so $v$ splošnem pokazali na velik pomen vpliva okolja in družin otrok na razvoj značilnosti otrok. $V$ prečnih raziskavah pa se podatke od udeležencev zbere le enkrat. Pregledne raziskave praviloma vključujejo veliko število vključenih (ali vzorec) in so usmerjene v posploševanje, ne omogočajo pa natančnega in celostnega vpogleda $v$ zgodnje otroštvo in $v$ obstoječe vzgojno-izobraževalne prakse, pa tudi niso usmerjene $v$ pridobivanje perspektive otrok o obravnavani tematiki (Mukherji in Albon 2010).

\section{Etnografska raziskava}

Za etnografsko raziskavo, ki jo uvrščamo med kvalitativne raziskave, je značilno, da si raziskovalec želi čimbolj »zliti se« s skupino, postati njen član, o tem voditi natančen dnevnik in izvajati opazovanje z udeležbo. Gre za raziskovanje vsakdanjega življenja neke ciljne skupine v njenem okolju (Mukherji in Albon 2010; Štemberger 2017). Pri raziskovanju zgodnjega otroštva je etnografska raziskava pogosto uporabljena za preučevanje otroštva $v$ različnih sociokulturnih kontekstih (James 2007). Take vrste raziskav trajajo dlje časa in so zato tudi uporabne za ugotavljanje in razumevanje otrokovega razvoja skozi čas, smiselne so za identifikacijo ključnih točk v otrokovem razvoju in v okolju (Buchbinder idr. 2006) kot tudi vsakdanjem življenju ter pri delu otrok v organizirani vzgoji in izobraževanju (kot npr. urnik obrokov, počitek, razvoj prijateljstev, dinamike $v$ oddelku). $V$ prid etnografske raziskave $v$ zgodnjem otroštvu govori dejstvo, da poteka v otrokovem okolju (Aubrey idr. 2000), v katerem se otroci počutijo varneje kot v laboratorijskem. Hkrati raziskovalcu omogoča, da raziskuje prakso na mikro in na makro nivoju, saj je dogajanje $v$ raziskovalnem polju - vrtcu - kompleksen preplet ciljev vladajoče politike, sociokulturnih prepričanj o vzgoji otrok znotraj družin in institucij kot tudi prepričanj vzgojiteljev o vzgoji v predšolskem obdobju. Raziskovalcu torej daje številne možnosti raziskovanja različnih vidikov otroštva (Aubrey idr. 2000). Vendarle pa je na tem mestu potrebno izpostaviti, da se etnografske 
raziskave, navkljub mnogim obetajočim prednostim in možnostim, na področju vzgoje in izobraževanje pojavljajo zelo redko (Buchbinder idr. 2006). Med glavne ovire sodita predvsem problematika vstopa v polje pa tudi dejstvo, da je z vidika raziskovalcev etnografsko raziskovanje precej zahtevno in časovno zamudno (npr. eno šolsko leto), poleg tega je potrebna stalna prisotnost raziskovalca (Štemberger 2017).

\section{Študija primera}

Prve študije primera v raziskavah zgodnjega otroštvu so bile v obliki biografij otrok in so služile predvsem terapevtskim namenom (Greig in Taylor 1999). Danes študija primera velja za raziskavo, ki je lahko primerna za raziskovanje zgodnjega otroštva - lahko se osredotoča na posameznega otroka, skupino otrok, oddelek otrok ali na celotni vrtec. Na njeni osnovi pridobimo informacije, ki nam omogočajo poglobljeno razumevanje otrok ali konteksta, ki ga preučujemo. Študije primera lahko vključujejo enega posameznika (eno skupino, eno institucijo ipd.) - v tem primeru gre za t. i. singularne študije primera -, lahko pa je vključenih več posameznikov (skupin, institucij ipd), pri čemer gre za t. i. pluralne študije primera (Mukherji in Albon 2010).

Cilj teh raziskav je lahko opisovanje ali razlaganje. Študije primera so lahko longitudinalne, torej trajajo dlje časa, ali pa prečne, se torej opravijo v nekem trenutku (Coolican 2004). P. Mukherji in D. Albon (2010) opredeljujeta tudi intrinzično, instrumentalno in že prej omenjeno pluralno študijo primera. Za intrinzično velja, da se usmerja v poglobljeno razumevanje posameznega primera - tako se lahko študija primera nanaša na enega otroka, ki ga natančno opazujemo ter se o njem pogovarjamo s starši in pomembnimi drugimi v njegovem življenju; ne gre le za opis otroka in njegovega razvoja, vse je tudi reflektirano in analizirano. $V$ instrumentalni študiji primera je primer instrument oz. orodje, ki raziskovalcu pomaga, da razume nek širši pojav.

Študija primera se ne usmerja v dokazovanje nečesa, pač pa v spoznavanje pojavov, odkrivanje novosti in novih spoznanj, prav zato je primerna za raziskovanje polj, ki še niso dobro poznana, saj na nek način odpira vrata nadaljnjemu raziskovanju.

\section{Akcijska raziskava}

Akcijska raziskava je usmerjena $v$ spreminjanje in izboljševanje vzgojnoizobraževalne prakse, izvajajo jo praktiki, občasno tudi v tesnem sodelovanju z raziskovalci (Robson 2006). Predpostavlja tudi sodelovanje različnih deležnikov. V institucijah, ki izvajajo zgodnje učenje, delujejo in sodelujejo različni strokovnjaki, ki tvorijo neko socialno skupino in za uvajanje spre- 
memb oz. izboljšav, k čemur stremi akcijska raziskava, je podpora te skupine oz. t. i. raziskovalnega tima (raziskovalci, praktiki) zelo pomembna. Vsak član tima ima natančno določene naloge, ki jih mora v okviru akcijske raziskave opraviti, med člani tima se običajno vzpostavi partnerski odnos. Raziskovalci posredujejo praktično-teoretska spoznanja, praktiki pa to povežejo s svojimi izkušnjami. Skupaj tako oblikujejo pomemben proces učenja (Sagadin 1989). Za akcijsko raziskavo je značilen tudi iterativni ciklični proces, ki vključuje opredelitev problema, analizo stanja, identifikacijo različnih rešitev, načrtovanje akcije, identifikacijo možnih ovir, izvajanje akcije in spremljanje, evalvacijo ter refleksijo (Kemmis in McTaggart 2005). Proces ima lahko več ponovitev, saj iz vsakokratne evalvacije in refleksije črpa nove izzive za raziskovanje ter izboljševanje prakse. Akcijsko raziskovanje se tesno povezuje tudi z vzgojiteljevim profesionalnim razvojem, saj vzgojitelj preko raziskovanja lastne prakse krepi svoje kompetence. Glede na to, je da je to raziskovanje »iz prakse za prakso«, ga vzgojitelji tudi lažje sprejmejo, kar dejansko omogoča raziskovalni pristop k uvajanju izboljšav oz. sprememb.

\section{Pristop kritičnega dogodka}

Pristop kritičnega dogodka je dobro poznan način raziskovanja različnih področjih kot npr. na področju psihologije, medicine, nekoliko manj pa na področju vzgoje in izobraževanja (Rous 2015). Flanagan (1954, po Rous 2015) definira pristop kritičnega dogodka kot fleksibilno raziskavo, ki poudarja zbiranje informacij o posebnem dogodku, aktivnosti ali vedenju, ki ga identificiramo kot kritični dogodek in ga lahko uporabimo za naslavljanje praktičnih problemov na nekem področju. Na načelni ravni sodi v okvir kvalitativne paradigme, lahko pa vključuje tudi nekatere značilnosti kvantitativne metodologije. Kritični dogodek je raziskovalni pristop, za katerega se zdi, da je $v$ luči možnosti, ki jih ponuja - premalo uporabljen na področju zgodnjega učenja in poučevanja. B. S. Rous (2015) izpostavlja tri prednosti takega raziskovanja: (i) sodelujočim omogoča, da upoštevajoč cilje raziskovalca sami izberejo dogodek, za katerega menijo, da je pomemben; (ii) uporaben je tudi za raziskovanje pojavov, o katerih le malo vemo in jih slabše razumemo; (iii) omogoča generiranje novih konstruktov, konceptov in teorij. Na ta način se pristop kritičnega dogodka usmerja v identifikacijo (ne)učinkovitih praks, povezanih z vsakdanjimi izzivi vzgojno-izobraževalne prakse, in lahko predstavlja pomembno izhodišče tako za izboljševanje vzgojno-izobraževalne prakse kot tudi nadaljnje raziskovanje odkritih področij oz. pojavov.

$\checkmark$ preglednici 2 povzemamo osnovne možnosti, ki jih na področju raziskovanja zgodnjega učenja in poučevanja omogočajo posamezne raziskave. 
Preglednica 2 Osnovne možnosti raziskovanja zgodnjega učenja in poučevanja glede na vrsto raziskave

\begin{tabular}{ll}
\hline Raziskava & Priložnosti v raziskovanju zgodnjega otroštva \\
\hline Pregledna raziskava & $\begin{array}{l}\text { Na osnovi večjega števila vključenih lahko dobimo širši pogled na } \\
\text { obravnavano tematiko. }\end{array}$ \\
\hline Etnografska raziskava & $\begin{array}{l}\text { Raziskovanje otrokovega razvoja v kontekstu in avtentičnem oko- } \\
\text { lju, kar omogoča spoznavanje otroka z različnih perspektiv. }\end{array}$ \\
\hline Študija primera & $\begin{array}{l}\text { Osredotoča se na en primer in tako omogoča poglobljeno razu- } \\
\text { mevanje primera in konteksta. }\end{array}$ \\
\hline Akcijska raziskava & $\begin{array}{l}\text { Izhaja iz prakse, iz zaznave praktikov, da je potrebno nekaj spre- } \\
\text { meniti; pomembno pripomore pri profesionalnem razvoju vzgoji- } \\
\text { teljev. }\end{array}$ \\
\hline $\begin{array}{l}\text { Pristop kritičnega } \\
\text { dogodka }\end{array}$ & $\begin{array}{l}\text { Identifikacija neučinkovitih vzgojno-izobraževalnih praks (in po- } \\
\text { sledično možnost iskanja rešitev). }\end{array}$ \\
\hline
\end{tabular}

\section{Tehnike zbiranja podatkov}

Podatke lahko zbiramo na različne načine oz. z različnimi tehnikami; izbor tehnike je odvisen od ciljev raziskave pa tudi od potencialnih vključencev $v$ raziskavo. Pri raziskovanju zgodnjega učenja in poučevanja pa moramo biti še posebej pozorni tudi na to, da moramo, $v$ kolikor so $v$ raziskavo vključeni tudi otroci, tehnike zbiranja podatkov prilagoditi njihovim zmožnostim in značilnostim. Uporabljajo se tako tradicionalne tehnike (npr. opazovanje, intervju) kot tudi tehnike, ki se razvijajo $v$ zadnjem obdobju in se usmerjajo $v$ aktivno vlogo otrok $v$ raziskovanju (npr. fotografija, pripovedovanje zgodb ipd.).

\section{Opazovanje}

V vzgojno-izobraževalni praksi je opazovanje dobro uveljavljeno kot orodje, s katerim vzgojitelj opazuje bodisi posameznega otroka bodisi celo skupino in na osnovi tega načrtuje svoje delo. Pri raziskovanju zgodnjega otroštva se opazovanje uporablja kot tehniko neposrednega zbiranja podatkov (Mukherji in Albon 2010). Otroke so prvotno opazovali izolirano, nato pa so opazovanje prenesli v običajno vsakdanje življenje otrok. M. Fawcett (1996) opazovanje otroka $v$ njegovem avtentičnem okolju poimenuje ekološki pristop k opazovanju, ki upošteva tudi vlogo lokacije, prisotnosti drugih ljudi, pričakovanj in pravil v kontekstu, kjer otrok živi. S. Rolfe (2001, v Mukherji in Albon 2010) pa izpostavlja, da je pri zelo malih otrocih in dojenčkih to edini način zbiranja informacij.

Poznamo več oblik opazovanja (Vogrinc 2008), pri čemer na tem mestu 
izpostavljamo le najosnovnejše izmed njih: opazovanje z udeležbo, opazovanje brez udeležbe, strukturirano opazovanje, nestrukturirano opazovanje ipd.

Opazovanje z udeležbo pomeni, da se opazovalec vključi v skupino in v njej prevzame eno izmed vlog, ki jo imajo drug člani skupine (Mesec 1998). Kot izpostavlja Vogrinc (2008), gre za tehniko zbiranja podatkov, pri kateri se socialni procesi preučujejo $v$ naravnih razmerah. Raziskovalec se za dlje časa vključi v skupino, opazuje vedenje članov te skupine, z njimi sodeluje in se skuša vživeti v njih.

Opazovanje brez udeležbe pa, nasprotno, označuje opazovanje, pri katerem opazovalec aktivno ne sodeluje s skupino, njegova vloga je natančno določena in se razlikuje od vlog drugih članov skupine.

Za nestrukturirano opazovanje je značilno, da raziskovalec opazuje na osnovi splošnejših smernic, nima vnaprej določenih kategorij (Vogrinc 2008), zapise pripravi v obliki anekdotskih zapisov (Mesec 1998); pri tem si zapisuje, kar vidi oz. sliši. Glavna prednost te vrste opazovanja je, da se nanjo ni potrebno zelo natančno pripraviti ( $v$ primerjavi s strukturiranim opazovanjem), se pa lahko med opazovanjem zaradi tega pojavi kaka dilema, prav tako se $\mathrm{v}$ primeru pestrega dogajanja lahko kaj izpusti. Ob koncu ima raziskovalec veliko zapisov, ki potrebujejo natančno analizo, rezultate različnih opazovanj pa je težko primerjati (Mukherji in Albon 2010). Na drugi strani pa strukturirano opazovanje temelji na vnaprej določenem načinu in predmetu opazovanja, torej na tem, kaj in kako se bo opazovalo (Vogrinc 2008; Cohen, Manion in Morrison 2007). Pri opazovanju se uporabljajo različni instrumenti oz. protokoli opazovanja, kot so npr. časovni vzorci, sledenje dogodkom, kontrolna lista. Pri časovnih vzorcih raziskovalec opazuje otroka ali skupino otrok v določenih rednih intervalih. Ob tem natančno opredeli, koga in kaj bo opazoval, kaj bo beležil, kako pogosto bo beležil in trajanje vsakega opazovanja. $V$ ta namen si pripravi nek opazovalni formular, tabelo. Sledenje dogodkom sledi podobnim zakonitostim, s tem, da se osredotoča na določene dogodke, v času, ko se ti dejansko dogodijo.

\section{Intervju}

Intervju je ena od najpogosteje uporabljenih tehnik zbiranja podatkov, ki se uporablja tako $v$ kvantitativnem kot $v$ kvalitativnem raziskovanju (Vogrinc 2008). Načeloma gre za pogovor med dvema osebama, pri čemer ena oseba sprašuje, druga pa odgovarja (Sagadin 1995). Raziskovalec preko intervjuja ugotavlja, kaj udeleženci raziskave menijo o neki temi, spoznava njihova čustva, misli, namere itd. Zaradi nekaterih prednosti pred drugimi tehnikami je 
intervju zelo pogosto uporabljena tehnika v raziskovanju vzgoje in izobraževanja, med drugim je zelo primeren tudi za raziskovanje populacije mlajših otrok, ki ne znajo (dobro) brati in pisati (Vogrinc 2008). Poznamo več vrst raziskovalnih intervjujev, in sicer: (i) neposredni intervju, kjer pogovor poteka z osebo, o kateri zbiramo podatke; (ii) posredni intervju, pri katerem podatke o osebi, ki nas zanima, zbiramo s pomočjo drugih ljudi, ki to osebo poznajo; (iii) individualni intervju, kjer spraševalec intervjuva eno samo osebo; (iv) skupinski intervju, pri katerem se spraševalec pogovarja s skupino ljudi (Mužić 1986). Intervjuji so nadalje lahko (v) strukturirani, pri katerih se raziskovalec usmerja v zbiranje podatkov, ki se lahko preoblikujejo v številske podatke, vprašanja pa so natančno določena; (vi) polstrukturirani, za katere so značilna vnaprej pripravljena vprašanja, ki se lahko dopolnjujejo in niso usmerjeni v zbiranje številskih podatkov, ter (vii) nestrukturirani, ki so odprti in zelo podobni vsakdanjemu pogovoru - raziskovalec vodi pogovor na osnovi nekih izhodišč in ne vprašanj (Mukherji in Albon 2010). Avtorja navajata, da je za intervjuje z otroki najprimernejši nestrukturiran intervju ali pa intervju v fokusnih skupinah, zato ti dve obliki podrobneje predstavljamo. Nestrukturirani intervju se prične kot pogovor z vprašanji, ki vzniknejo med pogovorom, pri čemer lahko pobudo prevzame tudi spraševanec. Prav zaradi slednje značilnosti naj bi bil ta intervju primeren za intervjuvanje mlajših otrok, saj slednjim omogoča, da lahko soodločajo o tempu in intervju usmerjajo v različne teme, ki se jim zdijo pomembne. Pri fokusnem intervjuju se raziskovalec pogovarja z več udeleženci hkrati (Vogrinc 2008), običajno je v skupini od 6 do 12 udeležencev. Raziskovalec navadno zavzame vlogo moderatorja, ki spodbudi razpravo in skrbi, da imajo vsi udeleženci možnost sodelovati, da ni dominantnega člana ter da se razprava ne oddalji od cilja. Z vidika uporabe fokusnega intervjuja z malimi otroki P. Lancaster in V. Broadbent (2003) navajata naslednje pozitivne vidike uporabe te tehnike:

- ko se otroci (udeleženci) med seboj poznajo, so fokusne skupine še posebej uspešne;

- spodbujana je interakcija med otroki;

- otroci lahko izpostavijo teme, o katerih bi radi govorili;

- otrokom je pripoznana vloga »strokovnjakov« njihovega področja;

- raziskovalec pridobi vpogled v skupne poglede otrok na vsakdanje življenje;

- skozi interakcijo se porodijo nove ideje;

- tak način »pogovora« je otrokom prijaznejši kot sistem vprašanje - odgovor; 
- otroci so običajno takšnih diskusij že vajeni iz dejavnosti branja oz. jutranjih krogov.

Poudarjata pa, da morajo raziskovalci, če želijo izpeljati fokusni intervju z otroki, znati delati s skupinami otrok, predvsem morajo biti pozorni na morebitne dominantne udeležence.

Pri raziskovanju z otroki se pogosto uporablja tudi narativni ali pripovedni intervju (Cameron 2015), katerega glavna značilnost je, da se skuša čim bolj približati vsakdanji komunikaciji med ljudmi. Spraševalec le usmerja spraševanca in mu pusti, da govori in izraža svoje misli ter ga pri tem ne omejuje (Vogrinc 2008). H. L. Cameron (2015) meni, da je izvajanje takih intervjujev z otroki zelo prijetna in koristna aktivnost. Otroci namreč lahko raziskovalcem omogočijo pomembne vpoglede v svoj vsakdanjik in izkušnje. Avtorica pri tem poudarja, da mora raziskovalec pri intervjuju otrok še toliko bolj upoštevati njihove značilnosti kot pri intervjuvanju odraslih, zlasti starost, udobje in varnost. Pozoren je, da otrok ohranja svoj tempo pogovora, v katerem lahko izrazi svoja stališča, videnje, tudi če se ta vedno ne navezujejo na cilj raziskave.

\section{Kontrolne liste}

Kontrolne liste (tudi »ček liste«) so zelo pogost način zbiranja podatkov za obdobje zgodnjega otroštva. Uporablja se jih lahko za spremljanje (in spodbujanje) otrokovega napredka, hkrati pa se vzgojitelje na ta način spodbuja $\mathrm{k}$ raziskovalnemu pristopu pri načrtovanju dejavnosti (Mukherji in Albon 2010; Dunst, Trivette in Rabb 2015). Kontrolne liste lahko uporabljajo za zbiranje različnih podatkov, kot so npr. podatki o vsakdanjem življenju in delu v predšolskih institucijah, napredku otrok, dejavnostih, uresničevanju ciljev, interesu otrok, sodelovanju s starši.

\section{Vprašalniki}

Vprašalnik razumemo kot instrument zbiranja podatkov, ki lahko vključuje različne tehnike zbiranja podatkov, kot npr. lestvice stališč, ocenjevalne lestvice, anketna vprašanja ipd. (Cencič 2009). V splošnem se pri raziskovanju vzgoje in izobraževanja zelo veliko uporabljajo različni vprašalniki, kar je, ko gre za anketiranje strokovnih delavcev sprejemljivo, kakor hitro pa začnemo razmišljati o raziskovanju z otroki, se glede vprašalnikov porajajo mnoge dileme oz. omejitve. E. De Leeuw meni (2011, v Bratož 2018), da otroci pred sedmim letom kognitivno še niso sposobni sistematično izpolnjevati vprašalnikov. Pri sedmih letih pa se pri otrocih zgodijo pomembni premiki v kognitivnem in socialnem razvoju, zato jih raziskovalci lahko že neposredno anke- 
tirajo, pri tem pa vprašalnike ustrezno prilagodijo (npr. grafični, slikovni odgovori ipd.). Raziskovalci z vprašalniki pri otrocih zbirajo predvsem tiste podatke, za katere so najzanesljivejši respondenti, tj. njihova stališča, občutja ipd. Poleg navedenih tradicionalnih tehnik zbiranja podatkov se $v$ raziskovanju z otroki v zadnjih desetletjih oblikujejo tudi druge, na otroka osredotočene tehnike zbiranja podatkov, ki se usmerjajo $v$ aktivno vključevanje otrok $\checkmark$ raziskovanje.

V tem kontekstu se pojavlja koncept »ustvarjalnega poslušanja otrok«, ki se povezuje s konceptom stotih jezikov otrok - razumevanjem, da otroci »govorijo«/se izražajo o svojih izkušnjah, dojemanjih, skrbeh preko glasbe, govora, oblikovanja, risanja in podobnih nebesednih sredstev (Robertson-Holmes 2005). Razumevanje in upoštevanje otrokovega "glasu « v raziskovanju izpostavlja Malewski (2005), ki spomni, da je pri raziskovanju z otroki potrebna previdnost oz. da je potrebno razviti metodologijo, ki bo otroke opolnomočila za sodelovanje $v$ raziskavi ter na ta način ponudila ustrezno alternativo že uveljavljenim metodološkim postopkom, ki običajno niso prilagojeni vključevanju otrok. Gre torej za razmišljanje, da je potrebno razviti raziskovalne tehnike, ki bodo omogočile izražanje otrok na njim prilagojen način in ne »le« preko verbalnega odgovora na vprašanje. Slednje nikakor ne pomeni, da je potrebno opuščanje tradicionalnih tehnik, saj, kot opozarjata P. Mukherji in D. Albon (2010), tudi pri raziskovanju otrok ne gre zanemariti vloge intervjujev in pomembne vloge opazovanja, zlasti pri raziskovanju, ki vključuje zelo majhne otroke oz. dojenčke.

Pomembno je, da raziskovalci ne podcenjujejo ali precenjujejo otrok, pač pa razvijajo pristope oz. tehnike, ki lahko sledijo otrokovim interesom ter ravni znanja in razumevanja. Tako Malewski (2005) navaja primer dveletnika, od katerega ne moremo pričakovati odgovorov na vprašanja na ravni odraslega človeka, od malčka tudi ne moremo pričakovati, da bo v času intervjuja dlje časa mirno sedel na mestu. Ob tem spet izpostavljamo etični vidik, torej da otroka pri raziskovanju ne smemo spraviti v položaj, ki mu povzroča tesnobo. Poleg tega je potrebno izbrati tehnike, ki ustrezajo otrokom v specifični raziskavi. $V$ nadaljevanju predstavljamo nekaj tehnik zbiranja podatkov, ki jih lahko - poleg tradicionalnih, vendar prilagojenih otrokom - tudi uporabimo pri raziskovanju zgodnjega otroštva.

\section{Fotografija}

Fotografija se pogosto uporablja pri raziskovanju otrok. T. Cook in E. Hess (2007) izpostavljata nekaj pomembnih prednosti rabe fotografije pri raziskovanju otrok, glavna od njih je aktivna vključenost otrok: 
- uporaba fotoaparata je aktivnost, ki otroke zelo pritegne;

- otroci lahko z (moderno) opremo ustvarijo zelo dobre fotografije;

- otroci so običajno zelo vešči uporabe fotoaparatov in imajo na ta način nadzor nad svojim početjem, zato obstaja velika verjetnost, da bodo fotografije odsevale otrokove dejavnosti, interese, skrbi ipd.

- raziskovanje preko fotografij predstavlja za otroka mnogo oprijemljivejšo izkušnjo, pogosto se preko fotografije tudi lažje izrazi (Clark 2011);

- uporaba digitalnih fotoaparatov omogoča, da je fotografija vidna (in tudi natisnjena) takoj, kar povečuje otrokovo motivacijo (Clark 2011).

Fotografija hkrati raziskovalcu tudi omogoča, da jo uporabi kot vizualno oporo otroku tudi kasneje v raziskovalnem procesu (Clark 2011) oz. jo uporabi kot motivacijsko sredstvo ob pričetku intervjuja oz. diskusije (Winter 2015). Potrebno pa je upoštevati tudi etični vidik, in sicer soglasje vključenih za fotografiranje ter lastništvo fotografij. Smiselno je, da raziskovalec poskrbi, da tudi otrok dobi fotografije, ki jih je posnel.

$S$ hitrim razvojem tehnologije, predvsem $z$ uporabo pametnih telefonov, je fotografiranje postalo zelo preprosto, bistveno pa se je povečala tudi možnost za izdelovanje videoposnetkov, ki jih tudi lahko uporabimo $v$ raziskovalne namene. Podobno kot pri fotografiji (Prosser in Burke 2007) lahko otrokom damo nalogo, da posnamejo nek dogodek, osebo ali situacijo in tako pridobimo njihovo perspektivo glede tega.

\section{Risbe}

A. Veale (2005, v Mukherji in Albon 2010) meni, da se otroške risbe že vrsto let uporabljajo kot orodje za ocenjevanje kognitivnega in emocionalnega funkcioniranja otrok. Pri tem pa nekateri (npr. Cox 1998) opozarjajo, da je to ocenjevanje podrejeno pričakovanjem zahodnih kultur in da ocenjevanje realističnih momentov postavlja na stranski tir simbolizem risbe, predvsem pomen, ki ga risbi pripisuje njen avtor. Risbe pa so vendarle lahko pomembno raziskovalno orodje za obdobje zgodnjega otroštva. Za otroke risba predstavlja pomembno sredstvo komuniciranja pomenov tem, ki imajo za njih pomen, razumevanja tem, njihove perspektive (Einarsdottir, Dockett in Perry 2009). Je pa pri risbah potrebna velika previdnost glede interpretacije, zato je ključno, da se raziskovalci z otroki o njihovih risbah pogovorijo, brez pogovora gre namreč le za golo (subjektivno) raziskovalčevo razlago narisanega. $\checkmark$ pogovoru z otrokom lahko raziskovalec namreč ugotovi, kako je potekal proces risanja, kaj je bil otrokov namen vključevanja elementov v risbo, in na ta način razume ter interpretira proces risanja. Risanje pomeni konstruktiven 
proces razmišljanja $v$ akciji in ne toliko razvijanje sposobnosti vizualne prezentacije svetu (Cox 2005). Pri risbah je potrebno upoštevati tudi kontekst, v katerem so nastale. Kot ugotavlja K. Winter (2015), raziskovalci k risanju pristopajo na dva načina: načrtovano (otroci rišejo glede na navodila raziskovalca) in spontano (otroci rišejo brez navodil raziskovalca). Med načrtovanimi nalogami so tako risanje sebe, nekoga drugega, vključenega v nek dogodek, dogodka samega, nekega mesta (npr. moj najljubši park), čustva ... Raziskovalci nato spodbudijo $k$ pripovedovanju o narisanem in na ta način dobijo vpogled $v$ otrokovo perspektivo in izkušnje.

Poleg tega, splošnejšega, pristopa $\mathrm{k}$ uporabi risbe se $\mathrm{v}$ raziskovanju uporabljajo tudi specifičnejši načini risanja, kot je, denimo, kartiranje (risanje zemljevida socialnega in fizičnega okolja). A. Clark (2011) je uporabila kartiranje s skupinami mlajših otrok, ki so skupaj (tudi s sodelovanjem raziskovalca) ustvarili zemljevid igralnice, pri čemer je bila začetna točka te naloge fotografiranje igralnice. Uporabljajo se lahko tudi različni diagrami (časovne premice, Vennov diagram, dnevna rutina, ipd.), ki jih otroci ustvarijo skupaj z raziskovalci (Winter 2015). K. Anderson in S. Baladin (2011) omenjata tudi t. i. zgodbe v obliki ilustracij (angl. storybooks), ko, denimo, otroci v knjižici predstavijo neke situacije, dogodke ipd.

\section{Pripovedovanje zgodb}

V raziskovanju otrok je pripovedovanje zgodb (angl. storytelling) dokaj uveljavljena tehnika zbiranja podatkov (Marjanovič Umek, Fekonja in Kranjc 2004). Na področju zgodnjega učenja in poučevanja se pripovedovanje zgodb pogosto povezuje z lutkami, ki spodbudijo otroka, da govori o svojih čustvih, lahko pa otroci pripovedujejo tudi svoje zgodbe. V okviru uporabe lutk se velikokrat omenja koncept t. i. Persona Dolls (osebnostne lutke) - gre za lutke, ki imajo vsaka svojo zgodbo. Na ta način se otroka spodbudi, da preko lutk spregovori o svojih čustvih (Mukhjeri in Albon 2010). Lahko pa se uporablja tudi druge lutke; pomembno je, da ima otrok na razpolago različne lutke in jih lahko po lastni izbiri vključi v svoje pripovedovanje. Izbrane lutke predstavi raziskovalcu in pripoveduje zgodbo. Pripovedovanje se lahko spodbudi tudi z vizualnimi izhodišči (slika, posnetek) (Cameron 2015).

\section{Igra dopolnjevanja zgodb}

Igra dopolnjevanja zgodb zapolnjuje vrzel v raziskovanju socio-emocionalnega razvoja otrok. Pri raziskovanju tega segmenta se raziskovalci največkrat opirajo na poročila in opazovanja odraslih ter veliko manj na poglede in izkušnje otrok (Yuval-Adler in Oppenheim 2015). Pri igri dopolnjevanja zgodb 
otroci nadaljujejo zgodbo, ki jo na različne načine prične odrasli, $z$ uporabo nekih izhodišč (zelo pogosta je prav lutka). Preko izhodišča se otroka sooči s čustveno evokativnim pričetkom zgodbe, ki jo nato otrok nadaljuje, razvije in ponudi rešitev. Preko pripovedovanja in iskanja rešitev tako raziskovalec odkrije odnose, čustva otrok. Hkrati pa zaključevanje zgodbe od otroka zahteva, da čustva organizira $v$ koherentno zgodbo, da jih regulira in gradi na prezentaciji notranjega sveta, svojih edinstvenih izkušenj pa tudi kulturnega ter etničnega ozadja. Raziskovalec mora znati zelo dobro usmerjati otroke oz. jim pomagati pri razvijanju pripovedovanja in se čim bolj oddaljiti od sistema vprašanj in odgovorov. A. Greig in Y. Taylor (1999) dopolnjevanje zgodb omenjata predvsem kot način ocenjevanja kakovosti navezanosti predšolskega otroka na starše.

Fotografija, risba, pripovedovanje zgodb ter igra dopolnjevanja zgodb sodijo med t.i. ustvarjalne tehnike, torej takšne, pri katerih od otrok pričakujemo, da ustvarijo fotografijo, risbo ali zgodbo. Na ta način otrokom omogočajo na eni strani sodelovanje na način, ki se bolj prilega njihovemu svetu (v primerjavi z običajnim procesom intervjuja) ter njihovemu načinu izražanja (koncept stotih jezikov), obenem pa jim omogoča, da so $v$ raziskovanje tudi aktivno vključeni, torej niso »le« predmet raziskave, pač pa slednjo tudi soustvarjajo.

\section{Zaključek}

V prispevku smo se usmerili v nekaj vidikov raziskovanja področja zgodnjega učenja in poučevanja, pri čemer smo se dotaknili vprašanja etičnosti pri raziskovanju tega občutljivega obdobja, predstavili smo možnosti različnih pristopov $\mathrm{k}$ raziskovanju, različnih vrst raziskav ter različnih, tako tradicionalnih kot nekaterih novejših, tehnik zbiranja podatkov. Na osnovi zapisanega ugotavljamo predvsem dvoje:

- Pri raziskovanju zgodnjega učenja in poučevanja je potrebno zaradi ranljivosti otrok in zaradi skrbi za njihovo dobrobit dosledno upoštevati etična načela pri raziskovanju; paziti je potrebno, da raziskava ne bi na kakršenkoli način škodila otroku. Starše otrok, ki jih povabimo v raziskavo, je potrebno natančno in jasno seznaniti s cilji in z načinom vključevanja otrok ter njihovo vlogo v raziskavi. Pri tem naj starši, če je le mogoče (glede na starost), upoštevajo voljo otrok, raziskovalec pa naj bo ves čas pozoren na morebitne znake, ki nakazujejo, da otrok ne želi (več) sodelovati v raziskavi.

- V raziskovanju zgodnjega učenja in poučevanja poznamo različne pri- 
stope, vrste raziskav ter tehnike zbiranja podatkov. Smiselno je, da se raziskovalec o izboru odloča na podlagi vsakokratnih ciljev raziskave in pri tem upošteva tudi zmožnosti ter sposobnosti udeležencev in razmisli, na kakšen način lahko le-ti sodelujejo $v$ raziskavi. Možno je tudi kombinirati: tako lahko, denimo, v raziskavi uporabimo elemente kvantitativnega in kvalitativnega raziskovanja ali študijo primera, ki vsebuje elemente akcijskega raziskovanja. Podobno velja tudi za tehnike zbiranja podatkov - možne, celo zaželene so različne kombinacije tehnik oz. t. i. multimodalnost, ki daje možnost celostnega pogleda in multiple perspektive.

\section{Literatura}

Anderson, K., in S. Balandin. 2011. "The Storybook Method: Research Feedback with Young Participants."Augmentative and Alternative Communication 27 (4): 279-291.

Aubrey, C., T. David, R. Goodfrey in L. Thompson. 2000. Early Childhood Research: Issues in Methodology and Ethics. London: Routledge.

Bratož, S. 2018. »Anketiranje tretješolcev s spletnim vprašalnikom. V Oblikovanje inovativnih učnih okolij, ur. T. Štemberger, S. Čotar Konrad, S. Rutar in A. Žakelj, 237-251. Koper: Založba Univerze na Primorskem.

Buchbinder, M., J. Longhofer, T. Barrett, P. Lawson in J. Floersch. 2006. »Ethnographic Approaches to Child Care Research: A Review of the Literature.« Journal of Early Childhood Research 4 (1): 45-63.

Cameron, H. L. 2015. »Ethical, Narrative, and Projective Processes in Research Interviews with Young Children. "V Handbook of Research Methods in Early Childhood:Research Methodologies, ur. O. N. Sarcho, 277-323. Charlotte, NC: Information Age Publishing.

Cencič, M. 2009. Kako poteka empirično pedagoško raziskovanje. Ljubljana: Zavod Republike Slovenije za šolstvo.

Clark, A. 2011. »Multimodal Map Making with Young Children: Exploring Ethnographic and Participatory Methods." Qualitative Research 11 (3): 311-330.

Cohen, L., L. Manion in K. Morrison. 2007. Research Methods in Education. London: Routledge.

Cook, T, in E. Hess. 2007. »What the Camera Sees and from Whose Perspectivein Enlightening Adults ." Childhood 14 (1): 29-45.

Coolican, H. 2004. Research Methods and Statistics in Psychology. London: Hodder Arnold.

Cox, M. 1998. »Drawings of People by Australian Aboriginal Children: The Intermixing of Cultural Styles." Journal of Art and Design Education 17 (1): 71-79.

Cox, S. 2005. »Intention and Meaning in Young Children's Drawing.«International Journal of Art and Design Education 24 (2): 115-125. 
Creswell, W. J. 2008. Educational Research: Planning, Conducting, and Evaluating Quantitative and Qualitative Research. Upper Saddle River, NJ: Pearson Education.

- 2014. Research Design: Qualitative, Quantitative and Mixed Methods Approach. Thousand Oaks, CA: Sage.

De Leeuw, E. 2011. »Improving Data Quality When Surveying Children and Adolescents: Cognitive and Social Development and Its Role in Questionnaire Construction and Pretesting." Predstavljeno na Annual Meeting of the Academy of Finland, Naatali, 10.-12. maj.

Dunst, C. J., C. M. Trivette in M. Rabb. 2015. »Utility of Implementation and Intervention Performance Checklists for Conducting Research in Early Childhood Eudcation. "V Handbook of Research Methods in Early Childhood: Research Methodologies, ur. O. N. Sarcho, 247-277. Charlotte, NC: Information Age Publishing.

Dunn, J. 2005. »Naturalistic Observations of Children and Their Families. « V Researching Children Experience: Approaches and Methods, ur. S. Greene in D. Hogan, 87-101, London: Sage.

Einarsdottir, J., S. Dockett in B. Perr. 2009. »Making Meaning: Children's Perspectives Expressed through Drawings."Early Childhood Development and Care 179 (2): 217-232.

Fawcett, M. 1996. Learning Through Child Observation. London: Jessica Kingsley.

Flanagan, J. C. 1954. »The Critical Incident Technique.« Psychological Bulletin 51 (4): 327-358.

Greig, A., in J. Taylor. 1999. Doing Research with Children. London: Sage.

James, A. 2007. „Giving Voice to Children's Voices: Practices and Problems, Pitfalls and Potentials." American Anthropologist 109 (2): 261-272.

Kemmis, S., in R. McTaggart. 2005. »Participatory Action Research: Communicative Action and Public Sphere.«V The Sage Handook of Qualitative Research, ur. N. k. Denzin in Y. S. Lincoln, 559-603: London: Sage.

Kodelja, Z. 2017. »Etičnost edukacijskega raziskovanja.«Šolsko polje 27 (1-2): 73 87.

»Konvencija o otrokovih pravicah.« 1989. Uradni list Socialistične Federativne Republike Jugoslavije, št. 15.

Lancaster, P., in V. Broadbent. 2003. Listening to Young People. Maidenhead: Open University Press.

Langston, A., L. Abbott, V. Lewis in M. Kellett. 2004. »Early Childhood."V Doing Research with Children and Young People, ur. S. Fraser, V. Lewos, S. Ding, M. Kellett in C. Robinson, 147-160. London: Sage.

Lincoln, S. Y., in G. E. Guba. 2000. »Paradigmatic Controversies, Contradictions, and Emerging Confluences.« V Handbook of Qualitative Research, ur. K. N. Denzin in Y. Norman, 163-189. Thousand Oaks, CA: Sage.

Malewski, E. 2005. »Epilogue: When Children and Youth Talk Back.«V Power and 
Voice in Research with Children, ur. D. S. Soto in B. B Swadener, 215-222. New York: Peter Lang.

Marentič Požarnik, B. 1990. »Za pluralizem modelov spoznavanja, raziskovanja in delovanja v pedagoških znanostih.«Sodobna pedagogika 39 (1-2): 1-14.

Marjanovič Umek, L., U. Fekonja in S. Krajnc. 2004. »Pripovedovanje zgodbe kot pristop za ugotavljanje otrokovega govornega razvoja.«Psihološka obzorja 13 (1): 43-64.

Mažgon, J. 2006. »Od monometod h kombiniranim raziskovalnim pristopom.« Sodobna pedagogika 57 (5): 98-108.

_. 2008. Razvoj akcijskega raziskovanja na temeljnih predpostavkah kvalitativne metodologije. Ljubljana: Filozofska fakulteta.

Mesec, B. 1998. Uvod v kvalitativno raziskovanje $v$ socialnem delu. Ljubljana: Visoka šola za socialno delo.

Mukherji, P., in D. Albon. 2010. Research Methods in Early Childhood. Los Angeles: Sage.

Mužić, V. 1994. »Sinteza paradigem pedagoškega raziskovanja - zakaj? kako?« Sodobna pedagogika 43 (3-4): 162-173.

Prosser, J., in C. Burke. 2007. »Childlike Perspectives through Image-Based Educational Research."V Handbook of the Arts in Qualitative Research: Perspectives, Methodologies, Examples and Issues, ur. J. G. Knowles in A. Cole, 407421. Oxford: Oxford University Press.

Rayna, S., in F. Laevers. 2011. »Understanding Children from o to 3 Years of Age and its Implications for Education: What's New on the Babies' Side Origins and Evolutions." European Early Childhood Education Research Journal 19 (2): 161-172.

Robertson-Holmes, G. 2005. Doing Your Early Research Project: A Step-by-Step Guide. London: Sage.

Robson, C. 2006. Developing Thinking and Understanding in Young Children: An Introduction for Students. London: Taylor and Francis.

Rolfe, S. 2001. »Direct Observation.«V Doing Early Childhood Research: International Perspectives on Theory and Practice, ur. G. MacNaughton, S. Rolfe in I. Siraj-Blatchford, 309-325. Buckingham: Open University Press.

Rous, B. S. 2015. »Using the Critical Incident Technique in Early Childhood Research."V Handbook of Research Methods in Early Childhood: Research Methodologies, ur. O. N. Sarcho, 225-247. Charlotte, NC: Information Age Publishing.

Sagadin, J. 1989. »Akcijsko in tradicionalno empirično pedagoško raziskovanje.«Sodobna pedagogika 39 (5-6): 242-256.

—_. 1995. »Nestandadizirani intervju. Sodobna pedagogika 46 (7-8): 311322.

Rutar, S. 2014. »Ali imajo otroci resnično priložnost za samoizražanje v vzgoji in izobraževanju?« V Communication, ur. P.-M. Rabensteiner in G. Rabenstei- 
ner, 170-186. Internationalization in Teacher Education 4. Baltmannsweiler: Schneider Verlag Hohengehren.

Štemberger, T. 2017. »Etnografska raziskava na pedagoškem področju.« Revija za elementarno izobraževanje 10 (1): 73-83.

Veale, A. 2005. „Creative Methodologies in Participatory Research with Children."V Researching Children's Experiences: Approaches and Methods, ur. S. Greeene in D. Hogah, 253-273. London: Sage.

Vogrinc, J. 2008. Kvalitativno raziskovanje na pedagoškem področju. Ljubljana: Pedagoška fakulteta.

Winter, K. 2015. »Innovative Qualitative Research Methods With Children Aged 4-7 Years."V Handbook of Research Methods in Early Childhood: Research Methodologies, ur. O. N. Sarcho, 479-523. Charlotte, NC: Information Age Publishing.

Yuval-Adler, S., in D. Oppenheim. 2015. "Story Completion Play Narrative Methods for Preschool Children."V Handbook of Research Methods in Early Childhood: Research Methodologies, ur. O. N. Sarcho, 323-383. Charlotte, NC: Information Age Publishing.

\section{Some Aspects of Research in Early Childhood Education}

The field of educational research is very wide and diverse. In this context, some subfields in the educational research have been developed, focusing on particular areas within education. One of this specific fields is the research of phenomena in early childhood, which has, under the influence of Anglo-Saxon tradition made a shift from the traditional positivist approach towards more constructivist approach In the paper we emphasise the particularities of the research in early childhood research, and address ethics in research, approaches in research and the data collection methods when doing the research within the early childhood education

Keywords: educational research, early childhood, ethics, research methods 



\title{
Akciono istraživanje i predškolska vaspitna praksa
}

\author{
Jelena Stamatović \\ Univerzitet u Kragujevcu \\ jelena.stamatovic22@gmail.com
}

\author{
Lidija Zlatić \\ Univerzitet u Kragujevcu \\ Izlatic@ptt.rs
}

U radu se razmatraju mogućnosti primene akcionih istraživanja u predškolskom vaspitanju. Naglašava se razvojni karakter ove vrste istraživanja i funkcija unapređivanja vaspitne prakse. Potreba savremenog vrtića je usmerena na planiranje razvoja u skladu sa potrebama, a akciono istraživanje menja praksu i razvija je. Za realizaciju akcionog istraživanja neophodno je da vaspitači, praktičari poseduju kompetencije koje pretpostavlaju spremnost za drugačije promišljanje problema u vaspitnoj praksi, kao i refleksivni pristup vaspitnom procesu u praksi.

Ključne reči: akciona istraživanja, predškolska ustanova, refleksivna praksa, vaspitači

\section{Uvod}

Savremena gledišta akciona istraživanja uglavnom aktualizuju kao put unapređivanja vaspitne prakse. Mnogi pristupi njegovog određenju ovog ukazuju na to da pored menjanja prakse, menja se i uloga onoga ko realizuje istraživanje, praktičari su ti koji organizuju i sprovode istraživanje samostalno ili u timu (Galini i Efthymia 2010; Lee i Goh 2012; Maksimović 2012; Pešić 2004). Potreba savremene prakse u vaspitno-obrazovnim institucijama je usmerena na stalno menjanje i unapređivanje. Mnogi aktuelni problemi, svojstveni neposrednim situacijama u radu vaspitača mogu postati problemi i istraživačka pitanja koja praktičari rešavaju, istražuju, uvode novine i prate promene.

U predškolskim ustanovama koje teže promenama i kvalitetu za vaspitača nije dovoljno da bude samo korisnik rezultata istraživanja koje uglavnom realizuju profesionalni istraživači, već i oni sami moraju postati aktivni realizatori u procesu istraživanja u svom domenu rada. Svrha ovog rada je da se analizira mogućnost i adekvatnost primene akcionih istraživanaja u unapređivanju rada predškolskih ustanova i uloga vaspitača kao nosioca tih istraživanja i da se ponude novi izazovi za razmišljanje vaspitača praktičara. 


\section{Akciona istraživanja i vaspitna praksa}

Akciona istraživanja se najčešće povezuju sa menjanjem kvaliteta vaspitne prakse, pri čemu istraživači, praktičari, polaze od svojih specifičnih problema sa kojima se susreću u praksi (Maksimović i Banđur 2013; McNiff i Whitehead 2006). Ova istraživanja su usmerena i na razumevanja same prakse i procesa u njoj, ali istovremeno i doprinose unapređivanju i razvoju onih koji ga realizuje, jer u tom procesu tragaju za rešenjima postavljenih problema ili nerešenih situacija u praksi (Bognar 2009).

Lankshear i Knobel (2004) ističu da je cilj i svrha istraživača, praktičara usmerena u dva pravca: na poboljšanje osećaja praktičara o sopstvenoj profesionalnoj ulozi i identitetu i na to da istraživanja praktičara mogu doprineti boljoj i kvalitetnijoj praksi. Ono što se može apstrahovati iz različitih definicija akcionih istraživanja pokazuje da se ona zasnivaju na pristupu praksi kroz različite metode u radu i usmereni su na rad na promenama kroz različite oblike interakcije u grupi, timu, među generacijama ili samostalno. Akcionim istraživanjima se pokušavaju rešiti konkretni problemi sa kojima se praktičari suočavaju u svom radu sa decom, roditeljima, u lokalnoj zajednici, u vaspitnoj ustanovi. Time se menja njihova uloga u profesionalnom razvoju i razvoju kompetencija kao istraživača. Ishodi istraživanja vlastite prakse i pozitivne promene doprinose povećanju osećaja sopstvene vrednosti i samopouzdanja kod praktičara, vaspitača, takođe doprinose povećanju svesti vaspitača o realnim problemima u grupi, među decom i jačaju njihov pozitivan odnos prema refleksiji sopstvene prakse.

Savremeni trendovi u istraživanju praktičara, učitelja, nastavnika, vaspitača ukazuju da su ona često kvalitativna, da se bave istraživanjem vlastite prakse i time doprinose sopstvenom razvoju i pozitivnim promenama u vaspitnom procesu (Lankshear i Knobel 2004). Jasno je da akciona istraživanja imaju niz prednosti i da ona pružaju pomoć svima onima koji se bave vaspitnim procesima da sebe aktiviraju i doprinesu kvalitetu tih procesa, brizi za decu ali kroz istraživanje i procenjivanje sopstvene delatnosti u okviru tih procesa (McNiff i Whitehead 2006). Sam proces akcionih istraživanja se odlikuje višedimenzionalnim spiralnim pristupom koji ukazuje na spontanost u stvaralačkom i razvojnom procesu akcionih istraživanja (Bognar 2006; Maksimović 2010).

Mnogi autori koji su se bavili pitanjima realizacije akcionih istaživanja naglašavali su paricipativni karakter ove vrste istraživanja (Gojkov 2007; Park 1999; Petrović 2008). To podrazumeva da učesnici u socijalnoj situaciji koja se proučava nužno su i učesnici u svim fazama istraživanja. Ovakav pristup još odlikuje, pored participacije i angažovanost, demokratičnost i inkluziv- 
nost. Imajući u vidu kontekst predškolske ustanove u kome se može sprovoditi akciono istraživanje nameće se pitanje uloge deteta kao učesnika. U ovom slučaju akciona istraživanja se uglavnom sprovode u okruženju koja su bliska deci, koje deca poznaju (vrtić, vaspitna grupa i sl.). Takođe posmatranje i organizovanje aktivnosti u ovakvim okolnostima donekle zahtevaju od istraživača da posmatra pojave i fenomene uzimajući u obzir perspektivu dece. I iz takvih situacija odrasli uče, odnosno pokušavaju da razumeju situacije i određene pojave (Emond 2006). Često se otvara dilema koliko deca na ranom uzrastu mogu biti akteri participativnih akcionih istraživanja? Vranješević (2015) naglašava važnost i mogućnosti dece kao ko-istraživača gde se ističe da i deca na ranom uzrastu mogu da govore o svom iskustvu u vrtiću ili kod kuće ili da na neki način izraze svoje doživljaje (kroz crteže, priče, igru i sl.). Uloga praktičara, istraživača je da pažljivo sluša i posmatra decu i da kroz princip refleksivnosti pokuša da razume perspektivu deteta i da kroz razgovor zajedno sa decom dođu do zajedničkog tumačenja dečjeg iskustva (Vranješević 2015). To podrazumeva izmeštanje odraslog iz sveta uvreženih vrednosti i stavova koji mogu da utiču na sam tok istraživanja, na tumačenje rezultata, samu metodologiju dolaženja do odgovora. Takođe se smatra važnim u samom istraživanju uvažavanje kompetencija deteta koje treba da postanu važan deo metodologije u procesu istraživanja (Woodhead \& Faulkner 2008).

Posmatrajući akciona istraživanja u funkciji menjanja i unapređivanja vaspitne prakse potreba istraživača je usmerena na njeno razumevanje i nalaženje načina da se poboljša racionalnost i opravdanost aktivnosti i promena koje se uvode. Sagledavajući različta određenja ove vrste istraživanja u funkciji unapređivanja prakse može se istaći participatorska, saradnička i samorefleksivna priroda akcionog istraživanja. Ova istraživanja polaze od realnih fenomena u praksi koji su utemeljeni na životnom i praktičnom iskustvu, razvoj se temelji na zajednikom radu kroz parnerstvo, zajedno sa akterima vaspitnog procesa što doprinosi razvijanju novih načina posmatranja i interpretiranja realnosti kao i rezultata koji su pozitivni ishodi kao trag procesa istraživanja (Bredbury i Reason 2003).

\section{Unapređivanje predškolske ustanove kroz akciono istraživanje}

Specifičnost $u$ istraživanjima praktičara jest da se oni aktivno odnose prema saznanjima, prema primjeni postojećih i prema sticanju novih saznanja. U predškolskim ustanovama se mogu uspešno sprovoditi akciona istraživanja. Mnogi aktuelni problemi, svojstveni neposrednim situacijama u radu vaspitača mogu postati problemi i istraživačka pitanja koja praktičari rješavaju, is- 
tražuju, uvode novine i prate promene. Analizirajući literaturu koja na različite načine objašnjava i razmatra pristupe akcionim istraživanjima u praksi, malo je onih koji se konkretno bave njihovom primenom u predškolskim ustanovama. Uglavnom se praktična primena vezuje za školu i ulogu ovih istraživanja u njenom menjanju i razvoju (Harris 2002; Hopkins 2001; Kundačina i Banđur 2004; Stoll i Fink 2000). Međutim, potreba savremenog vrtića podrazumeva menjanje i razvoj ustanove polazeći od realnih potreba i okolnosti u kojima ta ustanova funkcioniše. Ostvarivanje unapređivanja uglavnom zavisi od potencijala u samoj ustanovi koji će stvarati pogodne uslove za promene. U takvim uslovima razvija se podsticajna atmosfera učenja, razvoja i vaspitanja dece i međusobna pomoć u tome.

Neka iskustva u svetu koja su proistekla iz realizacije projekata unapređivanja vaspitno-obrazovnih ustanova mogu se primeniti i u razvoju predškolskih. Kao ključne stavke izdvajaju se sledeće, koje smo prilagodili predškolskoj ustanovi a koje je istakao Haris, oslanjajući se na školu (Harris 2002): bitno za razvoj predškolske ustanove je stvaranje zajedničke vizije svih koji su uključeni u vaspitni proces; uvođenje promena na svim nivoima - od ustanove, preko vaspitne grupe do promena u profesionalnom razvoju vaspitača; podsticanje istraživanja vaspitača i njihov refleksivni pristup praksi koji kada postane svakodnevna profesionalna rutina doprinosi kvalitetu vaspitnih procesa koji se realizuju.

Akciona istraživanja se mogu koristiti kao deo nastojanja da predškolska ustanova i njeni akteri preuzmu aktivnu ulogu u ostvarivanju promena i razvoja. Teoretičari navode da akciona istraživanja uvek treba započeti pitanjem koje je usmereno na unapređivnje prakse, na razumevanje te prakse i na širu vaspitno-obrazovnu situaciju (McNiff i Whitehead 2002). Neka od tih pitanja mogu biti:

- Kako podsticati kreativnu komunikaciju među decom?

- Kako podsticati saradnju i solidarnost među decom?

- Kako ostvariti interakciju dece različitog uzrasta u ustanovi?

- Kako učiniti situacije za igru i učenje podsticajnim za istraživanje dece, rešavanje problema i slično?

- Kako poboljšati organizacione uslove u grupi?

- Kako funkcionalno primeniti digitalnu tehnologiju u radu sa decom?

- Kako unaprediti stručno usavršavanje vaspitača u okviru predškolske ustanove?

- Kako unaprediti saradnju vaspitača i roditelja i uključiti ih više u rad predškolske ustanove? 
Planiranje procesa koji će na kraju dovesti do kvalitativnih odgovora na postavljena istraživačka pitanja podrazumeva postavljanje akcionog plana koji bi trebao da ima određenu strukturu od pitanja: šta je predmet mog interesa, preko pitanja koja se odnose na motiv zainteresovanosti za konkretan problem, realnih mogućnosti za preduzimanje određenih aktivnosti i njihovo preciziranje vremenski i organizaciono, preko pitanja kako će se prikupiti dokazi koji će pokazati da se uticalo na situaciju i kako će se osigurati prihvatljivost $\mathrm{i}$ istinitost procena efekata i promena koje su se desile. Akciona istraživanja podrazumevaju krug planiranja, akcija, praćenja i posmatranja, kao i refleksije. Markovic (Markowitz 2011) navodi da je na početku istraživanja potrebno da svaki istraživač utvrdi svoj plan istraživanja i jasno definiše vrednosti od kojih polazi u vaspitnom delovanju. Prispitivanje vaspitne prakse vaspitačima pomaže da objasne svoja verovanja i stavove i time utvrđuju da li ih je potrebno poboljšati i unaprediti. Oni vaspitači koji vaspitne situacije promišljaju na nov način, koji identifikuju probleme u vaspitnoj sredini su refleksivni praktičari. $U$ takvim sitauacijama oni samokritički pristupaju situacijama, promišljaju svoje aktivnosti i delovanja, prikupljaju podatke o tome analiziraju ih i dolaze do nekih saznanja. Istraživanja vaspitača i saradnika u predškolskoj ustanovi podrazumevaju proučavanje vaspitnih fenomena, a to zahteva određen nivo profesionalnosti i spremnosti da unapređuju svoj rad.

Kako se akciona istraživanja najpre odnose na ličnu praksu i unapređenje, malo je objavljenih rezultata ovih istraživanja u stručnoj i naučnoj literaturi. Kao primere sprovedenih akcionih istraživanja u oblasti predškolskog vaspitanja prikazaćemo rezultate nakoliko istraživanja koji su objavljeni. Istraživanja su predmetno usmerena na decu i na vaspitače. Jedno od istraživanja sprovedeno je u Sigapuru u nekoliko prigradskih vrtića, gde je akcenat na uvođenju aktivnosti koje bi pomogle deci predškolskog uzrasta da se lakše adaptiraju na nove uslove u daljem vaspitanju i obrazovanju. Efekti aktivnosti su se reflektovale na pozitivne stavove predškolske dece prema školi i kasnije smanjenje stresa i anksioznosti u prvim danima škole (Lee i Goh 2012). Rezultati još jednog objavljenog istraživanja su usmerena na decu predškolskog uzrasta i govore o primeni video snimanja komunikacije trogodišnje dece u predškolskoj igri i mogućnost kroz analizu kombinovanja vizuelnog, auditivnog i pisanog materijala (dnevnici beleženja) dolaženja do saznanja o načinima unapređivanja i razvijanja komunikacije te dece (Flewitt 2006). Prikazana istraživanja govore da se unapređivanje prakse u konkretnim aktivnostima može ostvariti kroz akciona istraživanja i refleksiju vaspitača.

Takođe, predmet akcionih istraživanja može biti usmeren i na same vaspitače u funkciji njihovog profesionalnog razvoja. O tome govore rezultati sle- 
dećih istraživanja. Jedno je sprovedeno u vrtiću u severnoj Grčkoj. Izvršena je implementacija procesa interne evaluacije u vrtiću, a rezultati su pokazali da su uvedene aktivnosti pomogle vaspitačima da prevaziđu svoje predrasude o evaluaciji kao kontroli prakse i da iskoriste prednosti evaluacije za refleksiju u svom radu i time poboljšaju vaspitne procese (Galini i Efthymia 2010). Stojanović (2011) je sproveo istraživanje o značaju samorefleksivnosti vaspitača, a ipitivano je kako vaspitači procenjuju odnos samorefleksivnosti i metodičkih inovacija. Rezultati su pokazali da vaspitači kod kojih je razvijena svest i sposobnost samorefleksije u značajnoj meri primenjuju metodička rešenja koja apostrofira savremena predškolska pedagogija. Takođe je zaključeno da je samorefleksivnost vaspitača (promišljanje o metodičkim rešenjima koja se primenjuju, sagledavanje rezultata, svest o svojim stavovima, sistemu vrednosti, pedagoškom stilu, kritičko procenjivanje stila komunikacije s decom, njihovim roditeljima i kolegama itd.) značajno povezana sa metodičkim rešenjima u vrtiću koja se smatraju savremenim (Stojanović 2011). Istraživački rad vapitača i njihova uloga kao refleksivnih praktičara u vaspitnom procesu zahteva različite preduslove i okolnosti, od bazičnog obrazovanja i razvijanja istraživačkih i refleksivnih kompetencija, do uslova u samoj ustanovi u kojima vaspitači rade (organizacija rada, sredstva, kolegijalna i profesionalna podrška i sl.). Jedan od uslova je njihova kompetentnost za unapređivanje prakse, njeno istraživanje i kritičko-refleksivni pristup.

\section{Kompetencije vaspitača za istraživanje prakse}

Potreba savremene predškolske prakse nameću vaspitačima ulogu samostalnog istraživača, a ne samo učesnika $u$ istraživanjima vaspitne prakse. Kompetentnost vaspitača je rezultat kontinuiranog učenja u toku bazičnog obrazovanja, a naročito u toku profesionalnog rada u praksi. Kompetentnost podrazumeva znanja, umenja, stavove i vrednosti profesionalca koja se stalno menjaju, nadograđuju, unapređuju. Definisan okvir kompetencija vaspitača je često nastaje kao potreba funkcionisanja sistema vaspitanja i obrazovanja i u funkciji je obezbeđivanja kvaliteta predškolskog vaspitanja. Metodološka kompetentnost vaspitača za primenu akcionog istraživanja pretpostavlja potrebu drugačijeg promišljanja osnovnih pedagoških fenomena kao i inovativni i permanentni refleksivni pristup vaspitnom procesu u praksi i promenama. Kompetentnost vaspitača se može razvijati kroz istraživanje sopstvene prakse, profesionalno umrežavanje, razvojne projekte, sardničke aktivnosti u praksi svog delovanja (Pavlović Breneselović i Krnjaja 2012). Polazeći od definisanih kompetencija vaspitača Pravilnikom o standardima kompetencija za profesiju vaspitač u Republici Srbiji, prepoznajemo definisana znanja i umenja koja su neophodna za realizaciju akcionih istraživanja. Precizirano je da 
vaspitač treba da razvija projekte zasnovane na učenju kroz istraživanje, razmenu i saradnju sa decom; da razvija pedagoška znanja preispitivanjem reorije i prakse kroz praćenje i slušanje dece i konsultovanje sa njima; da sarađuje sa kolegama u razmeni iskustava, zajedničkom učenju i istraživanju; da preuzima inicijativu i vodi aktivnosti tima i proces razvoja dečjeg vrtića; da kritički sagledava i razvija svoju praksu kroz vlastita istraživanja i samorefleksiju (Pravilnik o standardima kompetencija za profesiju vaspitač i njegovog profesionalnog razvoja 2018).

Navedina umenja od vaspitača traže da on mora biti praktičar i teoretičar prakse koji je orijentisan na permanentno obrazovanje. On mora biti aktivni pojedinac koji je spreman da preispituje vlastito mišljenje, da istražuje mogućnosti i različite načine delovanja kako bi pronašao odgovor na praktične probleme (Maksimović i Banđur 2013). Otežavajuće okolnosti za realizaciju ovih kompetencija ugalvnom se pronalaze u nedovoljnoj stručno-metodološkoj osposobljenosti vaspitača ili nastavnika (Kundačina i Banđur 2004; Maksimović 2012; Stamatović 2015). Ono što nedostaje u metodološkom obrazovanju vaspitača u okviru fakulteta jeste segment praktične obuke za samostalna istraživanja, jer se teorija i praktični pristup istraživanju ne povezuje. Zaključak koji navodi Stojanović (2011) u svom istraživanju odnosi se na preporuku da u okviru obrazovanja vaspitača se mora težiti formiranju refleksivnih praktičara čija će refleksija biti dobro teorijski zasnovana i kojima će evaluacija i samoevaluacija biti sastavni deo svakodnevne prakse. Dalje usavršavanje vaspitača u toku profesionalnog rada takođe ne nudi vezu istraživanja i prakse u dovoljnoj meri kroz različite oblike i načine usavršavanja. Vaspitna ustanova mora postati mesto učenja i usavršavanja i podsticajna sredina za razvoj profesionalnosti vaspitača gde vaspitači stalno uče kroz zajedničko učešće sa decom, kolegama i roditeljima i u tom procesu definišu probleme vlastite prakse težeći da je unapređuje, traže odgovore na pitanja i preispitivanja sebe šta znači biti dobar vaspitač.

Često je u vrtićima realizacija akcionih istraživanja ili refleksivni pristup praksi stvar entuzijazma pojedinaca, koji se najčešće suočavaju sa problemima realizacije ili nemaju dovoljnu podršku od strane svojih kolega ili rukovodstva ustanove. Popularizaciju ove vrste istraživanja mogu doprineti pozitivni rezultati koji dovode do promena i pokazuju neku vrednost koja je važna ne samo za pojedinca već i za ostale učesnike.

\section{Zaključak}

Doprinos akcionog istraživanja u predškolskom vaspitanju može se posmatrati u pravcu razvoja predškolskih ustanova i vaspitne prakse i u pravcu profesionalnog razvoja vaspitača. $U$ kontekstu razvoja predškolske ustanove 
značaj se vidi u mogućnostima donošenja odluka na nivou ustanove gde je odgovornost za planiranje razvoja i unapređivanja na samoj ustanovi i zaposlenima u njoj. Postavljanje akcionog istraživanja u fokus razvoja prakse podrazumeva biranje problema istraživanja u skladu sa potrebama ustanove, vaspitne grupe ili pojedinca. $U$ toku istraživanja prikupljaju se podaci da bi se otkrio problem, traga se za rešenjima, preduzimaju se akcije i prati se uspešnost dolaska do rešenja problema. Istraživački cikluse se mogu ponavljati dak se ne nađe zadovoljavajuće rešenje. $U$ tom procesu mogu se javiti i neka nova istraživačka pitanja koja usmeravaju istraživanja u drugom pravcu.

Jasno je da akciona istraživanja jesu korisna i vaspitačima. Kao način usavršavanja i dolaženja do novih saznanja otvaraju vidike, menjaju njihov sistem vrednosti i uverenja, doprinose razvoju lične vrednosti i samopoštovanja. Kroz rezultate istraživanja dolazi se do usklađivnja teorijskih znanja i prakse, mnogo se bolje razumeju teorijska znanja kao polazišta istraživačke prakse. Akciona istraživanja razvijaju i podstiču sposobnosti refleksije i šire perspektive sagledavanja problemskih fenomena u praksi.

\section{Bibliografija}

Bredbury, H., i P. Reason. 2003. »Action Research: An Oportunity for Revitalision Research Purpose and Practices." Qualitative Social Work 2 (2): 155-175.

Bognar, B. 2006. »Akcijska istraživanja u školi.» Odgojne znanosti 8 (1): 209-228. - 2009. „Ostvarivanje suštinskih promjena u odgojnoj praksi posredstvom akcijskih istraživanja." Odgojne znanosti 11 (2): 147-163.

Emond, R. 2006. »Ethnographic Research Methods with Children and Young People." U Researching Children's Experience: Approaches and Methods, ur. S. Greene i D. Hogan, 123-140. London: Sage.

Flewitt, R. 2006. »Using Video to Investigate Preschool Classroom Interaction: Education Research Assumptions and Methodological Practices.« Visual Comunication 5 (1): 25-50.

Galini, R., i P. Efthymia. 2010. »A Collaborative Action Research Project in the Kindergarten: Perspectives and Challenges for Teacher Development through Internal Evaluation Processes."New Horizons in Education 58 (2): 18-33.

Gojkov, G. 2007. Kvalitativna istraživačka paradigma u pedagogiji. Vršac: Visoka škola strukovnih studija za obrazovanje vaspitača.

Harris, A. 2002. School Improvement: What's in it for Schools? London: Routledge. Hopkins, D. 2011. School Improvement for Real. London: RoutiedgeFalmer.

Korthagen, F. A. J. 2011. »Making Techer Education Relevant for Practice: The Pedagogy of Realistic Teacher Education. «Orbis Scholae 5 (2): 31-50.

Kundačina, M., i V. Banđur. 2004. Akciona istraživanja u školi (nastavnici kao istraživači). Užice: Učiteljski fakultet u Užicu. 
Lankshear, C., i M. Knobel. 2004. A Handbook for Teacher Research: From Design to Implementation. Minton Keynes: Open University Press.

Lee, S., i G. Goh. 2012. "Action Research to Address the Transition from Kindergarten to Primary School: Children's Authentic Learning, Construction Play, and Pretend Play.« Early Childhood Research \& Practice 14 (1): 26-38.

Maksimović, J. 2010. »Elementi i postulate akcionih istraživanja u pedagogiji.» Radovi filozofskog fakulteta 12 (2): 189-198.

—. 2012. Akciona istraživanja u pedagoškoj teoriji i praksi. Niš: Filozofski fakultet.

Maksimović, J., i V Banđur. 2013. „Savremena akciona istraživanja i metodološkqa obrazovanost nastavnika refleksivnog praktičara.« Teme 37 (2): 595610.

Markowitz, A. 2011. »Akcijska istraživanja učitelja u nastavi: drugačiji pogled.» U Akcijsko istraživanje i profesionalni razvoj učitelja i nastavnika, ur. M. Mićanović, 11-27. Zagreb: AZOO.

McNiff, J., i J. Whitehead. 2006. Action Research: Living Theory. London: Sage.

Pavlović Breneselović, D., i Ž. Krnjaja. 2012. »Sistemski pristup profesionalnom usavršavanju vaspitača.« Andragoške studije 2:143-161.

Park, P. 1999. »People Knowledge and Change in Participatory Research.« Management Learning 30 (2): 141-157.

Petrović, D. 2008. »Akciono istraživanje: neka teorijska i praktična pitanja.«U Metateorijske osnove kvalitativnih istraživanja, ur. D. Stojnov, 237-275. Beograd: Zepter Bookworld.

Pešić, M. 2004. Pedagogija u akciji: metodološki priručnik. Beograd: Institut za pedagogiju i andragogiju Filozofskog fakulteta u Beogradu.

Pravilnik o standardima kompetencija za profesiju vaspitač i njegovog profesionalnog razvoja. 2018. Službeni glasnik Republike Srbije: Prosvetni glasnik, br. 16.

Stamatović, J. 2015. Kvalitet i samovrednovanje rada nastavnika. Beograd: Institut za pedagogiju i andragogiju Filozofskog fakulteta.

Stojanović, A. 2011. "Samorefleksivnost vaspitača kao determinanta metodičkih inovacija u predškolskom vaspitanju. «Inovacije u nastavi 24 (3): 114-121.

Stoll, L., i D. Fink. 2000. Mijenjajmo naše škole. Zagreb: Educa.

Vranješević, J. 2015. »Deca kao (ko)istraivači: participativna istraživanja i najbolji interes deteta.«Primenjena psihologija 8 (2): 187-202.

Woodhead, M., i D. Faulkner. 2008. "Subjects, Objects or Participants? Dilemas of Psychological Research with Children.« U Research with Children, ur. P. Christensen i A. James, 10-39. London: Routledge.

\section{Akcijsko raziskovanje in predšolska vzgoja}

Raziskovanje v izobraževanju je zelo široko in raznoliko področje. Zaradi tega so se razvila posamezna podpodročja raziskovanja v izobraževanju, ki se os- 
redotočajo samo na določena področja znotraj izobraževanja. Eno od podpodročij je raziskovanje zgodnjega otroštva, ki se je pod vplivom anglosaške tradicije raziskovanja premaknilo od tradicionalnega pozitivističnega $\mathrm{k}$ bolj konstruktivističnemu pristopu. $V$ članku izpostavljamo posebnosti raziskovanja zgodnjega otroštva in obravnavamo etiko ter pristope $\mathrm{k}$ raziskovanju in načine zbiranja podatkov pri raziskovanju zgodnjega otroštva.

Keywords: raziskovanje v izobraževanju, zgodnje otroštvo, etika, raziskovalne metode 


\title{
Nekateri vidiki udeležbe otrok v raziskavah
}

\author{
Martina Kovačič Kuzmić \\ Univerza na Primorskem \\ martina.kovacickuzmic@pef.upr.si
}

\author{
Jurka Lepičnik Vodopivec \\ Univerza na Primorskem \\ jurka.lepicnik@pef.upr.si
}

Prispevek se osredotoča na razlike med raziskovanjem z udeležbo otrok in odraslih, s poudarkom na pravnem vidiku. Uvedba nove evropske zakonodaje o varstvu osebnih podatkov je področje varstva zasebnosti in varstva osebnih podatkov postavila pred številne procesne in druge administrativne izzive, tudi na področju raziskovanja, še posebej občutljivi pa so ravno posegi v zasebnost najranljivejših skupin, med katere sodijo tudi otroci. Na podlagi analize sodobnih pristopov in pojmovanj otroka, pri čemer posebno pozornost namenjamo t. i. teoriji nove sociologije otroštva, ki otroka razume kot samostojni subjekt v družbi, ugotavljamo, da je raziskovanje z udeležbo otrok v mnogokaterih pogledih drugačno od raziskovanja, ki vključuje odrasle osebe. Pri tem izpostavljamo nekatera ključna izhodišča, ki narekujejo drugačen pristop k raziskovanju otrok, ter v razpravo vključujemo tudi pravni vidik varstva zasebnosti in varstva osebnih podatkov.

Ključne besede: pravica do zasebnosti, človekove pravice, varstvo osebnih podatkov, nova sociologija otroštva, soglasje

\section{Uvod}

Z razvojem družbe, industrije in ekonomije se je skozi zgodovino razvijalo tudi pojmovanje otroštva (Lawson, Jones in Moores $2004 \mathrm{v}$ Haumptman in Komotar 2010, 31). Tako je otrok v 18. oz. 19. stoletju že zelo zgodaj povsem sodil v svet odraslih in pomenil pomembno ekonomsko pridobitev za družino. $S$ prehodom v 20. stoletje se je položaj otrok začel korenito spreminjati. Njihov ekonomski prispevek je z omejitvami otroškega dela in uvedbo obveznega šolanja pričel kopneti, otrok pa je bil vse bolj prepoznan kot čustveno bitje, predvsem potrebno ljubezni in zaščite pred svetom odraslih. Otroški svet je bil tako povsem ločen od sveta odraslih (Haumptman in Komotar 2010, 32). Kot meni James (2007 v Boljka 2016, 49), je »otroštvo sčasoma prešlo v družbeno kategorijo in ni več razumljeno samo skozi razvojni kontekst, kot nekaj, kar bodo otroci šele postali«. Boljka $(2016,49)$ zaključuje, da so »otroci danes bitja z lastnim družbenim in kulturnim potencialom in vedno bolj profilirani kot družbena skupina«. 
Tudi sociologija je otrokom in otroštvu vse do nedavnega namenjala le malo pozornosti (Corsaro 2005, 27). Corsaro $(2005,27)$ to pripisuje dolgo prisotni miselnosti, da ima otrok $v$ družbi zgolj pasivno vlogo. To miselnost je konec 80 . in $v$ začetku 90 . let prejšnjega tisočletja nadomestila t. i. nova teorija otroštva. Kot povzemata A. Quennerstedt in Quennerstedt $(2014,118)$, je ta teorija, ki je znana tudi kot nova sociološka teorija otroštva, nastala kot odgovor na "prevladujoče poglede na otroka v razvojni psihologiji in tradicionalni sociološki teoriji«. Bistvo nove teorije otroštva je v opredelitvi otrok kot aktivnih socialnih bitij, ki ustvarjajo svojo lastno kulturo, hkrati pa prispevajo tudi k družbi odraslih (Corsaro 2005, 3). Tako ne presenečajo ugotovitve P. Alderson in V. Morrow $(2011,1)$, da se številne ustanove, ki se ukvarjajo z javnimi in drugimi storitvami, usmerjenimi v potrebe otrok, že rutinsko posvetujejo z njimi in upoštevajo njihova mnenja ter stališča in usmeritve pri pripravi načrtov ter evalvacij. Avtorici (2011) se pri tem naslanjata na Konvencijo o otrokovih pravicah (1989), ki v 12. členu otroku, ki je sposoben izoblikovati lastna mnenja, zagotavlja pravico do svobodnega izražanja le-teh $v$ vseh zadevah v zvezi z njim, o tehtnosti izraženih mnenj pa se presoja $v$ skladu z otrokovima starostjo in zrelostjo (Konvencija o otrokovih pravicah 1989, 12. člen). Ta načelna pravica, h kateri so se zavezale podpisnice dokumenta, skupaj $z$ drugimi pravicami otrok iz Konvencije o otrokovih pravicah, vse bolj pridobiva na veljavi tudi na področju raziskav, pri katerih pa se v ospredje postavlja vprašanja etike, ki so lahko ključna za sam proces raziskave, izbor metod ter nenazadnje tudi za interpretacijo rezultatov (Alderson in Morrow 2011, 1).

Sodobni trendi poimenovanja otrok so tako korenito spremenili tudi vlogo otrok $v$ raziskavah. $S$ tem so otroci prešli iz pasivnih $v$ aktivne subjekte raziskav, ki pa zaradi specifičnosti skupine, ki ji pripadajo, zahtevajo prilagojene pristope ter posebno varstvo pred posegi v svojo zasebnost.

\section{Metodologija}

Spremenjeni pogledi na otroka in otroštvo se kažejo tudi v postopku izvajanja raziskav. Pojavil se je trend premika iz raziskovanja »na« otrocih v raziskovanja »z« otroki (Corsaro 2005, 58). Številni raziskovalci tako na otroke ne gledajo več kot na objekte raziskovanja (oz. kot na vire, iz katerih pridobivajo podatke), ampak jih upoštevajo kot subjekte, ki sodelujejo v procesu raziskovanja (Darbyshire 2000 v Mortari in Mazzoni 2010, 3). Novi pogledi na otroke in otroštvo, ki so oblikovali tudi t. i. novo sociologijo otroštva, skupaj z vse večjim poudarkom na pravicah otrok, prav tako narekujejo nove pristope do raziskovanja $z$ udeležbo otrok, ki se nanašajo tudi na pravne vidike raziskovanja. 
Namen prispevka je tako ugotoviti, kakšne so razlike med raziskovanjem z otroki in tistim z odraslimi ter kako vplivajo na sam proces raziskovanja, pri čemer je izpostavljen pravni vidik. Zastavili smo si naslednji raziskovalni vprašanji:

1. Katera so temeljna izhodišča, zaradi katerih je raziskovanje z udeležbo otrok drugačno?

2. Kako se razlike v raziskovanju z otroci zrcalijo na polju varstva zasebnosti in privolitvi oz. soglasju k posegu vanj?

Prispevek temelji na deskriptivni metodi pedagoškega raziskovanja. S pomočjo le-te bomo opisovali, kakšno je stanje, ki ga preučujemo. Pri tem se bomo opirali na slovensko in tujo literaturo. Uporabili bomo komparativno metodo ter metodo analize in sinteze, s pomočjo katerih bomo primerjali in analizirali različne raziskave $z$ navedenega področja.

\section{Razprava}

\section{Posebnosti glede raziskovanja z udeležbo otrok}

Po Pavloviću $(1993,129)$ je »otrok človek, toda drugačen človek«. Kaj torej razumemo s pojmom »otrok«? V slovenski zakonodaji pojem otroka do sprejetja Družinskega zakonika (2017) ni bil izrecno opredeljen. To se je zgodilo šele s sprejetjem zakonika, ${ }^{1}$ saj lahko v šestem členu najdemo definicijo, ki pravi, da je otrok oseba, ki še ni dopolnila 18 let, razen če je že prej pridobila popolno poslovno sposobnost. Definicijo otroka tako prvič najdemo v uvodoma omenjeni Konvenciji o otrokovih pravicah (1989), ki določa, da se za otroka šteje vsaka oseba, mlajša od 18 let, razen če ji status otroka v skladu z nacionalno zakonodajo preneha pred 18. letom (Kraljić 2014, 134). S. Kraljić $(2014,134)$ povzema, da s pravnega vidika roditeljska pravica praviloma traja do otrokovega 18. leta, ko nastopi »ipso iure emancipacija otroka« (str. 135). V sociološkem smislu pa npr. M. Zidar $(2003,359)$ pravi, da v sodobnem družboslovju otroka dojemamo kot »neoblikovano, nedoraslo, nedolžno bitje [...] za katerega velja, da ga je potrebno vsaj de iure zaščititi«.

Kako lahko takšno pojmovanje in dojemanje otrok razumemo v kontekstu raziskovanja z njihovo udeležbo? S. Punch $(2002,321)$ trdi, da raziskovalčevo dojemanje umeščenosti otroka in otroštva (ang. childhood) v družbi vpliva na njegovo razumevanje teh pojavov. Avtorica (Punch 2002, 321) navaja, da ob-

${ }^{1}$ Družinski zakonik je bil sprejet 21. marca 2017, vendar se je večina njegovih določb začela uporabljati dve leti po njegovi uveljavitvi, to je 15. aprila 2019. 
stajata dva skrajna pola dojemanja raziskav z otroki - enako ali povsem drugače kot raziskave z odraslimi. Glede na posamezno percepcijo raziskovalca je odvisen tudi njegov izbor raziskovalnih metod. S. Punch (2002, 323-324) tako prepoznava tri temeljna izhodišča, zaradi katerih je raziskovanje z udeležbo otrok drugačno od raziskovanja, ki vključuje odrasle osebe. Eno takih izhodišč je, da so otroci, kot družbena skupina, marginalizirani v družbi, ki je osredotočena na odrasle. Otroci, navajeni, da v njihovem življenju vlada premoč odraslih, tudi ne pričakujejo, da bi jih odrasli obravnavali kot sebi enake. Kot drugo izhodišče navaja, da odrasli otroke dojemajo drugače. Strahovi, predpostavke in stališča odraslih vplivajo na njihovo vedenje do otrok. Lastne predpostavke raziskovalca o položaju otrok v družbi vplivajo na izbrane metode in interpretacijo zbranih podatkov. In nenazadnje J. Boyden in J. Ennew (1997 v Punch 2002, 324) ugotavljata, da so otroci preprosto drugačni od odraslih. Obstajajo nekatere ključne razlike, ki predstavljajo mejnik med otrokom in odraslo osebo. Med temi so npr. drugačna uporaba besedišča in razumevanje besed, relativno manj izkušenj s svetom in manjša sposobnost ohranjanja pozornosti.

Muha $(2011,36)$ ugotavlja, da je pojmovanje otroka v skladu z novo sociologijo otroštva prineslo številne metodološki izzive $v$ celotnem procesu raziskovanja z otroki, pri čemer je pravzaprav največji izziv izbor metode. Ta temelji na temi in kontekstu raziskave, raziskovalci pa pri tem upoštevajo tudi kompetenčno zrelost otrok. Punch $(2002,338)$ opozarja, da je pri izboru metod napačno izhajati izključno iz delitve na metode, ki so primernejše za raziskovanje z otroki in metode za raziskovanje z odraslimi, temveč je potrebno upoštevati tudi druge dejavnike, kot so okolje in kultura, $v$ kateri se raziskovanje odvija, ravno tako pa tudi kompetence raziskovalca.

Corsaro $(2005,58)$ izpostavlja trend, ki se je iz raziskovanja »na« otrocih prelevil v raziskovanje "z« otroki. Metode raziskovanja se sicer ne razlikujejo glede na to, ali gre za odrasle ali otroke, vendar mora raziskovalec izkazati veliko mero prilagodljivosti in inovativnosti pri prilagajanju različnih metod otrokovim fizičnim, sociološkim, čustvenim in kognitivnim sposobnostim.

\section{Varstvo zasebnosti pri raziskovanju z udeležbo otrok}

Evropski sistem za varstvo človekovih pravic velja za enega najučinkovitejših na svetu (Letnar Černič, 2014). Med te pravice sodi tudi varstvo zasebnosti, ki je kot človekova pravica praviloma priznana v vseh evropskih pravnih sistemih, kot tudi v širšem mednarodnem okolju (González Fuster 2015, 5).

Pomen zasebnosti je veliko več kot zgolj pravni pojem. Psihologi ga prepoznavajo $v$ dveh različnih sferah človekovega udejstvovanja, in sicer kot pov- 
zema González Fuster (2015) je prva sfera intimnosti, pri kateri čutimo potrebo po ohranjanju svoje zasebnosti na ravni telesa, čustev in občutij, tej sferi nasprotna pa je javna sfera, ki zajema človekovo delovanje in izražanje v javnosti, pri katerem pa prav tako nastopa potreba po ohranjanju določene mere zasebnosti. Obe sferi zasebnosti sta pomembni in potrebni za ohranjanje lastne vrednosti ter za zaščito posameznikove podobe $v$ družbi in odnosih na splošno (González Fuster 2015).

Novakova $(2004,248)$ navaja, da sodobna pravna teorija »opredeljuje zasebnost kot področje delovanja posameznika, $v$ katerega ne sme nihče posegati brez posebnega (zakonskega) pooblastila«. Avtorica povzema tudi mnenje teorije, da je pravica do zasebnega življenja omejena $z$ varstvom pravic in koristi drugih ter vedenjem posameznika v javnosti, pri čemer izpostavlja, da »interes posameznika po zasebnosti raste z osebnim duševnim razvojem, zato je različen od otroka do otroka celo pri isti starosti« (str. 249).

Eno izmed aktualnih področij, ki se vežejo na pravico do varstva zasebnosti je varstvo osebnih podatkov. Pirc Musarjeva, Prelesnik in Bien Karlovšek $(2006,13)$ povzemajo, da so bili v Evropi prvi zakoni o varstvu osebnih podatkov sprejeti v sedemdesetih letih prejšnjega stoletja. Kot pionirko na tem področju omenja Švedsko, ki je leta 1973 prva sprejela zakon s področja varstva osebnih podatkov. Švedskemu vzoru so v osemdesetih letih prejšnjega stoletja sledile Grčija, Madžarska, Francija in Finska. Nekaj let kasneje so nato tovrstno zakonodajo množično sprejele tudi druge evropske države, med katerimi naj omenimo Nemčijo, Avstrijo, Italijo, Norveško ...S prehodom v novo tisočletje je bila do tedaj veljavna zakonodaja nato usklajevana z evropsko direktivo s tega področja (Direktiva Evropskega Parlamenta in Sveta 95/46/ES 1995).

Področje varovanja osebnih podatkov je doživelo novo obdobje z uveljavitvijo t. i. GDPR (General Data Protection Regulation) Uredba (EU) 2016/679 (v nadaljevanju Splošna uredba o varstvu podatkov), je začela veljati 25. maja 2016, njene določbe pa se morajo neposredno uporabljati v vseh državah članicah v dveh letih po sprejetju. Na Splošno uredbo o varstvu podatkov je vezana tudi Direktiva (EU) 2016/680 (2016). Rok za implementacijo določb te direktive $v$ nacionalno zakonodajo je ravno tako znašal dve leti. Kot pojasnjuje Informacijski pooblaščenec Republike Slovenije, ${ }^{2}$ Splošna uredba o varstvu podatkov poudarja pomen posameznika, pri čemer namen varstva osebnih podatkov ni varovanje osebnih podatkov kot takih, temveč varovanje

\footnotetext{
${ }^{2}$ Samostojen in neodvisen državni organ, ustanovljen na podlagi Zakona o informacijskem pooblaščencu (2005).
} 
pravic posameznika, na katerega se ti podatki nanašajo (glej https://www.iprs.si/varstvo-osebnih-podatkov/pravice-posameznika). Ena izmed ključnih zahtev Splošne uredbe o varstvu podatkov je, da mora biti soglasje pri zbiranju osebnih podatkov na podlagi privolitve ${ }^{3}$ podano jasno in razumljivo, z nedvoumnim pritrdilnim dejanjem ter dokazljivo. Veljavna privolitev mora zadostiti štirim zahtevam, in sicer mora biti prostovoljna, specifična, informirana in nedvoumna (glej https://www.ip-rs.si).

Poudariti je potrebno, da je področje varstva osebnih podatkov različno urejeno za javni in zasebni sektor. Za obdelavo osebnih podatkov $v$ javnem sektorju (državni organi, organi lokalnih skupnosti in nosilci javnih pooblastil), kamor spada tudi javna mreža vrtcev (in šol) v državi, velja predvsem, da se ti lahko obdelujejo le, če je njihova obdelava določena z zakonom oz. če je z zakonom določeno, da se nekateri osebni podatki lahko obdelujejo le ob privolitvi posameznika ( $v$ primeru otrok - zakonitega zastopnika). Tako npr. izpostavljamo Zakon o vrtcih (2005), ki v 43. členu določa zbirke podatkov, ki jih vrtci lahko zbirajo, obdelujejo, shranjujejo, posredujejo in uporabljajo. Pomemben je tudi podzakonski predpis, naslovljen Pravilnik o zbiranju in varstvu osebnih podatkov na področju predšolske vzgoje (2004), ki v 16. členu ureja zbiranje osebnih podatkov, ki jih ne ureja zakon, ampak se zbirajo na podlagi osebne privolitve staršev. Pri tem je pomembno, da je jasen namen zbiranja in obdelave podatkov ter način shranjevanja, v skladu z zahtevami Splošne uredbe o varstvu podatkov. Potrebno je poudariti, da predpis ureja soglasje tako, da so vrtci tisti, ki te podatke shranjujejo, obdelujejo in vodijo. Gre torej za podatke, ki naj bi jih zbiral vrtec za svoje evidence in namene. $\mathrm{Ne}$ pokriva pa primerov, ko se $z$ otroci, vključenimi v vrtčevski program, izvaja npr. zunanja raziskava. Tak primer je pridobitev posebnega soglasja $s$ strani zakonitega zastopnika otroka, z vsemi potrebnimi elementi za podajo t. i. obveščenega oz. informiranega soglasja, ${ }^{4} v$ skladu z zahtevami Splošne uredbe o varstvu podatkov.

\footnotetext{
${ }^{3}$ Obdelava osebnih podatkov v skladu s prvim odstavkom 6. člena Splošne uredbe o varstvu podatkov se lahko izvaja, če: (1) posameznik, na katerega se nanašajo osebni podatki, je privolil $v$ obdelavo njegovih osebnih podatkov $v$ enega ali več določenih namenom, (2) obdelava je potrebna za izvajanje pogodbe, katere pogodbena stranka je posameznik, na katerega se nanašajo osebni podatki, ali za izvajanje ukrepov na zahtevo takega posameznika pred sklenitvijo pogodbe, (3) obdelava je potrebna za izpolnitev zakonske obveznosti organa, kot upravljavca, in (3) obdelava je potrebna za opravljanje naloge v javnem interesu ali pri izvajanju javne oblasti dodeljene organu kot upravljavcu.

${ }^{4}$ Ko posameznik razume vsebino privolitve (s čim soglaša) in tudi način, kako lahko privolitev oz. soglasje umakne (glej https://www.ip-rs.si/zakonodaja/reforma-evropskega-zakonodajnegaokvira-za-varstvo-osebnih-podatkov/kljucna-podrocja-uredbe/privolitev).
} 
S. Muha $(2011,23)$ navaja, da se vse pogosteje odpira tudi vidik otrokove privolitve k vključitvi v raziskavo. Kot tudi povzemata Mortari in Mazzoni (2010, 14), se po mnenju različnih avtorjev še nedolgo nazaj raziskovalci pravzaprav niso ukvarjali z vprašanjem pridobitve privolitve za sodelovanje $v$ raziskavi neposredno od otrok. V zvezi s tem je v raziskovalnih smernicah vse pogosteje mogoče zaslediti težnjo po pridobitvi tako soglasja (ang. consent) zakonitega zastopnika otroka, kot tudi privolitve otroka (ang. assent). Kot navajata Alderson in Morrow $(2011,102)$ izraz privolitev (ang. assent) se predvsem v anglosaških sistemih uporablja za privolitve s strani oseb, ki ne izpolnjujejo zakonskih pogojev (npr. starost) za podajo zakonitega soglasja. Ob tem se odpirajo vprašanja o tem, kdaj je otrok sposoben dati privolitev. Goršek $(2016,29)$ v zvezi s tem pojasnjuje, da otroci dosežejo privolitveno sposobnost prej kot poslovno sposobnost, in sicer pri petnajstih letih, kar sovpada s »t. i. standardom zrelega mladostnika«. Kot povzema Muha (2011, 23-24), podpisan obrazec pogosto ni zahtevan pri otrocih, mlajših od 10 let, predvsem zaradi še ne dovolj razvitih kompetenc. Tudi pri starejših otrocih, ki že znajo brati in se podpisati, je bistveno, da raziskovalec otroka ustrezno pouči o namenu in poteku raziskave ter s tem otroku tudi pojasni, k čemu pravzaprav podaja svoje soglasje oz. privolitev. Kot poudarjajo številni avtorji (glej Pyle in Danniels 2015, 3) je privolitev proces, ki je v vsakem trenutku podvržen možnosti, da se udeleženec premisli ali odloči, da privoli zgolj v nekatere dejavnosti.

L. Mortari in V. Mazzoni $(2010,15)$ ugotavljata, da je namen pridobitve privolitve otrok v tem, da se jim zagotovi pravica, da se lahko odločijo, če in na kakšen način je sodelovanje $v$ raziskavi v njihovem interesu. Kako lahko to omogočimo pri najmlajših otrocih? A. Clark in Moss (2011 v Pyle in Danniels $2015,2)$ ugotavljata, da raziskave z majhnimi otroki podpirajo miselnost, da so tudi najmlajši otroci že sposobni izražati mnenja o zadevah, ki vplivajo na njihova življenja. Tako številni avtorji (glej Payle in Danniels 2015, 2) ugotavljajo, da so že otroci pri treh letih sposobni izpostaviti, česa ne razumejo, in »zahtevati« več informacij, pri štiriletnikih se kaže sposobnost, da v primeru nestrinjanja z vrstniki vedo ponuditi alternativne predloge, šestletniki pa so sposobni tvoriti hipotetične izjave, kot npr. »kaj, če«. Temeljno vprašanje je tako otroška sposobnost razumevanja vsebine njihove privolitve. L. Mortari in V. Mazzoni $(2010,15)$ povzemata ugotovitve D. Harcourt in C. Conroy (2005), ki opisujeta metode, s katerimi sta pridobili t. i. obveščeno oz. informirano privolitev (assent) od skupine predšolskih otrok v Singapurju, tako da sta (Mortari in Mazzoni 2010, 15-16) svojo prošnjo za sodelovanje »dekonstruirali« v obliki, ki jo otroci lahko razumejo. Ta privolitev je bila pridobljena 
s pomočjo dialoga med njima in otroki. Kot nadalje povzemata (Mortari in Mazzoni 2010, 15-16), morajo izbrane oblike komunikacije otrokom omogočiti, da razumejo, kaj raziskovalec od njih zahteva. Tako sta raziskovalki (Harcourt in Conroy 2005) otrokom pokazali pripomočke, ki so uporabljeni v raziskavi - takšne pripomočke, povsem razumljive otrokom, kot so svinčnik, papir in snemalnik ipd. Obenem pa sta jim s pomočjo risb tudi ilustrirali, kaj bosta izvajali. L. Mortari in V. Mazzoni (2010) še izpostavljata način, na katerega so se lahko otroci hitro seznanili z »jezikom « raziskave in sami predlagali, kako bi želeli izraziti svojo privolitev. Podoben pristop navajata A. Pyle in E. Danniels $(2015,4)$, ki povzemata različne t. i. privolitvene protokole (ang. assent protocols) za otroke, ki so jih razvili različni raziskovalci. Avtorici (2015) sta po preučitvi protokolov ugotovili, da jih veliko temelji na pisnih obrazcih, sicer velikokrat na različne načine prilagojenih za otroke (besedišče, poenostavljanje oblike itd.), kar pa nasprotuje ugotovitvam različnih avtorjev (glej Payle in Danniels 2015, 5), da otroci besedilo bolje razumejo ob spremljavi slikovnega gradiva. Na podlagi tega sta razvili protokol za pridobitev privolitve otrok v vrtcu s pomočjo slikanice. Celoten protokol temelji na uporabi preprostega besedišča, ki zagotavlja primerno količino informacij o raziskavi in omogoča pridobitev (obveščene oz. informirane) ustne privolitve $v$ raziskavo s strani otrok. A. Pyle in E. Danniels $(2015,13-14)$ sta ta protokol za pridobitev obveščene oz. informirane privolitve otrok uporabili v dveh študijah. Rezultati so pokazali, da je bila slikanica sicer res uporabno, vendar ne samostojno orodje za pridobitev privolitve, ki ga je nujno potrebno kombinirati še z drugimi pristopi in interakcijo z udeleženci (odprtost razprave z udeleženci, možnost umika privolitve $v$ vsakem trenutku, odzivnost raziskovalca na vprašanja otrok ipd.).

\section{Sklep}

Kot smo v prispevku večkrat ugotavljali, otroci predstavljajo specifično družbeno skupino, ki jo označuje predvsem odvisnost od odraslih. Ker nimajo možnosti vplivanja na svoj položaj, so izjemno ranljivi in potrebujejo posebno skrb ter zaščito (Črnak Meglič in Kobal Tomc, 2016, 3). Boljka $(2016,51)$ povzema Keyjovo (1909), ki je pravilno napovedala, da bodo $v$ 20. stoletju otroci deležni zaščite in pozornosti, kot še nikoli poprej v zgodovini. Ta pozornost se je ob prehodu v 21. stoletje le še okrepila (Boljka 2016, 51).

Danes lahko trdimo, da so otroci $v$ širšem mednarodnem okolju prepoznani kot posebna kategorija ter osebnosti z vsemi pravicami človeka, ki potrebujejo posebno skrb in zaščito, kar je formalno prva zahtevala Konvencija o otrokovih pravicah, ki smo jo v tem prispevku večkrat omenili. Slove- 
nija je $v$ svojem pravnem redu uveljavila vse pomembne mednarodne dokumente, ki se navezujejo na zaščito in pravice otrok. V prispevku smo analizirali obstoječo domačo zakonodajo s področja varstva osebnih podatkov, ki pri raziskovanju predstavljajo enega izmed bolj izpostavljenih vidikov posega v zasebnost. Tako smo ugotovili, da so otroci še posebej ranljiva skupina, ki se sama pomena varstva zasebnosti še ne (more) zavedati, obenem pa se otroci tudi ne znajo ubraniti morebitnim nezavednim posegom vanjo. Zato je naloga staršev kot zakonitih skrbnikov in zastopnikov, da skupaj z državo kot zakonodajalcem poskrbi za ustrezno varstvo ter zaščito otrok pred nepooblaščenimi in škodljivimi vdori v sfero njihove zasebnosti. Posebno pozornost smo namenili pridobitvi soglasja oz. privolitve, pri čemur so otroci v drugačnem položaju od odraslih. Izpostavili smo težnjo, da raziskovalec tudi od otrok poskuša pridobiti obveščeno oz. informirano privolitev k sodelovanju v raziskavi, kar nekateri avtorji vidijo tudi kot odlično priložnost, da se z otroki ravna spoštljivo, obenem pa to lahko koristi otrokovemu razvoju in ga postavi v položaj samostojnega odločevalca (Ford $2007 \mathrm{v}$ Payle in Danniels 2015, 3).

V prispevku smo poskušali analizirati nekatere vidike raziskovanja z otroki, $s$ katerimi se raziskovalci srečujejo pri snovanju in izvajanju raziskav $z$ njihovo udeležbo, ki se razlikujejo od raziskav z odraslimi osebami. Pri razlikah smo se osredotočali na pravni vidik varstva zasebnosti in varstva osebnih podatkov kot na eno izmed področij, ki so predmet aktualnih razprav. Domet pričujočega prispevka prav gotovo ne (z)more prodreti $v$ globine, načenja pa razpravo o vse pomembnejši vlogi otroka kot aktivnega subjekta v raziskovanju in samostojnega nosilca pravic.

\section{Literatura}

Alderson, P., in V. Morrow. 2011. The Ethics of Social Research with Children and Young people. London: Sage.

Boljka, U. 2016. »Otroci v sodobni družbi.« V Položaj otrok v Sloveniji danes: situacijska analiza, ur. A. Črnak Meglič in B. Kobal Tomc, 48-65. Ljubljana: Inštitut Republike Slovenije za socialno varstvo.

Boyden, J., in J. Ennew. 1997. Children in Focus: A Manual for Experiential Learning in Participatory Research with Children. Stockholm: Rädda Barnen.

Clark, A., in P. Moss. 2001. Listening to Young Children: The Mosaic Approach. London: National Children's Bureau.

Corsaro, W. A. 2005. The Sociology of Childhood. 2. izd. London: Sage.

Črnak Meglič, A., in B. Kobal Tomc, ur. 2016. Položaj otrok v Sloveniji danes: situacijska analiza. Ljubljana: Inštitut Republike Slovenije za socialno varstvo. 
Darbyshire, P. 2000. „Guest Editorial: From Research on Children to Research with Children."V Neonatal, Paediatric and Child Health Nursing 3 (1): 2-3.

Direktiva Evropskega parlamenta in Sveta 95/46/ES z dne 24. oktobra 1995 o varstvu posameznikov pri obdelavi osebnih podatkov in o prostem pretoku takih podatkov. 1995. Uradni List Evropskih Skupnosti, L 281/31.

Direktiva (EU) 2016/680 Evropskega Parlamenta in Sveta z dne 27. aprila 2016 o varstvu posameznikov pri obdelavi osebnih podatkov, ki jih pristojni organi obdelujejo za namene preprečevanja, preiskovanja, odkrivanja ali pregona kaznivih dejanj ali izvrševanja kazenskih sankcij, in o prostem pretoku takih podatkov ter o razveljavitvi Okvirnega sklepa Sveta 2008/977/PNZ. 2016. Uradni list Evropske unije, L 119.

Družinski zakonik (DZ). 2017. Uradni list Republike Slovenije, št. 15.

Ford, K., J. Sankey in J. Crisp. 2007. „Development of Children's Assent Documents Using a Child-Centred Approach. « Journal of Child Health Care 11:1928.

González Fuster, G. (ur.). 2015. »Evropski priročnik za učenje zasebnosti in varstva osebnih podatkov v šolah - gradivo za učitelje.« https://safe.si/sites/ default/files/arcades_prirocnik_o.pdf.

Goršek, A. 2016. »Otrokova avtonomija in varstvo njegovih pravic pri medicinskih posegih.« Doktorska disertacija, Evropska pravna fakulteta v Novi Gorici.

Hauptman, G., in M. Komotar. 2010. Otroci in mladostniki v sodobni družbi. Ljubljana: Zavod IRC.

Harcourt, D., in C. Conroy. 2005 »nformed Assent.« Early Child Development and Care 175 (6): 567-577.

James, A. 2007. »Giving Voice to Children's Voices: Practices and Problems, Pitfalls and Potentials." American Anthropologist 109 (2): 261-272.

Key, E. 1909. The Century of The Child. New York and London: The Knickerbocker Press.

Konvencija o otrokovih pravicah. 1989. http://www.varuh-rs.si/pravni-okvir-inpristojnosti/mednarodni-pravni-akti-s-podrocja-clovekovih-pravic/ organizacija-zdruzenih-narodov/konvencija-o-otrokovih-pravicah-ozn/

Kraljić, S. 2014. „Nadstarševstvo ali quo vadis sodobno starševstvo.« V Zbornik v čast Karla Zupančiča: družinsko in dedno pravo pred izzivi prihodnosti; zbornik znanstvenih razprav $v$ čast 8o. rojstnega dne zaslužnega profesorja dr. Karla Zupančiča, ur. V. Žnidaršič Skubic, A. Vlahek in K. Podobnik, 129155. Ljubljana: Pravna fakulteta Univerze v Ljubljani.

Lawson, T., M. Jones in R. Moores. 2004. Sociologija: shematski pregledi. Ljubljana: Tehniška založba Slovenije.

Letnar Černič, J. 2014. »Dozorevanje Listine Evropske unije o temeljnih pravicah.«Insolvinfo, 24. januar. https://www.insolvinfo.si/DnevneVsebine/ Kolumna.aspx?ld=111652. 
Mortari, L., in V. Mazzoni. 2010. »La ricerca con i bambini.«Rassegna bibliografica infanzia e adolescenza 4:4-27.

Muha, S. 2011. „Otroci kot aktivni udeleženci raziskave: etični in metodološki izzivi.« Magistrsko delo, Fakulteta za družbene vede Univerze v Ljubljani.

Novak, B. 2004. Šola in otrokove pravice. Ljubljana: Cankarjeva založba.

Pavlović, Z. 1993. Psihološke pravice otroka: otrokove pravice onstran pravnega varstva. Radovljica: Didakta.

Pirc Musar, N., M. Prelesnik in M. Bien Karlovšek. 2006. Varstvo osebnih podatkov: vstop v zasebnost prepovedan! Ljubljana: Informacijski pooblaščenec.

Pravilnik o zbiranju in varstvu osebnih podatkov na področju predšolske vzgoje. 2004. Uradni list Republike Slovenije, št. 80.

Punch, S. 2002. »Research with Children: The Same or Different from Research with Adults?« Childhood 9 (3): 321-341.

Pyle, A., in E. Danniels. 2015. »Using a Picture Book to Gain Assent in Research with Young Children.« Early Child Development and Care 186 (9): 1438-1452.

Quennerstedt, A., in M. Quennerstedt. 2014. »Researching Children's Rights in Education: Sociology of Childhood Encountering Educational Theory.«British Journal of Sociology of Education 35 (1): 115-132.

Uredba (EU) 2016/679 Evropskega parlamenta in Sveta z dne 27. aprila 2016 o varstvu posameznikov pri obdelavi osebnih podatkov in o prostem pretoku takih podatkov ter o razveljavitvi Direktive 95/46/ES (Splošna uredba o varstvu podatkov). 2016. Uradni list Evropske unije, L 119.

Zakon o Informacijskem pooblaščencu (ZInfP). 2005. Uradni list Republike Slovenije, št. 113.

Zakon o vrtcih (ZVrt-UPB2). 2005. Uradni list Republike Slovenije, št. 100.

Zidar, M. 2003. »Nove-stare reprezentacije otrok in otroštva: dekonstrukcija sprotektivnegar otroštva." Teorija in praksa 40 (2): 357-374.

\section{Certain Aspects of Children's Participation in Research}

The article focuses on the differences between research with children and adults with a focus on the legal aspect. The introduction of new European legislation on the protection of personal data placed the area of protection of privacy and the protection of personal data under a number of procedural and other administrative challenges, including in the field of research. Particularly sensitive are the encroachments on the privacy of the most vulnerable groups, including children. Based on the an analysis of contemporary approaches and conceptions of the child, with particular attention on the so-called theory of the new sociology of childhood, which understands the child as an independent subject in society, we find that research with children's participation is in many respects different from research involving adults. In this context, we highlight some key starting points, which dictate a different approach to chil- 
dren's research, and we also include the legal aspect of protecting privacy and the protection of personal data.

Keywords: right to privacy, human rights, protection of personal data, new sociology of childhood, consent 


\title{
Video Recording as a Research Method for Investigating Children under Three Years of Age
}

\author{
Tuulikki Ukkonen-Mikkola \\ Tampere university \\ tuulikki.ukkonen-mikkola@tuni.fi \\ Juliene Madureira Ferreira \\ Tampere university \\ juliene.madureiraferreira@tuni.fi
}

\begin{abstract}
This paper explores the use of video recording as a method to investigate the under-three-year-old age group's interactions, learning, and development in kindergarten. Despite the continuous growth in the numbers of infants and toddlers attending early childhood education and care (ECEC) services in OECD countries, educational research focusing on children under three years of age is still scarce. One of the reasons for this scarcity is methodological, and this paper briefly addresses some issues for ECEC practitioners to reflect on in terms of toddlers as informants. The paper presents two different methods of video recording, points out issues concerning ethical procedures when video recording young children, and discusses ideas on what kinds of actions could be implemented in order to assure the participation of children in the research process.
\end{abstract}

Keywords: video recording, infants, toddlers, research method

\section{Introduction}

The latest OECD follow-up report highlights the increase in the numbers of infants and toddlers attending early childhood education and care (ECEC) services (OECD 2015). The report suggests this is indicative of the improving quality of ECEC. Nevertheless, at the same time as the numbers have grown, research has revealed that educators face more challenges in implementing pedagogical activities for young children (Davis, Torr, and Degotardi 2015). Practices have been developed based on teachers' beliefs, which have influenced how children experience opportunities for participation in ECEC contexts (Brownlee, Berthelsen, and Segaran 2009). Pedagogy for toddlers is under researched, as studies concerning ECEC settings tend to focus on older children and pre-schoolers (Sumsion and Harrison 2014). In addition, the developmental trajectories and learning of toddlers are often overlooked in na- 
tional curricula, resulting in an important information gap for this particular age group.

There are several reasons for the scarcity of research on children under three years of age, methodology being one of them. Qualitative educational research has historically used observations, interviews, field diaries, and document analysis to investigate different aspects of children's interaction, learning, and development, but when the child has not yet developed verbal communication, such methods of data collection become very limited. In this paper, we are particularly interested in discussing the challenges of participatory research with this age group and looking at how we can explore the use of video recording as the main method to investigate toddlers' interactions, learning, and development in ECEC contexts. We start by describing the characteristics of the data that can be gathered with video, then we present two different techniques that can be applied to video recording, and in sequence we discuss the analysis using a qualitative theoretical framework. To conclude, we discuss how the research in ECEC, particularly concerning toddlers, can be investigated through video analysis and point out the advantages and limitations of this method.

\section{Toddlers as Informants and Earlier Studies}

In this section, we describe some earlier studies concerning toddlers and the role of the ECEC teacher in toddler groups. In addition, we characterise toddlers as informants. The sensitivity and observation skills of educators are important in pedagogy and interaction with toddlers. Children's communication can be observed through verbal dialogues and/or non-verbal behaviours and activities (Bae 2009). Salomon, Sumsion, and Harrison (2017) have described the capacity of infants and toddlers to communicate using different kinds of facial expressions (e. g. smiles and crying) and other sophisticated emotional strategies as 'emotional capital.' Likewise, Clark (2005) emphasises the sensitivity of educators. He proposes that toddlers' non-verbal communication should be linked to everyday decision-making and pedagogy. In this way, children learn to understand and trust that these messages are taken into account in their daily activities. In addition, the observation skills of educators are important in pedagogy and interaction with toddlers.

Concerning the learning environments, younger children are often considered less capable of participation compared to their older peers (Smith 2002). The learning environment plays a significant role in pedagogy for toddlers, and Rutanen (2012) has emphasised the meaning of space and place in pedagogy and the learning environment. Rutanen (2014) has also implemented 
ethnographic studies on the learning environment of toddlers from the perspective of lived spaces using Lefebre's (1991) ideas. The data were gathered with video recording. The results indicate that the day care centre is an institution where the space is produced and reproduced by adults and toddlers using different approaches. Each actor participates in the production from particular starting points, experiences, and emotions. In addition, Rutanen (2012) states that children construct their lived space and relations to space through embodied, verbal, and non-verbal negotiations with their peers and upon the basis of observing the actions of others. In addition, toddlers negotiate the meanings related to their own space by defending their physical and symbolic territories and setting boundaries for actions.

Video recording can be used to reach out the children's perspective. For example, video recording has been used to investigate the infants' transition from home to day care (Dolby, Hughes, and Friezer 2014). Cameras were situated at floor level; sometimes the infants were filmed or sometimes the camera reflected the children's points of view. A step-by-step procedure was developed in this study that supported the infants' transition to day care and created a feeling of belonging to the children's group. Another way to gain the perspective of the infant is to use baby-cam. It is a small video camera that infants can wear at the side of their head on a hat. Baby-cam provide possibilities for infants to generate video-data from their own bodily position (Elwick 2015).

\section{Methods, Challenges, and Benefits of Video Recordings}

As opposed to using pre-existing videos as material to elicit specific behaviours or learning situations, here we discuss the use of video as a resource or tool to gather data and analyse the interactions, learning, and development of children under three years old. In this sense, video recordings are recognised as a potent source of information that provide a wide range of different kinds of observable elements, such as behaviours, actions, dynamics, materials, and dialogues. The data can be accessed countless times and understood within a time frame that allows the perception of continuity, sequence, and possible relations of cause and consequence (Pedrosa and Carvalho 2005).

According to Loizos (2008), the use of video recording becomes necessary 'whenever any set of human actions is too complex and difficult to be comprehensively described by a single observer as it unfolds' (p. 149). Teaching in the classroom, children's play, and specific situations of learning are highlighted by Loizos (2008) as examples of such complex sets of human action. 
Likewise, previous research applying video recordings to investigate small children's interactions (Lucena 2010; Ferreira 2017; 2018) points out that the ability to work with complexity is a major benefit of video recordings. Amorin, Dentz and Costa (2018) highlight the use of such a tool implies that we are looking at (1) multiple interactions at the same time; (2) interactions among peers in the same age group or different age groups, which impacts the type of communication established between children; (3) interactions between children and adults; and (4) interactions between children and materials in a certain space, affording different opportunities for learning and development. Ferreira (2017) shows that videos allow the complexity within interactive processes to be broken down into different dimensions, and by doing so, it is possible to address phenomena from different points of focus.

Therefore, the use of video recordings is appropriate when the researcher needs to analyse (i. e. treat the whole by relation to its single parts) the multiple aspects of a continuity of actions in order to understand the essence of the phenomenon he/she is investigating. It is not just a matter of the quantity of actions and participants (e.g. many children in the same play situation), but the many possible relations that such actions may constitute. Additionally, for the under threes, video recording can be an appropriate tool in studies that aim to give visibility to the children's wishes, intentions, reasoning, learning, and meaning-making process by means other than verbalisation. Through video recordings, it is possible to make explicit children's agency in play (Lucena 2010) or the leading role of children in adult-child play dynamics (Fantasia et al. 2014). As such, the analysis of children's interactions can be a potent tool for assessing children's development and the quality of learning processes in ECEC.

However, recognising the relevance of video recording as an interesting and appropriate tool is not enough. Knowledge on how to construct the data (what to record, when, how, and for how long) is what determines the efficacy of the method. Below, we give examples of two different techniques the mobile camera and the fixed, strategically positioned camera - and the justifications for their use.

The mobile camera is recommended for the apprehension of specific events in which the occurrences can be programmed and clearly followed (e.g. a specific situation of play, the interaction of a specific pair or group of children, the teacher's instructions for a particular activity). The ability to move the camera during the event allows the researcher to focalise particular aspects of the event and collect the type of information that he/she is looking for. Ferreira, Mäkinen, and De Souza Amorim (2016) video recorded a 
child with an intellectual disability during pretend play. The ability to follow the child, record his movements across the playroom while interacting with other children, and capture the interaction from different angles provided evidence both for the interpretation of the use of space during the pretend play and the gesture dynamics that revealed the content of the communication. Therefore, the mobile camera allows the researcher to make decisions on what elements are most relevant to record during the process. This technique positions the researcher as an active tool-maker during the data collection (Rossetti-Ferreira et al. 2008) and demands a clear understanding and vision of what elements can best reveal the phenomenon being examined.

On the other hand, the use of the mobile camera challenges the skill of the camera operator, as the constant movement and rapid change of focus can result in poor quality images and sound. Other issues should also be considered, such as the weight and price of the equipment. Appropriate equipment is required for high quality images, which can be heavy to carry and/or very expensive.

The fixed camera allows the researcher to record (1) events that are not programmable (e.g. the free play of children outside); (2) events involving several participants at the same time who all have equal relevance to the study (e. g. the teacher's interaction with the group); and (3) situations where no particular focus is yet defined. Additionally, the ability to leave the equipment operating independently allows the researcher to participate in the event or collect data with other methods simultaneously (e. g. a field diary). With a fixed camera, it is also possible for the researcher to make decisions during the recording; however, there are limitations concerning the adjustments that the equipment and its position in the environment allows, and this should be tested before the data collection starts. For example, if the study involves following how children use different toys and spaces, it is necessary to make sure the camera can reach all the areas in focus. The fixed camera is limited in terms of angles, and the researcher might lose sight of a specific subject depending on the setting.

Vasconcelos and Rossetti-Ferreira (2004) also argue that the positioning of the camera reveals the phenomenon from a specific point of view or through the perspective of the researcher looking at the phenomenon. Therefore, it is important to consider that all the distinctions the researcher can make of children's interactions, gestures, eye contact, and vocalisations are constituted by a specific point of view that generated a framing of the event. 
When considering these issues before planning the data collection, the researcher should also keep in mind that not all the images captured will be used in the study, especially when using the fixed camera. Due to the dynamics and speed of image apprehension, this technique provides a large volume of information that may or may not be relevant to the study. Therefore, the time saved by being able to let the camera run independently (not demanding the presence of the researcher during the recording itself) is added in the following phase of preparing the data for analysis. Data preparation (i. e. editing and selecting images based on pre-established criteria on the nature of the phenomenon, the theoretical reference adopted, and the research questions) will then be essential and more laborious for the researcher.

With both the mobile camera and the fixed camera, there are two considerations that should be highlighted. The first is related to the camera operator. In situations where the equipment operator is not the researcher him/herself, the researcher in charge should consider using techniques that demand less decision-making during the data collection or training the person collecting the data on the specific features of the event being examined. Likewise, if the operator is the researcher him/herself, proper training on the use of the equipment might be necessary. Therefore, although the quality of the image and sound are directly related to the quality of the equipment, it should also be considered that other aspects play a role, such as the skill of the operator, the arrangement of cameras and furniture in the environment, the lighting, the number of cameras required for the environment, etc.

Another consideration is related to the time and duration of the video recordings. For both techniques, the time of the filming must be planned according to the nature of the phenomenon and the frequency of its occurrence; and these factors must be constantly reconsidered by evaluating the quality of the images and sounds captured in terms of technical and conceptual aspects. In any case, the schedule of the video recordings must also factor in two preparatory stages: (1) time to adjust or become familiar with the environment and the equipment, and (2) time to build a rapport with the participants, allowing them to become familiar with the researcher and the equipment. Familiarisation with the equipment is essential to obtain quality images and sounds; the equipment must be adjusted and tested at the beginning of each recording session so that the data can be effectively used in the research. If the researcher is not the operator of the equipment, a pilot recording is suggested. The pilot recording serves as a test to find the optimal angles and the correct light and sound levels, but it also enables the researcher to sharpen his/her view regarding the object of the research within 
the framework adopted, thus making it possible to guide the operator in capturing the most useful material.

When considering the time required to build a rapport with the research participants (Olson and Peytchev 2007; Guillemin and Heggen 2009), one must also remember that people can change their behaviour in front of cameras or when they are observed. Participants - in this case especially the teacher, care takers, and other adults - may act according to what they believe to be the researcher's expectations in the study, or they may present very formal behaviours, harming the unveiling of the phenomenon. Thus, the researcher can be seen as a disturbing factor in the daily routine, and the camera itself can be an element that arouses the children's curiosity.

\section{Ethical Considerations}

Ethical questions must be carefully addressed when investigating young children. There are challenges in terms of balancing openness and the rights to anonymity and privacy - how does one obtain permission for the research from the young participants? In addition, there are ethical challenges concerning video data that present images of children and their environments. Respecting the informants and their relativities is also significant issue (Rutanen et al. 2018). These challenges are considered by local (university-level) and national ethics committees in many countries. The committees have based their norms on the Code of Nuremberg ( $\mathrm{NIH}$ 1947). However, there have been a number of culturally specific and complex interpretations (Alasuutari \& Alasuutari 2012). Ultimately, the implementation of research ethics seeks to ensure research that guarantees the protection of the informants (Rutanen et al. 2018).

When investigating toddlers, consent must be sought from the parents, and if the research is carried out in early childhood education settings, from the municipality, the ECEC director, and the educators. Naturally, the opinion of the children involved is important, and this point is challenging especially with young children (Alasuutari 2005). Nevertheless, the dialogue between researchers and the research participants is important in all aspects of the research (Rutanen et al. 2018).

A further significant ethical issue is how materials are shared with national and international research groups. Diverse cultural contexts and different ethical concepts and interpretations can cause tension between researchers from different countries. Therefore, more discussion and dialogue concerning the ethics of video research is needed among researchers, both locally and internationally (Rutanen et al. 2018). 


\section{Discussion and Conclusions}

In this paper, we reflected on the use of video recording as a method to investigate toddlers. We described some earlier studies, presented different ways using video recording, and highlighted the method's benefits and challenges. In addition, we reflected on the ethical considerations of video recording young children.

Video recording is versatile research method, albeit on with some restrictions. We have offered some examples of video recording; however, there are many other opportunities to utilise the method. One interesting alternative is letting children video record by themselves. This paper has briefly addressed some of the benefits and challenges of video recordings as tool for data collection. One benefit is that the method provides very detailed data that can be reused and re-analysed from different points of view. The potential down sides are the ethical questions raised, the huge amount of data produced, and the time required for transcriptions and analysis. Despite these challenges, we argue that video recording is a very useful method for gathering exact data on the learning, relationships, and interaction of young children (Rutanen 2012; 2014). Pedagogy for infants and toddlers is a very significant area in the field of ECEC, partly because of the growth in the numbers of infants and toddlers attending ECEC services. This research and the related discussion are also important for ECEC professionals, since in some debates, even the role of the ECEC teacher in the infants' and toddlers' groups is questioned when the focus of the activities is taking care of children.

\section{References}

Alasuutari, M. 2005. 'Miten rakentaa vuorovaikutusta lapsen haastattelussa?' In Haastattelu, tutkimus, tilanteet ja vuorovaikutus, edited by J. Ruusuvuori and L. Tiittula, 145-162. Tampere: Vastapaino.

Alasuutari, P., and M. Alasuutari. 2012. 'The Domestication of Early Childhood Education Plans in Finland.' Global Social Policy 12 (2): 129-148.

Bae, B. 2009. 'Children's Right to Participate - Challenges in Everyday Interaction.' European Early Childhood Education Research Journal 17 (3): 391-406.

Brownlee, J., D. Berthelsen, and N. Segaran. 2009. 'Childcare Workers' and Centre Directors' Beliefs about Infant Childcare Quality and Professional Training.' Early Child Development and Care 179 (4): 453-475.

Clark, A. 2005. 'Listening to and Involving Young Children: A Review of Research and Practice.' Early Child Development and Care 175 (6): 489-505.

Davis, B., J. Torr, and S. Degotardi. 2015. 'Infants and Toddlers: How Visible Are They in the Early Years Learning Framework?' International Journal of Child Care and Education Policy 9 (12). https://doi.org/10.1186/s40723-015-0014-y 
Amorin, K. S., M. V. Dentz, and N. M. S. Costa. 2018. 'Videogravação nas Ciências Humanas: O dilema entre potencial da imagem e direito de preservação da identidade.' In Pesquisa aplicada em psicologia implicações éticas, edited by M. S. Leme, S. Cagnin, and S. A. S. Leite, 13-48. Campinas: Mercado de Letras.

Dolby, R., E. Hughes, and B. Friezer. 2014. 'Playspaces: Educators, Parents and Toddlers.' In Lived Spaces of Infant-Toddler Education and Care: Exploring Diverse Perspectives on Theory, Research and Practice, edited by L. Harrison and J. Sumsion, 89-102. New York: Springer.

Elwick, S. 2015. "'Baby-Cam" and Researching with Infants: Viewer, Image and (Not)Knowing.' Contemporary Issues in Early Childhood 16 (4): 322-338.

Fantasia, V., A. Fasulo, A. Costall, and B. López. 2014. 'Changing the Game: Exploring Infants' Participation in Early Play Routines.' Frontiers in Psychology 5 (522): 1-9.

Ferreira, J. M. 2017. 'Crianças com déficit intelectual e processos interacionais com pares na pré-escola: reflexões sobre desenvolvimento.' PhD Dissertation, University of Sao Paulo.

- 2018. 'Inclusive Early Childhood Education and the Role of Peer Interaction: Brazil and Finland in dialogue.' PhD Dissertation, Tampere University.

Ferreira, J. M., M. Mäkinen, and K. De Souza Amorim. 2016. 'Intellectual Disability in Kindergarten: Possibilities of Development through Pretend Play.' Procedia: Social and Behavioral Science 217:487-500.

Guillemin, M., and K. Heggen. 2009. 'Rapport and Respect: Negotiating Ethical Relations between Researcher and Participant.' Medicine, Health Care, and Philosophy 12 (3): 291-299.

Lefebre, H. 1991. The Production of Space. Malden, MA: Blackwell.

Loizos, P. 2008. 'Video, filme e fotografias como documentos de pesquisa.' In Pesquisa qualitativa com texto, imagem e som: um manual pràtico, edited by M. W. Bauer and G. Gaskell, 137-155. Petròpolis: Vozes.

Lucena, J. 2010. 'Examinando os processos de assimilação, transformação, construção e compartilhamento de cultura entre crianças de dois anos no ambiente de creche.' Master's Thesis, Federal University of Pernambuco.

$\mathrm{NIH}$. 1947. Nuremberg Code. https://history.nih.gov/research/downloads/ nuremberg.pdf

OECD. 2015. Starting Strong 4: Monitoring Quality in Early Childhood Education and Care. Paris: OECD.

Olson, K., and A. Peytchev. 2007. 'Effect of Interviewer Experience on Interview Pace and Interviewer Attitudes.' Public Opinion Quarterly 71:273-286.

Pedrosa, M. I., and A. M. A. Carvalho. 2005. 'Análise qualitative de epoódio de interacao: uma reflexao sobre procedimentose formas de uso.' Psicologia: Reflexao e Critica 18 (3): 431-442.

Rossetti-Ferreira, M. C., K. De Souza Amorim, A. P. Soares-Silva, and Z. Ramos 
De Oliveira. 2008. 'Desafios metodológicos na perspectiva da rede de significacoes.' Cadernos de Pesquisa 38 (133): 147-170.

Rutanen, N. 2012. 'Socio-Spatial Practices in a Finnish Daycare Group for 1- to 3-Year-Olds.' Early Years 32 (2): 201-214.

- 2014. 'Lived Spaces in a Toddler Group: Application pf Lefebvre's Spatial Triad.' In Lived Spaces of Infant-Toddler Education and Care: Exploring Diverse Perspectives on Theory, Research and Practice, edited by L. Harrison and J. Sumsion, 17-28. New York: Springer.

Rutanen, N., K. De Souza Amorim, H. Marwick, and J. White. 2018. 'Tensions and Challenges Concerning Ethics on Video Research with Young Children's Experiences from an International Collaboration among Seven Countries.' Video Journal of Education and Pedagogy 3 (7): 1-14.

Salomon, A., J. Sumsion, and J. Harrison. 2017. 'Infants Draw on "Emotional Capital" in Early Childhood Education Contexts: A New Paradigm.' Contemporary Issues in Early Childhood 18 (4): 362-374.

Smith, A. B. 2002. 'Interpreting and Supporting Participation Rights: Contributions from Sociocultural Theory.' International Journal of Children's Rights 10:73-88.

Sumsion, J., and L. Harrison. 2014. 'Infant and Toddler Play.' In The SAGE Handbook of Play and Learning in Early Childhood, edited by L. Brooker, M. Blaise, and S. Edwards, 206-318. Los Angeles: Sage.

Vasconcelos, C. R. F., and M. C. Rossetti-Ferreira. 2004. 'Criancas pequenas brincando em creche: a possibilidade de múltiplos pontos de vista.' In Rede de significacoes e o estudo do desenvolvimento humano, edited by M. C. Rossetti-Ferreira, K. De Souza Amorim, and A. P. Soares-Silva, 113-126. Carvalho: Artmed.

\section{Videosnemanje kot raziskovalna metoda za raziskovanje otrok, mlajših od treh let}

Članek obravnava uporabo videosnemanja kot metode preučevanja odnosov v skupini, učenja in razvoja v vrtcu pri otrocih, mlajših od treh let. Kljub vedno večjemu številu dojenčkov in malčkov, ki v državah OECD obiskujejo programe zgodnjega izobraževanja in nege, je še vedno malo raziskav, ki se osredotočajo na otroke do treh let starosti. Eden od razlogov za pomanjkanje takšnih raziskav je metodološki, zato pričujoči članek na kratko obravnava nekaj vprašanj pri obravnavi malčkov kot vira informacij. Članek predstavlja dve različni metodi videosnemanja, opozarja na etična vprašanja pri snemanju majhnih otrok in razpravlja o idejah o tem, katere vrste ukrepov bi bilo mogoče izvesti, da bi zagotovili sodelovanje otrok $v$ raziskovalnem procesu.

Ključne besede: videosnemanje, dojenčki, malčki, raziskovalne metode 


\title{
Perspektive vaspitanja djece jasličke dobi u Bosni i Hercegovini
}

\author{
Aleksandra Šindić \\ Univerzitet u Banjoj Luci \\ aleksandra.sindic-radic@ff.unibl.org
}

Uočavajući protivrječnosti između savremenih naučnih istraživanja i trendova koji ukazuju na presudan uticaj ranog djetinjstva i podrške najmlađoj djeci za razvoj čovjeka i prosperitet društva i zbilje u predškolstvu u Bosni i Hercegovini kao zemlji u tranziciji i poslijeratnim godinama, pristupilo se istraživanju. Kvalitativnim istraživanjem putem SWOT-analize, ulazeći u polje pedagoške futurologije, nastojalo se istražiti i dugoročno sagledati, iz vaspitačkog ugla, strateške komponente razvoja i organizovanja predškolskog vaspitanja djece prvog starosnog doba (do tri godine) u BiH. Istraživački cilj je sagledavanje vizije vaspitača, razumijevanje misije vrtića, te ukazivanje na interne i eksterne mogućnosti i ograničenja za optimalno vaspitanje djece prvog starosnog doba (do tri godine). Kao glavno polje djelovanja predškolskih radnika za unapređenje podrške dječijem razvoju, pored dodatnog stručnog usavršavanja i istraživanja, osavremenjavanja i obogaćivanja vaspitne prakse s bebama, ističe se i promovisanje struke i vlastitog rada kao i senzibiliranje društva o značaju ranog djetinjstva.

Ključne reči: vaspitanje, predškolska djeca prvog starosnog doba, jednake mogućnosti

\section{Uvod}

Tokom prošlog i ovog vijeka, naučnici različitih profila, pedagozi, psiholozi, neurolozi, ekonomisti i dr. putem svojih istraživanja žele da sagledaju i objasne značaj najranijeg djetinjstva. Da je beba ta koja stvara čovjeka, da smo mi ono što je beba izgradila u prve dvije godine naglasila je još ljekar i pedagog Marija Montessori početkom prošlog vijeka, uočavajući snagu i konstruktivnu energiju nesvjesnog upijajućeg uma malog djeteta (Montessori 2003; Kordeš Demšar 2007, 80-81). lako dijete samo sebe stvara čovjekom, iako okolina (socijalna i materijalna) ništa ne kreira, ona može da podstiče, da ometa i čak da deformiše dječiji razvoj. Zato se Marija Montessori sa posebnom pažnjom ophodi prema prvim godinama djetetovog života i vaspitanju najmlađih u montessori ustanovama. Emmi Pikler, pedijatrica i pedagog, po drugom svjetskom ratu, daje smjernice za njegu jasličke djece (Gerber $\mathrm{i}$ Johnson 1997). Hranjenje, presvlačenje, uspavljivanje su intimne aktivnosti u kojima beba treba da se osjeća ugodno i da razvija povjerenje u odraslog. Od- 
rasli nije tu da prestimuliše bebe nego da podrži razvoj pokreta i inicijative (Šindić 2018, 24). Piklerova smatra da je za razvoj bebe presudan odnos koji razvija odrasli dok je njeguje. Značaj interpersonalnih odnosa bebe sa majkom (ili zamjenom za majku) u svojoj teoriji afektivne vezanosti predočava psihoanalitičar John Bowlby (Bowlby 1995) početkom druge polovine prošlog vijeka. Istovremeno, Erik Bern, tvorac transakcione analize naglašava da je socijalno stimulisanje razvojna potreba svakog djeteta (Jovanović Magyar 2008). Uporedo sa ovim nalazima, neurolog Marien Diamond otkriva mogućnosti poboljšanja mozga mladunaca kroz evolutivno-podržavajuće aktivnosti (Diamond 2001). Danas, zahvaljujući razvoju nauke i tehnologije, možemo da provirimo u ljudski mozak, da sagledamo aktivnost dječijeg upijajućeg uma, razvoj sinapsi i neuro-puteva te uočimo spoljnji uticaju na dozrijevanje dječijih nervnih mijelinskih omotača, što i medicinski dokazuje napredne pedagoške i psihološke promisli iz prošlog vijeka. Neuronauke u interdisciplinarnom pristupu s pedagogijom utiču na sagledavanje i iznalaženje evolutivno-podržavajućih aktivnosti za razvoj djece provog starosnog doba (Rajović 2010; Rajović, Šindić i Čampara 2014; Rajović, Šindić i Suzić 2015). Danas znamo da na razvoj beba utiču naslijeđe, aktivnost same bebe, sredina (socijalna i materijalna) i interakcija s njom i da je to presudan period u životu.

Zato nisu iznenađujući rezultati ekonomskih istraživanja Jamesa Heckmana (2013), jer ukazuju da je novac uložen u predškolsko vaspitanje djece najbolje investirani kapital svake države. Djeca se optimalno razvijaju i kao izgrađeni pojedinci svojim radom više doprinose boljitku društva i ostvarenju državnog kapitala. James Heckman objasnio je da je najviši povrat novca od ulaganja u djecu najranije dobi (od rođenja do tri godine), a posebno za djecu iz materijalno ili socijalno depriviranih porodica. Ako se s ulaganjima počne tek sa tri ili četiri godine već je puno propušteno jer se vještine stiču na komplementaran i dinamičan način (Heckman 2013). Autor zaključuje da bi se najveća pažnja i napori trebali usmjeriti na kvalitetan razvoj u ranom djetinjstvu, a posebno na institucionalizovano vaspitanje dojenčadi i djece do tri godine iz depriviranih porodica pošto se na taj način amortizuju negativne porodične prilike i omogućava bolji razvoj. Danas je predškolskim vaspitanjem i obrazovanjem obuhvaćen veliki broj mališana, a širom svijeta postoje uspješni i brojni rani kompenzatorski programi koji podržavaju djecu čije su porodične prilike neadekvatne (Barnett 2008; Stojaković 2000).

\section{Predškolci i predškolstvo u Bosni i Hercegovini danas}

Bosna i Harcegovina je zemlja u tranziciji u poslijeratnim godinama, pogođena teškom ekonomskom, socijalnom i političkom krizom. Cjelokupna dru- 
štvena situacija se odražava na život najmlađih članova društva. Ono što najviše zabrinjava je dječije siromaštvo.

Kriza u zemlji i siromaštvo više obuhvata djecu nego ostatak stanovništva. Ako još tome pridodamo rezultate savremenih istraživanja o dječijem razvoju, možemo nažalost zaključiti, da su najmlađa djeca najranjivija i najviše pogođeni članovi društva države Bosne i Hercegovine. Studije pokazuju da $28 \%$ stanovništva u BiH u 2016. godini živi ispod granice siromaštva ( $\mathrm{Pa}$ pić 2017). Djeca koja žive u većim porodicama su najzastupljenija među siromašnom djecom u poređenju sa opštom populacijom (Iniciativa za bolju i humaniju inkluziju 2013). Tri četvrtine sve siromašne djece živi u ruralnim područjima (74\%). Podaci Agencije za statistiku BiH ukazuju da u vrtić idu djeca roditelja koji nisu siromašni, iz porodica gdje oba roditelja rade $(75,5 \%)$, dok manje od $2 \%$ nezaposlenih roditelja, a samo $0,5 \%$ djece sa sela. Sve to ukazuje na velike razlike i nejednaka mogućnosti.

Druga otežavajuća okolnost jeste i nerazvijenost mreže predškolskih ustanova u Bosni i Hercegovini. 2013. godine je po istraživanjima koje je izveo UNICEF ova zemlja imala najmanji obuhvat djece predškolskim vaspitanjem i obrazovanjem od svih evropskih i srednjoazijskih država (Camović i Hodžić 2017, 34). Obuhvat djece koja su išla u predškolske ustanove 2017/2018 radne godine u Bosni i Hercegovini je iznosio 25889 djece uzrasta od jedne do šest godina što je 13,98\% ukupne djece tog uzrasta u državi (Agencija za statistiku Bosne i Hercegovine 2017; 2018). Za djecu koja kreću u školu, a nisu obuhvaćena redovnim vrtićkim programom organizuje se Program pripreme za školu koji je obavezan i traje tri mjeseca (Okvirni zakon o predškolskom odgoju i obrazovanju u Bosni i Hercegovini 2018, 16 član). Njime se ublažava ovako slab obuhvat djece (Camović i Hodžić 2017, 32). Uprotekloj radnoj 2017/2018 godini vrtiće u BiH je pohađalo 5023 djeteta do tri godine starosti što je 4,44\% od ukupnog broja djece tog uzrasta. Od toga je 232 djeteta uzrasta do godinu dana, 1872 od godine do dvije, a 2780 od dvije do tri godine (Agencija za statistiku Bosne i Hercegovine 2017; 2018). Za poređenje dajemo podatke o procentu obuhvata djece do tri godine u evropskim zemljama prije osam godina. Evropska komisija i SURS su u 2011. godini izračunali da je obuhvat djece do tri godine institucioanlizovanim programom u Danskoj iznosio $74 \%$ djece, u Sloveniji 55,6\%, Holandiji $52 \%$, Švedskoj $51 \%$, Francuskoj i Luksemburgu $44 \%$, Islandu, Belgiji i Španiji $39 \%$... dok je manji bio u Hrvatskoj $15 \%$, Austriji 14\%, Malti 11\%, Mađarskoj $8 \%$, u Češkoj $5 \%$, Slovačkoj 4 \%, Poljskoj 3 \% i Rumuniji 2 \% (Hočevar i Kovač Šebart 2017). U radnoj 2017/18. po podacima do kojih je došao SURS u Republici Sloveniji je institucionalizovanim predškolskim vaspitanjem obuhvaćeno $63,5 \%$ djece do 
tri godine. lako Ustav Bosne i Hercegovine (1995) obavezuje poštovanje dječijih prava u skladu sa Konvencijom o ljudskim pravima (1950) i Konvencijom UN o pravima djeteta (1989) gdje se pravo na obrazovanje smatra progresivnim pravom, moglo bi se reći da je Bosna i Hercegovina još daleko od željene realizacije.

U Bosni i Hercegovini većina predškolskih ustanova (javnih i privatnih) radi po entitetskim programima i vrlo neujednačeno. U Republici Srpskoj službeni dokument je Program predškolskog vaspitanja i obrazovanja (2007) gdje postoje posebne upute za rad (njega, vaspitanje i obrazovanje) sa djecom jasličkog uzrasta.

Da bismo bolje razumjeli današnje predškolsto u BiH, a viziju i misiju predškolstva (sa posebnim osvrtom na bebe) sagledali očima vaspitača, realizovala sam SWOT analizu s vaspitačima i stručnim saradnicima u banjalučkim vrtićima.

\section{Metod}

U ovome radu sam putem kvalitativnog futurološkog istraživanja nastojala sagledati vrtićku realnost, ali i njenu idelnu projekciju u budućnosti. Futurološka istraživanja ukazuju da je budućnost predvidljiva, a možemo je spoznati kao moguću prije nego li unaprijed datu i programiranu (Suzić 2012). Vrtićka stvarnost može se gledati kao kompleksan i dinamičan socijalni entitet (Slunjski 2011) koji se neprestano razvija. Različiti ljudi na različite načine tumače objektivnu stvarnost (Jovanović Magyar 2008; Stewart i Joins 2011; Slunjski 2011). Kvalitativna istraživanja nastoje razumjeti značenje koje ljudi pripisuju pojedinim fenomenima i odnosima, a tehnike koje koristi su fleksibilne i osjetljive na socijalni kontekst. Ovakva istraživanja uključuju empatički uvid, socijalo kontekstualnu osjetljivost, naglasak na procesu i promjenama, autentično viđenje učesnika, direktan kontakt istraživača s problemom, a vaspitač ne samo da može, već je i poželjno da bude istraživač vlastite prakse. Da bih zajedno s vaspitačima evaluirala prednosti, slabosti, mogućnosti i prepreke ostvarenja idelano organizovanog i realizovanog predškolskog vaspitanja za djecu do tri godine u BiH primjenila sam kvalitativnu analitičku metodu SWOT-analizu s futurološkim elementima. Putem SWOT analize vaspitači su postali istraživači vlastite prakse kroz proces dugoročnog sagledavanja uloge predškolstva, uz iznalaženje ideja i elemenata planiranja i kreiranja strategija razvoja.

Predmet istraživanja se odnosi na dugoročno sagledavanje podržavajućeg vaspitanja djece do tri godine iz ugla vaspitača.

Istraživački cilj je utvrđivanje vizije vaspitača, misije vrtića, te internih i ek- 
sternih mogućnosti i ograničenja za postizanje optimalnog vaspitanja djece do tri godine.

Istraživanje je realizovano u mjesecu januaru 2019. godine na uzorku - fokus grupi od trideset praktičara - vaspitačica i stručnih saradnica Javne ustanove Centra za predškolsko vaspitanje i obrazovanje iz tri banjalučka vrtića Kolibri, Lana i Plavi čuperak.

Pri istraživačkoj proceduri prvi korak je bio da se ustanovi kako vaspitačice sebi predočavaju idealnu organizaciju vaspitno-obrazovnog rada s djecom do tri godine - tj. da se odredi njihova vizija optimalne podrške razvoju djece do tri godine starosti. Drugi korak se odnosio na sagledavanje i razumijevanje uloge vrtića u tome, uzimajući u obzir i širi društveni kontekst u kojem ustanova djeluje. Sljedeća četiri koraka predstavljaju vaspitačku analizu vrtićkih i širih društvenih faktora koji utiču na postizanje optimalne zaštite i vaspitanja djece do tri godine starosti (ostvarenje vizije putem misije).

\section{Vizija i misija}

Predškolski radnici fokus grupe izveli su idealizovanu projekciju vaspitanja djece do tri godine u predškolskim ustanovama Bosne i Hercegovine u budućnosti - viziju i način kako do nje doći - misiju.

\section{Vizija}

Vaspitačka idealizovana projekcija vaspitanja djece do tri godine u Bosne i Hercegovine u budućnosti realizuje se u izuzetno povoljnoj materijalnoj i socijalnoj sredini. Ta sredina može biti bebina primarna porodica i idealna predškolska institucija.

1. Ako dijete do tri godine ima funkcionalne i optimalne uslove za razvoj u primarnoj porodici cilj je da u prvim godinama života bude $s$ majkom koliko je god moguće i da s njom ostvari sigurnu afektivnu vezu. O značaju adekvatnih primarnih vezanosti i potrebe socijalne stimulacije malog djeteta od strane majke govore brojna istraživanja (Bowlby 1965; Stewart i Joins 2011). Ovakvi roditelji bi trebali dobiti maksimalnu stručnu podršku (Roberts 2009).

2. Ako je majka zaposlena i/ili dijete živi u depriviranoj sredini (materijalno i/ili soc-emocionalno) potrebno je da pohađa predškolsku ustanovu. Nedostatak optimalne podrške u primarnoj porodici beba može nadoknaditi u jaslenoj grupi. To je naročito bitno za djecu marginalizovanih grupe, u prilog čemu govore brojna istraživanja pozitivne prakse (Barnett 2008; Stojaković 2000). Ulaganje u najmlađe je najefikasnije 
ulaganje u ljudske resurse, dugoročno je isplatljivo i samoobnovljivo (Heckman 2013), a najisplatljivije je za bebe koje žive u nepovoljnim porodičnim prilikama.

3. Pored socijalnog faktora vaspitanje djece do tri godine zahtijeva i bolju organizaciju rada ustanove, kao i kvalitetniju kadrovsku obučenost.

4. Vrtić budućnosti je podržan sa svih državnih i društvenih nivoa, jer su svi članovi društva svjesni značaja zaštite i ranog vaspitanja.

\section{Misija}

Uvažavajući realne društvene, kulturne, političke, ekonomske i socijalne aspekte koji uslovljavaju ostvarenje njihove vizije, vaspitači fokus grupe su iznijeli svoje viđenje rješenja. Ono se ogleda u razvijanju i unapređenju predškolskog vaspitanja djece do tri godine u skladu sa savremenim naučnim saznanjima i dobrom praksom.

1. Podrška u sferi osnaživanja roditeljstva i razvoja malog djeteta treba da bude pružena u zakonskom, prostornom, materijalnom, finansijskom, programskom, stručnom, savjetodavnom, zdravstvenom, socijalnom, vaspitno-obrazovnom smislu.

2. Obzirom da je u BiH zastupljeno dječije siromaštvo bitno je svu siromašnu djecu, naročito bebe, obuhvatiti predškoskim programom. To podrazumjeva veća ulaganja u predškolstvo od strane nadležnih institucija (drugačija preraspodjela sredstava), finansiranje od strane lokalne zajednice ne samo javnih nego i privatnih vrtića. Potrebno je omogućiti besplatnu uslugu za svu siromašnu djecu, kao i umanjenje cijene vrtića porodicama sa nižim prihodima. To zahtjeva formiranje platnih razreda finansija roditelja i određivanje visine participacije za vrtić. Komparativno proučavanje dobre vaspitne prakse i organizacionih rješenja predškolskih programa u drugim državama glede obuhvata siromašne djece takođe je jedan od zadataka misije. Potrebno je osmisliti nove predškolske programe i organizovati nove oblike predškolskih ustanova: putujuće vrtiće, mobilne vrtiće i mobilne timove volontera studenata-vaspitača, eko, šumske i vrtiće u prirodi koji bi omogućili obuhvat djece iz ruralnog područja gdje je naglašenije siromaštvo, a predškolske ustanove malobrojne. Poznato je da su neki od veoma uspješnih vaspino-obrazovnih pravaca upravo i opstali zahvaljujući naporima i podršci porodica u vrijeme siromaštva, poput programa Reggo Emillio (Gardner 2005) koji je nastao u teškim postratnim godinama u Italiji iz stava da su najmlađi zajednička odgovornost cijele za- 
jednice. Nezaposlenost, siromaštvo i dječije razvojne poteškoće podstakli su vaspitača, učitelje i roditelje (mahom iz italijanskih sela) da djeluju skupa te su upravo zahvaljujući svojoj otvorenost prema socijalnoj sredini ove ustanove i opstale. Obzirom da su najugroženija djeca u BiH uglavnom iz višečlanih porodica, nedovoljno obrazovanih i nezaposlenih roditelja, gdje više generacija živi skupa (Iniciativa za bolju i humaniju inkluziju 2013) pomoć djeci bi se mogla pružiti i kroz edukaciju i obrazovanje drugih članova porodice. Edukacija roditelja je veoma korisna (Roberts 2009), uključivanje porodica u v/o program, adekvatna komunikacija i interakcija samo su još neke od ideja o kojima bi trebalo promišljati jer su se pokazale podsticajne u nekim kulturama (Devjak, Novak i Lepičnik Vodopivec 2009, 204-205). Ovakvi napori trebali bi doprinjeti ostvarenje jednakih mogućnosti za sve bebe na području BiH. Takođe, bitno je inicirati i informisati domaće i inostrane donatore, osmisliti i/ili se priključiti predškolskim projektima koji bi omogućili proširenje mreže predškolskih ustanova i besplatno predškolsko vaspitanje najmlađih iz ugroženih porodica.

3. Vaspitačice fokus grupe smatraju da je bitno ispuniti određene organizacione uslove u ustanovi manji broj djece u grupi, homogene jasličke grupe, duži vremenski period boravka oba vaspitača u grupi, tri radnika u jaslenoj grupi, personalni asistent $u$ grupi za dijete $s$ poteškoćama, obavezan medicinski radnik za grupu, a pedijatar za vrtić, pojačan savjetodavni rad stručnih saradnika s roditeljima, uključivanje roditelja i baka i djedova u vaspitni rad vrtića, poštovanje pravila dovođenja zdrave djece u vrtić, obavezna soba za izolaciju za bolesnu djecu. Takođe, bitno je usavršiti i proširiti pedagoška, metodička, zdravstveno-higijenska znanja predškolskih radnika za rad s bebama u vrtićima. To podrazumijeva modernizovati programske koncepcije, poboljšati stručnu osposobljenost za rad s bebama uvodeći dodatne predmete za njegu i vaspitanje beba na Studijskim programima za predškolsko vaspitanje, uvesti studentsku praksu u vrtićima specijalno u jaslenim grupama, povećati broj seminara i intenzivirati stručno usavršavanje vaspitača za rad s bebama, poboljšati razmjenu iskustava dobre prakse; istraživati vaspitni rad u jaslicama. Vaspitači fokus grupe pokazuju spremnost za dodatno stručno usavršavanje iz ove oblasti s ciljem ostvarivanja efikasnije podrške bebinom razvoju. Unatoč važnosti prvih godina života, nedovoljno pažnje im se posvećuje i u naučnonastavnom programu, kako na dodiplomskom i postdiplomskom studiju tako i na obaveznim edukacijama vaspitača. lako postoje brojni 
metodički pristupi i načini u radu s jaslenom djecom koji su efikasni i lako ispitljivi u našim predškolskim ustanovama (Rajović, Šindić i Suzić 2015; Rajović, Šindić i Čampara 2014) mali broj naučnih radova je na tu temu, što se svakako može i treba promijeniti.

4. Da bi se postigle povoljne sredinske prilike za optimalan rad i djelovanje predškolskih ustanova potrebno je da su svi članovi društva svjesni značaja ranog razvoja i učenja za pojedinca i čitavu državu. Nažalost, u Bosni i Hercegovini svjest o tome je na veoma niskom nivou. Zato je potrebno raditi na edukaciji i senzibilizaciji bosansko-hercegovačkog društva o značaju ranog djetinjstva i podrške holističkom razvoju djece do tri godine starosti. To povlači za sobom uključivanje u ovu problematiku nadležne institucije izvan predškolske ustanove (ministarstvo, prosvjetno pedagoški zavod, visokoškolske ustanove, medije, naučne, socijalne i zakonodavne institucije).

\section{Interna i eksterna analiza}

Putem interne i eksterne analize trebalo je izdvojiti i sagledati prednosti, atribute i pretpostavke (strenghts) i slabosti (weaknesses) vrtića i predškolskog kadra, s jedne strane, te mogućnosti i povoljne prilike (oportunities) i ograničenja (threats) roditelja i zajednice, s druge strane (preglednica 1). Nastojalo se odgovoriti na pitanja kako iskoristiti snage predškolske ustanove, roditelja i šire zajednice, te kako izbjeći i ublažiti nepovoljne uticaje i ograničenja predškolske ustanove, porodice i šire društvene sredine u kontekstu ranog razvoja i učenja, $\mathrm{tj}$. unapređenja vaspitanja djece do tri godine.

Kao što se vidi u tabelii 1, vaspitači su izdvojili jake i slabe strane predškolske ustanove i društvene zajednice bitne za strateški razvoj vaspitanja djece do tri godine. Naveli su i nekoliko prijedloga kako ublažiti poteškoće. Uočavaju da je neophodna edukacija roditelja i društva o ranom djetinjstvu, značaju vaspitanja i obrazovanja na ranom uzrastu. Potrebno je informisati javnost o tome da rani obuhvat djece iz rizičnih siromašnih porodica neutrališe uticaja nepovoljnih porodičnih prilika na razvoj beba i male djece (siromaštvo, nažalost, postaje naglašen društveni problem). Naglašava se potreba informisanja roditelja i javnosti o radu predškolskih ustanova i potrebama šireg obuhvata djece institucionalizovanim predškolskim vaspitanjem i obrazovanjem, uspostavljanje zakonskih akata kojima će se apostrofirati značaj prvog stepena vaspitno-obrazovnog sistema i inicirati materijalna ulaganja u ovoj oblasti života i rada, obezbjediti besplatno pohađanje vrtića siromašnoj djeci i smanjene troškove vrtića određenim kategorijama djece. Bitno je organizovati i edukaciju roditelja o roditeljstvu, adekvatnom vaspitanju djece do tri 
Tabela 1 Interna i eksterna analiza

\begin{tabular}{lll}
\hline \multirow{2}{*}{$\begin{array}{l}\text { Interni } \\
\text { elementi }\end{array}$} & Snage & Slabosti \\
\cline { 2 - 3 } & Školovan i stručan kadar: vaspitači, & Nedostatak kadra: pedijatrijskih se- \\
& stručni saradnici; entuzijazam i krea- & stara, ljekara pedijatra, psihologa, pe- \\
& tivnost v/o radnika; saradnja, timski & dagoga i socijalnih radnika; slabija pri- \\
rad u vrtiću i razmjena iskustava pozi- & premljenost studenata za rad s djecom \\
tivne prakse; adekvatna oprema, mate- & do tri godine u odnosu na uzrast od 3- \\
rijal i prostor za igru i iskustveno uče- & 6 godina; zanemareno stručno usavr- \\
nje beba; inkluzija. & šavanje (propisano od nadležnih insti- \\
& tucija - Ministarstva, Pedagoškog za- \\
& voda i sl.) i nedostatak v/o seminara za \\
& uzrast do tri godine, nedovoljno pro- \\
& jekata (u odnosu na uzrast 3-6); nedo- \\
& voljno razrađen program za rad s dje- \\
& com do tri godine.
\end{tabular}

\begin{tabular}{|c|c|c|}
\hline & Povoljne prilike & Prijetnje \\
\hline $\begin{array}{l}\text { Eksterni } \\
\text { elementi }\end{array}$ & $\begin{array}{l}\text { Mogućnost preraspodjele budžet- } \\
\text { skih sredstava u korist najmlađih ko- } \\
\text { risnika; podrška domaćih i stranih do- } \\
\text { natora, UNICEFa i sl.; zainteresovanost } \\
\text { porodice za djecu: majke, oca, bake i } \\
\text { dede ...; spremnost članova porodice } \\
\text { da budu pomagači i volonteri u v/o } \\
\text { procesu; pomoć studenata na univer- } \\
\text { zitetskoj praksi; studenti i vaspitači vo- } \\
\text { lonteri; personalni asistenti koje rodite- } \\
\text { lji angažuju za pomoć pri radu; sarad- } \\
\text { nja sa institucijama: dom zdravlja, pe- } \\
\text { dagoški zavod, fakultet, centar za so- } \\
\text { cijalni rad, nadležna ministarstva i za- } \\
\text { konodavna tijela, opština - osnivač i } \\
\text { sl.; promovisanje i podrška predškol- } \\
\text { skih ustanova, edukacija i senzibiliza- } \\
\text { cija javnosti o ranom djetinjstvu u me- } \\
\text { dijima kroz edukativne emisije o pred- } \\
\text { školstvu. }\end{array}$ & $\begin{array}{l}\text { Ekonomska i politička kriza u zemlji; loš } \\
\text { kvalitet života i loša društvena atmo- } \\
\text { sfera; nedovoljna budžetska sredstva; } \\
\text { visoke cijene vrtića u odnosu na plate- } \\
\text { žnu moć roditelja; šire društveno nera- } \\
\text { zumjevanje i neosjetljivost za pitanje } \\
\text { najmlađih, neznanje o značaju prvih } \\
\text { godina života za razvoj čovjeka i ne- } \\
\text { zainteresovanost; neprovođenje i neu- } \\
\text { sklađenost zakonskih propisa; mediji u } \\
\text { podršci manipulaciji, širenju nekulture } \\
\text { i neznanja i senzacija; nedovoljna po- } \\
\text { drška mladim porodicama (u edukaciji, } \\
\text { materijalnoj i stručnoj pomoći). }\end{array}$ \\
\hline
\end{tabular}

godine, evolutivno podržavajućim aktivnostima, različitim dječijim poteškoćama, komunikaciji isl, organizovati redovne savjetodavne razgovore roditelja djece s poteškoćama integrisane u grupu s timovima stručnjaka, vaspitača i menadžmenta predškolske ustanove.

\section{Zaključak}

Vaspitanje i obrazovanje djece je društveno uslovljen fenomen. Kada su prilike u nekom društvu nepovoljne, ako se ne iznađu adekvatne mjere i pra- 
vovremeno se ne odreaguje, najugroženiji su oni najranjiviji i najmlađi članovi društva. Država koja ulaže dovoljno sredstava u najmlađe, osigurava i podržava svoju budućnost - djecu. Dakle, u interesu svih članova društva je da se osigura dobar start svakoj bebi (Heckman 2013), što bi trebao biti posebno značajan zadatak u svim državama u kojima su nepovoljne ekonomske prilike. Mada mnoge uskraćenosti na ranom uzrastu koje ometaju razvoj cjelokupne djetinje ličnosti nisu finansijske prirode (Bowlby 1965; Jovanović Madyar 2008; Stewart i Joins 2011), potrebno je posebnu pažnju posvetiti činjenici da je stopa siromašne djece u Bosni i Hercegovini visoka. Prema podacima Agencije za statistiku Bosne i Hercegovine (2013), u 2011. godini 30,5\% djece živi u siromaštvu, a među njima su najbrojnija djeca koja žive u ruralnim oblastima, u višečlanim porodicama, gdje roditelji imaju skromno obrazovanje i mahom su nezaposleni. Takođe, ono što je specifično za ovu zemlju je izuzetno niska stopa obuhvata djece predškolskim ustanovama (oko $14 \%$ djece do šest godina idu u vrtić, a 4,44\% djece do tri godine pohađa vrtić) (Agencija za statistiku Bosne i Hercegovine 2017; 2018). Obuhvat djece iz rizičnih skupina je neznatan.

Da bih futurološki sagledala strateške razvojne elemente vaspitanja djece do tri godine u Bosni i Hercegovini pristupila sam SWOT-analizi. Nastojala sam timski istražiti i dugoročno sagledati vaspitanje djece do tri godine $u \mathrm{BiH}$ iz ugla predškolskih radnika, njihovu viziju optimalne podrške najmlađima, ranom razvoju i učenju, promišljanje o tome kako je ostvariti, organizovati i metodički oblikovati te predispozicije i ograničenja za to. Ono što vaspitači vide kao viziju kojoj treba stremiti je veći obuhvat djece predškolskim vaspitanjem u BiH i besplatno uključivanje sve djece iz rizičnih skupina institucionalizovanim predškolskim programima. Glavno oruđe na tom putu je senzibilizacija javnosti i edukacija o značaju i specifičnosti ranog djetinjstva, informisanje društva i pojedinaca s ciljem optimalnije preraspodjele sredstava budžeta, ulaganja i donacija, donošenja i primjena adekvatne vaspitnoobrazovne strategije i zakonske regulative. Takođe, vaspitači uočavaju potrebu bolje organizacije rada sa bebama u predškolskim ustanovama, dodatnog stručnog obrazovanja studenata i vaspitača za vaspitanje djece do tri godine starosti i naglašenije uključivanje porodice u vaspitno-obrazovni proces, osavremenjavanje dijela Programa predškolskog vaspitanja i obrazovanja (2007) koji se odnosi na uzrast do tri godine i sl.

U mnogim evropskim zemljama je prepoznat značaj predškolske ustanove i vaspitanja za djecu do tri godine što rezultire visokom stopom uključenosti djece u predškolske programe u prvom starosnom dobu (od završetka porodiljskog odsustva pa do tri godine starosti) u tim državama (Hočevar i Kovač 
Šebart 2017). Vaspitači iz fokus grupe prepoznaju svoju ulogu za unapređenje podrške dječijem razvoju. Pored dodatnog stručnog usavršavanja i istraživanja, osavremenjavanja i obogaćivanja vaspitne prakse s bebama, organizovanja raznih oblika programa predškolskog vaspitanja (kao dopunu osnovnim), ističe se i promovisanje vlastite struke i vlastitog rada kao i nastojanje senzibilizacije društvene zajednice o značaju ranog razvoja i potrebi ranog obuhata djece institucionalizovanim predškolskim vaspitanjem slijedeći dobre primjere razvijenih evropskih zemalja.

\section{Bibliografija}

Agencija za statistiku Bosne i Hercegovine. 2013. Anketa o potrošnji domaćinstava u BiH 2011. Sarajevo: Agencija za statistiku Bosne i Hercegovine.

— 2017. Bosna i Hercegovina u brojevima 2017. Sarajevo: Agencija za statistiku Bosne i Hercegovine.

Agencija za statistiku Bosne i Hercegovine. 2018. „Statistika obrazovanja.« Saopćenje 13 (2): 1.

Barnet, W. S. 2008. »Preschool Education and Its Lasting Effects: Research and Policy Implications.«http://greatlakescenter.org/docs/Policy_Briefs/ Barnett_EarlyEd.pdf

Bowlby, J. 1965. Child Care and the Growth of Love. London: Penguin Books.

- 1995. Maternal Care and Mental Health. London: Jason Aronson.

Camović, Dž., i L. Hodžić. 2017. »Analiza stanja na področjo predšolske vzgoje v Bosni in Hercegovini z vidika pravičnosti in enakih možnosti za vse otroke." Sodobna pedagogika 68 (3): 28-45.

Devjak, T., L. Novak i J. Lepičnik Vodopivec. 2009. »Kakovostna interakcija in komunikacija."U Izzivi pedagoškega koncepta Reggio Emilia, ur. T. Devjak i D. Skulic. 189-207. Ljubljana: Pedagoška fakulteta.

Diamond, M. 2001. »Response of the Brain to Enrichment.« Annals of the Brazilian Academy of Sciences 73 (2): 211-222.

Gardner, H. 2005. Disciplinirani um. Zagreb: Educa.

Greber, M., i A. Johnson. 1997. Your Self-Confident Baby. New York: Wiley.

Heckman, J. 2013. Giving Kids a Fair Chance. Boston, MA: MIT Press.

Hočevar, A., i M. Kovač Šebart. 2017. »Pravičnost in dostopnost predšolske vzgoje v državah nekdanje Jugoslavije: skupna zgodovina, različne možnosti.« Sodobna pedagogika 68 (3): 8-27.

Iniciativa za bolju i humaniju inkluziju. 2013. »Siromaštvo u BiH 2011 - trendovi i dostignuća 2013."http://www.ibhi.ba/Documents/Publikacije/2013/ IBHI_Siromastvo_u_BIH_2011_Trendovi_i_dostignuca.pdf

Jovanović Magyar, A. 2008. Zašto to radiš? Beograd: Centar za primenjenu psihologiju.

Konvencija o ljudskim pravima. 1950. https://www.echr.coe.int/Documents/ Convention_SRP.pdf 
Konvencija o pravima djeteta. 1989. http://ombudsman.co.me/djeca/docs/ konvencijaopravimadjeteta.doc

Kordeš Demšar, M. 2007. »Pedagogika Montessori.«Sodobna pedagogika 58 (4): 80-91.

Montesori, M. 2003. Upijajući um. Beograd: DN Centar.

Okvirni zakon o predškolskom odgoju i obrazovanju u Bosni i Hercegovini. 2018. Službeni glasnik Bosne i Hercegovine, br. 12.

Papić, Ž. 2017. Siromaštvo i radničko siromaštvo u BiH. Sarajevo: Forum lijeve inicijative.

Rajović, R. 2010. Metodički priručnik za vaspitače. Vršac: Visoka škola strukovnih studija za obrazovanje vaspitača Mihajlo Pavlov.

Rajović, R., A. Šindić i D. Čampara. 2014. "NTC program na jasličkom uzrastu.« U Kvalitet vaspitno-obrazovnog rada: zbornik radova 2. skupa pedagoga, ur. M. Ilić, 145-159. Banja Luka: Društvo pedagoga RS.

Rajović, R., A. Šindić i N. Suzić. 2015. »Habit of Solid Food Conformmation Preschool-Aged Children and Its Potential Role in Cognitive Development. « U Vzgojno-izobraževalne perspektive: obzorja učenja, ur. T. Grušovnik, 378-393. Koper: Univerza na Primorskem.

Roberts, K. 2009. Early Home Learning Matters. London: Family and Parenting Institute.

Slunjski, E. 2011. Kurikulum ranog odgoja. Zagreb: Školska knjiga.

Suzić, N. 2012. Futurologija. Banja Luka: Ektos.

Stewart, I., i V. Joins. 2011. Savremena transakciona analiza. Novi Sad: Psihopolis institut.

Stojaković, P. 2000. Darovitost i kreativnost. Srpsko Sarajevo: Zavod za udžbenike i nastavna sredstva Republike Srpske.

Šindić, A. 2018. Upoznavanje predškolske djece s okolinom i društvenom sredinom. Banja Luka: Filozofski fakultet.

Ustav Bosne i Hercegovine. 1995. http://www.ccbh.ba/public/down/USTAV _BOSNE_I_HERCEGOVINE_srp.pdf

\section{Perspektive vzgoje otrok prvega starostnega obdobja v Bosni in Hercegovini}

Raziskavo so spodbudila protislovja med sodobnimi znanstvenimi raziskovanji in trendi, ki kažejo na odločilen vpliv zgodnjega otroštva in podpore najmlajšim otrokom na razvoj osebnosti in družbe, ter realnost predšolske vzgoje v BiH. S kvalitativno analizo SWOT, z vstopanjem na področje pedagoške futurologije, smo poskusili raziskati in dolgoročno opredeliti strateške komponente razvoja ter organizacije vzgoje otrok v prvem starostnem obdobju v $\mathrm{BiH}$, in sicer s stališča vzgojiteljev. Cilji raziskave so ugotovljanje vizije vzgojiteljev, razumevanje misije vrtca ter prikaz internih in eksternih možnosti ter ovir za optimalno organizacijo predšolske vzgoje otrok v prvem starostnem 
obdobju. Za uresničenje ciljev misije vrtca - ti so povečanje števila otrok v oddelkih, $v$ različnih programih, s poudarkom na otrocih iz depriviligiranih družin - morajo vzgojitelji prepoznati svoje naloge. Poleg dodatnega strokovnega usposabljanja in raziskovanja, posodabljanja in bogatenja vzgojne prakse je potrebno izpostaviti tudi promoviranje stroke ter dela kot tudi senzibilizacijo družbe glede pomena zgodnjega otroštva.

Keywords: vzgoja, otroci prvega starostnega obdobja, enake možnosti 



\title{
Izgorelost in samoučinkovitost strokovnih delavk v vrtcu
}

\author{
Sonja Čotar Konrad \\ Univerza na Primorskem \\ sonja.cotarkonrad@pef.upr.si \\ Maja Lebeničnik \\ Univerza na Primorskem \\ maja.lebenicnik@pef.upr.si
}

\begin{abstract}
V raziskavi smo ugotavljali stopnjo izgorelosti in občutka samoučinkovitosti pomočnic vzgojitelja predšolskih otrok v vrtcu. Zanimale so nas tudi razlike v merjenih konceptih med pomočnicami različnih starostnih skupin otrok, ki so na različni stopnji profesionalnega razvoja. Ugotovljamo, da je poročana stopnja izgorelosti razmeroma nizko izražena, saj pomočnice kažejo visoko stopnjo osebne izpolnitve na delovnem mestu ter nižjo stopnjo čustvene izčrpanosti in depersonalizacije. Poročajo tudi o razmeroma visokem občutku samoučinkovitosti, pri čemer se kažejo razlike glede njenih komponent: pomočnice, ki delujejo v prvi starostni skupini (otroci starosti od 1 do 3 leta), ugodneje ocenjujejo občutek samoučinkovitosti na področju spodbujanja motivacije otrok kot pomočnice, ki delajo z drugo starostno skupino otrok (3-6 let starosti). Poročana samoučinkovitost je različna tudi glede na stopnjo profesionalnega razvoja, pri čemer pomočnice začetnice (do 3 let delovne dobe) občutijo najnižjo stopnjo samoučinkovitosti na delovnem mestu, pomočnice $v$ fazi poklicne stabilizacije pa najvišjo stopnjo samoučinkovitosti.
\end{abstract}

Ključne besede: izgorelost, samoučinkovitost, pomočnice vzgojitelja predšolskih otrok, profesionalni razvoj

\section{Uvod}

V zadnjih desetletjih zahteve do pedagoških delavcev naraščajo, kar lahko pomeni povečano tveganje zaposlenih za izgorelost. Nekatere študije (Košir idr. 2014; Slivar 2013) kot najpogostejše stresorje pedagoških delavcev navajajo tako strukturne (npr. prevelike skupine, pomanjkanje opreme, preveč administrativnega dela) kot tudi procesne dejavnike (npr. težave $v$ odnosu $z$ otroki/učenci, s starši in sodelavci) ter druge sistemske vidike njihovega dela (način vodenja, status poklica v družbi itd). Študije izgorelosti poleg organizacijskih dejavnikov pogosto poudarjajo tudi vlogo osebnostnih značilnosti (npr. motivacije, prepričanj, emocionalne inteligentnosti ipd.) in interakcij le-teh z organizacijskimi dejavniki na delovnem mestu. V okviru omenje- 
nih ugotovitev lahko sklepamo, da je delo pomočnika vzgojitelja predšolskih otrok ( $v$ nadaljevanju pomočnice) še posebej kompleksno in $z$ vidika tveganja za izgorelost rizično. V skladu z določili Zakona o vrtcih (2005) ${ }^{1}$ se namreč naloge pomočnic nanašajo predvsem na sodelovanje, pomoč in podporo vzgojitelju predšolskih otrok, ki na področjih načrtovanja, izvajanja in priprave vzgojnega dela, uporabe in oblikovanja didaktičnega materiala itd. lahko v celoti določa zahteve in pričakovanja do pomočnice. Slednje lahko od pomočnic zahteva ne zgolj odzivanje na potrebe otrok v skupini in njihovih staršev, ampak tudi povečano občutljivost in odprtost za sodelovanje z vzgojiteljem. Omenjeno lahko v primerjavi s položajem delovnega mesta vzgojitelja predšolskih otrok že $v$ izhodišču pomeni nižji poklicni status v vzgojno-izobraževalni ustanovi, slabše plačilo in veliko obremenjenost pomočnic. Predvidevamo torej lahko, da so različni dejavniki na delovnem mestu pomočnic zanje manj ugodni, kar posledično lahko vodi k višjemu tveganju za izgorelost.

\section{Izgorelost}

Posameznik lahko kot odgovor na kronični stres na delovnem mestu razvijejo psihološki sindrom izgorelosti, ki negativno vpliva na njihovo delovno, telesno in psihološko funkcioniranje. Najširše uveljavljeni model izgorelosti je model C. Maslach in S. E. Jackson (1981), ki zajema tri komponente: čustveno izčrpanost, depersonalizacijo in osebno izpolnitev. Po tem modelu izgorelost pri posamezniku ni zgolj bodisi prisotna ali odsotna, ampak ima razpon od nizko ter zmerno do visoko izraženih občutij. Na visoko izgorelost kažejo kombinacija visoke čustvene izčrpanosti, visoke depersonalizacije in nizke osebne izpolnitve (Maslach, Schaufeli in Leiter 2001).

Čustvena izčrpanost predstavlja osrednjo komponento izgorelosti. Pri visoko čustveno izčrpanem posamezniku so močno in pogosto prisotni občutki čustvene utrujenosti, preobremenjenosti in pomanjkanja fizične ter psihološke energije za delo. Čustvena izčrpanost sčasoma vodi v način dela, za katerega sta značilna čustvena in miselna odmaknjenost od dela ter otopel,

\footnotetext{
'Zakon o vrtcih (2005) v 41. členu predvideva, da delovna obveznost vzgojitelja obsega pripravo na vzgojno delo, načrtovanje in izvajanje vzgojnega dela, delo s starši ter sodelovanje pri organizaciji življenja in dela v vrtcu. Delovna obveznost vzgojitelja predšolskih otrok - pomočnika vzgojitelja obsega sodelovanje z vzgojiteljem pri načrtovanju, izvajanju in pripravi vzgojnega dela v oddelku, samostojno izvajanje nekaterih dejavnosti predšolske vzgoje ter sodelovanje pri ostalih dejavnostih in opravljanje drugih nalog, povezanih z dejavnostjo vrtca. V okviru z zakonom in kolektivno pogodbo določenega polnega tedenskega delovnega časa vzgojiteljevo delo z otroki obsega 30 ur, delo vzgojitelja predšolskih otrok - pomočnika vzgojitelja pa 35 ur tedensko.
} 
neobčutljiv in odklonilen odnos do oseb, $s$ katerimi zaposleni prihaja $v$ stik pri svojem delu, kar C. Maslach in S. E. Jackson (1981) imenujeta depersonalizacija (tudi cinizem). Tretja opredeljujoča sestavina izgorelosti je znižana osebna izpolnitev, kar pomeni, da posameznik občuti pomanjkanje kompetentnosti in produktivnosti na delovnem mestu (npr., čuti se nesposobnega, neprimernega za specifično delovno mesto). Model izgorelosti predvideva, da je čustvena izčrpanost predhodnica depersonalizacije, obe skupaj pa pripeljeta do nizke osebne izpolnitve (Depolli Steiner 2011). Nekateri avtorji pri preučevanju izgorelosti obravnavajo le dve komponenti izgorelosti, in sicer izraženost čustvene izčrpanosti ter depersonalizacijo (Aloe, Amo in Shanahan 2014), vendar pa so statistične analize pokazale večjo primernost trifaktorskega kot dvofaktorskega modela izgorelosti za različne poklicne skupine (Bakker, Demerouti in Schaufeli 2002; Maslach, Schaufeli in Leiter 2001).

Izgorelost so sprva povezovali z zahtevnimi čustvenimi situacijami, ki so jim izpostavljeni predvsem zaposleni v službah pomoči in storitvenih dejavnostih, ki morajo pogosto zadovoljevati potrebe ali reševati probleme prejemnikov svojih storitev (npr. strank, pacientov, učencev itd.) (Maslach, Schaufeli in Leiter 2001). Takšno delo je povezano s tveganjem, da se posameznik čustveno izčrpa (Maslach 2003). Kasneje pa sta C. Maslach in Leiter (1997, v Maslach, Schaufeli in Leiter 2001) poudarila, da je izgorelost posledica kroničnega neujemanja med osebnostjo in zahtevami delovnega mesta ter se pojavlja v vseh poklicih.

Raziskovalci izgorelosti (Maslach, Schaufeli in Leiter 2001) zato že dolgo poudarjajo, da so, poleg osebnih značilnosti, tudi organizacijske značilnosti (npr. socialna klima, pomanjkanje nagrad, delovne obremenitve, premalo nadzora nad lastnim delom ipd.) med pomembnimi dejavniki, ki prispevajo $\mathrm{k}$ izgorelosti na delovnem mestu. Intervencije za zmanjševanje in preprečevanje izgorelosti so zato vezane tako na posameznika (npr. treningi emocionalnih kompetenc, učenje veščin asertivnosti, sproščanja, spoprijemanja s stresom itd.) kot na organizacijo (npr. razvijanje sodelovalne klime, spodbujanje pravičnosti in enakopravnosti itd.).

\section{Izgorelost pedagoških delavcev}

Pedagoški delavci se na vseh stopnjah šolskega sistema pogosto soočajo $s$ stresorji, ki so medosebne, čustvene in organizacijske narave, zato se med njimi pojavlja tudi izgorelost. Raziskave o slovenskih pedagoških delavcih (Demšar 2003 v Slivar 2009; Depolli Steiner 2011; Slivar 2009) neprekinjeno kažejo, da okrog $10 \%$ pedagoških delavcev poroča o visoki, $25 \%$ do $40 \%$ pa o zmerni izgorelosti. Na osnovi primerjave raziskav je opaziti tudi trend nara- 
ščanja zmerne ter nižanje deleža nizke izgorelosti, pri čemer se - po raziskavi K. Depolli Steiner (2011) - proces izgorelosti še ni pričel le pri $5 \%$ slovenskih pedagoških delavcev.

Ob tem je pomembno tudi dejstvo, da pedagoški delavci, ki so visoko izgoreli, drugače zaznavajo svoje učence, z njimi vzpostavljajo drugačne, manj ustrezne odnose in ustvarjajo manj ugodno učno okolje (Depolli Steiner 2011). Raziskovalka podrobneje ugotavlja, da se pedagoški delavci, ki so $\checkmark$ večji meri čustveno izčrpani, čutijo kronično utrujene in imajo občutek, da svojim učencem s pedagoško-psihološkega vidika ne zmorejo »dati toliko, kot s[m]o jim nekoč«. Zagotavljanje ustreznega odnosa in procesa med pedagoškim delavcem in učencem je namreč ena ključnih nalog pedagoškega delavca in in eno ključnih pričakovanj učencev $v$ »dobri šoli«, ki - kot pravi S. Rutar (2018) - od učiteljev pričakujejo spodbudo, podporo in pomoč, česar pa izgoreli učitelj ne (z)more. Pedagoški delavci tako postopoma izgubljajo pozitivno naklonjenost do svojih učencev in do njih oblikujejo negativnejša stališča, kar se kaže kot eden pomembnih elementov izgorelosti, to je depersonalizacija (Maslach, Schaufeli in Leiter 2001). Pedagoški delavci, ki na delovnem mestu doživljajo slednjo, svoje učence pogosteje označujejo, žalijo, so do njih kritičnejši, hladnejši in povečajo fizično distanco (Maslach, Jackson in Leiter 1997; Maslach, Schaufeli in Leiter 2001). Dokazano je bilo tudi, da občutek depersonalizacije pedagoškega delavca na vedenjske težave $v$ razredu vpliva tudi posredno, preko znižanega entuziazma, ki ga pedagoški delavci občutijo ob opravljanju svojega dela (Benita, Butler in Shibaz 2019). Skaalvik in Skaalvik (2010) poročata, da so pri pedagoških delavcih posamezne dimenzije izgorelosti povezane $z$ različnimi kontekstualnimi dejavniki. Tako npr. težavni odnosi s starši pozitivno napovedujejo depersonalizacijo pedagoškega delavca, časovna stiska pri delovnih zadolžitvah pa čustveno izčrpanost.

Kljub temu, da je delovno mesto strokovnega delavca $v$ vrtcu, $v$ večji meri kot delo učiteljev, neposredno povezano z zadovoljevanjem psihofizičnih potreb otrok ter uravnavanjem njihovega vedenja in je obenem tudi socialno-statusno ter finančno pogosto nižje ovrednoteno (Tsai, Fung in Chow, 2006), so raziskave izgorelosti pedagoških delavcev pogosteje izvedene na populaciji učiteljev. Čeprav se izgorelost na predšolski stopnji ne preučuje pogosto (Rentzou 2015), nekateri raziskovalni izsledki (Baran idr. 2010; Radic Hozo, Sucic in Zaja 2015; Al-Adwan in Al-Khayat 2017; Jeon, Buettner in Ashley 2018) kažejo, da bi bilo to potrebno in smiselno. E. Radic Hozo, G. Sucic in I. Zaja (2015) tako npr. ugotavljajo, da približno polovica vzgojiteljic kaže znake izgorelosti na delovnem mestu, novejše študije (Jeon, Buettner in 
Ashley 2018) pa poročajo o povezanosti občutka samoučinkovitosti in organizacijskih dejavnikov delovnega mesta s čustveno izčrpanostjo strokovnih delavk vrtca (Al-Adwan in Al-Khayat 2017). Nadalje raziskave kažejo tudi to, da vzgojitelji v primerjavi z osnovnošolskimi učitelji poročajo o višje izraženi depersonalizaciji in nižji osebni izpolnitvi, medtem ko pri čustveni izčrpanosti ne prihaja do razlik med omenjenimi skupinami pedagoških delavcev (Baran idr. 2010). Podobno kažejo rezultati študije na slovenskih strokovnih delavcih v vrtcu, ki v primerjavi z učitelji kot nekoliko stresnejše zaznavajo odnose na delovnem mestu (s sodelavci v skupini in z vodstvom) (Rutar 2019).

\section{Pomanjkanje študij na področju izgorelosti strokovnih delavk v vrtcu}

Nekatere slovenske študije pa poročajo o nasprotujočih si rezultatih v zaznavanju stresa in izgorelosti v vrtcu glede na delovno mesto strokovnih delavk. Tako npr. Slivar (2009) ugotavlja, da vzgojiteljice v primerjavi s pomočnicami vzgojiteljic občutijo več stresa zaradi administrativnih zahtev dela in pomanjkanja podpore pri delu, medtem ko V. Rutar (2019) poroča, da pomočnice vzgojiteljic doživljajo več stresa kot vzgojiteljice zaradi pomanjkanja podpore znotraj vrtcev. O razlikah v poročani stopnji doživljanja stresa in izgorelosti strokovnih delavk glede na starostno skupino, $v$ kateri delajo, pa poroča K. Rentzou (2015), ki je na grškem vzrocu strokovnih delavk v vrtcih ugotovila, da zaposleni, ki delajo $z$ drugo starostno skupino (starost otrok od 3 do 6 let) občutijo višjo čustveno izčrpanost v primerjavi z zaposlenimi, ki delajo s prvo starostno skupino (starost otrok 1 do 3 let). Po drugi strani strokovne delavke pri prvih starostnih skupinah izražajo močnejši občutek depersonalizacije kot vzgojitelji drugih starostnih skupin (Rentzou 2015).

Vzrok za izgorelost je mogoče iskati v prepletu organizacijskih in osebnostnih dejavnikov, zato se med osebnostnimi dejavniki v zvezi z izgorelostjo pedagoških delavcev pogosto preučuje tudi njihova samoučinkovitost.

\section{Samoučinkovitost kot osebnostni dejavnik izgorelosti}

Samoučinkovitost je Bandura (1986) opredelil kot posameznikovo prepričanje o lastnih sposobnostih za učinkovito izvedbo določene aktivnosti. Občutek samoučinkovitosti pedagoškega delavca pomeni prepričanje, da je sposoben na učenje in motivacijo vplivati tudi pri otrocih, ki kažejo malo ali nič zanimanja (Woolfolk Hoy in Davis 2006). Pri samoučinkovitosti ne gre za samopodobo posameznika, saj gre za kognitivno in ne čustveno sodbo o lastni kompetentnosti (Schunk in Pajares 2002). M. Tschannen-Moran in A. Woolfolk Hoy (2001) sta ugotovili, da samoučinkovitost pedagoškega delavca združuje prepričanja o lastnih sposobnostih v okviru treh komponent: (i) poučevanja, 
(ii) motiviranja učencev in (iii) uravnavanja vedenja v razredu. Samoučinkovitost ima še posebej pomembno vlogo, ko se pedagoški delavec sooča s težavami na delovnem mestu, saj tisti z višjim občutkom samoučinkovitosti vlagajo več truda in kljub oviram dlje časa vztrajajo (Tschannen-Moran in Woolfolk Hoy 2001). Študije kažejo, da je prepričanje o višji samoučinkovitosti pedagoškega delavca povezano tudi z ugodnejšimi učnimi izzidi pri učencih (višja motivacija za učenje, učni dosežki in učenčeva lastna prepričanja o samoučinkovitosti, glej Tschannen-Moran in Woolfolk Hoy 2007), saj pedagoški delavci z višjo samoučinkovitostjo ustvarjajo spodbudnejše učno okolje za učenje (Bandura 2006).

Ugodnejše prepričanje o lastnih sposobnostih pa je povezano tudi s pozitivnejšimi psihološkimi posledicami za učitelje, na primer z višjim entuziazmom in večjo predanostjo poklicu (Tschannen-Moran in Woolfolk Hoy 2001). Raziskave namreč konsistentno kažejo (pregled v Aloe, Amo in Shanahan 2014; Skaalvik in Skaalvik 2010) pomembno negativno povezanost med samoučinkovitostjo učiteljev in komponentami izgorelosti, manj konsistentni pa so rezultati o smeri vpliva med konstruktoma. Brouwers in Tomic (2000) sta z longitudinalno študijo ugotovila, da čustvena izčrpanost vpliva na znižanje samoučinkovitosti, ta pa najprej na zmanjšanje osebne izpolnitve in kasneje na dvig depersonalizacije (Depolli Steiner 2011). Vendar so nekatere kasnejše longitudinalne študije pokazale, da samoučinkovitost vpliva na doživljanje izgorelosti in ne obratno (Aloe, Amo in Shanahan 2014; Schwarzer in Hallum 2008): višja samoučinkovitost naj bi v odnosu do izgorelosti nastopala kot zaščitni dejavnik (angl. stress buffer), ker zmanjšuje doživljanje stresa na delovnem mestu in motivira za uporabo učinkovitih strategij spoprijemanja z njim (Schwarzer in Hallum 2008).

Izmed treh zgoraj navedenih dimenzij samoučinkovitosti pedagoškega delavca so bile predhodne študije še posebej osredotočene na povezavo med samoučinkovitostjo na področju uravnavanja vedenja otrok v skupini in izgorelostjo pedagoških delavcev. Ugotovljeno je bilo, da ta dimenzija samoučinkovitosti napoveduje čustveno izčrpanost predvsem takrat, ko je zaznana samoučinkovitost nizka (Dicke idr. 2014). Osebe z nizko samoučinkovitostjo na področju uravnavanja vedenja menijo, da so v manjši meri sposobne nadzorovati skupino v smislu vzpostavljanja discipline, uvajanja pravil, učinkovitega odzivanja na neustrezno vedenje otrok ipd. Pedagoški delavci s temi prepričanji imajo v razredu več nemira in vedenjskih težav otrok, kar verjetno nadalje botruje višji čustveni izčrpanosti (Dicke idr. 2014). Prepričanja glede lastne sposobnosti uravnavanja vedenja $\mathrm{v}$ razredu so $\mathrm{v}$ največji meri povezana s poročano višjo osebno izpolnitvijo, sledi negativna 
povezanost omenjene komponente samoučinkovitosti z depersonalizacijo in čustveno izčrpanostjo (Aloe, Amo in Shanahan 2014; Wang, Hall in Rahimi 2015). Znižana samoučinkovitost, vezana na motiviranje učencev, pa je bila napovednik višje depersonalizacije in višje čustvene izčrpanosti (Wang, Hall in Rahimi 2015).

\section{Izgorelost in samoučinkovitost glede na delovno dobo}

Raziskovalci so preučevali tudi razlike v izgorelosti in samoučinkovitosti pedagoških delavcev glede na delovno dobo pedagoških delavcev. Ugotovljeno je bilo, da mlajši pedagoški delavci dosegajo višjo čustveno izčrpanost v primerjavi s starejšimi (Maslach, Jackson in Leiter 1997), za kar je literaturi navajajo več možnih vzrokov. Tako npr. mlajši zaposleni v primerjavi s starejšimi kot stresnejše zaznavajo več dogodkov na delovnem mestu, saj nekatere študije (npr. Manassero idr. 2006) kažejo, da se starost negativno povezuje $z$ zaznavanjem stresnosti več vidikov dela pedagoškega dela. Kot stresnejše so mlajši pedagoški delavci zaznavali: uravnavanje vedenja otrok, pomanjkanje časa za opravljanje delovnih nalog, neustrezno obnašanje učencev, konflikte z učenci, poučevanje nadomestnih predmetov in doživljanje manjše kompetentnosti, medtem ko so starejši pedagoški delavci kot stresnejši dejavnik zaznavali le obilico admininstrativnega dela na delovnem mestu.

Podobno o razlikah med starostnimi skupinami udeležencev $v$ študiji glede občutka samoučinkovitosti na delovnem mestu poročata tudi M. Tschannen-Moran in A. Woolfolk Hoy (2007), ki ugotavljata, da imajo pedagoški delavci začetniki (do 3 let delovnih izkušenj) nižjo samoučinkovitost (tako splošno samoučinkovitost kot tudi samoučinkovitost za poučevanje in za uravnavanje vedenja) kot pa izkušenejši učitelji (nad 4 leta izkušenj). Razlog naj bi bil v tem, da pedagoški delavci na začetku svoje poklicne poti še nimajo veliko lastnih izkušenj (Javrh 2007; Čotar Konrad in Štemberger 2018), ki predstavljajo enega izmed ključnih virov oblikovanja občutka samoučinkovitosti. Prepričanja o lastni učinkovitosti se namreč razvijajo na podlagi štirih virov: (i) s pomočjo lastnih izkušenj, (ii) preko posrednih izkušenj ( $z$ opazovanjem drugih), (iii) preko povratne informacije s strani drugih (prepričevanje, spodbude, nasveti) ter (iv) preko sovplivanja različnih psihofizičnih stanj (npr. tesnoba, ugodje), ki spremljajo izvedbo aktivnosti. Študija M. Tschannen-Moran in A. Woolfolk Hoy (2007) kaže, da so za učitelje začetnike pomembnejši napovedniki samoučinkovitosti povratne informacije s strani drugih in še vedno manj bogate lastne izkušnje, pri izkušenejših učiteljih pa samoučinkovitost napoveduje predvsem lastna izkušnja.

Slednje ugotovitve o razlikah $v$ stopnji samoučinkovitosti glede na de- 
lovno dobo pedagoških delavcev lahko smiselno utemeljimo tudi skozi modele profesionalnega razvoja učiteljev ${ }^{2}$ oz. modele poklicne rasti učiteljev, ki poteka na dveh medsebojno povezanih ravneh: (i) pojmovanja učitelja (tj. spoznavanje, sprejemanje in ponotranjenje pojmovanj poučevanja in učenja v procesu izkustveno-konstruktivističnega modela pouka) in (ii) učiteljeva ravnanja (pridobivanje in izpopolnjevanje poklicnih spretnosti). Učiteljeva pojmovanja vodijo njegovo akcijo, ki pomeni temeljno izhodišče za refleksijo, ta pa v povratni zanki nadalje ozavešča pojmovanja in izboljšuje pedagoška ravnanja (Marentič Požarnik 200o). Učitelj naj bi se s pridobivanjem izkušenj premikal od manjše k vse večji avtonomnosti, prožnosti in zmožnosti, ob tem pa iz učitelja začetnika postajal učitelj ekspert. Omenjeni proces so opisovali mnogi modeli profesionalnega razvoja učiteljev (več v Čotar Konrad in Štemberger 2018), vendar se bomo mi za namene pričujoče študije osredotočili zgolj na Hubermanov model profesionalnega razvoja (Huberman, Grounauer in Marti 1993) in iz tega izhajajočo slovensko verzijo S-modela profesionalnega razvoja učiteljev (preglednica 1) (podrobneje v Javrh 2007).

Glede na rezultate študij o izgorelosti in občutku samoučinkovitosti lahko sklepamo, da bodo pedagoški delavci prvega obdobja profesionalnega razvoja v primerjavi s kasnejšimi stopnjami profesionalnega razvoja poročali o višji stopnji izgorelosti in nižji stopnji samoučinkovitosti.

\section{Namen in cilji raziskave}

Glavni namen pričujoče študije je bil preveriti stopnjo izgorelosti med pomočnicami vzgojiteljic predšolskih otrok glede na delovno dobo in starostno skupino otrok, s katero delajo. Kot smo že omenili v teoretičnem delu prispevka, ugotavljamo pomanjkanje študij, ki se ukvarjajo z vprašanjem izgorelosti in občutka samoučinkovitosti pomočnic na različnih stopnjah profesionalnega razvoja. Čeprav se morebiti zdi, da so obremenitve na delovnem mestu tako učiteljev kot strokovnih delavk vrtca v nekaterih elementih podobne (interakcija in pričakovanja staršev otrok, sodelavci, soočanje s prevelikimi skupinami/razredi ipd), so zahteve delovnega mesta strokovnih delavk $v$ vrtcu zaradi večje razvojne občutljivosti in relativno manjše samostojnosti predšolskega otroka gotovo drugačne. Ker posledično ocenjujemo, da na osnovi študij izgorelosti učiteljev ne moremo neposredno sklepati na izgorelost in občutek samočinkovitosti strokovnih delavk $v$ vrtcu, smo v okviru raziskave želeli ugotoviti stopnjo izgorelosti in samoučinkovitosti pomočnic

\footnotetext{
${ }^{2}$ Termin »učitelj« je tukaj uporabljen kot generični pojem, s katerim želimo zaobjeti strokovne delavce vrtca in pedagoške delavce osnovnih šol.
} 
Preglednica 1 Prikaz temeljnih značilnosti Hubermanovega in S-modela profesionalnega razvoja učiteljev

\begin{tabular}{|c|c|c|c|}
\hline Hubermanov model & S-model & Usmerjenost & Ravnanja \\
\hline $\begin{array}{l}\text { Vstop v poklic, faza pre- } \\
\text { živetja in odkrivanja ( } 1 \\
\text { do } 3 \text { leta delovnih izku- } \\
\text { šenj). }\end{array}$ & $\begin{array}{l}\text { Preživetje in odkri- } \\
\text { vanje. }\end{array}$ & $\begin{array}{l}\text { Razumevanje te- } \\
\text { meljnih pravil in po- } \\
\text { stopkov. }\end{array}$ & $\begin{array}{l}\text { Togo upošteva na- } \\
\text { vodila: ni občutljiv } \\
\text { na kontekst dogaja- } \\
\text { nja. }\end{array}$ \\
\hline $\begin{array}{l}\text { Poklicna stabilizacija in } \\
\text { utrditev } \\
\text { ( } 4 \text { do } 6 \text { let delovnih iz- } \\
\text { kušenj). }\end{array}$ & Stabilizacija. & $\begin{array}{l}\text { Usmerjenost v kon- } \\
\text { tekst. Razvijanje ce- } \\
\text { lostnega ravnanja. }\end{array}$ & $\begin{array}{l}\text { Od pravil k situaciji: } \\
\text { pri odločanju in rav- } \\
\text { nanju že upošteva } \\
\text { dol. situacijo. }\end{array}$ \\
\hline $\begin{array}{l}\text { Poklicna aktivnost, eks- } \\
\text { perimentiranje ali vno- } \\
\text { vična ocenitev lastnega } \\
\text { dela, negotovost ( } 7 \text { do } \\
18 \text { let delovnih izku- } \\
\text { šenj). }\end{array}$ & $\begin{array}{l}\text { Poklicna } \\
\text { aktivnost/eksperi- } \\
\text { mentiranje ali } \\
\text { negotovost/revizija. }\end{array}$ & $\begin{array}{l}\text { Razvijanje splošnih } \\
\text { principov. }\end{array}$ & $\begin{array}{l}\text { Od situacije k na- } \\
\text { črtu: pri odločanju } \\
\text { in ravnanju ga vodi } \\
\text { splošni načrt. }\end{array}$ \\
\hline $\begin{array}{l}\text { Vedrina, distančni od- } \\
\text { nosi ali konservatizem } \\
\text { (19 do } 30 \text { let delovnih iz- } \\
\text { kušenj). }\end{array}$ & $\begin{array}{l}\text { Kritična odgovor- } \\
\text { nost ali sproščenost } \\
\text { ali nemoč. }\end{array}$ & $\begin{array}{l}\text { Povezovanje izku- } \\
\text { šenj v enovit scena- } \\
\text { rij. }\end{array}$ & $\begin{array}{l}\text { Od načrta k intuiciji: } \\
\text { pri odločanju in rav- } \\
\text { nanju ga vodi intui- } \\
\text { cija. }\end{array}$ \\
\hline $\begin{array}{l}\text { Poklicno slovo, ki se } \\
\text { kaže kot vedrina in } \\
\text { umirjenost ali zagrenje- } \\
\text { nost ( } 31 \text { do } 40 \text { let delov- } \\
\text { nih izkušenj). }\end{array}$ & $\begin{array}{l}\text { Izpreganje - spro- } \\
\text { ščeno ali zagre- } \\
\text { njeno. }\end{array}$ & $\begin{array}{l}\text { Oblikovanje prede- } \\
\text { lane in požlahtnjene } \\
\text { intuicije. }\end{array}$ & $\begin{array}{l}\text { Akcija in situacija } \\
\text { pomenita enako. }\end{array}$ \\
\hline
\end{tabular}

Opombe Povzeto po Javrh (2007) ter Čotar Konrad in Štemberger (2018).

pri prvi in pomočnic pri drugi starostni skupini otrok. Ob tem nas je zanimalo tudi, ali obstajajo razlike glede na stopnjo izgorelosti in občutek samoučinkovitosti glede na delovno dobo/stopnjo profesionalega razvoja pomočnic vzgojiteljic predšolskih otrok.

\section{Metodologija}

\section{Vzorec}

V študiji je sodelovalo 183 pomočnic vzgojitelja predšolskih otrok, od tega 174 $(95,1 \%)$ pomočnic in $9(4,9 \%)$ pomočnikov vzgojiteljev predšolskih otrok, $s$ povprečno starostjo 29,17 let ( $v$ razponu od 20 do 49 let). Vsi obiskujejo študijski program Predšolska vzgoja Pedagoške fakultete Univerze na Primorskem. Struktura vzorca glede na delovno dobo na področju predšolske vzgoje je glede na modela profesionalnega razvoja prikazana $v$ preglednici 2. Vključeni udeleženci pa so bili v šolskem letu 2018/2019 zaposleni kot delavci z 
Preglednica 2 Struktura vzorca udeležencev študije glede na stopnje profesionalnega razvoja po Huberman, Grounauer in Marti (1993), Čotar Konrad in Štemberger (2018) in po slovenskem S-modelu (Javrh 2007)

\begin{tabular}{llr}
\hline Hubermanov model & S-model & $f(\%)$ \\
\hline $\begin{array}{l}\text { Vstop v poklic, faza preživetja in odkrivanja (1 } \\
\text { do } 3 \text { leta delovnih izkušenj). }\end{array}$ & Preživetje in odkrivanje. & $88(48,1)$ \\
\hline $\begin{array}{l}\text { Poklicna stabilizacija in utrditev (4 do 6 let de- } \\
\text { lovnih izkušenj). }\end{array}$ & Stabilizacija. & $26(14,2)$ \\
\hline $\begin{array}{l}\text { Poklicna aktivnost, eksperimentiranje ali vno- } \\
\text { vična ocenitev lastnega dela, negotovost (7 }\end{array}$ & $\begin{array}{l}\text { Poklicna aktiv- } \\
\text { nost/eksperimentiranje ali } \\
\text { do 18 let delovnih izkušenj). }\end{array}$ & $61(33,3)$ \\
\hline $\begin{array}{l}\text { Vedrina, distančni odnosi ali konservatizem } \\
\text { (19 do 30 let delovnih izkušenj). }\end{array}$ & $\begin{array}{l}\text { Kritična odgovornost ali spro- } \\
\text { ščenost ali nemoč. }\end{array}$ & $8(4,4)$ \\
\hline $\begin{array}{l}\text { Poklicno slovo, ki se kaže kot vedrina in umir- } \\
\text { jenost ali zagrenjenost (31 do 40 let delovnih }\end{array}$ & $\begin{array}{l}\text { Izpreganje - sproščeno ali za- } \\
\text { grenjeno. }\end{array}$ & \\
izkušenj). & & \\
\hline
\end{tabular}

različnimi starostnimi skupinamo, od tega jih je bilo dobra tretjina v prvi (69; $37,7 \%)$ in nekoliko več v drugi starostni skupini 81 (44,3\%), preostali udeleženci v vrtcu niso bili zaposleni trenutno (33; 18,0\%), ampak v prejšnjih šolskih letih.

\section{Pripomočki}

Izgorelost na delovnem mestu. Vprašalnik izgorelosti (Maslach Burnout Inventory - prirejeno po Maslach in Jackson 1981) je sestavljen iz 22 trditev, ki se nanašajo na izgorelost na delovnem mestu, in vključuje tri dimenzije: čustveno izčrpanost ( $v$ nadaljevanju $\breve{C})$, odtujen odnosa do dela (tj. depersonalizacija, v nadaljevanju D) in zmanjšane osebne izpolnjenosti ( $v$ nadaljevanju OI). Udeleženci na vprašalniku s pomočjo 7-stopenjske lestvice pogostosti (o - nikoli; 1 - nekajkrat na leto; 2 - enkrat na mesec; 3 - nekajkrat na mesec; 4 enkrat na teden; 5 - nekajkrat na teden; 6 - vsak dan) označijo, kako pogosto doživijo ali občutijo posamezne situacije. Glede na različne predhodne študije (npr. Demerouti idr., 2001;) vprašalnik kaže zadovoljivo zanesljivost in veljavno faktorsko strukturo vprašalnika, podobno velja za psihometrične značilnosti slovenske verzije vprašalnika (Depolli Steiner 2011). Koeficienti notranje skladnosti pričujoče študije za čustveno izčrpanost znašajo o,95, za depresonalizacijo o,84, za podlestvico osebne izpolnjenosti pa 0,92.

Samoučinkovitost na delovnem mestu. V študiji smo uporabili krajšo verzijo Lestvice samoučinkovitosti učiteljev (Teacher's sense of efficacy scale TSES, Tschannen-Moran in Woolfolk-Hoy 2001; slovenska verzija Čotar Konrad 
2015), ki meri tri komponente samoučinkovitosti: instrumentalno učinkovitost, učinkovito uravnavanje vedenja strokovnih delavcev $v$ skupini otrok in učinkovitost pri motiviranju otrok za učenje. Notranja zanesljivost lestvice iz slovenskih predhodnih študij (Čotar Konrad 2015) kaže zadovoljive vrednosti notranje skladnosti $(0,86)$, pri čemer se koeficienti notranje zanesljivosti posameznih komponent lestvice gibljejo od o,78 do o,81.

\section{Postopek in obdelava podatkov}

Spletno obliko baterije testov smo pripravili v novembru 2018 in jo poslali na skupni spletni naslov udeležencev, ki jim je bila ves čas raziskave zagotovljena anonimnost. Vprašalnik je bil dostopen dva meseca. Pridobljene podatke smo obdelali s statističnim paketom SPSS 25.0. Najprej smo analizirali deskriptivne vrednosti podatkov in preverjali normalnost njihove porazdelitve. Analiza normalnosti porazdelitve odgovorov na posameznih podlestvicah je pokazala, da porazdelitev ni normalna, zato smo v nadaljevanju za ugotavljanje razlik glede na delovno dobo strokovnih delavk in glede na skupino, v kateri delujejo, uporabljali neparametrične teste. Povezanost posameznih dimenzij izgorelosti in komponent zaznanega občutka učinkovitosti na delovnem mestu smo preverjali s Spearmanovim $\rho$ koeficientom.

\section{Rezultati in razprava}

Glavni namen študije je bil preveriti stopnjo izgorelosti in občutka samoučinkovitosti strokovnih delavk v vrtcu ter medsebojno povezanost omenjenih konceptov. Nadalje pa nas je zanimalo, ali obstajajo razlike v poročani stopnji izgorelosti in samoučinkovitosti strokovnih delavk glede na delovno dobo (in s tem ustrezno stopnjo profesionalnega razvoja po Huberman, Grounauer in Marti 1993) ter glede na starostno skupino otrok, s katerimi trenutno delajo.

Najprej smo preverili opisne statistike in normalnost distribucij posameznih merjenih spremenljivk (preglednica 3). Rezultati izraženosti posameznih dimenzij izgorelosti kažejo, da strokovne delavke v povprečju poročajo o nizki stopnji čustvene izčrpanosti in depersonalizacije ter o visoki stopnji osebne izpolnjenosti na delovnem mestu. Takšna izraženost posameznih dimenzij izgorelosti nakazuje, da pomočnice v povprečju poročajo o nizki izgorelosti. Dobljeni podatki se ne ujemajo s predhodnimi študijami na vzorcih pedagoških delavcev (npr. Radic Hozo, Sucic in Zaja 2015; Depolli Steiner 2011), ki kažejo na visok odstotek (okrog 50 \%) pedagoških delavcev, ki občutijo ali kažejo znake izgorelosti. Skladno z raziskavo K. Depolli Steiner (2011) o učiteljih tudi pomočnice vzgojiteljic našega vzorca depersonalizacijo doživljajo zelo redko. Izredno nizka samoocena na lestvici depersonalizacije pri 
Preglednica 3 Opisne statistike dimenzij izgorelosti in samoučinkovitosti

\begin{tabular}{lrrrrrrrrrrr}
\hline Dimenzija & & $N$ & Min & Max & $M$ & $s$ & $A s$ & $s$ & $S p l$ & $s$ & $K S$ \\
\hline Izgorelost & $(1)$ & 183 & 0,00 & 4,67 & 1,38 & 1,03 & 0,96 & 0,18 & 0,28 & 0,36 & $0,13^{* * *}$ \\
& $(2)$ & 183 & 1,75 & 6,00 & 4,75 & 0,92 & $-0,84$ & 0,18 & 0,48 & 0,36 & $0,09^{* *}$ \\
& $(3)$ & 183 & 0,00 & 3,00 & 0,35 & 0,56 & 2,22 & 0,18 & 5,31 & 0,36 & $0,28^{* * *}$ \\
\hline Samoučin- & $(4)$ & 183 & 2,75 & 5,00 & 4,05 & 0,47 & 0,06 & 0,18 & $-0,21$ & 0,36 & $0,15^{* * *}$ \\
kovitost & $(5)$ & 183 & 3,00 & 5,00 & 4,06 & 0,49 & 0,08 & 0,18 & $-0,26$ & 0,36 & $0,21^{* * *}$ \\
& $(6)$ & 183 & 3,00 & 5,00 & 3,95 & 0,50 & 0,40 & 0,18 & $-0,41$ & 0,36 & $0,15^{* * *}$
\end{tabular}

Opombe Naslovi vrstic: (1) čustvena izčrpanost, (2) osebna izpolnjenost, (3) depersonalizacija, (4) instrumentalna, (5) uravnavanje vedenja, (6) motivacija. $N$ - numerus; $M$ - aritmetična sredina; s - standardna deviacija, Min/max - najnižja in najvišja vrednost; $A s$ - asimetričnost; Spl - sploščenost; KS - Kolmogorov-Smirnov koeficient; ${ }^{* *}$ koeficient KS je statistično pomemben na nivoju $p<0.01 ;{ }^{* *}$ koeficient KS je statistično pomemben na nivoju $p<0.001$.

populaciji pedagoških delavcev ni povsem nepričakovana, saj nekateri raziskovalci opozarjajo, da učitelji postavke na tej lestvici zaznavajo kot manj primerne ter se zato skušajo izogniti odgovarjanju ali podajajo bolj socialno zaželene odgovore in so rezultati zato pogosto omejeni (Benita, Butler in Shibaz 2019). V primeru uporabe drugih vprašalnikov so raziskovalci (Benita, Butler in Shibaz 2019) na lestvici depersonalizacije dobili bolj razpršene rezultate.

Po drugi strani pa analize podatkov kažejo (preglednica 3) na visoko stopnjo samoučinkovitosti na področju instrumentalne učinkovitosti in učinkovitega uravnavanja vedenja otrok v skupini; pomočnice izražajo nekoliko nižjo kompetentnost pri motivaciji otrok za učenje v dejavnostih. To pomeni, da pomočnice poročajo o tem, da učinkovito znajo in zmorejo otrokom podati alternativne razlage o pojavu, ki ga ne razumejo, da se čutijo kompetentne pri implementaciji alternativnih strategij poučevanja v skupini. Podobno poročajo visoko stopnjo samoučinkovitoti na področju uravnavanja in usmerjanja vedenja otrok v skupini ali umirjanja otroka, ki je bodisi nemiren ali se drugače neustrezno vede. O nekoliko nižji kompetentnosti pomočnice poročajo na področju spodbujanja otrokove motivacije za delo, pri čemer se ocenjujejo kot manj sposobne motivirati otroka, ki za sodelovanje kaže manj interesa, oz. otroka, ki manj zaupa v lastne sposobnosti.

Povezanost posameznih dimenzij izgorelosti in komponent zaznanega občutka učinkovitosti na delovnem mestu pokaže (glej preglednico 4) pomembno povezanost med vsemi merjenimi variablami. Ugotavljamo lahko, da strokovne delavke, ki poročajo o višji stopnji osebne izpolnitve na delovnem mestu, poročajo o višjem občutku učinkovitosti tako na področju pomoči in izvedbe dejavnosti (instrumentalna komponenta) kot tudi na pod- 
Preglednica 4 Povezanost med dimenzijami izgorelosti in komponentami samoučinkovitosti

\begin{tabular}{|c|c|c|c|}
\hline \multirow[t]{2}{*}{ Izgorelost } & \multicolumn{3}{|c|}{ Samoučinkovitost } \\
\hline & Inštrumentalnost & Uravnavanje vedenja & Motivacija \\
\hline Čustvena izčrpanost & $-0,257^{* *}$ & $-0,231^{* *}$ & $-0,205^{* *}$ \\
\hline Osebna izpolnjenost & $0,535^{* *}$ & $0,394^{* *}$ & $0,384^{* *}$ \\
\hline Depersonalizacija & $-0,276^{* *}$ & $-0,197^{* *}$ & $-0,273^{* *}$ \\
\hline
\end{tabular}

Opombe ${ }^{* *}$ Spearmanov $\rho$ koeficient statistično pomemben na nivoju $p<0.01$.

ročju uravnavanja vedenja otrok $v$ skupini (komponenta uravnavanja vedenja $v$ skupini) in motiviranja otrok za sodelovanje v dejavnostih ter učenju. Rezultati niso presenetljivi, saj sta si konstrukta samoučinkovitosti in osebne izpolnitve $v$ določeni meri sorodna in medsebojno povezana.

Kot poročajo mnoge študije (Aloe, Amo in Shanahan 2014; Dicke idr. 2014; Skaalvik in Skaalvik 2010), tudi rezultati dotične raziskave (preglednica 4) potrjujejo negativno pomembno povezanost med samoučinkovitostjo in ključnima pokazateljema izgorelosti posameznika, torej čustveno izčrpanostjo in depersonalizacijo. Ugotavljamo namreč nizko do zmerno negativno pomembno povezanost med dimenzijo čustvene izčrpanosti in vsemi komopnentami samoučinkovitosti. Podoben vzorec povezanosti lahko razberemo tudi med komponentami samoučinkovitosti in depersonalizacije, kar pomeni, da strokovne delavke, ki poročajo o višjem občutku odtujenosti od dela, pomembno pogosteje poročajo o nižji stopnji samoučinkovitosti na delovnem mestu. Prav tako je vzorec korelacij med dimenzijami samoučinkovitosti in izgorelosti zelo podoben povezavam predhodnih študij, kjer so ugotovili, da se dimenzije samoučinkovitosti v najvišji meri povezujejo z osebno izpolnjenostjo, $v$ najnižji pa s čustveno izčrpanostjo (Wang, Hall in Rahimi 2015). Manjše odstopanje od predhodnih študij (Aloe, Amo in Shanahan 2014; Wang, Hall in Rahimi 2015), ki pa so bile izvedene na učiteljih, je v tem, da se samoučinkovitost glede uravnavanja vedenja $v$ našem primeru močneje povezuje $s$ čustveno izčrpanostjo kot pa $z$ depersonalizacijo. Slednje pomeni, da strokovne delavke v primerjavi z učitelji z morebitno nižjo stopnjo občutka samoučinkovitosti na področju uravnavanja vedenja otrok pogosteje poročajo predvsem o lastni čustveni izčrpanosti in manj pogosto o depersonalizaciji, tj. občutku oddaljenosti od otrok, povečani ciničnosti in zaznavanju otrok le še kot objektov. Čeprav je naša raziskava korelacijska in ne dopušča interpetacije o smeri vpliva med samoučinkovitostjo in izgorelostjo, pa iz predhodnih longitudinalnih raziskav (Schwarzer in Hallum 2008) vemo, da je samoučinkovitost zaščitni dejavnik in napovednik izgorelosti. 
Nizka stopnja izgorelosti v našem vzorcu se zato smiselno povezuje $z$ visoko izraženostjo vseh treh komponent samoučinkovitosti.

$V$ nadaljevanju nas je zanimalo, ali obstajajo razlike $v$ stopnji izgorelosti in poročani stopnji samoučinkovitosti glede na delovno dobo na področju predšolske vzgoje. Udeležence študije smo glede na delovno dobo razdelili v skupine profesionalnega razvoja glede na Hubermanov in S-model (Javrh 2007), in sicer so bile v raziskavo vključene štiri skupine: (i) skupina začetnikov $v$ t. i. preživetveni fazi in fazi odkrivanja, ki šele vstopa na področje vzgoje in izobraževanja (o-3 leta delovne dobe); (ii) skupina $v$ fazi stabilizacije $v$ poklicu (4-6 let delovne dobe); (iii) skupina v fazi aktivnega eksperimentiranja - negotovosti (7-18 let delovne dobe) in (iv) skupina sproščenosti v poklicu - občutka nemoči (19-30 let delovne dobe). V preglednici 5 prikazujemo razlike v dimenijah izgorelosti in občutka samoučinkovitosti glede na delovno dobo. Zaradi premajhnega števila pomočnic z najdaljšo delovno dobo, te skupine $v$ interpretacijo ne bomo zajeli.

Rezultati kažejo (preglednica 5), da pomočnice ne poročajo o različni stopnji izgorelosti na delovnem mestu, ampak se razlike glede na delovno dobo v profesionalnem delovanju kažejo pri dveh komponentah samoučinkovitosti. Tako ugotavljamo, da o najvišji stopnji instrumentalne samoučinkovitosti poročajo strokovne delavke $v$ fazi poklicne stabilizacije, kar pomeni, da se $v$ primerjavi z drugimi strokovnimi delavkami ocenjujejo kot kompetentnejše na področju uporabe različnih strategij za spremljanje otrokovega napredka in poznavanja različnih načinov dela z otroki. Glede na vzorec dotične študije (pomočnice vzgojiteljic) težko govorimo o samostojnem načrtovanju in izvajanju dejavnosti, saj delovno mesto pomočnice vzgojiteljic predšolskih otrok tega ne zahteva, gotovo pa lahko trdimo, da strokovne delavke $v$ stadiju stabilizacije pogosteje kot strokovne delavke $v$ začetnem stadiju (do 3 let delovne dobe) profesionalnega razvoja poročajo o poznavanju in rabi različnih strategij spremljanja otrokovega napredka in spodbujanja njegovega učenja. Podoben vzorec razlik med skupinama o oceni samoučinkovitosti strokovnih delavk ugotavljamo tudi pri zaznani kompetentnosti na področju motiviranja otrok za učenje. Tako o najvišji stopnji samoučinkovitosti na področju motivacije poročajo strokovne delavke v obdobju poklicne stabilizacije, nato v obdobju eksperimentiranja na poklicnem področju, kot najmanj kompetentne pa se na področju motiviranja otrok za učenje zaznavajo novinke pomočnice vzgojitelja predšolskih otrok (preglednica 5). Na osnovi omenjenega lahko sklepamo, da je ključno vprašanje, kateri dejavniki vplivajo na oblikovanje samoučinkovitosti ob koncu študija in na začetku kariere. Kot so pokazale raziskave (Tscahnnen-Moran in Woolfolk Hoy 2007), se namreč zaradi 
Preglednica 5 Razlike $v$ dimenzijah izgorelosti in samoučinkovitosti glede na delovno dobo strokovnih delavk

\begin{tabular}{|c|c|c|c|c|c|c|}
\hline Dimenzija & & Del. doba (let) & $N$ & $\overline{\bar{R}}$ & $H$ & $p$ \\
\hline \multirow[t]{12}{*}{ Izgorelost } & \multirow[t]{4}{*}{ Čustvena izčrpanost } & $0-3$ & 88 & 94,93 & 3,50 & 0,32 \\
\hline & & $4-6$ & 26 & 74,15 & & \\
\hline & & $7-18$ & 61 & 94,44 & & \\
\hline & & $19-30$ & 8 & 99,13 & & \\
\hline & \multirow[t]{4}{*}{ Osebna izpolnjenost } & $0-3$ & 88 & 91,71 & 0,15 & 0,99 \\
\hline & & $4-6$ & 26 & 89,06 & & \\
\hline & & $7-18$ & 61 & 93,24 & & \\
\hline & & $19-30$ & 8 & 95,31 & & \\
\hline & \multirow[t]{4}{*}{ Depersonalizacija } & $0-3$ & 88 & 94,99 & 1,35 & 0,72 \\
\hline & & $4-6$ & 26 & 82,23 & & \\
\hline & & $7-18$ & 61 & 91,81 & & \\
\hline & & $19-30$ & 8 & 92,31 & & \\
\hline \multirow{12}{*}{$\begin{array}{l}\text { Samoučin- } \\
\text { kovitost }\end{array}$} & \multirow[t]{4}{*}{ Instrumentalna } & $0-3$ & 88 & 81,76 & 8,29 & $0,04^{*}$ \\
\hline & & $4-6$ & 26 & 112,08 & & \\
\hline & & $7-18$ & 61 & 98,62 & & \\
\hline & & $19-30$ & 8 & 88,94 & & \\
\hline & \multirow[t]{4}{*}{ Uravnavanje vedenja } & $0-3$ & 88 & 84,34 & 6,93 & 0,07 \\
\hline & & $4-6$ & 26 & 104,46 & & \\
\hline & & $7-18$ & 61 & 100,87 & & \\
\hline & & $19-30$ & 8 & 68,19 & & \\
\hline & \multirow[t]{4}{*}{ Motivacija } & $0-3$ & 88 & 76,94 & 15,80 & $0,001^{*-*}$ \\
\hline & & $4-6$ & 26 & 115,10 & & \\
\hline & & $7-18$ & 61 & 104,29 & & \\
\hline & & $19-30$ & 8 & 88,94 & & \\
\hline
\end{tabular}

Opombe $N$-numerus; $\bar{R}$ - povprečni rang; $H$ - Kruskal-Wallisov test; ${ }^{*}$ razlika je statistično pomembna na nivoju 0,$05 ;{ }^{* *}$ razlika je statistično pomembna na nivoju o,01.

pomanjkanja lastnih izkušenj na začetku kariere pri oblikovanju občutka samoučinkovitosti začetnik močneje opira na druge vire, kot so npr. posredne izkušnje z opazovanjem drugih, občutja ob izvajanju dejavnosti ter prejeta povratna informacija in spodbuda s strani drugih (npr. starši, sodelavci, vodstvo). Ker začetna samoučinkovitost vpliva na nadaljnje vedenje in pridobivanje izkušenj pedagoškega delavca (npr. koliko vztraja, vlaga trud in ali pri reševanju problemov na delovnem mestu išče nove rešitve ipd.), omenjeno vedno znova vodi v potrjevanje obstoječih prepričanj o lastni učinkovitosti. Na tem mestu je torej pomembno razmisliti tudi o vprašanju praktičnega usposabljanja, pomenu vpliva mentorstva ter začetnih izkušenj, ki jih strokovne 
Preglednica 6 Razlike $v$ dimenzijah izgorelosti in samoučinkovitosti glede na starostno skupino otrok, v kateri strokovne delavke trenutno delujejo

\begin{tabular}{llllrrr}
\hline Dimenzija & & Skupina & $N$ & $\bar{R}$ & $U$ & $p$ \\
\hline Izgorelost & Čustvena izčrpanost & Prva & 69 & 64,67 & 3707,00 & 0,06 \\
& & Druga & 81 & 84,73 & & \\
\cline { 2 - 7 } & Osebna izpolnjenost & Prva & 69 & 83,10 & 3831,00 & 0,77 \\
& & Druga & 81 & 69,02 & & \\
\cline { 2 - 7 } & Depersonalizacija & Prva & 69 & 68,68 & 3942,00 & 0,98 \\
& & Druga & 81 & 81,31 & & \\
\hline Samoučin- & Instrumentalna & Prva & 69 & 80,36 & 3553,50 & 0,27 \\
\cline { 3 - 7 } & & Druga & 81 & 71,36 & & \\
\cline { 2 - 7 } & Uravnavanje vedenja & Prva & 69 & 76,48 & 3582,50 & 0,30 \\
& & Druga & 81 & 74,67 & & \\
\cline { 2 - 7 } & Motivacija & Prva & 69 & 77,78 & 3208,00 & $0,03^{*}$ \\
& & Druga & 81 & 73,56 & & \\
\hline
\end{tabular}

Opombe $N$-numerus; $\bar{R}$ - povprečni rang; $U$-Mann-Whitneyev koeficient; ${ }^{*}$ razlika je statistično pomembna na nivoju 0,05.

delavke začetnice pridobijo na delovnem mestu. Menimo namreč, da bi prav sistematično in visoko strokovno vodeno ter izvedeno praktično usposabljanje bodočih strokovnih delavk $v$ vrtcu lahko pomembno olajšalo in pripomoglo $k$ višjemu občutku samoučinkovitosti na delovnem mestu ter zmanjševalo možnosti za izgorelost strokovnih delavk.

V okviru tretjega raziskovalnega vprašanja smo ugotavljali razliko v poročani stopnji izgorelosti in občutkom samoučinkovitosti glede na to, v kateri starostni skupini otrok trenutno delujejo strokovne delavke.

Analiza dimenzij izgorelosti pokaže, da v stopnji izgorelosti ni statistično pomembnih razlik glede na to, $s$ katero starostno skupino trenutno delajo strokovne delavke, opazimo pa lahko nakazan trend $v$ dimenziji čustvene izčrpanosti, pri čemer pomočnice pri delu z drugo starostno skupino izražajo večjo stopnjo čustvene izčrpanosti kot pomočnice pri delu s prvo. Podobno poročajo tudi predhodne študije (Rentzou 2015), ki pravijo, da strokovne delavke v drugi starostni skupini občutijo višjo čustveno izčrpanost kot strokovne delavke $v$ prvi.

Analiza dimenzij samoučinkovitosti pa pokaže (preglednica 6) razlike zgolj $v$ eni komponenti samoučinkovitosti, natančneje $v$ tem, $v$ kolikšni meri se strokovne delavke čutijo kompetentne vzpodbujati in ohranjati motivacijo otrok za učenje. Ugotavljamo, da strokovne delavke, ki so trenutno zaposlene v prvi starostni skupini, poročajo o višjem občutku kompetentnosti za 
vzpostavljanje in spodbujanje motivacije otrok za učenje. Slednje pomeni, da sebe ocenjujejo kot sposobnejše za to, da otroke spremljajo in pohvalijo ob dobro opravljenih nalogah, da otrokom osmislijo učenje in posledično krepijo njihov interes za učenje ter sodelovanje v pripravljenih dejavnostih.

\section{Sklepi}

V raziskavi smo preučevali izraženo stopnjo izgorelosti na delovnem mestu in občutka samoučinkovitosti, pri čemer so nas zanimale razlike $v$ merjenih konceptih med pomočnicami vzogjiteljic, ki delajo z različnimi starostnimi skupinami otrok, ter razlike glede na stopnjo profesionalnega razvoja strokovnih delavk. Rezultati kažejo, da je poročana stopnja izgorelosti razmeroma nizko izražena, saj pomočnice kažejo visoko stopnjo osebne izpolnitve na delovnem mestu ter nižjo stopnjo čustvene izčrpanosti in depersonalizacije, ugotavljamo pa lahko trend, ki se nakazuje $v$ dimenziji čustvene izrpanosti pomočnic, ki delajo z drugo starostno skupino. Iz omenjenega lahko sklepamo, da bi bilo smiselno in potrebno - upoštevajoč spoznanje, da je preučevanje izgorelosti zaposlenih na predšolski stopnji v Sloveniji empirično močno podhranjeno - podrobneje preučiti vprašanje dejavnikov izgorelosti strokovnih delavk v vrtcih. Dejstvo je namreč, da je koncept izgorelosti bistveno kompleksnejši kot zgolj merjenje posameznih dimenzij, ki nakazujejo posameznikovo izčrpanost. V raziskavi nismo preučevali organizacijskih dejavnikov, ki skupaj z osebnostnimi dimenzijami pomembno sovplivajo na doživljanje komponent izgorelosti (Benita, Butler in Shibaz 2019; Maslach, Schaufeli in Leiter 2001). Kot poudarja C. Maslach (2003), pa bi se bilo potrebno na sistemskem nivoju usmeriti ne le $v$ zmanjševanje izgorelosti, temveč predvsem $v$ opolnomočenje strokovnih delavk in podporo za doseganje dimenzije osebne izpolnjenosti na delovnem mestu, torej občutka moči, učinkovitosti in predanosti nalogam na delovnem mestu. Ena izmed ključnih dimenzij doseganja osebne izpolnjenosti je tudi visok občutek samoučinkovitosti na delovnem mestu, ki ga je podobno kot koncept izgorelosti potrebno obravnavati celostno (Fakler in Malmberg 2016). Pomočnice $v$ dotični študiji namreč poročajo o razmeroma visokem občutku samoučinkovitosti, pri čemer se kažejo razlike glede dimenzije učinkovitega motiviranja otrok za dejavnosti: pomočnice, ki delujejo v prvi starostni skupini, ugodneje ocenjujejo občutek samoučinkovitosti na področju spodbujanja motivacije otrok kot pomočnice $v$ drugi starostni skupini. Poročana samoučinkovitost je različna tudi glede na stopnjo profesionalnega razvoja strokovnih delavk, pri čemer pomočnice $v$ začetni fazi (do 3 leta delovne dobe) občutijo najnižjo samoučinkovitost, pomočnice $v$ fazi poklicne stabilizacije pa najvišjo 
stopnjo samoučinkovitosti na delovnem mestu. Iz omenjenega lahko sklepamo, da je pri oblikovanju občutka samoučinkovitosti na delovnem mestu ključnega pomena prepoznavati vire, na osnovi katerih pomočnice na različnih stopnjah profesionalnega razvoja in pri opravljanju delovnih nalog z različnimi starostnimi skupinami oblikujejo prepričanja o lastnih sposobnostih na delovnem mestu. Eden ključnih momentov v tem razvoju je prepoznavanje pomena prakse ob zaključku šolanja in mentoriranja pomočnic začetnic ob vstopanju na delovno mesto.

\section{Literatura}

Al-Adwan, F., E. Zaid in M. M. Al-Khayat. 2017. „Psychological Burnout in Early Childhood Teachers: Levels and Reasons." International Education Studies 10 (1): 179-189.

Aloe, A. M., L. C. Amo in M. E. Shanahan. 2014. "Classroom Management SelfEfficacy and Burnout: A Multivariate Meta-Analysis."Educational Psychology Review 26:101-126.

Bandura, A. 1986. Social Foundation of Thought and Action: A Social Cognitive Theory. Englewood Cliffs, NJ: Prentice Hall.

- 2006. »Adolescent Development from an Agentic Perspective.« V SelfEfficacy Beliefs of Adolescents, ur. T. Urdan in F. Pajeres, 1-44. Greenwich, CT: Information Age Publishing.

Bakker, A. M., E. Demerouti in W. B. Schaufeli. 2002. "Validation of the Maslach Burnout Inventory - General Survey: An Internet Study across Occupations." Anxiety, Stress, and Coping 15:245-260.

Baran, G., M. Y. Biçakçi, F. Inci, M. Öngör, A. Ceran in G. Atar. 2010. »Analysis of Burnout Levels of Teachers."Procedia Social and Behavioral Sciences 9:975980.

Benita, M., R. Butler in L. Shibaz. 2019. „Outcomes and Antecedents of Teacher Depersonalization: The Role of Intrinsic Orientation for Teaching. « Journal of Educational Psychology 111 (6): 1103-1118.

Brouwers, A., in W. Tomic. 2000. »A Longitudinal Study of Teacher Burnout and Perceived Self-Efficacy in Classroom Management."Teaching and Teacher Education 16:239-253.

Čotar Konrad, S. 2015. „Validacija nove lestvice profesionalnega razvoja pedagoškega delavca.«Pedagoška obzorja 30 (3-4): 118-135.

Čotar Konrad, S., in T. Štemberger. 2018. Children Matter: Empowering Teachers for Generations to Come. Schriften zur pädagogischen Psychologie 70. Hamburg: Kovač.

Demšar, I. 2003. »Sindrom izgorelosti pri učiteljih.« Magistrsko delo, Univerza v Ljubljani.

Depolli Steiner, K. 2011. »lzgorelost osnovnošolskih učiteljev.« Vzgoja in izobraževanje 42 (4): 72-32. 
Dicke, T., H. W. Marsh, P. D. Parker, M. Kunter, A. Schmeck in D. Leutner. 2014. "Self-Efficacy in Classroom Management, Classroom Disturbances, and Emotional Exhaustion: A Moderated Mediation Analysis of Teacher Candidates." Journal of Educational Psychology 106 (2): 569-583.

Fakler, S., in L. Malmberg. 2016. »Teachers' Self-Efficacy in 14 OECD Countries: Teacher, Student Group, School and Leadership Effects."Teaching and Teacher Education 56:185-195.

Huberman, M., M. Grounauer in J. Marti. 1993. The Lives of Teachers. London: Cassell.

Javrh, P. 2007. »Fazni model razvoja kariere slovenskih učiteljev.« Sodobna pedagogika 58 (5): 68-87.

Jeon, L., C. K. Buettner in A. A. Grant. 2018. »Early Childhood Teachers' Psychological Well-Being: Exploring Potential Predictors of Depression, Stress, and Emotional Exhaustion.« Early Education and Development 29 (1): 53-69.

Košir, K., M. Licardo, S. Tement in K. Habe. 2014. »Doživljanje stresa in izgorelosti, povezanih z delom z učenci s posebnimi potrebami pri učiteljih v osnovni šoli.«Psihološka obzorja 23:110-124.

Manassero, M. A., E. Garcia Buades, G. Torrens, C. Ramis, A. Vazquez in V. A. Ferrer 2006. »Teacher Burnout: Attributional Aspects. Psychology in Spain 10 (1): 66-74.

Marentič Požarnik, B. 2000. Psihologija učenja in pouka. Ljubljana: DZS.

Maslach, C. 2003. Burnout: The Cost of Caring. Cambridge: Malor Books.

Maslach, C., in M. Leiter. 1997. The Truth about Burnout. San Fracisco: JosseyBass.

Maslach, C., in S. E. Jackson. 1981. »The Measurement of Experienced Burnout.« Journal of Organizational Behaivor 2 (2): 99-113.

Maslach, C., S. E. Jackson in M. P. Leiter. 1997. »Maslach Burnout Inventory.« In Evaluating Stress: A Book of Resources, ur. C. P. Zalaquett in R. J. Wood, 191218. Lanham, MD: Scarecrow Education.

Maslach, C., W. B. Schaufeli in M. P. Leiter. 2001. »Job Burnout.« Annual Review of Psychology 52 (1): 397-422.

Radic Hozo, E., G. Sucic in I. Zaja. 2015. »Burnout Syndrome Among Educators in Pre-School Education.«Materia Sociomedica 27 (6): 399-403.

Rentzou, K. 2015. »Prevalence of Burnout Syndrome of Greek Child Care Workers and Kindergarten Teachers." Education 3-13 43 (3): 249-262.

Rutar, S. 2018. »Kakovost šole s perspektive učencev s priseljensko izkušnjo kot izhodišče za zagotavljanje inkluzivnega izobraževanja." Dve domovini: razprave o izseljenstvu 48:109-127.

Rutar, V. 2019. »Zaznavanje in posledice stresa pri vzgojiteljih in učiteljih v slovenskih vzgojno-izobraževalnih ustanovah: doktorska disertacija.« Doktorska disertacija, Univerza na Primorskem.

Schunk, D. H., in F. Pajares. 2002. »The Development of Academic Self-Efficacy.« 
V Development of Achievement Motivation, ur. A. Wigfield in J. S. Eccles, 1531. San Diego, CA: Academic Press.

Schwarzer, R., in S. Hallum. 2008. »Perceived Teacher Self-Efficacy as a Predictor of Job Stress and Burnout: Mediation Analyses. « Applied Psychology 57:152171.

Skaalvik, E. M., in S. Skaalvik. 2010. »Teacher Self-Efficacy and Teacher Burnout: A Study of Relations." Teaching and Teacher Education 26:1059-1069.

Slivar, B. 2009. Raziskava o poklicnem stresu pri slovenskih vzgojiteljih in učiteljih. Ljubljana: SVIZ.

_ 2013. Na poti k dobremu počutju: obvladovanje stresa $v$ šoli - teoretični vidik: knjiga za ravnatelje in učitelje o obvladovanju stresa na ravni šole in na ravni posameznika. Ljubljana: Zavod RS za šolstvo.

Tsai, E., L. Fung in L. Chow. 2006. "Sources and Manifestations of Stress in Female Kindergarten Teachers. «International Education Journal 7 (3): 364370.

Tschannen-Moran, M., in A. Woolfolk Hoy. 2001. »Teacher Efficacy: Capturing an Elusive Construct." Teaching and Teacher Education 17:783-805.

- 2007. »The Differential Antecedents of Self-Efficacy Beliefs of Novice and Experienced Teachers."Teaching and Teacher Education 23:944-956.

Wang, H., N. C. Hall in S. Rahimi. 2015. »Self-Efficacy and Causal Attributions in Teachers: Effects on Burnout, Job Satisfaction, Illness, and Quitting Intentions. "Teaching and Teacher Education 47:120-130.

Woolfolk Hoy, A., in H. Davis. 2006. „Teacher Self-Efficacy and Its Influence on the Achivement of Adolescents. "V Self-Efficacy Beliefs of Adolescents, ur. T. Urdan in F. Pajeres, 117-133. Greenwich, CT: Information Age Publishing.

Zakon o vrtcih (ZVrt-UPB2). 2005. Uradni list Republike Slovenije, št. 100.

\section{Burnout and Self-Efficacy of Preschool Teachers in Kindergarten}

The aim of the study was to determine preschool teachers' level of the burnout and level of self-efficacy. We also wanted to establish whether there were any differences in burnout and in self-efficacy according to preschool teachers age group position and according to the level of professional development. We found out that the reported level of burnout is relatively low, as preschool teachers show a high level of personal fulfillment at the workplace and a lower level of emotional exhaustion and depersonalisation. Also, relatively high level of self-efficacy was reported by preschool teachers, showing differences in selfefficacy components: preschool teachers who work in the first age group (13 years old) reported higher level of self-efficacy in supporting child motivation in comparison to preschool teachers working who work in the second age group (3-6 years old). Reported self-efficacy is also different regarding the level of professional development, where the novice preschool teacher ( 1 to 3 years of work experience) felt the lowest level of self-efficacy, while the preschool 
teachers in the phase of professional stabilization reported the highest level of self-efficacy in the kindergarten.

Keywords: burnout, self-efficacy, preschool teachers, professional development 



\title{
The Importance of Preschool Teacher-Child Attachment for Healthy Childhood Development
}

\author{
Petra Dolenc \\ University of Primorska \\ petra.dolenc@pef.upr.si
}

\begin{abstract}
The last decades have seen a growing interest in researching preschool teacher-child relationships, particularly how the quality of attachment to a teacher impacts children's overall development. In this context, preschool teachers represent an important figure who, away from home environment, provide care, physical security, and emotional support. This article offers an overview of relevant studies dealing with various aspects of attachment at an early age, highlighting the importance of preschool teacher-child attachment quality for children's developmental outcomes. Secondly, the article offers some suggestions for promoting secure relationships in early childhood education, especially during settling a child into the kindergarten environment.
\end{abstract}

Keywords: attachment theory, preschool teacher-child relationships, early childhood education

\section{Attachment and Attachment Theory}

Attachment theory developed by John Bowlby (2005) is one of the betterknown theories of contemporary developmental psychology. It assumes that infants need a consistent nurturing relationship with one or more sensitive caregivers in order to develop into healthy individuals. Positive ad close relationships in early years are predictive of later social competence and mental health and resilience in children (World Health Organization 2004; Winston and Chicot 2016) Inappropriate relationships are considered to contribute to aberrant behavior and in combination with other risk factors to psychopathology (Rosmalen, Van der Veer and Horst 2015).

Attachment can be defined as a strong and reciprocally positive relationship between two people (Marjanovič Umek and Zupančič 2009). An affectionate bond between a child and his or her caregiver (usually a parent), is established based on innate signals that an infant uses to seek proximity of another person at times of distress. On the other hand, the caregiver has also got an inherent capacity to respond to child's specific signals, providing both 
protection and comfort (Bowlby 1991; Cugmas 2003). The key element within the attachment theory is the concept of the secure base that refers to the provision of a reliable and safe base by caregiver from which the infant can venture out and explore into the environment and to which the child can return in case of perceived threat (Bowlby 2005).

Attachment develops gradually; this process includes several stages that depend on children's experiences in the interaction with their caregiver and on their overall development and maturation (Marjanovič Umek and Zupančič 2009). Drewery and Bird (2004 in Du Plessis 2009) argue that attachment relationships are particularly relevant in the earliest years of life when infants are not yet able to care for themselves and, therefore, need a reliable caregiver to provide care. Attachment can be understood as a complex bidirectional relationship influenced by individual characteristics of both members of the dyad. According to Sierra (2012) these include characteristics of parents (e. g., their health status, psychological state, possible problems with addiction, stress or background of insecure attachment), children's characteristics (e. g. health problems, premature birth, temperament) and characteristics of the context (e. g. extreme deprivation, violent environment).

Bowlby's attachment theory underlines the importance of child's attachment to the mother which, according to experts, represents the primary object of attachment, in the sense of her sensibility to offer support and comfort to an infant (Cugmas 2009). The history of mother-child interactions is the foundation for shaping an attachment pattern which further influences various aspects of development (Cortazar and Herreros 2010).

\section{Quality of Attachment}

Mary Ainsworth provided empirical support for Bowlby's theory by using the Strange Situation procedure as an analytical tool to assess attachment style and the quality of early attachments. This procedure assumes short separations and reunions between the child and the parent. Different attachment patterns are a result of repetitive experiences of caregiving and can be divided in two basic categories: secure and insecure (Mooney 2010).

The quality of attachment is established according to the following principles: attachment behaviors and relationships between two people are continuously growing; mother-child interactions influence the psychological capacities of both; the emotional bond between a mother and a child is shaped by a specific social context (Sierra 2012).

In the optimal situation, infants experience care by mothers which are mostly reliable, sensitive and attuned to their needs and temperament char- 
acteristics. The synchrony between the child's needs and mother's responses is a good predictor of secure attachment (Ainsworth 1978 in Mooney 2010). Secure relationships enable infants to express distress and accept consolation easily and encourage the exploration of the environment with the certainty that their caregiver will be available if needed (Furnivall et al. 2012). Avoidant attachment is a form of insecure attachment, which is not characterized by a child's protest or distress at separation from the reference person, nor pleasure on reunion (Ainsworth 1978 in Mooney 2010). Avoidantly attached infants learn to inhibit negative emotions (such as anger and sadness) because they realize that the caregiver is unable to tolerate their distress and react either aggressively or by withdrawal (Furnivall et al. 2012). Infants with anxious-resistant attachment style tend to respond with anger and resistant behavior towards the parent, exhibiting extreme distress at the time of separation and difficulties in calming on the reunion (Ainsworth 1978 in Mooney 2010). They are preoccupied whether the caregiver will reliably respond to their needs. Caregivers of those infants were found to be inconsistent in responses and insufficiently sensitive to signals of the child. Disorganized attachment was subsequently added to the Ainsworth classification system as fourth attachment style, characteristic of children who respond in situations of separation and reunion with their caregiver in a confusing, contradictory and unpredictable way (e.g., after the return of the reference person they begin to cry when it already seemed that they have been comforted (Marjanovič Umek and Zupančič 2009). Some authors claim that these conflicting behaviors are the consequence of the infant being exposed to extremely frightened or frightening reactions by a caregiver. This leaves the child unable to develop a consistent strategy that would bring to a sense of security (Furnivall et al. 2012).

Even though the primary purpose of the attachment is to ensure proximity of the primary caregiver in order to receive protection and reduce stress in case of perceived danger, the attachment behaviors affect various aspects of cognitive, social and emotional development (Cortazar and Herreros 2010; Stefanović-Stanojević, Tosić-Radev and Velikić 2015). Commodari (2013a) summarizes a number of studies according to which attachment security in the earliest years of life influences cognitive performance in childhood, promote prosocial behaviors, self-esteem, and life satisfaction in adolescence, as well as social adjustment and psychological well-being in early adulthood. More recent research in the field of neurodevelopment (Newman, Sivaratnam, and Komiti 2015) emphasizes the importance of safe and supportive emotional environment for healthy brain functioning. 


\section{Preschool Teacher-Child Attachment}

Many studies have shown that infants and toddlers, irrespectively of their attachment to parents, can develop attachment to other non-parental figures. The transition from home to preschool is a particularly critical period characterized by numerous changes in children's early life, such as separation from parents, being in a new setting, unknown people and unfamiliar routines (Datler et al. 2012). Young children begin to spend more and more time with early childhood caregivers or preschool teachers, so they can be seen as attachment-relevant and represent some kind of 'secondary' attachment figures (Cugmas 2009; Pedditzi and Rollo 2014; Sierra 2012; Verschueren and Koomen 2012).

Over the past decade there has been an increased research interest in the study of children's attachment to preschool teacher (Cugmas 2011; Du Plessis 2009; Pedditzi and Rollo 2014; Veríssimo et al. 2017; Verschueren and Koomen 2012), who play a key role in providing care, safety and education in out-of-home environment. Children's attachment to teachers co-exists with the attachment to their parents and bears similar attachment patterns. Howes and Ritchie (1999) describe four types of attachment to teachers: secure, avoidant, resistant and near-secure. The avoidant type is characteristic of children who are more interested in the materials in the playroom rather than in the teacher or peers. When experiencing frustration, they do not seek the teacher, or even move away if the teacher tries to console them. In a resistant pattern of attachment, children are irritable with the teacher, even without reason, and often demanding and impatient. Children with secure attachment seek comfort and spontaneously hug the teacher when feeling distressed or angry; they like to share activities with the teachers and others and ask for help if needed. In a near-secure attachment, children show a combination of moderately avoidant and secure behaviors. They tend to distrust the teacher, but they participate in all activities. Therefore, the teacher often fails to recognize a problem in such a relationship.

Veríssimo et al. (2017) have found that building a close, attachment-relevant relationship with a teacher in early childhood is, only in part, a function of the quality of parent-child attachment relationships. Furthermore, some authors suggest the idea that attachment styles can be discontinued by life circumstances or new relationship (Cortazar and Herreros 2010). In this regard, secure preschool teacher-child attachment may compensate for a more problematic parent-child relationship. Buyse, Verschueren, and Doumen (2011) have found that especially for children who are less securely attached to 
their mothers, sensitivity of the preschool teacher may be the crucial factor in the development of close teacher-child relationship and reduction the risk of aggressive behavior among children.

As noted by Pianta the key qualities of teacher-child relationship appears to be related to the ability of an adult at accurately reading the child's signals, to respond contingently on the basis of these signals, to convey acceptance and emotional warmth, to offer assistance as necessary, and to model regulated behavior (Pianta 1999, 67, in Du Plessis 2009). Similarly, Cugmas (2009) explains that the teacher's sensitivity to children's needs most strongly determines the pattern of their attachment behavior.

Preschool teacher-child attachment depends on several factors, including attributes of teachers, attributes of children, as well as environmental factors. Recent research findings have provided evidence that higher education level of teachers, lower perceived stress and higher self-efficacy are related with higher quality relationships with young children (Chen and Phillips 2018; Choi and Dobbs-Oates 2016). There is a growing body of research demonstrating that preschool teacher-child relationships are also predicted by children's temperamental characteristics (Acar et al. 2018). Especially reactivity as a sub-dimension of temperament was found to have a significant impact on teacher-child relationships (Yoleri 2016).

Within early childhood education, teachers play a critical role in providing emotional and social security, promoting children's language and cognitive development, encouraging children in the process of socialization with adults and peers outside their family. They also play an extremely important role during settling into childcare helping children navigate through this new experience. Therefore, it is among teachers' priorities to build a good affective bond based on sensitive responsiveness to children's needs. The fact that preschool teacher represents a secure base is very important especially with younger and more vulnerable children who come from an emotionally less supportive environment (Buyse et al. 2011; Verschueren and Koomen 2012).

\section{Preschool Teacher Attachment and Children's Development}

Recent research results suggest that quality of a preschool teacher-child relationships predict children's emotional, social and cognitive development during the early childhood period as well as through elementary years and even later in life (Commodari 2013b; Mashburn et al. 2008; Mortensen and Barnett 2015).

Sroufe (2005) stressed the importance of infant attachment, both because of its place in initiating pathways of development and because of its con- 
nection with so many critical developmental functions - social relatedness, arousal modulation, emotional regulation, and curiosity. Children with histories of secure attachment (assessed at 12 and 18 months) faced less social problems in preschool years, displayed more curiosity and flexibility in handling problems than children with histories of insecure attachment. Moreover, preschool children with early secure attachment were much more empathic and popular among peers, exhibited less aggressive behavior than the children with histories of insecure attachment. Failure to develop secure attachments in early life may lead to later difficulties in communicating and managing emotions with peers (Sroufe 2005). Cugmas (2010) summarizes the research findings according to which the quality of preschool education and of teacher's relationships is closely associated with children's well-being and integration in preschool classrooms. When children feel well and relaxed at kindergarten, they are more satisfied and confident, they express their needs and desires, they are open to new experiences and adapt easily. It was discovered that there is a positive connection between a secure preschool teacherchild attachment and children's success in social interaction, speech development, and symbolic play. Children with a secure attachment style are more co-operative and more likely to accept tasks given by their teachers. Moreover, children who experience a secure attachment showed more perseverance and they were more successful in solving mental tasks (Commodari 2013a). Mortensen and Barnett (2015) assume that the teacher-child relationships that develop in infant/toddler child care provide a critical caregiving context for young children's socioemotional development.

A review of relevant research has revealed that there is a positive connection between secure attachment to teacher and children's cognitive development. A study conducted by Howes and Smith (1995 in Commodari 2013a) including infants, toddlers, and pre-schoolers, examined children's play activities and cognitive activities as well as their relationships with caregivers within the child care setting. It has been established that preschool teacher's social interactions (e. i., encouragements, smiles, physical proximity) and children's feeling of security and attachment to the teacher were related to enhanced cognitive activities and more exploration during play activities in all three developmental stages.

Early observational studies (Main 1983 in Commodari 2013b) showed that three-year-olds with secure attachment experiences manifested larger attention spans during play compared to those with insecure attachment patterns. Some researchers have discovered that securely attached preschool children tend to have improved attention abilities and better scholastic 
skills before entering school compared to insecurely attached preschoolers (Bergin and Bergin 2009). More specifically, Commodari (2013b) demonstrated that children with secure preschool teacher attachment presented better attention skills, in terms of higher reaction time and better selectivity and maintenance. Mashburn et al. (2008) who examined the development of academic, language and social skills among four-year-olds in preschool programs found that positive and close preschool teacher-child interactions may facilitate their school readiness. A recent study, exploring children's representations of attachment and positive teacher-child relationships, revealed that a close attachment-relevant relationship with preschool teachers in early childhood may be related to higher children's verbal capacity (Veríssimo et al. 2017).

According to several authors (Buyse et al. 2011; Cortazar and Herreros 2010; Mortensen and Barnett 2015; Sierra 2012) early childhood education has an extremely important role in child development, especially when it comes to children from a deprived environment or at risk due to adverse caregiving experiences. The author states that preschool teachers represent significant attachment figures, which can create a safe and friendly environment that promotes development and learning, as well as contributes to social acceptance of the child. Many studies have also shown that children's attachment to their mothers as their primary caregivers should not be always compared to a teacher-child attachment. However, children can build a secure attachment to other non-parental figures despite having experienced an insecure parental attachment in the past (Pedditzi and Rollo 2014; Sierra 2012). Thus, encouraging a secure preschool teacher-child attachment may compensate an eventually anxious parental attachment (Cugmas 2010). High-quality early childhood education and positive attachment to preschool teacher have proven to be an important factor of compensation with children coming from less supportive home environments in the sense of insufficient sensitivity and responsiveness for the child's needs.

\section{Conclusions and Proposals for Applying Attachment Theory in Early Childhood Education}

There is a growing body of literature trying to integrate attachment theory into early childhood settings (Cortezar and Herreros 2010; Niecki 2017; Shirvanian and Michael 2017). In order to bridge attachment theory and early childcare practice, Shirvanian and Michael (2017) highlight the importance of training and professional development within attachment theory for preschool teachers. Research shows that interventions within attachment 
theory for preschool teachers, such as education and training programs enhance children's secure attachment and sensitivity in the caregivers (Shirvanian and Michael 2017). Pedditzi and Rollo (2014) suggest that additional teacher training should be introduced to early childhood education which would allow preschool teachers to learn about attachment theory in order to identify actual characteristics of a secure attachment and consequently respond appropriately to children's needs.

A child's transition to childcare or kindergarten represents the first experience away from home with an alternate caregiver. Thus, attachment theory allows for an adequate explanation of a child separation anxiety. Taking into account the principles of the theory, teachers can alleviate children's distress also by letting parents be present in the group for a few days during the settling-in period. A child can be also encouraged to bring a favorite toy or other objects which have the role of a transitory object that replaces home environment and parents, and make a child feel safe and more easily comforted during parental absence.

Some children experience the transition to kindergarten even before attachment is fully developed, therefore, consistency in caregiving is essential for the child's attachment (Goldberg, Muir, and Kerr 2013). For this reason, the practice of keeping a group of children with the same teacher for more than a year has the potential to provide a consistent caregiver during the young child's critical period of attachment and emotional development (Nitecki 2017). Cugmas (2010) assumes that preschool teachers can help relieve children's distress due to separation from their parents with using symbolic play or through storytelling. Preschool teachers who become familiar with attachment theory have better insight into the structure and dynamics of relationships between children and caregivers and therefore, better understand children's behavior. Teachers can also evaluate how children's behaviors relate to the quality of parental attachment by observing the reactions of children and their parents after morning separation and after reunion when parents come to pick their children up from kindergarten.

Early childhood educators can play an important compensatory role for the most vulnerable children with insecure attachment patterns with primary caregivers. They can foster secure secondary attachment offering a predictable environment, consistent and sensitive care, appropriate frequent physical contacts, and a space where needs, emotions, and temperament characteristics of children are recognized (Cortezar and Herreros 2010; Shirvanian and Michael 2017).

Higher education can also play an important role by including more spe- 
cialized courses on implementing attachment theory within the context of infant/toddler child care in preschool teachers preparation programs. Practical training for future preschool teachers should promote sensitivity to differences in attachment styles in order to facilitate secure relationships and healthy socioemotional outcomes for young children.

\section{References}

Acar, I. H., J. C. Torquati, A. Encinger, and A. Colgrove. 2018. 'The Role of Child Temperament on Low-Income Preschool Children's Relationships with Their Parents and Teachers.' Infant and Child Development 27 (1): e2045. http://www.researchgate.net/publication/318169236_The_role_of_child _temperament_on_low-income_preschool_children\%27s_relationships _with_their_parents_and_teachers

Ainsworth, M. S. 1978. Patterns of Attachment: A Psychological Study of the Strange Situation. Hillsdale, NJ: Erlbaum.

Bergin, C., and D. Bergin. 2009. 'Attachment in the Classroom.' Educational Psychology Review 21:141-170.

Bowlby, J. 1991. Separation: Anxiety and Anger. Vol. 2 of Attachment and Loss. New York: Penguin.

- 2005. A Secure Base: Clinical Applications of Attachment Theory. London: Routledge.

Buyse, E., K. Verschueren and S. Doumen. 2011. 'Preschoolers' Attachment to Mother and Risk for Adjustment Problems in Kindergarten: Can Teachers Make a Difference?' Social Development 20:33-50.

Chen, S., and B. Phillips. 2018. 'Exploring Teacher Factors that Influence TeacherChild Relationships in Head Start: A Grounded Theory.' The Qualitative Report 23 (1): 80-97.

Choi, J. Y., and J. Dobbs-Oates. 2016. 'Teacher-Child Relationships: Contribution of Teacher and Child Characteristics.' Journal of Research in Childhood Education 30 (1): 15-28.

Commodari, E. 2013a. 'Preschool Teacher Attachment, School Readiness and Risk of Learning Difficulties.' Early Childhood Research Quarterly 28 (1): 123133.

_ 2013b. 'Preschool Teacher Attachment and Attention Skills.' SpringerPlus 2:673. https://www.ncbi.nlm.nih.gov/pmc/articles/PMC3872284/

Cortazar, A., and F. Herreros. 2010. 'Early Attachment Relationships and the Early Childhood Curriculum.' Contemporary Issues in Early Childhood 11 (2): 192-202.

Cugmas, Z. 2003. 'Odraz socialnega vedenja otrok z različnim vzorcem navezanosti na vzgojiteljico v otroški risbi.' Psihološka obzorja 12 (2): 49-63.

- 2009. 'Kakovost vrtca in otrokova navezanost na vzgojiteljico.' Sodobna pedagogika 60 (3): 40-50. 
. 2010. 'Uporaba teorije navezanosti v vrtcih.' Pedagoška obzorja 25 (1): 3-18.

- 2011. 'Relation between Children's Attachment to Kindergarten Teachers, Personality Characteristics and Play Activities.' Early Child Development and Care 181 (9): 1271-1289.

Datler, W., K. Ereky-Stevens, N. Hover-Reisner, and L. E. Malmberg. 2012. 'Toddlers' Transition to Out-of-Home Day Care: Settling into a New Care Environment.' Infant Behavior \& Development 35 (3): 439-451.

Drewery, W., and L. Bird. 2004. Human Development in Aotearoa: A Journey through Life. Auckland: McGraw Hill.

Du Plessis, K. 2009. 'Early Childhood Teacher-Child Attachment: A Brief Review of the Literature.' He Kupu 2 (1). http://www.hekupu.ac.nz/article/early -childhood-teacher-child-attachment-brief-review-literature

Furnivall, J., M. McKenna, S. McFarlane, and E. Grant. 2012. Attachment Matters for All - An Attachment Mapping Exercise for Children's Services in Scotland. N. p.: CELCIS.

Goldberg, S., R. Muir, and J. Kerr. 2013. Attachment Theory: Social, Developmental, and Clinical Perspectives. London: Routledge.

Howes, C., and S. Ritchie. 1999. 'Attachment Organizations in Children with Difficult Life Circumstances.' Development and Psychopathology 11 (2): 251268.

Howes, C., and E. Smith. 1995. 'Relations among Child Care Quality, Teacher Behavior, Children's Play Activities, Emotional Security, and Cognitive Activity in Child Care.' Early Childhood Research Quarterly 10:381-404.

Main, M. 1983. 'Exploration, Play, and Cognitive Functioning Related to Infant-Mother Attachment.' Infant Behavior and Development 6: 167-174.

Marjanovič Umek, L., and M. Zupančič. 2009. Razvojna psihologija. Ljubljana: Znanstvenoraziskovalni inštitut Filozofske fakultete.

Mashburn, A. J., R. C. Pianta, B. K. Hamre, J. T. Downer, O. A. Barbarin, D. Bryant, M. Burchinal, D. M. Early, and C. Howes. 2008. 'Measures of Classroom Quality in Prekindergarten and Children's Development of Academic, Language, and Social Skills.' Child Development 79:732-749.

Mortensen, J. A., and M. A. Barnett. 2015. 'Teacher-Child Interactions in Infant/Toddler Child Care and Socioemotional Development.' Early Education and Development 26 (2): 209-229.

Mooney, C. G. 2010. Theories of Attachment: An introduction to Bowlby, Ainsworth, Gerber, Brazelton, Kennell, and Klaus. St. Paul, MN: Redleaf Press.

Newman, L., C. Sivaratnam, and A. Komiti. 2015. 'Attachment and Early Brain Development: Neuroprotective Interventions in Infant-Caregiver Therapy.' Translational Developmental Psychiatry 3 (1). http://www.tandfonline.com/ doi/full/10.3402/tdp.v3.28647

Nitecki, E. 2017. 'Looping and Attachment in Early Childhood Education: How 
Applications of Epigenetics Demand a Change.' Journal of the Scholarship of Teaching and Learning 17 (2): 85-100.

Pedditzi, M. L., and D. Rollo, D. 2014. 'L' attacamento nell'asilo nido: Le educatrici hanno una visione monotropica o poliadica?' Psicologia clinica dello sviluppo 18 (1): 143-152.

Pianta, R. C. 1999. Enhancing Relationships between Children and Teachers. Washington, DC: American Psychological Association.

Rosmalen, L., R. Van der Veer, and F. Horst. 2015. 'Ainsworth's Strange Situation Procedure: The Origin of an Instrument.' Journal of the History of the Behavioral Sciences 51 (3): 261-284.

Sierra, P. G. 2012. 'Attachment and Preschool Teacher: An Opportunity to Develop a Secure Base.' International Journal of Early Childhood Special Education 4 (1): 1-16.

Shirvanian, N., and T. Michael. 2017. 'Implementation of Attachment Theory into Early Childhood Settings.' The International Education Journal: Comparative Perspectives 16 (2): 97-115.

Sroufe, L. A. 2005. 'Attachment and Development: A Prospective, Longitudinal Study from Birth to Adulthood.' Attachment \& Human Development 7 (4): 349-367.

Stefanović-Stanojević, T., M. Tosić-Radev, and D. Velikić. 2015. 'Maternal Attachment and Children's Emotional and Cognitive Competences.' Psychological Topics 24 (1): 51-69.

Veríssimo, M., N. Torres, F. Silva, C. Fernandes, B. E. Vaughn, and A. J. Santos. 2017. 'Children's Representations of Attachment and Positive Teacher-Child Relationships.' Frontiers in Psychology 8:2270. http://www.ncbi.nlm.nih.gov/ pmc/articles/PMC5743748/

Verschueren, K., and H. M. Y. Koomen. 2012. 'Teacher-Child Relationship from an Attachment Perspective.' Attachment \& Human Development 14 (3): 329336.

Winston, R., and R. Chicot. 2016. 'The Importance of Early Bonding on the LongTerm Mental Health and Resilience of Children.' London Journal of Primary Care 8 (1): 12-14.

World Health Organization. 2004. The Importance of Caregiver-Child Interactions for the Survival and Healthy Development of Young Children: A Review. Geneva: World Health Organization.

Yoleri, S. 2016. 'Teacher-Child Relationships in Preschool Period: The Roles of Child Temperament and Language Skills.' International Electronic Journal of Elementary Education 9 (1): 210-224.

\section{Pomen navezanosti na vzgojiteljico za zdrav razvoj otroka}

V zadnjih desetletjih je opaziti povečan raziskovalni interes na področju preučevanja odnosa med otrokom in vzgojiteljco v vrtcu, zlasti v smislu pomena ka- 
kovosti otrokove navezanosti na vzgojiteljico za njegov celostni razvoj. Vzgojiteljica v tem kontekstu pomeni tisto pomembno osebo, ki otroku izven domačega okolja zagotavlja nego, fizično varnost in čustveno oporo. V prispevku predstavljamo pregled relevantnih raziskav, ki obravnavajo različne vidike in dejavnike otrokove navezanosti na vzgojiteljico, pri čemer poudarjajo pomen kakovostne navezanosti na vzgojiteljico za otrokov razvoj na različnih področjih, ter izpostavimo načine, s katerimi lahko spodbujamo varno navezanost med otrokom in vzgojiteljco v vrtcu, zlasti v obdobju otrokovega uvajanja v vrtčevsko okolje.

Ključne besede: teorija navezanosti, odnos med vzgojiteljico in otrokom, predšolska vzgoja 


\title{
Nega in vzgoja mlajšega otroka kot pomembna temelja razvoja
}

\author{
Janja Perko \\ Osnovna šola Destrnik - Trnovska vas \\ janja.perko@gmail.com
}

\section{Zlatka Cugmas}

Univerza v Mariboru

zlatka.cugmas@um.si

\section{Mateja Pšunder \\ Univerza v Mariboru \\ mateja.psunder@um.si}

V prispevku nas zanimajo sodobna spoznanja o negi in vzgoji mlajšega otroka. Podrobneje predstavimo področja, vezana na najneposrednejše načine zadovoljevanja otrokovih potreb v najzgodnejšem obdobju, ki vplivajo na vzpostavljanje odnosa z otrokom. Ta odnos, ki ustvarja temelj kasnejše vzgoje v pravem pomenu besede, se začne vzpostavljati takoj po rojstvu otroka. Pozornost namenimo joku, spanju, telesnemu stiku in hranjenju. Ugotovimo, da je mnogo praks pri odnosu do dojenčka in malčka v današnjem času v nasprotju s praksami nekoč, kar je predvsem posledica družbenega napredka in znanstvenih spoznanj na področjih, ki so neposredno ali posredno povezana z odnosom do otroka. Nekatera spoznanja se tesno navezujejo na nego in vzgojo otroka v družini, druga so splošnejša, uporabna tudi v predšolskih institucijah. Pomembno je, da so s sodobnimi znanstvenimi pogledi na vzgojo in nego otroka seznanjene strokovne delavke oz. delavci v vrtcu, saj bodo le tako lahko svoje delo opravljali profesionalno.

Ključne besede: mlajši otrok, jok, hranjenje, telesni stiki, spanje

\section{Uvod}

Družina kot sistem obstaja v okolju, ki se nenehno spreminja, zato se nenehno spreminja tudi sama, z njo pa posledično zaznavanje in odnos do otrok ter načini vzgajanja, ki so prav tako odraz časa in prostora (Čačinovič Vogrinčič 1998; Švab 2001).

Socialni zgodovinarji pišejo, da se je pojem otroštva v Evropi izoblikoval med 16. in 18. stoletjem, na Slovenskem pa z zamikom šele v prejšnjem stoletju. Na Slovenskem je v 19. stoletju vladala izrazito avtoritarna vzgoja, ki je temeljila na strahospoštovanju in telesni kazni, otroci pa so bili pogosto žrtve zanemarjanja in nasilja. O začetkih občutenja otroštva in starševstva, kot ga 
poznamo danes, pri nas govorimo šele po drugi svetovni vojni (Puhar 1982; Rožman 2004; Škoro Babić idr. 2012).

$\checkmark$ prispevku obravnavamo nego in vzgojo mlajšega ${ }^{1}$ otroka danes. Danes zahvaljujoč znanosti neprimerljivo bolje poznamo potrebe otroka, kot so jih poznale generacije pred nami. Vemo, da jih je otroku treba zadovoljevati z veliko mero odzivnosti in občutljivosti, da bo lahko razvil varno navezanost. Pojave v odnosu mati - otrok, kot so zadovoljevanje dojenčkovih osnovnih potreb, materina odzivnost, razvijanje občutka varnosti in proces navezovanja v prvih mesecih otrokovega življenja, nekateri avtorji (Kompan Erzar in Poljanec 2009) strnejo v pojem stik z otrokom. Stik med otrokom in starši pomeni "sposobnost soustvarjanja edinstvenega čustvenega in fizičnega ritma, ki je za vsak par otrok - odrasli drugačen. Pomeni sposobnost matere in očeta, da prepoznata otrokove potrebe, njegov življenjski ritem, njegov način doživljanja in mu ga pomagata soustvariti« (Kompan Erzar in Poljanec 2009. 11). Avtorji pojasnjujejo, kako stik z otrokom udejanjiti skozi situacije, vezane na otrokov jok, hranjenje (dojenje), spanje in uravnavanje čustev. Omenjena področja zadovoljevanja otrokovih potreb so neločljivo povezana z materinimi in otrokovimi hormoni ter $z$ njunim neposrednim medsebojnim telesnim stikom, kar ima velik pomen za otrokov razvoj. $O$ tem in o pomenu posameznih področij zadovoljevanja otrokovih potreb z različnimi poudarki in v različnem obsegu pišejo tudi drugi avtorji (Bigelow idr. 2012; Hoyer 2011; Hrovat-Kuhar 2010; McKenna in McDade 2005; Sears in Sears 2004; 2008; Sunderland 2008; Zeifman 2001). Kot najpogostejše okoliččine, v katerih prihaja do neposrednega in intenzivnega vzpostavljanja stika z dojenčkom, omenjeni avtorji največkrat izpostavljajo dojenčkov jok, hranjenje, spanje in telesni stik.

V poljudni literaturi se je za posebej občutljiv in intenziven način zadovoljevanja dojenčkovih potreb v situacijah, kot so jok, dojenje, spanje in telesni stik, uveljavil termin povezovalno starševstvo (ang. attachment parenting) (Sears in Sears 2008; Šoster Olmer 1999), ki ga nekateri (Turgeon 2011) tudi kritizirajo oz. problematizirajo pretirano poudarjanje tovrstne prakse, čeprav ji zlahka najdemo znanstveno zaledje (Dewar 2008). Drži pa, da takšna praksa (ne glede na poimenovanje) od starša zahteva veliko mero občutljivosti, požrtvovalnosti, predanosti ter (začasnega) odrekanja lastnim interesom in udobju. V ospredje postavlja zadovoljevanje dojenčkovih potreb na čim naravnejši način, brez uporabe sodobnih pripomočkov in praks, ki staršem skrb

\footnotetext{
${ }^{1}$ V prispevku mlajši otrok predstavlja otroka v obdobju dojenčka in malčka, ki traja od rojstva do tretjega leta otrokove starosti (Zupančič 2009).
} 
za otroka sicer olajšajo, vendar pogosto na račun zmanjšanega ali celo onemogočenega stika $z$ dojenčkom.

Kljub ljudskemu reku, da se vzgoja otroka začne že v zibelki, $v$ tej začetni fazi še ne moremo govoriti o vzgoji otroka v pravem pomenu besede, hkrati pa je težko postaviti točno starostno mejo, kdaj naj bi se ta vendarle začela (Peček Čuk in Lesar 2011; Sunderland 2008). Zagotovo se odnos med starši in otrokom, ki ustvarja temelj kasnejši vzgoji v pravem pomenu besede in ima nanjo pomemben (čeprav le posreden) vpliv, začne vzpostavljati takoj po rojstvu otroka (Erzar in Kompan Erzar 2011; Sunderland 2008). Zato pri obravnavi vzgoje otroka začenjamo na začetku - v njegovem najzgodnejšem obdobju življenja.

\section{Dojenčkov jok}

Jok je dojenčkovo najpomembnejše sredstvo komuniciranja, kadar je v stiski, in vedno pomeni klic na pomoč odraslemu, naj se nemudoma odzove, mu pomaga zadovoljiti osnovne potrebe in poskrbi zanj (Kompan Erzar in Poljanec 2009; Sunderland 2008; Zeifman 2001). Če ga odrasli dosledno tolaži in njegov jok obravnava resno, v njegovih možganih nastanejo zelo učinkoviti sistemi za obvladovanje stresa tudi kasneje v življenju (Dawson 2000 v Sunderland 2008; Gunnar 1989 v Sunderland 2008). Dosledno odzivanje na dojenčkov jok pomeni dosledno odzivanje na potrebe otroka in zadovoljevanje le-teh. To po teoriji navezanosti spodbuja razvoj varne navezanosti, ki pozitivno vpliva na otrokov vsestranski razvoj, kar se pozitivno odraža tudi skozi kasnejše življenje v odraslosti. Varna navezanost ugodno vpliva na socialne in spoznavne zmožnosti otroka. Če je otrok varno navezan, lažje postane samostojen in razvija dobre odnose $z$ drugimi. Nasprotno otrok, ki ne razvije varne navezanosti, postane odvisen od drugih in negotov glede lastnih sposobnosti (Cugmas 1998; 2003; Erzar in Kompan Erzar 2011; Marjanovič Umek in Zupančič 2009; Kompan Erzar in Poljanec 2009; Papalia idr. 2003).

Nekateri svtorji (Puhar 1982; Rožman 2004; Sunderland 2008) pravijo, da so ljudje v preteklosti zagovarjali stališče, da je dojenčke in malčke najbolje pustiti jokati, saj so menili, da si ti tako »krepijo pljuča» in da jih odrasli samo »razvadijo«, v kolikor jih nenehno jemljejo v naročje. Še dandanes se mnogi sprašujejo, ali dojenček jok uporablja za to, da z njim manipulira s starši in uveljavlja oblast nad njimi. Dejstva o razvoju otrokovih možganov pričajo, da dojenček še nima dovolj razvitih spoznavnih sposobnosti za manipulacijo $z$ drugimi osebami (Kompan Erzar in Poljanec 2009; Sunderland 2008). Tudi nekateri drugi avtorji (Sroufe, Cooper in DeHart 1996 v Cugmas 1998) razmišljajo podobno, ko pravijo, da je odveč skrb, da bi dosledno in takojšnje od- 
zivanje na dojenčkov jok povzročilo, da bi ta začel jokati za vsako malenkost. Otrok se od odzivne in dosledne matere nauči, da bo ob njegovem doživljanju stresa vselej hitro in pravilno ukrepala. Tako bo sčasoma manj intenzivno izražal stres in manj jokal, saj bo vedel, da zelo močne reakcije niso potrebne. Omenjeno potrjujejo ugotovitve raziskave (Erdman in Caffery 2003), da so otroci mater, ki so se v prvih mesecih hitro in dosledno odzivale na njihov jok, pri enem letu manj jokali in so se hitreje pomirili kot otroci, ki so kot dojenčki morali čakati na materin odziv.

Ob tem danes obstajajo dokazi o občutljivosti dojenčkovih možganov na stres - ko joka, nadledvični žlezi izločata hormon kortizol, katerega raven v krvi se ob doslednem tolaženju spet zniža. V kolikor odrasli dojenčka pusti jokati in se na njegov klic na pomoč ne odzove, ostane raven kortizola ves čas visoka, kar na možgane deluje toksično in jih lahko trajno poškoduje. Znanstveniki takšen stres $v$ zgodnjem otroštvu pogosto povezujejo $s$ kasnejšimi težavami v odraslosti, ki se med drugim lahko kažejo kot anksioznost, depresivne motnje, nagnjenost $\mathrm{k}$ alkoholizmu, razne telesne bolezni itd. (Caldji, Diorio in Meaney 2000 v Sunderland 2008; Hsu idr. 2003 v Sunderland 2008).

Dojenčkov jok zahteva dosledno odzivnost odraslega, kar seveda ne pomeni, da je treba k otroku planiti v trenutku, ko se ta oglasi. Problematična je torej dolgotrajna stiska, ki jo otrok izraža z dolgotrajnim jokom, ki se običajno zaključi takrat, ko se otrok utrudi ali ko obupan ugotovi, da pomoči ne bo od nikoder (Sunderland 2008). Ko, skladno z otrokovim razvojem, jok, ki je $v$ začetku pomenil enega osnovnih načinov komunikacije, zamenja govor, otrok postopoma razvija sposobnost ubesedovanja svojih potreb, starši pa so postavljeni pred težko nalogo ločevanja med otrokovimi legitimnimi potrebami in zgolj željami (Sunderland 2008).

\section{Spanje}

Vprašanje, kje in kako bi moral otrok (za)spati, je za človeštvo nekaj novega. $\checkmark$ dveh milijonih let evolucije so namreč ljudje (kot vsi ostali primati) vedno spali skupaj s svojimi dojenčki. Kot vsi mladiči sesalcev bi hitro postali hrana plenilcem, če bi jih starši pustili nenadzorovane v temi (Sunderland 2008). Poleg tega so otrokovo spanje, njegov srčni utrip in dihanje stimulirani z dražljaji, ki jih oddajajo odrasli. To je verjetno posledica evolucije, da bi se kot vrsta kar najbolje prilagodili nevarnostim iz okolja (Chisholm 1986).

Ob pregledu raziskav (McKenna in McDade 2005; McKenna, Mosko in Richard 1997; Mosko, Richard in McKenna 1997) o spanju dojenčkov ugotovimo, da se je »moderni spalni model « razvil le v t. i. zahodni razviti družbi, ki od čim mlajših dojenčkov pričakuje čim prejšnjo samostojnost pri spanju. Avtorji 
opozarjajo na razkorak med naravnimi zakonitostmi glede spanja dojenčkov in družbenimi pričakovanji. Slednja so namreč posledica mitov, nerealnih pričakovanj in nepoznavanja biološkega razvoja naše vrste. Vse to pogosto vodi do tega, da starši v želji po dojenčkovem samostojnem spanju in uspavanju uporabljajo razne tehnike »učenja spanja« ter metode izjokavanja, ki na otrokov psihofizični razvoj ne vplivajo ugodno.

Potreba odraslih, da dojenček spi ločeno od njih, je verjetno posledica več sto- ali celo tisočletnih socialnih in bivanjskih sprememb ter spreminjanja vlog in nalog članov družine. Najverjetneje je takšna praksa posledica strahu in tisočletnih svaril pred t. i. "zaležanjem« dojenčka, ki naj bi bil v zgodovini večkrat vzrok smrti dojenčkov (Puhar 1982). Zato so v evropskem civilizacijskem prostoru v 9. stoletju "zaležanje« prvikrat opredelili kot kaznivo dejanje, materam pa s strani najvišjih cerkvenih dostojanstvenikov zapovedali ločeno ležišče za dojenčka. Prepričanje, da so matere s skupnim ležiščem svojim otrokom nevarne, je vztrajalo stoletja. A. Puharj (1982) se sprašuje o utemeljenosti tega strahu, saj v istem delu govori tudi o takratnih bivanjskih in socialnih razmerah ter odnosu do otrok, na podlagi česar bralec hitro podvomi v takratno, še bolj pa $v$ današnjo utemeljenost strahu pred tovrstno nevarnostjo za dojenčka.

Strokovnjaki so preučevali morebitno povezanost med sindromom nenadne smrti v zibki (SNSD) in skupnim spanjem. Ugotovitve raziskav (Kompan Erzar in Poljanec 2009; McKenna in McDade 2005; McKenna, Mosko in Richard 1997, Mosko, Richard in McKenna 1997; Sears in Sears 2008; Sunderland 2008) kažejo nasprotno, in sicer da se matere med spanjem zavedajo prisotnosti dojenčka in da je ob upoštevanju varnostnih ukrepov manjša verjetnost za SNSD, če mati in dojenček spita skupaj. V delih sveta, kjer je spanje z dojenčkom samoumevno, omenjenega pojava skorajda ne poznajo. Strokovnjaki skupno spanje odsvetujejo le $v$ določenih okoliščinah (npr. pri kadilcih, po konzumiranju alkohola, ob izčrpanosti itd.).

Dandanes materam nihče več ne zapoveduje, da dojenček nujno potrebuje svoje ležišče. Tudi skupno spanje jim je vedno pogosteje predstavljeno kot možnost. A v naši kulturi je postalo ločeno spanje nekaj samoumevnega in običajnega, prakticiranje skupnega spanja ima pogosto negativen predznak in je hitro označeno kot slaba vzgojna praksa, ki se ji je potrebno izogibati. Zdi se, da se starši bolj kot nesreče z zadušitvijo bojijo, da bodo otroka »razvadili«, če bodo spali skupaj z njim (Sears in Sears 2008).

Raziskovalci (Fifer in Moon 1994; McKenna in McDade 2005; McKenna, Mosko in Richard 1997, Mosko, Richard in McKenna 1997) ugotavljajo, da je zelo priporočljivo, da dojenček prve mesece spi v neposredni bližini staršev, saj 
ima naravno potrebo, da začuti telesno bližino matere, ki mu daje občutek varnosti in zaupanja. Tak način spanja, ki je popolnoma naraven, tudi materi pomaga, da se uglasi z otrokom in da skupaj sproščeno ustvarjata svoj odnos. Ugotovili so tudi (McKenna, Mosko in Richard 1997), da skupno spanje spodbuja dojenje, ki je dandanes, zaradi številnih ugodnih učinkov na otroka in mater, zelo zaželeno in spodbujano. Prav tako je znano (Sunderland 2008), da skupno spanje za otroka pomeni več telesnega stika z materjo, kar uravnava njegove telesne sisteme. Izsledki raziskav (Sunderland 2008) kažejo še, da so otroci, ki niso nikoli spali v isti postelji s starši, manj vodljivi.

Strokovnjaki (Pantley 2003; Sunderland 2008) poudarjajo, da bi moral dojenček oziroma malček ob uspavanju imeti občutek varnosti. $S$ tem se prepreči aktiviranje stresnih kemičnih snovi v njegovih možganih, otrok se počuti varnega in ljubljenega, ko zaspi. Obstajajo mehanizmi (npr. pomirjujoče vedenje odraslega, rutina), ki to pomagajo doseči ne glede na to, ali otrok spi sam ali s staršem.

\section{Telesni stik}

Tako kot dosledno odgovarjanje na dojenčkov jok in skupno spanje z dojenčkom tudi nudenje telesnega stika otroku nekateri ljudje označujejo kot slabo vzgojno prakso, ki vodi v t. i. razvajenost, predvsem ko govorimo o vsakokratnem pestovanju otroka $v$ naročju, ko ta pokaže potrebo po tem. Takšna miselnost je najverjetneje posledica vzgojne prakse v zgodovini, ki v obliki tovrstnih klišejev seže še $v$ današnji čas. V skladu z znanstvenimi ugotovitvami s področja otrokovega joka, spanja in razvoja varne navezanosti je nemogoče ravnati, v kolikor starši dojenčku oz. mlajšemu otroku nenehno odrekajo ali omejujejo telesne stike. Prav dotik je namreč prva poteza, ki jo instinktivno naredi mati, ki želi pomiriti jokajočega dojenčka in odgovoriti na njegove potrebe. Poleg tega je človekova potreba po telesnem stiku že dolgo prepoznana in priznana (Bigelow idr. 2012).

Strokovnjaki poudarjajo, da ima telesni stik (z materjo), še posebej stik kože $s$ kožo, blagodejen učinek na otrokov razvoj in da ga otrok nujno potrebuje. Telesni stik v njegovih možganih aktivira t. i. »hormone sreče« (oksitocin in opioide), ki znižujejo raven stresnih kemičnih snovi (Anisfeld idr. 1990; Bigelow idr. 2012; Kompan Erzar in Poljanec 2009; Sears in Sears 2008; Sunderland 2008).

Potreba po telesnem stiku je značilna za vse sesalce in človek ni nobena izjema. Mladiči oz. mlajši otroci se oklepajo varnega odraslega, kadarkoli se počutijo ogrožene. Za otroke takšno oklepanje ne pomeni, da se neprimerno vedejo ali da iščejo pozornost, temveč je to naravni način za zmanj- 
šanje stresa. Če se odrasli na otroka, ki ima željo po oklepanju zaradi stiske, odzivajo potrpežljivo in sočutno, je to dragocena naložba v njegovo sposobnost za neodvisnost kasneje $v$ življenju, kajti če se otrok počuti varnega v svetu, se vanj vključuje brez težav (Sunderland 2008). Raziskave o drugih sesalcih (Fleming, O'Day in Kraemer 1999) so med drugim pokazale, da so bili sesalski mladiči, ki so bili deležni veliko materinih dotikov, v odraslosti veliko pogumnejši od tistih, ki so bili deležni manj dotikanja - ti so bili kot odrasli veliko bojazljivejši in so se s stresom spopadali slabše kot mladiči iz prve skupine. Na pomen telesnega stika opozarja tudi dejstvo, ki ga je pokazala terapevtska praksa z osebami, ki so $v$ otroštvu utrpele pomanjkanje telesnega stika - te osebe imajo $v$ odraslosti različne težave, povezane $z$ vzpostavljanjem zadovoljujočih intimnih odnosov. Pomanjkanje ljubkovanja, tolaženja in dotikov v otroštvu se v odraslosti lahko kaže tudi kot samopoškodovanje, kajenje, motnje hranjenja, zloraba mamil in alkohola ter zanemarjanje telesa (Orbach 2004a; 2004b; v Sunderland 2008).

Da se bo otrok v odraslosti počutil varno ter da bo sprejemal sebe in druge, mu mora odrasla oseba v otroštvu zagotoviti varen telesni stik in telesno pomirjanje njegove stiske (Fleming, O'Day in Kraemer 1999). Vsaka oblika ljubečega telesnega stika med odraslim in otrokom ima lahko pozitiven vpliv na otrokov razvoj. Tako pri mlajših kot tudi pri starejših osebah je opaziti izjemen vpliv dotikov na delovanje možganov. Raziskave (Montagu 1971 v Sunderland 2008; Prescott 1971 v Sunderland 2008) kažejo, da imajo družbe in družine, kjer si družinski člani pogosto izkazujejo telesno naklonjenost, veliko manj težav $z$ jezo in agresijo.

Neomejenemu nudenju telesnih stikov otroku pritrjuje tudi teorija navezanosti, ki pravi, da je za razvoj varne navezanosti potrebno dosledno odgovarjanje na otrokove potrebe, kamor spada tudi potreba po telesnem stiku. Seveda ob poudarjanju zadovoljevanja te potrebe ni mišljeno, da je otroku telesni stik potrebno nuditi tudi takrat, kadar je povsem zadovoljen sam s seboj in ne izraža nobenih potreb po njem. $V$ takem primeru bi telesni stik na pobudo odraslega za otroka lahko pomenil vsiljivost, kar lahko doseže nasproten učinek in povzroči katerega izmed vzorcev t. i. nevarne navezanosti (Belsky Rovine in Taylor 1984 v Cugmas 1998).

\section{Hranjenje}

Glede hranjenja dojenčka so avtorji enotni (Hoyer 2011; Kompan Erzar in Poljanec 2009; Praper 1995; McKenna in McDade 2005), da je najboljša hrana zanj v prvih šestih mesecih izključno materino mleko, kot priporočata tudi Svetovna zdravstvena organizacija (SZO) (World Health Organization 1998) in 
UNICEF. Dojenje ima poleg prehrambene in zdravstvene vrednosti za otroka in mater še druge koristi. Ob njem se vzpostavljajo in krepijo čustvene vezi med njima. Dojenje lahko ima različne razsežnosti in ga opredelimo kot izključno dojenje, skoraj izključno dojenje, delno dojenje, minimalno dojenje in nikoli dojen. Razlogov, zakaj se dojenje ne vzpostavi ali se prekmalu prekine, je več. Eden izmed najpogostejših je pomanjkanje mleka, ki je v resnici le redko primarni razlog, temveč je $v$ večini primerov posledica drugih dejavnikov, najpogosteje pomanjkanja socialne opore materi in pravih informacij, ki so ključnega pomena pri vzpostavljanju in ohranjanju dojenja (Hoyer 2011; Hrovat Kuhar 2010; Kompan Erzar in Poljanec 2009; Sears in Sears 2009; Šoster Olmer 1999).

Čeprav je dojenje naravno, je z razvojem kulture postalo veščina, ki se je je potrebno naučiti. $V$ socialnih skupnostih, $v$ katerih so bili otroci $v$ davni preteklosti (ali kot je to pri preprostih ljudstvih še danes) že od rojstva vsakodnevno obkroženi $z$ doječimi materami, se je veščina dojenja prenašala iz generacije $v$ generacijo preko zgleda in učenja s posnemanjem. Danes se ženska prvič zares sreča z dojenjem šele takrat, ko sama postane mati (Šoster Olmer 1999).

Če dojenje povežemo s prejšnjimi temami (jok, telesni stik in spanje), ugotovimo, da so $v$ vzajemnem odnosu: dojenje $v$ primerjavi $z$ drugimi načini hranjenja omogoča takojšen odziv na dojenčkov jok, če je ta posledica lakote; vzpostavlja najtesnejši in najnaravnejši telesni stik ter je v vzajemnem odnosu s skupnim spanjem, saj skupno spanje olajša dojenje, dojenje spodbuja skupno spanje, vse skupaj spet olajša tolaženje otroka in odzivanje nanj. Praper (1995) ob zdravstvenih koristih dojenja za otroka navaja že omenjene psihološke koristi. Pravi, da je pomembno, da je narava poskrbela, da mora biti otrok pri dojenju aktiven. Dobro mora namreč prijeti in sesati, šcimer njegova samoaktivnost že na začetku postane pomemben dejavnik njegovega lastnega razvoja. S tem se nauči vložiti napor, ki ga pripelje do zadovoljitve potrebe. Z vidika znanja o objektnih odnosih vemo, da otrok v prvih mesecih potrebuje konstantni odnos v paru, zato je pomembno, da ga vsaj prvih šest mesecev hrani ena oseba, četudi hranjenje poteka po steklenički. Pomembno je, da ima ta oseba z otrokom dober stik in da ob hranjenju tečejo taktilna, očesna in gibalna komunikacija med skrbnikom in otrokom. To trditev potrjuje tudi raziskava (Heinrichs idr. $2001 \mathrm{v}$ Sunderland 2008), ki je pokazala, da tako dojenje kot hranjenje po steklenički, pri katerem oseba pestuje dojenčka ob svojem telesu, znižujeta raven stresnih hormonov in s tega vidika ni občutne razlike med obema načinoma hranjenja.

Čeprav nekateri avtorji (Folden Palmer 2007 v Kompan Erzar in Poljanec 2009) trdijo, da so dojeni otroci pogosteje varno navezani, druga raziskava 
(Britton 2006) tega ne potrdi. Iskali so namreč povezavo med dojenjem, varno navezanostjo otroka ter občutljivostjo matere. Ugotovili so, da neposredne povezave med dojenjem in vzorcem navezanosti ni in da so doječe matere pokazale večjo občutljivost za svoje otroke, kar spodbuja razvoj varne navezanosti. To je mogoče razložiti z drugo raziskavo (Heinrichs idr. 2001 v Sunderland 2008), ki je pokazala, da dojenje odlično vpliva na materino razpoloženje, ker pomirja sistem za odzivanje na stres v njenih možganih. Ker je mati mirna in sproščena, lažje pomiri in potolaži dojenčka. Iz tega lahko sklepamo, da ima dojenje vsaj posreden vpliv na razvoj varne navezanosti.

Raziskavi Kramerja idr. (2008) ter Quinna idr. (2001) kažeta, da izključno dojenje vsaj prvih šest mesecev pozitivno vpliva tudi na otrokov spoznavni razvoj. V vzdolžni raziskavi (Oddy idr. 2010) so raziskali vpliv izključnega dojenja vsaj prvih šest mesecev na kasnejše psihično zdravje otrok ter mladostnikov. Ugotovili so, da so manj kot šest mesecev dojeni oz. nedojeni otroci kasneje imeli več težav s psihičnim zdravjem in vedenjskih težav kot otroci, ki so bili izključno dojeni vsaj šest mesecev.

Vedenjski psihologi poudarjajo, da mati zadovoljuje otrokovo primarno biološko potrebo po hrani, njeno zadovoljevanje daje otroku občutek zadovoljstva. Navzočnost matere pri doživljanju tega zadovoljstva postane za otroka sekundarna potreba, saj vzljubi vse dražljaje, ki se pojavljajo skupaj s hranjenjem: materino toplino, nasmeh, besede ipd. (Berk 1996 v Cugmas 1998). Vendar za ustvarjanje čustvenega odnosa med materjo in otrokom ne zadostuje le materino zadovoljevanje otrokovih osnovnih bioloških potreb, temveč je potrebna širša interakcija med njo in otrokom. To potrjujejo tudi ugotovitve raziskav z opicami (Sroufe, Cooper in DeHart 1996 v Cugmas 1998), na podlagi katerih je mogoče sklepati, da otrok lahko razvije varno navezanost na mater, čeprav ga ta ne hrani (Berk 1996 v Cugmas 1998). Ta ugotovitev je pomirjujoča v primerih, kadar dojenje ne uspe ali to ni izvedljivo.

Glede na statistiko v Sloveniji (Nacionalni Inštitut za javno zdravje Republike Slovenije 2018; Fajdiga Turk 2013) je delež izključno dojenih dojenčkov v prvih mesecih še vedno na nezadovoljivi ravni oz. ni v skladu s priporočili SZO. Konec prvega meseca je izključno dojenih štiri petine dojenčkov, konec petega meseca štirje od desetih. Delež nedojenih otrok je višji pri materah z nižjim socialno-ekonomskim statusom in nižjo izobrazbo. Izsledki pilotske raziskave v Sloveniji kažejo, da se obdobje dojenja v Sloveniji podaljšuje. Povprečna dolžina dojenja je 10,2 meseca (Rebernik 2014). Današnjim materam je na področju dojenja na voljo bistveno več virov informacij in socialne opore, kot so je bile deležne matere prejšnjih generacij (Fleming, O'Day in Kraemer 1999).

Ob uspešni vzpostavitvi dojenja se kmalu porodi vprašanje o trajanju do- 
jenja. Večina priročnikov ter drugih strokovnih in znanstvenih virov (Hoyer 2011; Kompan Erzar in Poljanec 2009; Sears in Sears 2008; Šoster Olmer 1999) se opira na SZO in UNICEF, ki priporočata izključno dojenje vsaj prvih šest mesecev, nato ob drugi hrani še do dveh let ali dlje (t. i. podaljšano dojenje), $v$ kolikor to ustreza otroku in mami. Točne zgornje starostne meje SZO ne postavlja, saj večina otrok potrebo po dojenju preraste med drugim in četrtim letom starosti. Praper (1995) prav tako ne postavlja jasne starostne meje za odstavitev otroka od dojenja, ima pa drugačen pogled na način odstavljanja. Meni, da mora pobuda za odstavljanje zmeraj priti z materine strani, vendar postopoma. $Z$ vidika objektnih odnosov opozarja, da je podaljšano dojenje lahko tudi znak t. i. prolongirane in vampirske simbioze, ko mati vztraja pri dojenju iz lastnih potreb in otroka zapira v krog simbioze.

\section{Zaključek}

Pogledi na nego in vzgojo mlajšega otroka so se skozi zadnjih nekaj generacij postopoma in počasi, a korenito spremenili. Gre za posledico spremenjenega občutenja starševstva in odnosa do otroštva, ki temelji na znanstvenih spoznanjih na področju nege in vzgoje otrok ter na splošnem družbenem napredku. Znanost je ovrgla mnogo mitov iz preteklosti, nekateri se še ohranjajo. Slednji se najbolj odražajo v pojmovanju razvajenosti, saj se izraz pogosto uporablja neustrezno. Čeprav smo danes ob mnogih pričevanjih, ki govorijo o odnosu do otrok v preteklosti, osupli, pretreseni in prizadeti, menimo, da namen takratne vzgoje zagotovo ni bil otrokom škodovati. Bila je odraz časa, prostora in družbenih razmer. Enako velja za sodobno vzgojo in sodoben odnos do (mlajših) otrok. Še vedno ne vemo vsega in se še učimo. In prav tako menimo, da bi verjetno le izjemoma našli starše, ki bi pri skrbi za svojega otroka uporabljali določena sredstva z motivom škodovati otroku. Sklepamo, da starši poteze, ki niso optimalne za otrokov razvoj in medosebne odnose, izbirajo zato, ker drugače ne znajo, ne morejo ali imajo napačna prepričanja o negi in vzgoji.

Spoznanja, ki smo jih predstavili v tem prispevku, niso pomembna le pri vzgoji v družini, temveč imajo pomembno mesto tudi pri delu v vrtcu. Tudi tam otrok potrebuje zanesljive odrasle osebe, ki bodo sposobne razumeti njegove razvojne potrebe, prepoznati njegove stiske in strahove ter se znati nanje ustrezno odzvati.

\section{Literatura}

Anisfeld, E., V. Casper, M. Nozyce in N. Cunningham. 1990. »Does Infant Carrying Promote Attachment? An Experimental Study of the Effects of Increased 
Physical Contact on the Development of Attachment.« Child Development 61 (5): 1617-1627.

Belsky, J., M. Rovine in D. Taylor. 1984. »The Pennsylvania Infant and Famuly Development Project.« Child Development 55:718-728.

Berk, L. E. 1996. Children and Adolescents. 2. izd. Boston, MA: Allyn and Bacon.

Bigelow, A., M. Power, J. MacLellan-Peters, M. Alex in C. McDonald. 2012. »Effect of Mother/Infant Skin-to-Skin Contact on Postpartum Depressive Symptoms and Maternal Physiological Stress. « Journal of Obstetric, Gynecologic \& Neonatal Nursing 41 (3): 369-382.

Britton, J. R., H. L. Britton in V. Gronwaldt. 2006. »Breastfeeding, Sensitivity and Attachment.«Pediatrics 118 (5): 1436-1443.

Caldji, C., J. Diorio in M. J. Meaney. 2000. „Variations in Maternal Care in Infancy Regulate the Development of Stress Reactivity.« Biological Psychiatry 48 (12): 1164-1174.

Chisholm, J. 1986. Navajo Infancy: An Ethological Perspective. New York: Aldine de Gruyer.

Cugmas, Z. 1998. Bodi z menoj, mami: razvoj otrokove navezanosti. Ljubljana: Produktivnost, Center za psihodiagnostična sredstva.

- 2003. Narisal sem sonce zate: izbrana poglavja o razvoju otrokove navezanosti in samozaznave. Ljubljana: Center za psihodiagnostična sredstva.

Čačinovič Vogrinčič, G. 1998. Psihologija družine. Ljubljana: Znanstveno publicistično središče.

Dawson, G. 2000. »The Role of Early Experience in Shaping Behavioural and Brain Development and Its Implications for Social Policy.« Developmental Psychology 12 (4): 695-712.

Dewar, G. 2008. »The Science of Attachment Parenting.« http://www .parentingscience.com/attachment-parenting.html

Erdman, P., in T. Caffery. 2003. Attachment and Family Systems: Conceptual, Empirical and Therapeutic Relatedness. New York, NY: Brunner-Routledge.

Erzar, K., in K. Kompan Erzar. 2011. Teorija navezanosti. Celje: Celjska Mohorjeva družba.

Fajdiga Turk, V. 2013. »Bi lahko povečali delež izključno dojenih šestmesečnikov v Sloveniji?« http://www.nijz.si/sites/www.nijz.si/files/uploaded/picture1 -6970.pdf

Fifer, W. P., in C. M. Moon. 1994. »The Role of Mother's Voice in the Organization of Brain Function in the Newborn. "Acta Paediatrica 83 (397), 86-93.

Fleming, A. S., D. H. O'Day in G. W. Kraemer. 1999. »Neurobiology of MotherInfant Interactions: Experience and Central Nervous System Plasticity across Development and Generations." Neuroscience and Biobehavioral Reviews 23 (5): 673-685.

Folder Palmer, L. 2007. Baby Matters: What Your Doctor May Not Tell You about Caring for Your Baby. San Diego, CA: Baby Reference. 
Gunnar, M. R. 1989. »Studies of the Human Infant's Adrenocortical Response to Potentially Stressful Events.« New Directions for Child Development 45:3-18. Heinrichs, M., G. Meinlschmidt, I. Neumann, S. Wagner, C. Kirschbaum, U. Ehlert in D. H. Hellhammer. 2001. „Effects of Suckling on HPA Axis Responses to Psychosocial Stress in Postpartum Lactating Women. "The Journal of Clinical Endocrinology and Metabolism 86 (10): 4798-4804.

Hoyer, S. 2011. Uspešno dojenje za dobro zdravje otrok in mater. Ljubljana: Društvo UNICEF Slovenija.

Hrovat Kuhar, E. 2010. Poporodni izziv: ko dvojina postane množina. Ljubljana: Mladinska knjiga.

Hsu, F. C., G. J. Zhang, Y. S. Raol, R. J. Valentino, D. A. Coulter in A. R. Brooks-Kayal. 2003. »Repeated Neonatal Handling with Maternal Separation Permanently Alters Hippocampal GABAA Receptors and Behavioral Stress Responses."Proceedings of the National Academy of Sciences of the United States of America 14:12213-12218.

Kompan Erzar, K., in A. Poljanec. 2009. Rahločutnost do otrok: stik z otrokom v prvem letu življenja. Ljubljana: Brat Frančišek.

Kramer, M. S., F. Abound, E. Mironova, I. Valinovich, R. W. Platt in L. Matush. 2008. »Breastfeeding and Child Cognitive Development."JAMA 65 (5): 578-584.

Marjanovič Umek, L., in M. Zupančič. 2009. Razvojna psihologija. Ljubljana: Znanstvena založba Filozofske fakultete.

McKenna, J. J., in T. McDade. 2005. „Why Babies Should Never Sleep Alone: A Review of the Co-Sleeping Controversy in Relation to SIDS, Bedsharing and Breast Feeding." Paediatric Respiratory Reviews 6:134-152.

McKenna, J. J., S. Mosko in C. A. Richard. 1997. »Bedsharing Promotes Breastfeeding."Pediatrics 100 (2): 214-219.

Montagu, A. 1971. Touching: The Human Significance of the Skin. London: Harper and Row.

Mosko, S., C. A. Richard in J. J. McKenna. 1997. "Maternal Sleep and Arousals During Bedsharing with Infants."Sleep 20 (2): 142-150.

Oddy, W. H., G. E. Kendall, J. Li, P. Jacoby, M. Robinson in B. A. Psycha. 2010. »The Long-Term Effects of Breastfeeding on Child and Adolescent Mental Health: A Pregnancy Cohort Study Followed for 14 Years. «The Journal of Pediatrics 156 (4): 568-574.

Orbach, S. 2004a. »The Body in Clinical Practice, Part One: There's No Such Thing as a Body." In John Bowlby Memorial Lecture in Touch, Attachment and the Body, ur. Kate White, 17-34. London: Karnac.

Orbach, S. 2004b. »The Body in Clinical Practice, Part Two: When Touch Comes to Therapy. «In John Bowlby Memorial Lecture in Touch, Attachment and the Body, ur. Kate White, 35-47. London: Karnac.

Pantley, E. 2003. Otroško spanje - brez joka v sanje. Radovljica: Didakta.

Papalia, D. E., S. W. Olds in R. D. Feldman. 2003. Otrokov svet. Ljubljana: Educy. 
Peček Čuk, M., in I. Lesar. 2011. Moč vzgoje: sodobna vprašanja teorije vzgoje. Ljubljana: tehniška založba Slovenije.

Praper, P. 1995. Tako majhen, pa že nervozen!? Predsodki in resnice o nevrozi pri otroku. Nova Gorica: Educa.

Prescott, J. W. 1971. „Early Somatosensor Deprivation As an Ontogenetic Process in the Abnormal Development of Brain and Behaviour.«In Proceedings of the Second Conference on Experimental Medicine and Surgery in Primates, ur. E. I. Goldsmith in J. Mody-Janokowski, 356-375. Bazel: Karger.

Puhar, A. 1982. Prvotno besedilo življenja: oris zgodovine otroštva na Slovenskem $v$ 19. stoletju. Ljubljana: ČGP Delo.

Quinn, P. J., M. O'Callaghan, G. M. Williams, J. M. Najman, M. J. Andersen in W. Bor. 2001. »The Effect of Breastfeeding on Child Development at 5 Years: A Cohort Study." Journal of Paediatrics and Child Health 37 (5): 465-469.

Rebernik, A. 2014. Zakaj devet od desetih mater konča dojenje prej, kot bi si želele? Siol.net, 1. avgust. http://www.siol.net/trendi/intimno/druzina_in _prijatelji/2014/o8/dojenje_zalka_drglin.aspx

Rožman, I. 2004. Peč se je podrla! Kultura rojstva na slovenskem podeželju v 20. stoletju. Ljubljana: Slovensko etnološko društvo.

Sears, W., in M. Sears. 2004. Uspešen otrok. Radovljica: Didakta.

- 2008. Povezovalno starševstvo. Ljubljana: Mladinska knjiga.

Sroufe, L. A., R. G. Cooper in G. B. DeHart. 1996. Child Development: Its Nature and Course. 3. izd. New York: McGraw-Hill.

Sunderland, M. 2008. Znanost o vzgoji: praktični nasveti o spanju, joku, igri in ustvarjanju čustvenega ravnovesja za vse življenje. Radovljica: Didakta.

Nacionalni Inštitut za javno zdravje Republike Slovenije. 2018. "Svetovni teden dojenja 1. do 7. avgust 2018.« http://www.nijz.si/sl/svetovni-teden -dojenja-1-do-7-avgust-2018

Škoro Babić, A., M. Jeraj, M. Košir, B. Balkovec, M. Rebolj, D. Čeč. 2012. Zgodovina otroštva. Ljubljana: Zveza zgodovinskih društev Slovenije.

Šoster Olmer, K. 1999. Dojenje in materinstvo iz srca. Ljubljana: Vale Novak.

Švab, A. 2001. Družina: od modernosti k postmodernosti. Ljubljana: Znanstveno in publicistično središče.

Turgeon, H. 2011. »How Much Attachment Parenting Is Necessary? The Real Keys to Bonding.«http://www.babble.com/baby/how-much-attachment -parenting-is-necessary/

World Health Organization. 1998. Evidence for the Ten Steps to Successful Breastfeeding. Geneva: World Health Organization.

Zeifman, D. M. 2001. »An Ethological Analysis of Human Infant Crying." Developmental Psychobiology 39:265-285.

Zupančič, M. 2009. »Predmet in zgodovina razvojne psihologije.« V Razvojna psihologija, ur. L. Marjanovič Umek in M. Zupančič, 6-27. Ljubljana: Filozofska fakulteta. 


\section{Care and Education of a Young Child as an Important Developmental Basis}

The focus of the article is on care and education of a child. The areas where the most direct ways of satisfying the need of a child in his or hers earliest period that affect establishing the relationship with the child are presented in more detail. This relationship is established right after child's birth and represents a basis for later upbringing. Cry, sleep, physical contact and feed are being taken into the account. We find that many practices in relation to infants and toddlers in the present day are in great contradiction with practices in the past, which is largely a consequence of social progress and scientific knowledge in areas that are directly or indirectly related to the attitude towards children. Some findings are highly related to child's family care and upbringing, whereas more general ones can be used in preschool education institutions. What is important is that professional preschool teachers and workers are familiarized with modern scientific views of child's upbringing, education and care since then their work can be done professionally.

Keywords: young child, crying, feeding, body contact, sleeing 


\title{
Uporaba dobrih praks za spodbujanje socialno-emocionalnega razvoja pri otrocih prvega starostnega obdobja v vrtcu
}

\author{
Marta Licardo \\ Univerza v Mariboru \\ marta.licardo@um.si \\ Metka Purgaj \\ Vrtec Sladki Vrh \\ metka.purgaj@gmail.com
}

\begin{abstract}
V prispevku je predstavljen pomen uporabe dobrih praks za spodbujanje socialno-emocionalnega razvoja pri otrocih starosti od enega do treh let. Namen raziskave je bil ugotoviti, kakšna je ocena strokovnih delavcev glede pomembnosti socialno-emocionalnega področja v primerjavi z drugimi področji razvoja (npr. estetski razvoj, moralno-etični razvoj, kognitivni razvoj, motorika), kakšna je ocena pomembnosti področja družba $v$ primerjavi z drugimi področji dejavnosti v kurikulumu (umetnost, naravoslovje, jezik, gibanje, matematika) ter ali pri uporabi dobrih praks za to področje obstajajo razlike med homogenimi in heterogenimi skupinami. Rezultati kažejo, da strokovni delavci, ki delajo z otroki v prvem starostnem obdobju, socialno-emocionalno področje uvrščajo med najpomembnejša področja razvoja. Rezultati kažejo tudi, da se $v$ homogenih skupinah dobre prakse za otrokov socialno-emocionalni razvoj uporabljajo pogosteje kot $v$ heterogenih skupinah prvega starostnega obdobja ter da strokovni delavci najpogosteje uporabljajo tiste prakse, ki so del vsakodnevnih interakcij, manj pogosto pa uporabljajo prakse, za katere je potrebno vsaj delno načrtovanje ali poznavanje specifičnih strategij.
\end{abstract}

Ključne besede: socialno-emocionalni razvoj, metode, dobre prakse, zgodnje otroštvo, predšolska vzgoja

\section{Uvod}

Dobre prakse za spodbujanje socialno-emocionalnega razvoja otrok v zgodnjem otroštvu so lahko vezane na postopke, dejavnosti, aktivnosti, metode ali procese, ki prinašajo najboljše rezultate in temeljijo na dokazih raziskav ali izkušenj. Socialno-emocionalni razvoj in njegovo spodbujanje sta pomemben dejavnik, ki vpliva na celosten in daljnosežen razvoj otroka. Otroci, ki imajo razvite socialno-emocionalne veščine, lažje razumejo, izražajo in 
regulirajo lastna dejanja in čustvovanja (Woolfolk 2002). Učenje socialnoemocionalnih veščin ima lahko takojšnje in neposredne učinke, saj se otrok nauči, kako se sporazumevati z vrstniki in drugimi bližnjimi osebami, hitreje in učinkoviteje lahko sodeluje pri učenju novega, doživlja več pozitivnih povratnih informacij, kar ugodno vpliva na njegovo samopodobo in dobro počutje v primerjavi z otroki, ki imajo socialno-emocionalne veščine slabše razvite (Goodman idr. 2015). Raziskave kažejo, da obstajajo pozitivne korelacije med razvojem socialno-emocionalnih veščin v zgodnjem otroštvu in pripravljenostjo na vstop v šolo, šolskim uspehom in razvojem kognicije (Durlak idr. 2011; Elias idr., 1997; DiPerna in Elliot 2002).

Od strokovnih delavcev $v$ vrtcih se pričakuje, da bodo podpirali otrokov razvoj na vseh področjih, pri čemer ima socialno-emocionalno področje izjemen pomen, saj se $v$ zgodnjem obdobju oblikujejo temelji za razvoj otrokovih veščin na tem področju, ki jih je v kasnejših obdobjih težje oblikovati ali preoblikovati. Strokovni delavci v vrtcih naj bi torej spodbujali otroke k medsebojni komunikaciji, skrbeli naj bi za primerno dobro čustveno in socialno počutje otrok, razvoj zavedanja samega sebe, razvoj samoregulacije v skladu z razvojno stopnjo, razvoj pozitivne samopodobe itd., kar so vse pomembni prediktorji otrokovega uspeha in dobrega počutja (Petty 2016; DiPerna in Elliot 2002). Skrb za omenjena področja naj ne bi bila le del vsakodnevnih rutin in komunikacije, temveč bi morala biti tudi del premišljenih načrtovanih dejavnosti izvedbenega kurikuluma, kjer se otroci učijo socialno-emocionalnih veščin in kjer se spremljajo razvojni mejniki za to področje ter kjer vzgojitelj zna in zmore ustrezno ukrepati, kadar pri posameznem otroku zazna odstopanja.

Raziskave o uporabi dobrih praks za razvoj socialno-emocionalnih veščin v zgodnjem otroštvu v vrtcu kažejo, da je vrtčevsko okolje prvo socialno okolje otroka zunaj družine in s tem pomembno polje njegovih socialnih in emocionalnih izkušenj, kjer izkazuje in preizkuša svoje veščine (Phillips, McCartney in Sussman 2006). Prav tako otroci v tem obdobju doživljajo hitre in pomembne spremembe, ki vključujejo učenje jezika ter razvoj možganov, ki sta oba ključnega pomena za učenje komunikacijskih veščin, socialnih veščin, razumevanja čustev, samoregulacije ipd. (Thompson in Lagattuta 2006; Blair 2002). Zato je v vrtcu pomembno zagotoviti varno, sprejemajoče okolje, $v$ katerem se vzpostavljajo in ohranjajo prijetni odnosi med otroki in odraslimi, kjer se uporabljajo dobre prakse $v$ vsakodnevnih interakcijah in kjer znajo odrasli po potrebi tudi strokovno intervenirati v primeru čustvenih ali vedenjskih težav otrok (Hyson 2004). Ob tem pa je treba tudi načrtovati dejavnosti, ki vključujejo igre, branje in druge vodene dejavnosti za učenje socialno-emocionalnih 
veščin (Cohen 2001). Namreč, različni programi za učenje slednjih v zgodnjem otroštvu kažejo mnoge pozitivne učinke (Payton idr. 2008; Joseph in Strain 2003; Pianta idr. 2009).

Namen pričujoče raziskave je bil preveriti, kako strokovni delavci, ki imajo v skupini otroke od 1 do 3 let starosti, ocenjujejo socialno-emocionalno področje ter kako pogosto izvajajo posamezne dobre prakse. Postavke, ki se nanašajo na dobre prakse, vključujejo oceno strokovnih delavcev o pogostosti različnih vsakodnevnih interakcij in pogostosti izvedbe različnih dejavnosti. Preverjali smo tudi, ali obstajajo razlike pri uporabi dobrih praks glede na skupino (homogena/heterogena). Z raziskovalnimi vprašanji smo želeli osvetlili pojmovanja strokovnih delavcev o socialno-emocionalnem razvoju otrok v primerjavi s področji razvoja in področji dejavnosti ter preveriti, katere dobre prakse so najpogosteje izvajane.

\section{Metodologija}

\section{Vzorec}

Rezultati, ki so predstavljeni v prispevku, so del večje raziskave, v kateri je sodelovalo 209 strokovnih delavcev iz različnih regij v Sloveniji, od teh jih je 121 delalo $z$ otroki drugega starostnega obdobja in $88 \mathrm{z}$ otroki prvega starostnega obdobja. Ker je $v$ glavni del rezultatov zajeta samo populacija strokovnih delavcev, ki dela z otroki prvega starostnega obdobja, v nadaljevanju podrobneje predstavljamo ta vzorec. V vzorcu strokovnih delavcev $(n=88)$, ki delajo z otroki prvega starostnega obdobja, je bila starostna struktura precej enakomerno razpršena, 22,7\% je bilo starih 51 ali več let, 9,1\% je bilo starih med 46 in 50 let, 10,2\% je bilo starih med 41 in 45 let, 17,0\% je bilo starih od 36 do 40 let, $19,3 \%$ je bilo starih od 30 do 35 let, $18,2 \%$ je bilo starih od 24 do 29 let in 3,4\% je bilo starih med 18 in 23 let. 40,9\% strokovnih delavcev je imelo zaključeno srednješolsko izobrazbo, $38,6 \%$ je imelo zaključeno višjo ali visoko izobrazbo, 19,3 je imelo zaključeno univerzitetno izobrazbo in le 1,1\% je imelo končan magisterij ali več. V vzorcu je imela tretjina (29,5\%) 6 do 10 let delovnih izkušenj, 23,9\% jih je imelo do 5 let delovnih izkušenj, 20,5\% jih je imelo 26 ali več let delovnih izkušenj, 12,5\% jih je imelo 11 do 15 let delovnih izkušenj, 9,1\% jih je imelo 21 do 25 let delovnih izkušenj in 4,5\% jih je imelo 16 do 20 let delovnih izkušenj. 52,3\% strokovnih delavcev je bilo na delovnem mestu pomočnika vzgojitelja, $47,7 \%$ pa na delovnem mestu vzgojitelja. Večina $(87,5 \%)$ je imela v skupini 9 do 14 otrok, 2,3\% jih je imelo manj kot 9 otrok, $10,2 \%$ je bilo takih, ki so imeli več kot 15 otrok, ker so imeli heterogene ali kombinirane skupine. Več kot dve tretjini $(67,2 \%)$ strokovnih delavcev je bilo vključenih v izobraževanje o socialno-emocionalnem razvoju otrok pred 
manj kot dvema letoma, le 3,4\% jih je takšno izobraževanje imelo pred več kot 10 leti in $19,3 \%$ pred več kot 5 leti.

\section{Instrumentarij}

Uporabili smo anketni vprašalnik, ki je nastal za potrebe te raziskave in vsebuje vprašanja zaprtega tipa. Postavke v vprašalniku smo oblikovali na podlagi strokovne literature (Ward Platt 2006; Ivić, Novak in Ašković 2002; Early Learning Guidelines for Children Birth to Age Three 2015; Marjanovič Umek idr. 2004; Licardo 2016). Vprašalnik je sestavljen iz več sklopov: (a) vprašanja o demografskih podatkih; (b) vprašanja o pomembnosti posameznih področij razvoja in področij dejavnosti za otrokov nadaljnji razvoj in uspešnost v življenju; (c) vprašanja o poznavanju in spodbujanju socialnoemocionalnega razvoja; (č) vprašanja o izvajanju aktivnosti, ki spodbujajo socialno-emocionalni razvoj v prvem starostnem obdobju, in vprašanja o izvajanju aktivnosti, ki spodbujajo socialno-emocionalni razvoj v drugem starostnem obdobju. V sklopu a smo uporabili zaprti tip vprašanj, kjer je možen le en odgovor. V sklopu b smo uporabili ocenjevalno lestvico Likertovega tipa od 1 do 5 ( 1 - ni pomembno, 2 - malo pomembno, 3 - srednje pomembno, 4 - precej pomembno, 5 - zelo pomembno). Sklop c je prav tako sestavljen z ocenjevalno lestvico Likertovega tipa od 1 do 5 (1 - sploh se ne strinjam, 2 - se ne strinjam, 3 - ne morem se opredeliti, 4 - se strinjam, 5 - popolnoma se strinjam). Tudi pri zadnjem d sklopu je uporabljena Likertova ocenjevalna lestvica d 1 do 5 ( 1 - nikoli, 2 - redko, 3 - srednje pogosto, 4 - pogosto, 5 vedno). Veljavnost anketnega vprašalnika smo preverili s poskusnim reševanjem ankete. Po končani pilotski izvedbi smo opustili ali spremenili dvoumna ali nejasna vprašanja. Zanesljivost smo preverjali s Cronbachovim koeficientom alfa. Koeficient zanesljivosti pri oceni pomembnosti posameznih področij razvoja in področij dejavnosti za otrokov nadaljnji razvoj ter uspešnost v življenju za lestvico b je o,93. Koeficient zanesljivosti pri samooceni poznavanja in spodbujanja socialno-emocionalnega razvoja za lestvico c je o,82 in pri samooceni aktivnosti, ki spodbujajo socialno-emocionalni razvoj v prvem starostnem obdobju, za lestvico d je o,84. Koeficienti dokazujejo ustrezno raven notranje konsistentnosti lestvic (DeVellis 2003).

\section{Postopki zbiranja podatkov in analize}

Anketne vprašalnike smo poslali v vrtce po Sloveniji, kjer so jih izpolnjevali vzgojitelji in pomočniki vzgojiteljev. Podatke smo zbirali aprila 2017 s spletno anketo, nato pa smo vprašalnike še natisnili in jih maja ter junija 2017 razdelili v tiskani obliki, ker je bila pri zbiranju podatkov s spletno anketo odzivnost 
premajhna. Tiskane vprašalnike smo nato razdelili po vrtcih $v$ različnih regijah. Za primerjavo področij razvoja in področij dejavnosti pri strokovnih delavcih, ki delajo z otroki v prvem in drugem starostnem obdobju, smo analizirali deskriptivno statistiko $(\min , \max , M, S D)$. S $t$-testom za neodvisne vzorce smo preverjali tudi razlike glede na skupine (homogene nasproti heterogenim skupinam).

V prispevku navajamo le pomembnejše rezultate za prvo starostno obdobje: (a) primerjavo ocen pomembnosti socialnega in emocionalnega področja glede na druga področja razvoja, (b) primerjavo ocen pomembnosti področja družba v primerjavi z drugimi področji dejavnosti, (c) pogostost uporabe dobrih praks za spodbujanje socialno-emocionalnega razvoja v prvem starostnem obdobju in (č) razlike glede na heterogene in homogene skupine pri uporabi dobrih praks za socialno-emocionalni razvoj v prvem starostnem obdobju.

\section{Rezultati}

V nadaljevanju predstavljamo sklope posameznih rezultatov. $V$ vseh rezultatih so zajeti strokovni delavci, ki delajo $\mathrm{v}$ vrtcih z otroki, starimi od 1 do 3 let, v sklopu a in b pa tudi tisti, ki delajo $z$ otroki, starimi od 3 do 6 let.

\section{(a) Primerjava ocen pomembnosti socialnega in emocionalnega področja glede na druga področja razvoja}

Na sliki 1 so prikazane povprečne ocene strokovnih delavcev glede pomembnosti posameznih področij razvoja za otrokov optimalni razvoj. Področja razvoja smo povzeli po Kurikulumu za vrtce (Ministrstvo za šolstvo in šport 1999). Ocene so razdeljene $v$ dve skupini: na levi so povprečja ocen strokovnih delavcev, ki delajo $z$ otroki starosti od 1 do 3 let ( $v$ nadaljevanju 1. SO), na desni pa povprečja ocen strokovnih delavcev, ki delajo $z$ otroki starosti od 3 do 6 let (v nadaljevanju 2. SO).

Iz rezultatov lahko razberemo, da so vse povprečne vrednosti pričakovano precej visoke. Po ocenah za 1. SO so najpomembnejša tri področja, jezik in govor $(M=4,84 ; S D=0,39)$, socialno področje $(M=4,82 ; S D=0,41)$ in emocionalno področje $(M=4,82 ; S D=0,41)$, pri čemer so za socialno in emocionalno področje ocene za 1. SO popolnoma izenačene. Temu sledijo področja motorike $(M=4,72 ; S D=0,50)$, kognicije $(M=4,51 ; S D=0,66)$, motivacije $(M=$ $4,50 ; S D=0,71)$, moralno-etičnega razvoja $(M=4,48 ; S D=0,71)$ in kot najmanj pomemben je ocenjen estetski razvoj $(M=3,90 ; S D=0,87)$. Pri preverjanju statistično značilnih razlik med ocenami glede na SO smo ugotovili, da statistično pomembnih razlik ni (motorika: $t(207)=-0,07 ; p=0,94$; socialno po- 


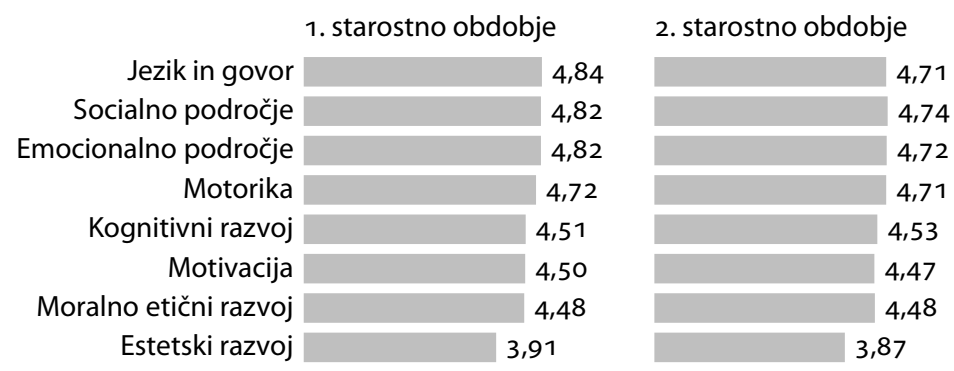

Slika 1 Ocene strokovnih delavcev, ki delajo v 1. in 2. starostnem obdobju, o pomembnosti posameznih področij razvoja (povprečna vrednost na lestvici od 1 do 5 )

dročje: $t(207)=-1,20 ; p=0,22$; emocionalno področje: $t(207)=-1,34 ; p=0,18$; estetski razvoj: $t(207)=-0,35 ; p=0,73$; motivacija: $t(207)=-0,28 ; p=0,77$; moralno-etični razvoj: $t(207)=0,02 ; p=0,98$; kognitivni razvoj: $t(207)=0,18$; $p=0,85)$.

Če rezultate za 1. SO primerjamo z rezultati za 2., lahko sklenemo, da sta socialno in emocionalno področje $v$ obeh obdobjih med najpomembnejšimi področji, pri čemer strokovni delavci nekoliko višje povprečne vrednosti ocen pripisujejo $v 1$. SO.

V nadaljevanju smo preverjali, kako strokovni delavci ocenjujejo pomembnost področja dejavnosti družba v primerjavi s preostalimi področji, saj vodene dejavnosti glede učenja in poučevanja socialno-emocionalnega razvoja sodijo na to področje (Ministrstvo za šolstvo in šport 1999).

\section{(b) Primerjava ocen pomembnosti področja družba v primerjavi z drugimi področji dejavnosti}

Rezultati ocen pomembnosti po področjih kažejo, da strokovni delavci v 1. SO presenetljivo kot najpomembnejše ocenjujejo področje matematike $(M$ $=4,27 ; S D=0,78)$, temu sledijo gibanje $(M=4,24 ; S D=0,74)$, jezik $(M=4,20$; $S D=0,74)$, družba $(M=4,12 ; S D=0,78)$, naravoslovje $(M=4,06 ; S D=0,75)$ in umetnost $(M=4,04 ; S D=0,80)$. Vse povprečne ocene so pričakovano precej visoke, kljub temu pa lahko razberemo, da družba kot področje ni prepoznano kot najpomembnejše, kar bi bilo v skladu z visokimi ocenami za področja razvoja. Domnevamo lahko, da morda strokovni delavci 1. SO v svojih pojmovanjih socialno-emocionalnega področja ne ocenjujeo kot nekaj, česar se otrok kar najbolje uči predvsem skozi načrtovane in vodene dejavnosti na področju družba.

Če primerjamo rezultate med 1. in 2. SO, lahko ugotovimo, da v 2. SO strokovni delavci kot najpomembnejše ocenjujejo področje gibanja $(M=4,38$; 


\begin{tabular}{r|rc}
\multicolumn{2}{|c}{ 1. starostno obdobje } & 2. starostno obdobje \\
Matematika & 4,27 & 4,19 \\
Gibanje & 4,24 & 4,38 \\
Jezik & 4,20 & 4,07 \\
Družba & 4,19 & 4,19 \\
Naravoslovje & 4,07 & 4,04 \\
Umetnost & 4,05 & 4,07
\end{tabular}

Slika 2 Ocene strokovnih delavcev, ki delajo v 1. in 2. starostnem obdobju, o pomembnosti posameznih področij dejavnosti po Kurikulumu za vrtce (Ministrstvo za šolstvo in šport 1999) (povprečna vrednost na lestvici od 1 do 5)

$S D=0,78)$, kot enako pomembno pa ocenjujejo področji družba $(M=4,12$; $S D=0,72)$ in matematika $(M=4,12 ; S D=0,75)$. Pri preverjanju razlik povprečij med 1. in 2 . SO s $t$-testom za neodvisne vzorce smo ugotovili, da statistično pomembnih razlik med skupinama ni, nakazuje se le tendenca razlik pri področju jezika $(t(207)=-1,81 ; p=0,07)$, kjer strokovni delavci v 1. SO temu področju pripisujejo večji pomen kot tisti v 2 . SO.

Sledi analiza rezultatov glede razlik pri uporabi dobrih praks za socialnoemocionalni razvoj v prvem starostnem obdobju.

\section{(c) Pogostost uporabe dobrih praks za spodbujanje socialno-emocionalnega razvoja v prvem starostnem obdobju}

Podatki kažejo, da strokovni delavci v prvem starostnem obdobju najpogosteje vzpostavljajo prijeten in ljubeč odnos z otrokom $(M=4,73 ; S D=0,50)$, vzpostavljajo primerno interakcijo pri prihodih in odhodih otrok $(M=4,60$; $S D=0,52)$, so dosledni pri uveljavljanju meja in pravil, primernih starosti $(M=$ $4,47 ; S D=0,72)$, ter se odzivajo s poslušanjem, kadar želi otrok povedati kaj o sebi $(M=4,36 ; S D=0,83)$. Manj pogosto spodbujajo otroke, da izražajo čustva na različne načine $(M=3,88 ; S D=0,76)$, manj pogosto tolažijo otroka, kadar je vznemirjen in pri tem uporabljajo metodo potrjevanja čustev $(M=3,74 ; S D$ $=1,09$ ), ter manj pogosto namenjajo čas branju $z$ enim ali dvema otrokoma $(M=3,59 ; S D=0,85)$.

Iz rezultatov lahko razberemo, da strokovni delavci pogosteje uporabljajo dobre prakse, ki so del vsakodnevnih interakcij z otroki in zanje ni potrebno posebno načrtovanje, kot so prihodi in odhodi, vsakodnevne interakcija ter komunikacija v odnosu z otrokom, uveljavljanje meja in pravil. Manj pogosto pa izvajajo dobre prakse, za katere je potrebno vsaj delno načrtovanje (npr. skupno branje) ali pa celostno načrtovanje, kot je spodbujanje izražanje čustev skozi glasbo, ples ali likovno umetnost. Manj pogosto uporabljajo tudi strategijo potrjevanja čustev. 
Preglednica 1 Uporaba dobrih praks za spodbujanje socialno-emocionalnega razvoja v 1. starostnem obdobju

\begin{tabular}{|c|c|c|}
\hline Spremenljivke & $M$ & $S D$ \\
\hline $\begin{array}{l}\text { Vzpostavljam prijeten in ljubeč odnos z otrokom, kadar si otrok zaželi } \\
\text { bližino odraslega. }\end{array}$ & 4,73 & 0,50 \\
\hline $\begin{array}{l}\text { Pri odhodu otroka domov mu pojasnim, da se kmalu vidimo, in } \\
\text { vzpostavim primerno interakcijo, npr. pomaham, pozdravim. }\end{array}$ & 4,60 & 0,52 \\
\hline $\begin{array}{l}\text { Sem dosledna pri uveljavljanju meja in pravil, ki so primerna starosti in } \\
\text { realnim pričakovanjem. }\end{array}$ & 4,47 & 0,72 \\
\hline Otroka poslušam in se nanj odzovem, ko mi poskuša povedati kaj o sebi. & 4,36 & 0,83 \\
\hline Poudarjam pomen deljenja igrač in stvari. & 4,30 & 0,76 \\
\hline Kadar je otrok vznemirjen, ga potolažim in ubesediva doživljanje čustev. & 4,22 & 0,76 \\
\hline Zagotovim čas za domišljijsko in simbolno igro. & 4,18 & 0,71 \\
\hline Otrokom ponudim igrače, pri katerih sta za igro potrebna dva ali več otrok. & 4,14 & 0,67 \\
\hline $\begin{array}{l}\text { Z otroki se pogovarjam o čustvih in tem, da je v redu, če doživlja različna } \\
\text { čustva. }\end{array}$ & 4,02 & 0,79 \\
\hline $\begin{array}{l}\text { Opazujem izražanje otrokovih čustev in ustrezno ukrepam, preden } \\
\text { izbruhnejo negativna čustva. }\end{array}$ & 4,00 & 0,69 \\
\hline $\begin{array}{l}\text { Otroke spodbujam, da čustva izražajo na različne načine, npr. skozi } \\
\text { likovno umetnost, ples, glasbo, domišljijsko igro. }\end{array}$ & 3,88 & 0,76 \\
\hline $\begin{array}{l}\text { Uporabljam slike otrok in njihovih bližnjih, kadar se pogovarjam o } \\
\text { konceptih, vezanih na zavedanje sebe in drugih. }\end{array}$ & 3,81 & 0,93 \\
\hline $\begin{array}{l}\text { Tolažim otroka, kadar je vznemirjen, tako da izgovarjam čustva, ki jih } \\
\text { otrok doživlja, npr. »ezen si«. }\end{array}$ & 3,74 & 1,09 \\
\hline Vsak dan namenim čas branju skupaj z dvema, tremi otroki. & 3,59 & 0,85 \\
\hline
\end{tabular}

(d) Razlike glede na heterogene in homogene skupine pri uporabi dobrih praks za socialno-emocionalni razvoj v prvem starostnem obdobju

Podatki glede razlik $v$ uporabi metod za socialno-emocionalni razvoj med heterogenimi in homogenimi skupinami v prvem starostnem obdobju kažejo, da strokovni delavci, ki delajo $v$ homogenih skupinah, statistično značilno večkrat uporabljajo socialno-emocionalno interakcijo $z$ otrokom pri odhodu domov kot tisti, ki delajo $v$ heterogenih skupinah $(t(83)=2,34 ; p=0,02)$, prav tako so doslednejši pri uveljavljanju meja in pravil, primernih starosti in realnim pričakovanjem $(t(83)=2,40 ; p=0,02)$, pogosteje poslušajo otroka in se nanj odzovejo, kadar poskuša povedati kaj o sebi $(t(83)=4,05 ; p=0,00)$, pogosteje z njim vzpostavljajo prijeten in ljubeč odnos $(t(83)=3,33 ; p=0,00)$, pogosteje ga potolažijo, kadar je vznemirjen, in ubesedijo doživljanje čustev $(t(83)=1,98 ; p=0,05)$ ter pogosteje poudarjajo pomen deljenja igrač ( $t(82)$ $=2,08 ; p=0,04)$.

Izmed petnajst navedenih postavk za spodbujanje socialno-emocionalne- 


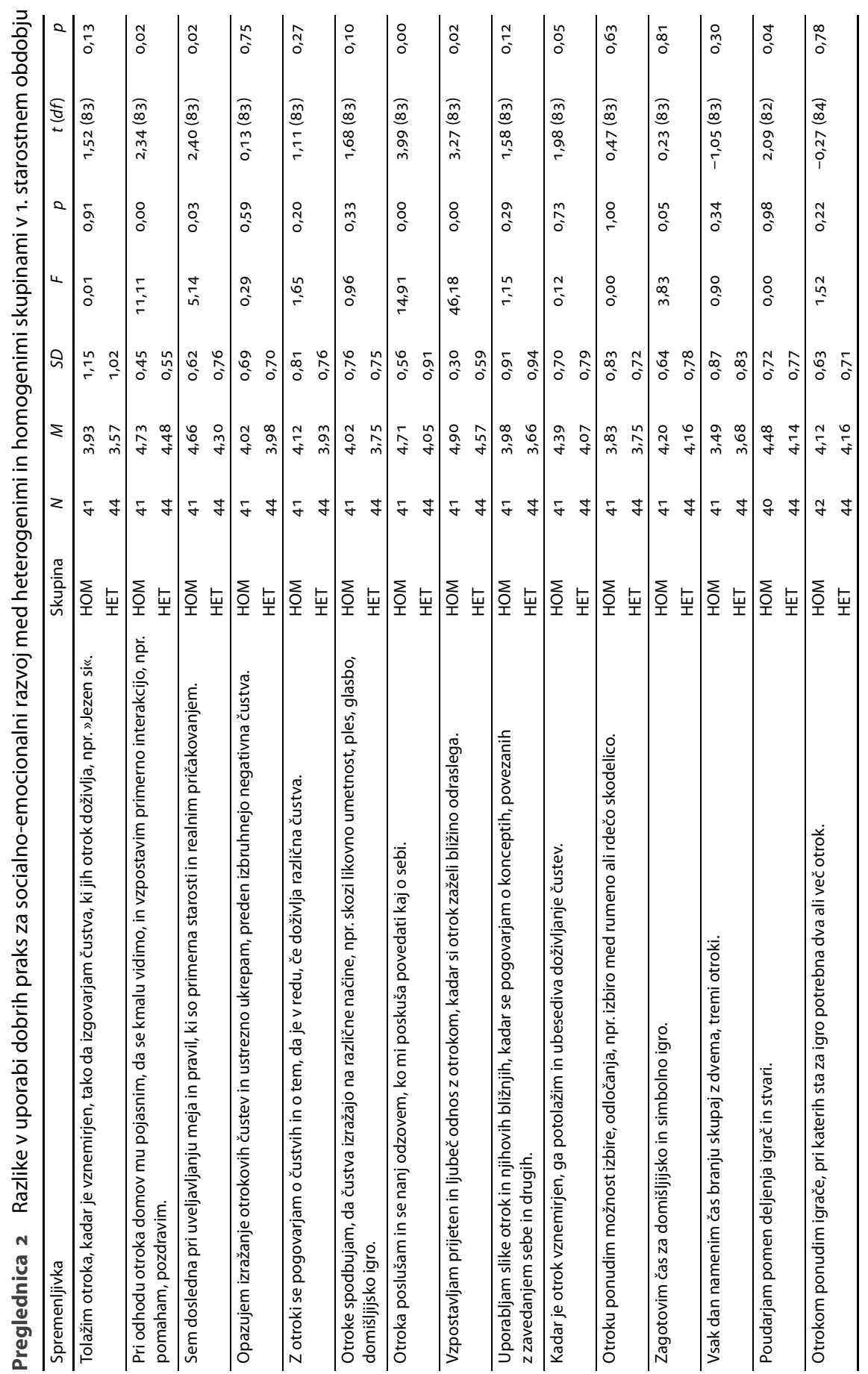


ga razvoja otrok v prvem starostnem obdobju se statistično značilno višje povprečne vrednosti pri strokovnih delavcih, ki delajo $v$ homogenih skupinah, pojavljajo pri šestih postavkah, iz česar lahko sklepamo, da delo v homogenih skupinah omogoča lažje razmere in več časa za uporabo dobrih praks, namenjenih spodbujanju socialno-emocionalnega razvoja.

\section{Razprava}

Rezultati raziskave osvetlijo nekaj pomembnih vidikov uporabe dobrih praks v 1. SO. Iz povprečnih vrednosti v sklopih a in b lahko razberemo, da strokovni delavci socialno-emocionalno področje ocenjujejo kot zelo pomembno, uvrščajo ga celo med tri najpomembnejša področja otrokovega razvoja in 1. SO glede pomembnosti socialno-emocionalnega področja razvoja prepoznavajo kot nekoliko pomembnejše v primerjavi z 2. SO, kar nakazujejo tudi druge raziskave (Rimm-Kaufmann, Pianta in Cox 2000; Durlak idr. 2011).

Nekoliko manj jasno je povezovanje področja družba $z$ učenjem in poučevanjem, povezanim s socialno-emocionalnim področjem, saj je po oceni pomembnosti strokovnih delavcev $v$ našem vzorcu $v 1$. SO področje družba šele na 4. mestu. To pomeni, da bi bilo zelo dobrodošlo, če bi bilo v Kurikulumu za vrtce (Ministrstvo za šolstvo in šport 1999) to področje bolj poudarjeno v smislu navajanja več primerov dejavnosti in ciljev, s katerimi bi strokovni delavci lahko spodbujali otrokov socialno-emocionalni razvoj ter kompetence. V Kurikulumu za vrtce (Ministrstvo za šolstvo in šport 1999) bi bilo torej treba posodobiti zapise, povezane s primeri vodenih dejavnosti, s katerimi razvijamo socialno-emocionalno področje za prvo in drugo starostno obdobje, kar bi pomenilo sistemsko podporo in poudarek na razvoju tako pomembnih veščin, podobno, kot to lahko zasledimo v tuji literaturi (Early Learning Guidelines For Children Birth to Age Three 2015).

Iz rezultatov v sklopu c lahko sklepamo, da strokovni delavci v 1 . SO v raziskovalnem vzorcu pogosteje uporabljajo dobre prakse, ki so del vsakodnevnih interakcij z otroki in zanje ni potrebno posebno načrtovanje. Manj pogosto pa izvajajo dobre prakse, za katere je potrebno vsaj delno načrtovanje (npr. skupno branje) ali pa celostno načrtovanje, kot je spodbujanje izražanja čustev skozi glasbo, ples ali likovno umetnost. Manj pogosto uporabljajo tudi specifične strategije za čustveno samoregulacijo. Zaradi tega lahko sklenemo, da bi bilo treba več poudarka nameniti strokovnemu usposabljanju glede specifičnih metod za spodbujanje, učenje in poučevanje socialnoemocionalnih veščin otrok $v 1$. SO, saj lahko tako strokovni delavci vzpostavijo bolj osmišljen sistem za razvoj socialno-emocionalnih veščin in preprečitev morebitnih težav otrok na tem področju (Powell, Dunlap in Fox 2006) 
Pri ugotavljanju razlik med homogenimi in heterogenimi skupinami smo ugotovili, da delo $v$ homogenih skupinah $v 1$. SO omogoča lažje razmere in več časa za uporabo dobrih praks, namenjenih spodbujanju socialnoemocionalnega razvoja. Morda zato, ker strokovni delavci v heterogenih skupinah ne morejo veliko časa nameniti delu s posameznim otrokom, saj so razlike med otroki večje in je potrebno veliko truda za samo vodenje skupine, zato so homogene skupine $v 1$. SO ugodnejše za otrokov socialnoemocionalni razvoj, čeprav bi bilo potrebno dodatno raziskovanje, da bi lahko ta rezultat posplošili.

\section{Literatura}

Blair, C. 2002. "School Readiness: Integrating Cognition and Emotion in a Neurobiological Conceptualization of Children's Functioning at School Entry." American Psychologist 57 (2): 111-127.

Cohen, J. 2001. Caring Classrooms, Intelligent Schools: The Social and Emotional Education of Young Children. New York: Teacher College Press.

DeVellis, R. F. 2003. Scale Development:Theory and Applications. Thousand Oaks, CA: Sage.

DiPerna, J. C., in S. N. Elliot. 2002. »Promoting Academic Enablers to Improve Student Achievement: An Itroduction to the Mini-Series." School Psychology Review 31:293-297.

Durlak, J. A., R. P. Weiessber, K. B. Schellinger, A. B. Dymnicki in R. D. Taylor. 2011. »The Impact of Enhancing Students' Social and Emotional Learning: A Meta-Analysis of School Based Universal Interventions." Child Development 81 (1): 405-432.

Early Learning Guidelines for Children Birth to Age Three: Standards, Age Descriptors, Indicators for Children, and Strategies for Interaction. 2015. Ilinois: University of Ilinois at Urbana-Champaign.

Elias, M. J., J. E. Zins, R. P. Weissberg, K. S. Frey, M. T. Greenberg in N. M. Haynes. 1997. Promoting Social and Emotional Learning: Guidelines for Educators. Alexandria: Association for Supervision and Curriculum Development.

Goodman, A., H. Joshi, B. Nasim in C. Tyler. 2015. Social and Emotional Skills in Childhood and Their Long-Term Effects on Adult Life. London: University College London.

Hyson, M. 2004. The Emotional Development of Young Children. New York: Teachers College Press.

Ivić, l., J. Novak, N. Atanacković in M. Ašković. 2002. Razvojni koraki: pregled osnovnih značilnosti otrokovega razvoja od rojstva do sedmega leta. Ljubljana: Inštitut za psihologijo osebnosti.

Joseph, G. G., in P. S. Strain. 2003. »Comprehensive, Evidence-Based SocialEmotional Curricula of Young Children: An Analysis of Efficacious Adoption Potential.« Topics in Early Childhood Special Education 23 (2): 65-76. 
Licardo, M. 2016. Razvojni mejniki jezikovnih zmožnosti, socialno-emocionalnega področja in opolnomočenje staršev za uporabo literature, iger in drugih didaktičnih sredstev: gradivo za multiplikatorje. Maribor: Pedagoška fakulteta.

Ministrstvo za šolstvo in šport. 1999. Kurikulum za vrtce: predšolska vzgoja v vrtcih. Ljubljana: Ministrstvo za šolstvo in šport.

Marjanovič Umek, L., M. Zupančič, U. Fekonja, T. Kavčič, M. Svetina, T. Ravnik, in B. Bratanič. 2004. Razvojna psihologija. Ljubljana: Znanstvenoraziskovalni inštitut Filozofske fakultete.

Payton, J. W., R. P. Weissberg, J. A. Durlak, A. B. Dymnicki, R. D. Taylor in K. B. Schellinger. 2008. The Positive Impact of Social and Emotional Learning from Kindergarten to Eighth-Grade Students: Findings from Three Scientific Reviews. Chicago: Collaborative for Academic, Social and Emotional Learning.

Petty, K. 2016. Developmental Milestones of Young Children. St. Paul, MN: Redleaf Press.

Phillips, D., K. McCartney in A. Sussman. 2006. „Child Care and Early Development. "V Blackwell Handbook of Early Childhood Development, ur. K. McCartney in D. Phillips, 471-489. Malden, MA: Blackwell.

Pianta, R. C., W. S. Barnett, M. Burchinal in K. R. Thornburg. 2009. »The Effects of Preschool Education: What We Know, How Public Policy Is Or Is Not Aligned with Evidence Base, and What We Need to Know.«Psychological Science in the Public Interest 10:49-88.

Powell, D., G. Dunlap in L. Fox. 2006. »Prevention and Intervention for Challenging Behaviors of Toddlers and Pre-Schoolers.« Infants and Young Children 19 (1): 25-35.

Rimm-Kaufman, S. E., R. C. Pianta in M. L. Cox. 2000. »Teachers' Judgements of Problems in the Transition to Kindergarten«. Early Childhood Research Quarterly 15 (2): 147-166.

Thompson, R. A., in K. H. Lagattuta. 2006. Feeling and Understanding: Early Emotional Development. Malden, MD: Blackwell.

Ward Plat, M. 2010. Moj čudežni malček: popoln vodnik po otrokovem razvoju od rojstva do 5. leta. Ljubljana: Mladinska knjiga.

Woofolk, A. 2002. Pedagoška psihologija. Ljubljana: Educy.

\section{The Use of Good Practices for Social-Emotional Development with Children Age One to Three Years in Kindergarten}

This paper presents the purpose of good practices for social-emotional development of children from one to three years. In the research we analysed the teachers' assessment of social-emotional development in comparison to other developmental areas (e. g. aesthetic development, moral ethical development, cognitive development, motoric development) and the assessment of social sciences in comparison with other subject areas of curriculum (art, science, 
language, sport, mathematics). Analysed were also differences in use of good practices among homogeneous and heterogeneous groups. Results indicate that preschool teachers who work with 1 to 3 years old children assess social emotional development as one of most important. Results also indicate that in homogenous groups ( 1 to 3 years) practices for social emotional development are used more often than in heterogeneous groups. Preschool teachers most often use practices which are part of daily interaction, less often they use practices which demand planning and knowledge about specific strategies.

Keywords: social-emotional development, methods, good practices, early childhood, preschool education 



\title{
Mnenja strokovnih delavcev $\mathrm{v}$ vrtcu o medpodročnem povezovanju v prvem starostnem obdobju
}

\author{
Barbara Baloh \\ Univerza na Primorskem \\ barbara.baloh@pef.upr.si \\ Petra Furlan \\ Univerza na Primorskem \\ petra.furlan@pef.upr.si \\ Giuliana Jelovčan \\ Univerza na Primorskem \\ giuliana.jelovcan@pef.upr.si

\section{Bojana Kralj \\ Univerza na Primorskem \\ bojana.kralj@pef.upr.si}

Otrok odkriva znanje samostojno ali po pedagoško vodeni poti, vendar raziskave in izkušnje kažejo, da je naključnost šibka vrednost procesa učenja. Za izobraževanje $v$ prihodnosti morajo raznolike potrebe otrok vzgojitelju, ki načrtuje in izvaja dejavnosti v vrtcu, predstavljati izziv, kako oblikovati učni proces, da bo vsak otrok dosegel optimalne rezultate. To je pot raziskovanja, sodelovanja, spreminjanja in nikoli zaključenega procesa iskanja optimalnih rešitev, ki jih v vrtcu vidimo predvsem v medpodročnem povezovanju in sodobnih učnih strategijah, podprtih s sodobnim spodbudnim in inovativnim učnim okoljem. V prispevku bodo predstavljeni rezultati raziskave, s katero smo želeli ugotoviti, kako strokovni delavci spodbujajo kurikularna področja jezik, narava, gibanje in glasba ter kje vidijo možnosti medpodročnega povezovanja navedenih področij v prvem starostnem obdobju.

Ključne besede: medpodročno povezovanje, jezik, gibanje, glasba, narava, mnenja strokovnih delavcev, prvo starostno obdobje

\section{Uvod}

Medpodročno povezovanje je didaktični pristop, ki otroke pripravi na vseživljenjsko učenje, jim omogoči spoznavanje nove snovi z več vidikov in povezovanje informacij oz. spoznanj (Hodnik Čadež in Filipčič 2005). V glavnem posnema resnične življenjske situacije, kar za otroke pomeni dober zgled, močan motiv za učenje in dobro pripravo na vseživljenjsko učenje. Tako se 
delo $v$ vrtcu približa ciljem holističnega (celostnega) učenja in poučevanja, ki bolje odražata realni, interaktivni svet in njegovo kompleksnost, odpravljata meje med posameznimi disciplinami ter podpirata načelo, da je vse znanje povezano (Hodnik Čadež 2008).

Predšolski otrok je po naravi radoveden in vedoželjen. Zelo zgodaj izraža željo po raziskovanju (Hvala 2012), zato je ključna vloga odraslega, ki mora s svojim zgledom in spodbudo otroku ponuditi različne situacije raziskovanja ter spoznavanja. Izkoristiti mora to razvojno fazo in uporabiti otrokovo notranjo motivacijo za spodbujanje k učenju ter spoznavanju sveta. Če otroci teh dragocenih izkušenj v predšolskem obdobju ne dobijo, pogosto razvijejo neutemeljene predsodke in strahove, ki predstavljajo resno oviro za poznejše spoznavanje življenja (Wilson 2008).

L. Plut Pregelj (2005) poudarja, da je najboljši način pridobivanja znanja preko lastnih izkušenj. B. Marentič Požarnik (1998) izpostavlja, naj tako poučevanje temelji na trajnem spreminjanju posameznika in ne le na pridobivanju znanja, spretnosti in stališč. Ena izmed uspešnejših učnih strategij, ki omogoča samostojno iskanje in razmišljanje z lastno aktivnostjo ter s tem pridobivanje lastnih izkušenj in trajno spreminjanje posameznika, je izkustveno učenje (Hus in Ivanuš Grmek 2006).

Kurikulum za vrtce (Ministrstvo za šolstvo in šport 1999) vključuje dejavnosti, ki jih razvrščamo v naslednja področja: gibanje, jezik, umetnost, družbo, naravo, matematiko. Zapisani cilji pri posameznih področjih dejavnosti predstavljajo okvir, znotraj katerega so vsebine in dejavnosti strokovna podlaga vzgojiteljem. Kot poudarjajo slovenski strokovnjaki, med njimi Kroflič (2001), B. Marentič Požarnik (2000) in L. Marjanovič Umek (2001), slovenski Kurikulum za vrtce (Ministrstvo za šolstvo in šport 1999) sodi med sodobne predšolske kurikule, ki niso visoko strukturirani, ampak odprtejši in fleksibilnejši. To pomeni, da določa predvsem temeljna načela in zaželene cilje predšolske vzgoje, ne predpisuje pa konkretnih (operativnih) ciljev, metod in vsebin dejavnosti v vrtcu. Zagovarja nedirektivno vlogo vzgojiteljev, ki skušajo slediti željam ter interesom otrok, in jim ponuja dejavnosti, med katerimi lahko izbirajo. Sodobni kurikuli poudarjajo tudi načelo aktivnega učenja, torej dejstvo, da se predšolski otrok najbolje uči na osnovi konkretnih izkušenj in praktične udeležbe $v$ dejavnostih, tako da konkretno ravna s predmeti iz okolja in okolje doživlja z vsemi čutili. V nadaljevanju bomo predstavili kurikularna področja jezik, naravo, gibanje in glasba, kot se kažejo v Kurikulumu za vrtce (Ministrstvo za šolstvo in šport 1999). V raziskavi, ki bo sledila teoretičnemu delu, smo povprašali pedagoške delavce $v$ vrtcu, kakšno je njihovo mnenje o medpodročnem povezovanju ter ali vidijo možnost medpodročnega pove- 
zovanja v prvem starostnem obdobju. Zdi se nam pomembno, da pri povezovanju vsako od področij ohrani svojo integriteto, da torej eno ne prevlada nad drugim (Kranjc 2008; Ministrstvo za šolstvo in šport 1999).

\section{Kurikularno področje jezik}

Ko govorimo o slovenščini v vrtcih v Republiki Sloveniji, imamo v mislih temeljni cilj, zapisan v Kurikulumu za vrtce (Ministrstvo za šolstvo in šport 1999, 14), ki definira vse globalne cilje na področju jezika, od katerih je temeljni spodbujanje razumevanja jezika kot temelja lastne identitete. Pri tem je potrebno upoštevati, da ima slovenščina v vrtcih v Republiki Sloveniji vlogo maternega, drugega in tujega jezika, hkrati pa je področje jezika v Kurikulumu za vrtce (Ministrstvo za šolstvo in šport 1999) opredeljeno kot področje dejavnosti in učni jezik, ki ga določa Ustava RS, opredeljen pa je tudi v področnih zakonih, ter učno načelo. Jezikovne vzgoje v vrtcu ne smemo razumeti samo v ožjem smislu, le kot spodbujanje razvoja jezikovne zmožnosti, saj je slovenščina učni jezik in kot tak zavezujoč za vsa kurikularna/predmetna področja v vrtcu.

Kot zapiše S. Kranjc (2008), so v Kurikulumu za vrtce (Ministrstvo za šolstvo in šport 1999) prepoznavna temeljna načela in cilji predšolske vzgoje, kot tudi spoznanja, da otrok dojema in razume svet celostno, da se razvija in uči v aktivni povezavi s svojim socialnim ter fizičnim okoljem, da v vrtcu v interakciji $z$ vrstniki in odraslimi razvija svojo lastno družbenost ter individualnost.

Cilji in vsebine za področje jezika so v Kurikulu za vrtce (Ministrstvo za šolstvo in šport 1999) oblikovani za dve starostni obdobji, in sicer za 1. od 1 do 3 let ter za 2. od 3 do 6 let starosti. Področje jezika je načrtovano tako, da otroku omogoča dejavno udeležbo $v$ sporazumevalnem procesu.

Kot je zapisano v priročniku h Kurikulumu za vrtce (Marjanovič Umek 2001), kurikulum zaradi razvejanosti jezikovnega področja cilje in dejavnosti opredeljuje na 4 ravneh: govorne vzgoje, književne vzgoje, predopismenjevanja in knjižne vzgoja kot dela informacijskega opismenjevanja. Dejavnosti so med seboj povezane, prav tako je jezik povezan z drugimi področji kurikula. Vse sporazumevalne dejavnosti ves čas so del vsakdanjega življenja. Dejavnosti je mogoče izvesti v obeh starostnih obdobjih, prilagoditi je treba predvsem metode in oblike dela. Z vsako dejavnostjo je namreč mogoče dosegati več ciljev hkrati, prav tako lahko en cilj dosegamo z različnimi dejavnostmi. Vloga vzgojitelja je, da pri vseh dejavnostih daje govorni zgled, da je pri tem pozoren na svoj besedni in nebesedni slog ter tako neposredno vpliva na razvoj otrokove jezikovne in sporazumevalne zmožnosti.

Kot navaja Kurikulum za vrtce (Ministrstvo za šolstvo in šport 1999, 18-19), se 
otroci v tem obdobju učijo izražati izkušnje, čustva, misli in razumeti sporočila drugih. Jezikovne dejavnosti so povezane z vsemi jezikovnimi ravninami fonološko, morfološko, leksikalno, skladenjsko-pomensko (in pragmatično) -, razvoj jezika pa je naravno vpleten v vsa področja dejavnosti.

Otroci se učijo jezika ob poslušanju vsakdanjih pogovorov in pripovedovanja literarnih besedil, ob poslušanju glasnega branja odraslih, s pripovedovanjem, z opisovanjem, ob rabi jezika v domišljijskih igrah, dramatizacijah, izmišljanju zgodbic in pesmic, ob učenju otrok od otrok, in sicer ob različnih socialnih igrah, pravljicah, izštevankah, rimah, šaljivkah, ugankah itn., ki so skozi generacije preživele kot skupna lastnina.

Pomemben del jezikovnih dejavnosti so enostavna besedila, ki so vezana na vsakodnevno življenje, npr. kratka sporočila, zapis otrokovega komentarja k njegovi risbi, kuharski recept za priljubljeno jed itn. Prav tako pomembno je zbliževanje s knjigo kot pisnim prenosnikom, tudi kot virom informacij. Pri tem gre predvsem za rabo raznih otroških priročnikov, slovarjev, leksikonov ipd. ter za zgodnje navajanje nanjo. Gledano širše je vključevanje otrok v pisno kulturo pomembna sestavina demokratizacije družbe.

Otroci morajo imeti možnost, da jih na njim ustrezen način seznanimo z nekaterimi jezikovnimi spoznanji, predstavimo razlike med socialnimi zvrstmi ali registri (knjižno : neknjižno), jeziki, jezikovnimi skupinami itn.

Cilji učnega jezika se udejanjajo v pedagoškem govoru, in sicer v obeh njegovih sestavinah, spoznavnem in odnosnem. $V$ spoznavnem govoru vzgojitelj posreduje spoznanja določenega področja, $v$ odnosnem pa gre za sporazumevanje med vzgojiteljem in otroki. Vzgojitelj je pri vseh dejavnostih otroku govorni zgled in tako neposredno vpliva na razvoj njegove jezikovne (slovnične in pragmatične) zmožnosti.

\section{Kurikularno področje narava}

V Kurikulumu za vrtce (Ministrstvo za šolstvo in šport 1999, 37) je zapisano, da naj bo pri spoznavanju narave poudarek na pridobivanju izkušenj z živimi bitij in naravnimi pojavi ter na veselju pri raziskovanju in odkrivanju. Procesi raziskovanja (postavljanje hipotez, povzemanje bistva, reševanje problemov) v predšolskem obdobju potekajo nezavedno (preko igre), vendar moramo otroku omogočiti spodbudno okolje. U. Fekonja $(2004,382)$ in R. Wilson (2008) poudarjata, da je najspodbudnejš naravno okolje, saj spodbuja celostni razvoj otroka (kognitivni, socialni, emocionalni in gibalni).

Hunt (1989), ki predstavlja enega izmed prvih zagovornikov učenja v naravnih učnih okoljih, je opisal številne modele pouka, ki se jih izvaja v naravnih učnih okoljih. Glavni nameni učenja na prostem so namreč stimulacija 
osebnega in socialnega razvoja, izobraževanje, uporaba neposredne izkušnje, razvijanje spoštljivega odnosa do narave in do samega sebe.

M. Hohmann in Weikart (2005) sta natančno opredelila sestavine spodbudnega okolja. Te so: (1) materiali (otrokovi starosti primerni in različni), (2) rokovanje (možnost spoznavanja), (3) izbira (možnost samostojne izbire), (4) govor (povezava obstoječega znanja z novimi izkušnjami) in (5) podpora odraslega (ki otroku sledi in ga spodbuja). Ob tem ne smemo pozabiti, da smo odrasli s svojim vedenjem in odnosom otroku vzor (Katalinič 2007). Nuditi mu moramo možnosti in spodbude, da sprašuje o tem, kar vidi, in se uči iskati odgovor tako, da opazuje, raziskuje, eksperimentira opisuje, razlaga (Kulikulum za vrtce 1999, 37).

Za otroka prvega starostnega obdobja je najbolje, če mu ponudimo različne naravne materiale (semena, liste, cvetove, veje, mivko, pesek, kamenje, sadje, zelenjavo, ipd.), mu omogočimo igro $v$ različnih spodbudnih okoljih (travnik, gozd, potok, vrt, sadovnjak, morska obala ipd.) oz. ob pojavih v naravnem okolju (dež, megla, sneg, ipd.). Otroci navedenega ne bodo samo gledali (opazovali), temveč bodo to skušali tudi prijeti, vonjati, okušati, poslušati ali preizkušati.

\section{Kurikularno področje gibanje}

Gibanje je v predšolskem obdobju izjemno pomembno za razvoj vseh podsistemov organizma človeka, ki se pomembno oblikujejo prav v otroštvu (Jelovčan in Pišot 2016, 127). Z gibanjem otrok zaznava in odkriva svoje telo, preizkuša, kaj le-to zmore, doživlja veselje in ponos ob razvijajočih se sposobnostih in spretnostih ter gradi zaupanje vase. Gre za dinamični proces, s pomočjo katerega otrok pridobiva gibalne spretnosti in vzorce, kar je rezultat interakcije med dednimi in okolijskimi vplivi (Gallahue in Ozmun 2006, 171; Marjanovič Umek in Zupančič 2001, 2; Pišot in Planinšec 2005, 17; Videmšek in Pišot 2007, 39). Otrokovo doživljanje in dojemanje sveta temelji na informacijah, ki izvirajo iz njegovega telesa, zaznavanja okolja, izkušenj, ki jih pridobi $z$ gibalnimi dejavnostmi ter gibalno ustvarjalnostjo $v$ različnih situacijah. Razvoj nadzora lastnega telesa poteka vzporedno z razvojem gibalnih centrov v možganih; razvoj nadzora mišic pa je deloma rezultat procesa zorenja živčnega sistema in deloma tudi rezultat učenja (Gallahue in Ozmun 2006, 63). Individualni razvoj pri otrocih je zelo različen, vsekakor pa ustrezno strokovno vodena zgodnja vadba zelo koristi, saj otrok s tem doživlja in usvaja različne gibalne vzorce, ki pripomorejo k ustreznejšemu razvoju osrednjega živčnega sistema. M. Montessori $(2011,169)$ dodaja, da se otroci učijo skozi aktivnost, večinoma z uporabo rok. Gre za povezavo med možgani in gibanjem. A. Ce- 
mič in J. Gregorc $(2013,132)$ poudarjata, da je otrokov naravni način učenja učenje z gibanjem, igro in igrivo postavljenim okoljem. Številne študije prav tako nakazujejo, da zgodnje gibalno obnašanje igra pomembno vlogo pri socialnih, čustvenih in spoznavnih dejavnostih (Bobbio, Gabbard in Caçola 2009). Neodvisna hoja povečuje otrokovo mobilnost in priložnost za socialne interakcije, medtem ko gibalni razvoj pomembno vpliva na kognitivni in jezikovni razvoj (Iverson 2010). Zato je pomembno, kakšne izkušnje omogočimo otroku v tem zgodnjem otroštvu. $V$ tem obdobju otrokovega dojemanja in spoznavanja sveta pa imajo odločilno vlogo tudi način dela, pristop in odnos pri delu z otrokom (Pišot in Planinšec 2005, 23; Videmšek in Pišot 2007, 103; Pišot in Jelovčan 2012, 33).

\section{Kurikularno področje umetnost (s poudarkom na glasbi)}

Kurikulum za vrtce (Ministrstvo za šolstvo in šport 1999) v področje umetnosti vključuje: likovno, glasbeno, plesno, dramsko in AV-dejavnost. Glasbena vzgoja je sestavni del estetske in umetnostne vzgoje, ki omogoča temelje za otrokov celostni razvoj. Z glasbenimi dejavnostmi mu omogočamo oblike glasbenega izražanja, vzbujamo veselje do zvokov, igre, gibanja, razvijamo sposobnosti zaznavanja, pozornosti, motorične spretnosti, jezikovno komunikacijo idr. Na odnosih procesov čustvenega, spoznavnega in gibalnega razvoja temelji glasbeni razvoj otroka, ki v predšolskem obdobju obsega razvoj elementarnih glasbenih sposobnosti (Denac 2010, 37).

Povezovanje glasbe $z$ drugimi področji in umetnostmi je kakovostno, če smiselno vključujemo vsebine, procese, znanja in spretnosti, ki spodbujajo učenje na različnih stopnjah otrokovega razvoja. Tako nastajajo zmožnosti, ki na podlagi čustev, motivacije in stališč otroku omogočajo ustvarjalno ter umetnostno delovanje (Sicherl Kofol, Denac in Borota 2011, 92).

Sistematično zasnovana glasbena vzgoja otroku omogoča glasbeni razvoj. S cilji vzbujamo veselje in sproščenost, spodbujamo doživljanje glasbenih vsebin, vplivamo na razvoj glasbenih sposobnosti in spretnosti, razvijamo glasbeno občutljivost otroka (Denac 2010, 37) in zagotavljamo vzpodbudno učno glasbeno okolje (Borota 2006, 35).

Predšolsko obdobje je pomemben dejavnik za razvoj glasbenih sposobnosti otrok, ta pa je odvisen od dednosti, okolja in lastne aktivnosti. Aktivnost otroku omogoča, da se dispozicije razvijejo $v$ sposobnosti, ob pomoči zunanjih pogojev - to sta družinsko in družbeno okolje (Denac 2010, 69). To pa zavzema vplive in vzorce iz okolja, kot so: motivacija, namen, cilji posameznika ter njegove izkušnje, spretnosti, znanja in razumevanje (Borota 2006, 17).

Delo v predšolskem obdobju je zasnovano na spodbujanju doživljanja 
glasbenih vsebin in na metodah, ki temeljijo na otroški igri. Igro kot dejavnost otrok upoštevamo pri načrtovanju različnih glasbenih dejavnosti - izvajanja, poslušanja in ustvarjanja glasbe - ter pri razvoju glasbenih sposobnosti, spretnosti in znanj. Vse to pa omogoča integracijo različnih področij dejavnosti medpodročnega povezovanja z namenom otrokovega razvoja in učenja.

Kot zapiše S. Kranjc (2008), so v Kurikulumu za vrtce (Ministrstvo za šolstvo in šport 1999) prepoznavni temeljna načela in cilji predšolske vzgoje kot tudi spoznanja, da otrok svet dojema in razume celostno, da se razvija in uči v aktivni povezavi s svojima socialnim in fizičnim okoljem, da v vrtcu v interakciji $z$ vrstniki in odraslimi razvija svojo lastno družbenost ter individualnost, zato je potrebno posamezna kurikularna področja med seboj povezovati. Seveda pa je izrednega pomena, katere didaktične poti in strategije pri tovrstnem povezovanju uberemo, še posebno, ker nam jih kurikulum posebej ne ponuja. Zdi se, da je potrebno na novo razmisliti o ključnih konceptih medpodročnega povezovanja $v$ vrtcu, ki bi upoštevalo integriteto posameznih kurikularnih področij in jih hkrati povezalo $v$ celoto. $V$ ta namen smo opravili raziskavo, katere izsledke bomo predstavili v nadaljevanju.

\section{Namen in cilji raziskave}

Namen raziskave je bralcem prispevka predstaviti praktične dejavnosti medpodročnega povezovanja jezika, narave, gibanja in glasbe $v$ prvem starostnem obdobju, njen cilj pa je bil preučiti mnenja strokovnih delavcev $v$ vrtcu o možnosti medpodročnega povezovanja v prvem starostnem obdobju.

\section{Raziskovalna vprašanja}

Zastavili smo si naslednja raziskovalna vprašanja:

1. Kakšna je afiniteta strokovnih delavcev $v$ vrtcu do jezika, narave, gibanja in glasbe?

2. Kakšna so mnenja in prepričanja strokovnih delavcev $v$ vrtcu do kurikularnih področij jezik, narava, gibanje in glasba?

3. Kakšna so mnenja in prepričanja strokovnih delavcev $\mathrm{v}$ vrtcu do medpodročnega povezovanja?

\section{Raziskovalne metode}

Izvedli smo neeksperimentalno kvantitativno raziskavo, v kateri sta prevladovali deskriptivna in kavzalna neeksperimentalna metoda empiričnega pedagoškega raziskovanja. 


\section{Raziskovalni vzorec}

Raziskava temelji na neslučajnostnemu, priložnostno izbranemu vzorcu. Sodelovalo je 42 strokovnih delavk, zaposlenih v vzgojno-izobraževalnem zavodu.

\section{Pripomočki}

V naš namen smo razvili anketni vprašalnik, ki je bil vsebinsko razdeljen na 3 sklope. $V$ prvem sklopu smo pridobili podatke o letih delovne dobe anketirancev ter mnenje o usposobljenosti za delo v prvi oz. drugi starostni skupini. Udeleženci so odgovor podali na zaprto vprašanje in ga pojasnili. V drugem sklopu vprašalnika so udeleženci ocenili svojo afiniteto do vseh kurikularnih področij (gibanje, jezik, umetnost, družba, narava, matematika) s pomočjo lestvice ( 1 - najmanj mi je všeč, 5 - najbolj mi je všeč). $V$ tretjem sklopu smo želeli izvedeti, kakšno je njihovo mnenje o povezovanju različnih kurikularnih področij. Trditve so vključevale pravilne in napačne predstave o medpodročnem povezovanju, ki izhajajo iz praktičnih izkušenj strokovnjakov. Udeleženci so svoje mnenje ocenili na štiristopenjski lestvici stališč (1 - se sploh ne strinjam, 2 - se ne strinjam, 3 - se strinjam, 4 - se popolnoma strinjam). Možnost odgovora »niti se ne strinjam, niti se strinjam« smo namenoma izpustili, s čimer smo želeli doseči bolj reflektirane odgovore.

\section{Postopek zbiranja in obdelave podatkov}

Zbiranje podatkov je potekalo v januarju 2019. Anketiranci so bili predhodno obveščeni o raziskavi in njenem namenu. Reševanje vprašalnikov je bilo prostovoljno. Udeleženci so vprašalnik reševali približno 15 minut, po metodi papir - svinčnik. Zagotovili smo anonimnost pridobljenih podatkov, anketne vprašalnike so reševali samostojno.

\section{Rezultati in razprava}

$\checkmark$ raziskavo smo zajeli 42 strokovnih delavcev, zaposlenih $v$ vrtcu, $z$ različno dolgo delovno dobo, kar je prikazano v preglednici 1. Dolžina delovne dobe največ udeležencev je bila več kot 20 let.

Posebej nas je zanimalo, kakšno je v zajetem številu vprašanih število strokovnih delavcev, ki so zaposleni v prvem starostnem obdobju, kar prikazujemo $v$ preglednici 2.

Največ zaposlenih z delovno dobo od o-5 let se je odločilo, da se čutijo bolj usposobljene za delo v drugi starostni skupini, kar za načrtovalce programov višješolskega študijskega programa Vzgojitelj pomeni izziv, da ponovno premislijo o vsebinah študijskih programov. Zaposleni več kot 20 let so navajali, 


\begin{tabular}{|c|c|c|}
\hline $\begin{array}{l}\text { Preglednica } 1 \\
\text { Število }(f) \text { in str } \\
\text { odstotki }(f \%) \text { vz } \\
\text { na delovno dob }\end{array}$ & 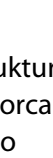 & lede \\
\hline Delovna doba & $f$ & $f \%$ \\
\hline $0-5$ & 9 & 21,4 \\
\hline $5-10$ & 5 & 11,9 \\
\hline $10-15$ & 5 & 11,9 \\
\hline $15-20$ & 7 & 16,7 \\
\hline$>20$ & 16 & 38,1 \\
\hline Skupaj & 42 & 100 \\
\hline
\end{tabular}

\begin{tabular}{|c|c|c|}
\hline \multicolumn{3}{|c|}{$\begin{array}{l}\text { Preglednica } 2 \\
\text { Število (f) in strukturni } \\
\text { odstotki (f \%) vzorca glede } \\
\text { na usposobljenost za delo }\end{array}$} \\
\hline Star. skupina & $f$ & $f \%$ \\
\hline $0-3$ & 14 & 33,3 \\
\hline $3-6$ & 23 & 54,8 \\
\hline Neopredeljeni & 5 & 11,9 \\
\hline Skupaj & 42 & 100 \\
\hline
\end{tabular}

Preglednica 3

Ocena afinitete do posameznih kurikuarnih področij (1 - najmanj mi je všeč, 5 - najbolj mi je všeč)

\begin{tabular}{lrr}
\hline Področje & $N$ & $\bar{x}$ \\
\hline Narava & 14 & 4,14 \\
Jezik & 14 & 4,07 \\
Družba & 14 & 3,93 \\
Gibanje & 14 & 3,93 \\
Umetnost & 14 & 3,86 \\
Matematika & 14 & 3,28 \\
\hline
\end{tabular}

da lahko delajo $v$ obeh starostnih skupinah, da pa jim delo $v$ prvi starostni skupini pomeni izziv. Med vzroki so navajali, da že dolgo delajo z otroki v prvem starostnem obdobju, da raje delajo z mlajšimi otroki, da se jim mlajši otroci zdijo vodljivejši, da jih pritegne vsaka malenkost, največkrat pa so navajali, da imajo otroci v tem obdobju zelo omejeno spoznavno zmožnost in da jih lahko veliko naučijo.

Zato smo v nadaljevanju raziskali afiniteto vprašanih do posameznih kurikularnih področij. Rezultati anketiranja strokovnih delavcev, ki so zaposleni v prvem starostnem obdobju, glede afinitete posameznih kurikularnih področij so prikazani v preglednici 3. Iz preglednice je razvidno, da imajo anketiranci največjo afiniteto do kurikularnega področja narave, vendar v raziskavi vzrokov za ta odgovor nismo raziskali.

V nadaljevanju smo želeli ugotoviti, koliko vzgojitelji poznajo specifike posameznih kurikularnih področij in kje vidijo možnosti medpodročnega povezovanja, upoštevajoč dejstvo, da je pri tem potrebno ohranjati integriteto posameznega področja. Postavili smo jim 12 trditev, o katerih so svoje mnenje izrazili na štiristopenjski lestvici stališč (1 - se ne strinjam, 4 - se zelo strinjam). Rezultate predstavljamo v preglednici 4.

Analiza trditev (preglednica 4) kaže, da so se udeleženci najbolj strinjali s trditvijo $(\bar{x}=3,78)$, da je primerna motivacija za doživljanje književnega besedila, če otroke peljemo na sprehod $v$ naravo, kar ni res. $Z$ otroki beremo različna besedila in se $z$ njimi o le-teh pogovarjamo, tako pa otroku ponudimo spoznavno, etično in estetsko razsežnost umetnostnega besedila. Skozi pogovor otroku odpremo pot v domišljijsko sooblikovanje literarnega sveta, spodbujamo njegovo sposobnost neosebnega in čustvenega sodelovanja $v$ literarnem svetu ter njegovo sposobnost odkrivanja vrat za identifikacijo $z$ 
Preglednica 4 Strinjanje s trditvami (rangirane po aritmetičnih sredinah)

\begin{tabular}{|c|c|c|}
\hline Trditev & $N$ & $\bar{x}$ \\
\hline $\begin{array}{l}\text { Primerna motivacije za doživljanje književnega besedila je, da otroke pe- } \\
\text { ljemo na sprehod v naravo. }\end{array}$ & 14 & 3,78 \\
\hline $\begin{array}{l}\text { Pripovedovanje je širok pojem, zato ga lahko povezujemo z vsemi predme- } \\
\text { tnimi področji. }\end{array}$ & 14 & 3,64 \\
\hline $\begin{array}{l}\text { Otrok se preko naravnih oblik gibanja (hoja, tek, skoki, plazenje, lazenje) } \\
\text { identificira z realno izkušnjo (naravoslovje/opazovanje, jezik/poslušanje in } \\
\text { glasba/zvok). }\end{array}$ & 14 & 3,28 \\
\hline $\begin{array}{l}\text { Pravljica pri poslušalcu izzove pripoved, zato se ob glasbi poglobijo dožive- } \\
\text { tja in razpoloženja. }\end{array}$ & 14 & 3,21 \\
\hline Branje pravljice je dobra motivacija za obravnavo naravoslovnih vsebin. & 14 & 3,07 \\
\hline Pri gibalni/športni aktivnosti otrok ves čas sodeluje. & 14 & 3,07 \\
\hline $\begin{array}{l}\text { Ni pretežkih/prelahkih književnih besedil, saj sta globina in obseg razume- } \\
\text { vanja kakega besedila odvisna tudi od sodelovanja odrasle osebe pri raz- } \\
\text { lagi besedila. }\end{array}$ & 14 & 3,07 \\
\hline $\begin{array}{l}\text { Z doživljanjem književnega besedila se otrok istoveti z izvajanjem in ustvar- } \\
\text { janjem ob in v glasbi. }\end{array}$ & 14 & 3,00 \\
\hline $\begin{array}{l}\text { Oponašanje gibanja živali je primerna poustvarjalna dejavnost za doživlja- } \\
\text { nje književnega besedila. }\end{array}$ & 14 & 2,93 \\
\hline Branje književnih besedil v skupini zahteva pogovor o prebranem. & 14 & 2,86 \\
\hline $\begin{array}{l}\text { Temeljno načelo izbire književnega besedila v predšolskem obdobju je iz- } \\
\text { ključno izhajanje iz otrokovih interesov in tudi medpodročna povezava te- } \\
\text { melji na tem. }\end{array}$ & 14 & 2,71 \\
\hline $\begin{array}{l}\text { Književna besedila v vrtcu beremo pred kosilom in pred spa- } \\
\text { njem/umirjanjem. }\end{array}$ & 14 & 2,50 \\
\hline
\end{tabular}

literarnim besedilom. Poleg tega so razlage in poimenovanja, ki si jih otroci ustvarijo v predšolskem obdobju odločilnega pomena, saj vplivajo tudi na kasnejše oblikovanje in razumevanje pojmov (Dolenc Orbanić in Battelli 2015, 27). Ker se otrok $z$ junaki v pravljici večkrat poistoveti in jih obravnava kot resnične osebe le-ta nikakor ni primerna za obravnavo naravoslovnih vsebin, kot so se $v$ večini strinjali $(\bar{x}=3,07)$ udeleženci.

Velik delež vprašanih $(\bar{x}=3,64)$ meni tudi, da je pripovedovanje širok pojem, zato ga lahko povezujemo z vsemi predmetnimi področji. Kot meni $B$. Baloh (2015), mora pripovedno besedilo vključevati določene prvine, ki pripoved določajo: besedišče, ki se nanaša na osebe, kraje in dogajanje, $v$ besedilu iščemo odgovore na vprašanja, kdo? (osebe), kje? (kraj), kdaj? (zgodovinski trenutek, čas in trajanje), kaj? (konkretna dejanja) in s katerim namenom? (zakaj?), uporabljeni so glagoli v pretekliku, sedanjiku in prihodnjiku, značilna je uporaba časovnih izrazov, prislovov in predložnih zvez (nekoč, 
pred letom dni, naslednjega dne, okoli desete ure ...), imeti mora začetno situacijo (zasnovo), ki se preko vrste dogodkov (zaplet, razplet dogajanja) spreminja v novo, končno situacijo (končno rešitev). Ko pripovedujemo, poslušalcu/bralcu posredujemo dogodke, ki so časovno in prostorsko umeščeni. Vsako pripovedovanje zgodbe mora biti strukturirano in mora vsebovati problem. Na podlagi značilnosti pripovednega besedila si posamezni pripovedovalec ustvari lastno pripovedovalno shemo. Otrok si ustvari lastno pripovedovalno shemo ob poslušanju in pomnjenju različnih vrst in načinov pripovedovanja, ki jih sčasoma posvoji v tolikšni meri, da postanejo neločljivi del njegovega izražanja. Na podlagi pridobljene pripovedovalne sheme tvori lastna pripovedna besedila. Razvoj pripovedovanja zgodb pri otroku poteka od enostavnih zgodb, v katerih opisuje preproste dogodke, praviloma iz svojega resničnega življenja, do konvencionalnih, koherentnih in kohezivnih zgodb, ki jih ob upoštevanju njihove zgradbe (začetek, vrhunec, konec) z opisovanjem časovnih in vzročnih povezav, motivov, čustev junakov ter odnosov med njimi pripovedujejo otroci od zgodnjega šolskega obdobja dalje. V predšolskem obdobju se otrok šele uči samostojnega pripovedovanja, pri čemer mu je potrebno ponuditi tako shemo za tvorjenje umetnostnih (domišljijskih) besedil kakor tudi shemo za tvorjenje neumetnostnih (pragmatičnih) besedil.

Najpomembnejši cilj književne vzgoje v vrtcu je otrokovo doživljanje literarnega besedila, torej dialog z literarnim besedilom in iz tega izhajajoče literarnoestetsko doživetje. Do tega lahko pride samo preko ustvarjalne komunikacije $z$ literarnim besedilom, ki pa jo $v$ času dnevne rutine, torej pred kosilom in pred spanjem, težko dosežemo. Otroku je potrebno literarno besedilo ponuditi v času usmerjenih dejavnosti, saj lahko le tako spodbujamo odzivanje na celovito umetniško izkušnjo $v$ književnem besedilu.

Pravljica z glasbo je glasbeno delo, v kateri glasba poglablja doživljanje, zato je glasba $v$ pravljici barvita in slikovita. Pri poslušalcu izzove pripoved, zato se ob glasbi poglobijo doživetja in razpoloženja (Borota 2015, 199), kot je tudi pravilno podala mnenje večina udeležencev $(\bar{x}=3,31)$. $Z$ doživljanjem književnega besedila se otrok istoveti z izvajanjem in ustvarjanjem ob in v glasbi. Izvajanje in ustvarjanje glasbe sta glasbeni dejavnosti, ki otroku omogočata glasbeni razvoj. Glasba in beseda sta tesno povezani, saj je beseda $\checkmark$ glasbi njeno izrazno sredstvo (Denac 2010, 65). B. Oblak meni, da besedne vsebine razkrivajo najrazličnejša občutja, situacije in okolja, glasba pa stopnjuje izraznost in doživljanje (Oblak 1987, 78).

Oblike dejavnosti naj bodo različne po vsebini, trajanju, prostoru in vlogi odraslih. Otrokom omogočajmo, da imajo vsakodnevno možnosti za različne 
gibalne dejavnosti (Ministrstvo za šolstvo in šport 1999, 19). Glede na odgovore pedagoških delavcev, da se otrok preko naravnih oblik gibanja identificira z realno izkušnjo $(\bar{x}=3,28)$, lahko ugotovimo, da je namen gibanja veliko več kot doseganje boljšega apetita ali krepitev pljuč. Pojavljanje posameznih naravnih oblik gibanja (hoja, tek, skoki, plazenje, lazenje ...) v vseh okoljih, usmerjenih $\mathrm{k}$ različnim ciljem in na različne načine, je tesno povezano $z$ otrokovim celostnim razvojem in posledično vpliva na izboljšanje gibalne izraznosti (Pistotnik, Pinter in Dolenc 2002). Izkušnje, vtisi in znanja, ki jih otrok sprejme $v$ tej zgodnji fazi razvoja, se $v$ njem zakoreninijo veliko trajnostneje kot pa to, kar je kasneje naučeno zavestno in z namernim naporom. Gibanje je del delovanja živčnega sistema in brez njega se možgani razvijajo drugače (Montessori 2011, 166). Otrok, ki se ustrezno razvija, ima ugodnejše možnosti za komuniciranje in socialno interakcijo $z$ okoljem ter za oblikovanje novih spoznanj o sebi in okolici (Videmšek in Pišot 2007, 47). Naravne oblike gibanja (hoja, tek, skok, plezanje, plazenje, lazenje in drugi) so izjemno pomembne pri nadaljnjem razvoju gibalnih stereotipov, ki otroku omogočajo interakcijo z okoljem in kakovostno gibalno manipulacijo (Plevnik in Pišot 2016,29 ). Ustrezne gibalne kompetence lahko pridobi le otrok, ki je v zgodnjem razvojnem obdobju deležen ustrezne količine in kakovosti gibalnih izkušenj (Plevnik in Pišot 2016, 32).

\section{Sklepne ugotovitve}

V kontekstu predšolske vzgoje igra jezik zelo pomembno vlogo. Pomemben je pri oblikovanju posameznikove lastne identitete, pri identifikaciji z lastno kulturo, vključevanju v tradicijo naroda in spoznavanju ter sprejemanju drugih kultur in civilizacij pa tudi kot jezik posamezne discipline, zato je jezik ključni element pri medpodročnem povezovanju. Vsak vzgojitelj bi moral, ko med seboj povezuje različna kurikularna področja, razmišljati tudi o tem, katere so posebnosti jezika za posamezno kurikularno področje, kako z jezikom izraža znanje specifične stroke, kako z jezikom izraža stališčno dimenzijo stroke in kako se njegov jezik razlikuje od splošnega jezika, ki ga uporabljajo otroci.

Kurikularne prenove doma in v tujini kažejo, da ni dovolj le posodabljanje učnih načrtov posameznih predmetov na ravni načel, temveč je potrebno vzpostaviti medsebojne odnose in interakcije med posameznimi predmeti oziroma področji znotraj kurikula. Medsebojno povezovanje je potrebno povezati s cilji, z vsebinami, oblikami ter s temeljnim načelom integriranja - to je interdisciplinarnost, kar smo dokazali tudi z rezultati naše raziskave. Strokovni delavci imajo namreč veliko napačnih predstav o tem, kako vsebine 
medpodročno povezovati, da vsako od področij ohrani svojo integriteto.

Skozi pedagoški proces otrok pridobiva in si izoblikuje znanje, oblikuje strategije za pristopanje $\mathrm{k}$ problemom in raziskovanje sveta ter vzpostavljanje odnosov v njem in do njega, zato je izrednega pomena vzgojiteljevo oblikovanje koncepta pridobivanja znanja. Vzgojitelji in pomočniki prevzemajo skupno odgovornost za razvijanje otrokove sporazumevalne zmožnosti znotraj okvirov splošnih in specifičnih ciljev kurikula za vrtce. Vprašanje, ki se pojavlja v slovenski strokovni javnosti, je, ali se vzgojitelji te vloge dovolj zavedajo in kako spodbujajo dialoško interakcijo v skupinah, kako prepoznavajo napredek pri razvijanju jezikovne zmožnosti posameznega otroka, kako ga spodbujajo in kako oblikujejo osnove za jezikovno ozaveščenost, ki se bo šele pozneje razvila do take mere, da bo vplivala na identiteto posameznika v družbi znanja. Ali se sprašujejo tudi o ključnih kompetencah v vrtcu? Te razumemo kot kompleksen sistem znanja in spretnosti, ravnanja in mnenj, ki jih posameznik potrebuje za učinkovito vključenost v družbo, zaposlitev, nadaljnje učenje in za osebni razvoj. Posameznik naj bi jih začenjal pridobivati v predšolskem obdobju ter jih pridobil ob zaključku osnovnošolskega izobraževanja kot osnovo za vseživljenjsko učenje. Zato je potrebno razvijati pedagoške kompetence vzgojiteljev, poskrbeti za specialna znanja in veščine, za širjenje in podajanje znanja ter najti rešitve in izzive, ki pred vzgojitelje postavljajo raznolike potrebe sodobnega otroka na jezikovnem področju. Ravno tako je potrebno v vzgojiteljih spodbuditi željo po pridobivanju znanja in izkušenj.

\section{Literatura}

Baloh, B. 2015. »Aplikativni vidik otrokovega pripovedovanja v predšolskem obdobju. Revija za elementarno izobraževanje 8 (4): 5-27.

Borota, B. 2006. »Otrok, glasba in učno okolje.« V Otroci v svetu glasbe, lutk in plesa, ur. B. Borota, 11-51. Koper: Pedagoška fakulteta.

-2015. Glasbene dejavnosti in vsebine. Koper: Annales.

Bobbio, T., C. Gabbard in P. Caçola. 2009. »Interlimb Coordination: An Important Facet of Gross-Motor Ability." ECRP Early Childhood Research \& Practice 11 (2). http://ecrp.uiuc.edu/v11n2/bobbio.html

Cemič, A., in J. Gregorc. 2013. "Svobodna igra in igrivost v avtonomiji načrtovanja po konceptu sigra-gibanje-razvoj‘.« Vodenje v vzgoji in izobraževanju 11 (3): 121-134.

Dolenc Orbanić, N., in C. Battelli. 2015. »Z ustreznimi pristopi do preoblikovanja alternativnih pojmovanj." Vodenje v vzgoji in izobraževanju 13 (1): 25-37.

Denac, O. 2010. Teoretična izhodišča načrtovanja glasbene vzgoje v vrtcu. Ljubljana: Debora. 
Fekonja, U. 2004. »Razvoj otroške igre.«V Razvojna psihologija, ur. L. Marjanovič Umek in M. Zupančič, 382-393. Ljubljana: Znanstvenoraziskovalni inštitut Filozofske fakultete.

Gallahue, D., in J. Ozmun. 2006. Understanding Motor Development:Infants, Children, Adolescents, Adults. 6. izd. New York: McGraw-Hill.

Hodnik Čadež, T. 2008. »Povezovalni kurikulum.« www.pef.uni-lj.si/ tatjanah/ gradiva/povezovalni_kurikulum_thc.ppt

Hodnik Čadež, T., in T. Filipčič. 2005. »Medpredmetno povezovanje v prvem razredu osnovne šole.« Pedagoška obzorja 20 (3-4): 3-15.

Hohman, M., in L. Weikart. 2005. Vzgoja in učenje predšolskih otrok. Ljubljana: DZS.

Hunt, J. 1989. In Search of Avantures: A Study of Opportunities for Advanture and Challenge for Young People. Bournemouth: Bourne.

Hus, V., in M. Ivanuš Grmek. 2006. „Odprti pouk pri predmetu spoznavanje okolja."Sodobna pedagogika 57 (2): 68-83.

Hvala, B. 2012. „Naravoslovje za najmlajše - aktivno učenje.« V Ekološka in etnična zavest skozi edukacijskiodnos do narave in družbe, ur. M. Duh, 56-65. Maribor: Pedagoška fakulteta.

Iverson, J. 2010. »Developing Language in a Developing Body: The Relationship between Motor Development and Language Development. « Journal of Child Language 2:229-261.

Jelovčan, G., in R. Pišot. 2016. »Pomen in razvoj drobnih gibalnih spretnosti v zgodnjem otroštvu. $\mathrm{V}$ Razvoj elementarnih vzorcev v zgodnjem otroštvu, ur. M. Plevnik in R. Pišot, 127-143. Koper: Annales.

Katalinič, D. 2007. Sejemo, sadimo in raziskujemo že v vrtcu. Ljubljana: Zavod Republike Slovenije za šolstvo.

Kranjc, S. 2008. »Slovenščina v vrtcu. « V Jeziki v izobraževanju: zbornik prispevkov konference; Ljubljana, 25.-26. september 2008, ur. M. Ivšek, 129-134. Ljubljana: Zavod Republike Slovenije za šolstvo.

Kroflič, R. 2001. »Temeljne predpostavke, načela in cilji kurikula za vrtce.« V Otrok v vrtcu: priročnik $h$ kurikulu za vrtce, ur. L. Marjanovič Umek, 7-25. Maribor: Obzorja.

Marentič Požarnik, B. 1998. »Kako pomembna so pojmovanja znanja, učenja in poučevanja za uspeh kurikularne prenove."Sodobna pedagogika 49 (3): 244-261.

—, ur. 2000. Psihologija učenja in pouka. Ljubljana: DZS.

Marjanovič Umek, L. 2001. »Psihologija predšolskega otroka.« V Otrok v vrtcu: priročnik $h$ kurikulu za vrtce, ur. L. Marjanovič Umek, 26-54. Maribor: Obzorja.

— ur. 2010. Otrok v vrtcu: priročnik h kurikulu za vrtce. Maribor: Obzorja.

Marjanovič Umek, L., in M. Zupančič. 2001. »Teorija otroške igre.« V Psihologija otroške igre: od rojstva do vstopa v šolo, ur. L. Marjanovič Umek in M. Zupančič, 1-37. Ljubljana: Znanstveni inštitut Filozofske fakultete. 
Ministrstvo za šolstvo in šport. 1999. Kurikulum za vrtce: predšolska vzgoja v vrtcih. Ljubljana: Ministrstvo za šolstvo in šport.

Montessori, M. 2011. Srkajoči um. Ljubljana: Uršulinski zavod za vzgojo, izobraževanje, versko dejavnost in kulturo.

Oblak, B. 1987. »Ustvarjalno učenje v glasbeni vzgoji na stopnji razrednega pouka osnovne šole.« Doktorska disertacija, Univerza v Ljubljani.

Pistotnik, B., S. Pinter in M. Dolenc, ur. 2002. Gibalna abeceda, naravne oblike gibanja $v$ športni praksi. Ljubljana: Fakulteta za šport.

Pišot, R., in J. Planinšec. 2005. Struktura motorike v zgodnjem otroštvu. Koper: Annales.

_. 2012. Vsebine gibalne/športne vzgoje v predšolskem obdobju. Koper: Annales.

Plevnik, M., in R. Pišot. 2016. »Vloga in pomen elementarnih gibalnih vzorcev v razvoju otroka. $V$ Razvoj elementarnih gibalnih vzorcev $v$ zgodnjem otroštvu, ur. M. Plevnik in R. Pišot, 29-36. Koper: Annales.

Plut Pregelj, L. 2005. »Sodobna šola ostaja šola: kaj se je spremenilo?« Sodobna pedagogika 56 (1): 16-32.

Sicherl Kofol, B., O. Denac in B. Borota. 2011. »Glasbena umetnost.« V Kulturnoumetnostna vzgoja: priročnik s primeri dobre prakse iz vrtcev, osnovnih in srednjih šol, ur. N. Bucik, 75-93. Ljubljana: Ministrstvo za šolstvo in šport in Zavod Republike Slovenije za šolstvo.

Videmšek, M., in R. Pišot. 2007. Šport za najmlajše. Ljubljana: Fakulteta za šport. Wilson, R. 2008. Nature and Young Children: Encouraging Creative Play and Learning in Natural Environments. London: Routledge.

\section{Preschool Teachers Opinion on Cross-Sectoral Integration of Children in the First Age Period}

The child discovers knowledge independently or following a path guided by pedagogues, however, research and experience show that coincidence does not prove to be a strong value within the process of learning. For future education, the diverse needs of children need to present a challenge to a teacher who plans and implements activities in kindergarten, and a challenge of how to shape the learning process so that every child can achieve optimal results. This is the path of research, cooperation, modification and a never-ending process of finding the optimal solutions. In kindergarten, we can see these solutions primarily in cross-sectoral integration and modern learning strategies, supported by modern stimulating and innovative learning environment. The paper presents the results of the research that was aimed at finding out how the teachers promote the curricular areas of learning about language, nature, movement and music and where they see the possibilities of cross-sectoral integration of these areas in the first age period.

Keywords: cross-sectoral integration, language, movement, music, nature, opinion of pedagogues, first age period 



\title{
Izzivi zgodnje obravnave predšolskih otrok
}

\author{
Karmen Drljić \\ Univerza na Primorskem \\ karmen.drljic@pef.upr.si
}

Sodobno razumevanje zgodnje obravnave otrok izhaja iz sistemsko-ekološke teorije, ki omogoča poglobljeno prepoznavanje rizičnih dejavnikov v otrokovem razvoju in njegovem okolju. Namen zgodnje obravnave je zagotoviti ustrezno preventivo ter pravočasno obravnavo otroka, ki izkazuje posebnosti v razvoju, tj. že v najzgodnejšem obdobju njegovega življenja. V začetku leta 2019 je v Sloveniji stopil v veljavo Zakon o celostni zgodnji obravnavi predšolskih otrok s posebnimi potrebami, ki naj bi to področje celostno uredil. Zanimalo nas je, kako svetovalni delavci vrtca razumejo pomen zgodnje obravnave, kakšne prednosti in slabosti zaznavajo $v$ omenjenem zakonu ter kako v njem prepoznavajo svojo vlogo. Z dvema svetovalnima delavkama smo opravili intervju. Ugotovili smo, da novi zakon prinaša številne prednosti na področju zgodnje obravnave, a tudi izzive. Slednji se nanašajo predvsem na sodelovanje z različnimi akterji, ki so vključeni v zgodnjo obravnavo. Poudarjata, da še niso zagotovljeni vsi pogoji, da bi zakon udejanjali.

Ključne besede: svetovalni delavci, zakon, otroci s posebnimi potrebami, vrtec, zgodnja obravnava

\section{Uvod}

Razumevanje koncepta zgodnje obravnave ( $v$ nadaljevanju ZO) temelji na sistemsko-ekološki teoriji (Soriano 2005) ter sloni na sodobnem razumevanju (nevrološkega) razvoja dojenčkov, malčkov in otrok (Krek in Metljak 2011). Ekosistemski model omogoča razumevanje kompleksnosti odnosov in različnih situacijskih okoliščin v otrokovem okolju (Bronfenbrenner 1995). Omogoča tudi razumevanje, na kakšen način potekajo interakcije med otrokom in okoljem ter kako le-te prispevajo k njegovemu razvoju (Renn 2003). Razumevanje kompleksnosti okolja in bolj ali manj zapletenih interakcij med njim ter otrokom lahko prispeva k oblikovanju okolja, ki spodbudno vpliva na otrokov razvoj in učenje (Renn 2003). Ekosistemska teorija temelji na dveh ključnih predpostavkah. Prva pravi, da je otrokov razvoj odvisen od čedalje kompleksnejših in recipročnejših interakcij med aktivnim in razvijajočim se posameznikom (torej otrokom) ter drugo osebo, objektom in simbolom, ki se nahaja v njegovem neposrednem okolju (Bronfenrenner 1995). Druga predpostavka pa pravi, da so bližnje neposredne interakcije odvisne od otrokovih lastnosti, njegove razvojne stopnje ter neposrednega in posrednega okolja.

Čotar Konrad, S., B. Borota, S. Rutar, K. Drljić in G. Jelovčan, ur. 2022. Vzgoja in izobraževanje predšolskih otrok prvega starostnega obdobja. Koper: Založba Univerze na Primorskem.

(c) Br.sA https://doi.org/10.26493/978-961-293-134-6.169-188 
Razumevanje ZO z ekosistemskega vidika omogoča celostno in poglobljeno prepoznavanje rizičnih dejavnikov tveganja v otrokovem razvoju, ki so lahko posledice njegovih razvojnih posebnosti in/ali specifičnosti neposrednega in posrednega okolja, znotraj katerega se razvija, ter pravočasno in učinkovito ciljno naravnano obravnavo.

\section{Opredelitev zgodnje obravnave}

Porter (2002 v Soriano 2005) ZO, ki je osnovana na ekosistemski teoriji, opredeli $s$ holističnega, $z$ dinamičnega, $s$ transakcijskega in posamičnega vidika. Holistični vidik pomeni, da otroka v okviru ZO obravnavamo celostno, tako da skrbimo za vsa področja njegovega razvoja, to je: kognitivno, govornojezikovno, telesno, socialno-čustveno. Dinamični vidik izpostavlja pomen spreminjanja okolja glede na vedno se spreminjajoče se potrebe otroka. Transakcijski vidik poudarja pomen recipročnega odnosa medsebojnega vplivanja med otrokom in drugo odraslo osebo, v okviru katerega se oba razvijata. Posamični vidik pa pomeni, da je otrok individuum in sta zato njegov proces izgrajevanja znanja in njegov razvoj glede na druge specifična oz. edinstvena (Porter 2002 v Soriano 2005).

Namen ZO je spodbuditi otrokov razvoj ter delovati preventivno pri preprečevanju ali zmanjševanju zaostanka v razvoju (Majnemer 1998). Začne se ob rojstvu otroka in se zaključi ob njegovem vstopu v šolo (Globačnik 2012). Sicer pa so otroci s primanjkljaji, z motnjami oz. s težavami deležni specialnoinkluzivne strokovne pomoči tudi po vstopu v šolo. L. Marjanovič Umek in M. Zupančič (2009 v Globačnik 2012) sta mnenja, da lahko ZO sega že v prenatalno obdobje, torej $v$ obdobje od spočetja do rojstva. Za to obdobje in obdobje od dojenčka do malčka (o-3 let) je značilno, da ZO poteka v okviru zdravstvenih služb. V obdobju od dojenčka do malčka je lahko prisotna tudi pedagoško-rehabilitacijska obravnava (Marjanovič Umek in Zupančič $2009 \mathrm{~V}$ Globačnik 2012). Slednje je otrok deležen tudi v obdobju zgodnjega otroštva (3-6 let). S. Fillis, L. Dunne in B. McConnell (2018) na podlagi različnih študij ZO omejijo na obdobje od dojenčka do malčka, saj se v njem najpogosteje kažejo prve razvojne posebnosti in zaostanki v razvoju.

\section{Značilnosti zgodnje obravnave}

ZO je namenjena otrokom in njihovim družinam, pri katerih so prisotni biološki in/ali socialni dejavniki tveganja (Globačnik 2012). Otrok in njegova družina sta deležna ZO, ko je pri njiju prepoznana težava, ne pa tudi v primeru prepoznanega tveganja zanjo (Globačnik 2012). Ločimo dve skupini otrok, ki jim je ZO namenjena, to so: (1) rizični otroci in (2) otroci s primanjkljaji, mo- 
tnjami oz. težavami (Majnemer 1998). Za skupino rizičnih otrok je značilno, da so mlajši od treh let in je prisotno tveganje za nadaljnji razvoj na kognitivni, gibalni, komunikacijski ter čustveni ravni otrokovega delovanja (Globačnik 2008). V skupino otrok s primanjkljaji, motnjami in težavami pa uvrščamo otroke s senzornimi okvarami, z gibalno oviranostjo in motnjami v duševnem razvoju. Pri teh otrocih so primanjkljaji, motnje oz. težave dokaj zgodaj prepoznane. Po drugi strani A. Majnemer (1998) navaja tri skupine otrok, ki so lahko deležne pomoči in podpore v okviru ZO:

- otroci, ki so ranljivi zaradi depriviligiranih razmer v fizičnem in socialnem okolju,

- otroci, ki so ranljivi zaradi specifičnih bioloških dejavnikov (npr. nedonošenost, fetalni alkoholni sindrom, hipoksija),

- otroci s prepoznano motnjo, primanjkljajem ali težavo, ki pomembno vpliva na otrokov razvoj.

S. Fillis, L. Dunne in B. McConnell (2018) so identificirale sedem oblik ZO: (1) ZO v programih predšolske vzgoje, (2) ZO, usmerjene $v$ družine otrok s posebnimi potrebami, (3) ZO, usmerjene v razvoj govorno-jezikovnih zmožnosti, (4) ZO, usmerjene v kognitivni razvoj, (5) ZO, usmerjene v socio-emocionalni razvoj, (6) ZO usmerjene v celostni razvoj. Za zagotavljanje ustrezne in učinkovite $Z O$ bi bilo treba zagotoviti ustrezna usposabljanja za strokovne delavce ter skrbeti za dosledno izvajanje podpore in pomoči. Posebno pozornost bi bilo treba nameniti tudi vključenosti družin $v$ ZO z upoštevanjem nekaterih posebnosti, kot so doživljanje zadovoljstva mater, usposobljenost staršev (tudi očetov) za pomoč otrokom v okviru njihovih zmožnosti ter kompetentnost strokovnih delavcev za educiranje staršev in spodbujanje njihove motiviranosti za delo z otrokom (Fillis, Dunne in McConnell 2018).

\section{Pomen, prednosti in izzivi zgodnje obravnave}

M. Nores in Barnett (2011) poudarjata, da je ZO pomemba, saj se zgodaj ciljno usmerja v otroke, ki v obdobju zgodnjega otroštva izkazujejo socialnoemocionalno-razvojne dejavnike tveganja, zato, da bi povečali možnosti za njihov boljši razvoj in boljšo učno uspešnost. Avtorja sta s pomočjo metaraziskave, $v$ katero sta vključila 24 različnih evropskih, azijskih, afriških ter južnoameriških držav, ugotovila, da je ZO otrok v glavnem usmerjena v štiri ključna področja otrokove delovanja in razvoja, in sicer:

- razvijanje kognitivnih zmožnosti otrok, in sicer besedišča, jezika, zgodnjih opismenjevalnih zmožnosti, zgodnjih matematičnih zmožnosti; 
- razvijanje socialno-emocionalnih veščin (samoregulacija, igra, obvladovanje agresivnega vedenja, hiperaktivnosti;

- izboljšanje pogojev za zdravje (telesna teža, prehranjenost, motorične veščine);

- izboljšanje pogojev za vzgojo in izobraževanja (obiskovanje šole, dolžina vključenosti v vzgojo in izobraževanje, zmanjševanje števila osipnikov).

ZO otrok, ki je usmerjena v njihovo skrbstvo ter vzgojo in izobraževanje in ne zgolj v njihovo prehranjenost, ima pozitivne učinke predvsem na razvoj otrokovih kognitivnih zmožnosti. Prav tako so se pozitivni učinki ZO izkazali pri razvoju njegovih socialno-čustvenih veščin (Nores in Barnett 2011). ZO, ki dovolj dolgo traja in je intenzivna ter usmerjena $v$ otrokove potrebe, ima prav tako pozitivne učinke na otrokov razvoj. Pri tem ne smemo zanemariti aktivno-participativne vloge staršev, ki imajo ključno vlogo pri razvoju otroka s prepoznanimi posebnimi potrebami. Starši, ki so izgradili ustrezna znanja in veščine, lahko pomembno prispevajo $\mathrm{k}$ rasti in razvoju otroka (Majnemer 1998).

\section{Zgodnja obravnava v Sloveniji}

Do nedavnega v Sloveniji nismo imeli ustreznega modela ZO otrok s posebnimi potrebami, tako kot so ga imele nekatere druge evropske države (Krek in Metljak 2011). V teh državah je skladno s teoretično opredelitvijo ZO le-ta usmerjena tako $v$ pomoč otroku kot njegovi družini in zajema storitve svetovanja, socialno pomoč, priložnostno varstvo in celostno obravnavo otroka pri različnih strokovnih delavcih. Avtorji Bele knjige (Krek in Metljak 2011) so po zgledu urejenosti ZO v drugih državah prav tako predlagali, da bi bila pomoč usmerjena ne le $v$ otroka, temveč tudi v njegovo družino. Poleg tega pa naj bi poimenovanje otroci s posebnimi potrebami pri otrocih, starih do treh let, nadomestil izraz otroci s pomembnim odstopanjem od značilnega razvoja, razen v primerih, ko je pri otroku motnja, primanjkljaj oz. težava že prepoznana.

V začetku leta 2019 je stopil v veljavo zakon, ki ureja področje ZO predšolskih otrok v Sloveniji. Zakon o celostni zgodnji obravnavi predšolskih otrok $s$ posebnimi potrebami (2017) (v nadaljevanju ZOPOPP) celostno zgodnjo obravnavo otrok $s$ posebnimi potrebami opredeli kot obravnavo otroka in njegove družine $z$ namenom zagotoviti in spodbuditi celosten otrokov razvoj, okrepiti zmogljivost družine in njuno socialno vključenost. Celostna ZO je tako namenjena otrokom s posebnimi potrebami in otrokom z rizičnimi 
dejavniki v predšolskem obdobju. Po ZOPOPP (2017) so otroci s posebnimi potrebami $\vee$ predšolskem obdobju otroci z razvojnimi zaostanki, primanjkljaji, ovirami oz. motnjami na telesnem, spoznavnem, zaznavnem, socialnočustvenem, sporazumevalnem področju ter dolgotrajnimi boleznimi. $\mathrm{S}$ tem se opredelitev otrok s posebnimi potrebami razlikuje od opredelitve $v$ Zakonu o usmerjanju otrok s posebnimi potrebami (ZUOPP-1 2011), ki navaja devet skupin otrok s posebnimi potrebami (npr. otroci z motnjami v duševnem razvoju, gibalno ovirani otroci, dolgotrajno bolni otroci ipd.) in se približuje opredelitvi, ki jo predlaga Bela knjiga (Krek in Metljak 2011). Otroci z rizičnimi dejavniki v predšolskem obdobju so otroci, pri katerih so prisotni rizični dejavniki za razvojne primanjkljaje, zaostanke, ovire oz. motnje. Pri tem so rizični dejavniki tisti, ki:

- nastanejo v pred-, med- ali poporodnem obdobju,

- so posledica bolezni ali

- socio-ekonomskega statusa družine otroka

in vplivajo na otrokov nadaljnji razvoj (ZOPOPP 2017).

Z ZOPOPP (2017) je opredeljeno, da ZO izvajajo centri za zgodnjo obravnavo ( $v$ nadaljevanju CZO) oz. na njihov predlog tudi vrtci, drugi vzgojnoizobraževalni zavodi, socialnovarstveni zavodi, centri za socialno delo, centri za duševno zdravje in svetovalni centri. CZO naj bi delovali v okviru javne mreže, zagotavljali naj bi tudi pokritost posamezne regije. $S$ tem bi zagotovili inkluzivno naravnost (Ainscow, Booth in Dyson 2006) in dostopnost ZO vsem. Znotraj centra naj bi delovali večdisciplinarni timi, ki bi jih tvorili pediater, diplomirana medicinska sestra, srednja medicinska sestra ali administrator, fizioterapevt, delovni terapevt, logoped, psiholog, strokovni delavci s področja specialne in rehabilitacijske pedagogike, socialni delavci ter drugi strokovnjaki (ZOPOPP 2017). V CZO naj bi imel ključno vlogo pediater - ta naj bi otroka glede na prepoznane težave in potrebe usmeril v nadaljnjo obravnavo $\mathrm{k}$ ustreznemu strokovnemu delavcu znotraj centra ali na center za socialno delo. Pediater bo oblikoval tudi večdisciplinarni tim oz. določil strokovne delavce centra, ki bodo vključeni v obravnavo otroka. Večdisciplinarni timi naj bi otrokom in družinam nudili podporo ter pomoč s področja zdravstva, vzgoje in izobraževanja in socialnega varstva (ZOPOPP 2017). Naloge večdisciplinarnega tima bodo zajemale: (1) postavitev diagnoze, (2) oceno zmožnosti in potreb otroka ter njegovih staršev, (3) pripravo individualnega načrta pomoči družini ter spremljanje in evalvacijo le-tega, (4) informiranje staršev o oblikah pomoči in socialnih pravicah, ki jih lahko koristijo, ter (5) pripravo na- 
črta prehoda v vrtec, osnovno šolo ali zavod za vzgojo in izobraževanje otrok s posebnimi potrebami ali socialnovarstveni zavod (ZOPOPP 2017). ZOPOPP (2017) predvideva tudi nov strokovni profil, ki je bil dotlej v slovenskem prostoru neznan. Gre za koordinatorja pomoči družinam. Tudi tega določi pediater. Koordinator pomoči družinam predstavlja nekakšen vezni člen med družino in člani večdisciplinarnega tima $\mathrm{CZO}$, centrom za socialno delo ter $\mathrm{s}$ strokovnimi delavci, ki delajo v programih predšolske vzgoje (ZOPOPP 2017). $\checkmark$ programih za predšolske otroke s prilagojenim izvajanjem in dodatno strokovno pomočjo se lahko v okviru ZO otrokom prilagodi organizacijo in način izvajanja programa ter zagotovi dodatno strokovna pomoč, deležni so lahko tudi fizične pomoči oz. pomoči strokovnega delavca za znakovni jezik ali prilagojeno komunikacijo (ZOPOPP 2017), kar je bilo že do sedaj do določene mere zagotovljeno otrokom s posebnimi potrebami, ki so bili usmerjeni v program s prilagojenim izvajanjem (ZUOPP 2011). Spodbudno je, da ZOPOPP (2017) poleg pomoči otrokom v vrtcu, ki se lahko izvaja v in izven skupine, predvideva tudi pomoč na domu. Poleg CZO je tudi vrtec dolžan oblikovati strokovno skupino za ZO, ki jo sestavljajo svetovalni delavec vrtca, strokovni delavec v oddelku (vzgojitelj) in strokovni delavec za ZO (vzgojitelj za zgodnjo obravnavo), ki sodeluje s koordinatorjem CZO.

\section{Metodologija}

ZOPOPP (2017), ki naj bi celostno uredil področje ZO otrok s posebnimi potrebami, v strokovni javnosti odpira različna vprašanja o svoji izvedbi. Z omenjenim zakonom namreč še niso bili sprejeti podzakonski akti in pravilniki, ki bi v celoti omogočali izvajanje posameznih določil ZOPOPP. Zato je bil naš namen $\mathrm{s}$ študijo primera ugotoviti, $\mathrm{s}$ katerimi izzivi se $v$ tem trenutku srečujejo svetovalni delavci pri uresničevanju ZOPOPP. Natančneje nas je zanimalo, kako svetovalni delavci v splošnem razumejo pomen ZO, kako ocenjujejo pogoje za uresničevanje ZOPOPP ter katere so po njihovem mnenju prednosti oz. slabosti ZOPOPP. Zastavili smo si naslednja raziskovalna vprašanja:

1. Kako svetovalni delavci vrtcev razumejo zgodnjo obravnavo in njen pomen za otroke s posebnimi potrebami?

2. Kako svetovalni delavci $v$ splošnem ocenjujejo pogoje za uresničitev zgodnje obravnave glede na ZOPOPP?

3. Katere prednosti in slabosti svetovalni delavci prepoznavajo $v$ ZOPOPP?

V raziskavi sta sodelovali dve svetovalni delavki z več kot petletnimi delov- 
nimi izkušnjami, ki sta zaposleni v dveh različnih vrtcih na območju primorske statistične regije. $V$ tej statistični regiji naj bila zagotovljena dva CZO.

S svetovalnima delavkama smo izvedli polsturkturirani intervju. Ključna vprašanja smo predhodno oblikovali, pri čemer smo izhajali iz raziskovalnih vprašanj. Vnaprej smo ju prosili za dovoljenje za snemanje intervjuja. Takoj po končanem intervjuju smo naredili transkripcijo zvočnih podatkov. Sledila je kvalitativna obdelava podatkov s programsko opremo Atlas.ti. Podatke smo kodirali ter oblikovali pojme, ki smo jih združili v kategorije. Z analizo sopojavnosti smo znotraj kategorij med posameznimi pojmi iskali povezave. Slednje nam je omogočilo razuvanje ne le, kako se pojmi med seboj (kvalitativno) povezujejo, temveč tudi, kako se medsebojno prepletajo.

\section{Rezultati $\mathbf{z}$ razpravo}

S kvalitativno obdelavo podatkov smo prepoznali 12 pojmov, ki smo jih združili v štiri kategorije, in sicer (1) razumevanje pomena ZO, (2) pogoji za uresničevanje ZO, (3) prednosti ZOPOPP in (4) izzivi uresničevanja ZOPOPP (preglednica 1). Prva kategorija vsebuje le en pojem, ki smo ga poimenovali pomen zgodnje obravnave. Druga kategorija vsebuje dva pojma, to sta nezadostni pogoji za uresničevanje ZOPOPP in nejasnosti glede uresničevanja ZOPOPP. $\checkmark$ tretjo kategorijo smo združili pet pojmov, ti so aktivno vključevanje staršev otrok s posebnimi potrebami, pomoč in podpora staršem otrok s posebnimi potrebami, zagotavljanje celostne obravnave in zagotavljanje pravočasne obravnave. Četrta in zadnja kategorija pa združuje štiri pojme, to so izzivi sodelovanja $z$ različnimi akterji, pomen varnega okolja, usmerjenost $v$ zdravstveno obravnavo in vloga socialnih delavk v ZO. Najpogosteje so bili omenjeni pojmi vloga svetovalnih delavk v ZO (17), izzivi sodelovanja z različnimi akterji (14) ter nejasnosti glede uresničevanja ZOPOPP. Kategorija izzivi uresničevanja ZO vključuje največ citatov (35).

\section{Razumevanje pomena zgodnje obravnave}

Obe svetovalni delavki, vključeni v raziskavo, pričakovano prepoznavata pomen ZO za otroke s posebnostmi v razvoju oz. s posebnimi potrebami. Ena svetovalna delavka je pomen ZO skušala razložiti s prikazom trenutnega stanja oz. stanja do sprejetja ZOPOPP, v katerem svetovalni delavci vrtcev niso imeli dovolj možnosti in pogojev, da bi lahko zagotovili ustrezno obravnavo vseh otrok, ki bi le-to potrebovali:

ZO je zelo pomembna in je bila v dosedanjih okoliščinah in pogojih, ki smo jih imeli, pravzaprav zelo otežena, marsikdaj nismo imeli pogo- 
Preglednica 1 Pogostost pojmov in kategorij

\begin{tabular}{|c|c|c|c|c|c|}
\hline Pojmi & $n$ & $f(\%)$ & Kategorije & $n$ & $f(\%)$ \\
\hline Pomen ZO & 3 & 3,45 & Razumevanje pomena ZO & 3 & 3,66 \\
\hline $\begin{array}{l}\text { Nezadostni pogoji za } \\
\text { uresničevanje ZOPOPP }\end{array}$ & 6 & 6,90 & $\begin{array}{l}\text { Pogoji za uresničevanje } \\
\text { ZO }\end{array}$ & 19 & 23,17 \\
\hline $\begin{array}{l}\text { Nejasnosti glede } \\
\text { uresničevanja ZOPOPP }\end{array}$ & 14 & 16,09 & & & \\
\hline $\begin{array}{l}\text { Aktivno vključevanje } \\
\text { staršev otrok s PP }\end{array}$ & 3 & 3,45 & Prednosti ZOPOPP & 25 & 30,49 \\
\hline $\begin{array}{l}\text { Obravnava širše skupine } \\
\text { otrok }\end{array}$ & 8 & 9,19 & & & \\
\hline $\begin{array}{l}\text { Pomoč in podpora } \\
\text { staršem otrok s posebnimi } \\
\text { potrebami }\end{array}$ & 5 & 5,75 & & & \\
\hline $\begin{array}{l}\text { Zagotavljanje celostne } \\
\text { obravnave }\end{array}$ & 5 & 5,75 & & & \\
\hline $\begin{array}{l}\text { Zagotavljanje pravočasne } \\
\text { obravnave }\end{array}$ & 4 & 4,60 & & & \\
\hline $\begin{array}{l}\text { Izzivi sodelovanja z } \\
\text { različnimi akterji }\end{array}$ & 14 & 16,09 & $\begin{array}{l}\text { Izzivi uresničevanja } \\
\text { ZOPOPP }\end{array}$ & 35 & 42,68 \\
\hline Pomen varnega okolja & 3 & 3,45 & & & \\
\hline $\begin{array}{l}\text { Usmerjenost v } \\
\text { zdravstveno obravnavo }\end{array}$ & 5 & 5,75 & & & \\
\hline $\begin{array}{l}\text { Vloga svetovalnih delavk v } \\
\text { zgodnji obravnavi }\end{array}$ & 17 & 19,54 & & & \\
\hline Skupaj & 87 & 100,00 & Skupaj & 82 & 100,00 \\
\hline
\end{tabular}

jev, da bi se lahko pri vseh otrocih, ki imajo take težave, ZO lahko sploh izvajala.

Tudi druga svetovalna delavka meni, da je ZO otrok pomembna zaradi ranljivosti in občutljivosti le-teh v najzgodnejšem obdobju njihovega razvoja:

Nam kot vrtcu pa tudi meni osebno se zdi ZO zelo pomembna. V predšolskem obdobju je čisto vsak mesec pomemben za otrokov razvoj in sama se ob zaznavi problematike pri otroku zelo hitro s starši pogovorim, jih usmerim, napotim [...].

Otrokovi možgani so že kmalu po rojstvu, nato pa v celotnem obdobju zgodnjega otroštva podvrženi hitremu razvoju, za katerega so značilna t. i. občutljiva oz. kritična obdobja (Blakemore in Frith 2005). V prvih petih letih otrokovega življenja pa poteka njegov intenzivni kognitivni in čustveno- 
Slika 1

Pogoji za uresničevanje zgodnje obravnave
Pogoji za uresničevanje ZOPOPP

socialni razvoj ter razvoj njegovih samoregulacijskih zmožnosti (Karoly, Kilburn in Cannon 2005). Prav zaradi omenjenega je ZO otrok s posebnimi potrebami oz. posebnostmi v razvoju izredno pomembna, saj lahko s pravočasnim ukrepanjem ter $z$ ustrezno spodbudo in usmerjanjem največ naredimo za njihov nadaljnji razvoj in razvoj njihovih potencialov (Koegel idr. 2014). Zamujene priložnosti v razvoju je namreč mogoče nadoknaditi le do določene mere (Blakemore in Frith 2005). Pri tem so ključne interakcije, ki se vzpostavijo med otrokom in njegovim neposrednim (npr. družina, vrtec) ter posrednim (npr. urejenost ZO) okoljem (Bronfenbrenner 1995; Renn 2003) - tako oblikujejo spodbudno okolje za razvoj. Le usklajeno delovanje omenjenih okolij omogoča učinkovito obravnavo otroka, ki potrebuje dodatno podporo in pomoč.

\section{Pogoji za uresničevanje zgodnje obravnave}

Svetovalni delavki sta poudarili, da je v procesu uresničevanja ZOPOPP še veliko nejasnosti oz. neznank, prav tako še niso uresničeni vsi pogoji, ki bi omogočali neovirano uresničevanje omenjenega zakona. Nezadostni pogoji v svetovalnih delavkah ustvarjajo občutek, da je način izvedbe ZO v okviru ZOPOPP še vedno nejasen (slika 1).

Ena svetovalna delavka je trenutne okoliščine opisala kot zelo negotove in nejasne, saj je znanih premalo informacij o tem, kako se bo ZOPOPP uresničeval:

V trenutni situaciji smo v velikem vakumu - veliko je informacij, malo je potrjenih, ministrstva, ${ }^{1}$ ki so sodelovala pri ZOPOPP, še niso izpeljala potrebnih stvari, da bi lahko zakon zaživel, kljub temu pa je s 1. 1. 2019 stopil v uporabo.

\footnotetext{
${ }^{1}$ Ministrstvo za izobraževanje, znanost in šport, Ministrstvo za zdravje in Ministrstvo za delo, družino, socialne zadeve in enake možnosti, op. avt.
} 
Nejasnosti glede uresničevanja ZOPOPP se nanašajo tudi na definicijo otrok, ki bodo upravičeni oz. deležni podpore in pomoči v okviru ZO. ZOPOPP (2017) namreč predvideva, da je ZO namenjena otrokom s posebnimi potrebami in otrokom $\mathrm{z}$ rizičnimi dejavniki v predšolskem obdobju. Otroke $\mathrm{s}$ posebnimi potrebami v predšolskem obdobju pa definira širše in ne glede na specifične skupine. Pri tem je ena svetovalna delavka izpostavila, da je širša definicija otrok s posebnimi potrebami ali z rizičnimi dejavniki, ki potrebujejo ZO, prednost, ne more pa si še predstavljati, na kakšen način se bo uporaba te definicije uresničevala v konkretnih okoliščinah:

Prednost je $v$ tem, da je tako poimenovanje možno razumeti širše, ker ne določa posameznih kategorij, kar smo videli v preteklosti, kako je bilo, ko še ni bila določena kategorija otroci $z$ avtističnimi motnjami. [...] Če so naštete točno določene kategorije, se lahko zgodi, da otrok ima težave (izpostavila bi npr. otroke s čustveno-vedenjsko problematiko), vendar ne more biti uvrščen v nobeno od teh kategorij. Predvidevamo lahko, da bo v bodoče lažje zajeti več otrok. Vprašanje pa je, kako bo $v$ praksi.

Tudi literatura navaja, da je $v$ predšolskem obdobju smiselno govoriti o področjih, na katerih se posebnosti v razvoju izkazujejo, in ne o posameznih skupinah otrok s posebnimi potrebami (Krek in Metljak 2011; Simpson in Warner 2010).

Druga svetovalna delavka je izrazila zaskrbljenost nad tem, na kakšen način bo potekalo sodelovanje med različnimi akterji, kot so svetovalna delavka centra, zdravnik pediater idr., ki bodo oz. so odgovorni za uresničevanje celostne ZO. Pri tem je izrazila predvsem skrb ob prezgodnjem vključevanju centra za socialno delo $v$ obravnavo otroka, kar bi lahko starše odvrnilo od sodelovanja:

Upam, da bo tim dovolj fleksibilen, da bo znal razbrati, kdaj je za posameznega otroka $v$ določeni fazi obravnave tako sodelovanje koristno in potrebno [...] če sem prav razumela, bodo otroci, ki so obravnavani v vrtcu, obravnavani tudi na CZO. [...] Starše je velikokrat težko pripraviti k sodelovanju, saj že tako težko sprejemajo vso situacijo, sedaj, ko bo vključenih v obravnavo otroka in celotne družine toliko več ljudi, pa je skrb, da bodo starši še težje sodelovali, toliko večja.

Ena svetovalna delavka je tudi poudarila, da ko je v obravnavo otroka vključenih veliko strokovnih delavcev, se lahko zgodi, da to ustvari občutek zme- 
denosti staršev, predvsem takrat, kadar strokovni delavci v svojih stališčih niso poenoteni oz. so le-ta celo diametralno nasprotujoča si:

Postavitev posamezne diagnoze (hiperaktivnost, motnja pozornosti, avtizem) se velikokrat določa na podlagi vedenja, zato so lahko mnenja posameznikh strokovnjakov različna. Zavedati se moramo, da tudi okolje vpliva na vedenje otroka in v skupini, kjer je 24 otrok, je vedenje zagotovo drugačno kot v individualni situaciji (npr. pri pediatru). Starši od različnih strokovnjakov prepogosto dobivajo različne informacije in so zmedeni ter seveda sprejmejo tisto, kar jim je lažje slišati.

Sodelovanje $z$ različnimi strokovnimi sodelavci oz. z večdisciplinarnim timom je za svetovalnega delavca zahtevno tudi $z$ vidika organiziranosti dela in časa, ki ga ima na razpolago za enega otroka:

Sicer se lahko dobimo na sestanku, vprašanje pa je, ali nam bo to časovno uspelo za vse otroke. Glede na to, da imamo kar veliko število obravnavanih otrok (letno najmanj 40), se sprašujem, ali bomo imeli tudi časovne možnosti sprotne izmenjave informacij za vsakega otroka posebej. Velikokrat je problem sploh uskladitev terminov. Skrbi me, da nam bo za sprotno evalvacijo in sprotno izmenjavo informacij $z$ vsemi člani tima zmanjkalo časa. Samo s kontinuiranim delom pa lahko staršem in otroku ponudimo možnost za napredek in razvoj v pravo smer [...]

Po drugi strani pa svetovalna delavka prepoznava tudi prednosti sodelovanja z različnimi akterji, saj bo to lahko priložnost, da poenotijo svoje ugotovitve in stališča ter jih staršem tudi enotno predstavijo:

Prednost novega zakona je tudi ta, da bomo imeli več priložnosti za srečevanje in se bomo lahko pogovarjali in enako tudi staršem predstavljali.

Sodelovanje pa jim bo omogočilo, da z različnih vidikov - tako pedagoškega kot medicinskega - detektirajo otroke, ki potrebujejo ZO, kar pomeni, da bo le-te deležnih več otrok, kot jih je je bilo do sedaj:

Število otrok v obravnavi se bo zagotovo spremenilo, saj mi prepoznavamo nekaj, zdravniki nekaj drugega. Težave se lahko zazna takoj po rojstvu (npr. slabši mišični tonus) ali pa kasneje $v$ otrokovem razvoju (npr. avtizem). Pogosto se zgodi, da v vrtcu nimamo informacije, 
da je otrok obravnavan $v$ razvojni ambulanti in obratno, lahko se pri otroku kaže primanjkljaj na govorno-jezikovnem področju in otrok ne obiskuje razvojne ambulante, vendar mu je $v$ vrtcu nudena pomoč. Pri nas bo nabor otrok, ki bodo obravnavani, večji, hkrati bomo tudi mi večje število otrok, ki jih zdravstvo prej ni obravnavalo, predali zdravstvu oz. skupni obravnavi.

Svetovalni delavki sta poudarili tudi, da trenutno niso zagotovljeni vsi pogoji za udejanjanje določil ZOPOPP, pri čemer sta omenili: odsotnost pravilnika, ki bi podrobneje urejal zakonska določila, še ne oblikovane normative za zaposlitev vzgojiteljev za zgodnjo obravnavo, neopredeljeno financiranje zaposlitev ter pomanjkanje strokovnega kadra v CZO ipd. Vse našteto onemogoča, da bi se v prehodnem obdobju uvajanja ZOPOPP ta lahko v celoti udejanjal in s tem zagotovil pravočasno obravnavo predvsem otrokom $\mathrm{s}$ posebnostmi v razvoju, ki še niso bili usmerjeni v ustrezen program vzgoje in izobraževanja:

Po novem naj bi bili ti postopki krajši, vendar ne vem, koliko je realno, otroci naj bi prej dobili pomoč, vprašanje pa je, kako bodo to kadrovsko zmogli CZO.

Pri tem si predvsem ena svetovalna delavka želi, da bi pediatri, ki so z ZOPOPP osrednji koordinatorji ZO, prisluhnili njihovemu mnenju in predlogom:

Po novem zakonu ob zaznavi težav pri otroku starše usmerimo k pediatru, pediater pa je tisti, ki odloča, ali otroka usmeriti v CZO. Pediater otroka ima torej veliko vlogo pri odločanju in nadaljnji usmeritvi. [...] Upam, da bodo pediatri razumeli, da je obravnava nujna, če smo v vrtcu določeno težavo zaznali. Večkrat se je že zgodilo, da so rekli staršem: počakajte, videli boste, da bo steklo, pustite otroku čas, obravnava trenutno ni potrebna. Otrok v predšolskem obdobju nima časa in vsak mesec brez ustrezne pomoči je velika izguba zanj. Pomembno je, da nam tudi pediatri zaupajo [...].

Ne glede na to, da je pediater osrednji koordinator ZO, je pri tem treba upoštevati, da ta zajema različne vidike otrokovega razvoja in življenja (Globačnik 2012) ter predvideva različne vrste obravnave, ki so bodisi zdravstvene bodisi pedagoške in specialno-rehabilitacijske. Ob tem pa ne smemo zanemariti tudi skrbi za (socialno) inkluzijo otrok s posebnimi potrebami - prav tu je lahko vloga svetovalne delavke vrtca ključna. 


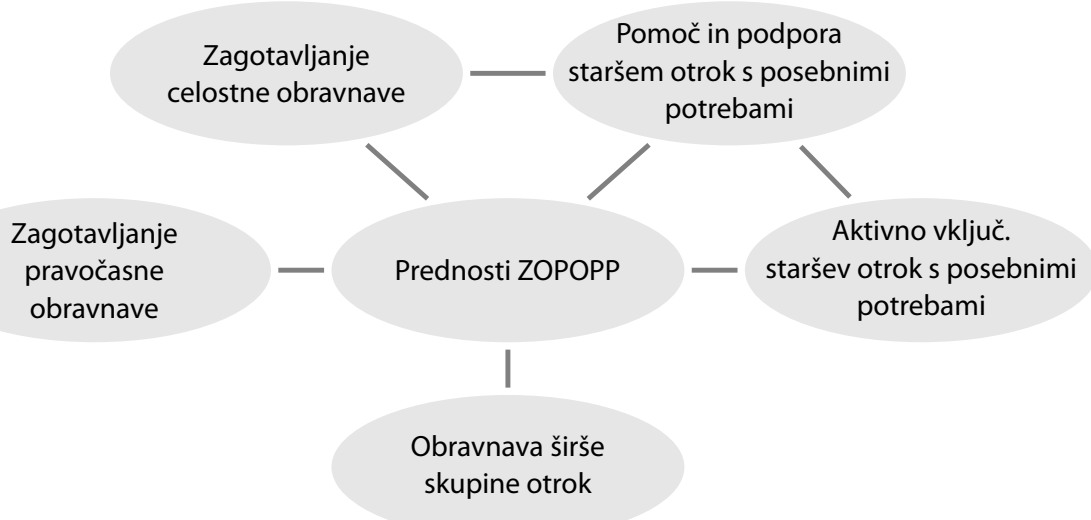

Slika 2 Prednosti ZOPOPP

\section{Prednosti Zakona celostne zgodnje obravnave predšolskih otrok s posebnimi potrebami}

Svetovalni delavki v ZOPOPP prepoznavata tudi različne prednosti. Nekatere, ki jih omenjata, se tudi medsebojno povezujejo in prepletajo (slika 2). Prednost ZOPOPP zagotovo predstavlja pomoč in podpora staršem otrok s posebnimi potrebami, ki se bo uresničevala tudi skozi njihovo večje aktivno vključevanje v celostno ZO. ZOPOPP (2017) namreč predvideva tudi pripravo individualnega načrta pomoči družini, ki ga bodo na CZO tudi sprotno evalvirali. Usmerjenost ZOPOPP v pomoč in podporo družini pa posredno in neposredno zagotavlja tudi celostno obravnavo otroka s posebnimi potrebami. Ozaveščeni starši ter straši, ki so izgradili potrebna znanja in veščine za nudenje ustrezne pomoči in podpore svojim otrokom, lahko pomembno prispevajo $\mathrm{k}$ njihovemu uspešnemu razvoju (Majnemer 1998). Svetovalni delavki kot prednost ZOPOPP navajata tudi zagotavljanje pravočasne obravnave, ki je bo deležna širša skupina otrok, ki zaradi posebnosti v razvoju potrebujejo pomoč.

Prednost ZOPOPP (ki je lahko $v$ tem trenutku lahko še razumljena kot nejasnost) je zagotovo ta, da predvideva obravnavo širše skupine otrok, ki imajo posebne potrebe oz. so pri njihovem razvoju in/ali okolju prisotni rizični dejavniki. Pri tem sta obe svetovalni delavki izpostavili, da ZOPOPP ponuja boljše možnosti, da bodo ustrezno podporo in pomoč dobili tudi otroci, ki izkazujejo čustveno-vedenjske posebnosti. Po ZUOPP-1 (2011) komisija za usmerjanje otrok s posebnimi potrebami oz. otrok s posebnostmi v čustvovanju ter vedenju ni usmerjala $v$ ustrezni program vzgoje in izobraževanja, 
saj se otroci v tem obdobju še niso osebnostno izoblikovani. Ena svetovalna delavka je tako opisala dosedanjo obravnavo otrok s čustveno-vedenjskimi posebnostmi:

V predšolskem obdobju se otrok s čustveno-vedenjskimi motnjami ne usmerja oz. se ne opredeljuje, da imajo na tem področju težave. Mi pa se srečujemo $z$ otroki, pri katerih lahko govorimo, da so prisotne težave na čustveno-vedenjskem področju, ki zahtevajo našo pozornost in obravnavo, da se ne razvijejo $v$ motnje.

Obenem lahko delo z otroki s čustveno-vedenjskimi težavami, ki niso ustrezno obravnavani, pedagoškim delavcem predstavlja vir stresa (Kyriacou 2001), saj nezmožnost obvladovanja vedenj otroka zmanjšuje doživljanje njihove samoučinkovitosti (Tschannen-Morana in Hoy 2007), kar se odraža v njihovem zmanjšanem doživljanju učinkovitosti pri delu z omenjenimi otroki. Ne glede na omenjeno pa velja, da se pri preozko usmerjeni definiciji otrok s posebnimi potrebami oz. posebnostmi v razvoju ter otrok, ki potrebujejo dodatno specifično pomoč in podporo, lahko zgodi, da slednjih niso deležni vsi, ki ju v resnici potrebujejo.

Obe svetovalni delavki sta prednost ZOPOPP prepoznali tudi v zagotavljanju pravočasne ter celostne obravnave, saj bodo $v$ obravnavo vključeni različni strokovnjaki, ki se bodo povezovali v večdisciplinarnem timu, obravnava otroka pa bo potekala na enem mestu:

Imeli bomo več možnosti, da se pogovorimo, si izmenjamo mnenja in otroka tako celostno obravnavamo. Starši pa bodo na enem mestu dobili vse potrebne in koristne ter enotne informacije. [...].

Obenem pa naj bi ZOPOPP predvideval tudi podporo in pomoč družinam otrok s posebnimi potrebami ter aktivno vključevanje staršev pri zagotavljanje podpore in pomoči otroku. Ena svetovalna delavka je povedala naslednje:

Če bodo starši obravnavani v CZO, jim bodo bistveno lažje dostopne vse te storitve, od logopeda, specialno-rehabilitacijskega pedagoga, ki se bodo tam povezovali z razvojno pediatrinjo, delovno terapevtko, $s$ fizioterapevtko in socialno delavko ter delovali usklajeno in bolj učinkovito. Skrbi nas, ali bodo CZO zmogle vse družine voditi in obravnavati na tovrsten način.

Izpostavila je tudi, da bodo lahko starši odslej veliko bolj sodelovali pri obravnavi svojega otroka oz. bili v obravnavo bolj vključeni: 


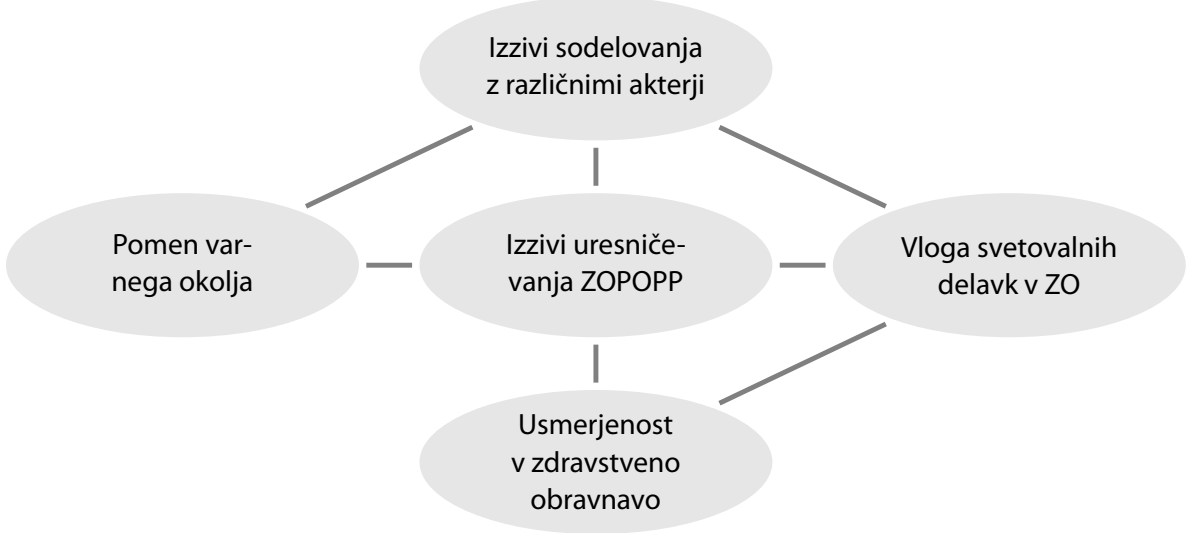

Slika 3 Izzivi uresničevanja ZOPOPP

Bistveno bolj aktivno bodo lahko sodelovali, čeprav po drugi strani starši, ki so bili doslej aktivni, ki so sprejemali naše usmerjanje in vodenje, so lahko tudi sami uspešno prispevali k pomoči svojemu otroku.

Sodelovanje med starši in svetovalnimi delavci mora izhajati iz temeljnega medsebojnega zaupanja. Odnos s starši pa je treba postopno izgrajevati in negovati, tudi s pomočjo neformalnih pogovorov (McWilliam 2010). S tem ko starši zaupajo strokovnemu delavcu, lahko ta podrobneje spozna, na kakšen način deluje družina (Prater 2010). Vključevanje staršev otrok s posebnimi potrebami oz. posebnostmi v razvoju predstavlja tudi enega izmed štirih temeljnih področij kompetenc in vrednot, ki omogočajo zagotavljanje inkluzije in inkluzivne vzgoje ter izobraževanja (Borg idr. 2011), zato je skrb za njihovo (aktivno) sodelovanje ključnega pomena.

\section{Izzivi uresničevanja Zakona celostne zgodnje obravnave predšolskih otrok s posebnimi potrebami}

Svetovalni delavki sta navedli različne izzive, ki jih pred svetovalne delavce vrtca postavlja ZOPOPP. Izzivi, ki jih omenjata, se tudi medsebojno povezujejo in prepletajo (slika 3). Izziv zagotovo predstavlja usmerjenost ZOPOPP $v$ zdravstveno obravnavo - $s$ tem je pod vprašaj postavljena vloga svetovalnih delavk vrtca, istočasno pa so te postavljene pred izziv, kako sodelovati z različnimi strokovnimi delavci, člani večdisciplinarnega tima, izven vrtca ter pri tem zagotoviti okolje, $v$ katerem se starši otrok s posebnimi potrebami počutijo varne.

Eden izmed pomembnejših izzivov, ki sta ga svetovalni delavki navedli, se nanaša na usmerjenost ZO v zdravstvo. Iz ZOPOPP (2017) je namreč razvidno, 
da je težišče obravnave usmerjeno v CZO, v okviru katerega ima razvojni pediater poglavitno vlogo. Ena svetovalna delavka je izrazila zaskrbljenost nad tem pa tudi nad tem, da bo morda svetovalni delavec izgubil svojo temeljno vlogo:

Žal mi je, da se obravnava spet prenaša izven vrtca. Včasih otrok v vrtcu preživi več časa kot doma. V vrtcu se počuti varnega. Tudi starši nam zaupajo. Upam, da bomo tudi svetovalni delavci oz. drugi strokovni delavci vrtca slišani in upoštevani, ker smo prav mi tisti, pri katerih otrok preživi veliko časa in otroka dobro poznamo. Na žalost postajamo člani nekega tima zunaj vrtca, namesto da bi se na vrtce bolj obračali. Želimo si tudi več vključenosti strokovnih delavcev iz CZO v vrtce (v smislu opazovanja otroka v skupini) ter sodelovanja s strokovnimi delavkami v vrtcu.

Z Zakonom o usmerjanju otrok s posebnimi potrebami (ZUOPP-1 2011) smo želeli $\vee$ Sloveniji postaviti pogoje za inkluzijo otrok s posebnimi potrebami in $s$ tem osvetliti razumevanje otrokovih posebnih potreb tudi $z$ vidika okolja, $v$ katerega je vključen. Medicinski vidik razumevanja otrok $\mathrm{s}$ posebnimi potrebami izhaja zgolj iz otrokovih težav, neupoštevajoč okolje. Inkluzivno-socialno-pedagoški vidik razumevanja otroka s posebnimi potrebami pa poudarja, da so posebne potrebe otroka posledica ovir, ki mu jih postavlja okolje (Slee 2014; Pantić in Florian 2015). Pri udejanjanju ZOPOPP bo zato potrebno posebno skrb nameniti tesni povezanosti med medicinskim in inkluzivno-socialno-pedagoškim vidikom razumevanja posebnih potreb (Mitchell 2014).

Vloga svetovalnih delavcev vrtca je, da otroku zagotovijo pravočasno obravnavo tudi glede na to, kar opazijo pri njem v času njegovega bivanja v vrtcu. Zato sta se svetovalni delavki spraševali, kakšna bo odslej njuna vloga pri ZO otrok. Ena je menila, da bi morali bolj izpostaviti svoje kompetence, ki jih imajo za delo $z$ otroki s posebnimi potrebami:

Mislim, da si zaslužimo večjo veljavo, recimo, ko imamo otroke $z$ avtizmom ali z motnjo pozornosti, smo za pripravo prilagoditev bolj kompetentni. [...] Mi vemo, kaj otrok v skupini potrebuje, da bo lažje funkcioniral, sledil skupini ... sprašujem se, koliko tega lahko zdravnik ali nekdo, ki vidi otroka redko, dà.

Svetovalni delavki sta poudarili tudi, da vidita izzive v sodelovanju z različnimi akterji, to je s strokovnimi delavci z različnih področij, ki bodo sodelovali 
$\checkmark$ večdisciplinarnem timu v okviru CZO. Pri tem sta poudarili, da bo treba posebno skrb nameniti ustvarjanju varnega okolja, v katerem bodo starši čutili, da lahko iskreno spregovorijo o težavah, ki jih sami zaznavajo oz. jih zaznavajo strokovni delavci pri njihovem otroku. Ena svetovalna delavka je povedala naslednje:

Sedaj, ko bodo sestanki drugje, je vprašanje, koliko bomo mi imeli možnost individualnega pogovora $s$ starši, mogoče bo tega manj. Hodili bomo na sestanke, na katerih bo prisotnih pet ljudi, vprašanje je, koliko bomo imeli mi priložnost in koliko se bodo starši odprli, da bodo iskali rešitve.

Svetovalna delavka je poudarila pomen sodelovanja z različnimi strokovnimi delavci tudi zaradi pretoka informacij; do sedaj srečanja s pediatri pogosto niso bila mogoča, zato se ena svetovalna delavka nadeja, da bo z novo organizacijo zagotavljanja celostne obravnave to mogoče:

Velikokrat smo dobili otroke, ki so imeli hude zdravstvene težave, kar je področje zdravstva, prišli so $v$ vrtec in mi o tem nismo nič vedeli. [...] Veliko časa smo se borili, da smo uspeli pripraviti tako zdravniško potrdilo (obrazec), $v$ katerem piše, ali je otrok usmerjen ali je obravnavan $v$ razvojni ambulanti. [...] Z novim zakonom naj bi bila povezava z zdravstvom boljša [...]. Upam, da bo steklo tako, kot je načrtovano, in da bo pretok informacij tudi v praksi stekel.

Sodelovanje v strokovnih (večdisciplinarnih) timih predstavlja pomembno kompetenco pedagoških delavcev v inkluziji (Borg idr. 2011) in ima pri zagotavljanju zgodnje obravnave otrok ključno vlogo (Soriano 2005), zato je pomembno, da se svetovalni delavci počutijo dovolj okrepljene za vstopanje $v$ enakovredno komunikacijo s strokovnjaki z različnih bolj ali manj sorodnih strokovnih področij. V tej vlogi ZOPOPP svetovalnih delavk trenutno ne krepi, saj njihove vloge ne opredeli jasno. Razumevanje lastne profesionalne vloge pa je ključnega pomena za posameznikovo angažirano delovanje, ki se odraža tudi v njegovi zmožnosti sodelovanja z drugimi (Pantić in Florian 2015).

\section{Sklep}

ZO se začne že v prenatalnem obdobju, zaključi pa z otrokovim vstopom v vrtec, zato imajo pri njenem udejanjanju pomembno vlogo tako vzgoja in izobraževanje (vrtec) kot zdravstvo. Vlogi vzgoje in izobraževanja pa morata 
biti prepletajoči in dopolnjujoči se glede na lastno področje kompetenc. Interakcije med omenjeni področji, ki so $v$ svojem delovanju kompleksna, so zapletene, a kljub temu lahko pomembno prispevajo k oblikovanju spodbudnega okolja za uspešen otrokov razvoj (Renn 2003). Pomen prepletanja medicinskega in socialno-pedagoškega vidika obravnave otrok s posebnimi potrebami in dela z njimi poudarja tudi D. Mitchell (2014). Fokus ZO je usmerjen $\checkmark$ različne vidike otrokovega socialno-čustveno-kognitivnega delovanja ter $v$ zagotavljanje ustreznih pogojev za otrokov razvoj (Fillis, Dunnea in McConnell 2018). Učinkovita ZO otrok s posebnimi potrebami ali posebnostmi v razvoju predvideva tudi pomoč in podporo njihovim družinam. Pri oblikovanju ZOPOPP so njegovi avtorji sledili sodobnim smernicam na področju ZO. Njegov temeljni namen pa je zagotoviti ustrezno in celostno obravnavo otrok, ki jo ti potrebujejo.

S študijo primera ugotavljamo, da trenutno še niso vzpostavljeni temeljni pogoji za njegovo uresničevanje, saj so prisotne različne dileme pa tudi izzivi, ker med drugim še niso sprejeti temeljni pravilniki in podzakonski akti, ki bi v celoti omogočali udejanjanje ZOPOPP. Nejasnosti se glede na mnenje svetovalnih delavk nanašajo predvsem na konkretno izvedbo ZOPOPP. Izziv zagotovo predstavlja tudi sodelovanje s starši, ki bodo od slej sodelovali s timom strokovnjakov v CZO in timom strokovnjakov v vrtcu. Po eni strani bo to staršem omogočilo, da dobijo poenoteno mnenje ter oceno otrokovega razvoja in njegovih potreb, po drugi strani pa se bodo morali strokovnjaki pri podajanju mnenja poenotiti, kar je do sedaj predstavljalo težavo. Pomembna prednost ZOPOPP je, da bo lahko več otrok dobilo ustrezno, predvsem pa pravočasno obravnavo, pri tem je vredno izpostaviti otroke s čustveno-vedenjskimi težavami, ki do sedaj v predšolskem obdobju niso imeli zagotovljene pravočasne in ustrezne obravnave. Z ZOPOPP pa so vrtci oz. njihove svetovalne delavke postavljene pred zahtevo, da deloma preoblikujejo svojo vlogo, predvsem pa da $v$ komunikacijo $z$ drugimi strokovnimi delavci (tudi z zdravstvenega področja) vstopajo kot strokovnjaki, ki imajo kompetence za detekcijo in identifikacijo otrok s posebnostmi v razvoju, delo z njimi in njihovimi starši ter izvajanje prilagoditev, ki otroku omogočajo polno vključenost v vrtčevsko skupino.

\section{Literatura}

Ainscow, M., T. Booth in A. Dyson. 2006. Improving Schools, Developing Inclusion. New York: Routledge.

Krek, J., in M. Metljak, ur. 2011. Bela knjiga o vzgoji in izobraževanju v Republiki Sloveniji. 2011. Ljubljana: Pedagoški inštitut. 
Blakemore, S. J., in U. Frith. 2005. The Learning Brain: Lessons for Education. Oxford: Blackwell.

Borg, G., J. Hunter, B. Sigurjónsottír in S. D’Alessio. 2011. Ključna načela za spodbujanje kakovostiv inkluzivnem izobraževanju. Bruselj: Evropska agencija za razvoj izobraževanja na področju posebnih potreb.

Bronfenbrenner, U. 1995. »Developmental Ecology Through Space and Time: Future Perspective."V Examining Lives in Context: Perspectives on Ecology of Human Development, ur. P. Moen, G. H. Elder in K. Luscher, 619-647. Washington, DC: American Psychological Association Press.

Fillis, S., L. Dunne in B. McConnell. 2018. »Empirical Studies on Early Intervention Services for Toddlers Aged 24-36 Months: A Systematic Review.«International Journal of Educational Research 89:119-138.

Globačnik, B. 2012. Zgodnja obravnava. Ljubljana: Zavod Republike Slovenije za šolstvo.

Karoly, L. A., M. R. Kilburn in J. S. Cannon. 2005. Early Childhood Interventions: Proven Results, Future Promise. Santa Monica, CA: Rand.

Koegel, L. K., R. L. Koegel, K. Ashbaugh in J. Bradshaw. 2014. »The Importance of Early Identification and Intervention for Children with or at Risk for Autism Spectrum Disorders."International Journal of Speech-Language Pathology 16 (1): 50-56.

Kyriacou, C. 2001. »Teacher Stress: Directions for Future Research.« Educational Review 53 (1): 27-35.

Majnemer, A. 1998. »Benefits of Early Intervention for Children with Developmental Disabilities. "Seminars in Pediatric Neurology 5 (1): 62-69.

Marjanovič Umek, L., in M. Zupančič, ur. 2009. Razvojna psihologija. Ljubljana: Znanstvena založba Filozofske fakultete.

McWilliam, R. A. 2010. Working with Families of Young Children with Special Needs. New York: Guilford.

Mitchell, D. 2014. What Really Works in Special and Inclusive Education: Using Evidence-Based Teaching Strategies. London: Routledge.

Nores, M., in W. S. Barnett. 2010. »Benefits of Early Childhood Interventions Across the World." Economics of Education Review 29 (2): 271-282.

Pantić, N., in L. Florian. 2015. »Developing Teachers As Agents of Inclusion and Social Justice.« Education Inquiry 6 (3): 333-351.

Porter, L. 2002. Educating Young Children with Special Needs. London: Paul Chapman.

Prater, L. P. 2010. »Parent and Family Involvement in the Education of Children with Special Needs. «V International Encyclopedia of Education, ur. P. Peterson, E. Baker in B. McGaw, 788-793. Oxford: Elsevier.

Renn, K. A. 2003. »Understanding the Identities of Mixed-Race College Students Through a Developmental Ecology." Journal of College Student Development 44 (3): 383-399. 
Simpson, C. G., in L. Warner. 2010. Successful Inclusion Strategies for Early Childhood Teachers. Waco, TX: Prufrock Press.

Slee, R. 2014. "Discourses of Inclusion and Exclusion: Drawing Wider Margins." Power and Education 6 (1): 7-17.

Soriano, V. (2005). Zgodnja obravnava v otroštvu: analiza stanja v Evropi; ključni vidiki in priporočila. Bruselj: Evropska agencija za razvoj izobraževanja na področju posebnih potreb.

Tschannen-Moran, M., in A. W. Woofolk Hoy. 2007. »The Differential Antecedents of Self-Efficacy Beliefs of Novice and Experienced Teachers."Teaching and Teacher Education 23 (6): 944-956.

Zakon o celostni zgodnji obravnavi predšolskih otrok s posebnimi potrebami (ZOPOPP). 2017. Uradni list Republike Slovenije, št. 17.

Zakon o usmerjanju otrok s posebnimi potrebami (ZUOPP-1). 2011. Uradni list Republike Slovenije, št. 58.

\section{Challenges of Early Intervention of Preschool Children}

A modern understanding of the early intervention of children originates from the Ecological Systems Theory that enables an in-depth identification of risk factors in the child's development and the environment. The purpose of early intervention is to ensure adequate prevention and a timely treatment of children with developmental delay, already in the earliest period of their life. At the beginning of 2019, the Act Regulating the Integrated Early Treatment of Preschool Children with Special Needs, which was supposed to fully regulate this area, came into force in Slovenia. We were interested in how kindergarten counsellors understand the importance of early intervention, what advantages and disadvantages they perceive in the Act, and how they see their role in it. We interviewed two counsellors. The findings indicate that the new Act brings many advantages in the field of early intervention, as well as challenges. The latter mainly concern the cooperation with various participants involved in early intervention. They emphasize that all the conditions for implementing the Act have not yet been guaranteed.

Keywords: counsellors, act, children with special needs, early intervention, kindergarten 


\title{
Pripomočki za vzgojitelje za detekcijo otrok $z$ avtizmom $v$ prvem starostnem obdobju (1-3)
}

\author{
Vanja Riccarda Kiswarday \\ Univerza na primorskem \\ vanjariccarda.kiswarday@pef.upr.si \\ Maja Rejc \\ Univerza na primorskem \\ maja.rejc@gmail.com
}

Z zgodnjo detekcijo in obravnavo otrok z avtizmom lahko ublažimo razvoj motnje in pridruženih težav. To pomembno izboljša kakovost življenja otroka in družine ter poveča učinkovitost nadaljnjih obravnav, zato je vzgojiteljeva seznanjenost z zgodnjimi znaki, ki nakazujejo na avtizem že v najzgodnejšem obdobju, ter opremljenost z opazovalnimi pripomočki, pomembna. Želeli smo pregledati in analizirati lestvice za opazovanje in beleženje zgodnjih znakov avtizma v starosti od 1 do 3 let, ki so uporabne za vzgojitelja v okviru njegovega pedagoškega dela $v$ otrokovem avtentičnem okolju v vrtcu. Ugotovili smo, da je malo pripomočkov za zgodnjo detekcijo avtizma namenjenih vzgojiteljevemu pedagoškemu opazovanju. Vzgojiteljeva informacija se v anamnestične in diagnostične postopke vključuje premalo in še to zgolj posredno, kar zmanjša občutljivost presejalnih testov. Menimo, da bi aktivnejša vključenost vzgojiteljev v zgodnjo detekcijo avtizma pozitivno prispevala tudi k večji ozaveščenosti in pripravljenosti za prilagajanje vrtčevskega okolja potrebam otrok z avtizmom.

Ključne besede: avtizem, zgodnji znaki, pripomočki za zgodnjo detekcijo, prvo starostno obdobje (1-3), vzgojitelji

\begin{abstract}
Uvod
Vstop v vrtec lahko nekaterim otrokom, sploh tistim, ki imajo težave na področju prilagoditvenih spretnosti, predstavlja velik stres, ki ga navadno manifestirajo $z$ napornim, nepričakovanim in neprilagojenim vedenjem. Pogosto se tako otrokovo vedenje pripisuje neučinkovitemu vzgojnemu delu staršev, kar družini naloži dodatno breme neuspeha, prepreči priložnost za ustrezno zgodnjo detekcijo težav in s tem še oteži priložnost za napredovanje otroka. Glede na nacionalne in mednarodne statistične podatke, ki jih opisujemo $v$ prispevku, je število otrok $z$ diagnosticirano avtistično motnjo $v$ porastu,
\end{abstract}


hkrati pa je tudi jasno, da je zgodnja detekcija izjemnega pomena in da intenzivna zgodnja obravnava dokazano izboljša razvoj otroka ter pomembno vpliva na njegovo nadaljnje življenje, tudi v odraslosti. Vloga vrtca oz. vzgojitelja, ki neposredno vključuje otroka v vrtčevsko okolje, je zato izredno pomembna. Pomembno je vzgojiteljevo (pre)poznavanje zgodnjih znakov avtizma, za kar potrebuje tudi ustrezna orodja. Namen naše raziskave je bil pregledati, katere lestvice za opazovanje in beleženje zgodnjih znakov avtizma za prvo starostno obdobje (od 1 do 3 let) so prosto dostopne in uporabne za vzgojitelja.

\section{Opredelitev avtizma}

V Smernicah za delo v oddelkih za predšolske otroke z motnjami avtističnega spektra (Werdonig idr. 2009) je avtizem opredeljen kot kompleksna pervazivna nevrobiološko pogojena razvojna motnja, ki se kaže pred 3. letom in vpliva na vse vidike socialnega razvoja. M. Macedoni Lukšič (2006) poudarja, da je avtizem z etiološkega vidika zelo heterogen, glede pojavnosti pa, da je najhitreje naraščajoča razvojna motnja. Ocene ameriškega nacionalnega spremljanja pojavnosti avtizma v populaciji 8-letnikov za leto 2018 kažejo kar 15-odstotno porast glede na leto 2016, ko je bil avtizem diagnosticiran pri 1 od 68 otrok, medtem ko je bil leta 2018 diagnosticiran pri 1 od 59 otrok (Baio idr. 2018). Ista študija navaja, da je 4-krat pogosteje diagnosticiran pri dečkih kot pri deklicah (1/37 dečkov in 1/151 deklic). Prav tako ugotavljajo, da je večina diagnoz še vedno postavljena po 4. letu, čeprav se stanje da z visoko verjetnostjo prepoznati že $v$ starosti 2 let.

Konec 20. stoletja se je po teoriji nevrorazličnosti (Griffin in Pollak 2009; Singer 1999) avtizem začelo opredeljevati tudi kot povsem naravno variacijo, ki ne sme biti obravnavana kot motnja, ampak kot specifičnost, povezana z različnimi zmožnostmi zaznavanja in doživljanja okolja, odnosov in komunikacije. Te specifike niso nujno neugodne, nasprotno, pogosto se lahko pokažejo kot dragoceni potenciali, s pomočjo katerih lahko posameznik veliko prispeva, če so potenciali prepoznani in če je otrok oz. oseba z avtizmom ustrezno obravnavana, začenši s spodbujanjem zgodnjega razvoja (Ortega 2009).

\section{Pomen zgodnje detekcije in vloga vzgojitelja}

Zgodnja detekcija je ključna za zgodnjo obravnavo in zagotavljanje ustrezno prilagojene pomoči in podpore $v$ otrokovem razvoju, kar pozitivno vpliva tako na otroka kot na njegovo okolje in ima trajne pozitivne učinke (Christensen idr. 2010; Gillberg 2010; Rogers in Vismara 2008). G. Dawson idr. (2010) po- 
udarjajo, da lahko z zgodnjo detekcijo in obravnavo otrok z avtizmom ublažimo razvoj motnje ter ublažimo ali celo preprečimo razvoj pridruženih težav. S tem lahko pomembno izboljšamo kakovost življenja otroka in družine ter povečamo učinkovitost nadaljnjih obravnav, zato je pomembno, da zna zgodnje znake avtizma prepoznati čim več oseb, ki so vključene v otrokovo vsakdanje življenje. Med njimi so, poleg staršev in pediatrov, strokovni delavci vrtca med pomembnejšimi.

Vrtec malčku omogoča prvo obliko socializacije izven družine. $V$ prehodu med obema se odvijajo številni pomembni procesi, $v$ katerih imajo prilagoditvene zmožnosti (konceptualne, socialne in praktične spretnosti) pomembno vlogo, saj omogočajo zadovoljevanje lastnih potreb in zahtev okolja v vsakodnevnem življenju. S. Stropnik in J. Kodrič (2012) izpostavljata, da dobro razvite prilagoditvene spretnosti omogočajo večjo umirjenost in uglašenost $z$ okoljem ter se povezujejo $z$ večjo stopnjo posameznikove neodvisnosti in samostojnosti. Ocena zmožnosti prilagajanja otroka zahtevam okolja pa je po mnenju B. D. Jurišić (2011) lahko pomemben pokazatelj, saj je za otroke $z$ avtizmom to zelo zahtevna naloga.

Prepoznavanje oz. diagnostika avtizma temelji na opazovanju in analizi vedenja, komunikacije, socialne interakcije in zgodnjega učenja in je ni mogoče podati na osnovi bioloških ali organskih pokazateljev, na primer z analizo krvi ali urina, čeprav biološke teorije raziskujejo tudi genetske, nevrokemične in psihofiziološke faktorje (Dobnik Renko 2008). Pedagoško opazovanje in ocenjevanje je zato izredno dragocen vir podatkov o otrokovem vedenju, je pa pomembno, da vzgojitelj ve, v kaj mora usmerjati opazovanje, sploh, ko posumi, da pri otroku obstajajo posebnosti, ki bi lahko sodile v okvir avtističnih motenj.

Po najnovejši klasifikaciji duševnih motenj Diagnostic and Statistical Manual of Mental Disorders (2013) Ameriškega psihiatričnega združenja (APA) je avtizem opredeljen in diagnosticiran na podlagi dveh pomembnih kriterijev - govorimo o t. i. »diadi primanjkljajev«, ki vključuje (1) primanjkljaje na področju socialne komunikacije in socialne interakcije ter (2) omejene, ponavljajoče se vzorce vedenja, interesov ali aktivnosti.

Veliko posebnosti lahko vzgojitelj opazi pri igri otroka z avtizmom, saj je zaradi njegovih posebnih interesov in omejenih zmožnosti pretvarjanja ter domišljije ta pogosto neobičajna. Igra je za otroka $z$ avtizmom zelo pomembna, saj je osnova za zgodnje učenje. Ker pa otrok z avtizmom ne razvije spontano vseh oblik igre, mora vzgojitelj vedeti, da je otroka potrebno različnih oblik igranja učiti - npr. z modeliranjem, s postopnostjo, z vidnimi oporami in ponavljanjem (Christensen idr. 2010). Preko strukturirane igre otroka učimo tudi 
veščin socialne interakcije in komunikacije ter spodbujamo domišljijsko igro, ki je, zaradi slabše zmožnosti vživljanja, za otroke $z$ avtizmom manj značilna (Cotič Pajntar idr. 2017).

Otroci z avtizmom pomembno večji interes namenjajo konstrukcijskim igračam in igram, pri katerih lahko tudi nenavadno dolgo vztrajajo (Christensen idr. 2010; Werdonig idr. 2009). Značilno je tudi, da se otrok $z$ avtizmom raje igra sam in ne kaže zanimanja za vrstnike ter okolico (Dawson idr. 2004), pomembno manj se uči iz posnemanja (Andersson, Gillberg in Miniscalco 2013). L. Christensen idr. (2010) tudi ugotavljajo, da je pomembno pogosteje prisotna repetitivna in večinoma nefunkcionalna igra, ki ima funkcijo blažitve stisk. Značilen je tudi precej omejen in nenavaden izbor igrač, na katerih otroka pritegnejo deli, ki se drugim ne zdijo pomembni. Charman idr. (2000) kot pomemben diagnostični znak izpostavljajo tudi to, da je v njihovi igri izrazito opazen primanjkljaj na področju zmožnosti za vzpostavljanje združene (Jurišić 2011) oz. skupne vezane pozornosti - mehanizma, ko se v igri vzpostavi referenčni trikotnik, po katerem sta otrok in odrasel povezana in si delita (vežeta) pozornost na isti predmet/dogodek (Zupančič 2004).

Težave, ki se odražajo pri učenju, oblikovanju osebne identitete in socialnem vključevanju ter vplivajo na otrokovo sodelovanje $v$ vsakdanjih aktivnostih, so lahko pogojene tudi z motnjami senzorne integracije (Sterle idr. 2018), ki se pojavljajo pri avtizmu kot pridružena motnja kar v 80-90\% (Spitzer in Smith Roley 2001 v Sterle idr. 2018). Gričar in Kovačič (2017) navajata zgodnje znake motenj v senzorni integraciji, ki jih lahko opazimo v prvem letu otrokovega življenja, npr. slabo vizualno sledenje in fiksiranje, neodzivanje na ime, slabo vzdrževanje kontrole trupa in glave, močne negativne reakcije na dotik, vonj, okus in zvok, nedoseganje razvojnih mejnikov gibanja, slabo imitiranje obrazne mimike in kretenj, težave pri hranjenju, odsotnost čebljanja ipd.

Vse te značilnosti lahko v najpristnejših okoliščinah opazuje prav vzgojitelj in ker dobro pozna razvojne mejnike ter normativno vedenje otrok, lahko že v 1. starostnem obdobju v otrokovi igri zaznava posebnosti na nivoju vsebine, funkcije in socialne udeleženosti (Eikeseth 2009; Myers in Johnson 2007; Rogers in Vismara 2008).

Vzgojiteljeva detekcija zgodnjih znakov avtizma je pomembna, saj je lahko ključni sprožilec za zagotovitev ustrezne zgodnje obravnave. Pogoj za to je seveda vzgojiteljeva seznanjenost s simptomi, ki lahko nakazujejo na avtizem že v najzgodnejšem obdobju, ter opremljenost s pripomočki (vprašalniki, ček listami, lestvicami), ki omogočajo usmerjeno opazovanje in beleženje zgodnjih znakov. 
Po uvedbi Zakona o usmerjanju otrok s posebnimi potrebami (ZUOPP-1 2011) je v procesu zagotavljanja inkluzivnega vzgojno-izobraževalnega okolja Ministrstvo za izobraževanje, znanost in šport pripravilo programe, navodila in smernice za vzgojo in izobraževanje otrok s posebnimi potrebami. Za področje predšolske vzgoje so bili za kakovostnejšo inkluzijo otrok z avtistično motnjo pripravljeni naslednji dokumenti:

- »Navodila h Kurikulu za vrtce v programih s prilagojenim izvajanjem in dodatno strokovno pomočjo za otroke s posebnimi potrebami« (Čas, Kastelic in Šter 2003),

- "Smernice za delo v oddelkih za predšolske otroke z motnjami avtističnega spektra« (Werdonig idr. 2009),

- Dopolnitev Navodil h Kurikulumu za vrtce v programih s prilagojenim izvajanjem in dodatno strokovno pomočjo za otroke s posebnimi potrebami: za otroke z avtističnimi motnjami (Cotič Pajntar idr. 2017).

Ti dokumenti so pripravljeni za vzgojitelje oz. strokovne delavce vrtcev, da bi glede na potrebe otroka čim ustrezneje prilagodili izvajanje predšolskega kurikula in da bi bila otrok ter njegovo okolje deležna čim prejšnje ustrezne strokovne obravnave, podpore in pomoči. To predvideva tudi Zakon o celostni zgodnji obravnavi predšolskih otrok s posebnimi potrebami (ZOPOPP 2017), ki je nedavno stopil v veljavo.

Čeprav imajo omenjeni dokumenti veliko poučevalno vlogo, pa ne vsebujejo prilog v smislu ček list zgodnjih znakov avtizma, ki bi vzgojitelju omogočile sistematično opazovanje in beleženje. Slednje bi lahko, kot verodostojna informacija o identificiranih zgodnjih znakih avtizma, služilo tudi timu za zgodnjo obravnavo.

Vseeno so omenjeni dokumenti dobra opora vzgojitelju pri vzpostavljanju učinkovitih oblik pomoči in podpore ter pri oblikovanju ustrezno prilagojenega in varnega učno-vzgojnega okolja. Slednje je še posebej pomembno za otroka, ki ima ob vključevanju v novo okolje slabše prilagoditvene spretnosti. Vzpostavitev strukturiranega okolja in ustaljenega vzorca dnevnih rutin že čim bolj v začetku procesa uvajanja otroka v vrtec otroku pomaga zgraditi občutek predvidljivosti in varnosti ter preprečuje pojav pretiranih negativnih vedenjskih izpadov, ki so odraz notranje stiske in strahu in otroku še dodatno otežujejo vključevanje v dejavnosti kurikula. Obratno pa lahko, če vzgojitelj otroku ustrezno prilagodi okolje, to služi kot strategija pomoči in podpore pri razvoju socialnih interakcij ter prilagajanju na običajne in vsakodnevne življenjske okoliščine. 


\section{Stanje na področju zgodnje detekcije in diagnostike avtizma $\mathbf{v}$ svetu in pri nas}

Z namenom ozaveščanja o pomenu zgodnje detekcije in diagnostike avtizma ter $z$ usmerjenostjo $v$ iskanje učinkovitejših načinov za izboljšanje kakovosti življenja otrok z avtizmom in njihovih družin je Evropski parlament med letoma 2015 in 2018 financiral triletni projekt Autism Spectrum Disorders in the European Union - ASDEU. V okviru projekta so bila pripravljena priporočila za izboljšanje zgodnjega odkrivanja, diagnostike in intervencije oziroma terapevtskih pristopov. Poudarjajo predvsem, da bi bilo potrebno pozornost usmeriti v izboljšanje projektov zgodnjega prepoznavanja avtizma (Posada de la Paz 2018). Wieder (2011 v Mikuž 2015, 109) izpostavlja, da starši pogosto že $v$ dojenčkovem 1 . letu izražajo skrb v zvezi z njegovim razvojem, žal pa se temu v praksi pogosto ne posveča dovolj pozornosti.

V Sloveniji obravnava oziroma diagnostika otrok z avtizmom poteka na treh ravneh. Na primarni ravni pediater $v$ okviru preventivnih pregledov spremlja otrokov splošni razvoj v prvih dveh letih; pri tem je pozoren tudi na znake, ki bi lahko nakazovali na avtizem. Vzgojiteljevo poročilo bi imelo lahko že na tej ravni pomembno vlogo. M. Macedoni-Lukšič (2011) navaja, da na primarni ravni pediatri uporabljajo splošne presejalne teste, npr. Denverski razvojni presejalni test II (DRPT II) (Frankenburg idr. 1992). A. Mikuž (2015) opozarja, da je ta predpisan kot obvezen del sistematičnih pregledov, a se po podatkih Nacionalnega inštituta za javno zdravje ne izvaja dosledno ali $v$ celoti. Ta ugotovitev še dodatno podkrepi pomen kakovostnega vzgojiteljevega opazovanja in beleženja funkcioniranja otroka v vrtcu, kar je lahko pomembna informacija pediatru.

Če pediater pri otroku posumi na avtizem, ga usmeri na drugo raven, $\mathrm{ki}$ vključuje pregled otroka v razvojni ambulanti, pri pedopsihiatru oziroma pri strokovnjakih v centrih za duševno zdravje, kjer multidisciplinarni tim opravi otrokovo razvojno, osnovno nevrološko ter psihološko oceno, naredijo pa se tudi dodatni presejalni testi za avtizem (Macedoni-Lukšič 2011). Za zgodnje obdobje je primerna modificirana ocenjevalna lestvica avtizma pri malčkih Modified Checklist for Autism in Toddlers - M-CHAT (Robins idr. 2001), za katero Ameriška akademija za pediatrijo priporoča, da se v obdobju malčka opravi dvakrat - pri 18. in 24. mesecih (Johnson in Myers 2007 v Macedoni-Lukšič 2011, 9).

Za natančnejše diagnostično ocenjevanje avtizma se uporabljata diagnostična opazovalna shema za avtizem Autism Diagnostic Observation Schedule - ADOS (Lord idr. 2001) in diagnostični intervju za avtizem Autism Diagnostic 
Interview - ADI (Rutter, Le Couteur in Lord 2003), ki na področju diagnostike avtizma predstavljata »zlati standard« (Dobnik Renko 2016).

Pri nas je B. Dobnik Renko (2016) oblikovala psihološki ocenjevalni postopek za prepoznavanje zgodnjih napovednih znakov avtizma (SITKO). Usmerjen je $v$ opazovanje vedenja malčkov $v$ različnih igralnih situacijah ter ocenjevanje njihovega socialno-spoznavnega razvoja. Postopek temelji na oceni petih področij razvoja, na katerih se kažejo zgodnji znaki avtizma, in sicer na področju simbolne igre, komunikacije in socialne interakcije, skupne vezane pozornosti, teorije uma in empatije (Dobnik Renko 2016, 115). Vsa ta področja lahko opazuje in beleži tudi vzgojitelj, ki otroka dnevno spremlja v avtentičnem okolju.

Če se diagnostika na sekundarni ravni ne more zaključiti, se otroka napoti na terciarno raven, kjer ga obravnava multidisciplinarni tim, specializiran za avtizem (Macedoni-Lukšič 2011).

A. Mikuž (2015) opozarja, da so v Sloveniji kljub izpolnjenim pogojem za kakovostno presejanje za razvojne motnje pri dojenčkih in malčkih otroci, pri katerih so kasneje ugotovljene razvojne motnje, na oceno razvoja napoteni šele okoli 3. leta, ustrezno diagnozo in obravnavo pa dobijo šele po dopolnjenem 4. letu. $V$ istem viru je tudi opozarjeno, da so presejalni testi na primarni ravni (DRPT II) premalo občutljivi za detekcijo avtizma, saj ne zajemajo področij komunikacije, socialnega stika in prisotnosti specifičnih vedenj, ki so značilna za otroke $z$ avtizmom. Tako lahko otroci $z$ avtizmom na primarni ravni ostanejo spregledani, kar zopet potrdi pomen prispevka kakovostnega pedagoškega opazovanja v vrtcu.

\section{Problem, namen, cilj in raziskovalna vprašanja}

Ker sta zgodnja detekcija in obravnava ključnega pomena, je seveda pomen vloge strokovnih delavcev vrtca očiten in je sodelovanje med zdravstvom ter vzgojo in izobraževanjem izjemno pomembno. To poudarja tudi M. Macedoni-Lukšič (2011). Raziskovalni del prispevka smo usmerili v pregled in analizo presejalnih opazovalnih ter ocenjevalnih lestvic $v$ prvem starostnem obdobju (o-3 let), saj menimo, da lahko z natančnim opazovanjem in beleženjem otrokovega vključevanja ter prilagajanja na vrtčevsko okolje vzgojitelji v vrtcih pomembno prispevajo k zgodnji detekciji avtizma, vendar pa za to potrebujejo dobre opazovalne pripomočke. Zanimalo nas je, $v$ kolikšni meri so pripomočki, ki so namenjeni detekciji in identifikaciji avtizma, namenjeni tudi vzgojiteljem predšolskih otrok, in v kolikšni meri so ti dostopni tudi v slovenskem jeziku.

Naš cilj je bil pregledati in analizirati lestvice, ki so namenjene zgodnji de- 
Preglednica 1 Pregled lestvic za zgodnjo detekcijo avtizma, ki so lahko uporaben pripomoček za opazovanje vzgojitelja v vrtcu

\begin{tabular}{lll}
\hline Opazovalni pripomoček & (1) & (2) \\
\hline First Year Inventory - FYI (Pregled spretnosti pri 1 letu) & 12 & Starši/skrbniki \\
$\begin{array}{l}\text { Symptoms of Autism Before age 2 years - SAB o-2 (Znaki av- } \\
\text { tizma pred 2. letom starosti) }\end{array}$ & $0-24$ & Starši/skrbniki \\
$\begin{array}{l}\text { Early Screening of Autistic Traits - ESAT (Zgodnja detekcija } \\
\text { znakov avtizma) }\end{array}$ & $0-36$ & Starši/skrbniki \\
$\begin{array}{l}\text { Checklist for Early Signs of Developmental Disorders - CESDD } \\
\text { (Kontrolni seznam zgodnjih znakov razvojnih motenj) }\end{array}$ & $3-36$ & $\begin{array}{l}\text { Vzgojitelji oz. stro- } \\
\text { kovni delavci vrtca }\end{array}$ \\
$\begin{array}{l}\text { Infant Toddler Checklist - ITC (Vprašalnik za starše dojenčkov } \\
\text { in malčkov) }\end{array}$ & $6-24$ & Starši/skrbniki \\
$\begin{array}{l}\text { Revidirana modificirana ocenjevalna lestvica avtizma pri } \\
\text { malčkih z razširjenim intervjujem - M-CHAT-R/F }\end{array}$ & $16-30$ & Starši
\end{tabular}

Opombe Naslovi stolpcev: (1) starost otroka v mesecih, (2) opazovalec - oseba, ki izpolni pripomoček.

tekciji avtizma, in izluščiti tista področja otrokovega vedenja, ki lahko kažejo na zgodnje znake avtizma in jih lahko vzgojitelj v otrokovem avtentičnem okolju direktno opazuje ter beleži pri svojem pedagoškem delu.

Zastavili smo si naslednja raziskovalna vprašanja:

1. Kateri pripomočki za zgodnjo detekcijo avtizma so lahko $v$ pomoč vzgojiteljem in staršem, ki otroka spremljajo v vsakodnevnih okoliščinah vključevanja v življenjsko okolje?

2. Katera področja opazovanja se $v$ teh pripomočkih pojavljajo $v$ povezavi s prepoznavanjem zgodnjih znakov avtizma in jih vzgojitelj lahko opazuje ter beleži v okviru svojega običajnega pedagoškega dela?

3. Katera področja opazovanja prevladujejo v pripomočkih za zgodnjo detekcijo avtizma?

\section{Metodologija}

V kvalitativni raziskavi smo uporabili deskriptivno metodo pedagoškega raziskovanja. $V$ prosto dostopni strokovni literaturi smo pregledali, kateri pripomočki so namenjeni detekciji avtizma v zgodnjem obdobju (o-3 leta) in lahko služijo tudi vzgojiteljem v vrtcih. Eden od kriterijev za izbor lestvic je bil tudi, da so te podprte $z$ raziskavo in opisane $v$ znanstvenem viru. Na podlagi kriterijev smo izbrali šest lestvic, ki jih navajamo v preglednici 1.

Na podlagi kriterijev za opredelitev vrste in stopnje primanjkljajev, ovir oz. motenj otrok s posebnimi potrebami (Vovk-Ornik 2015), Diagnostic and Sta- 
tistical Manual of Mental Disorders (2013) in drugih virov smo iskali ključne pojme, ki smo jih nato združili v kategorije, $v$ katere smo razvrstili postavke uporabljenih lestvic. Oblikovali smo osem kategorij in sicer:

1. zanimanje za ljudi in okolico, razumevanje okolja, socialnih informacij in odzivanje nanje;

2. vzpostavljanje socialnih interakcij in izražanje v socialnem kontekstu (ekspresivna komunikacija);

3. nebesedna komunikacija (geste, mimika, očesni stik) ter zmožnost vzpostavitve skupne vezane pozornosti;

4. razumevanje čustev in izkazovanje naklonjenosti ter zmožnost empatije;

5. stereotipno vedenje in neobičajni omejeni interesi;

6. procesiranje senzornih dražljajev in zmožnost prilagajanja spremembam;

7. mišljenje, igra, imitacija in domišljija;

8. ostalo (npr. spalne in prehranjevalne navade, gibalni razvoj in motorične spretnosti).

\section{Rezultati in razprava}

V zadnjih dveh desetletjih je bilo $z$ namenom izboljšanja zgodnje detekcije razvitih več presejalnih pripomočkov za odkrivanje avtizma; razviti so bili z namenom preučevanja znakov avtizma $v$ najzgodnejšem obdobju ter iskanja indikatorjev, na podlagi katerih bi lahko že pred 2. letom starosti ustrezno ločili avtizem od motnje v duševnem razvoju. Nekatere izpolnjujejo starši, nekatere zdravstveno osebje, določeni so namenjeni tudi pedagoškemu osebju (Mikuž 2015), klinična ocena pa se oblikuje na podlagi vseh obstoječih opazovalnih poročil in ocen, pri čemer prevladujejo ocene zdravnikov in staršev (Dereu idr. 2012). Zdravniki klinično oceno podajo na podlagi kratkega opazovanja otroka in pogovora s starši, kar je lahko vzrok za nizko občutljivost teh instrumentov pri uporabi v splošni populaciji (Baird idr. $2000 \mathrm{v}$ Dereu idr. 2012, 781; Groen idr. 2007 v Dereu idr. 2012, 781), saj ne temelji na opazovanju otroka $v$ avtentičnem okolju.

$\checkmark$ nadaljevanju podrobneje analiziramo pripomočke, ki smo jih vključili v raziskavo. Ključen kriterij za izbor je bila možnost aplikacije pripomočka $v$ vzgojiteljevo vsakodnevno delo, tako da bi ga lahko uporabil z namenom opazovanja in beleženja funkcioniranja otrok pri izvajanju kurikula vrtca. Predstavljamo jih po naraščajočem vrstnem redu glede na starostno obdobje, za katero so pripravljeni. 


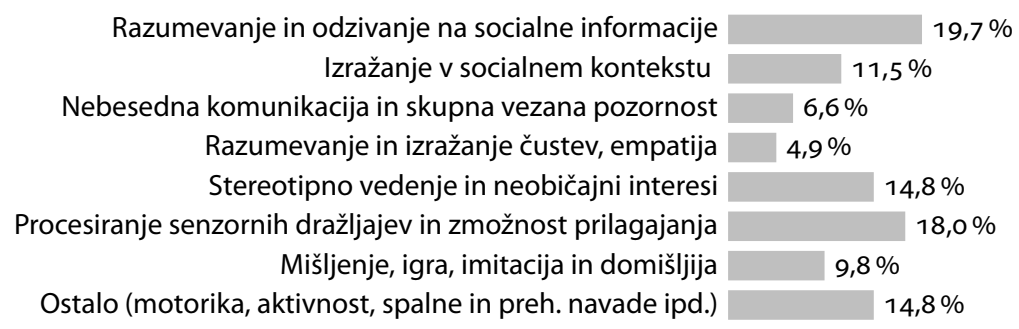

Slika 1 Porazdelitev vprašanj lestvice FYI po pojmovnih kategorijah

\section{Pregled spretnosti pri 1 letu (First Year Inventory - FYI)}

Pripomoček First Year Inventory (Baranek idr. 2003) je bil oblikovan za ocenjevanje vedenja 12-mesečnih dojenčkov, pri katerih obstaja sum na avtizem. Sestavljen je iz 63 vprašanj, od katerih se pri 46 izbira med odgovori »nikoli«, »redko«, »včasih« in "pogosto«, 14 vprašanj pa ima vnaprej podane možne odgovore. Pri trditvah od 1 do 46 odgovora »včasih« ali »pogosto« kažeta na tipično vedenje, »nikoli« ali »redko« pa na netipično. Pri vprašanjih od 47 do 60 se kot tipično vedenje smatrajo odgovori pod (a) ali (b), kot netipično pa pod c) ali d). Pri enem vprašanju starši v seznamu soglasnikov (p, b, t, d, k, g, m, $n, w, y, h, s)$ označijo tiste, ki jih otrok že tvori. Vprašanji odprtega tipa se nanašata na izpostavljanje področij otrokovega razvoja, ki starše najbolj skrbijo, in na opis neobičajnih telesnih ter zdravstvenih značilnosti otroka (Reznick idr. 2007; Watson idr. 2007).

V analizo smo vključili 61 od 63 vprašanj, izločili smo vprašanji odprtega tipa. Pripomoček vključuje vprašanja iz vseh osmih kategorij, ki smo jih oblikovali.

Kot je razvidno iz slike 1, v pripomočku FYI prevladujejo vprašanja iz 1. kategorije, ki poizvedujejo o otrokovem odzivanju v različnih (socialnih) situacijah, ter vprašanja iz 6. kategorije. Slednja preverjajo otrokovo hiper- oz. hiposenzibilnost na določene senzorne dražljaje (zvok, dotik ipd.) in odzivanje ob spremembah. Najmanj zastopana kategorija v pripomočku je 4., ki se nanaša na razumevanje in izražanje čustev ter na empatijo.

Pripomoček FYI pokriva vsa področja, ki so pomemba pri opazovanju vedenja otrok s sumom na avtizem, poudarek pa je na zgoraj omenjenih dveh področjih. Vprašalnik je namenjen pregledu spretnosti enoletnih otrok in zato ni primeren za opazovanje vedenja oz. spretnosti starejših (2- in 3-letnih) otrok. Zaradi števila vprašanj (63) je morda nekoliko preobsežen za uporabo v vrtcu, sicer pa bi bil lahko dober pokazatelj odstopanj v vedenju otrok $s$ sumom na avtizem. 


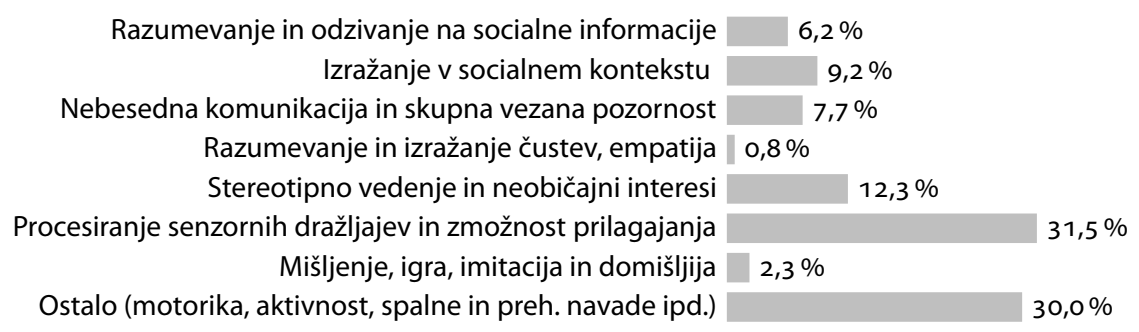

Slika 2 Porazdelitev vprašanj lestvice $S A B$ o-2 po pojmovnih kategorijah

\section{Znaki avtizma pred 2. letom starosti (Symptoms of Autism Before Age 2 Years - SAB 0-2)}

Gillbergov nevropsihiatrični center, ki deluje v okviru Univerze v Goethenburgu, na svoji spletni strani navaja, da je bil pripomoček Symptoms of Autism Before age 2 years - SAB o-2 (Dahlgren in Gillberg 1989) razvit z namenom preučevanja znakov avtizma $v$ najzgodnejšem obdobju ter iskanja indikatorjev, na podlagi katerih lahko že pred dopolnjenim 2. letom razločimo avtizem od motnje v duševnem razvoju. Pripomoček izpolnijo starši oz. skrbniki.

P. Dewrang in A. Dahlgren Sandberg (2009) navajata, da pripomoček vsebuje vprašanja z naslednjih področij: kontakt in socialna aktivnost, odzivanje na senzorne zaznave, komunikacija in jezik/govor, hranjenje in spanje, igra in fiksacija/rituali, gibanje in motorične spretnosti ter razvoj in vedenje.

Lestvica, dostopna na spletni strani Gillbergovega nevropsihiatričnega centra, vsebuje 130 trditev. Pri vsaki je potrebno označiti, ali za otroka opisano vedenje velja ali ne (drži/ne drži).

Kot je razvidno iz slike 2, je največ trditev pripomočka SAB o-2 uvrščenih v 6. kategorijo, ki vključuje posebnosti v procesiranju senzornih dražljajev, te pa predstavljajo enega izmed pomembnih indikatorjev prisotnosti avtizma pri malčkih. Precejšnje število trditev je uvrščenih v 8. kategorijo, ki vključuje predvsem trditve $s$ področja motorike, aktivnosti, spalne rutine, prehranjevanja ipd. Najmanj trditev je uvrščenih $v$ 4. kategorijo, zelo majhen poudarek pa je tudi na področju mišljenja in igralnih sposobnosti, kar predstavljajo trditve iz 7. kategorije. Ravno posebnosti na področju mišljenja in igre pa so po mnenju mnogih strokovnjakov pomemben pokazatelj avtizma.

Pomembno je poudariti, da bi se veliko postavk na lestvici lahko uvrstilo v različne kategorije, odločitev je pogosto mogoča šele ob poznavanju značilnosti konkretnega otroka in vzrokov, ki sprožijo določeno vedenje. Deleži pojmovnih kategorij so v pripomočku precej neenakomerno razporejeni, 


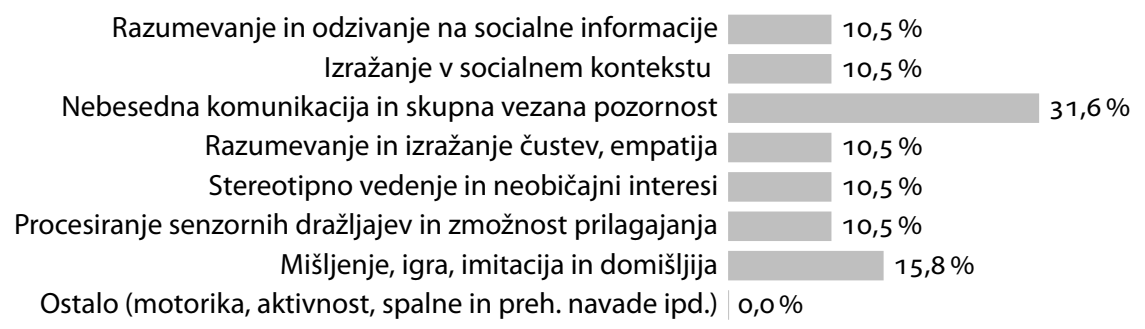

Slika 3 Porazdelitev vprašanj lestvice ESAT po pojmovnih kategorijah

obenem je pripomoček zelo obsežen (130 postavk) in z vidika časovne ekonomičnosti morda ni najprimernejši za pomoč vzgojiteljem pri opazovanju in beleženju funkcioniranja otrok.

\section{Zgodnja detekcija znakov avtizma (Early Screening of Autistic Traits - ESAT)}

Vprašalnik Early Screening of Autistic Traits - ESAT (Swinkels idr. 2006) je pripomoček za odkrivanje zgodnjih znakov avtizma pri malčkih do 36. meseca. Uporablja se ga lahko tudi pri starejših otrocih, kadar je prisoten razvojni zaostanek. Vprašanja preiskujejo odstopanja $v$ razvoju recipročne socialne interakcije, odstopanja $v$ razvoju komunikacije in omejene ter stereotipne vzorce vedenja. Testiranje lahko izvajajo dobro usposobljeni zdravstveni delavci (zdravniki, medicinske sestre), logopedi, fizioterapevti, psihologi in pedagogi. O utemeljenem sumu na avtizem (visoko tveganje) lahko govorimo, kadar so od 14 trditev vsaj 3 ocenjene negativno (Buitelaar idr. b. I.).

Pripomoček zajema 14 oz. 19 vprašanj zaprtega tipa (da/ne), na katera odgovarjajo starši ali skrbniki otroka (Swinkels idr. 2006). Vprašanja preiskujejo prisotnost ali odsotnost določenih vedenj na naslednjih 12 področjih (Buitelaar idr. b. l.; Dietz idr. 2006): zanimanje za različne igrače, raznolikost igre, izražanje čustev, reakcije na senzorne dražljaje, obrazna mimika, očesni stik, iskanje pozornosti, stereotipna gibanja, prinašanje in kazanje predmetov, zanimanje za ljudi, želja po objemih, socialni (na)smeh, sodelovanje v socialnih igrah in odziv na ogovarjanje.

Analizirali smo izvirno obliko vprašalnika (19 vprašanj). Kot je razvidno iz slike 3, močno izstopajo vprašanja iz 3 . kategorije, ki se nanašajo na nebesedno komunikacijo, uporabo gest ipd. Precej manj vprašanj je uvrščenih $v 7$. kategorijo, ki opisuje otrokove posebnosti v igri in mišljenju. Ostale kategorije vsebujejo še manjše število vprašanj in so glede na deleže precej enakomerno porazdeljene, $v 8$. kategorijo pa ni uvrščeno nobeno vprašanje. 


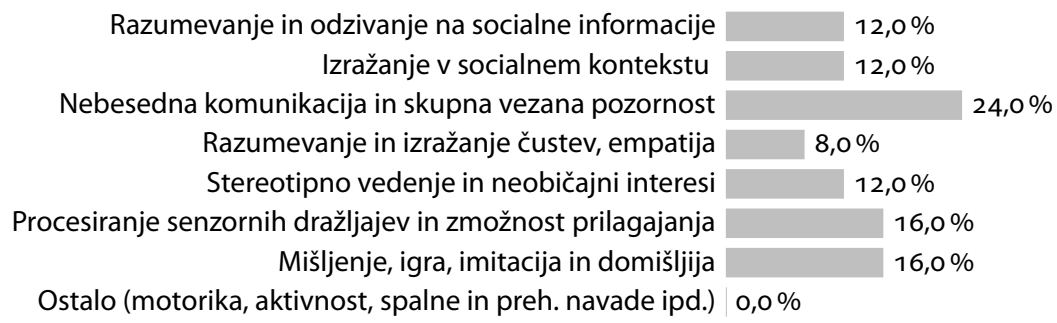

Slika 4 Porazdelitev vprašanj lestvice CESDD po pojmovnih kategorijah

Vprašalnik je torej precej raznolik in pokriva vsa pomembna področja, na katerih se kažejo odstopanja pri mlajših otrocih z avtizmom. Pripomoček bi bil lahko koristen in uporaben za vzgojitelje v vrtcih pri opazovanju in beleženju funkcioniranja otrok oz. prisotnosti določenih vedenj, saj so vprašanja zasnovana na način, ki omogoča opazovanje vedenja v vsakdanjem življenju, tudi v vrtcu, hkrati pa ni preobsežen. Opazovanje bi bilo možno izvajati tako v okviru (vodenih) dejavnosti in igre kot tudi v okviru dnevne rutine.

\section{Kontrolni seznam zgodnjih znakov razvojnih motenj (Checklist for Early} Signs of Developmental Disorders - CESDD)

Pripomoček CESDD (Dereu idr. 2010) je namenjen strokovnim delavcem v vrtcih pri identifikaciji otrok, starih od 3 do 36 mesecev, ki kažejo znake avtizma in potrebujejo nadaljnjo obravnavo. Instrument je sestavljen iz 25 postavk trditev dihotomnega tipa. Za otroke do 12. meseca se pri ocenjevanju upošteva le prvih 12 postavk, za otroke med 12. in 24. mesecem prvih 23, za starejše od 24 mesecev pa se upošteva vseh 25 postavk. Če sta pozitivni vsaj dve postavki, pri otroku obstaja sum na avtizem (Dereu idr. 2012). S. Dereu idr. (2010) so veljavnost pripomočka preverjali na vzorcu 6.808 otrok, starih od 3 do 39 mesecev, ki so bili vključeni v vrtce v Flandriji v Belgiji. Otroke so ocenjevali strokovni delavci vrtca, večinoma diplomirane medicinske sestre in varuhi (child care workers), s pripomočkom pa so uspešno identificirali 41 otrok $z$ avtizmom. Na podlagi rezultatov študije avtorji poudarjajo, da vključevanje strokovnih delavcev vrtca ter uporaba presejalnega pripomočka pozitivno pripomore k identifikaciji otrok z avtizmom v zgodnjem obdobju.

Slika 4 prikazuje rezultate analize lestvice, ki kažejo, da tudi tu največji delež trditev sodi $v 3$. kategorijo, ki se nanaša na posebnosti $v$ otrokovi nebesedni komunikaciji. 4. pojmovna kategorija, ki se nanaša na razumevanje in izražanje čustev ter empatijo, vsebuje najmanj trditev, sicer pa med deleži 
trditev $v$ ostalih kategorijah ni večjih odstopanj oz. razlik. V 8. kategorijo ni uvrščena nobena trditev.

Ker pripomoček zajema vsa področja, na katerih se pri otrocih s sumom na avtizem lahko kažejo odstopanja, menimo, da bi bil primeren za uporabo v vrtcih in detekcijo zgodnjih znakov avtizma pri otrocih v prvem starostnem obdobju.

\section{Vprašalnik za starše dojenčkov in malčkov (Infant Toddler Checklist - ITC)}

Vprašalnik Infant Toddler Checklist - ITC je eden izmed ocenjevalnih obrazcev pripomočka Communication and Symbolic Behavior Scales - Developmental Profile - CSBS DP (Lestvice komunikacije in simbolnega vedenja - razvojni profil) (Wetherby in Prizant 2002), ki je namenjen zgodnji identifikaciji otrok s tveganji za razvoj primanjkljajev v komunikaciji, pa tudi spremljanju sprememb v komunikaciji, izražanju in simbolni igri otroka (Wetherby in Prizant 2002 v Mikuž 2015). Vprašalnik je namenjen ocenjevanju sedmih napovednikov razvoja jezika: izražanja čustev in očesni stik, komunikacije, uporabe gest, uporabe glasov, uporabe besed, razumevanja govora in ustrezne uporabe predmetov (igrač) oziroma igre (Wetherby in Prizant 2001). Namenjen je ocenjevanju otrok med 6. in 24. mesecem, in sicer v okviru zdravniških (sistematskih) pregledov, lahko pa tudi v okviru dnevnega varstva (vrtca) ali drugih institucij, kamor so vključeni dojenček oz. malček ter njegovi starši. Obsega 24 vprašanj, na katera odgovarjajo starši ali oseba, ki dnevno skrbi za otroka (Wetherby in Prizant 2001). Izkazal se je kot učinkovit pri detekciji avtizma pri malčkih še pred nastopom kliničnih znakov (Wetherby idr. 2008).

Leta 2008 so A. M. Wetherby in sodelavci objavili rezultate obsežne raziskave, $v$ katero so vključili 5.385 otrok med 6. in 24. mesecem. S pripomočkom ITC (Infant/Toddler Checklist) so identificirali 56 (93\%) od 60 otrok, pri katerih je bil kasneje diagnosticiran avtizem. $\mathrm{S}$ študijo so dokazali veljavnost pripomočka za ugotavljanje zaostankov v komunikaciji, vključno $z$ avtističnimi motnjami, pri otrocih med 9. in 24 mesecem, ne pa tudi pri mlajših. Pomembno je opozoriti, da pozitiven rezultat pri vprašalniku ITC ne pomeni nujno, da gre pri otroku za avtizem; lahko namreč kaže tudi na druge zaostanke na področju komunikacije (Wetherby idr. 2008).

Glede na pojmovne kategorije, ki smo jih oblikovali, so vprašanja izrazito neenakomerno porazdeljena. Kot je razvidno $s$ slike $5, v$ pripomočku ITC močno prevladujejo vprašanja iz 2. kategorije, ki je najobsežnejša, in iz 3. kategorije. Vprašanja v omenjenih kategorijah se nanašajo na iskanje pozornosti ali pomoči odrasle osebe, uporabo soglasnikov ter (smiselnih) glasov in besed, uporabo preprostih gest, obrazne mimike, vzpostavljanju očesnega 


\begin{tabular}{|c|c|c|}
\hline \multirow{2}{*}{$\begin{array}{r}\text { Razumevanje in odzivanje na socialne informacije } \\
\text { Izražanje v socialnem kontekstu }\end{array}$} & $8,3 \%$ & \multirow[b]{2}{*}{$37,5 \%$} \\
\hline & & \\
\hline Nebesedna komunikacija in skupna vezana pozornost & & $33,3 \%$ \\
\hline Razumevanje in izražanje čustev, empatija & $4,2 \%$ & \\
\hline Stereotipno vedenje in neobičajni interesi & $0,0 \%$ & \\
\hline Procesiranje senzornih dražljajev in zmožnost prilagajanja & $0,0 \%$ & \\
\hline Mišljenje, igra, imitacija in domišljija & $8,3 \%$ & \\
\hline Ostalo (motorika, aktivnost, spalne in preh. navade ipd.) & $8,3 \%$ & \\
\hline
\end{tabular}

Slika 5 Porazdelitev vprašanj lestvice ITC po pojmovnih kategorijah

stika ipd. Najmanj vprašanj je uvrščenih v 4 . kategorijo, lestvica pa ne vključuje področij stereotipnega vedenja (5. kategorija) in procesiranja senzornih dražljajev (6. kategorija).

Rezultati so pričakovani, saj vprašalnik v osnovi ni namenjen prepoznavanju oz. opazovanju zgodnjih znakov avtizma, ampak predvsem ocenjevanju posebnosti v komunikaciji in izražanju, ki se lahko povezujejo tudi z drugimi razvojnimi motnjami. Vprašalnik smo kljub temu vključili v raziskavo, saj se je, kot že navedeno, izkazal kot učinkovit pri detekciji avtizma pri dojenčkih in malčkih. Pripomoček bi bil torej za vzgojitelje v vrtcih koristen predvsem za opazovanje posebnosti v komunikaciji, vzpostavljanju socialnih interakcij, skupni vezani pozornosti, nebesedni komunikaciji in tudi igri, ostala področja pa bi bilo potrebno opazovati in beležiti z drugimi pripomočki.

\section{Revidirana modificirana ocenjevalna lestvica avtizma pri malčkih z razširjenim intervjujem - $\boldsymbol{M - C H A T - R / F}$}

Revidirana modificirana ocenjevalna lestvica avtizma pri malčkih z razširjenim intervjujem - M-CHAT-R/F (Robins idr. 2009) predstavlja učinkovito presejalno orodje za odkrivanje znakov avtizma pri malčkih v starosti od 16 do 30 mesecev. Sestavlja ga 20 vprašanj in strukturiran intervju, ki se ga opravi s starši v primeru pozitivnega rezultata na presejalni listi. Vprašalnik vključuje področja, kot so senzorne posebnosti, posebnosti na področju gibanja, socialne interakcije, zgodnje skupne vezane pozornosti/teorije uma ter zgodnjega jezika in komunikacije (Magàn-Maganto idr. 2017). Vprašalnik so leta 2016 v slovenščino prevedli Andreja Mikuž, David Gosar in Jana Kodrič. Pripomoček je prosto dostopen $v$ klinične, raziskovalne in pedagoške namene.

Starši izpolnijo ocenjevalno lestvico in v primeru pozitivnega rezultata se glede na trditve, ki so k temu prispevale, v razširjenem intervjuju izbere vprašanja ter s starši opravi intervju. Pripomočku je priložen list za točkovanje, na katerem so označeni pričakovani odgovori pri posameznem vprašanju. Če je 


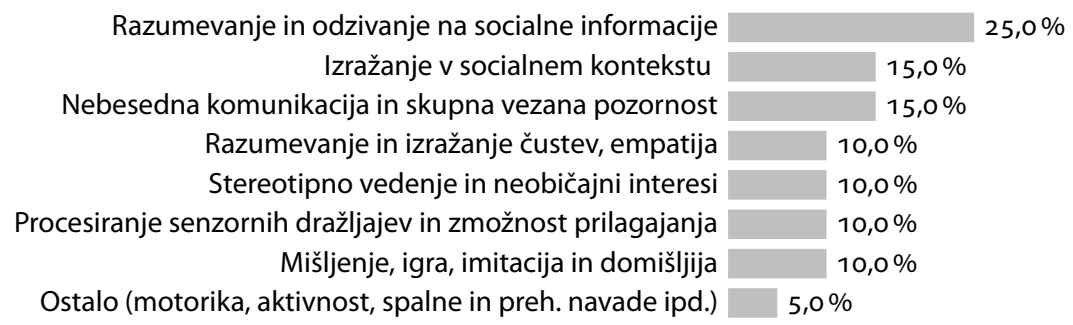

Slika 6 Porazdelitev vprašanj lestvice M-CHAT-R/F po pojmovnih kategorijah

odgovor skladen s pričakovanim, je vrednost odgovora o točk, če je neskladen, se ovrednoti $z 1$ točko. Na podlagi seštevka točk lahko določimo, ali gre pri otroku za nizko (o-2 točki), srednje (3-7 točk) ali visoko (8-20 točk) tveganje za avtizem.

$\checkmark$ primeru nizkega tveganja in v primeru, da otrok še ni dopolnil 24 mesecev, je ocenjevanje potrebno ponoviti. $V$ primeru srednjega tveganja se opravi razširjeni intervju ter ponovi točkovanje. Če je po opravljenem intervjuju število točk enako ali večje od 2, se otroka napoti v nadaljnjo obravnavo oz. diagnostiko. $V$ primeru visokega tveganja je otroka potrebno takoj napotiti na diagnostično oceno in oceno potrebe po zgodnji obravnavi (Mikuž, Gosar in Kodrič 2016).

$\checkmark$ analizo smo vključili 20 vprašanj s presejalne lestvice. Kot je razvidno $s$ slike 6 , smo največ vprašanj $z$ lestvice uvrstili $v 1$. kategorijo, kar vključuje predvsem otrokovo zanimanje za ljudi in okolico ter odzivanje na socialne pobude.

Razlika med omenjeno kategorijo in ostalimi je precej velika; z manjšim deležem sledita 2. in 3. kategorija, preostala vprašanja pa so dokaj enakomerno razporejena po pojmovnih kategorijah. Najmanj vprašanj je uvrščenih $v$ 8. kategorijo. Vprašalnik sicer zajema vsa pomembna področja, na katerih se pri mlajših otrocih $z$ avtizmom kažejo odstopanja, poudarjeno pa je predvsem otrokovo zanimanje za okolico, razumevanje ter odzivanje na socialne pobude. Lestvica bi vzgojiteljem v vrtcih torej lahko služila predvsem pri prepoznavanju posebnosti v komunikaciji in socialni interakciji, kar je možno opazovati tako v času izvajanja vodenih dejavnosti kot tudi v okviru dnevne rutine in proste igre.

\section{Sklepne ugotovitve}

Glede na raziskovalna vprašanja, ki smo si jih zastavili, ugotavljamo, da zaenkrat ne obstaja veliko pripomočkov, namenjenih zgodnji detekciji avtizma, 
ki bi bili v osnovi namenjeni vzgojiteljem $v$ vrtcih. $V$ prispevku smo analizirali šest znanstveno preverjenih pripomočkov, od katerih je bil le eden, CESDD, zasnovan za strokovne delavce vrtca. Ostali so v prvi vrsti namenjeni staršem, lahko pa so zelo dragoceni in uporabni tudi za vzgojitelje, ki otroka spremljajo v vsakodnevnih okoliččinah in lahko v okviru svojega pedagoškega dela otrokovo funkcioniranje neposredno opazujejo ter beležijo. $V$ povezavi s prepoznavanjem zgodnjih znakov avtizma so pripomočki usmerjeni v opazovanje socialne interakcije, jezika in komunikacije, uporabe gest, vzpostavljanja skupne vezane pozornosti, izražanja čustev, igre in imitacije, uporabe predmetov, procesiranja senzornih dražljajev, prisotnosti stereotipnega vedenja in neobičajnih, omejenih interesov ter drugih posebnosti.

V raziskavi smo ugotovili, da vsi pripomočki, ki smo jih analizirali - z izjemo vprašalnika za starše dojenčkov in malčkov (Infant Toddler Checklist - ITC) vključujejo vprašanja z vseh področij, ki so pomemba pri opazovanju otrok s sumom na avtizem. Pri vseh pripomočkih izstopa (vsaj eno) področje, na katero se nanaša večji delež vprašanj ali trditev, kar je pri njihovi uporabi z namenom detekcije zgodnjih znakov avtizma potrebno upoštevati.

V pripomočku M-CHAT-R/F prevladujejo vprašanja o otrokovem razumevanju okolja in odzivanju v socialnih situacijah, prav tako tudi v pripomočku FYl, ki vključuje tudi mnogo vprašanj o procesiranju senzornih dražljajev. $\mathrm{Na}$ lestvici SAB o-2 je prav tako poudarjeno področje procesiranja senzornih dražljajev, pripomoček pa hkrati vključuje precej trditev o motoriki, aktivnosti, spalni rutini in prehranjevanju otroka. V pripomočkih ESAT in CESDD prevladujejo vprašanja/trditve s področja nebesedne komunikacije ter skupne vezane pozornosti, pri obeh pripomočkih pa med deleži vprašanj/trditev v preostalih kategorijah ni velikih odstopanj oz. razlik. Vprašalnik ITC je izrazito usmerjen v opazovanje otrokovega besednega in nebesednega izražanja ter vzpostavljanja socialnih interakcij, ne vključuje pa vprašanj o posebnostih v procesiranju senzornih dražljajev in stereotipnem vedenju, saj v osnovi ni namenjen prepoznavanju znakov avtizma, ampak posebnosti v komunikaciji.

Z zgodnjim odkrivanjem razvojnih posebnosti, tudi avtizma, omogočimo, da strokovni delavci v vrtcu ustrezno razumejo otrokove posebnosti v vedenju in razvoju in se nanje ustrezneje odzivajo. S pravilnim in intenzivnim pristopom je namreč mogoče otrokove motnje in razvojne težave v precejšnji meri ublažiti, predvsem pa ne nacepiti nanje sekundarnih (npr. čustveno vedenjskih ali psihosomatskih) težav, ki se začenjajo pojavljati zaradi neprepoznavanja in neupoštevanja otrokovih primarnih razvojnih potreb ter posebnosti. Prav tako smo prepričani, da vzgojiteljeva ozaveščenost o posebnih potrebah otroka pozitivno vpliva na odnos in komunikacijo s starši otroka, kar bi 
se moralo odražati v partnerskem odnosu procesa načrtovanja ter udejanjanja individualiziranega programa vzgoje in izobraževanja otroka tako v vrtcu kot tudi na nadaljnjih ravneh izobraževanja. Menimo, da bi morala vzgojiteljeva aktivna vključenost $v$ detekcijo posebnih potreb (npr. prepoznavanje motnje avtizma) vplivati na njegovo večjo naklonjenost in pozitivno naravnanost do otrokovih posebnosti.

\section{Literatura}

Andersson, G. W., C. Gillberg in C. Miniscalco. 2013. »Pre-School Children with Suspected Autism Spectrum Disorders: Do Girls and Boys Have the Same Profiles?« Research in Developmental Disabilities 34 (1): 413-422.

Baio J., L. Wiggins, D. L. Christensen, M. J. Maenner, J. Daniels, Z. Warren, M. Kurzius-Spencer et al. 2018. »Prevalence of Autism Spectrum Disorder Among Children Aged 8 Years - Autism and Developmental Disabilities Monitoring Network, 11 Sites, United States, 2014." MMWR Surveillance Summaries 67 (6): 1-23.

Baird, G., T. Charman, S. Baron-Cohen, A. Cox, J. Swettenham, S. Wheelwright in A. Drew. 2000. »A Screening Instrument for Autism at 18 Months of Age: A 6-Year Follow-up Study." Journal of the American Academy of Child and Adolescent Psychiatry 39:694-702.

Baranek, G., L. Watson, E. Crais in S. Reznick. 2003. First Year Inventory (FYI). Chapel Hill, NC: University of North Carolina.

Buitelaar, J., E. van Daalen, C. Dietz, H. Van Engeland, R. J. Van Der Gaag, D. Van Steijn in S. Swinkels. B. I. »ESAT - Screening for Autism Spectrum in Infants: Practical Manual for Early detection, Screening and Assessment." https://webgate.ec.europa.eu/chafea_pdb/assets/files/pdb/2006127/ 2006127_10_esat_english.pdf.

Charman, T., S. Baron-Cohen, J. Swettenham, G. Baird, A. Cox in A. Drew. 2000. "Testing Joint Attention, Imitation, and Play as Infancy Precursors to Language and Theory of Mind. « Cognitive Development 15 (4): 481-498.

Christensen, L., T. Hutman, A. Rozga, G. S. Young, S. Ozonoff, S. J., Rogers, B. Baker in M. Sigman. 2010. »Play and Developmental Outcomes in Infant Siblings of Children with Autism." Journal of Autism and Developmental Disorders 40 (8): 946-957.

Cotič Pajntar, J., K. Geršak, M. Praprotnik, T. Prusnik in M. Žnidarščič, M. 2017. Dopolnitev Navodil h Kurikulumu za vrtce v programih s prilagojenim izvajanjem in dodatno strokovno pomočjo za otroke s posebnimi potrebami: za otroke z avtističnimi motnjami. Ljubljana: Zavod Republike Slovenije za šolstvo.

Čas, M., L. Kastelic in M. Šter. 2003. »Navodila h Kurikulu za vrtce v programih s prilagojenim izvajanjem in dodatno strokovno pomočjo za otroke s posebnimi potrebami.«http://www.mizs.gov.si/fileadmin/mizs.gov.si/ pageuploads/podrocje/posebne_potrebe/programi/Navodila_vrtci.pdf 
Dahlgren, S. O., in C. Gillberg. 1989. "Symptoms in the First Two Years of Life: A Preliminary Population Study of Infantile Autism. European Archives of Psychiatry and Neurological Sciences 238:169-174.

Dawson, G., K. Toth, R. Abbott, J. Osterling, J. Munson, A. Estes in J. Liaw. 2004. »Early Social Attention Impairments in Autism. "Developmental Psychology 40 (2): 271-283.

Dereu, M., R. Raymaekers, P. Warreyn, I. Schietecatte, M. Meirsschaut in H. Roeyers. 2012. "Can Child Care Workers Contribute to the Early Detection of Autism Spectrum Disorders? A Comparison Between Screening Instruments with Child Care Workers Versus Parents as Informants." Journal of Autism and Developmental Disorders 42:781-796.

Dereu, M., P. Warreyn, R. Raymaekers, M. Meirsschaut, G. Patty, I. Schietecatte in $\mathrm{H}$. Roeyers 2010. "Screening for Autism Spectrum Disorders in Flemish Day-Care Centres with the Checklist for Early Signs of Developmental Disorders." Journal of Autism and Developmental Disorders 40:1247-1258.

Dewrang, P., in A. Dahlgren Sandberg. 2009. »Parental Retrospective Assessment of Development and Behavior in Asperger Syndrome During the First 2 Years of Life." Research in Autism Spectrum Disorders 4:461-473.

Diagnostic and Statistical Manual of Mental Disorders (DSM-5). 2013. Washington, DC: American Psychiatric Association.

Dietz., C., S. H. Swinkels, E. van Daalen, H. van Engeland in J. K. Buitelaar. 2006. "Screening for Autistic Spectrum in Children Aged 14 to 15 Months. 2: Population Screening with the Early Screening of Autistic Traits Questionnaire (ESAT); Design and General Findings." Journal of Autism and Develompental Disorders 36:723-732.

Dobnik Renko, B. 2008. »Avtizem kot razvojna motnja.« https://www.kclj.si/ dokumenti/avtizem.pdf

_. 2016. »Psihološki ocenjevalni postopek za zgodnje odkrivanje avtizma pri malčkih."Anthropos 48 (3-4): 109-131.

Eikeseth, S. 2009. »Outcome of Comprehensive Psycho-Educational Interventions for Young Children with Autism. « Research in Developmental Disabilities 30 (1): 158-178.

Frankenburg, W. K., J. Dodds, P. Archer, H. Shapiro in B. Bresnick. 1992. »The Denver 2: A Major Revision and Restandardization of the Denver Developmental Screening Test.« Pediatrics 89 (1): 91-97.

Gillberg, C. 2010. »The ESSENCE in Child Psychiatry: Early Symptomatic Syndromes Eliciting Neurodevelopmental Clinical Examinations. «Research in Developmental Disabilities 31 (6): 1543-1551.

Gričar, N., in A. Kovačič. 2017. »Pasti sodobnega stila življenja za razvoj senzorne integracija.«http://scpomurje.splet.arnes.si/files/2017/o8/SI _predavanjePomurje.pdf

Griffin, E., in D. Pollak. 2009. »Student Experiences of Neurodiversity in Higher Education: Insights from the BRAINHE Project.« Dyslexia 15:23-41. 
Groen, W. B., S. H. Swinkels, R. J. van der Gaag in J. K. Buitelaar. 2007. »Finding Effective Screening Instruments for Autism Using Bayes Theorem. A Archives of Pediatrics and Adolescent Medicine 161:415-416.

Johnson, C. P., S. M. Myers in Council on Children with Disabilities. 2007. »Identification and Evaluation of Children with Autism Spectrum Disorders.«Pediatrics 120 (5): 1183-1215.

Jurišić, B. D. 2011. "Specialnopedagoška obravnava otrok z avtizmom.« V Izbrana poglavja iz pediatrije 23, ur. C. Kržišnik in T. Battelino, 340-356. Ljubljana: Medicinska fakulteta.

Lord, C., S. Risi, L. Lambrecht, E. H. Cook ml., B. L. Leventhal, P. C. DiLavore, A. Pickles in M. Rutter. 2001. »The Autism Diagnostic Observation ScheduleGenericAssociated with the Spectrum of Autism . Journal of Autism and Develompental Disorders 30 (3): 205-223.

Macedoni-Lukšič, M. 2006. »Spekter avtistične motnje - pregled področja.« V Izbrana poglavja iz pediatrije 18, ur. C. Kržišnik in T. Battelino, 115-126. Ljubljana: Medicinska fakulteta.

—. 2011. "Stopenjska obravnava otrok s spektroavtističnimi motnjami.« V Izbrana poglavja iz pediatrije 23, ur. C. Kržišnik in T. Battelino, 311-317. Ljubljana: Medicinska fakulteta.

Magàn-Maganto, M., A. Bejarano-Martìn, C. Fernàndez-Alvarez, A. Narzisi, P. Garcìa-Primo, R. Kawa, M. Posada in R. Canal-Bedia. 2017. »Early Detection and Intervention of ASD: A European Overview. « Brain Sciences 7 (12): 159.

Mikuž, A. 2015. »Možnosti zgodnjega odkrivanja dojenčkov in malčkov s tveganjem razvojnih motenj $v$ slovenskem zdravstvenem sistemu ter implikacije za zgodnjo obravnavo.« Anthropos 47 (3-4): 99-121.

Mikuž, A., D. Gosar in J. Kodrič. 2016. »Revidirana modificirana ocenjevalna lestvica avtizma pri malčkih z razširjenim intervjujem. «https://mchatscreen .com/wp-content/uploads/2016/o7/M-CHAT-R_F_Slovene.pdf

Myers, S. M., in C. P. Johnson. 2007. »Management of Children with Autism Spectrum Disorders."Pediatrics 120 (5): 1162-1182.

Ortega, F. 2009. »The Cerebral Subject and the Challenge of Neurodiversity.« Biosciences 4:425-445.

Posada de la Paz, M. 2018. »Autism Spectrum Disorders in the European Union (ASDEU): Executive Summary.«http://asdeu.eu/wp-content/uploads/2016 /12/ASDEUExecSummary27September2018.pd

Reznick, J. S., G. T. Baranek, S. Reavis, L. R. Watson in E. R. Crais. 2007. »A ParentReport Instrument for Identifying One-Year-Olds at Risk for an Eventual Diagnosis of Autism: The First Year Inventory." The Journal of Autism and Developmental Disorders 37 (9): 1691-1710.

Robins, D. L., D. Fein in M. L. Barton. 2009. »Modified Checklist for Autism in Toddlers, Revised with Follow-up (M-CHAT-R/F).« https://mchatscreen.com/ wp-content/uploads/2015/og/M-CHAT-R_F_Rev_Aug2018.pdf 
Robins, D. L., D. Fein, M. L. Barton in J. A. Green. 2001. »The Modified Checklist for Autism in Toddlers." The Journal of Autism and Developmental Disorders 31:131-144.

Rogers, S. J., in L. A. Vismara. 2008. „Evidence-Based Comprehensive Treatments for Early Autism. « Journal of Clinical Child and Adolescent Psychology 37 (1): 8-38.

Rutter, M., A. Le Couteur in C. Lord. 2003. ADI-R: Autism Diagnostic Interview Revised. Los Angeles: Western Psychological Services.

Singer, J. 1999. »'Why Can't You Be Normal for Once in Your Life?' From a 'Problem with No Name' to 425 the Emergence of a New Category of Difference.«V Disability Discourse, ur. M. Corker in S. French, 59-67. Buckingham: Open University Press.

Spitzer, S., in S. Smith Roley. 2001. »Sensory Integration Revisited: A Philosophy of Practice. «V Understanding the Nature of Sensory Integration with Diverse Populations, ur. E. I. Blanche in R. Schaaf, 3-27. San Antonio, CA: Therapy Skill Builders.

Sterle, M., M. Markovič, A. Kovačič in N. Gričar. 2018. »Terapija senzorne integracije pri otrocih z motnjo avtističnega spektra.« V Zbornik prispevkov konference Avtizem v Sloveniji - kje smo leta 2018? Ur. A. Werdonig, 131-135. Maribor: Center za sluh in govor Maribor.

Stropnik, S., in J. Kodrič. 2012. »Prilagoditvene spretnosti.« Psihološka obzorja 2(21): 41-50.

Swinkels, S. H., C. Dietz, E. van Daalen, I. H. Kerkhof, H. van Engeland in J. K. Buitelaar. 2006. "Screening for Autistic Spectrum in Children Aged 14 to 15 Months. 1: The Development of the Early Screening of Autistic Traits Questionnaire (ESAT)." Journal of Autism and Develompental Disorders 36:723732.

Vovk-Ornik, N., ur. 2015. Kriteriji za opredelitev vrste in stopnje primanjkljajev, ovir oz. motenj otrok s posebnimi potrebami. Ljubljana: Zavod Republike Slovenije za šolstvo.

Watson. L. R., G. T. Baranek, E. R. Crais, J. S. Reznick, J. Dykstra in T. Perryman. 2007. »The First Year Inventory: Retrospective Parent Responses to a Questionnaire Designed to Identify One-Year-Olds at Risk for Autism.« Journal of Autism and Developmental Disorders 31:131-144.

Werdonig, A., T. Vizjak Kure, M. Švaglič, M. Petrič Puklavec, L. Kornhauzer Robič, A. Turk-Haskič, M. Štok, M. Marenče in B. Caf. 2009. "Smernice za delo v oddelkih za predšolske otroke z motnjami avtističnega spektra - MAS." http://www.mizs.gov.si/fileadmin/mizs.gov.si/pageuploads/podrocje/ posebne_potrebe/programi/Smernice_predsolski_MAS.pdf

Wetherby A. M., S. Brosnan-Maddox, V. Peace in L. Newton. 2008. „Validation of the Infant-Toddler Checklist as a Broadband Screener for Autism Spectrum Disorders from 9 to 24 months of age.«Autism 12 (5): 487-511. 
Wetherby, A. M., in B. M. Prizant. 2001. Communication and Symbolic Behavior Scales Developmental Profile: Infant/Toddler Checklist. Baltimore, MD: Paul Brookes.

- 2002. Communication and Symbolic Behavior Scales:Developmental Profile Manual. Baltimore, MD: Paul Brookes.

Wieder, S. 2011. »ls Something Wrong with my Baby?« Zero to Three 31 (6).

Zakon o celostni zgodnji obravnavi predšolskih otrok s posebnimi potrebami (ZOPOPP). 2017. Uradni list Republike Slovenije, št. 17.

Zakon o usmerjanju otrok s posebnimi potrebami (ZUOPP-1). 2011. Uradni list Republike Slovenije, št. 58.

Zupančič, M. 2004. »Socialni razvoj dojenčka in malčka.«V Razvojna psihologija, ur. L. Marjanovič Umek in M. Zupančič, 255-277. Ljubljana: Znanstvenoraziskovalni inštitut Filozofske fakultete.

\section{Instruments for Preschool Teachers for Detecting Children with Autism in the First Age Group (1-3)}

Early detection and treatment of children with autism can alleviate the development of disorder and its associated problems. It significantly improves the quality of child's and his family's life and increases the effectiveness of further treatments. This is why the preschool teacher's familiarity with early signs that suggest autism in the earliest period and the equipment with observation instruments is important. Our aim was to review and analyze the scales for the observation and recording early signs of autism at the age of 1 to 3 years, which are useful for the preschool teacher as part of his/her pedagogical work in the child's authentic environment in kindergarten. We found that there are few instruments for the early detection of autism which are intended for preschool teacher's pedagogical observation. The teacher's information is rarely included in the anamnestic and diagnostic procedures, and is included only indirectly, which reduces the sensitivity of the screening tests. We believe that more active involvement of preschool teachers in the early detection of autism would contribute positively to increase awareness and willingness to adjust the preschool environment to the needs of children with autism.

Keywords: autism, early signs, instruments for early detection, first age group (1-3), preschool teachers 


\title{
Quality of Life of Families of Early Aged Children with Disabilities
}

\author{
Špela Golubović \\ University of Novi Sad \\ spela.golubovic@mf.uns.ac.rs \\ Jasna Maksimović \\ University of Kragujevac \\ jasnamaximovic@gmail.com \\ Jovana Uzelac \\ University of Novi Sad \\ jovanauzelac123@gmail.com

\section{Sandra Glamočak \\ University of Novi Sad \\ sandra97glamocak@gmail.com}

\begin{abstract}
Family is a primary social community that directs and encourages development of a child, shapes the child's personality, directs its participation in the environment whereas the functioning of a family has a significant impact on the quality of life of all its members. Starting from the point that raising a child with developmental disabilities is a serious challenge for parents that requires greater involvement and increased child care, the aim of this research was to examine to what extent the presence of disability in a child affects the quality of life of the family. As the predictor of family life quality, we highlighted the intensity of problems in the child's behaviour (physical, emotional, social and behaviour in the kindergarten). The survey was conducted on a sample of 81 parents of children in early age ( $44.4 \%$ of parents with children with disabilities and $55.6 \%$ with typical developed children. The parents' opinion on the intensity of the behavioural problems and impact of the chronic condition of the child on the functioning of their families was obtained by the PedsQL generic scale questionnaire - the family impact module. The research confirmed that the presence of disabilities and child behaviour problems certainly affect the functioning of the family and that the quality of life of these families differs considerably compared to the ones with typical developed children.
\end{abstract}

Keywords: family, quality of life of the family, parents of children with disabilities, a child with disabilities, typically developed children

\section{Introduction}

According to sociological system theory, family is most often defined as a dynamic, interdependent and target-oriented system, making an impact on 
the environment and receiving a reverse impact from it (Mugno et al. 2007). It represents primary social environment that shapes the child's personality and directs his/her participation in the environment, but also vice versa - the child inevitably affects everyday life and participation of other family members (McConnell, Savage, and Breitkreuz 2006). Establishing sense of security, development of speech, skills and abilities, attitudes, beliefs and values are just some of the influences family has over a child. At the same time, styles of life, authority and relationships among family members, the size of a family and many other factors are considered to be such great sources of difference that it is very difficult to find a common denominator for a community such is a family (Ristić-Stojković 2016; Hrnjica 2011). It represents an influential and important factor of social functioning because it refers to the primary small group in which emotional relationships are intense, interaction is longlasting and diverse, and the mutual dependence among members is high.

Despite the fact that every family is special for it forms an original system with its specific rules and modes of coexistence (Juhásová 2015, 3383), it is true for every family that all of its members are interconnected, and as a rule, what affects one of them, also reflects on the whole family system. The functioning of the family itself is reflected and has a positive or a negative impact on the quality of life of all its members (Smith-Bird and Turnbull 2005).

The quality of life can be seen and defined in many ways, though it is most often defined as an individual experience of satisfaction with all aspects of life, that is, the perception of one's own well-being and life satisfaction. This sociological dimension includes physical, social, economic and psychological well-being, as well as a sense of positive social involvement and the ability to realize one's own potentials (Araujo de Melo et al. 2012; Mugno et al. 2007; Park et al. 2003; Waters et al. 2005). The concept of quality of life includes numerous aspects of life at the present moment, as well as previous experiences of a person, so the quality of family life is a natural continuation of work on the individual quality of life (Poston et al. 2003). In order to ensure that the quality of family life is considered satisfactory, needs of a family need to be satisfied; family members should enjoy their life together and have the opportunity to deal with matters that are important to them (Park et al. 2003, 368). Health is certainly one of the factors of quality of life that plays a significant role, and any presence of illness or disability is a limiting factor in the fulfilment of the needs of an individual and his/her family members.

\section{Family and parenthood of children with disabilities}

Although every birth of a child extraordinarily mobilizes a family and has a significant impact on parents and other family members, the birth of a child 
with disabilities represents a serious new reality and has a strong stressful influence (Juhásová 2015; Hrnjica 2011). After a stressful situation and an initial shock that undoubtedly occurs upon knowledge of a diagnosis indicating that the child will have serious disorders in growth and development (Emerson 2003; Florian and Findler 2001; Hedderly, Baird and McConachie 2003; Osmančević-Katkić, Lang-Morović and Kovačić 2017; Rentinck et al. 2009) parents enter the phase of adaptation to the new situation that requires the reconstruction of both family and their personal identities. This adaptation implies solving the task of cognitive and emotional diagnosis procession, its implications on further development of a child and the future functioning of the family (Axelsson, Granlund, and Wilder 2013; Barnett et al. 2003). Research conducted in our country suggests relatively high percentage of parents who are unresolved towards diagnosis (Mihić et al. 2016). They did not fully understand and accepted the factual situation. A parent who has accepted a diagnosis with all its implications can be realistic in relation to the child's health and abilities. He/she can recognize the possibilities and limitations of the child, successfully align his parental role with the child's needs and be sensitive towards the needs of the child. If the parent has not resolved his/her dilemmas in relation to the child's diagnosis, he/she makes no progress over time, but focuses on the moment of learning and is emotionally overwhelmed, which leads to unrealistic expectations of the child and lower quality of care (Marvin and Pianta 1996 in Rajić and Mihić 2015, 139).

Whether and to what extent, the experience of the birth of a child with developmental disability will be traumatic, and the way the next phase in establishing relationship with the child will be resolved, depend on a number of factors. The most important factors affecting the acceptance of the newly emerging situation are the 'type and severity of developmental disorder, emotional characteristics of the child (calmness, irritability), emotional stability of family members, the quality of interpersonal relations within the family, motivation of the family to overcome difficulties, etc.' (Hrnjica 2011, 72). This points to the fact that being a parent of a child with developmental disabilities is significantly more demanding compared to the parenting of children of typical development since it is burdened with factors such are specific needs of the child, increased demands related to additional health care, as well as taking responsibility for making important decisions concerning the future of the child (Brown et al. 2003).

Both our and worldwide experiences and research suggest that the birth of a child with developmental disability often changes the current functioning and quality of life of all family members. The influence of developmental disturbance on various aspects of family life - household, recreation, social- 
ization, feelings, own identity, education and professional development, etc., are described (Price et al. 2000). Demands that arise due to such impact may require significant financial costs and complicate other aspects of life.

Apart from the initial request for reorganization and strengthening of the family relationships structure, the family is faced with numerous demands for increased childcare and a number of aggravating circumstances in relation to these requirements. Parents are constantly confronted with the needs of the child, which are often unclear and far different from the needs of children of typical development; therefore, they are not always sure how to satisfy them. The characteristics of developmental disorder, such as communication difficulties, significantly hampered motor development, lack of feedback from the child, reduced ability to interpret social signals, etc., often interfere with the child's signal behaviour and parents' response, leading to reduced sensitivity and a lesser chance of adequate responses (Van ljzdendoorn et al. 2007). Parents often invest all their resources in the treatment of the child, but ignore or insufficiently encourage the child's psychosocial development. Many of them, due to lack of information on who could help them, often feel completely helpless. Also, many families with children with serious disabilities and developmental disorders are impoverished for additional costs and endangered by limited employment opportunities (Juhásová 2015; McConnell, Savage, and Breitkreuz 2014).

All this is associated with an increased level of stress, mental health disorder, low self-esteem, difficulties in physical functioning, chronic fatigue and exhaustion of parents (Milićević 2015; Gardiner and larocci 2012). This leads to the conclusion that the quality of family life goes beyond the needs of a child with developmental disability and summarizes the needs of all family members as well as the strong sides of the family functioning (Smith-Bird and Turnbull 2005). That the presence of disturbance in development is not the only factor determining the quality of family life. However, studies show that families of children with developmental disabilities tend (Gardiner and larocci 2012)

\section{Research Methodology}

The quality of family life can be observed in relation to an individual and in relation to all family members (Milićević 2015). The aim of this survey is to determine whether the presence of a disability in a child affects the quality of life of its family, and in which domains it differs from the same in the families with typical developed children. The research focus has been directed to perception of certain problems in the functioning of such children by their 
Table 1 Examples of Behavioural Problems' Indicators (PEDsQL Generic Scale)

\begin{tabular}{ll}
\hline Domain & Indicator \\
\hline Physical & Participation in an active game or physical activity \\
& Help with collecting toys \\
& Feeling pain \\
& Low energy level \\
\hline Emotional & Feeling fear \\
functioning & Sleep difficulties \\
& Feeling anger \\
\hline Social & Other kids do not want to play with your child \\
functioning & Unable to do things other kids of his/her age can \\
\hline Functioning & Does not perform same activities in the kindergarten as his/her peers \\
in a kindergarten & Absence from the kindergarten for not feeling well \\
& Absence from the kindergarten to go to the doctor's or hospital \\
\hline
\end{tabular}

parents, which can serve as one of the indicators of the quality of family life. Problems can be manifested as problems in the physical, social or emotional functioning of a child. We started from the assumption that the problems associated with certain areas of child functioning would be significantly more present in children with disabilities.

The research was conducted through an on-line survey that was forwarded to parents' associations of children with disabilities as well as parents of typical children who attend the kindergarten. Parents' opinion on the impact of the disabilities of the child on the functioning of their families was obtained by the PEDsQL generic scale questionnaire - the family impact module. PED$S Q L$ is a generic instrument that measures the quality of life of a wide population in relation to the health of children aged 2 to 18 . It is used both for clinical and research purposes. The survey used part of the questionnaires filled in by parents of children aged 2 to 4 . It consists of 23 items and assesses the quality of life through 4 domains: physical functioning (8 items); emotional functioning ( 5 items); social functioning ( 5 items); functioning in kindergarten (5 items). Answers to questions range from o to 4 , where o refers to behaviours that never pose a problem to a child, 1 - almost never, 2 - sometimes, 3 often, while 4 refers to behaviours that almost always represent a problem. The questions relate to behavioural problems that have occurred over the past month compared to the time of the survey. Table 1 presents some of the behavioural indicators that affect the quality of life of the whole family.

The survey sample consisted of 81 respondents ( $44.4 \%$ of parents of children with disabilities, $55.6 \%$ of parents of children with typical development). 
Table 2 Respondents' Demographic Data

\begin{tabular}{llrr}
\hline Item & Category & $f$ & $f \%$ \\
\hline Gender of a child & Male & 43 & 53.09 \\
& Female & 38 & 46.93 \\
Presence of a developmental disorder & Yes & 36 & 44.40 \\
& No & 45 & 55.60 \\
\hline Parents' education level & Primary school & $2(1.7)$ & 0 \\
& Secondary school & $28(23.5)$ & $35(29.4)$ \\
& High school - college & $12(10.1)$ & $11(9.2)$ \\
& Higher school - university & $34(28.6)$ & $29(24.4)$ \\
\hline Parents live in & marital community & 63 & 77.78 \\
& extramarital community & 13 & 16.05 \\
& divorced & 2 & 2.47 \\
& single parents & 3 & 3.70 \\
\hline
\end{tabular}

The sample is dominated by female respondents, i.e. the answers were mostly given by mothers of children aged 2 to 4 attending a pre-school institution. According to the data collected from parents, most children suffered from autism, speech or language disorder, developmental delay, cerebral palsy, or other physical disorder. The demographic data of the respondents are presented in Table 2.

In data processing, methods and procedures from the descriptive statistics framework, as well as from the domain of locking statistics - $t$-test, were used.

\section{Research Results and Discussion}

The quality of life of a family of children with disabilities can be viewed through different indicators such are: 'factors related to the child - the degree of child's disability and the intensity of manifestation of problems in his/her behaviour; financial situation of the family, family relations, social status of all family members, adequacy of services provided, etc.' (Milićević 2015, 39). As in some other studies (Davis and Gavidia-Payne 2009), our research also singled out intensity of manifestation of behavioural problems in a child as a predictor of the quality of family life. The assessment includes the frequency of certain behaviour patterns in the area of emotional, physical, social and behaviour in the kindergarten, as well as the intensity of these behaviours (behaviour patterns are shown in table 1). The summary results of the research are shown in Table 3.

By analysing summarized scores, a statistically significant difference $(p<$ 0.05 ) was found on all the subscales in the quality of life of families of children 
Table 3 Differences between Examined Groups

\begin{tabular}{lllrrrr}
\hline Domains & $(1)$ & $(2)$ & $(3)$ & $(4)$ & $t$ & $p$ \\
\hline Physical functioning & Yes & 36 & 26.97 & 25.79 & 3.25 & 0.00 \\
& No & 45 & 14.80 & 5.14 & & \\
\hline Emotional functioning & Yes & 36 & 12.08 & 3.13 & 2.22 & 0.02 \\
& No & 45 & 11.07 & 3.00 & & \\
\hline Social functioning & Yes & 36 & 27.54 & 5.90 & 2.93 & 0.00 \\
& No & 45 & 20.00 & 6.40 & & \\
\hline Functioning in a kindergarten & Yes & 32 & 12.09 & 6.00 & 2.60 & 0.01 \\
& No & 43 & 8.60 & 5.56 & & \\
\hline
\end{tabular}

Notes Column headings are as follows: (1) the presence of a disability in a child, (2) number of respondents, (3) average value, (4) standard deviation.

with disabilities in relation to the families of typical children. By reviewing the obtained average summation scores of each individual domain, one can see that the domain of emotional functioning was rated best in children with developmental disorders (average value 12.08), while the domain of social functioning is rated the worst (average value 27.54). In the group of typical developed children the domain of functioning in the kindergarten was rated best (average value 8.6), while the domain of social functioning was rated the worst (average value 20).

The results obtained in the field of emotional functioning of children with developmental disorders indicate that these children have least problems with expressing negative emotions such as anger, fear, sadness, as well as with sleep. This can lead us to conclude that families of children with developmental disabilities are functional and caring, since the presence of difficulties in emotional functioning often reflects inadequate care, nursing or traumatisation within the family (Mitić, Radojević, and Piper 2011), and that this domain does not significantly affect the quality of family life.

Mitić and associates state that 'autistic and children with other perverting and developmental difficulties can manifest disinterest or fear, retreat from peers and are often also victims of peer violence' (Mitić, Radojević, and Piper 2011, 122). The results of our research, in the domain of social functioning, show that children with disabilities at an early age have significant difficulties in relation to the expected indicators of development (a child cannot do things like other children of his/her age and has difficulty in keeping pace with other children) or in relation to peers (other kids tease him/her; other kids do not want to play with the child). This fact can significantly reduce family interactions as well as ordinary family activities that might become 
complicated or impossible. Similarly, parents can be concerned about the safety of their child in the park or at the playground and whether other children relate to their child friendly or in a brutal manner (McConnell et al. 2014; Hrnjica 2011). All this affects the quality of family life as it requires additional engagement and development of new parental skills that are not involved in the corpus of standard competences related to the parentage of a typical child.

Difficulties the child has in physical behaviour (uncontrollable, inappropriate and non-directional movements) at the age of up to 4, may be related to the lag in physical and/or mental development (Mitić 2011) and could lead to reduced participation in active games or physical activity, which also considerably undermines the dynamics of family relationships. The research of Mainmer et al. (2007) shows that physical functioning as an indicator of the quality of life is closely related to the type and severity of a disorder that is present in a child. The results show that children with diagnosed cerebral palsy have the worst scores in this domain (Maimner et al. 2007; Milićev and Nedović 2017; Waters et al. 2005). In other studies, we find somewhat different results, thus according to the research of Škrbić et al. (2011), which included children with hearing disorders, their quality of life was equally impaired in all domains (Škrbić et al. 2011).

Within the domain of functioning of a child in a kindergarten, parents indicate that children with developmental disabilities also have significantly more problems than their typical peers (they do not perform the same activities in kindergarten as their peers; they are absent from the kindergarten due to going to a doctor or hospital, etc.). The demands placed on the family in this domain are not small, they can greatly undermine and jeopardize its functioning (Mitić 2011) since parents are often deprived of the pre-school institution services due to evident problems their child has. Findings from some studies (Davis and Gavidia-Payne 2009; McConnell et al. 2014) show that the quality of family life is related to the availability of educational and culturally relevant resources rather than internal, individual or family factors. Regarding the quality of family life, strengthening social relationships and improving financial issues might be more important than modification of the child's behaviour.

\section{Conclusion}

The research we conducted in order to determine whether the presence of a disability in a child affects the quality of life of its family is based on two hypotheses. The first, which refers to the fact that the quality of life of fami- 
lies of children with developmental disabilities is significantly different from the same in the families with typical children, has been confirmed. The second one, referring to the fact that the quality of life of families of children with developmental disabilities is disturbed more in the domain of emotional and social than physical functioning, has been partly confirmed, since social functioning is truly poorly assessed, but in the emotional functioning we obtained diametrically opposite results.

The results we obtained in our study, as well as theoretical insight into the problem of the research, indicate that it is necessary to recognize risk factors when selecting and planning social activities aimed at empowering the family of a child with developmental disability and then promote measures that support and improve the quality of life of such family. Supporting families of early aged children with disabilities is important potential for development of inclusive society and leads to preservation of the family's capacity, given that the family represents primary and, at the same time, crucial social community.

\section{References}

Araujo de Melo, E. L., M. Badia Corbella, M. Begona Orgaz Baz, M. A. Verdugo, M. A. Alonso, B. Arias Martinez, M. Gomez-Vela, and A. M. Ullan. 2012. 'Quality of Life in Children and Adolescents with Cerebral Palsy.' Revista Brasileiraem Promocao da Saude 25 (4): 426-434.

Axelsson, A. K., M. Granlund, and J. Wilder. 2013. 'Engagement in Family Activities: A Quantitative, Comparative Study of Children with Profound Intellectual and Multiple Disabilities and Children with Typical Development.' Child: Care, Health and Development 39 (4): 523-534.

Barnett, D., M. Clements, M. Kaplan-Estrin and J. Fialka. 2003. 'Building New Dreams: Supporting Parents' Adaptation to Their Child with Special Needs.' Infants and Young Children 16 (3): 184-200.

Brown, I., S. Anand, W. A. Fung, B. Isaacs, and N. Baum. 2003. 'Family Quality of Life: Canadian Results from an International Study.' Journal of Developmental and Physical Disabilities 15 (3): 207-230.

Davis, K., and S. Gavidia-Payne. 2009. 'The Impact of Child, Family, and Professional Support Characteristics on the Quality of Life in Families of Young Children with Disabilities.' Journal of Intellectual and Developmental Disability 34 (2): 153-162.

Emerson, E. 2003. 'Mothers of Children and Adolescents with Intellectual Disability: Social and Economic Situation, Mental Health Status, and the SelfAssessed Social and Psychological Impact of the Child's Difficulties.' Journal of Intellectual Disability Research 47 (1): 385-399.

Florian, V., and L. Findler. 2001. 'Mental Health and Marital Adaptation among 
Mothers of Children with Cerebral Palsy.' American Journal of Orthopsychiatry 71 (3): 358-367.

Gardiner, E., and G. Iarocci. 2012. 'Unhappy (and Happy) in Their Own Way: A Developmental Psychopathology Perspective on Quality of Life for Families Living with Developmental Disability with and without Autism.' Research in Developmental Disabilities 33 (6): 2177-2192.

Hedderly, T., G. Baird, and H. McConachie. 2003. 'Parental Reaction to Disability.' Current Paediatrics 13 (1): 30-35.

Hrnjica, S. 2011. 'Roditeljstvo dece sa ometenošću: izazovi i teškoće u njegovoj realizacijji.' In Deca sa smetnjama u razvoju, edited by M. Mitić, 72-77. Beograd: Familija.

Juhásová, A. 2015. 'Comparison of Quality of Life of Families with Children with Disability and Families with Children without Disability.' Procedia: Social and Behavioral Sciences 174:3378-3384.

Maimner, A., M. Shevell, P. Rosenbaum, M. Law, and C. Poulin. 2007. 'Determinants of Life Quality in School-Age Children with Cerebral Palsy.' The Journal of Pediatrics 151 (5): 470-475.

Marvin, R. S., and R. C. Pianta. 1996. 'Mothers' Reaction to Their Child's Diagnosis: Relations with Security of Attachment.' Journal of Clinical Child Psychology 25:436-443.

Mihić, I., M. Rajić, T. Krstić, S. Divljan, and N. Lukić. 2016. '»Našapriča« - program podrške deci sa smetnjama u razvoju: primer dobre prakse u predškolskim ustanovama.' Specijalna edukacija i rehabilitacija 15 (4): 477-498.

Milićević, M. 2015. 'Kvalitet života porodica sa detetom sa ometenošću.' Beogradska defektološka škola 2 (2): 39-60.

Milićev, M., and G. Nedović. 2017. 'Povezanost porodičnog kvaliteta života i participacije u porodičnim aktivnostima dece s cerebralnom paralizom i dece tipičnog razvoja.' Beogradska defektološka škola 23 (3), 41-64.

Mitić, M. 2011. 'Porodica, roditelji i roditeljstvo.' In Deca sa smetnjama u razvoju, edited by M. Mitić, 56-65. Beograd: Familija.

Mitić, M., B. Radojević, and B. Piper. 2011. 'Od procene do donošenja odluka.' In Deca sa smetnjama u razvoju, edited by M. Mitić, 116-122. Beograd: Familija.

McConnell, D., A. Savage, and R. Breitkreuz. 2014. 'Resilience in Families Raising Children with Disabilities and Behavior Problems.' Research in Developmental Disabilities 35 (4): 833-848.

Mugno, D., L. Ruta, V. Genitori D'Arrigo, and L. Mazone. 2007. 'Impairment of Quality of Life in Parents of Children and Adolescents with Pervasive Developmental Disorder.' Health Qual Life Outcomes 5 (22): 1-9.

Osmančević Katkić, L., M. Lang Morović, and E. Kovačić. 2017. 'Parenting Stress and a Sense of Competence in Mothers of Children with and without Developmental Disabilities.' Hrvatska revija za rehabilitacijska istraživanja 53 (Supplement): 63-76. 
Park, J., L. Hoffman, J. Marquis, A. P. Turnbull, D. Poston, H. Mannan, and L. L. Nelson. 2003. 'Toward Assessing Family Outcomes of Service Delivery: Validation of a Family Quality of Life Survey.' Journal of Intellectual Disability Research 47 (4-5): 367-384.

Poston, D., A. Turnbull, P. Jiyeon, M. Hasheem, M. Janet, and W. Mian. 2003. 'Family Quality of Life: A Qualitative Inquiry.' Mental Retardation 41 (5): 313-328.

Price, B. J., K. Y. Mayfield, A. C. McFadden, and G. E. Marsh. 2000. 'Collaborative Teaching: Special Education for Inclusive Classrooms.' Kansas City, MO: Parrot Publishing.

Rajić, M., and I. Mihić. 2015. 'Socio emocionalna posvećenost roditelja dece sa smetnjama u razvoju:razlike između majki i očeva.' Godišnjak Filozofskog fakulteta u Novom Sadu 40 (2): 137-153.

Rentinck, I., M. Ketelaar, M. Jongmans, E. Lindeman, and J. W. Gorter. 2009. 'Parental Reactions Following the Diagnosis of Cerebralpalsy in Their Young Child.' Journal of Pediatric Psychology 34 (6): 671-676.

Ristić-Stojiljković, R. 2016. 'Dečji doživljaj roditeljskog sukoba i emotivna sigurnost deteta.' Zbornik radova Učiteljskog fakulteta Užice 19 (18): 87-100.

Smith-Bird, E., and A. P. Turnbull. 2005. 'Linking Positive Behavior Support to Family Quality-of-Life Outcomes.' Journal of Positive Behavior Interventions 7 (3): 174-180.

Škrbić, R., V. Milankov, M. Veselinović, and A. Todorović. 2011. 'Uticaj oštećenja sluha na kvalitet života adolescenata.' Medicinski pregled 66 (1-2): 32-39.

Van ljzendoorn, M. H., A. H. Rutgers, M. J. Bakermans-Kranenburg, S. H. Swinkels, E. Van Daalen, C. Dietz, F. B. A. Naber, J. K. Buitelaar, and H. Van Engeland. 2007. 'Parental Sensitivity and Attachment in Children with Autism Spectrum Disorder: Comparison with Children with Mental Retardation, with Language Delays, and with Typical Development.' Child Development 78 (2): 597-608.

Waters, E., E. Maher, L. Salmon, D. Reddihough, and R. Boyd. 2005. 'Development of a Condition-Specific Measure of Quality of Life for Children with Cerebral Palsy: Empirical Thematic Data Reported by Parents and Children.' Child: Care, Health and Development 31 (2): 127-135.

\section{Kakovost življenja otrok s posebnimi potrebami v obdobju zgodnjega otroštva}

Družina predstavlja primarno družbeno skupnost, ki usmerja in spodbuja razvoj otroka, oblikuje otrokovo osebnost, usmerja njegovo udeležbo v družbi, njeno delovanje pa pomembno vpliva na kakovost življenja vseh njenih članov. Izhajajoč iz dejstva, da je vzgoja otroka z motnjami v razvoju resen izziv za starše, zahteva večjo vključenost in večjo skrb za otroke, je bil cilj te raziskave ugotoviti, v kolikšni meri prisotnost otrok s posebnimi potrebami vpliva na kakovost življenja družine. Kot napovedovalec kakovosti družinskega življenja je 
poudarjena intenzivnost vedenjskih težav pri otrokovem vedenju (fizično, čustveno, socialno in vedenje $v$ vrtcu). Raziskava je bila izvedena na vzorcu 81 staršev predšolskih otrok ( $44,4 \%$ staršev otrok s posebnimi potrebami in $55,6 \%$ staršev otrok normativnega razvoja). Mnenje staršev o intenzivnosti vedenja in vplivu kroničnega stanja otroka na življenje njihovih družin smo pridobili z vprašalnikom generičnega tipa PedsQL - dejavnik družinskega vpliva. Raziskava je potrdila, da prisotnost posebnih potreb in specifičnega vedenja otrok vpliva na delovanje družine in da se kakovost življenja le-te bistveno razlikuje od družin z otroki normativnega razvoja razvoja.

Ključne besede: družina, kakovost življenja družine, starši invalidnih otrok, otrok s posebnimi potrebami, tipično razviti otroci 


\title{
Sensory Integration as the Path for Nurturing Toddlers' Wellbeing
}

\author{
Sanja Tatalović Vorkapić \\ University of Rijeka \\ sanjatv@uniri.hr
}

\author{
Lana Osojnak \\ Kindergarten Kastav \\ lane1509@yahoo.com
}

Sensory development, activities, and stimuli are extremely important for toddlers' optimal growth and development. Sensory integration development is one the fundamental neurobiological activities of toddlers that represents the basis for learning and presents a very important and actual research field in contemporary science and practice. At the same time, the early childhood educators' role and the sensory activities which are extremely important external stimuli for the sensory integration development. Considering the very small amount of scientific studies in this research field, especially research carried out by early childhood educators working with toddlers in everyday regular preschool class, this study was focused on testing the implemented sensory activities and stimuli in everyday teaching. Based on that study aim, a comparison was made between two toddler groups - the one that was exposed to all mentioned stimuli and the one that was not, so that the wellbeing for children's development could be determined. Generally, it was determined that there are significant differences between the control and experimental groups of children due to the application of sensory tools and materials in the experimental group of toddlers. Since there were no significant differences in all elements of sensory development, just in some, the discussion was based on the optimal conditions in nursery schools for the sensory integration for toddlers.

Keywords: toddlers, wellbeing, sensory integration, sensory activities and stimuli

\section{Introduction}

Although every child is born with the ability of sensory integration, the adults included in the child's development have the responsibility to ensure relevant relations with various items from the environment so that the child could learn how to adjust his own brain and body to the many challenges he faces during childhood in order to successfully develop his sensory integration. During the first seven years 'a child learns how to feel his own body and 
the world around him, and how to move more effectively in it' (Ayres 2009, 27). Gaining sensory input from all of the items surrounding him (furniture, clothing, footwear, cutlery, toys, pencils, books, people ...), 'a child should develop sensory integration so he could use these information and act effectively' (Ayres 2009, 27). Our inner drive aiming for the sensory integration enables our entire development.

Sensory-motoric systems develop and form our own experiences, while at the same time being formed by them; therefore, if we really want to understand how we learn, first we need to learn how these systems develop. Hannaford (2007) emphasizes that thought, creativity, and learning develop from sensations through which the information is imported so that we could build neural networks and be able to use this information for better understanding of the world and how to succeed in it. We receive many experiences from our surroundings through our senses: eyes, ears, taste buds, nose, skin, and the nervous receptors in every muscle and organ; something like Proust's magical cookie that awakens all our early childhood memories all the way to maturity with its scent and taste - like it can magically stop the time and grant us our past in the palm of the hand.

The role of the preschool and, at the same time, the role of the preschool educator is crucial in gaining sensory integration in early childhood or, to be more exact, in the nursery school (Boyd and Sobieraj 2013). Contemporary childhood and children's needs are distinctly different in relation to children's needs in the past and many researches indicate the increased need of the sensory experiences domain, interrelations between them, and, finally, integration. Therefore, this research paper focuses on exploring the significance of sensory activities implemented in early childhood education and care as well as on an experimental testing of the implemented sensory activities in the nursery school, which are used to stimulate sensory integration. The implications of the research findings are more than significant, considering science and the everyday practice, which we need to be constantly attentive to and improve with relevant scientific knowledge.

\section{Sensory Integration and the Wellbeing of Toddlers}

Sensory integration theory, research, findings, interventions, and therapeutic equipment were originally developed by A. Jane Ayres (2009). This therapeutic approach is also known as the Ayres Sensory Integration (Ayres 1989) theory, which was implemented in her therapeutic work with individuals with special needs.

Sensory integration represents an organization of the senses of use, which 
give us information about the physical state of our body in the environment (Bundy, Lane, and Murray 2002). For a person to move, learn, and act normally, his brain has to organize its senses, locate them, classify, regulate exceedingly many sensory information bits that enter his brain at every moment from all parts of the body. Well-organized or integrated form of senses development gives our brain the opportunity to use them in a way to form perception, behavior, and learning. Unorganized senses development results with a life that seems like a 'traffic rush hour' as Ayres $(2009,16)$ scenically points out.

Our senses are 'food to our brain,' which reassures energy and knowledge required to control our body and mind, and if our sensory process ritual is not well organized, our senses are be able to feed our brain. Dr. Ayres $(2009,15)$ continues to describe this in a simple way, explaining how a 'sense tells the brain what the body does' and how the 'brain tells the body what to do,' in the attempt to explain the way of mutual communication between the brain cells. Our brain has the ability to integrate sensory impulses in meaningful forms and relations, which grants us the possibility to perceive our own body, other people, and things, and exact integration is what turns the senses into perception (Bundy, Lane, and Murray 2002).

Primary features of the sensory integration process disorder are the presence of difficulties in detecting, coordinating, interpreting, and/or organizing sensory stimulating impulse, which are so strong that they make someone's life routine harder. Slower learning and bad behavior are often the result for unsuitable sensory integration in a child's brain. Sensory integration problems are not that obvious but are still present with children all over the world. They are the reason why many bright children have problems with learning and they are the cause of bad behavior despite the involvement of caring parents and beneficial social surroundings. Children have to effectively and successfully act on their environment (Ahn et al. 2004; Ben-Sasson, Carter and Briggs-Gowan 2009; Gouze et al. 2009).

Dr. Ayres (2009) explains the sensory integration term through neurobiological process - she described it as the way our central nervous brain system translates information into action. Her theory is based on the idea that our behavior is connected with neurological process and that the level of brain cells sensory treatment is enabling the development and improvement of the higher neuron centers. She claims that a disorganized neuron process leads to disorganized behavior.

She hypothesized that the assurance of rich sensory possibilities processed on the brain cells level and the stimulation of the child's motivation through the limbic system with exactly defined sensory and motoric chal- 
lenges would lead to the a child providing a generally higher level of adaptive answers and him being prepared to cope with the challenges of everyday life. Her interventions focused on the activation of a child's inner motivation for learning and development through satisfactory but challenging sensorymotoric activities that lead to increasingly, complex motor-somatic adaptive reactions.

The Croatian National Curriculum for Early and Preschool Care and Education (Ministarstvo znanosti, obrazovanja i sporta 2014), accentuates the child's wellbeing assurance as one of its most important goals, defining it as a 'multidimensional, interactive, dynamic, and contextually process, which integrates healthy and successful individual functioning and positive social relations in quality preschool surroundings' (p. 24). Ensuring a child's wellbeing implies focusing the planning of the educational process on the child and his benefit, which makes the role of the early education institution more than significant. The educator must raise his awareness about his knowledge and expectations as well as the way he understands the child, childhood, socialization, and education. He also needs to direct the planning of the educational process towards a consideration of the wellbeing and ways it can be accomplished instead of on partial goals or areas and contents of learning, apart from individual characteristics of each child (Sylvester 2000). There is an accentuation in the National Curriculum for Early and Preschool Care and Education on personal, emotional, and physical wellbeing as well as on the educational and social wellbeing. Personal, emotional, and physical wellbeing implies a subjective feeling (to be healthy, satisfied, and to feel good) and it includes, among other things, 'motor skills development, enjoyment of different interactions and activities, a child's openness to the world around him and to new experiences, child's self-acceptance, self-respect and self-awareness, the ability to temporary put off satisfying his needs, identity development, development of independent thinking and doing, to be initiative and innovative, self-imitative and self-organized activities, consideration, and self-assessment of his activities and achievements' (Ministarstvo znanosti, obrazovanja i sporta 2014, 25). By developing sensory integration through different sensory activities and stimulation, we can influence a person's change - personal, emotional, and physical - while research shows us how to properly set the surroundings that enable movement with ease and exploration through all of his senses and various forms of stimulation, what influences a child's self-organization of his brain, and, finally, more efficient functioning of the brain as a whole (Cantu 2002; Fisher, Murray, and Bundy 1991). 
By providing an overview of the existing studies from the neuroscientific and sensory integration area, we have tried to emphasize the significance of sensory integration growth from an early age. Also, this contributes to raising the educators' awareness about this highly important area for early age education because, 'if sensory-motoric processing is well organized in first seven years of our lives, a child will learn mental and social skills in the forthcoming time much easier' (Ayres 2009, 19). One more important goal to achieve, as highlighted in National Curriculum for Early and Preschool Care and Education (Ministarstvo znanosti, obrazovanja i sporta 2014), refers to integral development, children's education, and their competencies development, and it is based on understanding the child as the whole being and excepting the integrating nature of his various ways of learning in the organization of the educational process in the preschool institution. Ayres' $(2009,48)$ definition of sensory integration can be attached to this since she explains it as the process of sensory input organization, which classifies, arranges, and combines all of the sensory inputs in complete brain functioning. She concluded that, 'when the functioning of the brain is completely balanced, the body movement is highly adaptive, learning is easy, and good behavior is natural outcome.'

\section{The Role of the Preschool/Nursery School in Sensory Stimulation and Activities with Toddlers}

The research paper (Olson et al. 2016) that used 'the sensory processing measure - preschool test' (Miller Kuhaneck et al. 2010) for children in the age 2-5 years, is guided as the initial and final test so they could evaluate the effects of sensory processing challenges with four preschool children, in their home and in preschool institution. The selection and implementation of strategies based on the knowledge about sensory integration and from parents' and educators' point of view, during the three and a half months' period have been monitored. The results of the test conducted in the preschool institution have shown much more progress than the ones conducted at home. Parents and educators have highlighted the evident progress in social participation and the everyday activities that depend on the sensory processing as well as in the praxis, which is, according to dr. Ayres, the ability to understand, organize, and exhibit control in (for a child) new unknown everyday actions such as washing his teeth, eating, and sleeping. As the child displays difficulties in the sensory modulation at an early age, it can pose a challenge for his ability to focus on important senses and simulative incentives. Sensory modulation is the ability of regulating and organizing intensity and the nature of responses to sensory input in a way that the responses are appropriately di- 
rected towards a constant change of the sensory experiences in everyday life (James et al. 2011).

In educational practice, there is a frequent need for developing the educators' competencies to identify those children at an early age so that they could be introduced to the early intervention (Mamić, Fulgosi Masnjak, and Pintarić Mlinar 2010, Tatalović Vorkapić, Vlah and Vujičić 2012). Experiences from the surroundings and the expectations from the child play an important role in enabling the exposure to different forms of sensory intensiveness. Surroundings shape the way the child learns to self-regulate and to develop strategies for coping with stress (Dawson, Ashman, and Carver 2000). Therefore, the combination or cooperation between environmental factors, genetic features, neural activities and behaviors, and probably the timing of their collaboration can explain certain outcomes, i. e., the first steps, activities that include new and smudging materials that expose an early-age child to a wide range and intensity of sensations (Kraemer 2001). Two-year-olds also have a better ability to communicate the cause of their difficulties through verbal and nonverbal ways. These discoveries give us the opportunity to form new questions about whether the early critical period for sensory adaptation development really exists in their childhood as Hensch (2004) has suggested. The preschool institution is a place that provides a complete development and education for the child if it enables continuous creation of appropriate educational environment, which gives him the opportunity to involve in various interactions with the space, materials, other children, and adults (Ministarstvo znanosti, obrazovanja i sporta 2014). Complete development is also enabled for children if the educational process is formed in a way that every activity encourages different parts of the integral development at the same time; if it connects and combines different areas of his learning and maintains different children's activities at the same time.

\section{Methodology}

\section{The Research Aim, Problems, and Hypotheses}

This research paper aims to examine the wellbeing of early-aged children who are introduced to sensory activities and incentives use. Regarding that, two research tasks were postulated: (a) to examine the wellbeing of earlyaged children in the group in which sensory activities and incentives were implemented (experimental group) and in the group without that implementation (control group), in two measuring points: the initially and final phase (quasi-experimental research design), and (b) to compare experimental and control group results regarding: differences between groups and dif- 
ferences within each group. Based on the theory and prior results in this area, the next hypotheses could be articulated: (a) application of sensory activities and incentives can influence the children's sensory integration and behavior so that they could cope better with everyday life tasks (there will be improvement in psychophysical development in children's early-age development) and (b) there is a difference between the experimental and control group. In the experimental group, a child's progress will be increased because of everyday implementation of sensory activities and the use of sensory-motoric incentives, while changes in children's behavior are not expected in the control group.

\section{Participants}

Toddlers. The research involved the experimental $(N=17)$ and control $(N=$ 13) group of children. Altogether, 30 children were involved in the research $(N=30)$ within the age range between 2 and 4 years. Considering the gender variable, in the experimental group, there were 9 boys and 8 girls, while in the control group, there were 8 boys and 5 girls. In the experimental group, the mean age was 37.06 months $(S D=4.72)$ and it was in the range between 27 and 45 months. In the control group the mean age was 35.23 months (SD = 3.39), with the range between 29 and 40 months.

Early childhood educators. The research involved two preschool educators, both female, aged 33 and 47 years and the length of service of 10 and 22 years, respectively. They had about five years of experience of working with sensory materials. The educators' role was to design sensory materials, gadgetry, device, incentives, and activities in cooperation with the parents and the expert team in the preschool institution and to adjust the indoor space to this material so that the children could use them every day with ease. In the initial phase, one educator tested 30 children in all of the 11 elements and after four months, in the final phase, she re-applied the same testing on the same group.

\section{Measure and Procedure}

The scale used in this research was created for the purpose of the research. It included 54 items with specified sensory-motoric activities that would preferably be implemented in everyday early-age practice so that we could stimulate the sensory integration development. The scale-creating criteria were: (a) the use of those elements in everyday practice in organizations for children with special needs, (b) experts' and occupational therapists' experiences in sensory integration. Due to their own engagement in everyday 
practice with children with certain developmental deviations and with the help to much conducted research in this area, the practitioners discovered the significance of using exactly these elements in accomplishing progress in children that have certain developmental deviations, which adds to dr. Ayres's (2009) discoveries from the sensory integration area. Items used in this questionnaire were recommended for use in the preschool practice by the following authors: Ayres (2009), Goddard Blythe (2008) and Biel and Peske (2007). These items are: trampoline, funnel spinning, therapy balls (a small ball, 'peanut-shaped' ball), balance board, platform swing, tactile paths, balancing pad, spongy stairs, and climbing cliff. Specified gadgetry allows primary sensory-motoric experiences, same as the higher level of vestibular and proprioceptive input through spinning, swinging, crawling, jumping, maintaining balance. In the first measurement, the scale showed a Cronbach alpha reliability $\alpha=0.858$ and in the second, $\alpha=0.921$, which is very satisfactory.

The research sample is convenient and comprises 30 children from one preschool in the Primorsko-Goranska County. The name of the institution is not revealed so as to ensure anonymity. In choosing the two groups of children (experimental and control), it was very important to fulfill the condition of homogeneity by age and gender. The children in the control group were not using sensory-motoric gadgetry and materials in the period between the first and the second measuring phase, while the children from the experimental group were able to use specified gadgetry and materials depending on their interest. Materials like those used in this research can be found in catalogues Ida Didacta, Astreja plus d. o. o., and Regoč. The testing started with referring an official letter from the Faculty of Teacher Education towards the preschool. The parents were thoroughly informed about the research aim and the way of examining both groups (experimental and control), after which their signed informed consent was collected. Children's anonymity was secured. The measurements were conducted in two phases: the initial and final phase during a four-month interval. In the experimental group, a preschool educator educated and licensed for applying sensory materials and activities conducted the measurement.

\section{Results and Discussion}

\section{Descriptive Results of the Sensory Activities Application on Toddlers from the Experimental and Control Group}

The obtained results demonstrated the frequency display of certain children's behaviors in the following activities: trampoline, funnel spinning, therapy balls (a small ball, 'peanut-shaped' ball), balance board, platform swing, 
Table 1 Presentation of the Achieved Results in the First and Second Measuring in the Experimental $(N=17)$ and Control Group $(N=13)$ of Children According to 11 Activities and Their Tasks

\begin{tabular}{|c|c|c|c|c|c|c|c|c|c|}
\hline \multirow[t]{3}{*}{ (1) } & \multirow[t]{3}{*}{ (2) } & \multicolumn{4}{|c|}{ Experimental group } & \multicolumn{4}{|c|}{ Control group } \\
\hline & & \multicolumn{2}{|c|}{ 1st measurem. } & \multicolumn{2}{|c|}{ 2nd measurem. } & \multicolumn{2}{|c|}{ 1st measurem. } & \multicolumn{2}{|c|}{ 2nd measurem. } \\
\hline & & $t=1$ & $-=0$ & $+=1$ & $-=0$ & $t=1$ & $-=0$ & $+=1$ & $-=0$ \\
\hline \multirow{7}{*}{ Trampoline } & 1 & 16 & 1 & 17 & 0 & 13 & 0 & 13 & 0 \\
\hline & 2 & 9 & 8 & 17 & 0 & 5 & 8 & 9 & 4 \\
\hline & 3 & 6 & 11 & 0 & 17 & 11 & 2 & 2 & 11 \\
\hline & 4 & 5 & 12 & 15 & 2 & 3 & 10 & 4 & 9 \\
\hline & 5 & 11 & 6 & 17 & 0 & 8 & 5 & 13 & 0 \\
\hline & 6 & 0 & 17 & 11 & 6 & 0 & 13 & 2 & 11 \\
\hline & Mean & \multicolumn{2}{|c|}{0.46} & \multicolumn{2}{|c|}{0.75} & \multicolumn{2}{|c|}{0.51} & \multicolumn{2}{|c|}{0.55} \\
\hline \multirow{9}{*}{$\begin{array}{l}\text { Therapy ball - } \\
\text { 'small' }\end{array}$} & 1 & 16 & 1 & 17 & 0 & 10 & 3 & 13 & 0 \\
\hline & 2 & 16 & 1 & 17 & 0 & 10 & 3 & 13 & 0 \\
\hline & 3 & 14 & 3 & 17 & 0 & 7 & 6 & 13 & 0 \\
\hline & 4 & 12 & 5 & 17 & 0 & 6 & 7 & 7 & 6 \\
\hline & 5 & 9 & 8 & 17 & 0 & 6 & 7 & 12 & 1 \\
\hline & 6 & 4 & 13 & 17 & 0 & 3 & 10 & 2 & 11 \\
\hline & 7 & 0 & 17 & 13 & 4 & 0 & 13 & $\mathrm{o}$ & 13 \\
\hline & 8 & 0 & 17 & 3 & 14 & 0 & 13 & $\mathrm{o}$ & 13 \\
\hline & Mean & \multicolumn{2}{|c|}{0.52} & \multicolumn{2}{|c|}{0.86} & \multicolumn{2}{|c|}{0.40} & \multicolumn{2}{|c|}{0.57} \\
\hline \multirow{9}{*}{$\begin{array}{l}\text { Therapy ball - } \\
\text { 'peanut- } \\
\text { shape' }\end{array}$} & 1 & 16 & 1 & 17 & 0 & 12 & 1 & 12 & 1 \\
\hline & 2 & 13 & 4 & 17 & 0 & 10 & 3 & 9 & 4 \\
\hline & 3 & 16 & 1 & 17 & 0 & 8 & 5 & 12 & 1 \\
\hline & 4 & 13 & 4 & 17 & 0 & 8 & 5 & 13 & 0 \\
\hline & 5 & 9 & 8 & 17 & 0 & 6 & 7 & 9 & 4 \\
\hline & 6 & 4 & 13 & 17 & 0 & 0 & 13 & 3 & 10 \\
\hline & 7 & 0 & 17 & 13 & 4 & 0 & 13 & o & 13 \\
\hline & 8 & 0 & 17 & 8 & 9 & 0 & 13 & o & 13 \\
\hline & Mean & \multicolumn{2}{|c|}{0.52} & \multicolumn{2}{|c|}{0.90} & \multicolumn{2}{|c|}{0.42} & \multicolumn{2}{|c|}{0.55} \\
\hline
\end{tabular}

Continued on the following page

balancing pad, obstacle course, walking and climbing on slopes and substrates (spongy stairs, climbing cliff, tactile paths), lifting and carrying, and pushing. All of the results frequencies of every task in the first and second measuring of children in the experimental $(N=17)$ and control group $(N=13)$ are shown in Table 1.

Experimental group. In the first measuring of the first activity 'trampoline, in the experimental group, 16 out of 17 children participated in the activity, 
Table 1 Continued from the previous page

\begin{tabular}{|c|c|c|c|c|c|c|c|c|c|}
\hline \multirow[t]{3}{*}{ (1) } & \multirow[t]{3}{*}{ (2) } & \multicolumn{4}{|c|}{ Experimental group } & \multicolumn{4}{|c|}{ Control group } \\
\hline & & \multicolumn{2}{|c|}{ 1st measurem. } & \multicolumn{2}{|c|}{ 2nd measurem. } & \multicolumn{2}{|c|}{ 1st measurem. } & \multicolumn{2}{|c|}{ 2nd measurem. } \\
\hline & & $t=1$ & $-=0$ & $t=1$ & $-=0$ & $t=1$ & $-=0$ & $+=1$ & $-=0$ \\
\hline \multirow{4}{*}{$\begin{array}{l}\text { Balance } \\
\text { board }\end{array}$} & 1 & 15 & 2 & 17 & 0 & 12 & 1 & 13 & 0 \\
\hline & 2 & 0 & 17 & 12 & 5 & 1 & 12 & 0 & 13 \\
\hline & 3 & 14 & 3 & 5 & 12 & 8 & 5 & 12 & 1 \\
\hline & Mean & \multicolumn{2}{|c|}{0.56} & \multicolumn{2}{|c|}{0.66} & \multicolumn{2}{|c|}{0.54} & \multicolumn{2}{|c|}{0.64} \\
\hline \multirow{5}{*}{$\begin{array}{l}\text { Funnel } \\
\text { spinning }\end{array}$} & 1 & 16 & 1 & 17 & $\mathrm{o}$ & 13 & 0 & 13 & 0 \\
\hline & 2 & 3 & 14 & 17 & 0 & 6 & 7 & 6 & 7 \\
\hline & 3 & 3 & 14 & 17 & 0 & 2 & 11 & 1 & 12 \\
\hline & 4 & 0 & 17 & 6 & 11 & 0 & 13 & 0 & 13 \\
\hline & Mean & \multicolumn{2}{|c|}{0.32} & \multicolumn{2}{|c|}{0.83} & \multicolumn{2}{|c|}{0.40} & \multicolumn{2}{|c|}{0.38} \\
\hline \multirow{5}{*}{$\begin{array}{l}\text { Balancing } \\
\text { pad }\end{array}$} & 1 & 16 & 1 & 17 & 0 & 12 & 1 & 13 & 0 \\
\hline & 2 & 9 & 8 & 12 & 5 & 0 & 13 & 0 & 13 \\
\hline & 3 & 4 & 13 & 16 & 1 & 1 & 12 & 10 & 3 \\
\hline & 4 & 1 & 16 & 16 & 1 & 0 & 13 & 4 & 9 \\
\hline & Mean & \multicolumn{2}{|c|}{0.44} & \multicolumn{2}{|c|}{0.89} & \multicolumn{2}{|c|}{0.22} & \multicolumn{2}{|c|}{0.30} \\
\hline \multirow{5}{*}{$\begin{array}{l}\text { Platform } \\
\text { swing }\end{array}$} & 1 & 16 & 1 & 17 & 0 & 13 & 0 & 13 & 0 \\
\hline & 2 & 15 & 2 & 17 & 0 & 11 & 2 & 11 & 2 \\
\hline & 3 & 6 & 11 & 16 & 1 & 5 & 8 & 8 & 5 \\
\hline & 4 & 4 & 13 & 16 & 1 & 1 & 12 & 2 & 11 \\
\hline & Mean & \multicolumn{2}{|c|}{0.60} & \multicolumn{2}{|c|}{0.97} & \multicolumn{2}{|c|}{0.57} & \multicolumn{2}{|c|}{0.65} \\
\hline \multirow{7}{*}{$\begin{array}{l}\text { Obstacle } \\
\text { course }\end{array}$} & 1 & 10 & 7 & 16 & 1 & 7 & 6 & 11 & 2 \\
\hline & 2 & 11 & 6 & 17 & 0 & 8 & 5 & 12 & 1 \\
\hline & 3 & 16 & 1 & 17 & 0 & 12 & 1 & 13 & 0 \\
\hline & 4 & 11 & 6 & 17 & 0 & 9 & 4 & 10 & 3 \\
\hline & 5 & 2 & 15 & 13 & 4 & 0 & 13 & 1 & 12 \\
\hline & 6 & 0 & 17 & 7 & 10 & 0 & 13 & 0 & 13 \\
\hline & Mean & \multicolumn{2}{|c|}{0.49} & & & o. & & o. & \\
\hline
\end{tabular}

while only one was not willing to participate. In the activity 'trampoline' in the second measuring in exercises 1,2 , and 5 , all of the 17 children made progress. In the second measuring of the same activity in the exercise 4 ('a child jumps inside the circle'), 15 children made progress, unlike the first measuring where only 5 of them achieved results in the exercise. In exercise 3 ('a child jumps with the help of the educator') in the same group, in the second measuring, all of the 17 children made progress, while all of them jumped without 
Table 1 Continued from the previous page

\begin{tabular}{|c|c|c|c|c|c|c|c|c|c|}
\hline \multirow[t]{3}{*}{ (1) } & \multirow[t]{3}{*}{ (2) } & \multicolumn{4}{|c|}{ Experimental group } & \multicolumn{4}{|c|}{ Control group } \\
\hline & & \multicolumn{2}{|c|}{ 1st measurem. } & \multicolumn{2}{|c|}{ 2nd measurem. } & \multicolumn{2}{|c|}{ 1st measurem. } & \multicolumn{2}{|c|}{ 2nd measurem. } \\
\hline & & $+=1$ & $-=0$ & $t=1$ & $-=0$ & $+=1$ & $-=0$ & $t=1$ & $-=0$ \\
\hline \multirow{8}{*}{$\begin{array}{l}\text { Walking and } \\
\text { climbing on } \\
\text { slopes and } \\
\text { substrates }\end{array}$} & 1 & 9 & 8 & 16 & 1 & 2 & 11 & 1 & 12 \\
\hline & 2 & 3 & 14 & 16 & 1 & 3 & 10 & 3 & 10 \\
\hline & 3 & 17 & 0 & 17 & 0 & 11 & 2 & 12 & 1 \\
\hline & 4 & 7 & 10 & 17 & 0 & 6 & 7 & 11 & 2 \\
\hline & 5 & 10 & 7 & 16 & 1 & 3 & 10 & 7 & 6 \\
\hline & 6 & 5 & 12 & 17 & 0 & 3 & 10 & 10 & 3 \\
\hline & 7 & 0 & 17 & 17 & 0 & 0 & 13 & 3 & 10 \\
\hline & Mean & \multicolumn{2}{|c|}{0.50} & \multicolumn{2}{|c|}{0.97} & \multicolumn{2}{|c|}{0.30} & \multicolumn{2}{|c|}{0.52} \\
\hline \multirow{3}{*}{$\begin{array}{l}\text { Lifting and } \\
\text { carrying }\end{array}$} & 1 & 12 & 5 & 17 & 0 & 13 & 0 & 13 & 0 \\
\hline & 2 & 4 & 13 & 13 & 4 & 2 & 11 & 4 & 9 \\
\hline & Mean & \multicolumn{2}{|c|}{0.47} & \multicolumn{2}{|c|}{0.88} & \multicolumn{2}{|c|}{0.57} & \multicolumn{2}{|c|}{0.65} \\
\hline \multirow[t]{3}{*}{ Pushing } & 1 & 12 & 5 & 17 & 0 & 7 & 6 & 10 & 3 \\
\hline & 2 & 6 & 11 & 15 & 2 & 0 & 13 & 8 & 5 \\
\hline & Mean & \multicolumn{2}{|c|}{0.53} & \multicolumn{2}{|c|}{0.94} & \multicolumn{2}{|c|}{0.25} & \multicolumn{2}{|c|}{0.69} \\
\hline
\end{tabular}

Notes Column headings are as follows: (1) sensory materials, (2) sensory activities.

holding the educator's hand, while 6 of them jumped holding the educator's hand in the first measuring. In the activity therapy ball - small, in the second measuring, all of the 17 children of the experimental group made progress in all exercises. The biggest progress was recoded in exercises 6 ('a child gets off the therapy ball onto the floor and makes 2 to 4 steps on his hands') and 7 ('a child gets off the therapy ball onto the floor and makes 4 to 6 steps on his hands') considering that, in the first measuring, 13 of them didn't achieve results in exercise 6 , nor 17 of them in exercise 7.

In exercise 8 ('a child gets off the therapy ball onto the floor and makes 6 to 8 steps on his hands'), three of them have shown better results unlike the first measuring where, in the same exercise, children did not achieve any results. In the activity peanut-shaped therapy ball, all of the 17 children of the experimental group made progress in all exercises. The children showed the biggest progress in the second measuring, in the exercises 6 ('a child gets off the peanut-shaped therapy ball onto the floor and makes 2 to 4 steps on his hands') and 7 ('a child gets off the peanut-shaped therapy ball onto the floor and makes 4 to 6 steps on his hands'). Considering the first measuring in exercise 6,13 children achieved no results, while in the same exercise, in the second measuring, all of the 17 children of the experimental group achieved 
results. In exercise 7 , in the second measuring, 13 children of the experimental group made progress, while, in the first measuring, no one achieved results. Five children showed better results as opposed to the first measuring, where, in the same exercise, children achieved no results. In exercise 8 ('a child gets off from the peanut-shaped therapy ball onto the floor and makes 6 to 8 steps on his hands'), while examining certain behavior of the same group children, eight of them showed better results as opposed to the first measuring, where, in the same exercise, children achieved no results. In the activity balance board, in exercise 2 ('a child is standing on the balance board by himself'), in the second measuring, 12 children of the group managed to 'stand on their feet on the balance board by themselves,' while, in the first measuring, none of the 17 children managed to do that. In the second measuring, twelve children managed to 'stand on their feet on the balance board without holding onto the wall,' while in the first measuring, 14 children could do that. The activity funnel spinning has shown the biggest progress among the children of this group in exercise 2 ('a child is using the funnel according to direction') and 3 ('a child is inside of the funnel for 1 minute'), in the second measuring, in which all of the 17 children 'used the funnel according to direction,' and the same number of children were inside of the funnel for 1 minute. In the same exercises ( 2 and 3 ), in the first measuring, 14 children of the experimental group did not achieve any results. In exercise 4 ('a child is inside of the funnel over 1 minute'), six children made progress in the second measuring as opposed to the first measuring where, in the same exercise, children achieved no results. In the activity balancing pad, the children of this group showed significantly better results in the second measuring in exercises 2, 3, and 4 . In exercises 3 ('a child is holding onto the balancing pad with his hands and is alternately lifting his left then right leg') and 4 ('a child is lying on his stomach on the balancing pad with his arms and legs raised above the floor ('a plain'), 16 of the 17 children performed the specified tasks. In the first measuring in exercise 3,13 children did not achieve any progress, while in exercise 4 , in the first measuring, 16 children did not achieve any results. In the activity platform swing, in the second measuring, in which 17 children participated, 16 of them did not achieve any results in exercise 3 ('a child is rocking in a swing lying on his back') and 4 ('a child is spinning in the swing'). In the first measuring, 13 children achieved no results in exercise 3, while 16 children made no results in exercise 4 . In the activity obstacle course, progress was recorded in exercise 5 ('obstacle course - walking backwards around peanuts') and 6 ('backwards obstacle course - jumping backwards in hoops'). In exercise 5, thirteen children in the second measuring achieved the task, while, in the first 
measuring, 15 children did not achieve progress in the same exercise. Seven out of 17 children accomplished the result in the experimental group in exercise 6, while, in the first measuring, in the same exercise, none of the children achieved a result. In the ninth activity walking and climbing on slopes and substrates, in the second measuring of the experimental group, 17 children participated, in exercise 4 ('walking on the sensory tactile path with three different substrates without holding onto something and picking items off the floor'), 16 children in exercise 5 ('climbing on a diagonal mat and jumping'), 17 children in exercise 6. ('climbing up and down the spongy stairs') and also 17 children in exercise ('climbing onto the climbing rock by yourself'). In the second measuring, in exercise 7 , all of the 17 children made substantial progress as opposed to the first measuring, where, in the same exercise, the children achieved no results. In the activity lifting and carrying, in the experimental group, in which 17 children participated, in exercise 2 ('lifting and carrying a therapy ball - prickly'), in the second measuring, 13 children achieved results, while in the first measuring the same number of children achieved no results. In the activity pushing, progress is evident in the second measuring in the experimental group, in the exercise 2 ('pushing a $5 \mathrm{~kg}$ box with your feet') in 15 children, while, in the first measuring, 11 children achieved no results in the same exercise.

Control group. In the activity trampoline, in exercise 3 ('a child is jumping with the help of the educator'), 11 out of 13 children jumped by themselves in the second measuring, while two of them couldn't do it. In the first measuring in the same exercise, 11 children out of 13 jumped with the help of the educator. In the second measuring in this group, in exercise 5 ('a child jumps up to 10 times'), all 13 children jumped up to 10 times, while, in the first measuring, only 8 of them could do it. In the activity therapy ball - small, in exercise 3 ('a child is moving on the ball back and forth while lying on the stomach') and 5 ('a child gets off the therapy ball onto the floor with his hands'), in the second measuring of the control group children, small progress was noted although they were not using specified gadgetry same as of the experimental group of children. In the activity peanut-shaped therapy ball, in the second measuring, in exercises 3 ('a child is lying on his stomach on a peanut-shaped therapy ball') and 4 ('a child is moving on the peanut-shaped therapy ball back and forth while lying on the stomach'), small progress can be noticed. None of the children from the control group achieved results in exercises 7 ('a child gets off the peanut-shaped therapy ball onto the floor and makes 4 to 6 steps on his hands') and 8 ('a child comes off the peanut-shaped therapy ball onto the floor and makes 6 to 8 steps on his hands'), unlike the 
children from the experimental group. In the activity balance board, in exercise 3 ('a child is standing on the balance board while holding onto the wall'), in the second measuring in the control group, 12 children stood on the balance board while holding onto the wall, while in the same exercise, in the experimental group of children, the same number of children (12) stood on the balance board by themselves. Almost the same results were achieved in the first and second measuring in all the exercises of the activity funnel spinning. In the activity balancing pad, 10 children achieved results in exercise 3 ('a child is holding onto the balancing pad with his hands and is alternately lifting his left and then his right leg') in the second measuring, while only one child has achieved results in the first measuring in the same exercise. In the activity platform swing, the children achieved almost the same results in all of the exercises. In the activity obstacle course, the children achieved small progress in exercises 1 and 2, while in the other exercises, they achieved almost the same results in the first and second measurement. In the activity walking and climbing on slopes and substrates, the children achieved small progress in the second measurement, in exercises 4 ('walking on the sensory tactile path with three different substrates without holding onto something and picking items off the floor') and 6 ('climbing up and down the spongy stairs-walking'), while they achieved almost the same results in the first and second measuring in other activities. In the activity lifting and carrying, they achieved almost the same results as in first and second measuring, and in the activity pushing, they achieved small progress in exercise 2 ('pushing a $5 \mathrm{~kg}$ box with your feet').

\section{Differences between the Experimental and Control Group in two Measurements Regarding the Applications of Sensory Stimulation}

Two statistical analyses were conducted with the aim of determining possible differences in children's psychomotor abilities. The Mann-Whitney (independent samples) test was applied to test the differences between the experimental and control group, separately for the first and second measurement., while the Wilcoxon test (dependent samples) was conducted to test the differences within the same group (separately for experimental and control) regarding the first and second measurement.

Experimental group - two measurements. Neither the children from the control nor from the experimental group had used the specified sensorymotoric gadgetry before the testing. After implementing the sensory-motoric activities, children from the experimental group $(N=17)$ were able to use the sensory-motoric gadgetry and devices on a daily basis. The statistically 
Table 2 The Results of Testing the Difference Significance in the Experimental Group Regarding the two Measurements

\begin{tabular}{|c|c|c|c|c|}
\hline \multirow[t]{2}{*}{ Sensory materials } & \multicolumn{2}{|c|}{ Measurement } & \multirow[t]{2}{*}{$z$} & \multirow[t]{2}{*}{$p$} \\
\hline & $1 s t$ & 2nd & & \\
\hline Trampoline & $2.76(1.09)$ & $4.53(0.62)$ & -3.695 & 0.000 \\
\hline Therapy ball - 'small' & $4.17(1.70)$ & $6.94(0.66)$ & -3.656 & 0.000 \\
\hline Therapy ball - 'peanut-shape' & $4.17(1.63)$ & $7.23(0.83)$ & -3.648 & 0.000 \\
\hline Balance board & $1.70(0.68)$ & $2.00(0.00)$ & -1.633 & 0.102 \\
\hline Funnel spinning & $1.29(0.84)$ & $3.35(0.49)$ & -3.391 & 0.001 \\
\hline Balancing pad & $1.76(0.97)$ & $3.58(0.61)$ & -3.656 & 0.000 \\
\hline Platform swing & $2.41(1.06)$ & $3.88(0.33)$ & -3.246 & 0.001 \\
\hline Obstacle course & $2.94(1.14)$ & $5.11(0.78)$ & -3.691 & 0.000 \\
\hline Walking and climbing* & $3.00(1.41)$ & $6.82(0.39)$ & -3.647 & 0.000 \\
\hline Lifting and carrying & $1.76(0.44)$ & $1.76(0.43)$ & 0.000 & 1.000 \\
\hline Pushing & $1.88(0.33)$ & $1.88(0.33)$ & 0.000 & 1.000 \\
\hline
\end{tabular}

Notes * On slopes and substrates (spongy stairs, climbing cliff, tactile paths). Standard deviations in parenthesis.

significant difference regarding all exercises except in the activities 'balance board,' 'lifting and carrying,' and 'pushing' were determined in this group between two measurements. Table 2 shows the differences between the first and second measurement in the experimental group. Statistically significant differences were determined in the activities that included the trampoline, a therapy ball - small, a peanut-shaped therapy ball, funnel spinning, a balance pad, a platform swing, an obstacle course, walking and climbing on slopes, and substrates. In other words, it has been confirmed that children's progress will be enhanced in the experimental group because the children were exposed to everyday conduct sensory activities and the use of sensory-motoric incentives. However, before running the test of significant differences in the control group between the two measurements, it could not be concluded that the changes in the experimental group are due only to activities implementation. Therefore, further analyses will reveal that. In addition, no change was recorded in the activities 'balance board,' 'lifting and carrying,' and 'pushing.' This can be explained in two ways that should be verifies empirically in future studies. First of all, it is possible that these activities don't really contribute significantly to a child's development and, secondly, the result can be assigned to measurement limitations in this study (the test items or the small group of participants), and to the educator's way of assessment.

Control group - two measurements. Table 3 shows the differences be- 
Table 3 The Results of Testing the Difference Significance in the Control Group Regarding the Two Measurements

\begin{tabular}{|c|c|c|c|c|}
\hline \multirow[t]{2}{*}{ Sensory materials } & \multicolumn{2}{|c|}{ Measurement } & \multirow[t]{2}{*}{$z$} & \multirow[t]{2}{*}{$p$} \\
\hline & $15 t$ & 2nd & & \\
\hline Trampoline & $3.07(0.95)$ & $3.31(0.95)$ & -0.952 & 0.341 \\
\hline Therapy ball - 'small' & $3.23(2.31)$ & $4.61(0.51)$ & -2.055 & 0.040 \\
\hline Therapy ball - 'peanut-shape' & $3.38(1.75)$ & $4.46(1.26)$ & -1.750 & 0.080 \\
\hline Balance board & $1.61(0.65)$ & $1.92(0.27)$ & -1.414 & 0.157 \\
\hline Funnel spinning & $1.61(0.76)$ & $1.53(0.66)$ & -0.333 & 0.739 \\
\hline Balancing pad & $1.000(0.41)$ & $2.07(0.76)$ & -2.739 & 0.006 \\
\hline Platform swing & $2.31(0.75)$ & $2.61(0.87)$ & -0.962 & 0.336 \\
\hline Obstacle course & $2.76(1.30)$ & $3.61(1.04)$ & -2.636 & 0.008 \\
\hline Walking and climbing* & $2.15(1.77)$ & $3.61(1.32)$ & -2.625 & 0.009 \\
\hline Lifting and carrying & $1.30(0.48)$ & $1.31(0.48)$ & 0.000 & 1.000 \\
\hline Pushing & $1.38(0.86)$ & $1.38(0.87)$ & 0.000 & 1.000 \\
\hline
\end{tabular}

Notes ${ }^{*}$ On slopes and substrates (spongy stairs, climbing cliff, tactile paths). Standard deviations in parenthesis.

tween the first and second measurement in the control group $(N=13)$. Statistically significant differences were obtained in the following activities: 'therapy ball - small,' 'balance pad,' 'walking and climbing slopes and substrates,' and 'obstacle courses.' Here are evident developmental enhancements in some exercises although the children in the control group were not using the specified sensory-motoric gadgetry and devices. Precisely because of these significant differences, the differences in these activities in experimental group could not be ascribed to the effect of the use of the sensory-motoric equipment, but rather to the maturation effect. Some progress can be noticed in the specified four activities just because of maturation and regardless of what the stimulation from the surroundings might be.

Experimental and control group - first measurement. The primary assumption for this research was that there wouldn't be any differences between the children in the experimental and in control group before introducing sensory activities. One of the prerequisites of the experimental design is to have an experimental and control group that are equal with regards to the critical variables, such as age, gender, and psychomotor abilities so that the final differences between the groups could be ascribed precisely to the effect of the sensory activities and not something else, such as maturation. Well, it was determined that this is not the case in this study, since the groups were significantly different from the starting point of the measurement due to non- 
Table 4 The Results of Testing the Difference Significance in the First Measurement Regarding the Two Groups

\begin{tabular}{lrrrr}
\hline Sensory materials & \multicolumn{2}{c}{ Group } & $z$ & $p$ \\
\cline { 2 - 4 } & Experimental & Control & & \\
\hline Trampoline & $2.76(1.09)$ & $3.07(0.95)$ & -0.465 & 0.680 \\
Therapy ball - 'small' & $4.17(1.70)$ & $3.23(2.31)$ & -1.048 & 0.320 \\
Therapy ball - 'peanut-shape' & $4.17(1.63)$ & $3.38(1.75)$ & -1.313 & 0.213 \\
Balance board & $1.70(0.68)$ & $1.61(0.65)$ & -0.679 & 0.621 \\
Funnel spinning & $1.29(0.84)$ & $1.61(0.76)$ & -1.453 & 0.229 \\
Balancing pad & $1.76(0.97)$ & $1.000(0.41)$ & -2.598 & 0.020 \\
Platform swing & $2.41(1.06)$ & $2.31(0.75)$ & -0.245 & 0.837 \\
Obstacle course & $2.94(1.14)$ & $2.76(1.30)$ & -0.307 & 0.773 \\
Walking and climbing* & $3.00(1.41)$ & $2.15(1.77)$ & -1.582 & 0.123 \\
Lifting and carrying & $1.76(0.44)$ & $1.30(0.48)$ & -2.461 & 0.035 \\
Pushing & $1.88(0.33)$ & $1.38(0.86)$ & -1.840 & 0.183 \\
\hline
\end{tabular}

Notes ${ }^{*}$ On slopes and substrates (spongy stairs, climbing cliff, tactile paths). Standard deviations in parenthesis.

random sample. This could be observed in the activities: 'lifting and carrying' and 'balance pad' (Table 4) since there had been significantly higher results already in the first, initial measuring with the children from the experimental group. For these two activities, it isn't possible to explain their changes in the experimental group by means of activities implementation, but rather with the starting differences between the children.

Experimental and control group - second measurement. In two activities, 'balance pad' and 'lifting and caring,' changes cannot be taken into consideration because the children from the two groups weren't on the same primary level of sensory-motoric abilities, i.e., they weren't equal considering their abilities. In other activities, children from the experimental and control group were equal and it is later possible to analyze the differences just from the perspective of the sensory activities' influence, which were introduced in the everyday practice with the experimental group. According to the results in Table 5, which shows the differences between the experimental and control group in the second measurement, it is possible to sum up the results and isolate those activities that show how the everyday use of specified sensory gadgetry, equipment, and activities affects the differences between the results in the experimental and control group. The used gadgetry included: a trampoline, a therapy peanut-shaped ball, and a platform swing.

Those activities in which changes were observed in the control group and 
Table 5 The Results of Testing the Difference Significance in the Second Measurement Regarding the Two Groups

\begin{tabular}{lrrrr}
\hline Sensory materials & \multicolumn{2}{c}{ Group } & $z$ & $p$ \\
\cline { 2 - 3 } & Experimental & Control & & \\
\hline Trampoline & $4.53(0.62)$ & $3.31(0.95)$ & -3.311 & 0.001 \\
Therapy ball - 'small' (+) & $6.94(0.66)$ & $4.61(0.51)$ & -4.777 & 0.000 \\
Therapy ball - 'peanut-shape' & $7.23(0.83)$ & $4.46(1.26)$ & -4.549 & 0.000 \\
Balance board & $2.00(0.00)$ & $1.92(0.27)$ & -1.144 & 0.742 \\
Funnel spinning & $3.35(0.49)$ & $1.53(0.66)$ & -4.602 & 0.000 \\
Balancing pad (o) & $3.58(0.61)$ & $2.07(0.76)$ & -4.100 & 0.000 \\
Platform swing & $3.88(0.33)$ & $2.61(0.87)$ & -4.044 & 0.000 \\
Obstacle course (+) & $5.11(0.78)$ & $3.61(1.04)$ & -3.765 & 0.000 \\
Walking and climbing* $(+)$ & $6.82(0.39)$ & $3.61(1.32)$ & -4.829 & 0.000 \\
Lifting and carrying (o) & $1.76(0.43)$ & $1.31(0.48)$ & -2.461 & 0.035 \\
Pushing & $1.88(0.33)$ & $1.38(0.87)$ & -1.840 & 0.183 \\
\hline
\end{tabular}

Notes ${ }^{*}$ On slopes and substrates (spongy stairs, climbing cliff, tactile paths). Standard deviations in parenthesis.

these differences can be only assigned to maturation and not to sensory stimulations are marked with a plus: therapy ball - small, obstacle course, and walking and climbing on slopes and substrates (spongy stairs, climbing cliff, tactile paths). In two activities, 'balance pad' and 'lifting and caring' (marked with a circle) no changes can be taken into consideration because the children from the two groups weren't on the same primary level of sensory-motoric abilities. These results might have been obtained due to the child's possibility of conducting these activities on a daily basis, such as climbing, walking, jumping, lifting, throwing, etc. so that hey develop their own specified biotic motoric knowledge. In addition, in the activity lifting and carrying, no differences were observed between the two series of measuring in the experimental group.

\section{Conclusion}

Our primary research hypothesis was that there would be differences between children in the experimental and control group before the introduction of sensory activities. It was clearly determined that the implementation of specified sensory activities at an early age could significantly affect an advanced sensory integration development in the nursery school. The inability to confirm this hypothesis with some materials and activities indicates the significance of carefully and accurately selected materials and activities in 
everyday practice, which is one of the most significant contribution of this research paper. Although this research has its own limitations (non-random and relatively small sample of children, choice of specific activities done with children), still, six activities and different materials indicate the significance of stimulating sensory-motoric activities in early-aged children.

It would be beneficial if future studies would make changes to some activities within the measuring instrument that did not render the expected results ('balance board,' 'lifting and carrying,' 'pushing'); or, more precisely, to formulate some exercises in the same measuring instruments in a different way. After the overview of research results, it appears desirable to formulate all the examination activities with the same number of exercises, at least six, so that the children's progress would be more noticeable while using the sensory materials and activities in the initial and final phase. Also, it would be advisable for future studies to maximally adjust the terms of assessment to the terms and the number of children in the group and, also, to the part of the day the examination is done, and to design the way of recording during the exercise presentation with another evaluator. One of the major contributions of this research is seen in the fact that similar research on this topic has not been carried out in Croatia, and the results show the evident effect of the pursuit of early-aged children's wellbeing, which is why sensory activities and incentives from an early age in everyday practice are recommended.

\section{Acknowledgements}

This work has been supported in part by the University of Rijeka under the project number uniri-drustv-18-11: Children's well-being in transition periods; the empirical validation of the ecological-dynamic model.

\section{References}

Ahn R. R., L. J. Miller, S. Milberger, and D. N. Mcintosh. 2004. 'Prevalence of Parents' Perceptions of Sensory Processing Disorders among Kindergarten Children.' The American Journal of Occupational Therapy 58 (3): 287-293.

Ayres, A. J. 1989. Sensory Integration and Praxis Tests. Los Angeles: Western Psychological Services.

- 2009. Dijete i senzorička integracija. Jastrebarsko: Slap.

Ben-Sasson, A., S. Carter, and M. J. Briggs-Gowan. 2009. 'Sensory Over-Responsivity in Elementary School: Prevalence and Social-Emotional Correlates.' Journal of Abnormal Child Psychology 37:705-716.

Biel, L., and N. Peske. 2007. Senzorna integracija iz dana u dan. Buševec: Ostvarenje. 
Boyd, L. A., and S. L. Sobieraj. 2013. 'Kindergarten Readiness: The Impact of Sensory Integration on Preschool Children's Readiness for the Transition to Kindergarten.' Master's Theses, Dominican University of California.

Bundy, A. C., S. Lane, and E. A. Murray. 2002. Sensory Integration: Theory and Practice (2nd ed.). Philadelphia, PA: F. A. Davis.

Cantu, C. O. 2002. 'An Introduction to Early Childhood Sensory Integration.' The Exceptional Parent 32 (4): 47-55.

Dawson, G., S. B. Ashman, and L. J. Carver, L. J. 2000. 'The Role of Early Experience in Shaping Behavioral and Brain Development and its Implications for Social Policy.' Development and Psychopathology 12:695-712.

Fisher, A. G., E. A. Murray, and A. Bundy. 1991. Sensory Integration: Theory and Practice. Philadelphia, PA: F. A. Davis.

Goddard Blythe, S. 2008. What Babies and Children Really Need: How Mothers and Fathers Can Nurture Children's Growth for Health and Wellbeing (Early Years). Howthorn House: Howthorn Press.

Gouze, K. R., J. Hopkins, S. A. LeBailly, and J. V. Lavigne. 2009. 'Re-Examining the Epidemiology of Sensory Regulation Dysfunction and Comorbid Psychopathology.' Journal of Abnormal Child Psychology 37 (8): 1077-1087.

Hannaford, C. 2007. Pametni pokreti. Buševec: Ostvarenje.

Hensch, T. K. 2004. 'Critical Period Regulation.' Annual Review of Neuroscience 27:549-579.

James, K., L. J. Miller, R. Schaaf, D. M. Nielsen, and S. A. Schoen. 2011. 'Phenotypes Within Sensory Modulation Dysfunction.' Comprehensive Psychiatry 52:715-724.

Kraemer, G. W. 2001. 'Developmental Neuroplasticity: A Foundation for Sensory Integration.' In Understanding the Nature of Sensory Integration with Diverse Populations, edited by S. Smith-Roley, E. I. Blanche, and R. C. Schaaf, 43-56. San Antonio, TX: The Psychological Corporation.

Mamić, D., R. Fulgosi Masnjak, and L. Pintarić Mlinar. 2010. 'Senzorna integracija u radu s učenicima s autizmom.' Napredak: časopis za pedagogijsku teoriju i praksu 151 (1): 69-84.

Miller Kuhaneck, H., C. E. Ecker, L. D. Parham, D. A. Henry, and T. J. Glennon. 2010. Sensory Processing Measure-Preschool (SPM-P): Manual. Los Angeles, CA: Western Psychological Services.

Ministarstvo znanosti, obrazovanja i sporta. 2014. Nacionalni kurikulum za rani i predškolski odgoj i obrazovanje. Zagreb: Ministarstvo znanosti, obrazovanja i sporta.

Olson, C. H., D. A. Henry, A. P. Kliner, A. Kyllo, C. M. Richter, J. Charley, M. C. Whitcher, K. R. Reinke, C. H. Tysver, L. Wagner, and L. Walworth. 2016. 'Effectiveness and Usability of the Sensory Processing Measure-Preschool Quick Tips.' Journal of Occupational Therapy, Schools, \& Early Intervention 9 (2): 142-162. 
Sylvester, R. 2000. A Biological Brain in a Cultural Classroom: Enhancing Cognitive and Social Development through Collaborative Classroom Management. Thousand Oaks, CA: Corwin.

Tatalović Vorkapić, S., N. Vlah, and L. Vujičić. 2012. 'Osnaživanje uloge budućih odgajatelja u očuvanju mentalnog zdravlja predškolske djece: promjene studijskog programa.' Život i škola 28 (2): 130-144.

\section{Senzorna integracija kot pot k zvečanju dobrobiti otrok prve starostne skupine}

Senzorični razvoj, dejavnosti in spodbude so več kot pomembni za optimalni razvoj otrok predšolske dobe. Realizacija senzorične integracije je ena od osnovnih nevrobioloških dejavnosti predšolskih otrok, ki je v sodobni znanosti ter praksi temelj za učenje ter danes predstavlja zelo pomembno in aktualno področje raziskav. Pri tem je vloga vzgojiteljev in uporaba različnih senzoričnih materialov in pripomočkov izredno pomembna zunanja spodbuda za otrokove dosežke. Glede na zelo majhno število raziskav na tem področju, zlasti z vidika dela vzgojiteljev $v$ rednih otroških skupinah otrok, je cilj te študije preveriti uporabne senzorične dejavnosti in spodbude za delo $z$ otroki $v$ zgodnji mladosti. Na podlagi tega cilja je narejena primerjava skupin otrok zgodnjega otroštva, v katerih so navedene spodbude prisotne, in tistih, $v$ katerih niso, $v$ namen določitev prednosti razvoja otrok. Eksperimentalna skupina je sestavljala sedemnajst otrok in nadzorna trinajst, starih od enega do dveh let. $\mathrm{Na}$ splošno je bilo potrjeno, da obstajajo znatne razlike med kontrolno in eksperimentalno skupino ravno zaradi uporabe senzoričnih materialov in naprav v eksperimentalni skupini. Ker razlike niso prisotne $v$ vseh pregledamih elementih senzoričnega razvoja, je razprava temeljila na zagotavljanju osnovnih pogojev v vrtcu, da bi spodbudila razvoj senzorične integracije otrok zgodnjega otroštva.

Ključne besede: otroci zgodnjega otroštva, dobro počutje, čutno povezovanje, senzorične dejavnosti in spodbude 



\title{
Slikanice v prvem starostnem obdobju
}

\author{
Janja Batič \\ Univerza v Mariboru \\ janja.batic@um.si \\ Dragica Haramija \\ Univerza v Mariboru \\ dragica.haramija@um.si
}

V prispevku se osredinjamo na branje slikanic otrokom v prvem starostnem obdobju. Razvoj pismenosti je vseživljenjski proces, ki ga odrasli prenašamo na otroke in smo zanj odgovorni. Od otrokovega prvega leta starosti dalje gre za razvijanje družinskega branja, ko otroku berejo njegovi bližnji odrasli (neprofesionalni posredniki branja), z vstopom v vrtec pa se otrok sreča z usmerjenimi izobraževalnimi dejavnostmi, povezanimi s pismenostjo. Slikanice za prvo starostno obdobje so predstavljene glede na oblikovne posebnosti: uporabljeni materiali, velikosti slikanic (za otrokovo rokovanje), oblike slikanic (knjige z zavihki, knjige z vrtljivimi elementi, »pop-up« knjige ...), slikanice z zvočnimi elementi, z dodanimi lutkami ipd. Vsebinske omejitve leposlovnih in informativnih slikanic so predstavljene glede na otrokov celostni razvoj.

Ključne besede: pismenost, slikanice, informativne slikanice, leposlovne slikanice, prvo starostno obdobje.

\section{Uvod}

Razvijanje bralne pismenosti, ki je vseživljenjski proces, se začne kmalu po otrokovem rojstvu s poslušanjem in z opazovanjem (tudi) raznolikega slikaniškega gradiva. Nujni pogoji za otrokov bralni razvoj so dostopna primerna bralna gradiva, ki jih ima otrok doma, obisk knjižnice, odrasli, ki otroku bere, se z njim o prebranem pogovarja in je otroku tudi bralni zgled, torej da ga otrok vidi, da bere (Krolak 2005, 4). Otrok razvija predbralne veščine in zavedanje o tisku, to so smer branja (od leve proti desni), listanje knjige, orientacija v bralnem gradivu, povezovanje slikovnega in besednega dela v slikanici (interakcija) v celostno multimodalno branje besedil; za vse to pa potrebuje seveda odraslega (neprofesionalnega in profesionalnega) posrednika. Pismenost je pomembna zato, ker omogoča posamezniku, da se v družbi udejstvuje, saj brez razumevanja prebranega v informacijski dobi ni mogoče funkcionirati. Branje ni pomembno zgolj za branje in poslušanje leposlovnih besedil, pač pa pismenost pomeni razumevanje vseh pisnih in govorjenih 
besedil.' Zato je zelo pomembno, da otroke izpostavljamo bralnemu gradivu vse od rojstva, hkrati pa menimo, da so slikanice $v$ tem obdobju najprimernejša oblika knjižnega gradiva. V prispevku se naslanjamo na Gradnike bralne pismenosti (gradivo je nastalo v okviru projekta OBJEM, zadnje spremembe I. 2018), ki veljajo za vsa področja dejavnosti predšolskega (in tudi poznejšega) izobraževanja. Posebej se posvečamo tretjemu gradniku, to je razumevanju koncepta bralnega gradiva, čeprav so seveda upoštevani tudi drugi gradniki bralne pismenosti (govor, motiviranost za branje, glasovno zavedanje, besedišče in razumevanje besedil, odziv na besedilo, kritično branje oz. bistvo prebranega besedila), izjema je 6 . gradnik (tekoče branje), ki ga v prvem starostnem obdobju v vrtcu ne moremo razvijati.

\section{Opredelitev slikanice}

Slikanica je posebna oblika knjige, ki združuje najmanj dva koda sporočanja, to sta jezikovni (besedilo) in likovni (ilustracije) kod, pri čemer je besedilni del navadno manj obsežen od slikovnega in (načeloma) ne presega 1.800 besed. Slikanice imajo tri osnovne sestavine, in sicer besedilo, ilustracije ter odnos med njima, ki ga imenujemo interakcija (Haramija in Batič 2013, 35).

Glede na funkcijske zvrsti jezika so besedila v otroških slikanicah pisana v umetnostnem (leposlovje) ali strokovnem jeziku (informativne slikanice) ali pa združujejo lastnosti obeh (leposlovno-informativne slikanice). Leposlovna besedila so po nastanku ljudska ali avtorska, glede na zvrstno opredelitev pa sodijo v poezijo ali prozo. Informativna besedila za predšolske otroke, izdana v slikaniški obliki, vsebinsko posegajo na vsa področja dejavnosti, ki jih predšolsko izobraževanje razvija (gibanje, jezik, umetnost, družba, narava, matematika). $V$ leposlovnih slikanicah za predšolske otroke so objavljene raznolike teme, med njimi najpogosteje vprašanja odnosov (otrok - odrasli, otrok - sorojenci, otrok - prijatelji) in sprejemanja različnosti, vključujočih odnosov; vprašanja okolja (kjer se kot zelo uporabna kaže ekosistemska delitev: npr. živali v gozdu, mlaka) in bivanjska vprašanja (predvsem razumevanje samega sebe). Ilustracije v slikanici lahko razdelimo na ilustracije, ki so del parabesedila (naslovnica, vezni listi in notranja naslovnica) ter notranje ilustracije (med seboj se ločijo po velikosti). Ilustracije v slikanicah se med seboj razlikujejo po likovnih tehnikah in materialih, ki jih izbirajo ilustratorji pri oblikovanju ilustracij. Ilustratorji vsebino podajajo tako $z$ načinom upodobitve (črta, barva, zorni kot, fokus ...) kot tudi z izbiro motivov, ki jih upodabljajo

${ }^{1}$ Zato pomemben premik pomeni Priporočilo sveta o ključnih kompetencah za vseživljenjsko učenje (2018), ki na prvo mesto med osmimi ključnimi kompetencami uvršča pismenost. 
(prikaz literarnih likov in prostora, medsebojni odnosi med literarnimi liki, geste, simboli ...). Ilustratorji velikokrat posežejo na področje besedilnega koda sporočanja, in sicer tako, da ilustracijo dopolnijo $z$ intraikoničnim besedilom (napisi v ilustraciji, ponovljeni deli besedila, avtorski zapisi ilustratorja ...).

Besedilo in ilustracije se med seboj povezujejo oblikovno in vsebinsko. Z oblikovnega vidika spremljamo umestitev ilustracij in besedila (npr. besedilo, vstavljeno v barvno enovite dele ilustracije); z vsebinskega vidika pa raziskujemo pomen, ki ga soustvarjajo besedilo in ilustracije. Nikolajeva (2003) govori o interakciji in izpostavi naslednje tri glavne kategorije: simetrična (informacije v ilustraciji in besedilu se ponovijo), komplementarna (informacije se dopolnjujejo) in stopnjevalna (slike presegajo besedilo ali obratno) interakcija.

Branje slikanic otrokom pomeni več kot le branje besedila in pasivno opazovanje ilustracij. »Branje« ilustracij pomeni njihovo natančno opazovanje, opisovanje, analiziranje in interpretiranje. Gre za proces, ki ga vodi odrasel posrednik branja (npr. vzgojitelj, starši). Cilj je otroke čimbolj usmeriti v pozorno opazovanje in iskanje informacij, ki pomenita sestavni del pri razbiranju pomena v slikanici. Posebno pozornost pri branju otrokom morajo odrasli posredniki branja nameniti tudi samemu tisku. Odrasli namreč otroke le redko usmerjajo v posebnosti tiska, npr. velikost in obliko črk, besedilo, zapisano v oblačku, intraikonično besedilo (Piasta idr. 2012). Hkrati pa raziskave kažejo na povezanost med zgodnjim spoznavanjem s tiskom in uspešnejšim razvijanjem bralnih veščin (Marjanovič Umek 2007; Piasta idr. 2012).

\section{Značilnosti slikanic v prvem starostnem obdobju}

J. Dwyer in S. B. Neuman (2008, 490-494) obdobje od rojstva do četrtega leta razdelita $v$ tri skupine, in sicer govorita o knjigah za: dojenčke (od rojstva do 12 mesecev), malčke (od 12 mesecev do treh let) in predšolske otroke (od treh do štirih let). $V$ nadaljevanju se bomo osredotočili (predvsem) na prvi dve skupini. Razumevanje besedil je $v$ tem obdobju močno odvisno od otrokovega govornega razvoja, njegovega obvladovanja besedišča, nenazadnje od njegovega ugodnega ali neugodnega jezikovnega položaja v družini (otrokov materni/prvi jezik; jezik izobraževanja; jezik okolja). L. Marjanovič Umek poudarja npr., da je za otrokov govorni razvoj pomembno malčkovo metajezikovno zavedanje, predvsem pa so za otrokove jezikovne kompetence (Marjanovič Umek 2007, 37) "pomembne že kakovostne socialne interakcije med malčki in starši, starševski govor (govor, ki ga starši namenijo malčkom) in starševski slog«.

Otrokov kognitivni razvoj pri branju in pisanju pogojuje njegovo zmožnost 
vidnega razločevanja (pri čemer mislimo na razločevanje črk in njihovo povezovanje $v$ besede), razumevanje jezikovnih struktur (na vseh jezikovnih ravninah) in besedni zaklad. S. Pečjak $(1995,11)$ navaja, da "pojem besedni zaklad pri branju označuje število besed v pisni obliki, ki jih posameznik prepozna. Bralno besedišče predstavlja pasivno (receptivno) besedišče, ki se razlikuje od besedišča v govoru in pri pisanju, ki je aktivno besedišče. [...] Vsako leto naj bi učenci pridobili od 2700 do 3000 novih besed. [...] Razmerje med aktivnim in pasivnim besediščem je v povprečju 1:3- do 4-kratno, kar pomeni, da je besedišče pri branju 3- do 4-krat večje kot besedišče $v$ govoru ali pri pisanju. Enako je z besednjakom pri dojenčkih in malčkih, pri čemer L. Marjanovič Umek navaja raziskave, ki so opravljene s pomočjo standardiziranega seznama besed (Bates in Goodman 2001), in sicer, da (Marjanovič Umek 2007, 38): »dojenčki, stari 12 mesecev, uporabljajo od o do 52 besed; malčki, stari 16 mesecev, od o do 347 besed; malčki stari 30 mesecev, od 208 do 675 besed. ${ }^{2}$

Pri dojenčkih in malčkih je treba ob besednjaku upoštevati tudi primerno temo, motive, skladnjo, stilistične elemente, vsebino, ki dojenčka ali malčka zanima in jo razume, nenazadnje primerno obliko slikanice. Slednja mora biti premišljeno izbrana tako $z$ vidika uporabljenih materialov kakor tudi velikosti: predvsem so uporabni manjši formati in mehkejši materiali.

J. Dwyer in S. B. Neuman (2008) poudarjata, da morajo biti knjige, ki so namenjene otrokom do enega leta, dovolj debele, da jih lahko otrok prime $v$ roke in obrača strani: strani iz tršega kartona ali mehke plastične mase lahko pripomorejo k razvoju spretnosti, potrebnih za listanje "pravih« knjig. Avtorici pravita tudi, da naj bi otrokom, ki so mlajši od štirih mesecev, ponudili slikanice $z$ močno kontrastnimi barvami, kot sta črna in bela ali rdeča in zelena, ter z večjimi vzorci (Dwyer in Neuman 2008). $Z$ likovnega vidika dojenčkom ponujamo preproste velike slike živali in poznanih vsebin, kot so družinsko življenje, obrazi, hrana, oblačila. Podobe naj bi bile večje in naj bi se nahajale na kontrastnem ozadju (Dwyer in Neuman 2008). V drugem obdobju (od enega do treh let) so otroci motorično spretnejši in obvladujejo knjige standardne velikosti, kljub temu pa morajo biti knjige še vedno iz močnejših in trajnejših materialov.

\footnotetext{
${ }^{2}$ Analiza težavnostnih stopenj besedil je lahko dober pripomoček za določanje (seveda povprečne) zmožnosti otrokovega razumevanja izbranega besedila, npr: A Parent's Guide to Guided Reading (https://www.scholastic.com/parents/books-and-reading/readingresources/book-selection-tips/parents-guide-to-guided-reading.html) ali na spletni strani založbe Harper Collins (https://www.icanread.com/levels/) ali na spletni strani The Lexile Analyser; https://lexile.com/educators/tools-to-support-reading-at-school/tools-to-determine-a -books-complexity/the-lexile-analyzer/).
} 
$V$ drugem letu starosti branje slikanic pomaga otrokom razumeti, da so slike v knjigi simboli oz. predstavitve objektov (Snow in Ninio 1986 po Dwyer in Neuman 2008). Prav zato je zelo pomembna stopnja podobnosti med sliko in predmetom (Ganea, Bloom Pickard in DeLoache 2008). Otroci v drugem letu starosti spoznajo novo besedo ob sliki v slikanici in jo prenesejo na realni predmet ter obratno, ko spoznajo novo besedo za realni predmet, jo prepoznajo tudi v realistični upodobitvi v slikanici. Hkrati pa tega niso sposobni narediti, če je namesto realistične upodobitve prisotna karikaturna. Slednje je pomembno predvsem pri oblikovanju informativnih slikanic. Z likovnega vidika $v$ drugem razvojnem obdobju za otroke izbiramo slikanice $s$ poznanimi podobami, npr. družina, obrazi, hrana, igrače, tematske vsebine, podobe pa naj bi bile na vsaki strani slikanice (Dwyer in Neuman 2008). Okoli tretjega leta otrokove starosti postane pomembna vsebina, otroci se že osredotočijo na zgodbo, in sicer prerastejo stopnjo preprostega opazovanja slik in poimenovanja (Dwyer in Neuman 2008).

$\checkmark$ predbralnem obdobju otroci razbirajo pomene iz ilustracij v slikanicah. Ob branju slikanic in slikanic brez besedila se naučijo rokovati s knjigo, komentirajo ilustracije, sledijo pripovedi in uporabljajo različne strategije. Te so: iskanje (iskanje podatkov iz besedila, slike, lastnih izkušenj), navzkrižno preverjanje (preverjanje, ali je neka nova informacija skladna s tem, kar že poznajo), popravljanje samega sebe (na podlagi novih informacij otroci spremenijo pomen tega, kar so že prebrali oz. slišali) in ponovno branje (Lysaker in Hopper 2015).

\section{Oblikovne posebnosti slikanic za najmlajše otroke}

Slikanice, ki so namenjene otrokom v prvem starostnem obdobju, se od drugih knjig bistveno razlikujejo po materialu. Izdelane so iz blaga, umetne mase ali največkrat iz kartona. Blago in umetne mase, torej mehkejši materiali, rokovanje s knjigo omogočajo že dojenčkom. Pojavljajo pa se tudi kartonke, ki imajo mehkejše platice (slika 1). Slikanice, ki so namenjene otrokom v prvem starostnem obdobju, se razlikujejo tudi po velikosti (slika 2) in obliki (slika 3).

Med slikanicami, ki so namenjene otrokom prvega starostnega obdobja, lahko najdemo takšne nepravilnih oblik, ki posnemajo upodobljene like (prim, avtobus, polh). Nekatere slikanice za malčke izhajajo kot zbirke, npr. dela Lorelle Rizzatti (1993); izdane so lahko tudi v kompletu, npr. škatla Moja knjižnica: prve besede, ki vsebuje osem slikanic (Hrana 2018), gre za prevode kompleta Building Blocks Learning Library: First Words. Nekaj je tudi slikanic, ki imajo dodane ročne lutke ali pa različne odprtine, npr. delo Erica Carla Zelo lačna gosenica (1997). 
Slika 1

Primer slikanice $z$ mehkimi listi (Otrokove prve besede 2011)
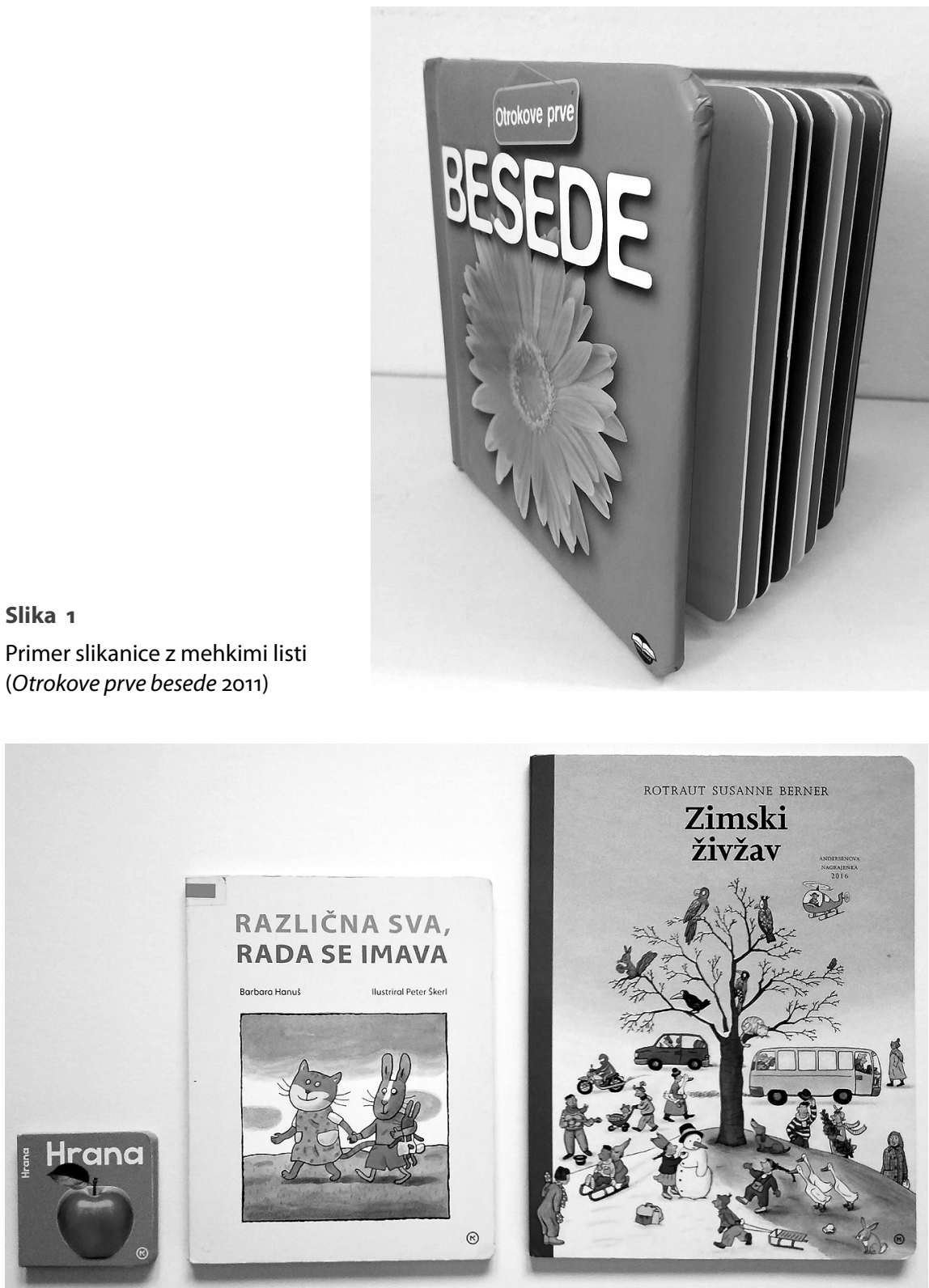

Slika 2 Različne velikosti slikanic (Hrana 2018; Hanuš 2013; Berner 2016)

Pogosta oblika slikanice je tudi leporelo ali zgibanka (slika 4). Marjana Kobe je v monografiji Pogledi na mladinsko književnost (1987, 30-33) povezovala 


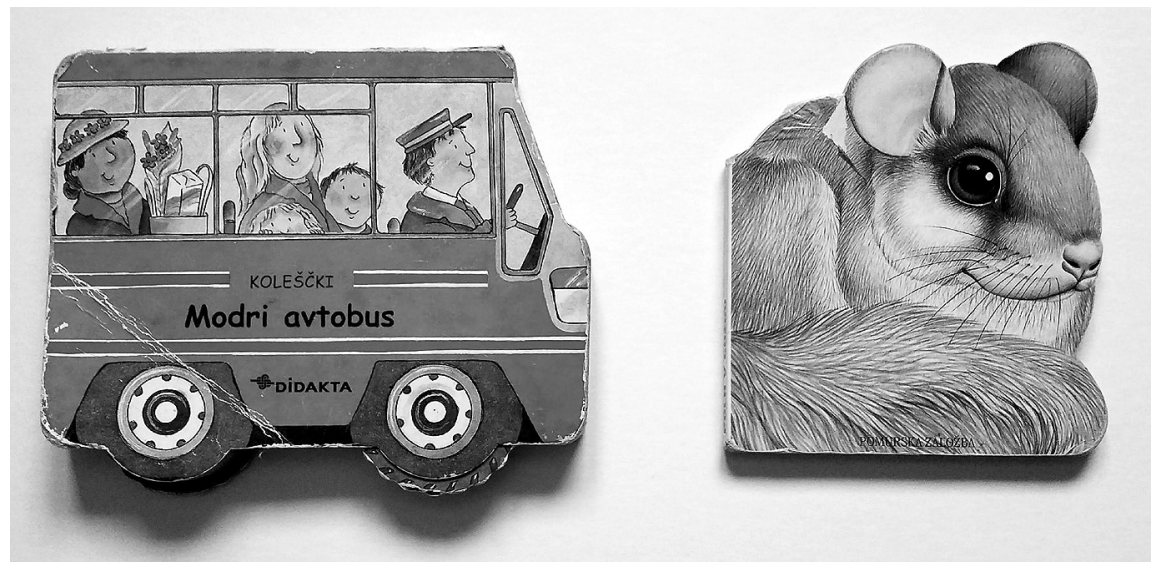

Slika 3 Različne oblike slikanic (Oliver 2010; Rizzatti 1993)

Slika 4

Primer leporela (Grafenauer 2018)

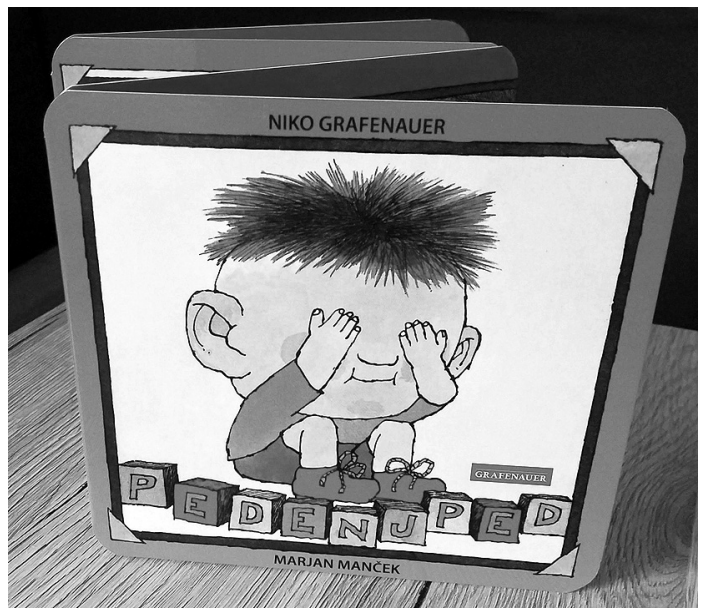

obliko slikanice s starostjo bralca, kar je bilo na podlagi do takrat izdanega gradiva utemeljeno. Teoretičarka je delila slikanice $v$ tri zahtevnostne stopnje: v prvo zahtevnostno stopnjo je uvrščala leporelo ali zložljivo kartonsko zgibanko, ki (Kobe 1987, 30) »še nima oblike knjige. [...] Namenjena je otrokom do 2., 3. leta, zato je po zunanji obliki še nekakšna prehodna stopnja med igračo in 'pravo' knjigo, po vsebini pa doživljajsko najpreprostejša. « Ta oblika slikanice je bila v preteklosti obravnavana kot slikanica za dojenčke, vendar je treba poudariti, da v zadnjem desetletju nastajajo tudi leporela, ki so naslovniško odprta (Peklar 2005), zato oblike knjige ne moremo (več) enačiti s starostno skupino najmlajših bralcev, čeprav še vedno prevladuje $v$ prvem 


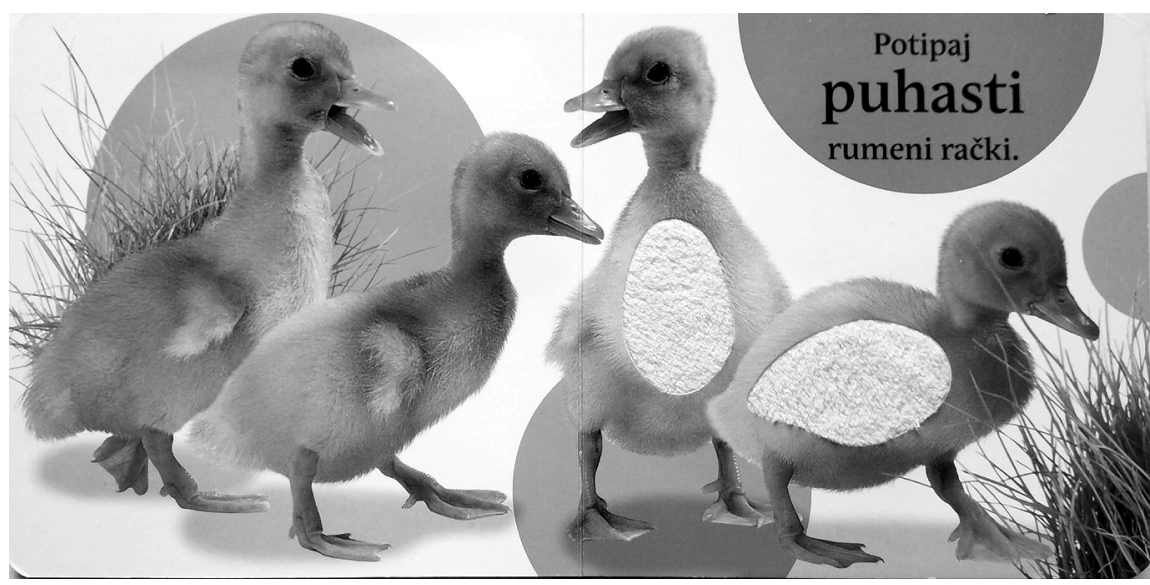

Slika 5 Primer slikanice potipanke (Živalski mladički 2014)

starostnem obdobju. Leporelo lahko ima besedilo (običajno posamezna beseda, največ do dve vrstici) ali pa gre za tip slikanice brez besedila.

Slikanice se razlikujejo tudi po stopnji interaktivnosti: opazujemo lahko, kako z različnimi elementi spodbujajo otroka k rokovanju s knjigo. Pogosto lahko zasledimo t. i. potipanke. Na posameznih straneh slikanice so prisotni različni materiali, ki otroka spodbudijo, da jih potipa in občuti določene lastnosti (gladko, hrapavo, mehko, trdo itd.) Problem, ki se pri tem pojavi, je vstavljanje različnih materialov v informativne slikanice.

Na sliki 5 lahko opazujemo kolaž podob - štiri račje mladiče, modre kroge na belem ozadju in travo. Trup dveh mladičev je oblikovan tako, da je v podobo vstavljeno blago (na otip spominja na brisačo). V vstavljenem besedilu je navodilo »Potipaj puhasti rumeni rački.« Informacija, ki jo dobi otrok, je povsem napačna, saj puh račjih mladičev na otip ni enak kot površina vstavljenega blaga. Glede na to, da je delež informativnih slikanic mnogo manjši od deleža leposlovnih slikanic (Ganea, Ma in DeLoache 2011), je zelo težko izbrati kakovostno informativno slikanico. Hkrati pa raziskave kažejo, da lahko štiriletni otroci informacije v slikanicah s področja naravoslovja prenesejo $v$ pojasnjevanje življenjskih situacij, npr. spoznavanje živali (Ganea, Ma in DeLoache 2011).

$V$ to skupino lahko uvrstimo tudi zvočne slikanice in slikanice s premičnimi elementi. Zvočne slikanice so največkrat oblikovane tako, da otrok pritisne na sličico in s tem aktivira zvok: oglašanje živali, prevozna sredstva ipd. (slika 6).

V originalu ima slikanica Kajetana Koviča Maček Muri (1975) približno 10 strani besedila ( $v$ to je všteto tudi 6 pesmi). Po obsegu torej Maček Muri pre- 


\section{Slika 6}

Primer zvočne knjige (Kovič 2014)

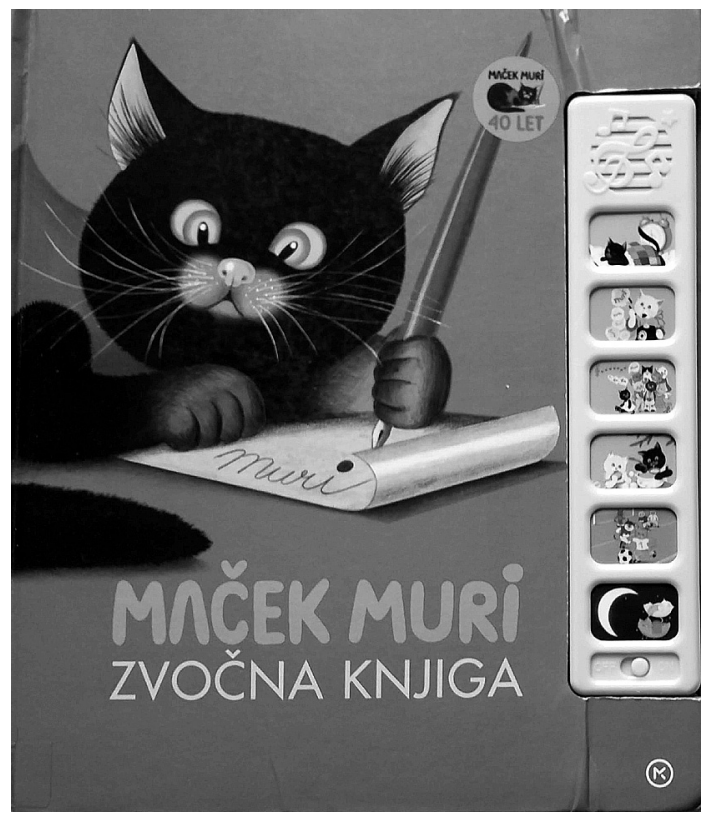

sega 1. otrokovo starostno obdobje, je pa res, da je Muri sam po sebi blagovna znamka. ${ }^{3}$ Zvočna knjiga vsebuje le po nekaj vrstic posamezne pesmi iz izhodiščne slikanice, je brez proznega besedila.

K aktivnosti otroke spodbujajo tudi knjige s premičnimi elementi: (1) »popup« knjige (ob odpiranju strani se v prostor dvigujejo tridimenzionalne oblike, (2) knjige z vrtljivimi elementi: $z$ vrtenjem posameznih elementov v slikanici se odkrivajo nove podobe, (3) knjige v obliki kukala, (4) knjige z zavihki: ta oblika knjig ima delčke, ki jih mora bralec dvigniti, da bi videl, kaj se skriva pod njimi (slika 7 zgoraj in spodaj), (5) knjige $z$ okenci »povleci in poglej« - po namenu enake slikanicam z zavihki, saj prav tako spodbujajo otrokovo aktivnost in radovednost. Začetnik slikanic s premičnimi elementi je Eric Hill, ki je leta 1980 izdal prvo knjigo o Pikiju, v slovenščini Kje je Piki? (Hill 1990). ${ }^{4}$

${ }^{3}$ Literarni lik mačka Murija srečamo tudi kot plišasto lutko, igralne kocke, posteljnino, mehko knjigo iz blaga, miniaturko, lonček, interaktivno multimedijsko knjigo ipd. Blagovno znamko je Mladinska knjiga ustvarila tudi s slikanico Ele Peroci Muca Copatarica (1957), ki je trenutno slikanica z drugo najvišjo naklado na Slovenskem (173.00o izvodov), Maček Muri (Kovič 1975) je na tretjem mestu (171.00o izvodov); na prvem mestu je naslovniško odprta slikanica Martin Krpan (1954) Frana Levstika (več kot 250.000 izvodov). Za podatke o številu izdaj se zahvaljujemo urednici pri Mladinski knjigi Ireni Matko Lukan.

${ }^{4}$ Eric Hill (1927-2014) je s serijo o Pikiju doživel nesluten uspeh: prevedena je v več kot 60 jezikov, 


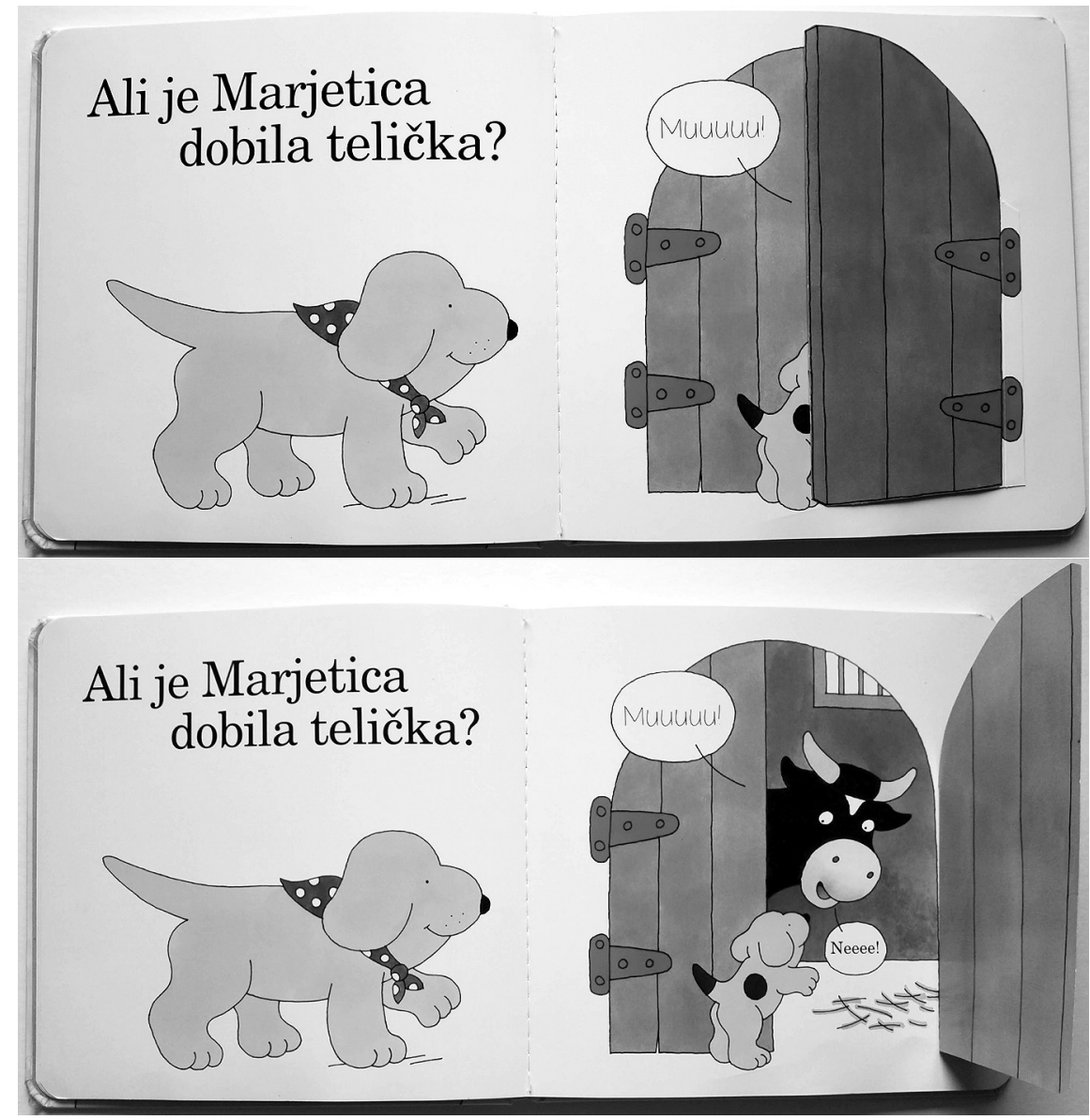

Slika 7 Primer knjige z zavihki (Hill 2014)

\section{Vsebinske posebnosti slikanic za najmlajše otroke}

Slikanice, ki so namenjene otrokom v prvem starostnem obdobju, se razlikujejo po količini besedila in ilustracij. Za najmlajše otroke so pogoste slikanice brez besedila ali z eno besedo na stran (fotografija ali ilustracija predmeta in njegovo poimenovanje). Sledijo slikanice $s$ krajšim besedilom, ki je običajno zasnovano kot naloga, usmerjajoča otrokovo pozornost. Tak primer je slikanica z naslovom Muca pa nagaja Slavice Remškar (2015), ki je sestavljena iz enajstih parov ilustracij (slika 8).

v nakladi več kot 60 milijonov knjig; za uspeh je gotovo zaslužna tudi produkcija animiranih filmov. 


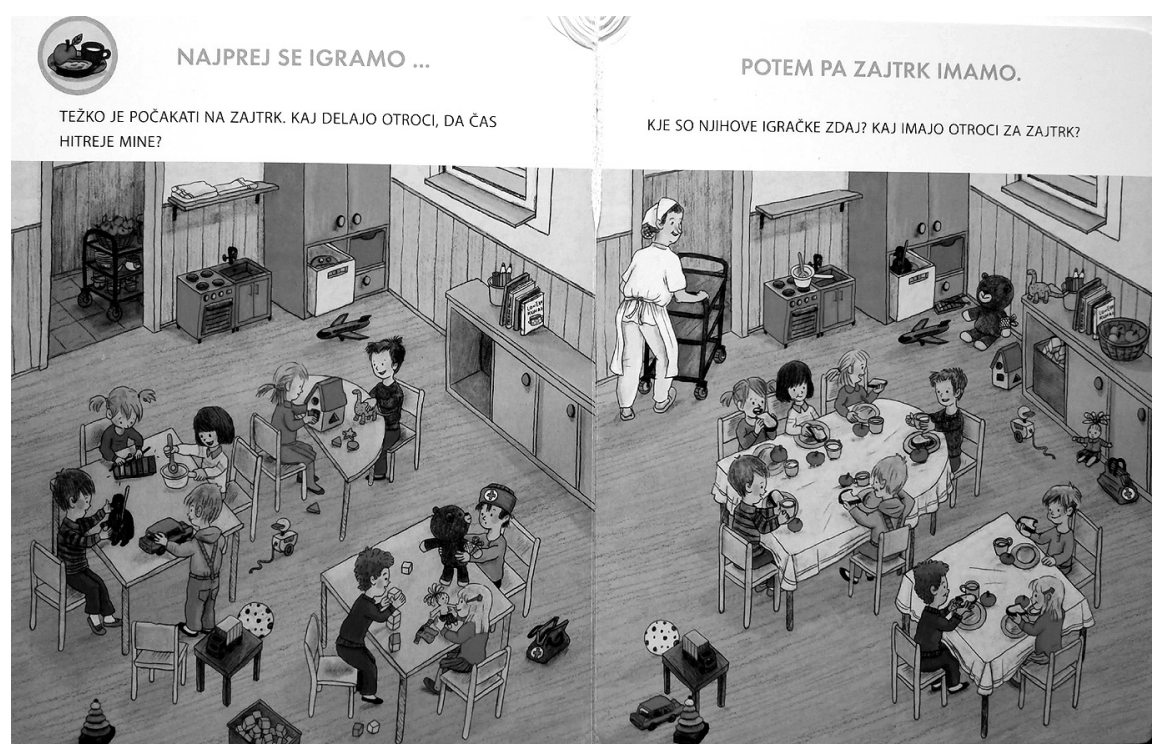

Slika 8 Primer slikanice z nalogo (Remškar 2015)

Pari ilustracij so zasnovani tako, da je upodobljeno stanje prej in potem. Pripadajoče besedilo na levi strani opiše stanje, npr. »Nobenega otroka ni več v vrtcu. Nobene vzgojiteljice. Niti snažilke. V igralnico pa je prišla mala vila!« (Remškar 2015), ali pa postavi vprašanje, npr. »Težko je počakati na zajtrk. Kaj delajo otroci, da čas hitreje mine?« (Remškar 2015). Ilustracije na desni strani pa so večinoma dopolnjene $z$ vprašanji, ki otroka usmerijo $v$ iskanje razlik med levo in desno stranjo $v$ slikanici.

Naslednji primer slikanice, ki otroka usmerja v aktivno sodelovanje, je slikanica z naslovom Medvedek, kaj delaš? Slavice Remškar (2014). Slikanica je sestavljena iz šestih zgodb, ki prikazujejo medvedka pri različnih dejavnostih. Interakcija med besedilom in ilustracijo je izrazito dopolnjujoča, saj pomena ne moremo razbrati, če med branjem besedila ne opazujemo ilustracij. Posamezna zgodba je dolga tri ali štiri strani. Na vsaki strani so štiri ali tri manjše ilustracije. Slikanica je zasnovana tako, da je skoraj pod vsako ilustracijo pripadajoče besedilo oz. vprašanje, ki spodbuja otrokovo opazovanje (slika 9).

V slikanici Barbare Hanuš Različna sva, rada se imava (2013) sta oblika in postavitev besedila takšni, da otroku v predbralnem obdobju omogočata sodelovanje pri branju besedila. Slikanica je zasnovana tako, da je v zgornjem delu strani postavljena ilustracija, pod njo je umeščeno besedilo. Besedilo vključuje manjši ilustraciji - glavo mačke in zajca -, na vsaki strani ti dve ilustraciji 


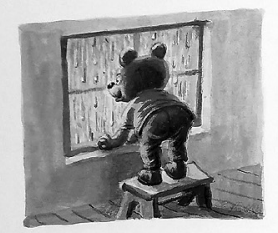

O, DEŽUJE!

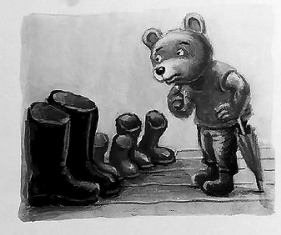

KATERI SKORNUI

SO MEDVEDKOVI?

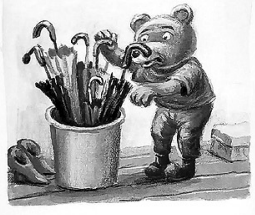

KJE JE MEDVEDKOV DEŻNIK?

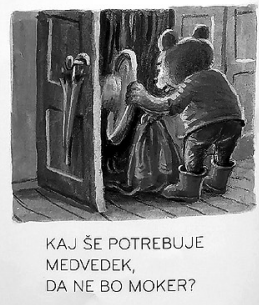

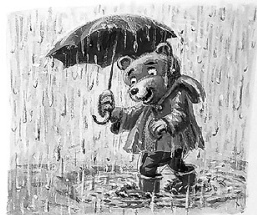

BODO NOGE MOKRE? NE MEDVEDEK IMA ŚKORNJE.

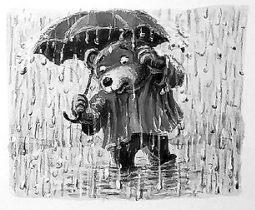

JOJ, NOGE SO MOKRE. ZAKAJ?

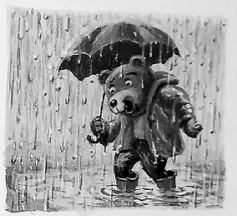

BODO NOGE MOKRE? HEJ VODE JE ZELO VELIKO

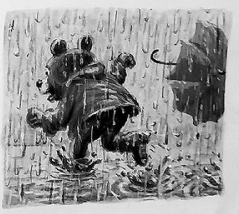

BO MEDVEDEK MOKER? MALO ŽE

Slika 9 Primer slikanice, ki otroka usmerja v aktivno sodelovanje (Remškar 2014)

opozarjata na dialog med literarnima likoma; gre torej za dramsko delo, saj slikanica vsebuje dialoge brez veznega besedila ali didaskalij. Besedilo je napisano v črni barvi, v vsaki povedi pa se pojavi beseda, ki je natisnjena v drugi barvi (npr. zajec pove, da hodi pod rumenim dežnikom; beseda dežnik je zapisana v rumeni barvi). Barva izpostavljene besede se likovno navezuje na zgornjo ilustracijo (slika 10). Ob koncu slikanice so dodane naloge, primerne za otroke v prvem starostnem obdobju.

K vsebinskim posebnostim slikanic za otroke v prvem starostnem obdobju lahko umestimo tudi odnos med besedilom in ilustracijo. Praviloma se informacija, ki je podana $v$ besedilu, ponovi v ilustraciji, zato govorimo o simetrični interakciji (Nikolajeva 2003) (slika 11). Tako lahko vidimo npr. fotografijo predmeta in poimenovanje (npr. beseda avto in fotografija avtomobila). Kljub temu je potrebno otroke usmerjati v opazovanje slikovnega dela (npr. spodbudimo otroka, da pokaže, kje ima avtomobil kolesa, brisalce ..., pove, kakšne barve je avto ipd.). Pri kompleksnejših ilustracijah v slikanicah, ki so primerne za prvo starostno obdobje, lahko $z$ otroki raziskujemo razpoloženje, čustvena stanja ipd. Dober primer simetrične interakcije je zbirka slikanic Gaje Kos o grdavših (2010; 2016; 2018).

Slikopisi so posebna oblika slikanic, ki imajo dopolnjevalno interakcijo: del pomena zgodbe izvemo iz besedila, $v$ vsaki povedi pa so posamezne besede 


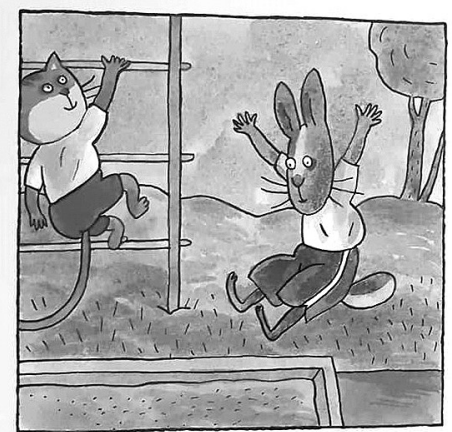

RAD SKAČEM

JAZ PA RADA PLEZAM.

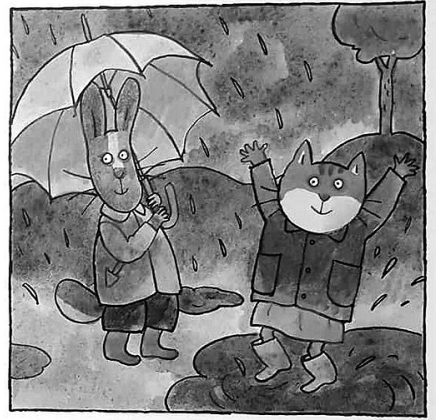

RADA HODIM PO LUŽAH.

KO DEŽUJE, SE SKRIJEM POD DEŽNIK.

Slika 10 Primer dialoga v slikanici (Hanuš 2013)

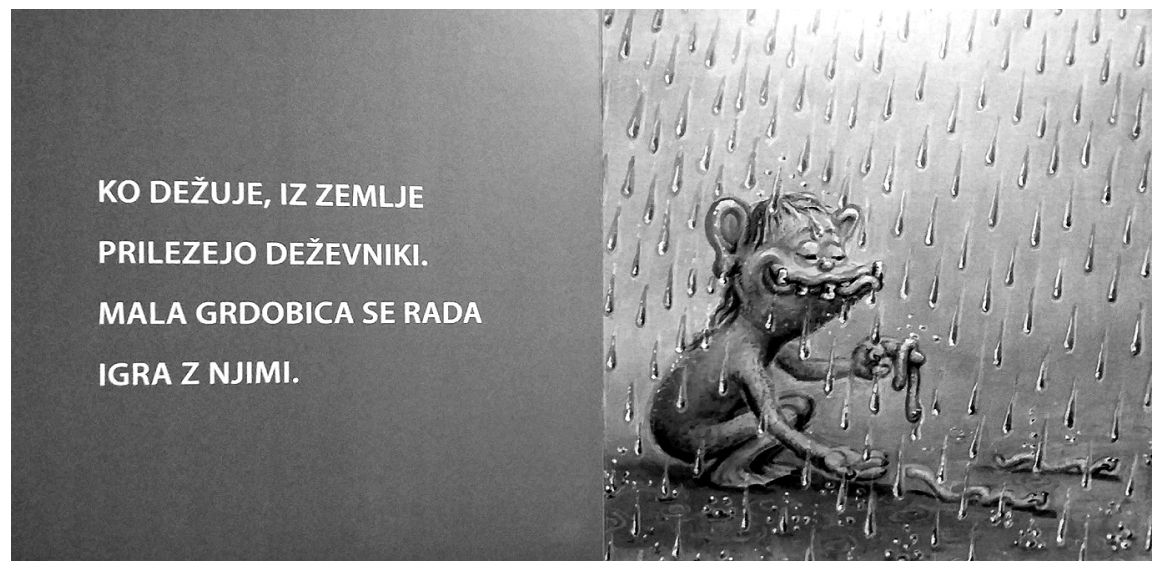

Slika 11 Primer simetrične interakcije (Kos 2016)

nadomeščene s sličicami, torej del zgodbe izvemo samo skozi ilustracije. Te nadomeščajo večinoma samostalnike, redkeje tudi glagole. Večinoma so slikopisi dobra spodbuda pri začetnem opismenjevanju, so pa tudi preizkušena bralna spodbuda za mlajše otroke. Sličice morajo biti takšne, da otrok nemudoma ugotovi, katere besede nadomeščajo sličice ( $v$ slabem slikopisu bralec ni povsem prepričan, ali je povedal pravo besedo za sličico). Veliko slikopisov za najmlajše ustvarjajo npr. Urša Krempl in ilustratorka Urška Stropnik Šonc 
kot stalni ustvarjalni tim (Krempl 2003; 2009a; 2009b), Cvetka Sokolov z različnimi ilustratorkami, npr. z Ano Zavadlav (Sokolov 2012) ali Tanjo Komadina (Sokolov 2014), ter Slavica Remškar z Bojano Dimitrovski (2013).

Proti koncu prvega starostnega obdobja otrokom ponudimo kakovostne leposlovne slikanice s trdimi platnicami in tankimi (navadnimi) vložnimi listi; paziti je treba, da besedila niso predolga in da motivno-tematsko ustrezajo tej starosti. Podajamo nekaj primerov kakovostnih izvirnih slovenskih slikanic, ki so bile preizkušene tudi z otroki tega starostnega obdobja. ${ }^{5}$

\section{Sklep}

Leposlovne in informativne slikanice, ki so primerne za prvo starostno obdobje, imajo enake zakonitosti kot vsa kakovostna literatura: spoznavna, etična in estetska plast morajo biti $v$ besedilu, ilustraciji in $v$ njuni interakciji (oz. vsebinsko-oblikovnem odnosu) odlične. Z vsebinskega stališča morajo biti izbrana takšna besedila, ki jih otrok zmore razumeti (paziti je potrebno na dolžino besedila, na število različnih besed, ki se v nekem besedilu pojavljajo, na temo in motive, ki so otroku blizu), zanemarljiva pa ni niti oblikovna podoba (materiali, velikost, oblika slikanic ipd.).

Leposlovne slikanice za dojenčke in malčke morajo biti skrbno izbrane, namenjene morajo biti njihovim kognitivnim zmožnostim. Različne skrajšave, ki jih najdemo na tržišču, so večinoma zgrešene, saj gre za prirejanje besedil, namenjenih bistveno starejšim otrokom. Ali, kakor opozarjajo v smernicah za otroške knjižnice, namenjene populaciji od o-18 let (International Federation of Library Associations 2018, 13): „Otroci niso homogena ciljna skupina. Njihove različne sposobnosti, nadarjenosti, talenti in potrebe se razlikujejo glede na njihovo starost, kulturno, sociološko in ekonomsko ozadje.« V prvem starostnem obdobju, ko se otrok šele uči besedišča in osnovnih konceptov razumevanja sveta, ne more razumeti besedil - četudi zelo skrajša-

\footnotetext{
${ }^{5}$ Npr. Pojte, pojte, drobne ptice, preženite vse meglice (2017), Pleši, pleši, črni kos! (2017), Biba buba baja (Voglar 2019), Živalske uspavanke (Prap 2018), Male živali (Prap 2006), Mojočka (Prap 2007), Kuža Pazi (Bitenc 2007), Lestev in sirček (Košuta 2001), Lončekna pike (Štefan 2019), Škratjev sadovnjaku (Gregorič Gorenc 2017č), Škratje na vrtu (Gregorič Gorenc 2017b), Škratje v gozdu (Gregorič Gorenc 2017c), Škratje na kmetiji (Gregorič Gorenc 2017a), Muca Copatarica (Peroci 1957), Plašček za Barbaro (Zupan 1974), Mali medo (Kovač 2019), Kako sta Bibi in Gusti preganjala žalost (Mlakar 2004), Kako sta Bibi in Gusti porahljala prepir (Mlakar 2006), Kako sta Bibi in Gusti sipala srečo (Mlakar 2010), Velika žehta (Möderndorfer 2011), Petelinček (Radovanovič 2014), Iščemo hišico (Štefan 2019), Žiga špaget gre v širni svet (Kermauner 2010), Žiga špaget je za punce magnet (Kermauner 2017), Sovica Oka (Makarovič 2017), O mrožku, ki si ni hotel striči nohtov (Svetina 1999), Mrožek dobi očala (Svetina 2003), Ringaraja (Svetina 2009), Medved in Miška 1 (Koren 2010), Medved in Miška 2 (Koren 2013).
} 
nih -, ki presegajo njegovo izkušnjo. Dober primer so npr. dela Davida McKeeja (1998a; 1998b; 1998c; 1998č) o slončku Elmerju, pri čemer ne gre za skrajšave, temveč za postopnost: otrokom v prvem starostnem obdobju so namenjene kartonke o Elmerjevih barvah, prijateljih ...v drugem starostnem obdobju pa preide na poslušanje izhodiščne slikanice o vključujočih odnosih. Kakovostne informativne slikanice se odlikujejo po slikovnem gradivu, ki nazorno prikazuje nek predmet (fotografijo ali realistično upodobitev nekega predmeta ali pojava). Kakovostne slikanice za otroke prvega starostnega obdobja so, ob nesporni jezikovni in likovni podobi, zasnovane tako, da na besedilni in oblikovni ravni otroka spodbujajo k aktivnemu sodelovanju, torej k poslušanju, natančnemu opazovanju ilustracij, sledenju natisnjenemu besedilu, iskanju informacij $v$ besedilu in sliki ter podajanju odgovorov na vprašanja.

\section{Zahvala}

Avtorici sta prispevek napisali v okviru projekta OBJEM - Bralna pismenost in razvoj slovenščine (Ozaveščanje, Branje, Jezik, Evalvacija, Modeli), šifra projekta OP20.01462, vodja dr. Sandra Mršnik, ki ga vodi Zavod RS za šolstvo; naložbo sofinancirata Republika Slovenija in Evropska unija iz Evropskega socialnega sklada.

Za dovoljenje za objavo ilustrativnega gradiva se avtorici zahvaljujeta založbam Mladinska Knjiga, Grafenauer in Miš.

\section{Literatura}

Bates, E., in J. C. Goodman. 2001. »On the Inseparability of Grammar and the Lexicon: Evidence from Acquisition. "V Essential Readings in Developmental Psychology: Language Development; The Essential Readings, ur. M. Tomasello in E. Bates, 134-162. Malden: Blackwell.

Berner, R. S. 2016. Zimski živžav. Ljubljana: Mladinska knjiga.

Bitenc, J. 2007. Kuža Pazi. Ilustrirala D. Simčič. Ljubljana: Erimas.

Carl, E., 1997. Zelo lačna gosenica. Ljubljana: Epta.

Dwyer, J., in B. S. Neuman. 2008. »Selecting Books for Children Birth Through Four: A Developmental Approach.« Early Childhood Education Journal 35 (6): 489-494.

Ganea, A. P., M. Bloom Picard in J. S. DeLoache. 2008. »Transfer between Picture Books and the Real World by Very Young Children." Journal of Cognition and Development 9 (1): 46-66.

Ganea, A. P., P. Ma in J. S. DeLoache, J. S., 2011. "Young Children's Learning and Transfer of Biological Information from Picture Books to Real Animals." Child Development 82 (5): 1421-1433.

Grafenauer, N. 2018. Pedenjped. Ilustriral M. Manček. Ljubljana: Grafenauer. 
Gregorič Gorenc, B. 2017a. Škratje na kmetiji. Ilustrirala A. Gregorič. Murska Sobota: Ajda.

- 2017b. Škratje na vrtu. Ilustrirala A. Gregorič. Murska Sobota: Ajda.

—. 2017c. Škratje v gozdu. Ilustrirala A. Gregorič. Murska Sobota: Ajda.

_. 2017č. Škratje v sadovnjaku. Ilustrirala A. Gregorič. Murska Sobota: Ajda.

Hanuš, B. 2013. Različna sva, rada se imava. Ilustriral P. Škerl. Ljubljana: Mladinska knjiga.

Haramija, D., in J. Batič. 2013. Poetika slikanice. Murska Sobota: Franc-Franc.

Hill, E. 1990. Kje je Piki? Ljubljana: Mladinska knjiga.

- 2014. Piki obišče kmetijo. Ljubljana: Mladinska knjiga.

Hrana. 2018. Ljubljana: Mladinska knjiga.

International Federation of Library Associations. 2018. IFLA Guidelines for Library Services to Children aged o-18. Ur. Carolynn Rankin. Haag: International Federation of Library Associations.

Kermauner, A. 2010. Žiga špaget gre v širni svet. Ilustriral Z. Čoh. Dob: Miš.

—. 2017. Žiga špaget je za punce magnet. Ilustriral Z. Čoh. Ljubljana: Zveza društev gluhih in naglušnih Slovenije.

Kobe, M. 1987. Pogledi na mladinsko književnost. Ljubljana: Mladinska knjiga.

Koren, M. 2010. Medved in Miška 1. Ilustriral B. Jurc. Čedad: Zadruga Novi Matajur.

- 2013. Medved in Miška 2. Ilustriral B. Jurc. Čedad: Zadruga Novi Matajur. Kos, G. 2010. Grdavši. Ilustriral Z. Čoh. Dob pri Domžalah: Miš.

. 2016. Grdavši in dež. Ilustriral Z. Čoh. Dob pri Domžalah: Miš. . 2018. Grdavši in presenečenje. Ilustriral Z. Čoh. Dob pri Domžalah: Miš.

Košuta, M. 2001. Lestev in sirček. Ilustrirala M. Kozjek. Ljubljana: Mladinska knjiga.

Kovač, P. 2019. Mali medo. Ilustrirala J. Reichman. Ljubljana: Mladinska knjiga.

Kovič, K. 1975. Maček Muri. Ilustrirala J. Reichman. Ljubljana: Mladinska knjiga.

—. 2014. Maček Muri. Ilustrirala J. Reichman. Zvočna knjiga. Ljubljana: Mladinska knjiga.

Krempl, U. 2003. Zgodbe v sličicah. Ilustrirala U. Stropnik Šonc. Domžale: Studio Hieroglif.

- 2009. Pravi prijatelj. Ilustrirala U. Stropnik Šonc. Mengeš: Izolit.

- 2009. Zajčkove počitnice. Ilustrirala U. Stropnik Šonc. Mengeš: Izolit.

Krolak, L., 2005. The Role of Libraries in the Creation of Literate Environments. Hamburg: UNESCO.

Levstik, F. 1954. Martin Krpan. Ilustriral T. Kralj. Ljubljana: Mladinska knjiga.

Lysaker, J., in E. Hopper. 2015. »A Kindergartner's Emergent Strategy Use during Wordless Picture Book Reading.« The Reading Teacher 68 (8): 649-657.

Makarovič, S. 2017. Sovica Oka. Ilusdtriral G. Vahen. Ljubljana: Mladinska knjiga. Marjanovič Umek, L. 2007. »Vloga otroškega govora v razvoju zgodnje in kasnejše pismenosti.«V Stopenjskost pri usvajanju pismenosti: postopen pouk 
bralne pismenosti na vseh ravneh šolanja, ur. J. Vintar, 36-47. Ljubljana: Zavod Republike Slovenije za šolstvo.

McKee, D. 1998a. Elmerjeve barve. Ljubljana: Korotan.

—. 1998b. Elmerjev dan. Ljubljana: Korotan.

-1998c. Elmerjevi prijatelji. Ljubljana: Korotan.

-1998č. Elmerjevo vreme. Ljubljana: Korotan.

Mlakar, I. 2004. Kako sta Bibi in Gusti preganjala žalost. Ilustrirala K. Krhin. Radovljica: Didakta.

_. 2006. Kako sta Bibi in Gusti porahljala prepir. Ilustrirala K. Krhin. Radovljica: Didakta.

- 2010. Kako sta Bibi in Gusti sipala srečo. Ilustrirala K. Krhin. Radovljica: Didakta.

Möderndorfer, V. 2011. Velika žehta. Ilustrirala T. Komadina. Ljubljana: Mladinska knjiga.

Nikolajeva, M. 2003. »Verbalno in vizualno: slikanica kot medij." Otrok in knjiga 30 (58): 5-26.

Oliver, J. 2010. Modri avtobus. Radovljica: Didakta.

Otrokove prve besede. 2011. Ljubljana: Mladinska knjiga.

Pečjak, S. 1995. Ravni razumevanja in strategija branja. Trzin: Different.

Peklar, A. 2005. Fant z rdečo kapico. Ljubljana: Inštitut za likovno umetnost.

Peroci, E. 1957. Muca copatarica. Ilustrirala A. Gošnik Godec. Ljubljana: Mladinska knjiga.

Pleši, pleši, črni kos! 2017. Ilustrirala M. Stupica. Ljubljana: Mladinska knjiga.

Pojte, pojte, drobne ptice, preženite vse meglice. 2017. Ilustrirala M. Stupica. Ljubljana: Mladinska knjiga.

Projekt OBJEM. 2018. »Gradniki bralne pismenosti.« Delovno gradivo, Zavod Republike Slovenije za šolstvo, Ljubljana.

Piasta, S. B., L. M. Justice, A. S. McGinty in J. N. Kaderavek. 2012. »Increasing Young Children's Contact With Print During Shared Reading: Longitudinal Effects on Literacy Achievement."Child Development 83 (3): 810-820.

Peroci, E. 1957. Muca copatarica. Ilustrirala A. Gošnik Godec. Ljubljana: Mladinska knjiga.

Prap, L. 2006. Male živali. Ljubljana: Mladinska knjiga.

- 2007. Moj očka. Ljubljana: Mladinska knjiga.

_. 2017. Živalske uspavanke. Ljubljana: Mladinska knjiga.

Priporočilo sveta o ključnih kompetencah za vseživljenjsko učenje. 2018. Uradni list Evropske unije $\mathrm{C} 189$.

Radovanovič, V. 2014. Petelinček. Ilustrirala K. Krhin. Murska Sobota: Ajda.

Remškar, S. 2013. Leto, leto pisano. Ilustrirala B. Dimitrovski. Ljubljana: Mladinska knjiga.

_. 2014. Medvedek kaj delaš? Ilustriral Z. Čoh. Ljubljana: Mladinska knjiga. 
. 2015. Muca pa nagaja. Ilustrirala T. Komadina. Ljubljana: Mladinska knjiga.

Rizzatti, L. 1993. Polh v gozdu. Murska Sobota: Pomurska založba.

Snow, C., in A. Ninio. 1986. »The Contracts of Literacy: What Children Learn from Learning to Read Books." V Emergent Literacy: Writing and Reading, ur. W. Teale in E. Sulzby, 116-138. Norwood, NJ: Ablex.

Sokolov, C. 2014. In kaj boš po poklicu ti? Ilustrirala T. Komadina. Ljubljana: Mladinska knjiga.

. 2012. V našem vrtcu. Ilustrirala A. Zavadlav. Ljubljana: Mladinska knjiga. Svetina, P. 1999. O mrožku, ki si ni hotel striči nohtov. Ilustrirala M. Osojnik. Ljubljana: Mladinska knjiga.

—. 2003. Mrožek dobi očala. Ilustrirala M. Osojnik. Ljubljana: Mladinska knjiga.

- 2009. Ringaraja. Ilustriral M. Manček. Ljubljana: Mladinska knjiga.

Štefan, A. 2016. Iščemo hišico. Ilustrirala A. Gošnik Godec. Ljubljana: Mladinska knjiga.

-2019. Lončekna pike. Ilustrirala J. Reichman. Ljubljana: Mladinska knjiga. Voglar, M. 2019. Biba buba baja. Ilustrirala L. Osterc. Ljubljana: Mladinska knjiga. Zupan, V. 1974. Plašček za Barbaro. Ilustrirala M. L. Stupica. Ljubljana: Mladinska knjiga.

Živalski mladički. 2014 Ljubljana: Mladinska knjiga.

\section{Picture Books in Early Childhood}

This paper focuses on reading picture books to children in early childhood. Literacy development is a lifelong process which adults pass to children and are responsible for. During the child's first year, the focus is on the development of family reading, as children are read by the adults within their family (nonprofessional reading intermediaries). However, when a child starts the kindergarten, he or she is faced with targeted learning activities related to literacy. Early childhood picture books are introduced according to their special design features: materials used, book size (child appropriate), form (lift-the-flap books, books with rotating elements, pop-up books, etc.), picture books using sound effects, puppets, etc. Content-related restrictions of literary and informative picture books are introduced in respect of children's integrated development. Keywords: literacy, picture books, informative picture books, literary picture books, early childhood 


\title{
Acquisizione linguistica precoce e ruolo dell'adulto: la formazione in servizio come occasione di crescita professionale
}

\author{
Sergio Crasnich \\ Istituto dell'Educazione della Repubblica di Slovenia \\ sergio.crasnich@zrss.si
}

\begin{abstract}
L'introduzione precoce all'acquisizione di una seconda lingua rappresenta una straordinaria opportunità in contesti etnicamente e linguisticamente misti. Una strategia per superare i vincoli posti dalla condizione di mancata padronanza, da parte del bambino, della lingua utilizzata nella scuola dell'infanzia è offerta dal ricorso a metodi e tecniche riconducibili all'approccio umanistico alla didattica della lingua. Il contributo presenta un percorso di formazione in servizio, che ha coinvolto educatori ed educatrici delle scuole dell'infanzia con lingua d'insegnamento italiana sul territorio nazionalmente misto dell'Istria slovena. Le attività dei partecipanti, realizzate in un contesto ispirato ai principi della ricerca-azione e dell'apprendimento cooperativo, si sono proposte di individuare elementi di connessione tra le indicazioni del Programma curricolare sloveno per le scuole dell'infanzia, alcune proposte glottodidattiche legate alla pedagogia della comunicazione verbale, e talune modalità di organizzazione delle attività formative, già poste in essere dal personale educativo.
\end{abstract}

Keywords: approccio naturale, formazione in servizio, scuole dell'infanzia, lingua italiana, Istria slovena

\section{Introduzione}

L'attuale riflessione pedagogica incoraggia l'accostamento, a partire dalle primissime fasi della vita, a un ventaglio di esperienze educative e formative il più ampio e il meglio calibrato possibile. Obiettivo di tale precoce stimolazione è di consentire lo sviluppo epigenetico di connessioni e reti neurali, in un percorso che considera ogni essere umano come un'entità unica e irripetibile, il cui farsi è espressione al tempo stesso del patrimonio genetico e delle esperienze ambientali. L'opportunità di predisporre contesti ottimali di stimolazione delle competenze del bambino assume cruciale importanza nel caso dell'acquisizione della lingua (Daloiso 2009). I più recenti studi sul bilinguismo hanno evidenziato che l'esposizione precoce a una lingua non materna produce effetti di competenza praticamente indistinguibili da quelli osservati su parlanti madrelingua, sia dal punto di vista morfosintattico e 
lessicale sia per quanto riguarda la pronuncia. Anche a livello di fluidità del pensiero, la prestazione del bilingue precoce è diversa da quella del bilingue esposto a una lingua in fase evolutiva successiva, poiché presenta un carattere di maggiore immediatezza e non passa attraverso il filtro della lingua materna (Balboni 2015). L'esposizione precoce a una seconda lingua costituisce una irrinunciabile opportunità in contesti etnicamente e linguisticamente misti, quali quello dell'Istria slovena, nel quale la lingua italiana costituisce per buona parte della popolazione una lingua seconda.

\section{Sviluppo linguistico e bilinguismo precoce: la specificità del contesto italiano dell'Istria slovena}

Il Programma curricolare per le scuole per l'infanzia, pur indicando esplicitamente nel bilinguismo la meta cui deve tendere l'impegno educativo e didattico nei territori etnicamente e linguisticamente misti (Ministero dell'Istruzione e dello Sport 2000, 8) non fornisce indicazioni specifiche in merito alle modalità di azione nei casi in cui la lingua materna del bambino non coincida con quella utilizzata all'interno dell'istituzione educativa. Quest'ultima circostanza emerge con particolare salienza nelle istituzioni educative con lingua d'insegnamento italiana sul territorio nazionalmente misto dell'Istria slovena.

A titolo di esemplificazione, saranno presentati i dati generali riguardanti gli anni 1999, 2010 e 2017, raccolti da parte dell'Istituto dell'educazione della Repubblica di Slovenia. Nel 1999 il numero complessivo di alunni era di 1020: di questi, gli iscritti alla scuola dell'infanzia corrispondevano al $23 \%$, quelli iscritti alla scuola elementare al $49 \%$, quelli iscritti alla scuola media al $28 \%$. $\mathrm{Nel} 2010$ il numero complessivo di alunni era di 983: di questi, gli iscritti alla scuola dell'infanzia corrispondevano al $44 \%$, quelli iscritti alla scuola elementare al 41\%, quelli iscritti alla scuola media al 15\%. Nel 2017 il numero complessivo di alunni era di 1216: di questi, gli iscritti alla scuola dell'infanzia corrispondevano al $42 \%$, quelli iscritti alla scuola elementare al $46 \%$, quelli iscritti alla scuola media al $12 \%$. Come si può osservare, accanto a un rilevante aumento generale del numero di alunni negli anni dal 2010 al 2017, va segnalato il marcato aumento proporzionale degli iscritti alle scuole dell'infanzia, che sono più che raddoppiati passando da circa un quinto (nel 1999) a oltre due quinti della popolazione scolastica complessiva (sia nel 2010, sia nel 2017).

La provenienza linguistica degli alunni frequentanti le istituzioni scolastiche con lingua d'insegnamento italiana sul territorio nazionalmente misto dell'Istria slovena non è rilevata al momento della loro iscrizione, né è finora divenuta oggetto di ricerca. Tuttavia, nell'ambito delle attività di formazione 
in servizio coordinate dall'Istituto dell'educazione della Repubblica di Slovenia sono state condotte alcune indagini esplorative (Crasnich 2014), grazie alle quali è possibile tratteggiare un quadro che comprende almeno le seguenti categorie: (1) monolingui italofoni (a casa parlano solamente l'italiano); (2) bilingui (a casa parlano l'italiano e lo sloveno/il croato); (3) bilingui (a casa parlano l'italiano e un'altra lingua delle repubbliche della ex Jugoslavia/di immigrazione); (4) bilingui (a casa parlano lo sloveno/il croato e un'altra lingua delle repubbliche della ex Jugoslavia/di immigrazione); (5) bilingui (a casa parlano due lingue delle repubbliche della ex Jugoslavia/di immigrazione); (6) monolingui non italofoni (a casa parlano lo sloveno/il croato/una lingua di immigrazione); (7) monolingui non italofoni (a casa parlano una lingua delle repubbliche della ex Jugoslavia/una lingua di immigrazione); (8) altre tipologie, legate ai flussi migratori che hanno recentemente interessato la Repubblica di Slovenia, con particolare riguardo all'area del Litorale.

L'introduzione precoce all'acquisizione della lingua italiana da parte di bambini e bambine non italofoni si impone dunque come un impegno inderogabile, cui il personale educativo operante nelle istituzioni minoritarie di lingua italiana deve essere tecnicamente e professionalmente preparato.

\section{Approccio glottodidattico umanistico e scuola dell'infanzia: le ragioni di una sinergia}

Una possibile occasione di soddisfacimento dei vincoli posti dalla condizione di non garantita padronanza, da parte del bambino, della lingua utilizzata all'interno delle istituzioni scolastiche è offerta dal ricorso a modalità, tecniche e metodi riconducibili all'approccio umanistico alla didattica della lingua. Obiettivo comune alle diverse proposte operative formulate da questo approccio (Pichiassi 1999; Caon 2005; Balboni 2015) è di individuare percorsi e strategie in grado di minimizzare ostacoli e resistenze di natura psicoaffettiva, che esercitano effetti particolarmente evidenti se la lingua utilizzata non è ancora pienamente padroneggiata. Tale opzione trova fondamento e giustificazione in istanze proprie della pedagogia umanistica (Rogers 1951; 1969) di cui si propone il trasferimento in ambito glottodidattico.

I presupposti teorici alla base dell'approccio umanistico muovono da un'intenzionale azione di confronto con le condizioni che promuovono l'acquisizione della lingua in contesti naturali. Nella teoria di Krashen e Terrell (1983), che gli autori stessi definiscono approccio naturale (natural approach), la quantità di input linguistico offerto è più importante della pratica, ed è fondamentale attendere il momento in cui l'apprendente inizierà a usare 
spontaneamente la lingua obiettivo, senza richiedere prestazioni premature e suscettibili di dare luogo a inibizione.

In condizioni spontanee, la lingua viene acquisita seguendo un percorso a spirale, che procede per approssimazioni e fasi di interlingua (Selinker 1992) oggetto di studio della linguistica acquisizionale (Chini 2005): in sostanza, da una iniziale semplificazione si procede alla risistemazione e all'incremento in quantità e qualità delle proprie competenze, in una successione di configurazioni uniche, originali, soggette a costante ristrutturazione. II passaggio da una configurazione all'altra è promosso dal costante arricchimento qualitativo dei messaggi indirizzati alla persona, che costituiscono l'input da comprendere. Un input è comprensibile se si colloca su un gradino immediatamente successivo a quello che caratterizza il livello di competenza già padroneggiato dall'ascoltatore: inoltre, se il parlante fornisce un sistema di supporto all'acquisizione del linguaggio (LASS, Language Acquisition Support System) i processi automatici di comprensione facenti capo al meccanismo di acquisizione della lingua (LAD, Language Acquisition Device) si attivano autonomamente e operano con efficacia. Krashen e Terrell (1983) sottolineano che l'input comprensibile permette il passaggio graduale da un livello di competenza meno articolato a un livello più articolato; i riferimenti psicopedagogici cui questo principio fa appello sono costituiti dall'area di sviluppo potenziale di Vygotskij e dalla zona di sviluppo prossimale di Bruner, nonché dalla metafora bruneriana dello scaffolding, costituito in questo caso dalle enunciazioni del parlante più esperto.

\section{La ricerca: contesto, partecipanti, finalità, obiettivi, metodo e procedura}

Il presente lavoro nasce da una richiesta esplicitamente rivolta all'autore (nel suo ruolo di consulente pedagogico) da parte del personale educativo, mirante a problematizzare due questioni: (1) la qualità dell'offerta formativa delle istituzioni rispetto sia alla normativa vigente, sia alla più recente, aperta e illuminata riflessione pedagogica, didattica ed educativa; (2) la qualità dell'input offerto dal personale educativo, rispetto all'esigenza di garantire le condizioni ottimali per il potenziamento delle competenze linguistiche dei bambini. Tale richiesta ha costituito il riferimento al quale sono state vincolate tutte le scelte di disegno adottate per l'intervento.

Alla ricerca ha partecipato un gruppo di venti educatrici ed educatori. L'intervento si è svolto nell'ambito delle attività di formazione in servizio organizzate dall'Istituto dell'educazione della Repubblica di Slovenia.

La ricerca, avente a oggetto le modalità di organizzazione dell'offerta formativa, si è posta la finalità di favorire l'integrazione tra queste ultime, defi- 
nite dal vigente Programma curricolare, e alcune proposte di buone pratiche legate alla glottodidattica umanistica.

Gli obiettivi della ricerca, sottesi dalla richiesta di intervento formativo, sono stati i seguenti:

1. individuare sinergie tra le modalità di organizzazione dell'offerta formativa delle scuole e le più rilevanti proposte della glottodidattica umanistica;

2. incoraggiare la riflessione dei partecipanti su alcune proposte della glottodidattica umanistica, in modo da promuoverne l'implementazione.

Gli interrogativi di ricerca che ci si è posti sono i seguenti:

1. È possibile individuare sinergie tra le modalità di organizzazione dell'offerta formativa delle scuole e alcune proposte della glottodidattica umanistica?

2. Ė possibile incoraggiare la riflessione dei partecipanti su alcune proposte della glottodidattica umanistica, in modo da promuoverne l'implementazione?

Il metodo di ricerca adottato si è ispirato all'approccio della ricerca-azione (De Landsheere 1982; Elliott, Giordan e Scurati 1993; Barbier 2007), considerato la modalità più idonea a favorire percorsi partecipativi di acquisizione di conoscenza, riflessione e promozione del cambiamento.

Per quanto riguarda la procedura attuata, il formatore ha diviso l'intervento in due parti (una per ciascuna delle questioni problematizzate), con incontri articolati in tre fasi: (a) una fase introduttiva dedicata alla presentazione della tematica da trattare; (b) una fase laboratoriale, in cui i partecipanti erano invitati a svolgere attività di lettura, confronto e riflessione secondo le modalità dell'apprendimento cooperativo (Comoglio e Cardoso 1996); (c) una fase di restituzione delle riflessioni dei gruppi, con l'individuazione di possibili punti di condivisione. Nella prima fase degli incontri, la condotta comunicativa del formatore è stata improntata all'uso di modalità discorsive basate sulla spiegazione, supportata dalla presentazione di diapositive in formato Powerpoint. Nella seconda e terza fase, invece, la condotta comunicativa è stata improntata all'adozione di interventi di risposta a riflesso o riformulazione a specchio (Rogers 1951), allo scopo di incoraggiare la verbalizzazione di idee, proposte e riflessioni da parte dei gruppi. Solo a verbalizzazione pienamente conclusa, il formatore ha proposto delle ricapitolazioni, miranti a sintetizzare i punti condivisi. 


\section{Risultati della ricerca e discussione}

Nei due successivi paragrafi saranno descritti gli esiti più salienti della prima e della seconda parte dell'intervento. Nella discussione si mostrerà che le riflessioni emerse nel corso delle due parti dell'intervento hanno permesso ai partecipanti: (1) di individuare sinergie tra le modalità di organizzazione dell'offerta formativa delle scuole dell'infanzia e le più rilevanti proposte della glottodidattica umanistica; (2) di riconoscere la validità di alcune proposte di intervento della glottodidattica umanistica, come condizione per promuoverne una successiva implementazione. Di conseguenza, si ritiene di poter dare risposta positiva a entrambi gli interrogativi che la ricerca si è proposta.

\section{Prima parte dell'intervento: i requisiti di un educatore umanistico}

Nella prima parte dell'attività formativa sono stati presentati gli elementi salienti dell'approccio naturale e della pedagogia umanistica, e si è proposto di riflettere criticamente sulle indicazioni del Programma curricolare per la scuola dell'infanzia (Ministero dell'Istruzione e dello Sport 2000), allo scopo di individuare il profilo di un educatore orientato in senso umanistico. L'attività del personale educativo coinvolto nell'iniziativa, incoraggiata e facilitata dal formatore, ha portato all'individuazione di quattro requisiti. Questi ultimi saranno ora presentati in riferimento alla letteratura scientifica che li supporta, e accompagnati dalla citazione dei passi del Programma curricolare per le scuole dell'infanzia cui risultano riconducibili.

II primo requisito è stato sintetizzato come la capacità di creare un ambiente caldo, supportivo, incoraggiante. II riferimento curricolare da esso sotteso (Ministero dell'Istruzione e dello Sport 2000, 39) sottolinea l'importanza di creare un'atmosfera tale che spinga il bambino a parlare, ad allargare la sua esperienza del discorso, ad esprimere i suoi sentimenti, desideri e bisogni. Di fondamentale importanza per l'acquisizione di questa capacità è stata giudicata la presenza, all'interno della sezione, del clima di ascolto attivo e incondizionato che la psicologia e la pedagogia umanistiche considerano come condizione di base per la promozione di qualsiasi forma di dialogo educativo (Kanizsa 2007); a questi elementi fa esplicito riferimento anche il documento curricolare, quando rimarca l'impegno dell'insegnante a creare un clima piacevole, di fiducia reciproca, nel quale il bambino venga sollecitato alla comunicazione, all'espressione, alla partecipazione e alla creatività (Ministero dell'Istruzione e dello Sport 2000, 54).

II secondo requisito è stato sintetizzato come la capacità di osservare i bambini per coglierne le diversità e reagire empaticamente, usando la comunicazione in tutte le sue sfaccettature. II riferimento curricolare da esso sotteso (Mini- 
stero dell'Istruzione e dello Sport 2000, 38) vede nell'osservazione da parte dell'adulto una condizione necessaria e preliminare per individuare le capacità comunicative dei bambini (Mantovani 1995; Reffieuna 2002), cercando di comprendere i messaggi espressi non verbalmente, come il linguaggio corporeo. Importante è anche la capacità di rispondere al bambino utilizzando il linguaggio corporeo e della comunicazione non verbale (Bonaiuto e Maricchiolo 2009), che assume particolare importanza quando il bambino, a causa dell'età, non dispone ancora di un grande patrimonio lessicale o quando desidera esprimere contenuti molto intimi, nascosti e difficilmente esprimibili con le parole (Ministero dell'Istruzione e dello Sport 2000, 55).

II terzo requisito è stato sintetizzato come la capacità di rispettare l'individualità del bambino, nei suoi stili ma anche nei suoi silenzi o nelle sue reticenze. Il riferimento curricolare da esso sotteso riguarda la necessità di adeguare le richieste allo sviluppo evolutivo del bambino e alle sue capacità discorsive, rispettando le sue modalità di interazione con l'ambiente e stimolando all'espressione dei sentimenti, prima in modo non verbale, in seguito combinando mezzi verbali e non verbali (Ministero dell'Istruzione e dello Sport 2000, 40). Inoltre, è stata considerata fondamentale l'esigenza di rispettare il principio alla riservatezza e all'intimità, che consente al bambino di non esprimere contenuti che preferisce tenere per sé (Ministero dell'Istruzione e dello Sport $2000,11)$. Congruenti con questo requisito curricolare sono state considerate le indicazioni glottodidattiche umanistiche riguardanti la gradualità nella richiesta di prestazioni linguistiche e l'importanza di rispettare la fase del silenzio: quest'ultima è considerata da alcuni autori (Pichiassi 1999; Balboni 2015) caratteristica del momento ricettivo propedeutico alla manifestazione di competenza linguistica produttiva.

Il quarto requisito è stato sintetizzato come la capacità di accettazione incondizionata e di riformulazione della comunicazione. L'incoraggiamento della comunicazione dell'interlocutore è stato oggetto di attenzione e riflessione da parte di autori quali Lumbelli (Lumbelli 1994; Lumbelli 2009) e Pontecorvo (Pontecorvo, Ajello e Zucchermaglio 1991; Pontecorvo 2005), che hanno individuato nella risposta a riflesso o riformulazione a specchio (Rogers 1951) la sua più proficua modalità di implementazione in ambito pedagogico e didattico. II principale vantaggio di tale atto comunicativo consiste nella sua efficacia nel fornire al parlante un feedback non valutativo, che promuove la prosecuzione della comunicazione e la verbalizzazione dei processi di pensiero. A esso pare riferirsi direttamente anche il Programma curricolare per le scuole dell'infanzia, quando rimarca la necessità di seguire con attenzione le conversazioni tra bambini, cercando di riprendere e approfondire gli argo- 
menti spontaneamente proposti da questi ultimi (Ministero dell'Istruzione e dello Sport 2000, 39), nonché di stimolare il bambino nei primi tentativi di verbalizzazione, ripetendo e facendo eco alle sue espressioni (p. 40).

L'applicazione dei requisiti fin qui individuati e riassunti dovrebbe permeare la globalità dell'azione educativa e didattica dell'adulto, attuandosi per mezzo di specifiche modalità di interazione verbale. In questo senso, assume decisiva importanza la capacità dell'adulto di fornire al bambino un sistema di supporto all'acquisizione linguistica sotto forma di input ampio, differenziato, comprensibile perché contestualizzato, in grado di attivare $\mathrm{i}$ meccanismi spontanei di acquisizione.

\section{Seconda parte dell'intervento: l'interazione verbale di un educatore umanistico}

Nella seconda parte dell'attività formativa, ai partecipanti è stato proposto di riflettere criticamente sulle proprie modalità comunicative allo scopo di individuare congruenze o incongruenze con il profilo dell'educatore umanistico precedentemente tratteggiato. L'attività del personale educativo coinvolto nell'iniziativa, anche in questo caso incoraggiata e facilitata dal formatore nei momenti di lavoro dei gruppi, ha portato all'individuazione di condotte verbali, suscettibili di arricchimento e potenziale influsso positivo sulle competenze linguistiche dei bambini.

Al personale educativo sono state proposte le consegne sottostanti:

1. Dividetevi in gruppi omogenei, all'interno dei quali siano presenti educatori, educatrici, aiuto-educatori e aiuto-educatrici.

2. Ogni gruppo scelga una fascia di età, corrispondente a quelle presenti all'interno della scuola dell'infanzia.

3. Discutendo e riflettendo su quanto previsto dal Programma curricolare per le scuole dell'infanzia, ogni gruppo individui i nuclei di attività implementati nella programmazione didattica.

4. Per ciascun nucleo di attività, ogni gruppo individui e trascriva le parole, espressioni o frasi solitamente utilizzate per comunicare con i bambini.

5. Discutendo e riflettendo su quanto emerso dal lavoro dei gruppi, il collettivo confronti le parole, espressioni o frasi trascritte e ne analizzi la struttura, proponendo eventuali integrazioni o modifiche.

6. Al termine, il collettivo dovrebbe disporre di un protocollo minimo, composto da parole, espressioni o frasi condivise da tutti gli operatori, e la cui struttura è stata analizzata e ottimizzata. 
Di seguito si propone la trascrizione degli enunciati proposti dagli educatori operanti con la prima fascia di età (da zero a tre anni).

Accoglienza

Buongiorno (nome del bambino), ben arrivato

Come stai?

Giochi liberi/attività

Vieni al tavolo

Guarda che bel libro

Mostrami cosa hai portato

Merenda

Riordiniamo i giochi e le sedie

Andiamo a lavarci le mani

Rimboccatevi le maniche

Apri il rubinetto

Poca acqua

Poco sapone

Sciacqua bene le mani

Chiudi il rubinetto

Prendi una carta (asciugamani) e asciugati le mani

Il pasto

Vai a sedere al tuo posto

Buon appetito

Grazie

Prego

Attività

Andate a sedere nell'angolino morbido/Sedetevi nell'angolino morbido

Ripetiamo/Ripeteremo le canzoncine imparate

E adesso il girotondo ... diamoci la mano, prendetevi per la mano

Riposo

Vieni andiamo a cambiare il pannolino

Mettiamo la crema

Dove il tuo pannolino

E adesso sul proprio lettino/sulla brandina e buon riposo

Risveglio

Ben svegliati 
Prendi le pantofole/le ciabatte

Dammi il ciuccio

\section{Congedo}

Arrivederci a domani

Ci vediamo domani

L'intervento di riflessione e confronto, sviluppato dal personale educativo con la mediazione del formatore, ha permesso di individuare una serie di aspetti critici.

Le attività si organizzano intorno ai momenti previsti dal Programma curricolare per le scuole dell'infanzia (Ministero dell'Istruzione e dello Sport 2000); tuttavia, non sembrano essere sufficientemente valorizzati i momenti dedicati al dialogo, allo scambio comunicativo, alla condivisione di esperienze. L'interazione educativa che emerge dalle enunciazioni rievocate dal gruppo evidenza vicinanza ed empatia, ma non assume come momento centrale la stimolazione, l'incoraggiamento, il potenziamento della comunicazione e del dialogo. Vi è indubbiamente cordialità (si vedano per esempio le formule relative ai momenti dell'accoglienza e del congedo) ma le formule utilizzate sono semplici e stereotipate: non presentano, quindi, quelle caratteristiche di ridondanza, ricchezza e naturalità attribuite a un input che, in quanto accompagnato da elementi non verbali, sarebbe comunque comprensibile ai bambini e si situerebbe all'interno della loro area di sviluppo potenziale.

Un altro commento riguarda la sottolineatura linguistica che accompagna i momenti di attività situati tra l'accoglienza e il congedo. Prevalgono brevi enunciati di tipo regolativo, il più delle volte proposti con l'uso della seconda persona singolare o plurale dell'imperativo (vieni ..., rimboccatevi ..., apri ..., sciacqua ..., chiudi ..., prendi ..., vai a sedere ..., andate a sedere/sedetevi ..., prendetevi ..., prendi ..., dammi ...). Meno marcata, invece, risulta la presenza della prima persona plurale del congiuntivo che, oltre ad assumere funzione esortativa, comunica al destinatario del messaggio la partecipazione e la vicinanza dell'emittente (riordiniamo ..., andiamo a lavarci ..., ripetiamo ..., diamoci la mano ..., andiamo a cambiare ..., mettiamo...).

Negli enunciati sono poi documentati esempi di frasi ellittiche (poca acqua ..., poco sapone ..., Dove il tuo pannolino ..., E adesso sul proprio lettino/sulla brandina), la cui comprensione è probabilmente garantita dal contesto extralinguistico all'interno delle quali sono collocate. Tuttavia, nell'ottica di favorire e accompagnare l'acquisizione naturale della lingua, esse potrebbero essere seguite da ulteriori riformulazioni complete, che sarebbero age- 
volmente processabili dai bambini (Pienemann 1998) dato il contesto, noto e quotidianamente condiviso, in cui ha luogo l'interazione con l'adulto.

A seguito della riflessione di cui si sono ora sintetizzati i punti salienti, è stato chiesto ai partecipanti di immaginare delle modifiche della propria condotta linguistica, miranti ad associare a tutte le attività delle enunciazioni e spiegazioni di carattere integrativo (Lumbelli 1989). Esse, accompagnando la scansione delle azioni e dei gesti compiuti dall'adulto o dai bambini, potrebbero creare le precondizioni per favorire il passaggio dall'input all'intake. $\mathrm{Di}$ seguito si propone l'esempio di una delle riformulazioni operate dal gruppo e rivista dal formatore, riguardante il momento dell'accoglienza mattutina: in essa, la condotta linguistica dell'adulto punteggia e sottolinea le azioni che il bambino compie, da solo o aiutato.

Buongiorno, ben arrivato. Come stai? Hai dormito bene? Vieni, andiamo a togliere il cappotto. Ecco, mettiamolo sull'appendiabiti ... così. Ora togliamo le scarpe e mettiamo le pantofole ... togliamo la scarpa destra ... ecco ... adesso invece togliamo la scarpa sinistra ... bene ... mettiamo le scarpe nella mensola che sta sotto il cappotto ... Benissimo, adesso siamo pronti per andare nella nostra aula ... Salutiamo la mamma ... Se vuoi, puoi darmi la mano... Andiamo ... adesso andremo a giocare per un po' con il gioco che preferisci ...

La riscrittura riprende gli aspetti topici del momento dell'accoglienza, e l'adulto accompagna l'esecuzione di azioni ben note al bambino poiché legate alle routine quotidiane. Le parole e le espressioni introdotte negli enunciati (cappotto, appendiabiti, scarpe, pantofole, mensola, aula, mano, gioco) arricchiscono l'input lessicale offerto, e la loro processabilità è assicurata dalla presenza dei referenti extralinguistici nell'esperienza condivisa. Alcune locuzioni accompagnano l'acquisizione di modalità descrittive di relazioni reciproche (destra, sinistra, sotto il) importanti per il successivo sviluppo di competenze spaziali e matematiche.

La verbalizzazione sottolinea le dimensioni di autonomia e scelta, che il Programma curricolare per le scuole dell'infanzia (Ministero dell'Istruzione e dello Sport 2000) pone quali linee guida dell'azione educativa (Se vuoi, puoi darmi la mano... con il gioco che preferisci).

L'esempio illustra altresì come, in un contesto autentico, una medesima espressione possa essere ripetuta più volte, e quindi consolidata, senza rischiare di indurre noia (ora togliamo ..., togliamo..., adesso invece togliamo). 
Al tempo stesso, i due momenti dell'azione (ingresso) e della rappresentazione (successiva attività di gioco) sono collocati nelle dimensioni temporali del presente e del futuro attraverso l'uso opportuno dei rispettivi tempi del verbo all'indicativo (andiamo a togliere il cappotto; andremo a giocare).

Infine, la riformulazione propone al bambino parole appartenenti alle principali categorie morfologiche della lingua italiana (articoli, sostantivi, aggettivi, verbi, preposizioni, pronomi, avverbi, congiunzioni) comprese quelle (come gli articoli determinativi e le preposizioni articolate) non presenti nella lingua slovena (il; sull'; le; la; nella).

\section{Conclusioni}

La valutazione del percorso descritto nel presente contributo richiede particolare cautela, date le caratteristiche partecipative dell'approccio in esso adottato (De Landsheere 1982). II più valido indicatore di bontà dell'intervento, infatti, consisterebbe in una modifica, rilevabile tramite osservazione, della condotta verbale del personale educativo, suscettibile di influire sull'acquisizione linguistica dei bambini (Mantovani 1995). Le condizioni in cui l'esperienza è stata realizzata non hanno reso possibile questo tipo di controllo. Tuttavia, essa ha stimolato l'attivazione di un atteggiamento critico e riflessivo, irrinunciabile per la crescita professionale del personale educativo e docente (Cencič 2015).

Un'occasione di controllo empirico delle istanze emerse dalla riflessione degli educatori potrebbe essere costituita dall'approfondimento di alcune problematiche riconducibili alla didattica acquisizionale (Rastelli 2009). In tale prospettiva, un input calibrato in modo da proporre elementi non presenti nella lingua materna del bambino potrebbe favorire la comparsa di enunciati attestanti il raggiungimento di livelli crescenti di competenza. Per esempio, nel caso di un bambino di madrelingua slovena, a una prima fase interlinguistica caratterizzata dall'uso di sostantivi privi di articolo, potrebbe fare seguito una fase in cui una delle forme dell'articolo determinativo viene introdotta senza riguardo alla concordanza di genere e/o numero con il sostantivo che la accompagna (p.e. il piatto, il bicchiere, il tovagliolo, il cucchiaio, il coltello, il forchetta, il bottiglia; il piede, il ginocchio, il gomito, il mano) prima di giungere all'uso corretto dell'articolo determinativo.

Un'ipotesi di lavoro quale quella ora abbozzata assegna all'educatore un ruolo di attiva riflessione sulla propria azione, alle istituzioni universitarie e ai centri di ricerca un ruolo di elaborazione e sperimentazione di metodologie e approcci innovativi, da introdurre nei percorsi di formazione inizia- 
le, e agli istituti di consulenza un ruolo di disseminazione di buone pratiche nell'ambito della formazione in servizio.

\section{Riferimenti bibliografici}

Balboni, P. E. 2015. Le sfide di Babele: insegnare le lingue nelle società complesse. Torino: Utet.

Barbier, R. 2007. La ricerca - azione. Roma: Armando.

Bonaiuto, M., e F. Maricchiolo. 2009. La comunicazione non verbale. Roma: Carocci.

Caon, F. 2005. Un approccio umanistico-affettivo all'insegnamento dell'italiano a non nativi. Venezia: Cafoscarina.

Cencič, M. 2015. Izbrani pristopi k spodbujanju refleksije učiteljev. Koper: Annales.

Chini, M. 2005. Che cos'è la linguistica acquisizionale. Roma: Carocci.

Comoglio, M., e M. A. Cardoso. 1996. Insegnare e apprendere in gruppo. Roma: LAS.

Crasnich, S. 2014. «Težave in izzivi poučevanja manjšinske materinščine (italijanščina).» Predstavljeno na konferenci Jeziki v izobraževanju, Ljubljana, 11. april.

Daloiso, M. 2009. Le lingue straniere nella scuola dell'infanzia: fondamenti di glottodidattica. Torino: Utet.

De Landsheere, G. 1982. La recherche expérimentale en education. Lausanne: UNESCO.

Elliott, J., A. Giordan e C. Scurati. 1993. La ricerca-azione: metodiche, strumenti, casi. Torino: Bollati Boringhieri.

Kanizsa, S. 2007. Il lavoro educativo. Milano: Mondadori.

Krashen, S. D., e T. Terrell. 1983. The Natural Approach: Language Acquisition in the Classroom. Hayward: Alemany.

Lumbelli, L. 1989. Fenomenologia dello scrivere chiaro. Roma: Editori Riuniti.

-1994. Pedagogia della comunicazione verbale. Milano: Franco Angeli.

-2009. La comprensione come problema. Roma e Bari: Laterza.

Mantovani, S., a cura di. 1995. La ricerca sul campo in educazione: i metodi qualitativi. Milano: Mondadori.

Ministero dell'Istruzione e dello Sport. 2000. Programma curricolare perle scuole materne. Ljubljana: Ministero dell'Istruzione e dello Sport.

Pichiassi, M. 1999. Fondamenti di glottodidattica. Perugia: Guerra.

Pienemann, M. 1998. Language Processing and Second Language Development: Processability Theory. Amsterdam: Benjamins.

Pontecorvo, C., a cura di. 2005. Discorso e apprendimento: una proposta per l'autoformazione degli insegnanti. Roma: Carocci.

Pontecorvo C., A. M. Ajello e C. Zucchermaglio. 1991. Discutendo si impara: interazione sociale e conoscenza a scuola. Roma: Carocci.

Rastelli, S. 2009. Che cos'è la didattica acquisizionale. Roma: Carocci. 
Reffieuna, A. 2002. Il bambino a scuola: cosa e come osservare. Roma: Carocci. Rogers, C. R. 1951. Client-Centered Therapy. Chicago: Houghton Mifflin. . 1969. Freedom to Learn. Columbus, OH: Charles E. Merrill. Selinker, L. 1992. Rediscovering Interlanguage. London: Longman.

\section{Zgodnje učenje jezika in vloga odraslega: strokovno izpopolnjevanje kot priložnost profesionalne rasti}

Zgodnje učenje drugega jezika predstavlja izredno priložnost za narodno in jezikovno mešana območja. Uporaba metod in tehnik, ki se navezujejo na humanistični pristop poučevanja jezika, je ena od možnih strategij za premagovanje ovir, na katere otrok naleti zaradi pomanjkljivega znanja jezika, ki se uporablja v vrtcu. Prispevek predstavlja primer strokovnega usposabljanja, v katerem je sodelovala skupina vzgojiteljev in vzgojiteljic vrtcev z italijanskim učnim jezikom na narodnostno mešanem območju slovenske Istre. Pri dejavnostih so bili uporabljeni elementi akcijskega raziskovanja in sodelovalnega učenja. Same dejavnosti udeležencev so se osredotočale in navezovale na smernice Kurikuluma za vrtce, didaktične predloge humanističnega pristopa v povezavi z govornim sporazumevanjem in sporočanjem ter načine organiziranja aktivnosti, ki jih vzgojitelji že uporabljajo.

Ključne besede: naravni pristop, strokovno izpopolnjevanje, predšolska vzgoja, italijanščina, slovenska Istra 


\title{
Kako otroci prvega starostnega obdobja zaznavajo različne jezike?
}

\author{
Anita Sila \\ Univerza na Primorskem \\ anita.sila@pef.upr.si \\ Silva Bratož \\ Univerza na Primorskem \\ silva.bratoz@pef.upr.si
}

Otroci imajo v predšolskem obdobju z izpostavljenostjo tujim jezikom različne izkušnje, ki nedvomno pomembno vplivajo na razvijanje zavedanja tako prvega kot drugih jezikov. Prispevek obravnava zaznavanje in razlikovanje različnih jezikov pri dvo- in triletnih otrocih. $Z$ raziskavo smo želeli ugotoviti, kako se otroci odzivajo na tujejezikovno situacijo, kako zaznavajo prvi in drugi/tuji jezik, na kakšen način izražajo razlikovanje med različnimi jeziki, kako zgodaj že znajo verbalno razlikovati med različnimi jeziki in ali lahko povežejo različne jezike z njihovimi govorci. V ta namen so bili otroci za kratek čas izpostavljeni vnaprej načrtovani situaciji, ki sta jo izvedli raziskovalki v dveh tujih jezikih (angleščina, italijanščina) s štirimi ponovitvami. Rezultati raziskave so pokazali, da lahko že kratkoročna izkušnja otrok s tujimi jeziki pozitivno vpliva na njihovo zaznavanje jezikov in razlikovanje med njimi.

Ključne besede: prvo starostno obdobje, zaznavanje jezikov, razlikovanje jezikov, drugi/tuji jezik, jezikovno zavedanje

\section{Uvod}

Izpostavljenost tujim jezikom je lahko pri otrocih prisotna že $v$ zgodnjem obdobju. Nekateri se z njimi seznanjajo že od rojstva v dvo- ali večjezičnih družinah in dvo- ali večjezičnih okoljih (npr. slovensko zamejstvo), drugi pa prek medijev (npr. televizija, radio, računalnik, telefon ipd.), jezikovnih tečajev in srečanj z ljudmi iz drugih jezikovnih in kulturnih okolij (npr. s priseljenci $v$ vrtcu, na igriščih ipd.). Izkušnje posameznih otrok z izpostavljenostjo drugim/tujim jezikom so različne, a izjemno pomembne za razvijanje zavedanja jezika. Na to kaže tudi primer, ki ga navaja Hakuta (v Marjanovič Umek, Kranjc in Fekonja 2006), v katerem 4-letni dvojezični deček svojemu 5-letnemu angleškemu prijatelju reče: »Jaz znam govoriti francosko in angleško!« Prijatelj, ki je govoril angleško, pa je vprašal: »Kaj je to angleščina?«

Dosedanje raziskave so pokazale, da imajo dvojezični otroci bolje razvito metajezikovno zavedanje kot enojezični, saj se osredotočajo na značilnosti 
dveh jezikov (Yelland, Pollard in Mercuri 1993; Bruck in Genesee 1995; Chen idr. 2004). Dvojezični otroci manipulirajo z jezikovnimi informacijami iz obeh jezikov in tako razvijajo sposobnost metajezikovnega zavedanja ter zavestnega razmišljanja o jeziku. Posledica tega so razvitejše sposobnosti jezikovnega zavedanja v obeh jezikih (Chow, McBride Chang in Burgess 2005). Zaradi izpostavljenosti dvema jezikoma so dvojezični otroci v primerjavi z enojezičnimi sposobni dalj časa zaznavati fonetične razlike med maternim in tujim jezikom (Petitto, Berens in Kovelman 2012). To sposobnost zaznavanja pa ohranijo tudi v odrasli dobi, saj odrasli dvojezični govorci bolje prepoznavajo nove jezike v primerjavi z enojezičnimi (Marks, Bond in Stockmal 2003).

Ravno tako na posameznikovo zaznavanje tujih jezikov tako $v$ otroški kot odrasli dobi vplivajo večjezične izkušnje, kar so potrdile številne raziskave (Marks, Bond in Stockmal 2003; Petitto, Berens in Kovelman 2012). Kljub temu pa dejavniki, ki vplivajo na sposobnost razlikovanja med jeziki pri otrocih, še niso dobro raziskani. Prav tako ni znano, ali lahko že kratkoročne izkušnje izboljšajo zaznavanje tujih jezikov pri otrocih, kot je to značilno za odrasle (Potter in Saffran 2015).

\section{Razvoj govora}

Razvojno obdobje otroka od prvega do tretjega leta otrokove starosti je najobčutljivejše za razvoj govora oziroma simbolnih sistemov, ki vplivajo tako na količinske kot kakovostne spremembe na spoznavnem področju: npr. na odmik mišljenja od zaznavne opore na raven predstavnosti, večjo fleksibilnost in tekočnost mišljenja, tematsko in taksonomsko oblikovanje pojmov ter socialno komunikacijo. Hiter razvoj govora $v$ tem obdobju je povezan z zgodnjim razvojem možganov (Peklaj in Marjanovič Umek 2009). Z ustreznimi spodbudami iz okolja lahko v prvih letih življenja optimalno izkoristimo otrokov umski potencial. Pestriejši in številnejši kot so dražljaji, kompleksnejše strukture se tvorijo. Do drugega leta se število teh povezav oz. sinaps poveča in okrepi, manj uporabljene oz. nerabljene povezave pa slabijo oz. krnijo. Strokovnjaki zato svetujejo, naj pri otroku začnemo čim bolj zgodaj spodbujati različne povezave (Lipavec Oštir in Jazbec 2010). Pozneje je z okoljem povezane primanjkljaje na področju govora zelo težko nadoknaditi (Marjanovič Umek 2001).

Razvijanje govora zahteva mnogostranske izhodiščne pogoje, posebne motorične spretnosti (temeljni predpogoj za govorni razvoj) in kognitivne sposobnosti (da lahko govori in tvori stavke) (Wilken 2012). Otroci se z neverbalnimi signali najprej odzivajo na neugodje oz. zadovoljstvo, nato neverbalne signale pričnejo uporabljati za vzpostavljanje stika z drugo osebo 
in zadovoljevanje želja in potreb, šele nato pričnejo komunicirati z verbalnimi signali, s katerimi so zmožni izraziti različne funkcije $v$ različnih socialnih kontekstih (Marjanovič Umek, Kranjc in Fekonja 2006). Za normalno realizacijo govora je potrebno ustrezno tvoriti posamezne glasove (artikulacija), upoštevati pravila pri besednem redu in stavčni strukturi (skladnja) ter z izgovorjenimi besedami povezati namen (pragmatika) (Wilken 2012). Otroci pri treh letih že poznajo osnovne strategije obvladovanja besedne in nebesedne komunikacije, s katerimi postavljajo vprašanja, nanje odgovarjajo, izražajo mnenja, želje ipd. (Marjanovič Umek, Kranjc in Fekonja 2006).

L. Marjanovič Umek, S. Kranjc in U. Fekonja (2006) na osnovi domačih in tujih raziskav povzemajo značilnosti govornega razvoja, obenem pa opozarjajo, da razvoja otrokovega govora ni mogoče enoznačno umestiti znotraj posameznih mejnikov, saj so med otroci lahko velike individualne razlike.

Komunikacijo pa poleg jezika označujejo tudi drugi načini vedenja in izrazne oblike, s katerimi drugim osebam nekaj sporočamo. Že majhni otroci z jokom in drugo vokalizacijo, s telesno držo, z očesnim stikom, s prijemanjem in kazanjem itd. jasno izražajo svoje potrebe in zanimanje za okolico. Na ta način se čedalje bolje sporazumevajo z osebami, ki so jim pomembne. Vsekakor pa so takšne komunikacijske oblike razumljive le v povezavi s kontekstom in potrebujejo interpretacijo odnosnih oseb, saj te njihova individualna izrazna znamenja razumejo relativno dobro, za druge ljudi pa niso razumljiva (Wilken 2012).

\section{Zgodnje zaznavanje in razlikovanje jezikov}

Med izsledki raziskav, ki so preučevale otrokove prirojene zmožnosti za fonološko učenje, je smiselno omeniti zlasti t. i. kategorialno zaznavanje (ang. categorical perception) glasov, pri katerem gre za dobro zmožnost razlikovanja glasov iz različne fonemske kategorije, in slabšo zmožnost razlikovanja glasov, ki pripadajo isti fonemski kategoriji (Liebenthal idr. 2003). Pri tem je predvsem pomembno to, da so otroci že od rojstva zmožni razlikovati tudi subtilne razlike med akustično podobo glasov, in sicer zlasti med tistimi glasovi, ki so pomembni za jezikovni razvoj (Kuhl 2004). Nekatere raziskave na tem področju (Kuhl 2004) preučujejo prepoznavanje akustične podobe samoglasnikov in ugotavljajo, da so otroci že zelo zgodaj dovzetni za relativne distribucijske frekvence glasovnih segmentov določenega jezika ter da se odzivajo s povezovanjem samoglasniških glasov. Strokovnjaki na tem področju poročajo še, da prihaja $v$ obdobju med 6 . in 12. mesecem do pomembnih sprememb, saj začenjajo otroci $v$ tem obdobju pri zaznavanju glasov dajati prednost prvemu oziroma maternemu jeziku, kar predstavlja enega ključnih 
Preglednica 1 Razvoj govora po mesecih

\begin{tabular}{|c|c|}
\hline Okvirna starost & Značilnosti \\
\hline Novorojenček & $\begin{array}{l}\text { Raje ima človeški glas. } \\
\text { Razlikuje med glasovi. } \\
\text { Razlikuje svoj govor od govora drugih. } \\
\text { Joka. }\end{array}$ \\
\hline 1-5 mesecev & $\begin{array}{l}\text { Razlikuje med samoglasniki. } \\
\text { Gruli. } \\
\text { Vokalizira dva ali več glasov. } \\
\text { Beblja (združuje samoglasnik in soglasnik). } \\
\text { Naredi govorni preobrat. }\end{array}$ \\
\hline 6-12 mesecev & $\begin{array}{l}\text { Čeblja in ponavlja posamezne zloge. } \\
\text { Uporablja geste za komuniciranje. } \\
\text { Razume že več besed. } \\
\text { Izpolni enostavne naloge. } \\
\text { Razlikuje jezik iz svojega okolja od drugega jezika. }\end{array}$ \\
\hline 12-18 mesecev & $\begin{array}{l}\text { Govori enobesedne izjave. } \\
\text { Razume več kot } 50 \text { besed. } \\
\text { Združuje samostalnik in glagol. }\end{array}$ \\
\hline 18-24 mesecev & $\begin{array}{l}\text { Naredi velik skok v razvoju besednjaka. } \\
\text { Začne oblikovati dvobesedne izjave. } \\
\text { Z besedami izraža čustva. } \\
\text { Uporablja telegrafski govor. }\end{array}$ \\
\hline $2,6-5$ let & $\begin{array}{l}\text { Govori večbesedne izjave. } \\
\text { Usvaja nova slovnična pravila. } \\
\text { Oblikuje nikalne in vprašalne izjave. } \\
\text { Besednjak še naprej narašča. } \\
\text { Rad ima humor in metafore. } \\
\text { Kaže napredek v sporazumevalnih spretnostih in drugih oblikah } \\
\text { pragmatične rabe govora. } \\
\text { Govor je razumljiv in tekoč. } \\
\text { Pripoveduje zgodbe. }\end{array}$ \\
\hline $6+$ let & $\begin{array}{l}\text { Kaže metajezikovno zavedanje. } \\
\text { Oblikuje celovite stavke. } \\
\text { Govor uporablja v različnih govornih položajih. }\end{array}$ \\
\hline
\end{tabular}

Opombe Povzeto po Marjanovič Umek, Kranjc in Fekonja (2006).

mejnikov v procesu usvajanja jezika (Kuhl 2007). Pri testiranju 6-mesečnih govorcev ameriške angleščine in švedščine so npr. ugotovili, da so ti dovzetnejši za distribucijske frekvence glasov, ki jih slišijo, in za lažje povezovanje samoglasniških glasov v prvem kot pa v drugem jeziku. Govorimo torej o prehodu od univerzalnega k jezikovno specifičnemu zaznavanju glasov. Gre za t. i. učinek magneta pri samoglasnikih prvega jezika, ki ga npr. pri eksperimentih z opicami niso zaznali, kar kaže na to, da se že v zgodnjem otroštvu razvi- 
jajo zmožnosti za razvoj jezika, ki so edinstvene človeku (Kuhl 1991). Zmožnost ločevanja med različnimi segmenti jezika so na besedni ravni raziskovali tudi J. R. Saffran, Aslin in E. L. Newport (1996) ter prišli do zaključka, da že 8-mesečni otroci razlikujejo med besedami na osnovi verjetnosti povezovanja med zlogi.

Številne raziskave so pokazale, da prične otrok razlikovati med jeziki zelo zgodaj (Karmiloff in Karmiloff-Smith 2001; Kuhl 2004; Werker 1989). Že nekaj dni stari novorojenčki dajejo pri poslušanju prednost maternemu jeziku pred drugimi, čeprav med obema še ne ločijo (Karmiloff in Karmiloff-Smith 2001). Poleg tega lahko ločujejo druge jezike, ki pa morajo biti med seboj dovolj različni, npr. ločujejo lahko med francoščino in ruščino ali med angleščino na eni strani in italijanščino in španščino na drugi (Mehler and Christophe 1994). Novorojenčki so še posebej dovzetni za ritmične lastnosti jezika, saj lahko na podlagi tega npr. francoski otroci razlikujejo med angleščino in japonščino, ki imata različne ritmične lastnosti, ne pa tudi med angleščino in nizozemščino, ki sta v tem pogledu sorodni (Nazzi, Bertoncini in Mehler 1998).

\section{Hipoteza kritičnega obdobja}

Hipoteza o kritičnem obdobju je povezana z eno od najvznemirljivejših dilem na področju tujejezikovnega pouka, in sicer z vprašanjem, ali obstaja kritično obdobje za učenje tujega jezika oz., z drugimi besedami, ali je zgodnejše učenje tujega jezika boljše in učinkovitejše. Gre za vprašanje, ki odraža globalni trend, po katerem se poučevanje tujega jezika pomika vedno nižje po starostni lestvici. Velja namreč splošno prepričanje (Brewster, Ellis in Girard 2002), da bomo določen tuj jezik bolje usvojili, če se ga začnemo učiti v zgodnjem obdobju, kar velja zlasti za usvajanje naravne izgovorjave in naglasa.

Med raziskavami, ki so poskušale dokazati povezavo med zmožnostjo ločevanja glasov v zgodnjem obdobju in uspešnostjo usvajanja tujega jezika, je smiselno omeniti študijo (Kuhl idr. 2005), s katero so ugotovili, da je manjša zmožnost ločevanja glasov tujega jezika povezana z učenjem glasovnih lastnosti prvega jezika. To se je pokazalo $v$ raziskavi, $v$ kateri so testirali jezikovne zmožnosti otrok $v$ različnih obdobjih, najprej pri 7. mesecu, nato pri 14., 18., 24. in 30. mesecu, pri čemer so uporabili standardizirani test percepcije govora na osnovi enostavnih minimalnih parov besed $z$ različnimi samoglasniškimi glasovi (npr. $v$ angleščini tea in two) in pogojevanja (premik glave). Na ta način so dokazovali, da zmožnost ločevanja glasov v zgodnjem obdobju lahko vpliva na njihovo poznejšo sposobnost usvajanja besed, morfologije in skladnje. Pomembno je tudi, da so raziskovalci ločevali med občutljivim in kritičnim obdobjem, pri čemer je za občutljivo obdobje značilno, da 
pride lahko na osnovi pridobljene izkušnje do sprememb v organizmu, medtem ko je kritično obdobje potrebno za določeno učenje, ki ima lahko dolgoročen vpliv. Lennebergova (1967) hipoteza o kritičnem obdobju predpostavlja, da je kritično obdobje za učenje jezika do začetka pubertete (12. leta), ko naj bi se lateralizacija možganov končala. Po tem obdobju naj bi bilo nemogoče popolnoma usvojiti določen jezik. Poznejše študije, npr. Krashnova (1973), so pokazale, da se lateralizacija zaključi veliko prej (pri petih letih) in da to ne predstavlja ovire za učenje tujega jezika po puberteti. Pomen kritičnega obdobja so potrdile npr. raziskave, ki so preučevale dvojezičnost. Kim idr. (1997) so s pomočjo magnetne resonance možganov ugotovili, da so se pri dvojezičnih osebah, ki so to postale v kasnejšem obdobju, v možganih (na področju Broca) aktivirala ločena območja (tj. za slovnico in fonologijo) za oba jezika, medtem ko so se pri osebah z zgodaj razvito dvojezičnostjo ta območja za oba jezika prekrivala.

Čeprav so torej številne raziskave poskušale potrditi prednosti zgodnjega učenja tujega jezika, številni strokovnjaki opozarjajo, da je o dokončnem odgovoru na vprašanje o najboljši starosti za začetek učenja jezika težko govoriti (Brewster idr. 2002; Lightbown in Spada 2006; Pinter 2011). Namesto tovrstnega zaključka je zato smiselneje govoriti o splošnem konsenzu med strokovnjaki, da obstajajo določene prednosti za posamezne starostne skupine. Ena od pomembnejših prednosti zgodnjega začetka učenja tujega jezika je nedvomno $v$ tem, kot smo doslej že omenili, da so otroci dovzetnejši za prepoznavanje in ločevanje glasov tujega jezika, kar lahko pomeni, da bodo $z$ večjo verjetnostjo razvili naravno njegovo izgovorjavo. Ob tem $A$. Pinter (2011) še dodaja, da so mlajši otroci večinoma manj zadržani od odraslih učencev in izražajo nižjo mero tesnobnosti pri učenju tujega jezika, v končni fazi pa z zgodnjim začetkom tudi več časa posvetijo tujejezikovnemu učenju.

Po drugi strani pa lahko govorimo tudi o prednostih učenja jezika v kasnejšem obdobju, $v$ puberteti in odrasli dobi. Birdsong (1992) je npr. prišel do zaključka, da je kljub številnim prednostim zgodnjega začetka z učenjem tujega jezika treba upoštevati, da obstajajo tudi osebe, ki so se jezika začele učiti v odrasli dobi in so kljub temu dosegle raven rojenega govorca. Za razliko od mlajših otrok so starejši učenci zmožni razumeti in analizirati pravila tujega jezika, kar jim omogoči, da razvijejo in uporabijo učinkovite učne strategije česa. Ravno tako se lahko zanesejo na visoko razvito pojmovno strukturo in kognitivne zmožnosti višje ravni (Pinter 2011). Na osnovi zapisanega lahko sklepamo, da je po puberteti težje usvojiti fonološko podobo tujega/drugega jezika, ni pa nemogoče. Pri tem imajo ključno vlogo motivacija, izkušnje, sposobnosti in predanost učenju vsakega posameznika. 


\section{Pomen socialne interakcije za razvoj jezika}

Kot poudarjajo nekatere teorije učenja (npr. Vigotskijeva in Brunerjeva), ima socialna interakcija ključno vlogo pri učenju in razvoju jezika. Bruner (1983, str. 39) npr. poudarja, da »če obstaja mehanizem za usvajanje jezika, potem do njega ne pridemo z izpostavljenostjo 'plohi' govorjenega jezika, temveč predvsem skozi interakcijo, oblikovano s pomočjo podpornega sistema, ki ga pri jezikovnemu usvajanju nudi odrasla oseba.«

P. K. Kuhl, Tsao in H.-M. Liu (2003) ugotavljajo, da so dojenčki, ki so bili izpostavljeni tujemu jeziku v socialnem okolju, bistveno bolje in trajnejše usvojili določene glasove jezika kot dojenčki, ki so bili tujemu jeziku izpostavljeni samo slušno in vizualno (npr. preko televizijskega sprejemnika). Ob tem se P. K. Kuhl (2007) sprašuje, na kakšen način socialna interakcija vpliva na učenje jezika. Ponujata se dva možna odgovora, in sicer najprej delovanje mehanizma pozornosti in spodbud, ki vključuje otrokovo motivacijo. Pozornost in spodbude vplivajo na učenje na različnih področjih, zato se lahko domneva, da bo njihov vpliv na učenje zaznan tudi pri izpostavljenosti novemu jeziku. Drugi razlog gre iskati v pomenu specifičnih informacij v naravnem okolju, ki lahko poleg glasovnega vnosa vključuje številne druge elemente, kot so predmeti, namera in pogled sogovornika ipd. Socialni signali pospešujejo učenje, saj omogočajo z informacijami bogato referenčno okolje (Kuhl 2007). Tomasello (1999, str. 213) poudarja, da kognitivnih procesov seveda ne ustvarja jezik sam; ti se oblikujejo, ko so otroci v intersubjektivni interakciji z drugimi osebami, od katerih prevzamejo komunikacijske norme - ta socialni proces ustvarja novo obliko kognitivne reprezentacije, ki je pri drugih živalskih vrstah ne najdemo.

Učinkovitejše učenje v socialni interakciji pa omogoča tudi čustveni element. Znano je namreč, da čustva občutno vplivajo na procese mišljenja, kot so zaznavanje, učenje, spomin, sklepanje, reševanje problemov, predvsem pa na pozornost. Čustva imajo tudi pomembno vlogo pri usmerjanju naše pozornosti, dejanj in vedenja (Tyng idr. 2017). Posledično pa sta zaradi usmerjene pozornosti boljša tudi učenje in spomin. Slednji je odvisen od konteksta. Dejavnosti, kot so simulacije, igre vlog, sodelovalni projekti, nudijo pomemben kontekstualni okvir, ki pomaga pri priklicu informacij iz spomina v podobnih situacijah v resničnem življenju.

Dosedanje raziskave (Floccia idr. 2009; Potter in Saffran 2015; Stockmal, Muljani in Bond 1994; Wagner, Clopper in Pate 2014), ki so bile usmerjene zlasti v sposobnost razlikovanja med narečnimi jezikovnimi posebnostmi in različnimi jeziki, so bile izvedene na populaciji otrok, starih od 4 do 7 let. Ugotovile 
so, da predvsem mlajši otroci težko razlikujejo med glasovnimi posebnostmi ali narečji določenega jezika. Prav tako imajo težave pri razlikovanju med izjavami v različnih jezikih, saj ne vedo, na katero jezikovno značilnost bi se osredotočili.

$\checkmark$ pričujočem prispevku smo se osredotočili na zaznavanje jezikov pri otrocih v prvem starostnem obdobju (dvo- in triletniki). Predvsem nas je zanimalo, kako bo izpostavljenost malčkov tujejezikovni situaciji, ki vključuje intersubjektivno interakcijo z osebo, ki govori drugi jezik, vplivala na njihovo sposobnost razlikovanja med jeziki, in sicer med prvim/maternim in drugim/tujim jezikom ter med obema drugima/tujima jezikoma. Poleg tega smo želeli ugotoviti, na kakšen način otroci prvega starostnega obdobja izražajo razlikovanje med različnimi jeziki, kako se odzivajo na tujejezikovno situacijo, kako zgodaj že znajo verbalno razlikovati med različnimi jeziki in ali lahko povežejo različne jezike z govorci.

V raziskavi, ki smo jo izvedli z otroki prvega starostnega obdobja, smo izhajali iz predpostavke, da imajo socialni dejavniki ključno vlogo pri zaznavanju tujega jezika, zato smo otroke izpostavili tujemu jeziku v določenem socialnem kontekstu, ki je vključeval predmet in osebo z jasno določeno namero.

\section{Namen raziskave}

Osnovni namen pričujoče raziskave je preučiti, kako 2-3-letniki zaznavajo različne jezike. Zanimalo nas je zlasti, kako pojmujejo razlike med prvim in drugimi jeziki ter kako se odzivajo na izvedbo simuliranega dogodka $v$ angleškem in italijanskem jeziku.

Iskali smo torej odgovore na naslednja vprašanja:

1. Kako se otroci prvega starostnega obdobja odzivajo na simuliran dogodek v tujem jeziku (verbalni in neverbalni odziv, razumevanje)?

2. Kako zaznavajo prvi in drugi/tuji jezik?

3. Na kakšen način izražajo razlikovanje med različnimi jeziki?

4. Kako zgodaj že znajo verbalno razlikovati med različnimi jeziki in ali lahko povežejo različne jezike $z$ njihovimi govorci?

\section{Metodologija}

\section{Opis vzorca}

$\checkmark$ raziskavi je sodelovalo 15 otrok iz treh skupin, od katerih je bila večina (11) enojezičnih, 3 dvojezični in 1 večjezičen. $V$ prvi skupini ( 5 otrok) so bili otroci, stari od 23 do 27 mesecev, v drugi od 25 do 31 mesecev (6 otrok), v tretji pa vsi nad 36 mesecev (4 otroci). 


\section{Pripomočki}

Zbiranje podatkov je potekalo na osnovi opazovalnega lista, ki so ga izpolnile vzgojiteljice (3) sodelujočih otrok, in na osnovi polstrukturiranega intervjuja s posameznimi otroki po zadnji ponovitvi dogodka v obeh jezikih. Na opazovalnem listu so vzgojiteljice beležile verbalni in neverbalni odziv otrok. Verbalni odziv je zajemal izjave in vprašanja otrok o dogodku po končani simulaciji. Neverbalni odziv je zajemal vedenje in čustveni element komuniciranja otrok med in po dogodku. V intervjuju so vzgojiteljice posameznega otroka vprašale, kako sta govorili raziskovalki (pri tem sta si pomagali tudi s fotografijami raziskovalk), ali sta govorili isti jezik, kot ga govorijo otroci in vzgojiteljice v vrtcu, ali sta govorili slovensko, angleško ali italijansko, ali so ju razumeli ter kaj sta raziskovalki hoteli. Odgovore smo analizirali po posameznih vprašanjih glede na starostne skupine otrok in pridobljene rezultate interpretirali v skladu $z$ ugotovitvami raziskav, predstavljenih $v$ teoretičnem delu.

\section{Postopek zbiranja in obdelave podatkov}

Pri raziskavi smo uporabili deskriptivno metodo empiričnega pedagoškega raziskovanja, predvsem kvalitativni pristop. Raziskava je sestavljena iz dveh delov. V prvem delu smo oblikovali dejavnost (iskanje medvedka) s štirimi ponovitvami, namen katere je bil izbrane otroke za kratek čas izpostaviti tujemu/drugemu jeziku. Odločili smo se za dva jezika, in sicer angleščino (ki je v izbranem okolju prvi tuji jezik) in italijanščino ( $k$ i v izbranem dvojezičnem okolju predstavlja drugi jezik oz. jezik okolja). Dejavnost smo nato izvedli v treh skupinah predšolskih otrok v prvem starostnem obdobju (z 2-3-letniki). Dejavnost sta izvedli dve odrasli osebi (raziskovalki), ki sta po načelu »ena oseba en jezik «' vedno govorili samo v angleščini ali samo v italijanščini. Dejavnost, ki sta jo štirikrat ponovili ${ }^{2} v$ dopoldanskem času (po zajtrku $v$ angleščini in pred kosilom v italijanščini), je trajala približno 3 minute. Pred izvedbo dejavnosti sta se raziskovalki z vzgojiteljicami dogovorili, da o izvedeni dejavnosti in uporabljenih jezikih otrokom nič ne razlagajo, saj bi to lahko vplivalo na njihove odgovore. $V$ dogovoru z vzgojiteljicami je raziskovalka (ena je govorila angleški jezik, druga pa italijanskega) vstopila v igralnico, kjer so bili otroci načrtno zbrani pri mizah in v izbranem jeziku pričela iskati medvedka

\footnotetext{
${ }^{1}$ Metoda vezave jezika na osebo (tudi na prostor, čas itd.) je tem priporočljivejša čim nižja je starostna stopnja razvoja otroka (Nećak Lük 1999). V našem primeru je ena vzgojiteljica govorila angleško, druga pa italijansko.

${ }^{2} Z$ dosledno večkratno ponovitvijo dejavnosti smo želeli ustvariti predvidljiv dogodek, ki malčkom omogoča, da se bolje učijo, kar velja tudi za učenje novih besed (Benitez in Saffran 2018).
} 
(ang. teddy bear, it. orsetto), ki ga je vzgojiteljica predhodno postavila na dogovorjeno mesto. Ob tem je neverbalno izražala občutek zaskrbljenosti. Poleg medvedka je vzgojiteljica na drugo dogovorjeno mesto postavila drugo plišasto igračo. Raziskovalka je pri iskanju medvedka najprej prišla do druge igrače in nakazala, da sicer išče igračo, vendar ta še ni bila prava. Nato pa je poiskala svojega medvedka in ko ga je našla, je z navdušenjem večkrat ponovila besedo teddy bear oz. orsetto ter z očesnim stikom usmerila pogled otrok na medvedka. Otrokom je zatem veselo pomahala in brez besed zapustila igralnico. Dogodek sta raziskovalki simulirali še trikrat $v$ treh tednih (vedno obe na isti dan).

\section{Rezultati raziskave in razprava}

Po vsaki izvedbi simuliranega dogodka v dveh tujih jezikih (angleščina, italijanščina) smo najprej poskušali ugotoviti, kako se sodelujoči otroci odzivajo na simulacijo dogodka. Vzgojiteljice so tako med opazovanjem situacije beležile verbalni in neverbalni odziv otrok, ki je podrobneje prikazan v preglednici 2.

Pri prvih dveh skupinah otrok sta vzgojiteljici zabeležili predvsem neverbalni odziv otrok, ki se je po ponovnih obiskih raziskovalk spreminjal. Njihov odziv je bil pri obeh jezikih podoben. Ob izvedbi dogodka so večinoma izražali začudenje in pozitivno presenečenje. Večina otrok je spremljala vsak vzgojiteljičin korak. Z vsako ponovitvijo dogodka so bili otroci veselejši in sproščenejši. Pomen angleške in italijanske besede so razbrali iz konteksta, razumevanje pa so kazali z neverbalnimi signali, kot sta kazanje z roko in očesni stik.

Iz preglednice je razvidno, da se je verbalni odziv z višjo starostjo otrok stopnjeval. Z vsakim nadaljnjim obiskom je vse več otrok medvedka že poimenovalo v izbranem jeziku. Predvidevamo, da je k priklicu besed iz tujih jezikov prispevalo več dejavnikov. Eden od njih je predvidljivost dogodka, saj so malčki z vsakim naslednjim obiskom že predvidevali, kaj bosta raziskovalki iskali. Poleg predvidljivosti pa je k temu prav gotovo pripomogla čustvena obarvanost dogodka. V našem primeru je šlo za simulacijo dogodka, v katerem sta raziskovalki zaskrbljeno iskali medvedka, in sočustvovanje otrok z njima se je pokazalo tudi na njihovih obrazih. Njihov izraz na obrazu se je pozitivno spremenil, ko sta raziskovalki medvedka našli in od navdušenja začeli skakati. Zaradi čustev, ki jih je simulacija v njih vzbudila, menimo, da so si besede $v$ tujem jeziku bolje zapomnili. Nenazadnje pa je k boljši motiviranosti in bolj usmerjeni pozornosti otrok $v$ danih situacijah nedvomno vplivalo tudi to, da so bili otroci postavljeni v intersubjektivno interakcijo z drugimi ose- 
Preglednica 2 Verbalni in neverbalni odziv glede na starost in dogodek $v$ obeh jezikih (angleščina, italijanščina)

\begin{tabular}{|c|c|c|c|c|}
\hline Skupina & $\begin{array}{l}\text { Verbalni odziv - } \\
\text { angleščina }\end{array}$ & $\begin{array}{l}\text { Verbalni odziv - } \\
\text { italijanščina }\end{array}$ & $\begin{array}{l}\text { Neverbalni od- } \\
\text { ziv - angleščina }\end{array}$ & $\begin{array}{l}\text { Neverbalni od- } \\
\text { ziv - italijanščina }\end{array}$ \\
\hline $\begin{array}{l}\text { Prva } \\
\text { skupina } \\
\text { (od } 23 \text { do } 27 \\
\text { mesecev) }\end{array}$ & $\begin{array}{l}\text { Prvo srečanje } \\
\text { En otrok se je z } \\
\text { mrmranjem od- } \\
\text { zval na besedo } \\
\text { teddy bear. }\end{array}$ & $\begin{array}{l}\text { Prvo srečanje } \\
\text { Deklica je zakli- } \\
\text { cala: „Ššš ... po- } \\
\text { slušam!» } \\
\text { Drugo srečanje } \\
\text { Trije otroci so de- } \\
\text { jali: } \\
\text { »u je.» } \\
\text { Ena deklica je za- } \\
\text { klicala: »Orsetto!» }\end{array}$ & $\begin{array}{l}\text { Prvo srečanje } \\
\text { Otroci so bili pre- } \\
\text { senečeni. Eden } \\
\text { od otrok se je na- } \\
\text { smehnil. } \\
\text { Drugo srečanje } \\
\text { Otroci so izražali } \\
\text { veselje in prije- } \\
\text { tno preseneče- } \\
\text { nje. Pomahali so } \\
\text { vzgojiteljici in ji } \\
\text { poslali poljubček. } \\
\text { En otrok je gle- } \\
\text { dal v medvedka } \\
\text { na mizi vsakič, ko } \\
\text { ga je vzgojiteljica } \\
\text { poimenovala. } \\
\text { Tretje srečanje } \\
\text { Dva otroka sta } \\
\text { usmerila pogled k } \\
\text { medvedu na mizi. } \\
\text { Otroci so bili ve- } \\
\text { seli, nasmejani. }\end{array}$ & $\begin{array}{l}\text { Prvo srečanje } \\
\text { Otroci so poslu- } \\
\text { šali in opazovali } \\
\text { vzgojiteljičino } \\
\text { premikanje po } \\
\text { prostoru. Bili so } \\
\text { presenečeni in za- } \\
\text { čudeni. } \\
\text { Drugo srečanje } \\
\text { Vsi otroci so poši- } \\
\text { ljali poljubčke. Bili } \\
\text { so nasmejani, po- } \\
\text { zitivno presene- } \\
\text { čeni. } \\
\text { Tretje srečanje } \\
\text { Otroci so začu- } \\
\text { deno gledali v } \\
\text { vzgojiteljico. En } \\
\text { otrok je pokazal } \\
\text { na medvedka na } \\
\text { mizi. Otroci so bili } \\
\text { veseli, ko jih je } \\
\text { vzgojiteljica poz- } \\
\text { dravila in jim po- } \\
\text { slala poljubček. }\end{array}$ \\
\hline $\begin{array}{l}\text { Druga } \\
\text { skupina } \\
\text { (od } 25 \text { do } 31 \\
\text { mesecev) }\end{array}$ & $\begin{array}{l}\text { Tretje srečanje } \\
\text { En deček je dejal: } \\
\text { »šče berija.» }\end{array}$ & $\begin{array}{l}\text { Drugo srečanje } \\
\text { Deček je dejal: } \\
\text { »šče Orsetto!» } \\
\text { Tretje srečanje } \\
\text { Štirje otroci so za- } \\
\text { klicali: »Orsetto!» }\end{array}$ & $\begin{array}{l}\text { Prvo srečanje } \\
\text { Vsi otroci so bili } \\
\text { začudeni. Strmeli } \\
\text { so in opazovali } \\
\text { vzgojiteljico. } \\
\text { Drugo srečanje } \\
\text { Otroci so prese- } \\
\text { nečeni opazovali } \\
\text { vzgojiteljico. }\end{array}$ & $\begin{array}{l}\text { Prvo srečanje } \\
\text { Vsi otroci so bili } \\
\text { začudeni. Opazo- } \\
\text { vali so vzgojite- } \\
\text { ljico. } \\
\text { Drugo srečanje } \\
\text { Otroci so bili ve- } \\
\text { seli. Opazovali so } \\
\text { vzgojiteljico. }\end{array}$ \\
\hline
\end{tabular}

Nadaljevanje na naslednji strani

bami. Otroci so prepoznavali socialne signale in z raziskovalkama verbalno in neverbalno iskali stik, kot je razvidno iz opisanih primerov. Iz odgovorov smo lahko tudi razbrali, da je eden od otrok celo uporabil novo besedo (kiss) v enem od ciljnih jezikov, da bi z raziskovalko navezal stik. 
Preglednica 2 Nadaljevanje s prejšnje strani

\begin{tabular}{|c|c|c|c|c|}
\hline Skupina & $\begin{array}{l}\text { Verbalni odziv - } \\
\text { angleščina }\end{array}$ & $\begin{array}{l}\text { Verbalni odziv - } \\
\text { italijanščina }\end{array}$ & $\begin{array}{l}\text { Neverbalni od- } \\
\text { ziv - angleščina }\end{array}$ & $\begin{array}{l}\text { Neverbalni od- } \\
\text { ziv - italijanščina }\end{array}$ \\
\hline $\begin{array}{l}\text { Tretja } \\
\text { skupina } \\
\text { (vsi } 36 \\
\text { mesecev } \\
\text { ali več) }\end{array}$ & $\begin{array}{l}\text { Prvo srečanje } \\
\text { Ena deklica je } \\
\text { dejala: »Ona se } \\
\text { smeji, ker je našla } \\
\text { teddy beara.» } \\
\text { Drugo srečanje } \\
\text { Deklica je dejala: } \\
\text { „Tam je teddy } \\
\text { bear, na mizi je.» } \\
\text { Tretje srečanje } \\
\text { Nekaj otrok je kli- } \\
\text { calo »teddy bear«. } \\
\text { Ena deklica je po- } \\
\text { mahala vzgojite- } \\
\text { ljici in rekla: »Kiss } \\
\text { kiss«. }\end{array}$ & $\begin{array}{l}\text { Prvo srečanje } \\
\text { Ena deklica je de- } \\
\text { jal: »Je šla ven, } \\
\text { ko je našla med- } \\
\text { vedka orsota.« } \\
\text { Ena deklica je de- } \\
\text { jala: »Je iskala } \\
\text { medvedka. Tam } \\
\text { na mizi je bil. Na } \\
\text { koncu je klicala } \\
\text { orsetto, orsetto!« } \\
\text { Drugo srečanje } \\
\text { Ena od deklic je } \\
\text { po koncu do- } \\
\text { godka klicala »or- } \\
\text { setto.« } \\
\text { Tretje srečanje } \\
\text { Otroci so dogo- } \\
\text { dek opazovali in } \\
\text { potiho ponavljali } \\
\text { »orsetto«. }\end{array}$ & $\begin{array}{l}\text { Prvo srečanje } \\
\text { Otroci so dogo- } \\
\text { dek opazovali v } \\
\text { tišini za mizo. Bili } \\
\text { so veseli in spro- } \\
\text { ščeni. En deček } \\
\text { dogodka in osebe } \\
\text { sploh ni zaznal. } \\
\text { Drugo srečanje } \\
\text { Otroci so s pr- } \\
\text { stom pokazali, } \\
\text { kje je medved, } \\
\text { in se med seboj } \\
\text { spogledovali. Bili } \\
\text { so veseli in spro- } \\
\text { ščeni. } \\
\text { Tretje srečanje } \\
\text { Otroci so dogo- } \\
\text { dek veselo opa- } \\
\text { zovali, se sme- } \\
\text { jali in spogledo- } \\
\text { vali. Očesno so } \\
\text { spremljali vzgo- } \\
\text { jiteljico. Vzgojite- } \\
\text { ljici so pomahali v } \\
\text { pozdrav. }\end{array}$ & $\begin{array}{l}\text { Prvo srečanje } \\
\text { Otroci so spre- } \\
\text { mljali vzgojiteljico } \\
\text { med iskanjem } \\
\text { medvedka. Spre- } \\
\text { mljali so jo z ve- } \\
\text { čjim zanimanjem } \\
\text { kot vzgojiteljico } \\
\text { zjutraj. Otroci so } \\
\text { bili veseli in še } \\
\text { bolj sproščeni. } \\
\text { Drugo srečanje } \\
\text { Ena od deklic je } \\
\text { pokazala s prstom } \\
\text { na drugo plišasto } \\
\text { igračo (kuža). } \\
\text { Druga deklica pa } \\
\text { je s prstom poka- } \\
\text { zala na mizo, kjer } \\
\text { se je nahajal med- } \\
\text { vedek. Otroci so } \\
\text { bili veseli. } \\
\text { Tretje srečanje } \\
\text { Otroci so veseli } \\
\text { očesno spremljali } \\
\text { vzgojiteljico. }\end{array}$ \\
\hline
\end{tabular}

Nadalje nas je zanimalo, kako otroci zaznavajo druge jezike. Vzgojiteljice so z vsakim otrokom posebej izvedle intervju, v katerem so jih spraševale o tem, kako sta govorili raziskovalki, ali sta govorili isti jezik, kot ga govorijo otroci in vzgojiteljice v vrtcu, ali sta govorili slovensko, angleško ali italijansko, ali so ju razumeli ter kaj sta raziskovalki hoteli.

V prvi skupini verbalnega odziva pri izvedbi intervjuja ni bilo. Otroci so bili ob vprašanjih začudeni in niso želeli sodelovati. Zaradi majhnega števila v raziskavi udeleženih otrok težko sklepamo, ali je enojezičnost/dvojezičnost otrok vplivala na njihove odgovore o jeziku raziskovalk. Glede na to, da sta samo dva triletna otroka od vseh udeleženih skušala raziskovalki povezati $z$ različnima jezikoma, ocenjujemo, da otroci te starosti zaradi pomanjkanja izkušenj v teh jezikih težko poimenujejo jezik raziskovalk. Otroci so zaznali, da sta raziskovalki govorili različna jezika (različna med seboj in drugačna od 
Preglednica 3 Odgovori otrok glede na posamezna vprašanja in starostno skupino

\begin{tabular}{|c|c|c|}
\hline Vprašanja & $\begin{array}{l}\text { Druga skupina } \\
\text { ( } 6 \text { otrok, starih od } 25 \text { do } 31 \\
\text { mesecev, } 1 \text { od teh } \\
\text { dvojezičen) }\end{array}$ & $\begin{array}{l}\text { Tretja skupina } \\
\text { ( } 4 \text { enojezični otroci, stari } 36 \\
\text { mesecev ali več) }\end{array}$ \\
\hline Kako je govorila vzgojiteljica A? & Ni odgovora. (6) & $\begin{array}{l}\text { Teddy bear (3) } \\
\text { Medvedka, teddy bear. (1) }\end{array}$ \\
\hline Kako je govorila vzgojiteljica B? & $\begin{array}{l}\text { Orsetto. (1) } \\
\text { Ni odgovora. (5) }\end{array}$ & $\begin{array}{l}\text { Orsetto. (2) } \\
\text { Orso. (1) } \\
\text { Ni odgovora. (1) }\end{array}$ \\
\hline $\begin{array}{l}\text { Ali govorita vzgojiteljici A in B } \\
\text { isti jezik kot mi v vrtcu? }\end{array}$ & $\begin{array}{l}\text { Ja. (5) } \\
\text { Ne. (1) }\end{array}$ & $\begin{array}{l}\text { Ne. (3) } \\
\text { Ne vem. (1) }\end{array}$ \\
\hline $\begin{array}{l}\text { Kako govorita vzgojiteljici - } \\
\text { slovensko, angleško, italijansko? }\end{array}$ & $\begin{array}{l}\text { Slovensko. (1) } \\
\text { Italijansko. (1 - dvojezičen } \\
\text { otrok) } \\
\text { Ni odgovora. (4) }\end{array}$ & $\begin{array}{l}\text { Slovensko in italijansko. (1) } \\
\text { Angleško in italijansko. (1) } \\
\text { Ne vem. (1) } \\
\text { Teddy bear, orsetto. (1) }\end{array}$ \\
\hline Ali si jih razumel/a? & $\begin{array}{l}\text { Ja. (4) } \\
\text { Ne. (1 - dvojezičen otrok) } \\
\text { Ni odgovora. (1) }\end{array}$ & $\begin{array}{l}\text { Ja. (3) } \\
\text { Kaj. (1) }\end{array}$ \\
\hline Kaj je hotela vzgojiteljica A? & $\begin{array}{l}\text { Orsetto. (1) } \\
\text { Tukaj. (1 - dvojezičen otrok) } \\
\text { Ni odgovora. (4) }\end{array}$ & $\begin{array}{l}\text { Medvedka. (1) } \\
\text { Medveda. (1) } \\
\text { Teddy bear. (1) } \\
\text { Teddy beara. (1) }\end{array}$ \\
\hline Kaj je hotela vzgojiteljica B? & Ni odgovora. (6) & $\begin{array}{l}\text { Tudi medvedka. (2) } \\
\text { Medveda. (1) } \\
\text { Iskala je medeka, klicala je } \\
\text { orsetto. (1). }\end{array}$ \\
\hline
\end{tabular}

maternega), vendar so imeli težave pri povezovanju, da je beseda »orsetto« italijanska, beseda »teddy bear« pa angleška ter, posledično, da je ena raziskovalka govorila angleško, druga pa italijansko. Da bi preverili njihovo razumevanje, smo jih vprašali, kaj sta raziskovalki želeli. Iz odgovorov lahko sklepamo, da so tujo besedo zagotovo razumeli otroci, stari 36 mesecev in več, saj so jo tudi jasno povedali, medtem ko lahko o razumevanju tujih besed pri posameznih mlajših otrocih le ugibamo, saj je bil njihov verbalni odziv v intervjuju bolj skop. Samo en otrok iz druge skupine je povedal, da je raziskovalka, ki je govorila angleško, želela »orsetto«. V tem primeru je pri raziskovalki, ki je govorila angleško, povedal italijansko besedo. Kljub skopemu verbalnemu odzivu v intervjuju ne moremo reči, da razumevanja besed ni bilo, saj je iz verbalnega odziva v preglednici 2 razvidno, da so kar štirje otroci zaklicali »orsetto«, ko ga je vzgojiteljica (raziskovalka) iskala. V nekaterih zgoraj predstavljenih primerih lahko opazimo tudi interference iz slovenskega jezika, in 
sicer pri sklanjanju besede teddy bear (npr. hotela je teddy beara; išče berija; je našla orsota). $V$ enem primeru pa takšnega negativnega transferja ni bilo (npr. v otrokovi izjavi »išče orsetto«). Predvidevamo, da gre za nezavedno izbiro besed, saj ti otroci obeh jezikov ne poznajo dovolj dobro, da bi se lahko za njihovo (ne)sklanjanje zavestno odločali.

Teden dni po izvajanju dejavnosti so vzgojiteljice $v$ pogovoru $z$ raziskovalko navedle tudi svoja opažanja iz vsakdanje prakse o tem, kako otroci zaznavajo jezike. Dejale so, da se nekateri otroci na tujejezikovno situacijo niso odzvali takoj, temveč šele čez kakšen teden. Ugotovile so, da otroci, ki doma govorijo več jezikov, prej zaznajo tuj jezik in se nanj tudi prej odzovejo. Ena od vzgojiteljic je omenila, da je otrok iz prve starostne skupine, $v$ kateri nismo zabeležili verbalnega odziva po simuliranih dogodkih, po enem tednu v stranišču iskal medvedka in govoril: »Kje je beri?« Prav tako so ob kasnejšem, nenačrtovanem obisku raziskovalke, ki je med raziskavo govorila v italijanščini, otroci samostojno pričeli klicati »orsetto«. To smo zaznali tudi v intervjujih, ko so otroci raziskovalko, ki je govorila angleško, prav tako povezali z besedo »teddy bear«, raziskovalko, ki je govorila italijansko, pa z besedo »orsetto«. Iz njihovih odgovorov je razvidno, da se je izvedba dejavnosti po načelu »ena oseba en jezik« pri otrocih te starosti obrestovala.

Pri najstarejših otrocih smo opazili tudi, da so v intervjujih uporabili oba izraza (medvedek in teddy bear ali medvedek in orsetto), kar pri tej starosti ne preseneča, saj tudi dvojezični otroci v obdobju od treh do štirih let razlikujejo med dvema različnima besednjakoma, vendar pa $v$ obeh jezikih uporabljajo enaka slovnična pravila (kot smo videli v primeru interferenc). $V$ tem obdobju so otroci sposobni prevajati en jezik v drugega, tisti otroci, ki so dvojezični, pa se svoje dvojezičnosti tudi zavedajo (Marjanovič Umek, Kranjc in Fekonja 2006). Iz vsega opisanega lahko sklenemo (tako kot sta ugotovila tudi $C$. E. Potter in J. R. Saffran 2015), da že kratkoročna zgodnja izpostavljenost več jezikom $v$ okolju lahko vpliva na otrokovo zaznavanje in razlikovanje tujih jezikov.

\section{Zaključek}

Z raziskavo smo želeli ugotoviti, kako se malčki odzivajo na simuliran dogodek v dveh tujih jezikih (angleščina, italijanščina), kako zaznavajo prvi in drugi/tuji jezik, na kakšen način izražajo razlikovanje med različnimi jeziki, kako zgodaj že znajo verbalno razlikovati med različnimi jeziki in ali lahko povežejo različne jezike $z$ njihovimi govorci. Rezultati opravljene raziskave so pokazali, da se otroci v tem starostnem obdobju na tujejezikovno situacijo odzivajo tako verbalno kot neverbalno. Neverbalni odziv je vključeval pred- 
vsem strmenje, začudeno opazovanje, smehljanje, navdušenje, usmerjanje pogleda, kazanje z roko na medvedka in pošiljanje poljubčkov. Starejši kot so bili otroci, več je bilo verbalnega odziva. $Z$ vsakim nadaljnjim obiskom je vse več otrok medvedka že poimenovalo $v$ izbranem jeziku, $k$ čemur je nedvomno pripomogla predvidljivost situacije, poleg tega pa tudi čustvena obarvanost dejavnosti in intersubjektivna interakcija z raziskovalkama. Nadalje so rezultati pokazali, da so predvsem starejši otroci iz prvega starostnega obdobja besedo »teddy bear « povezali z raziskovalko, ki je govorila v angleškem jeziku, besedo »orsetto « pa z raziskovalko, ki je govorila v italijanskem jeziku, kar je bil tudi namen izvajanja situacije po načelu »ena oseba, en jezik«. Zaznali so tudi, da sta raziskovalki govorili različna jezika (različna med seboj in drugačna od maternega), vendar so imeli težave pri poimenovanju jezika, kar kaže na kompleksnost razumevanja pojma jezika v tem obdobju. Z raziskavo smo želeli osvetliti pomen vključevanja različnih jezikov v okolje otrok že v zgodnjem obdobju, saj lahko že kratkoročne izkušnje z novim jezikom vplivajo na otrokovo zaznavanje in razlikovanje tujih jezikov. V prihodnje bi bilo smiselno na tem področju preučevati tudi vpliv drugih dejavnikov na jezikovno zaznavanje, zlasti upoštevajoč značilnosti dvojezičnih in večjezičnih okolij, iz katerih otroci prihajajo.

\section{Literatura}

Benitez, V., in J. R. Saffran. 2018. »Predictable Events Enhance Word Learning in Toddlers." Current Biology 28 (17): 2787-2793.

Birdsong, D. 1992. »Ultimate Attainment in Second Language Acquisition. Language 68 (4): 706-755.

Brewster, J., G. Ellis, in D. Girard. 2002. The Primary English Teacher's Guide. Harlow: Longman.

Bruck, M., in F. Genesee. 1995. »Phonological Awareness in Young Second Language Learners." Journal of Child Language 22 (2): 307-324.

Bruner, J. 1985. „Child's Talk: Learning to Use Language.« Child Language Teaching and Therapy 1 (1): 111-114.

Chen, X., R. C. Anderson, W. Li, M. Hao, X. Wu in H. Shu. (2004). »Phonological Awareness of Bilingual and Monolingual Chinese Children. « Journal of Educational Psychology 96 (1): 142-151.

Chow, B. W. Y., C. McBride Chang in S. Burgess. 2005. »Phonological Processing Skills and Early Reading Abilities in Hong Kong Chinese Kindergarteners Learning to Read English as a Second Language." Journal of Educational Psychology 97 (1): 81-87.

Floccia, C., J. Butler, F. Girard, and J. Goslin. 2009. „Categorization of Regional and Foreign Accent in 5- to 7-Year-Old British Children.« International Journal of Behavioral Development 33:366-375. 
Karmiloff, K., in A. Karmiloff-Smith. 2001. Pathways to Language. Cambridge, MA: Harvard University Press.

Kim, K. H., N. R. Relkin, K. M. Lee, in J. Hirsch. 1997. »Distinct Cortical Areas Associated with Native and Second Languages. N Nature 388 (6638): 171-174.

Krashen, S. D. 1973. »Lateralization, Language Learning, and the Critical Period: Some New Evidence."Language Learning 23:63-74.

Kuhl, P. K. 1991. »Human Adults and Human Infants Show a 'Perceptual Magnet Effect' for the Prototypes of Speech Categories, Monkeys do Not.«Perception \& Psychophysics 50:93-107.

- 2004. »Early Language Acquisition: Cracking the Speech Code.« Nature Reviews Neuroscience 5 (11), 831-843.

_. 2007. »/s Speech Learning 'Gated' by the Social Brain?« Developmental Science 10 (1): 110-120.

Kuhl, P. K., B. T. Conboy, D. Padden, T. Nelson in J. Pruitt. 2005. „Early Speech Perception and Later Language Development: Implications for the Critical Period. « Language Learning and Development 1 (3-4): 237-264.

Kuhl, P. K., F.-M. Tsao, and H.-M. Liu. (2003). »Foreign-Language Experience in Infancy.«Proceedings of the National Academy of Sciences 100:9096-9101.

Lenneberg, E. 1967. Biological Foundations of Language. New York: Wiley.

Liebenthal, E., J. R. Binder, S. M. Spitzer, E. T. Possing in D. A. Medler. 2003. »Neural Correlates of Categorical Perception of Speech.«https://pdfs .semanticscholar.org/145f/f8a373aoc2906de28a097afcc7bb644bc41a.pdf

Lightbown, P. M., N. Spada, L. Ranta in J. Rand. 2006. How Languages are Learned. Oxford: Oxford University press.

Lipavic Oštir, A., in S. Jazbec. 2010. »Zgodnje učenje tujega jezika z vidika nekih teorij.«https://www.zrss.si/projektiess/skladisce/sporazumevanje_v_tujih _jezikih/tuj-jezik-v-prvem-triletju/Strokovni\%20\%C4\%8Dlanki\%2oin \%2oprevodi/zgodnje_ucenje_tujega_jezika_z_vidika_razlicnih_teorij _lipavic_ostir.pdf

Marjanovič Umek, L. 2001. »Psihologija predšolskega otroka.« V Otrok v vrtcu: priročnik h kurikulu za vrtce, ur. L. Marjanovič Umek, 26-54. Maribor: Obzorja.

Marjanovič Umek, L., S. Kranjc in U. Fekonja. 2006. Otroški govor: razvoj in učenje. Domžale: Izolit.

Marks E. A., Z. S. Bond in V. Stockmal. 2003. "Language Experience and the Representation of Phonology in an Unknown Language." RESLA 16:23-31.

Mehler, J., in A. Christophe. 1994. »Language in the Infant's Mind.«Philosophical Transactions of the Royal Society of London, Series B - Biological Sciences, 346 (1315): 13-20.

Nazzi T., J. Bertoncini in J. Mehler. 1998. »Language Discrimination by Newborns: Toward an Understanding of the Role of Rhythm. «ournal of Experimental Psychology: Human Perception and Performance 24:756-766. 
Nećak Lük, A. 1999. »Modeli izobraževanja v etnično in jezikovno heterogenih okoljih: analiza strukturnih elementov za izbiro modelov izobraževanja v slovenskem etničnem prostoru.« Raziskovalno poročilo, Filozofska fakulteta, Ljubljana.

Fekonja Peklaj U. in Marjanovič Umek L. 2009. "Socialni konteksti in ocenjevanje govorne kompetentnosti malčkov in malčic." Sodobna pedagogika 3:18-39.

Petitto L., M. Berens in I. Kovelman. 2012. »The 'Perceptual Wedge' Hypothesis as the Basis for Bilingual Babies' Phonetic Processing Advantage: New Insights from fNIRS Brain Imaging."Brain and Language 121:130-143.

Pinter, A. 2011. Children Learning Second Languages. Houndmills: Palgrave Macmillan.

Potter, C. E., in J. R. Saffran. 2015. »The Role of Experience in Children's Discrimination of Unfamiliar Languages. « Frontiers in Psychology 6:1587. https://www.doi.org/10.3389/fpsyg.2015.01587

Saffran, J. R., R. N. Aslin in E. L. Newport. 1996. "Statistical Learning by 8-Month Old Infants.« Science 274:1926-1928.

Stockmal, V., D. Muljani in Z. Bond. 1994. »Can Children Identify Samples of Foreign Languages as Same or Different?« Language Sciences 16:237-252.

Tomasello, M. 2009. The Cultural Origins of Human Cognition. Cambridge, MA: Harvard University Press.

Tyng, C. M., H. U. Amin, M. N. M. Saad in A. S. Malik. 2017. »The Influences of Emotion on Learning and Memory. «Frontiers in Psychology 8:1454.

Wagner L., C. G. Clopper in J. K. Pate. 2014. »Children's Perception of Dialect Variation." Journal of Child Language 41:1062-1084.

Werker, J. F. 1989. »Becoming a Native Listener.« American Scientist 77:349-353.

Wilken, E. 2012. Jezikovno spodbujanje otrok z Downovim sindromom. Ljubljana: Pedagoška fakulteta.

Yelland, G., J. Pollard in A. Mercuri. 1993. »The Metalinguistic Benefits of Limited Contact with a Second Language. «Applied Psycholinguistics 14 (4): 423444.

\section{How Are Different Languages Perceived by Children in the First Age Group?}

The extent to which pre-school children are exposed to second languages may vary considerably and their experiences in this period have a significant impact on the development of language awareness. The present paper investigates the different ways in which two and three year old children perceive first and second languages and distinguish between them. The research presented was aimed at analysing the participants' reaction to a foreign language situation and identifying the ways in which they express the distinction between different languages. In addition, the study focused on analysing the time the 
children start differentiating between languages verbally and exploring the ways in which they associate a particular language with the speaker of that language. To this purpose, children who participated in the research were exposed to two foreign language situations created by two researchers in two languages (English and Italian), each repeated four times. The results of the research suggest that even short-term exposures may have a positive impact on the children's perception of different languages and the distinctions between. Keywords: two/three year old children, language awareness, language differentiation, language perception, second/foreign languages 


\title{
Learning Mathematics and Language through an Integrated Approach in Preschool Education
}

\author{
Sanja M. Maričić \\ University of Kragujevac \\ sanjamaricic1o@gmail.com \\ Mirjana M. Stakić \\ University of Kragujevac \\ mirjanastakico73@gmail.com
}

\begin{abstract}
The initial attitude in this paper argues that learning at preschool age should be characterised by a holistic approach which integrates different areas of knowledge. In this context, authors draw special attention to the importance of integrating language development and preschool mathematics education by means of literature for children. In the theoretical section, the authors define their goals - to determine the extent to which preschool teachers integrate language development and development of mathematical concepts, to learn which literary form is used most frequently as an integrative element and to determine the presence of integration in each content area of preschool mathematics education. Results show that preschool teachers most commonly integrate activities related to language development and mathematics, that the most frequently used integrative element is the prose and poetic text, and that literary content for children is commonly used as scaffolding to help children develop the concept of number and set.
\end{abstract}

Keywords: preschool education, integration, mathematics education, language development, child

\section{Introduction}

The period of preschool education is a very important period in the life of every individual, and the basics of learning laid out in this period are observed as the foundation for lifelong learning (Organisation for Economic CoOperation and Development 2006). Learning and development in preschool education are characterised by a holistic approach which 'integrates different areas of knowledge, thus uniting the cognitive, social, physical, emotional, cultural and spiritual aspect of child development' (Stakić and Maričić 2018, 369). 'Learning and teaching represent a comprehensive process seamlessly integrated in the context of everyday life' (Pavlović Breneselović and Krnjaja 
$2017,9)$. Preschool program argues that 'a child reacts with his/her whole being, and their intellectual, emotional, sensomotoric, social and speech development are interwoven and dependent on each other' (Pravilnik o osnovama programa predškolskog vaspitanja i obrazovanja 2018, 5).

Researches of preschool children's learning and development 'point to the fact that children cannot learn in the isolated subject disciplines, and that successful development of elementary mathematical concepts cannot occur if they are isolated in special learning situations' (Maričić, Stakić, and Malinović-Jovanović 2018, 632). Hence the decisive role of preschool teachers is to 'prepare and ensure the stimulating environment in order to give children the possibility for learning through touch, movement, sight and hearing' (Novaković 2015, 154). When developing their program, preschool teachers are encouraged to focus on 'creating learning opportunities as an integrated experience for the child, concentrating on things he does (action) and experiences (relationships), instead of focusing on preplanned individual activities based on development aspects, content areas or isolated teaching content' (Pravilnik o osnovama programa predškolskog vaspitanja i obrazovanja 2018, 35-36). The child will experience learning as an element integrated in his/her everyday life context, and through exchange with his environment. Learning is a cooperative and communication-based process (Pavlović Breneselović and Krnjaja 2017, 22).

When it comes to preschool mathematics education, recommendations stating that the process of mathematical learning should be integrated with other areas of knowledge at an early age reverberate even louder. This makes sense, given the abstract quality of mathematical concepts on the one hand, and the characteristics of the thinking process of children on the other hand. The National Association for the Education of Young Children (NAEYC) and the National Council of Teachers of Mathematics (NCTM) also recommend that we should 'integrate mathematics with other activities and other activities with mathematics' (National Association for the Education of Young Children and National Council of Teachers of Mathematics 2002, 7). Therefore, authors of this paper would like to draw attention to the importance of integrating preschool mathematics education and language development in teaching practice by means of literary content for children.

Our starting point is the idea that the development of mathematical concepts from an early age 'must be placed in a realistic context, the child must be movitated to participate in learning, and the learning process must be prompted by internal impulses of the child' (Stakić and Maričić 2018, 370), but also by the ideas of Vygotsky (Vigotski 1977) and his associates who ob- 
served learning as a social process occurring in interaction with others, in socially constructed situations where language plays a central role. 'Thinking, learning and language are interwoven. Children use oral, written and visual language to convey ideas, thoughts, emotions, values and beliefs, to learn to understand themselves and others, and to analyse their own learning process and thinking processes' (Pavlović Breneselović and Krnjaja 2017, 23).

The process of preschool mathematics education is characterised by numerous idiosynchrasies. A child of preschool age is a unique recipient and learning at this age greatly differs from the learning process of adults. Children learn on their own in situations which make sense to them, when they are prompted by intrinsic motivation to learn, and when learning is familiar, based on their personal experience and needs. These are situations in which mathematical context is pushed in the background, and learning is placed in a context familiar and interesting to the child, and when it comprises activities the child is willing to participate in. Both the National Association for the Education of Young Children and the National Council of Teachers of Mathematics emphasise the importance of 'weaving mathematics into children's experiences with literature, language, science, social studies, art, movement, music, and all parts of the classroom environment' (National Association for the Education of Young Children and National Council of Teachers of Mathematics 2002, 7). Children's literature creates such a context to a great extent, because it represents the basic content for language development activities, and in terms of mathematics education, it represents an integrative element which creates a foundation and a realistic learning context.

Numerous studies indicate there is a connection between mathematics and language development in preschool period, where both subjects contribute to child's development (Ojose 2008; Purpura et al. 2011; Welsh et al. 2010). Authors emphasise that this way, we get meaningful and authentic learning (Clements, Sarama, and DiBiase 2003; Kilpatrick, Swafford, and Findell 2001), and that this teaching strategy helps students use mathematics to connect to their own lives each day (Pomykal Franz and Pope 2005). An integrated approach to learning is in harmony with the idea of holistic preschool education. The teacher uses literary content to spontaneously create conditions for associating learning with the child's personal experience, to link practical activities with activities occurring in the realm of the abstract, thus ensuring a spontaneous transition from concrete, realistic concepts to abstractions and generalisations required by the very nature of mathematics. Mathematics is presented to children using a language they understand. The language is visualised through images generated by the literary text, 
all of which helps children understand mathematical ideas and concepts. In addition, literary content for children also creates a context for solving problems which are then translated to the domain of mathematics, whereas children are additionally encouraged to actively participate in problem solving, because mathematical context is pushed in the background. This manner of organising activities in preschool education allows children to experience mathematics as part of their everyday lives, not just as an abstract and isolated subject, which helps stimulate their interest in mathematics and their understanding of it. Literary content for children motivates students to learn by providing a meaningful context for mathematics, celebrates mathematics as a language, demonstrates that mathematics develops out of human experiences, fosters the development of number sense and integrates mathematics into other curriculum areas (Whitin and Wilde 1992). It represents the 'basis' for activities directed towards speech development in preschool children and, on the other hand, provides the basis for the development of abstract mathematical concepts in preschool education (Stakić and Maričić 2019, 185). This way, learning mathematics and learning language merge together, and their content and activities continuously permeate each other.

Reading can be comprehended as a problem-solving and constructive process, meaning that integrating mathematics and literature could be effective: integration not only develops mathematical skills but literacy, mathematical language, and problem solving as well (Wiburne and Napoli 2008 in Wikholm and Aerila 2016, 565). A child enjoys a literary text, identifies with a hero, and often becomes a creator itself, continuing the illusion of a depicted reality in its imagination (Stakić and Maričić 2019, 185).

Thematic structure of children's literature is close to the needs and interests of a preschool child, so any literary form (poetry, prose, play, short literary forms) can be used as an integrative element. The choice of literary form, as well as literary content depends primarily on the goals we want to achieve in each area of knowledge: language development and mathematics education. The same text plays a different role in each content area. Activities in this process are intertwined, first they occur separately, and then they merge together. This way, children develop language skills in addition to mathematical skills: speech sounds are correctly articulated and discriminated, child's active vocabulary is enriched and expanded, and finally, the child's sentence is developed and corrected. This way, reality portrayed by literary content is visualised through specific didactic material and placed in a realistic learning environment. Children readily participate in such activities and acquire 
knowledge on their own. They do not distinguish between the subjective and the objective, the real and fantasy world co-exist on the same plane. This is why children are so attracted to fairy tales, because they depict the world exactly as children imagine it (Purić and Maričić 2010).

For example, analysing the fairy tale Goldilocks and the Three Bears as part of language development helps develop the skills of listening, speaking, retelling, description, vocabulary enrichment, etc. When applied to mathematics education, the said fairy tale creates a realistic and rich context which, when coupled with didactic material, creates a basis for developing the concept of number three, but also proportional relationships (big-small), seriation by size, etc. There are three bears, three chairs, three tables, etc. in the fairy tale. These elements are presented with by means of didactic material and they help children create a clear mental image of number three. In addition, the fairy tale can be used as a starting point for introducing proportional relationships. Three bears are of different size, as well as their beds, chairs, food bowls, clothes, etc. Children will identify these separate elements and compare them to each other.

Numerous studies outline the benefits of this type of integrated mathematics education which utilises literary content for children in preschool education (Welsh et al. 2010; Ojose 2008; Purpura et al. 2011; Rosen and Hoffman 2009; Skoumpourdi and Mpakopoulou 2011; Van den Heuvel-Panhuizen and Elia 2011; Van den Heuvel-Panhuizen, Elia, and Robitzch 2016). Even a picture book as the first book in the child's life offers countless possibilities for integrated teaching aimed at developing language and mathematical skills. The fact these books contain little to no text helps teachers motivate their students to upgrade and complement the image/images by inventing a story of their own, which stimulates and channels their language development. In addition, cognitive context of the picture book is familiar to the child, so he will have no trouble identifying with it.

This way, the child will learn spontaneously, because reading the text from a picture book represents a natural continuation of learning through play which was a dominant teaching method during preschool education (Maričićm Maksimović, and Stakić 2018, 400). On the other hand, when it comes to the development of mathematical skills, research results confirm a threemonth reading program which uses picture books containing mathematical content has positive effects on the improvement of children's math performance even when no additional mathematical activities are involved (Van den Heuvel-Panhuizen, Elia, and Robitzch 2016).

Given the opinion stated above, i.e. that all literary forms can be used 
as an integrative element when teaching preschool children, and that the choice of a specific form is determined by the specific goals a teacher wants to acoomplish in each content area (language development and development of mathematical concepts), we wanted to examine the actual situation in preschool education. We examined the extent to which preschool teachers integrate language development and development of mathematical concepts, which literary form is used most frequently as an integrative element and the presence of integration in each content area of preschool mathematics education.

\section{Methodological Framework}

Our survey was conducted in May 2018 on a sample $(N=200)$ chosen from the population of preschool teachers working in preschool institutions in the Republic of Serbia. The sample had characteristics of a random sample. The preschool teachers have voluntarily agreed to the survey. Our survey encompassed preschool teachers with different professional experience, different level of education and teachers working in different models of education ( $A$ - open model of education, $B$ - closed model of education). The highest percentage of respondents have between 11 and 20, and 21 to 30 years of experience ( $32 \%$ each), followed by preschool teachers with less than 10 years of experience (20\%).

The lowest percentage of respondents have over 30 years of experience (16\%). Only $30 \%$ of all respondents have a degree of a vocational college, whereas $70 \%$ of the respondents have a university degree. $77 \%$ of the respondents use model B, whereas only $23 \%$ use model $A$.

Our survey is based on a descriptive method. The data necessary for the survey were collected through interviewing. We designed a closed-ended questionnaire. Teachers responded by selecting an answer that best expressed their opinion among several available answers. The survey was anonymous to ensure sincerity and avoid desirable answers. The value of the Cronbach's alpha coefficient (0.897) indicates realiability of instruments used and justifies their acceptability.

The following characteristics of preschool teachers comprise the independent variable: professional experience (less than 10 years, between 11 and 20 years, between 21 and 30 years, more than 30 years) and level of education (vocational college degree, university degree). The data were processed using the IBM SPSS Statistics 23 statistical software. Measures of descriptive statistics used include frequencies and percenteges. We also used the chisquare test and $F$-test as analysis methods enabling statistical reasoning. 
Table 1 Descriptive Statistics: Integrating Preschool Mathematics Activities with Other Areas of Knowledge

\begin{tabular}{lrrrrrrr}
\hline Areas of knowledge & 1 & 2 & 3 & 4 & 5 & $M$ & $S D$ \\
\hline Language development & 90 & 74 & 20 & $\begin{array}{r}10 \\
(45 \%)\end{array}$ & 6 & 1.84 & 1.002 \\
& 82 & 52 & 40 & 14 & 12 & 2.11 & 1.197 \\
\hline Getting to know one's & $(10 \%)$ & $(5 \%)$ & $(3 \%)$ & & \\
environment & $81 \%)$ & $(26 \%)$ & $(20 \%)$ & $(7 \%)$ & $(6 \%)$ & & \\
\hline Music education & 24 & 40 & 66 & 62 & 3.75 & 1.140 \\
& $(4 \%)$ & $(12 \%)$ & $(20 \%)$ & $(33 \%)$ & $(31 \%)$ & & \\
\hline Art education & 2 & 22 & 46 & 68 & 62 & 3.83 & 1.025 \\
\hline Physical education & $(1 \%)$ & $(11 \%)$ & $(23 \%)$ & $(34 \%)$ & $(31 \%)$ & & \\
\hline
\end{tabular}

\section{Results and Discussion}

The first research task was to determine the extent to which preschool teachers integrate learning activities within preschool mathematics education and language development with regard to other areas of knowledge. Preschool teachers are on a scale of 1 (highest) to 5 (lowest) evaluated the degree of integration learning activities of mathematical educational and other areas of knowledge. Results show that preschool teachers most frequently integrate activities related to preschool mathematics education with language development ( $M=1.84)$, followed by getting to know one's environment $(M=$ 2.11) (table 1). The third most frequent form of integration is integration with physical education $(M=3.47)$, whereas activities within mathematics education are seldom integrated with activities related to music education $(M=3.75)$ and art education $(M=3.83)$.

Results also validate our theoretical assumptions on the role and importance of integrating activities of mathematics education and language development. This means teachers are able to recognise and understand the connection between language development and mathematics education, and behave accordingly. Another proof of the validity of this practice in preschool mathematics education is the fact that, besides integrating activities related to mathematical content, preschool teachers also frequently integrate activities aimed at becoming familiar with one's environment. Through literary content, teachers create a basis for familiarising children with mathematical concepts, and by including activities aimed at familiarising oneself with one's environment, they link mathematics to real life and allow children to apply mathematical knowledge in practice. This way, they bridge the gap between 
Table 2 F-test: Differences in Teacher Attitudes on Integrated Teaching in Preschool Education with Regard to Professional Experience, Level of Education and Model of Preschool Education

\begin{tabular}{|c|c|c|c|}
\hline Areas of knowledge & $\begin{array}{l}\text { Professional } \\
\text { experience }\end{array}$ & Level of education & $\begin{array}{l}\text { Model of preschool } \\
\text { education }\end{array}$ \\
\hline Language development & $\begin{array}{l}F(3,196)=0.591 \\
p=0.623\end{array}$ & $\begin{array}{l}F(1,198)=1.286 \\
p=0.260\end{array}$ & $\begin{array}{l}F(1,198)=1.050 \\
p=0.308\end{array}$ \\
\hline $\begin{array}{l}\text { Getting to know one's } \\
\text { environment }\end{array}$ & $\begin{array}{l}F(3,196)=2.142 \\
p=0.100\end{array}$ & $\begin{array}{l}F(1,198)=1.081 \\
p=0.301\end{array}$ & $\begin{array}{l}F(1,198)=0.489 \\
p=0.486\end{array}$ \\
\hline Music education & $\begin{array}{l}F(3,196)=1.693 \\
p=0.174\end{array}$ & $\begin{array}{l}F(1,198)=0.082 \\
p=0,776\end{array}$ & $\begin{array}{l}F(1,198)=1.708 \\
p=0,194\end{array}$ \\
\hline Art education & $\begin{array}{l}F(3,196)=1.539 \\
p=0.209\end{array}$ & $\begin{array}{l}F(1,198)=0.687 \\
p=0,409\end{array}$ & $\begin{array}{l}F(1,198)=0.194 \\
p=0,660\end{array}$ \\
\hline Physical education & $\begin{array}{l}F(3,196)=0.218 \\
p=0.884\end{array}$ & $\begin{array}{l}F(1,198)=0.102 \\
p=0.750\end{array}$ & $\begin{array}{l}F(1,198)=5.253 \\
p=0.024\end{array}$ \\
\hline
\end{tabular}

children's interests and mathematics, making mathematics more familiar and understandable to the child's outlook on the world, but also creating a strong bond between mathematics and one's actual environment, which helps children understand this science and recognise ways to implement it in everyday life.

Analysing the opinions of preschool teachers with regard to the independent variable (professional experience, level of education and model of education) (table 2), we determined teachers are united in their attitudes on the integration of activities aimed at developing mathematical concepts and activities related to other areas of knowledge. The only statistically significant differences exist between teachers who work in different models of education $(F(1,198)=5.253 ; p=0.024)$, and they are reflected in their opinions about the frequency of integrating activities related to physical education and activities aimed at developing mathematical concepts. Teachers working by model $A$ integrate activities related to physical education with activities aimed at developing mathematical concepts more frequently than teachers working by model $\mathrm{B}$.

Results we obtained are the best proof preschool teachers share the opinion on the importance of integration between language development and elementary mathematical concepts, and the proof they actually organise and undertake activities aimed at integrating these two areas of knowledge.

We wanted to examine which literary forms are used most frequently for developing mathematical concepts. We offered the following literary forms in the questionnaire: poetic text, prose text (stories, fairy tales, fables, etc.), short 
Table 3 Descriptive Statistics: Presence of Literary Forms in Mathematical Concept Development

\begin{tabular}{lrrrrrr}
\hline Literary forms & 1 & 2 & 3 & 4 & $M$ & $S D$ \\
\hline Poetic text & 28 & 58 & 62 & 52 & 2.69 & 1.012 \\
& $(14 \%)$ & $(29 \%)$ & $(31 \%)$ & $(26 \%)$ & & \\
\hline Prose text & 100 & 46 & 48 & 6 & 1.80 & .910 \\
& $(50 \%)$ & $(23 \%)$ & $(24 \%)$ & $(3 \%)$ & & \\
\hline Short literary forms & 38 & 44 & 42 & 76 & 2.78 & 1.151 \\
& $(19 \%)$ & $(22 \%)$ & $(21 \%)$ & $(38 \%)$ & & \\
\hline Drama text & 34 & 52 & 48 & 66 & 2.73 & 1.100 \\
& $(17 \%)$ & $(26 \%)$ & $(24 \%)$ & $(33 \%)$ & & \\
\hline
\end{tabular}

Table 4 F test: Attitudes of Preschool Teachers about Literary Forms Most Frequently Used in the Development of Mathematical Concepts with Regard to Professional Experience, Level of Education and Model of Education Used

\begin{tabular}{llll}
\hline Literary forms & $\begin{array}{l}\text { Professional } \\
\text { experience }\end{array}$ & Level of education & $\begin{array}{l}\text { Model of preschool } \\
\text { education }\end{array}$ \\
\hline Poetic text & $F(3,196)=0.179$ & $F(1,198)=0.634$ & $F(1,198)=0.538$ \\
& $p=0.910$ & $p=0.428$ & $p=0.465$ \\
\hline Prose text & $F(3,196)=1.197$ & $F(1,198)=0.000$ & $F(1,198)=1.324$ \\
& $p=0.315$ & $p=1.000$ & $p=0.253$ \\
\hline Short literary forms & $F(3,196)=1.184$ & $F(1,198)=4.168$ & $F(1,198)=1.092$ \\
& $p=0.320$ & $p=0.044$ & $p=0.299$ \\
\hline Drama text & $F(3,196)=0.495$ & $F(1,198)=1.892$ & $F(1,198)=0.669$ \\
& $p=0.687$ & $p=0.172$ & $p=0.416$ \\
\hline
\end{tabular}

literary forms (riddles, tongue twisters, counting rhymes, etc.) and drama text, ranked from 1 (highest ranking) to 4 (lowest ranking) by the frequency with which a literary form appears in mathematical concept development.

Results show that the most frequently used literary forms in preschool mathematics education are prose text $(M=1.80)$, followed by poetic text ( $M$ $=2.69)$, drama text $(M=2.73)$, and finally, short literary forms $(M=2.73)$.

Statistical analysis shows that preschool teachers with different professional experience, level of education and working by different models are united in their outlook and that there are no statistically significant differences in their attitudes (table 4).

The data show teachers most frequently use prose texts, including stories, fairy tales, fables, etc. for mathematical concept development. This makes sense, given the nature of children on the one hand, and the content of prose texts for children on the other hand. The subject matter of prose texts is familiar and relatable to children. 'Apart from the world of childhood and differ- 
Table 5 Descriptive Statistics: Implementation of Literary Content for Children in Different Areas of Preschool Mathematics Education

\begin{tabular}{lrrrrrrr}
\hline Areas & 1 & 2 & 3 & 4 & 5 & $M$ & $S D$ \\
\hline Number & 76 & 58 & 30 & 18 & 18 & 2.22 & 1.292 \\
& $(38.0 \%)$ & $(29.0 \%)$ & $(15.0 \%)$ & $(9.0 \%)$ & $(9.0 \%)$ & & \\
\hline Set & 40 & 60 & 60 & 22 & 18 & 2.59 & 1.190 \\
& $(20.0 \%)$ & $(30.0 \%)$ & $(30.0 \%)$ & $(11.0 \%)$ & $(9.0 \%)$ & & \\
\hline Geometry & 14 & 30 & 46 & 60 & 50 & 3.51 & 1.219 \\
& $(7.0 \%)$ & $(15.0 \%)$ & $(23.0 \%)$ & $(30.0 \%)$ & $(25.0 \%)$ & & \\
\hline Spatial relations & 64 & 26 & 38 & 52 & 20 & 2.69 & 1.412 \\
& $(32.0 \%)$ & $(13.0 \%)$ & $(19.0 \%)$ & $(26.0 \%)$ & $(10.0 \%)$ & & \\
\hline Measurements & 6 & 26 & 26 & 48 & 94 & 3.99 & 1.185 \\
& $(3.0 \%)$ & $(13.0 \%)$ & $(13.0 \%)$ & $(24.0 \%)$ & $(47.0 \%)$ & & \\
\hline
\end{tabular}

ent life events, human and children's feelings, love, kindness, play, friendship, human altruism and humanity, love for parents and animals, imaginative and picturesque events, cheerful humour and painted scenes, flora and fauna, fictional worlds, sympathy and the first secret, are some of the common themes of children's literature' (Stakić 2014, 245). The topics mentioned above create a picturesque world a child can envision and complement through imagination, a place he/she can escape into, or identify with the heroes. From the standpoint of language, this contributes to the development of all linguistic elements, i. e. phonetic, morphological, lexical and syntactic. All of the above also has a positive psychological effect on children, because a first contact with prose texts occurs in an environment where the child feels safe and loved, in the family when parents read fairy tales to their children. This also represents the first spontaneous effort toward language development. Research studies also indicate that reading books together provides the first context in which children and their parents can participate in mathematical conversations (Anderson, Anderson, and Shapiro 2005)

The goal of the third task was to examine areas of preschool mathematics education where the literary content for children was used most frequently. The question for preschool teachers was defined as following - In what areas of preschool mathematics education do you most frequently integrate literary content for children? - and the available answers were the following: numbers, sets, geometry, relations, measurements, ranked from 1 (most frequently) to 5 (least frequently) in descending order. Based on this task, we set up a hypothesis: preschool teachers implement literary content for children most frequently to help children develop the concept of number.

The data we obtained show that teachers commonly use literary content 
Table 6 F test: Teachers' Attitudes on Content Integrated with Other Areas of Knowledge with Regard to their Professional Experience, Level of Education and Model of Education Used

\begin{tabular}{llll}
\hline Areas & $\begin{array}{l}\text { Professional } \\
\text { experience }\end{array}$ & Level of education & $\begin{array}{l}\text { Model of preschool } \\
\text { education }\end{array}$ \\
\hline Number & $\begin{array}{l}F(3,196)=0.407 \\
p=0.748\end{array}$ & $\begin{array}{l}F(1,198)=2.873 \\
p=0.093\end{array}$ & $\begin{array}{l}F(1,198)=0.004 \\
p=0.950\end{array}$ \\
\hline Set & $F(3,196)=0.354$ & $F(1,198)=0.002$ & $\begin{array}{l}F(1,198)=2.520 \\
p=0.116\end{array}$ \\
& $p=0.787$ & $p=0.964$ & $F(1,198)=2.639$ \\
\hline Geometry & $F(3,196)=1.963$ & $F(1,198)=1.077$ & $p=0.107$ \\
\hline Spatial relations & $p=0.125$ & $p=0.782$ & $F(1,198)=1.809$ \\
& $F(3,196)=0.661$ & $F(1,198)=0.878$ & $p=0.182$ \\
\hline Measurements & $p=0.578$ & $p=0.351$ & $F(1,198)=1.091$ \\
& $F(3,196)=0.155$ & $F(1,198)=1.400$ & $p=0.299$ \\
\hline
\end{tabular}

for children as scaffolding to help children develop the concept of number, $(M=2.22)$, to develop the concept of set $(M=2.59)$, and spatial relations (size and position) ( $M=2.69)$. Literary content is least frequently used to develop concepts related to geometry $(M=3.51)$ and measurements $(M=3.99)$ (table 5).

The fact that teachers most frequently use literary content to develop the concept of number makes perfect sense. Numbers from 1 to 10 appear quite often in preschool mathematics education in comparison to other content. In addition, there are numerous elements in children's literature that can be used to develop and understand the concept of numbers, their structure, position in a sequence, relationship with other numbers. Picture books can be used for this purpose because they are filled with sets whose cardinal number represents a natural number, poetic texts easy to memorise, stories where we repeatedly encounter a set whose cardinal number is the number children are trying to develop, short literary forms which teach children to count and name numbers, or fairy tales which have symbolic numbers that repeat over and over again (e.g. seven towers, seven seas, seven mountains, seven dwarves, seven little goats, etc.). From the aspect of language development, children name the concept of number within the context of a sentence, as the most common unit of communication; they use the concept in its different morphological forms and lexical combinations with other word classes, thus spontaneously adopting congruence and correct word usage in everyday communication.

The second most common usage of literary content in preschool mathematics education is to develop the basic elements of the set theory (element, 
membership), but also relations between sets. Literary content for children is least used for developing geometric concepts, the concept of measurements and for familiarising children with units of measurement, which stems from the fact that developing these concepts relies on practical activities, i. e. utilisation of didactic materials and tools that can be found in the immediate environment, so their models are already available to children and don't require additional context.

Analysis of teachers' opinions with regard to their professional experience, level of education and model of education used shows there are no statistically significant differences among these groups. Looking at table 6 , we can see there are no statistically significant differences in preschool teachers' attitudes with regard to the independent variables.

\section{Conclusion}

Results of our survey show that in preschool practice in Serbia, activities aimed at mathematics education are most frequently integrated with activities aimed at speech and language development of preschool children. Preschool teachers utilise literary content for children for this purpose, primarily short prose and poetic texts. Their suitability stems from their content which is interesting and familiar to children, but at the same time packed with mathematical examples conducive to the development of the concept of number, concept of set and spatial relations. In addition, these literary forms with integrated mathematical concepts help in language development through retelling, descriptions, dramatisation, etc, all of which is aimed at improving children's comprehension. Children practice correct articulation and discrimination of speech sounds, enrich and expand their vocabulary, and practice correct usage of morphological forms of word on lexical combinations realised within a sentence. At the same time, they enrich and develop their sentence, gradually increasing the number of sentence elements. It is a teacher's duty to devise and plan these activities in detail, to find suitable literary texts that can be used as the starting point in the integration of mathematics education and language development. Despite the fact many literary texts could be used for this purpose, there are other criteria they need to meet, e.g. they need to be suitable for preschool age and they need to meet the aesthetic criteria. This is why we recommend experts involved in the integration of language development and mathematics education should make a selection of appropriate literary texts containing teaching methods and methodology-related instructions that would greatly facilitate the efforts of preschool teachers. 


\section{References}

Anderson, A., J. Anderson, and J. Shapiro. 2005. 'Supporting Multiple Literacies: Parents' and Children's Mathematical Talk within Storybook Reading.' Mathematics Education Research Journal 16 (3): 5-26.

Clements, H. D., J. Sarama, and A. DiBiase. 2003. Engaging Young Children in Mathematics: Findings of the 2000 National Conference on Standards for Preschool and Kindergarten Mathematics Education. Mahwah, NJ: Lawrence Erlbaum.

Kilpatrick, J., J. Swafford, and B. Findell. 2001. Adding It up: Helping Children Learn Mathematics. Washington, DC: National Academy Press.

Maričić, S., M. Stakić, and N. Malinović-Jovanović. 2018. 'The Role of Literary Content for Children in Preschool Mathematics Education.' Eurasia Journal of Mathematics, Science \& Technology Education 4 (2): 631-642.

Maričić, S., J. Maksimović, and M. Stakić. 2018. 'Use of the Picture Book in Teaching Mathematics and Serbian Language to Children with Learning Disabilities.' In Oblikovanje inovativnih učnih okolij, edited by T. Štemberger, S. Čotar Konrad, S. Rutar, and A. Žakelj, 395-413. Koper: Založba Univerze na Primorskem.

National Association for the Education of Young Children and National Council of Teachers of Mathematics. 2002. 'Early Childhood Mathematics: Promoting Good Beginnings.' https://www.naeyc.org/files/naeyc/file/positions/ psmath.pdf

Novaković, S. 2015. 'Preschool Teacher's Role in the Art Activities of Early and Preschool Age Children.' Croatian Journal of Education 17 (1): 153-163.

Ojose, B. 2008. 'Applying Piaget's Theory of Cognitive Development to Math Instruction.' The Mathematics Educator 18:26-30.

Pravilnik o osnovama programa predškolskog vaspitanja i obrazovanja. 2018. http://zuov.gov.rs/wp-content/uploads/2018/10/Године-узлета.pdf

Organisation for Economic Co-operation and Development. 2006. Starting Strong II: Early Childhood Education and Care. Pariz: Organisation for Economic Co-operation and Development.

Pavlović Breneselović, D., and Ž. Krnjaja. 2017. Kaleidoskop: osnove diversifikovanih programa predškolskog vaspitanja i obrazovanja. Beograd: Institut za pedagogiju i andragogiju.

Pomykal Franz, D., and M. Pope. 2005. 'Using Children's Stories in Secondary Mathematics.' American Secondary Education 33 (2): 21-28.

Purić, D., and S. Maričić. 2010. 'Savremenost i funkcionalnost bajke u razvoju govora i početnih matematičkih pojmova.' In Savremeni trenutak književnosti za decu u nastavi i nauci, edited by M. Janjić, 467-477. Vranje: Učiteljski fakultet.

Purpura, J. D., E. L. Hume, M. D. Sims, and J. C. Lonigan. 2011. 'Early Literacy and Early Numeracy: The Value of Including Early Literacy Skills in the Predic- 
tion of Numeracy Development.' Journal of Experimental Child Psychology 110 (4): 647-658.

Rosen, D., and J. Hoffman. 2009. 'Integrating Concrete and Virtual Manipulatives in Early Childhood Mathematics.' Young Children 64:26-33.

Skoumpourdi, C., and I. Mpakopoulou. 2011. 'The Prints: A Picture Book for PreFormal Geometry.' Early Childhood Education Journal 39:197-206.

Stakić, M. 2014. 'The Specifics of Children's Literature in the Context of Genre Classification.' Mediterranean Journal of Social Sciences 5 (19): 243-252.

Stakić, M., and S. Maričić. 2018. 'Poezija Dragana Lukića kao integrativni element razvoja govora i matematičkih pojmova u predškolskom vaspitanju i obrazovanju.' In Književnost za decu u nauci i nastavi, edited by V. Jovanović and B. Ilić, 369-385. Jagodina: Fakultet pedagoških nauka.

Stakić, M., and S. Maričić. 2019. 'Integration of Activities of Mathematical Education and Language Development in Preschool Education.' In Implicit Pedagogy for Optimized Learning in Contemporary Education, edited by J. Vodopivec, L. Jančec and T. Štemberger, 184-204. Hershey, PA: IGI Global.

Van den Heuvel-Panhuizen, M., and I. Elia. 2011. 'Kindergartners' Performance in Length Measurement and the Effect of Picture Book Reading.' The International Journal on Mathematics Education 43 (5): 621-635.

Van den Heuvel-Panhuizen, M., I. Elia, and A. Robitzsch. 2016. 'Effects of Reading Picture Books on Kindergartners' Mathematics Performance.' Educational Psychology 36 (2): 323-346.

Vigotski, L. 1977. Mišljenje i govor. Beograd: Nolit.

Wikholm, M., and J. Aerila. 2016. 'Teaching Mathematics with Children's Literature in Finland.' International Journal of Learning and Teaching 8 (4): 253261.

Welsh, J. A., R. L. Nix, C. Blair, K. L. Bierman, and K. E. Nelson. 2010. 'The Development of Cognitive Skills and Gains in Academic School Readiness for Children from Low-Income Families.' Journal of Educational Psychology 102 (1): 43-53.

Wiburne, J. M., and J. Napoli. 2008. 'Connecting Mathematics and Literature: An Analysis of Preservice Elementary School Teachers' Changing Beliefs and Knowledge.' IUMPST: The Journal 2:1-10.

Whitin, J. D., and S. Wilde. 1992. Read Any Good Math Lately? Children's Books for Mathematical Learning, K-6. Portsmouth, $\mathrm{NH}$ : Heinemann.

\section{Učenje matematike in jezika s pomočjo integrativnega pristopa v predšolskem izobraževanju}

V prispevku avtorji trdijo, da je za predšolsko izobraževanje potreben celosten pristop k učenju, v katerem so integrirana različna področja znanja. $V$ tem kontekstu je posebna pozornost namenjena pomenu vključevanja jezikovnega razvoja in izobraževanja predšolske matematike s pomočjo vsebin iz literature 
za otroke. V raziskovalnem delu so si avtorji zastavili cilj, da preučijo, v kolikšni meri izobraževalci integrirajo razvoj jezika in razvoj matematičnih pojmov, ki jih večinoma uporablja literarna oblika kot sestavni element literarnega dela, in koliko je vključevanje vključeno v vsako od področij izobraževanja predšolske matematike. Dobljeni rezultati kažejo, da vzgojitelji v delu večinoma povezujejo dejavnosti jezikovnega razvoja in matematike kot integrativnega elementa, večinoma $z$ uporabo proze in poetičnega besedila, ter da se otroška književnost večinoma uporablja kot podpora, ko je potrebno razviti pojem števila in koncepta množice.

Ključne besede: predšolska vzgoja, integracija, matematična vzgoja, jezikovni razvoj, otrok 



\title{
Vključevanje staršev $v$ zgodnje učenje matematike
}

\author{
Nataša Živkovič \\ Vrtec pri OŠ Istrskega odreda Gračišče \\ natasa.zivkovic13@gmail.com
}

Sanela Mešinović

Univerza na Primorskem

sanela.mesinovic@pef.upr.si

Svetovna javnost $v$ zadnjih letih posveča veliko pozornost matematični pismenosti. Številne raziskave so pokazale, da lahko matematična znanja napovejo prihodnost otrok. Vplivajo namreč na doseženo stopnjo izobrazbe, akademski uspeh, kvaliteto službe in določajo višino njihove plače. Po nekaterih raziskavah naj bi bila matematična znanja močni napovedovalci socialnoekonomskega statusa. Razvijanje matematične pismenosti je dolgotrajen proces, ki se začne že v predšolskem obdobju. Ravno v tem obdobju imajo starši in domače okolje največji vpliv na razvoj otrok in s tem matematičnega mišljenja, zato lahko sklepamo, da je vključevanje staršev v zgodnje učenje matematike nujno. $V$ ta namen smo izvedli raziskavo, s pomočjo katere smo starše seznanili z zgodnjo matematiko ter otrokom omogočili, da so nekatere koncepte raziskovali v interakciji s svojimi starši v domačem okolju. Ugotovili smo, da si starši želijo postati sooblikovalci otrokovega znanja ter da so z vrtcem pripravljeni sodelovati, vendar si želijo smernic, kako to storiti.

Ključne besede: predšolska vzgoja, zgodnja matematika, domače okolje, starši, matematični nahrbtnik

\section{Uvod}

Razvijanje matematičnega mišljenja je dolgotrajen proces, ki se začne že zelo zgodaj. Dojenček se uči matematiko, še preden je sposoben sedeti, saj opazi razlike v količini, med seboj primerja predmete po obliki in velikosti ter pri igri in vsakodnevnih opravilih uporablja nekatere matematične koncepte (Gopnik idr. 2001).

Številne raziskave kažejo, da ima zgodnje razvijanje matematičnih spretnosti velik vpliv na kasnejše matematične pa tudi bralne zmožnosti otrok (Clements in Sarama 2014; Duncan idr. 2007). M. N. McCain in Mustard (1999) trdita, da so izkušnje, ki jih otrok pridobi v predšolskem obdobju, ključnega pomena za njegove kompetence v prihodnosti, za učinkovito reševanje problemov, hkrati pa vplivajo na njegovo zdravje in kasnejše možnosti zaposli- 
tve. Podobno nam lahko srednješolske matematične sposobnosti napovedo številne uspehe $v$ odraslem obdobju, predvsem visoko stopnjo izobrazbe (Murnane, Willett in Levy 1995) ter kvalitetno službo in plačo (Rivera-Batiz 1992), kar vpliva na ekonomsko uspešnost države. Vzajemni učinek se je pokazal tudi med matematičnimi zmožnostmi ob samem začetku osnovnošolskega izobraževanja in kasnejšimi osnovnošolskimi dosežki (Claessens, Duncan in Engel 2009; Duncan idr. 2007). Dolgoletna raziskava je pokazala, da zgodnje matematične zmožnosti napovedujejo matematične dosežke otrok vse do doseženega petnajstega leta starosti (Watts idr. 2014). Tovrstna spoznanja so vzbudila zanimanja za splošno zagotavljanje predšolske vzgoje kot sredstva za izboljšanje pripravljenosti otrok na šolo in drugih dosežkov (Zigler, Gilliam in Jones 2006). Natančno in jasno določeni cilji poučevanja matematike $v$ vrtcu koristijo vsem otrokom, tudi tistim s posebnimi potrebami (Claessens, Engel in Curran 2014).

Kljub temu, da navedene raziskave dokazujejo močno povezanost med matematičnimi dosežki predšolskih otrok in matematičnimi dosežki srednješolcev, je potrebno opozoriti na dejavnike, ki lahko bistveno vplivajo na te dosežke. Dejavniki kot so motivacija, učenje in poučevanje, domače okolje ter zanimanje za matematiko lahko tako pozitivno kot negativno vplivajo na dosežke pri matematiki (Watts 2014).

\section{Teoretična izhodišča}

\section{Zgodnja matematika}

Izraz "zgodnja matematika« se nanaša na osnovne matematične koncepte, kot so štetje, količinski odnosi, geometrijske oblike, prostorski odnosi, merjenje, vzorci itn. Otroci so po naravi radovedni, zato te koncepte raziskujejo v interakciji s svojim okoljem (Sarama in Clements 2009; Ginsburg, Inoue in Seo 1999). O matematičnih konceptih se učijo v situacijah, ki so blizu njihovemu resničnem življenju. Preko lastnih aktivnosti pridobivajo matematične izkušnje, ki vključujejo tudi logično-matematično mišljenje. Konkretne izkušnje so temelj za razvijanje matematičnega mišljenja pri otroku in za kasnejše učenje abstraktnih pojmov. Samostojno raziskovanje konceptov pa kljub temu ne zadošča za usvajanje matematičnih pojmov, ki jih je otrok doživel - nujna je še vsakodnevna komunikacija z odraslimi. Zato moramo natančno razmisliti, kako otrokom zagotoviti matematične izkušnje in katera sredstva uporabiti, da bodo lahko razvijali svoje matematično mišljenje.

Jasno je, da je vloga odraslega pri raziskovanju matematičnih konceptov zelo pomembna. Njegova naloga je, da otroku pomaga prepoznati matematiko $v$ raznih aktivnostih in pri tem izhajati iz konceptov, ki jih otrok že pozna, 
ter graditi nova matematična znanja (Saxe, Guberman in Gearhart 1987). Matematične dejavnosti lahko vključimo v pesmi, ples, likovno umetnost, športne aktivnosti, igro vlog in domišljijsko igro itn.

Štetje je eno izmed pomembnejših matematičnih konceptov v predšolskem obdobju, saj zmožnost zgodnjega štetja pozitivno vpliva na osnovnošolske in srednješolske matematične zmožnosti otrok (Watts idr. 2014; Bailey, Siegler in Geary 2014; Jordan idr. 2009). Biti številsko pismen ne pomeni le prepoznavati števila, pač pa števila in štetje uporabljati v vsakodnevnem življenju. Taka pismenost nam dodatno omogoča, da lahko razmišljamo in komuniciramo matematično $v$ specifičnem matematičnem kontekstu (Anning in Edwards 2006). Številsko pismenost razvijamo že v predšolskem obdobju, saj poznavanje števil in njihova uporaba pripomore k razvijanju matematičnega mišljenja, kar pa je dolg in kompleksen proces.

P. Munn (1997a) je ugotovila, da lahko otrok izgovarja imena za števila v ustreznem vrstnem redu, vendar ne moremo zagotovo trditi, da ima številske predstave. Zato vzgojitelje opozarja, naj bodo pozorni na razvoj številske pismenosti pri otrocih. Številska pismenost ni tako očitna kot zgodnje opismenjevanje, saj je smiselna raba števil odvisna od razumevanja koncepta števil, ki ga to število predstavlja (Munn 1997b). Saxe idr. (1987) menijo, da lahko otroci številske predstave razvijajo le ob pomoči odraslega, ki jim pomaga pri uporabi obstoječih številskih spretnosti za reševanje kompleksnejših problemov, kar omogoča razvoj novih spoznanj. Pri tem je pomembno, da sta $v$ reševanje problemov vključena igra in razgovor. To otrokom zagotavlja, da reševanje poteka v njihovem jeziku - tako postane zanje problem rešljiv in lahko varno raziskujejo matematične izzive. Ko otroci usvojijo števila in pridobijo številske predstave, lahko raziskujejo druge matematične koncepte, povezane s števili, kot sta obdelava podatkov in merjenje.

Za razumevanje geometrije moramo imeti dobro razvito prostorsko predstavo, saj je ta nujna pri vizualizaciji, načrtovanju in konstrukciji oblik, geometrijskem pogledu na fizični svet ter uporabi znakov za prikaz nevizualnih matematičnih konceptov in odnosov (Mešinović, Cotič in Žakelj 2017).

Na zmožnost prostorske predstavljivosti vplivajo predvsem izkušnje, ki jih imamo z oblikami in s prostorskimi odnosi. Prve izkušnje pridobimo kmalu (ob rojstvu) - z opazovanjem in manipuliranjem konkretnih predmetov $v$ prostoru. Fizična dejanja ponotranjimo in posplošimo v koncepte ter odnose (Dickson, Brown in Gibson 1984).

Tako kot pri vpeljevanju števil in štetja je pri pridobivanju prostorskih predstav prisotnost odrasle osebe nujna. Njena naloga je, da izbere in ponudi ustrezne didaktične pripomočke, ki jih bo otrok uporabil pri igri in reševanju 
geometrijskih problemov. Sredstva, ki jih ponudimo otroku, morajo vzpodbujati miselni napor ter povečevati motivacijo za reševanje problema. $V$ nasprotnem primeru ima didaktično sredstvo funkcijo posrednika oz. primitivnega kalkulatorja (Hodnik Čadež in Manfreda Kolar 2009), v nekaterih primerih ima lahko celo škodljiv učinek na učenje in uspešnost (McNeil in Jarvin 2007).

\section{Starši in domače okolje}

Zgodnje učenje matematike $v$ vrtcu ni in ne sme biti le pripravljanje otrok na šolsko matematiko, ampak priložnost, da z otroki razvijamo njihovo lastno učinkovitost. S konkretnimi izkušnjami se neformalno učijo osnovne matematične koncepte, na katerih lahko $v$ osnovni šoli gradijo formalnejše in abstraktnejše koncepte.

Prvih nekaj let otrokovega življenja imajo starši in domače okolje največji vpliv na razvoj možganov, kar se kaže $v$ šolskem uspehu in na drugih področjih življenja (Harris in Petersen 2017). Posledično interakcija med starši in otrokom vpliva na zgodnje razumevanje matematike. Melhuish idr. (2008) so pokazali, da poleg socialno-ekonomskega statusa domače učno okolje pomembno vpliva na otrokove matematične dosežke. Otroci, katerih starši se zavedajo pomembnosti svoje vpletenosti $v$ učno okolje in so seznanjeni $z$ njihovimi dosežki, oblikujejo pozitiven odnos do šole in so učno uspešnejši (Epstein 1992). Bogata učna okolja, ki vključujejo pomembne matematične izkušnje, so povezana z višjimi dosežki otrok (Biddulph, Biddulph in Biddulph 2003).

Otroci v domačem okolju delujejo bolj sproščeno, saj so čustveno navezani na starše in se počutijo varne, zato so tudi zmožni izraziti svoje znanje, ki ga v neznanem okolju ne bi. Cai (2003) je pokazal, da je vpletenost staršev statistično pomemben napovedovalec matematičnega dosežka njihovih otrok, prav tako pa spodbuja pozitivno vedenje in čustveni razvoj.

Otroci, ki v času od 1 do 3 let živijo v spodbudnem matematičnem okolju, so ob vstopu v šolo uspešnejši pri razumevanju matematičnih konceptov kot otroci, ki v tej razvojni dobi nimajo matematično spodbudnega okolja (Berkowitz idr. 2016; Levine idr. 2010).

Spodbujanje matematičnega mišljenja je lahko za nekatere starše zelo zahtevna naloga, saj jo spremljajo anksioznost, nemoč, strah in odpor do matematike, ki izvirajo iz lastne negativne izkušnje oz. negotovosti glede svojih matematičnih znanj (Harris in Petersen 2017; Haylock 2007). Strah pred matematiko se lahko prenese na otroka, začetni vtisi pa imajo lahko dolgotrajne učinke (Cannon in Ginsburg 2008). Mnogo staršev trdi, da je matematika pomembna, vendar meni, da je dolgočasna, saj temelji na pomnjenju pravil in 
procedur (Onslow 1992). R. Pritchard (2004) je analizirala številne raziskave, ki poročajo, da obstajajo povezave med stališči in prepričanji staršev o matematiki ter med odnosom njihovih otrok do matematike. Odnos staršev do matematike pomembno vpliva tudi na uspešnost otrok pri tem predmetu (Pritchard 2004).

Da bi malčkom omogočili vsakodnevno razvijanje matematičnih zmožnosti, bi bilo potrebno (Cannon in Ginsburg 2008; Harris, Petersen in SmitherWulsin 2017):

- seznaniti starše z zgodnjimi matematičnimi koncepti in s pomenom vpeljevanja le-teh v starostnem obdobju od 1 do 3 let,

- staršem omogočiti pomoč pri premagovanju strahov pred matematiko in

- staršem ponuditi konkretne pripomočke, ki omogočajo učenje matematičnih konceptov skozi dnevno rutino $v$ domačem okolju.

Starši so pripravljeni vključiti zgodnje matematične elemente $v$ domače okolje, če vedo, kako to storiti (Starkey in Klein 2000). Starkey in A. Klein (2000) sta pokazala, da je seznanjanje staršev o metodah učenja matematike učinkovito, saj so bili otroci staršev, ki so bili deležni matematičnih delavnic, uspešnejši pri matematiki kot otroci staršev, ki se delavnic niso udeležili. Seznanjanje $z$ metodami učenja pripomore $k$ temu, da so starši samozavestnejši pri vključevanju matematičnih konceptov v življenjske situacije (Tye 1993) in aktivneje sodelujejo v procesu učenja svojih otrok (Morgan in Tremere 1993). J. Bernie in M.-C. Lall (2008) sta ugotovili, da vključevanje staršev v učenje matematike pozitivno vpliva na dosežke učencev, izboljša matematično znanje staršev, zvišuje vključenost staršev v šolsko življenje in splošno izobraževanje njihovih otrok.

Vzgojitelj ima veliko priložnosti, kjer lahko tesno sodeluje s starši in jih seznani z zgodnjo matematiko ter strategijami vključevanja le-te $v$ vsakodnevna domača opravila, ki zahtevajo prepoznavanje matematike $v$ realnih situacijah. Starši morajo imeti podporo s strani vzgojitelja, da bodo lahko svojim otrokom ponudili široko paleto matematičnih izkušenj, ki so smiselno vključene $v$ njihove aktivnosti ter jim ponujajo užitek in veselje. Zato se zdi v ozaveščanje staršev o pomembnosti zgodnjega učenja matematike in njihovo seznanjanje z osnovnimi koncepti koristno vlogati čas in sredstva.

\section{Raziskovalni problem}

Otrok večino časa preživi v vrtcu s svojimi vrstniki in vzgojitelji. V procesu socializacije in učenja sta domače in vrtčevsko okolje kot dva sistema preple- 
tena, zato je smiselno, da sodelujeta za dobrobit otroka. $V$ obdobju zadnjih nekaj desetletij se je razumevanje in pričakovanje vključevanja staršev v ustanove, kot je vrtec, precej spremenilo - od stroge prepovedi prihajanja staršev $v$ vrtec do današnjega sodelovanja in partnerstva med starši in vzgojitelji; slednje narekuje tudi trenutno veljavna zakonodaja, ki jo mora vzgojitelj izpolnjevati (Logar 2012, 37). Razlogi za sodelovanje so pomembni iz več razlogov, saj je otrok v predšolskem obdobju bolj kot kadarkoli pozneje povezan $z$ in odvisen od staršev. $V$ tem obdobju je zaradi tesne povezanosti med njimi največ možnosti, da vzgojitelj posredno vpliva na stališča staršev in jih lahko tudi spreminja (Kunič 2003, 13). Zato smo v okviru naše raziskave starše seznanili s predšolsko matematiko, jim omogočili, da prepoznajo matematiko $v$ življenjskih situacijah, in omogočili, da izvajajo matematične aktivnosti v domačem okolju. Na ta način smo želeli, da bi starši otrok, ki so sodelovali v raziskavi, izgradili pozitiven odnos do matematike, kar pozitivno vpliva na dosežke otrok pri matematiki (Bernie in Lall 2008). Z raziskavo smo želeli ugotoviti, ali naš pristop vključevanja staršev v poučevanje predšolske matematike njihovih otrok omogoča aktivno sodelovanje med starši in vzgojiteljem ter ali omogoča pomoč pri premagovanju strahov pred matematiko. Zato smo si zastavil naslednji raziskovalni vprašanji:

1. Kakšen odnos do matematike imajo starši pred in po izvedbi raziskave?

2. Ali so starši pripravljeni vključiti zgodnje matematične elemente $v$ domače okolje, če vedo, kako to storiti?

\section{Metodologija}

$\checkmark$ raziskavi smo uporabili deskriptivno metodo empiričnega pedagoškega raziskovanja.

$\checkmark$ raziskavo je bila vključena vrtčevska skupina prvega starostnega obdobja, $v$ kateri so bili otroci, stari od 1 do 3 leta. Najmlajši otrok je bil v času izvajanja raziskave star 1 leto in 1 mesec, najstarejši pa 2 leti in 11 mesecev. Sodelovalo je 9 otrok, od tega 3 dečki in 6 deklic ter 18 staršev, od tega 9 moških in 9 žensk.

Raziskava je potekala v šolskem letu 2017/2018. V začetni fazi smo preučili literaturo in pripravili gradiva za starše. Starši otrok vrtčevske skupine so bili deležni izobraževanja oz. priprav na eksperiment, v okviru katerega so bile organizirane delavnice, katerih namen je bil seznaniti starše z zgodnjo matematiko. Razdelili smo jim gradivo, ki smo ga poimenovali »matematični nahrbtnik« in ki jim je bilo v pomoč pri načrtovanju ter izvedbi matematične aktivnosti v domačem okolju. Vsebino »matematičnega nahrbtnika« sta pred- 
stavljala torbica, $v$ kateri so bile kartonke $z$ matematično vsebino, in zvezek $z$ izbranimi matematičnimi nalogami. Zvezek je vseboval 27 nalog s področja števil, geometrije, razvrščanja, urejanja in prirejanja ter kombinatorike, opremljene s fotografijami.

$\checkmark$ uvodnem delu zvezka so bili zapisani navodila za starše ter spletni naslov, kamor so lahko poslali poljubno fotografijo s komentarjem. Navodilo je staršem narekovalo, da si z otrokom izberejo nalogo iz zvezka in po otrokovih zmožnostih ustvarijo oz. izdelajo matematično igro, ki jo nato prinesejo $v$ vrtec.

Podatke smo zbrali kvalitativno, in sicer z opazovanjem in s pogovorom $\mathrm{s}$ starši. Pred in po izvedbi raziskave smo starše povprašali o njihovem odnosu do matematike. Pogovor je potekal individualno z vsakim staršem, saj smo želeli ugotovili vzroke za pozitiven oz. negativen odnos do matematike. Da bi pridobili mnenje staršev o ustreznosti našega pristopa, smo jih zaprosili, da nam povratne informacije o aktivnostih, izvedenih doma, posredujejo na dani spletni naslov.

\section{Razprava in evalvacija}

Pred izvedbo raziskave smo se pogovorili s starši glede njihovega odnosa do matematike. Ugotovili smo, da ima večina staršev (16) negativen odnos do matematike, ki izvira iz lastne negativne izkušnje oz. negotovosti glede svojih matematičnih znanj. Le dva starša poročata, da nimata ne pozitivnih in ne negativnih matematičnih izkušenj. Strinjamo se $s$ trditvijo B. Japelj Pavešić (2014), ki pravi, da lahko matematika zaradi svoje specifičnosti vzbuja nelagodje pri starših zaradi lastne nesamozavestni oz. pretekle izkušnje. Nekateri starši so namreč to trdtiev potrdili. Zavedati se moramo, da izkušnje staršev pomembno vplivajo na pripisovanje pomena pomembnosti matematičnemu znanju. Otrok, ki znanje usvoji, vendar ne dobi povratne informacije ali potrditve o svojem znanju od odrasle osebe, ki ji zaupa, ne bo začel ceniti svojega znanja (Japelj Pavešić 2014, 28). Poleg tega, ni dovolj, da vrtec otroku ponuja veliko odličnih priložnosti za učenje matematike, treba je narediti še naslednji korak: vključiti starše v prepoznavanje otrokovega znanja, dvigniti njihovo zanimanje za dosežke in izdelke njihovih otrok ter uskladiti pričakovanja do otrokovega napredovanja $v$ matematiki z njegovimi domačimi (Japelj Pavešić 2014, 28).

Vsi starši (18) izbrane vrtčevske skupine otrok so se udeležili matematičnih delavnic, kjer so dobili potrebne informacije glede izvedbe raziskave. Starši, ki so se udeležili delavnic, so bili tudi pripravljeni sodelovati v raziskavi. Pri tem so pokazali veliko mero ustvarjalnosti in angažiranosti: tako so starši 
Slika 1

Izdelava

matematično-didaktične igre
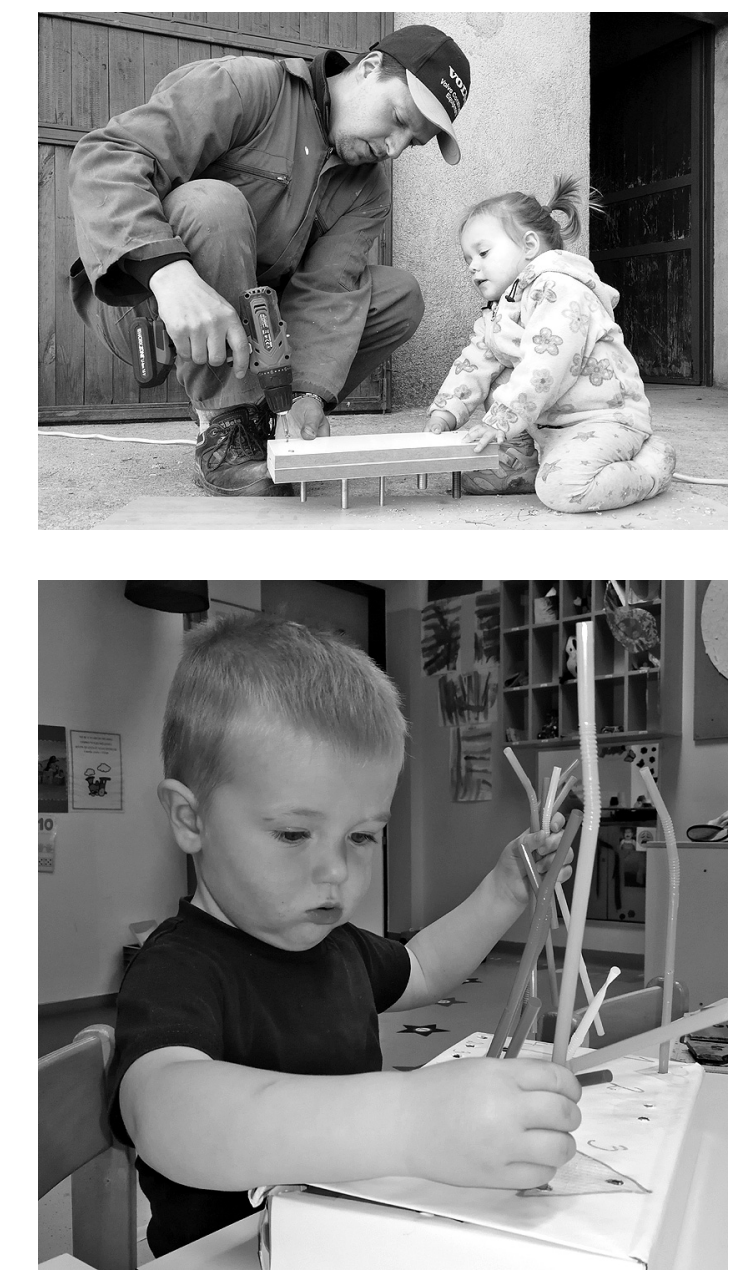

Slika 2

Igranje lastne igre

dveh otrok doma naredili po dve nalogi, starši treh otrok so uporabili predloge iz zvezka v nahrbtniku, starši šestih otrok pa so ustvarili svoje izvirne matematične igre. Vse igre, ki so jih ustvarili starši, so bile primerne za otroke in so pritegnile njihovo pozornost.

Med raziskavo smo starše prosili, da podajo svoje mnenje glede ustreznosti sodelovanja med starši in vrtcem na matematičnem področju. Poglejmo eno izmed mnenj, ki smo jih dobili v pisni obliki:

Iskreno povedano, da na prvo mi je bilo odveč, ker imam še dva šoloobvezna otroka. Rada se udeležim, če le imam čas. Hotela sem, da bo čisto nekaj drugačnega, kot je bilo prikazano na slikicah. In dobili smo 
Slika 3

Sodelovanje med otroki pri igri

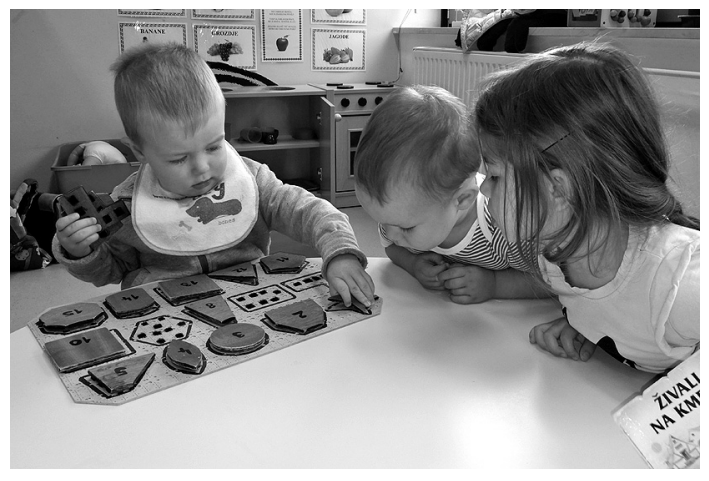

idejo. Vključili smo tudi očeta in na koncu bili navdušeni z izdelkom. Še najbolj pa A. Zaključek tega je, da je to odlično. (Mama 2,5-letne deklice)

Iz pisnih mnenj staršev o raziskavi lahko razberemo, da so pripravljeni in si želijo aktivno sodelovati z vrtcem, če se jim le ponudi ta možnost. Prednost takšnega sodelovanja je $v$ tem, da starši $z$ večjo povezanostjo in $s$ pogovori postajajo občutljivejši za otrokove socialne, intelektualne in čustvene potrebe. Starši na tak način pridobijo večje zaupanje vase in so se sposobni tudi pravilno odločati. Prav tako dobijo veliko koristnih informacij o razvoju njihovega otroka in tako začnejo uporabljati več pozitivnega spodbujanja in bolj spoštujejo delo vzgojiteljev (Lepičnik Vodopivec 2012, 13).

Z dejavnostmi »matematičnega nahrbtnika« smo želeli starše vključiti v načrtovanje učnega procesa, saj imajo pravico sodelovati pri načrtovanju življenja in dela v vrtcu in v oddelku. Načelo sodelovanja s starši (Ministrstvo za šolstvo in šport 1999, 8) razumemo kot načina prepletanja in razumevanja dveh svetov, ki otroku predstavljata skupen svet. Povezovanje s starši in izmenjavanje informacij o otrokovih dosežkih in sposobnostih za lažjo presojo o tem, kaj otrok zmore in kaj ga veseli, je ključno za spodbudno vzdušje pri matematičnih dejavnostih (Ministrstvo za šolstvo in šport 1999).

Cilj predšolske matematike je, da bi jo otrok doživljal kot prijetno izkušnjo (Ministrstvo za šolstvo in šport 1999). Vendar je treba dodati, tisti, ki jo lahko otrokom ponudi, odrasel. Otrokova sposobnost učenja se ob spodbudnem okolju lahko poveča tudi za četrtino (Bregant 2012, 299). Eden izmed načinov je, da v svojem okolju, preko vzgojitelja in staršev, pridobi izkušnje na konkretni ravni, s konkretnimi predmeti v različnih kontekstih, kjer s predmeti rokujejo, jih raziskujejo in se z njimi srečujejo ob vsakodnevnih situacijah. Znanje matematike navsezadnje ne pomeni samo reševanja matematičnih problemov, temveč komuniciranje, ocenjevanje in sklepanje, kar kot skupek pripo- 
more $\mathrm{h}$ konstruktivnemu in razmišljujočemu delovanju v naravnem, kulturnem in socialnem okolju (Nolimal 2012).

\section{Sklepne ugotovitve}

Pri sodelovanju s starši moramo iskati nove, spremenjene načine dela (Štular 1990) in starše sprejeti kot enakopravne sodelavce. Le tako bodo namreč začutili pomembnost ob skupnem načrtovanju in izvajanju vzgojnega dela ter lepoto in uživanje ob skupni igri z otroki. To smo, po mnenju staršev, dosegli z naš raziskavo.

Otrokov prvi stik z matematiko bo prijazen, če ga bo doživel celovito, preko občutkov, ki so mu blizu, ob katerih se počuti sproščeno in varno. Če mu bo uspelo ohraniti ta občutek, bo mnogo lažje premagoval ovire pri kasnejšem dojemanju vse zahtevnejših zakonitostih matematike, saj je vanjo vstopil skozi prava vrata (Zajc in Koželj 2001, 11).

Zavedamo se, da je bilo v našo raziskavo vključenih majhno število otrok in staršev, zato bi bilo potrebno raziskavo razširiti. Potrebovali bi več informacij o mnenjih in stališčih staršev o matematiki ter o celostnem sodelovanju staršev z vzgojitelji. Na tem mestu se odpirajo nova vprašanja, in sicer: ali si vsi starši želijo sodelovati in kdo so starši, ki si želijo sodelovati pri učenju svojih otrok? Poleg tega bi bilo treba preučiti še druge načine vpeljevanja zgodnje matematike $v$ sodelovanju s starši. Vrtec in starši imajo ključno vlogo pri matematičnem opismenjevanju, saj so prav matematične sposobnosti in veščine tiste, ki bodo vplivale na kasnejšo uspešnost otrok in s tem tudi države.

\section{Literatura}

Anning, A., in A. Edwards. 2006. Promoting Children's Learning Birth to Five: Developing the New Early Years Professional. 2. izd. Buckingham: Open University Press.

Bailey, D. H., S. R. Siegler in D. C. Geary. 2014. »Early Predictors of Middle School Fraction Knowledge.« Developmental Science 27 (5): 75-85.

Berkowitz, T., M. W. Schaeffer, E. A. Maloney, L. Peterson, C. Gregor, S. C. Levine in S. L. Beilock. 2016. »Math at Home Adds up to Achievement in School.» Science 350:196-198.

Bernie, J., in M. Lall. 2008. »Building Bridges between Home and School Mathematics: A Review of the Ocean Mathematics Project.« http://discovery.ucl .ac.uk/10004003/1/Building_Bridges.pdf

Biddulph, F., J. Biddulph in C. Biddulph. 2003. The Complexity of Community and Family Influences on Children's Achievement in New Zealand: Best Evidence Synthesis. Wellington, NZ: Ministry of Education. 
Bregant, T. 2012. »Učenje in možgani.«Proteus 74 (7): 295-303.

Cai, J. 2003. »Investigating Parental Roles in Students' Learning of Mathematics from a Cross-National Perspective.« Mathematics Education Research Journal 15 (2): 87-106.

Cannon, J., in H. P. Ginsburg, 2008. »'Doing the Math:' Maternal Beliefs about Early Mathematics versus Language Learning."Early Education and Development 19 (2): 238-260.

Claessens, A., G. Duncan in M. Engel. 2009. »Kindergarten Skills and Fifth-Grade Achievement: Evidence from the ECLS-K. « Economics of Education Review 28:415-427.

Claessens, A., M. Engel in F. C. Curran. 2014. »Academic Content, Student Learning, and the Persistence of Preschool Effects.« American Educational Research Journal 51 (2): 403-434.

Clements, D. H., in J. Sarama. 2014. Learning and Teaching Early Math: The Learning Trajectories Approach. New York, NY: Routledge.

Dickson, L., M. Brown in O. Gibson. 1984. Children Learning Mathematics: A Teacher's Guide to Recent Research. London: Cassell.

Duncan, G. J., C. J. Dowsett, A. Claessens, K. Magnuson, A. C. Huston, P. Klebanov in H. Sexton. 2007. "School Readiness and Later Achievement."Developmental Psychology 43 (6): 1428-1446.

Epstein, J. L. 1992. School and Family Partnership. Baltimore, MD: Center on Families, Schools, and Children's Learning.

Ginsburg, H. P., N. Inoue in K. H. Seo. 1999. "Young Children Doing Mathematics: Observations of Everyday Activities."V Mathematics in the Early Years, ur. J. V. Copley, 88-89. Reston, VA: National Council of Teachers of Mathematics.

Gopnik A., D. M. Sobel, L. E. Schulz in C. Glymour. 2001. »Causal Learning Mechanisms in Very Young Children: Two-, Three-, and Fouryear-Olds Infer Causal Relations from Patterns of Variation and Covariation." Developmental Psychology 37 (5): 620-629.

Harris, B., in D. Petersen. 2017. Developing Math Skills in Early Childhood. Issue Brief. Washington, DC: Mathematica Policy Research.

Harris, B., D. Petersen in C. Smither-Wulsin. 2017. Integrating Mathematical Thinking into Family Engagement Programs. Issue Brief. Washington, DC: Mathematica Policy Research.

Haylock, D. 2007. Mathematics Explained for Primary Teachers. 3. izd. Thousand Oaks, CA: Sage.

Hodnik Čadež, T., in V. Manfreda Kolar. 2009. »Didaktična sredstva z vidika motivacije pri pouku matematike.«V Poukv družbi znanja, ur. M. Cotič, V. Medved Udovič in M. Cencič, 232-247. Koper: Pedagoška fakulteta.

Japelj Pavešić, B., 2014. »Predšolsko znanje matematike v luči mednarodnih primerjav«. V Spodbujanje matematičnega mišljenja v vrtcu, ur. D. Belak, B. Vrbovšek in M. Domicilj, str. 18-30. Ljubljana: Supra. 
Jordan, N. C., D. Kaplan, C. Ramineni in M. N. Locuniak. 2009. »Early Math Matters: Kindergarten Number Competence and Later Mathematics Outcomes." Developmental Psychology 45 (3): 850-867.

Kunič, N. 2003. »Sodelovanje med vrtcem in starši.« Educa 12 (4): 13-17.

Ministrstvo za šolstvo in šport. 1999. Kurikulum za vrtce: predšolska vzgoja v vrtcih. Ljubljana: Ministrstvo za šolstvo in šport.

Lepičnik Vodopivec, J. 2012. Teorija in praksa sodelovanja s starši. Ljubljana: Pedagoška fakulteta.

Levine, S. C., L. W. Suriyakham, M. L. Rowe, J. Huttenlocher in E. A. Gunderson. 2010. »What Counts in the Development of Young Children's Number Knowledge?« Developmental Psychology 46: 1309-1319.

Logar, D. 2012. »Delovni odnosi med vzgojiteljem in starši.« V Sodelovanje med vrtcem in starši »družinami«, ur. M. Željeznov Seničar, 35-42. Ljubljana: MiB.

McCain, M. N., and J. F. Mustard. 1999. Early Years Study: Reversing the Real Brain Drain. Toronto: Publications Ontario.

McNeil N. M., in L. Jarvin. 2007. „When Theories Don't Add up: Disentangling the Manipulatives Debate." Theory into Practice: Research in the Service of Practice 46 (4): 309-316.

Melhuish, E. C., K. Sylva, P. Sammons, I. Siraj-Blatchford, B. Taggart in A. Malin. 2008. »Preschool Influences on Mathematics Achievement.«Science 321 (5893): 1161-1162.

Mešinović, S., M. Cotič in A. Žakelj. 2017. Učenje in poučevanje geometrije v osnovni šoli. Koper: Založba Univerze na Primorskem.

Morgan, A., in P. Tremere. 1993. »IMPACT: A Humberside perspective.« V Partherships in Maths: Parents and Schools; The IMPACT Project, ur. R. Merttens in J. Vass, 63-70. London, UK: Falmer.

Munn, P. 1997a. "Children's Beliefs about Couting." V Teaching and Learning Early Number, ur. I. Thompson, 19-33. Buckingham: Open University Press.

Munn, P. 1997b. »Writing and Number.« V Teaching and Learning Early Number, ur. I. Thompson, 9-19. Buckingham: Open University Press.

Murnane, R. J., J. B. Willett in F. Levy. 1995. "The Growing Importance of Cognitive skills in Wage Determination."Review of Economics and Statistics 78:251-266.

Nolimal, F. 2012. »Bralna pismenost kot opora naravoslovni in matematični pismenosti.« V Nacionalna konferenca Poti do kakovostnega znanja naravoslovja in matematike, Brdo pri Kranju, 11. in 12. december 2012, ur. M. Vidmar in T. Taštanoska, 23-26. Ljubljana: Ministrstvo Republike Slovenije za izobraževanje, znanost, kulturo in šport.

Onslow, B. 1992. »Improving the Attitude of Students and Parents through Family Involvement in Mathematics. "Mathematics Education Research Journal 4 (3): 24-31.

Pritchard, R. 2004. »Investigating Parental Attitudes and Beliefs in Mathematics 
Education."V Mathematics education for the third Millenium: Towards 2010, ur. I. Putt, R. Faragher in M. McLean, 478-485. Sydney: MERGA.

Rivera-Batiz, F. L. 1992. „Quantitative Literacy and the Likelihood of Employment among Young Adults in the United States." Journal of Human Resources 27:313-328.

Sarama, J., in D. H. Clements. 2009. Early Childhood Mathematics Education Research: Learning Trajectories for Young Children. New York: Routledge.

Saxe, G., S. Guberman in M. Gearhart. 1987. "Social Processes in Early Number Development."Monographs of the Society for Research in Child Development 52 (2): 100-200.

Starkey, P., in A. Klein. 2000. »Fostering Parental Support for Children's Mathematical Development: An Intervention with Head Start Families." Early Education and Development 11 (5): 659-680.

Štular, V. 1990. "Osnovni pogoji, ki omogočajo kreativno delo vzgojitelja.» V Vzgojitelj: kreator predšolske vzgoje, ur. M. Blažič, 221-225. Novo mesto: Skupnost varstvenih organizacij.

Tye, C. 1993. »IMPACT and the Early Years Classroom. V Partnerships in Maths: Parents and Schools; The IMPACT Project, ur. R. Merttens in J. Vass, 37-44. London, UK: Falmer.

Zajc, I., in M. Koželj. 2001. Matematika v srcu umetnosti. Ljubljana: Jutro.

Zigler, E., W. Gilliam in S. A. Jones. 2006. Vision for Universal Preschool Education. New York: Cambridge University Press.

Watts, T. W., G. J. Duncan, R. S. Siegler in P. E. Davis-Kean. 2014. „What's Past Is Prologue: Relations Between Early Mathematics Knowledge and High, School Achievement.« Educational Research 43 (7): 352-360.

\section{Involving Parents in Early Learning of Mathematics}

In the recent years, the general public has been paying more attention to mathematical literacy. A number of studies from around the world have shown that the mathematical knowledge children acquire could predict their future careers. Mathematical knowledge can affect their subsequent level of education, academic success, job quality, or even determine their wages. Some research has shown that the mathematical knowledge with children is supposed to be a powerful predictor of their socioeconomic status later in life. Facilitating mathematical literacy is a long-term process, which begins in pre-school. During this period, their parents and home environment prove to be the greatest influencers on their development, and thus the development of their abilities in mathematical thinking. Therefore, the involvement of parents in early learning of mathematics is crucial. For this purpose, we have designed and implemented the research, through which we taught the parents how to play with early mathematics and made it possible for children to explore certain mathematical concepts in interaction with their parents within their home environ- 
ment. We have found that parents want to be the co-creators of their children's knowledge and that they are willing to cooperate with kindergartens, but wish to receive guidelines on implementation.

Keywords: early childhood education, early mathematics, home environment, parents, mathematical backpack 


\title{
The Significance of the Constructivist Approach in Preschool Science Education
}

\author{
Janja Plazar \\ University of Primorska \\ janja.plazar@pef.upr.si
}

Science education is of crucial importance to many aspects of a child's development, therefore it is suggested that it should begin already during the early childhood period. Nowadays, science education is based predominantly on the principle of constructivism according to which children act as active participants in the learning process and construct their own knowledge on the basis of experience. This enables them to acquire scientific knowledge and develop the ability to think and solve problems in a logical way. Many authors recommend that it is necessary to start science education in the early preschool period, with competent preschool teachers, who could develop science concepts correctly and maintain positive attitude towards science in children. Alarmingly, many studies agree that science teaching all over the world tends to be deprioritized in early childhood education, compared to teaching literacy, numeracy and arts, mostly due to insufficient science knowledge of the preschool teachers. Therefore, solutions are proposed to provide positive outcomes to preschool science education by increasing both science knowledge and the skills of preschool teachers.

Keywords: preschool science education, constructivism, competent preschool teachers, science concepts, scientific literacy

\section{Introduction}

During the early preschool period, children establish the bases of knowledge and skills which are going to be used throughout their life. Very early in their lives, children start to observe nature and events, seek for answers and questions, and get to understand the primary science related concepts. Hence, there are several good reasons for starting science education already in the preschool period. The teachers working in preschool classrooms have a significant responsibility to develop science concepts correctly and to maintain positive attitudes towards science. Preschool science education should be therefore introduced using appropriate instructional approaches, in which children learn to pay attention, ask questions, observe, analyse, explore and make deductions. One of the most pronounced contemporary science teaching approaches of the last decades is constructivism, according to which chil- 
dren construct their own knowledge as active participants in the learning process on the basis of their own experience.

The aim of the present paper is to expose and emphasize the importance of implemented science education in the early years, and how early science education contributes to scientific literacy and learns scientific concepts to children. As demonstration, a few effective approaches towards teaching science to preschool children will be presented. Additionally, the paper discusses the reasons for the lack of science teaching in preschool classrooms and presents possible solutions to increase the quality of science education in the preschool years.

\section{Exposure to Science in the Early Years}

Science education is of great importance to many aspects of a child's development, and many researchers suggest science education should begin already during the early childhood period (Hadzigeorgiou 2002). Research studies in developmental and cognitive psychology indicate that environmental effects are important during the early years of development, and the lack of important stimuli may result in a child's development not reaching its full potential (Trundle 2010).

Implementing science learning in the early years can take advantage of children's disposition to learn about natural phenomena during their everyday activities. Science is all around us, therefore whether watching snails in an aquarium, blowing bubbles, using a flashlight to make shadows, or experimenting with objects to see what sinks or floats, a child is naturally curious and engaged in finding out about the world (Conezio and French 2002). In this way, already the youngest children actively engage with their environment to develop fundamental understandings of the phenomena they observe and experience. Children also acquire process skills essential to scientific interpretation, such as observing, classifying, sorting and others. These basic scientific concepts and science process skills begin to develop as early as infancy, with the sophistication of the child's competences developing with age (Trundle 2010).

Conezio and French (2002) believe that children are biologically prepared to learn about the world around them, just as they are biologically prepared to learn to walk and talk and interact with other people. Because they are ready to learn about their everyday world, they are highly engaged when opportunities to explore occur, creating strong and enduring mental representations of experiences through investigations of their everyday world. They readily acquire vocabulary to describe and share these mental repre- 
sentations and the concepts that naturally follow. Children then rely on the mental representations as the basis for further learning and for higher order intellectual skills such as problem solving, hypothesis testing, and generalizing across situations. Furthermore, in their study, Eshach and Fried (2005) summarize the reasons why even the smallest children should be exposed to science: (1) children naturally enjoy observing and thinking about nature; (2) exposing children to science develops positive attitudes towards science; (3) early exposure to scientific phenomena leads to better understanding of the scientific concepts studied later in life; (4) the use of scientifically informed language at an early age influences the subsequent development of scientific concepts; (5) children can understand scientific concepts and reason scientifically; (6) through experience science, children develop scientific thinking.

\section{The Importance of Preschool Science Education}

However, being only exposed to natural phenomena and observing the nature in the preschool period is not enough. To develop positive attitudes towards science, appropriate experience and engagement during development in combination with quality learning, are vital to help children understand the world, collect and organize information, and to apply and test their new ideas. For this, qualified adults, stimulating environments, and a good science education program are very important (Tu 2006), and results in all students gaining a solid foundation of core science knowledge and skills. This includes a coherent, well-designed curriculum, teachers who have the resources and skills to teach effectively; and communities and families that are committed to excellence (Mirzaie, Hamidi, and Anaraki 2009; Tu 2006).

Özbey and Alisinanoğlu (2008) believe that for science education, the primary school period is too late. Science education is necessary already in the preschool period, for the children to improve their creativity and learn about different perspectives. Moreover, science education in the preschool period forms the basis for the science education at primary school and that is why it is necessary early on. Children before the age of six need science education, so that they can learn about their living environment, natural phenomena, and generate original ideas (Mirzaie, Hamidi, and Anaraki 2009). Many researches in the last years have proven that preschool children have a much greater potential for learning and understanding science than previously thought - even in their earliest years. Both, the environment and the support of trained teachers, have a significant impact on the child's experience and subsequent lifelong learning of science (Garbett 2003; Worth 2010, 
Saçkes et al. 2011). Insufficient teaching of natural science in early childhood can lead to a negative attitude of pupils to science-related content that can persist until high school years and even longer (Mullis and Jenkins 1988). On the other hand, supporting children's natural thinking in the early years of childhood can lead children to transfer their own scientific way of thinking to other fields of science, and thus foster success and self-confidence in all areas of learning (Kuhn and Pearsall 2000).

\section{The Contribution of Early Science Education to Scientific Literacy}

What children of preschool age learn in terms of general science has shown to be a strong predictor of their future science achievement in school and later in life (Areljung 2018). Already early in life children develop a positive attitude towards science and lay the foundations for the further development of basic scientific concepts (Eshach and Fried 2005; Krnel 2008). The aims of science education are now commonly expressed in terms of developing 'scientific literacy', which is used as a term indicating the essential understanding that should be a part of everyone's education, rather than a detailed knowledge of facts and theories as required by scientists (Harlen and Qualter 2009). Science affects all our lives at every level. It governs the materials used to construct our homes, the way our food is grown and processed, the processes by which electricity is generated, the purpose of medicines and medical technology, and communication and transport technology. All fields children will be curious about at some time during development. A degree of scientific literacy is essential for everyone to enable making informed decisions about the scientific advances and developments which affect us all (Brunton and Thornton 2012). Therefore, the goal is to educate an individual who, in addition to the basic concepts, would be equipped with the abilities to understand abstract ideas and to discover nature and solve problems in a logical and scientific way (Krnel 2008). The PISA definition of scientific literacy is the capacity to use scientific knowledge, to identify questions and to draw evidence-based conclusions in order to understand and help make decisions about the natural world and the changes made to it through human activity (Organization for Economic Cooperation and Development 2003, 133).

\section{Learning Science Concepts}

Science is not just about exploration, but also about sharing and understanding accumulated knowledge. For children, the problem with science is to learn facts, which includes new words, or new contexts of words, because science, like many other activities, has its own technical vocabulary. A further 
difficulty is that some scientific explanations are counter-intuitive (Loxley et al. 2010; Allen 2014; Britten and Allen 2018). Children's everyday observations may lead them to hold firmly established ideas, which turn to be wrong in terms of science. For example, the Earth-centred model of the universe is an intuitive idea. When we watch the Sun rise in the east and set in the west, common sense tells us that it must be travelling around the Earth. The idea that this is an illusion caused by the spin of the Earth is counter-intuitive. Therefore, children sometimes find science too abstract and separate from their everyday understanding; the scientific accounts which they encounter do not map easily on to what children can see, feel and hear (Loxley et al. 2010).

Many different factors influence children's concepts of natural phenomena. In order to help children learn, and, even more importantly, understand science concepts, we must first comprehend the nature of their ideas about the world around them. Some authors suggest that children's concepts derive from their daily experiences, which are helpful and valuable in the child's daily life context (Driver, Guesne, and Tiberghien 1985; Duit and Treagust 1995; Trundle 2010). However, children's concepts are usually not scientific and these non-scientific ideas are called 'naïve concepts' or 'alternative concepts.' Duit and Treagust (1995) proposed six possible sources for alternative concepts: sensory experience, language experience, cultural background, peer groups, mass media, and even science instruction.

Children's interpretation of scientific concepts is influenced by the nature of their ideas. They tend to view the world and its phenomena from a selfcentred or human-centred, anthropocentric point of view, with which they often attribute human characteristics, such as feelings, will or purpose, to objects and phenomena (Piaget 1972; Bell 1993; Battelli and Dolenc-Orbanić 2006). For example, some children believe that the moon phases change because the moon gets tired. When the moon is not tired, we see a full moon. Then, as the moon tires, we see less of the moon (Trundle 2010). Of course, the natural explanation for this is that the lunar phases are created by changing relative positions of the Earth, the moon and the Sun, as the moon orbits the Earth.

Additionally, children usually focus on change rather than on static, steadystate situations, which make it difficult for them to recognize patterns on their own without the help of an adult or more knowledgeable peer. For example, when children observe mealworms over time they easily recognize how the mealworms' bodies change from larva to pupa and finally, to adult beetle. Still, they have difficulty noticing that the population count remains 
unchanged during the course of observation (Trundle 2010). In other words, the children would first notice that novel animals have populated the habitat, and only later that the earlier present animals have transformed. Children's concepts of natural processes are mostly undifferentiated. For example, children intuitively perceive the concept of living and non-living in a different way than adults or scientists do: plants are not living things to some young children because they do not move. However, the same children consider some non-living things, such as running water, fire and clouds, to be living things because they are not static (Allen 2014; Trundle 2010).

Children's ideas of scientific concepts are frequently extremely stable and can lead to misconceptions in science. Even after being formally taught in classrooms, children often do not change their ideas despite a teacher's attempts to challenge them by offering counter-evidence (Trundle 2010, 2014). As these misconceptions make a perfect sense to the child and can cause confusion with the alternate, scientifically correct ideas, presented later in class (Britten and Allen 2018), it is necessary that scientific concepts are always presented in a simple, but scientifically correct manner. These should be taught by a competent preschool teacher with suitable approaches, which will reduce the occurrence of misconceptions in preschool children.

\section{Effective Approaches towards Teaching Science to Preschool Children}

Science education in the last decades changed from a traditional, frontal way of teaching to contemporary instructional approaches as described in present-day science education literature (Trundle 2010). These latter draw heavily on the constructivist philosophy in which children act as active participants in the learning process and on the basis of their own experience, to construct knowledge. In this way, children's 'alternative concepts' are more likely to develop into correct science concepts later in their lives.

\section{Constructivist Philosophy}

Constructivism is the general name given to the dominant perspective on learning in education. It is grounded in the research and theories of Jean Piaget and Lev Vygotsky and the philosophy of John Dewey, and it is a natural extension of applied brain research. Many authors suggest that the nature and meaning of constructivism are open to interpretation and that there is not a single constructivist theory of learning (Gil-Pérez et al. 2002; Martin, Sexton, and Gerlovich 2014). Also Matthews (2000) states, that 'constructivism means different things to different researchers.' Some perspectives embrace the social nature of learning (Vygotsky), while radical constructivists place 
the importance on the individual's active, social participation in knowledge construction (Ernst von Glasersfeld). On the other hand, conservative constructivists (Piaget) use activity-based and problem-based learning experiences and teacher intervention to encourage conceptual constructions. Furthermore, the latter attempt to correct misconceptions in children by helping to construct understanding, based on concepts embraced by the scientific community (Gil-Pérez et al. 2002; Martin, Sexton, and Gerlovich 2014). Although there are many forms of constructivism, all of the instructional applications of constructivism view children as active agents in their personal construction of new knowledge. Furthermore, these instructional approaches aim to promote active learning through the use of hands-on activities with small groups and with sense-making discussions. A common expectation is that learners are more likely to construct an understanding of science content in this type of inquiry-based learning environment (Trundle 2010).

The theory of constructivism is based on the theory of Jean Piaget about mental equilibration and its interplay with assimilation and accommodation (Abruscato and DeRosa 2010; Martin, Sexton, and Gerlovich 2014):

- Equilibration. Learning is an active mental process, in which the child needs to construct knowledge by interacting with the environment. During that process, cognitive conflicts may arise between what is expected and what is observed (Driver, Guesne, and Tiberghien 1985). Each new interaction or conflict creates a dilemma in the child's mind how to maintain mental equilibrium (Martin, Sexton, and Gerlovich 2014). This principle is very important to the teachers of preschool children, because many children have naïve conceptions, which can persist up to the adult years. For a teacher, it is extremely difficult to help a child to construct new understanding if the child's naïve conceptions filter out new experiences (Abruscato and DeRosa 2010). With an attempt of restoring equilibrium, the learning child reaches a higher level of functional equilibration, and thus the formation of higher mental structures. However, equilibration is not a static mind-rest point, but a dynamic process (Martin, Sexton, and Gerlovich 2014).

- Assimilation is one way in which the mind can adapt to the learning challenge and restore equilibrium (Martin, Sexton, and Gerlovich 2014). Children try to reconcile new experiences and data with their present understanding so that the new data support and deepen, but do not change their fundamental mental model (Abruscato and DeRosa 2010).

- Accommodation. When no pre-existing mental structures are available 
to assimilate, children cannot reconcile new experience and data with their present understanding. Therefore, they need to change and adapt their mental model to logically explain the experience. This process of adaptation is called accommodation - the child's thinking is adapted to accommodate the dilemma (Abruscato and DeRosa 2010; Martin, Sexton, and Gerlovich 2014).

- Assimilation and accommodation are not mutually exclusive. They often complement each other in the learning process (Abruscato and DeRosa 2010).

A teacher, who accepts the constructivist philosophy, supports a different view of science, regards the roles of teacher and learner very differently, and selects and organizes teaching materials and the social learning environment with particular care (Martin, Sexton, and Gerlovich 2014; Trundle 2010). A constructivist perspective emphasizes the active role of the learner, in a physical, mental and social way. The constructivist teacher seeks ways to challenge and stimulate mental connection: offer order to enhance the active participation of learners in the learning process and encourage them to construct their own understanding of reality, which arises from their experience. In a simplified way, an ancient Chinese proverb encapsulates the intent of constructivism: 'I hear and I forget, I see and I remember, I do and I understand' (Martin, Sexton, and Gerlovich 2014).

\section{Inquiry-Based Learning}

An important didactic approach, based on the principles of constructivism, is the inquiry-based learning of which the beginners and supporters are many theorists, such as Kolb, Piaget, Dewey, Lewin, Neil and others (Marentič Požarnik 2000). The central idea of a guided inquiry approach is that individuals learn best by their own experiences and are active agents in the learning process. This strengthens children's sense of ownership in their work and enhances their motivation. With this approach, children usually work in a small group, which promotes their collaboration skills, mutual respect and tolerance and attitudes, inherent in the science education (Barell 2007; Ivanuš Grmek, Čagran, and Sadek 2009; Trundle 2010; Alveirinho, Bento, and Nunes 2017). Furthermore, the inquiry-based approach maintains children's curiosity and their permanent interest in knowledge, and further develops skills which are needed for solving problems independently (Petek 2012).

Meaningful science activities, which are relevant to children's daily lives, allow children to make connections between present and new knowledge. 
Sense-making discussions promote children's awareness of learning, concept development, and facilitate the restructuring of alternative ideas into scientific mental models. During the work of teachers with children their inquiry skills are developed, and the instructional strategies should move toward more open inquiry, where children are posing their own questions and designing their own investigations (Trundle 2010). One of the important components of inquiry-based learning is the experiment. Experiments in science through constructivist learning leads to the acquisition and development of a scientific literacy that involves skills, attitudes and values, which contribute to the formation of citizens, capable of dealing with everyday scientific aspects (Alveirinho, Bento, and Nunes 2017).

\section{The Reasons for the Lack of Science Teaching in Preschool Classrooms}

When preschool teachers are asked if they teach science, they might point to the plants on the shelf or the collection of stones and shells and indicate that science is taking place 'over there.' Other teachers see science as some kind of magic trick to perform on a Friday afternoon when children are already tired. They bring out the baking soda and vinegar to 'make a volcano.' While the children may be amazed and amused by this activity, it does not build accurate knowledge and does not represent real science. Real science begins with childhood curiosity, which leads to discovery and exploration with teachers' help and encouragement. It involves three major components: content, processes, and attitude. Young children prize information about the world around them, yet an emphasis on content is not enough. Young children, like scientists, need to practice the process skills of predicting, observing, classifying, hypothesizing, experimenting, and communicating. Like adult scientists, they need opportunities to reflect on their findings, how to they reach these, and how the findings compare to their previous ideas and the ideas of others. In this way, children are encouraged to develop the attitude of a scientist-that is, curiosity and the desire to challenge theories and share new ideas. Scientific exploration presents authentic opportunities to develop and use both receptive and expressive language skills (Conezio and French 2002).

As we already mentioned above, what children learn at the preschool age in terms of general science, has shown to be a strong predictor of their future science achievement in school (Morgan et al. 2016). Thus, it is worrying, that science teaching tends to be deprioritized in early childhood education, compared to teaching literacy, numeracy and arts (Areljung 2018). Several authors point out that many early childhood teachers are hesitant about introducing science in their preschool classrooms, often because of their own 
unpleasant science education experiences, or because of their insufficient content knowledge or alternative ideas about science topics (Conezio and French 2002; Kavalari, Kakana, and Christidou 2012; Broström 2015; Areljung 2018). Even Danish researches are showing that preschool teachers have a diffuse understanding of science education and they introduce children for science questions and phenomenon only in a limited range (Broström et al. 2014). A new Danish evaluation rapport shows that preschool children's study of 'nature and nature phenomenon' is the theme, which preschool teachers give less attention. Such a low priority is also seen in other countries (Broström 2015). American research reports that children's emergent skills on science learning are not taken into consideration in early childhood classroom (Tu 2006; Saçkes et al. 2011). Other studies show that teachers themselves do not have science competences and are not familiar with using science equipment, nor to follow children's science questions and wonder (Broström 2015). Also Kavalari, Kakana, and Christidou (2012) indicate that teachers show lack of confidence in approaching topics in science. Even more, teachers often doubt the benefits of science teaching (Eshach and Fried 2005).

Nevertheless, the reasons which lead to resisting pedagogical ideas for science teaching provide useful insights for designing professional development activities for preschool teachers (Areljung 2018). On the basis of their study and similar studies in the literature, Doğan and Simsar (2018) suggest some solutions, which could provide positive outcomes to preschool science education. They propose that teachers should increase their knowledge and skills by participating in various courses and seminars at regular intervals, thus following the innovations and changes related to science education. Further they suggest rearrangement of undergraduate preschool teacher education programs in terms of increasing the number and quality of courses of science education. In addition, it is suggested to decrease the number of children in the preschool classroom and include the parents into science activities when performed in the preschool classroom.

\section{Conclusions}

In their preschool years, children make the most significant progress in the development of cognitive, physical, linguistic, emotional, and social skills. In the last decades it is shown that science education is of great importance to the development of children, and many researchers suggest that science education should begin already during the early childhood period. The most important in early preschool science education is to choose appropri- 
ate instructional approaches and educate and employ competent preschool teachers. Under these circumstances, children's 'alternative conceptions' are more likely to develop into correct science concepts later in life and not stagnate in the form of undiscovered misconceptions.

\section{References}

Abruscato, J., and D. A. DeRosa. 2010. Teaching Children Science: A Discovery Approach. 7th ed. Boston, MA: Allyn \& Bacon.

Allen, M. 2014. Misconceptions in Primary Science. 2nd ed. Maidenhead: Open University Press.

Alveirinho, D., J. Bento, and M. Nunes. 2017. 'The Science Experiment and the Playful Learning: Window of Opportunity for Curricular Articulation in the Transition between Preschool Education and Primary Education.' In ICER/2017 Proceedings, edited by L. Gómez Chova, A. López Martínez, and I. Candel Torres, 8629-8635. Seville: IATED Academy.

Areljung, S. 2018. 'Why Do Teachers Adopt Or Resist a Pedagogical Idea for Teaching Science in Preschool?' International Journal of Early Years Education. https://doi.org/10.1080/09669760.2018.1481733

Barell, J. F. 2007. Problem-Based Learning: An Inquiry Approach. Thousand Oaks, CA: Corwin.

Batelli, C., and N. Dolenc-Orbanić. 2006. 'Zvita kot lisica, nesramna kot kukavica.' In Zgodnje učenje in poučevanje otrok, edited by V. Medved Udovič, M. Cotič, and D. Felda, 447-454. Koper: Annales.

Bell, B. 1993. Children's Science, Constructivism and Learning in Science. Burwood: Deakin University.

Britten, E., and M. Allen. 2018. Addressing Children Misconceptions through Talk: Unlocking Speaking and Listening; Developing Spoken Language in the Primary Classroom. 3rd ed. London: Routledge.

Broström, S. 2015. 'Science in Early Childhood Education.' Journal of Education and Human Development 2 (1): 107-124.

Broström, S., T. Frøkjær, I. Johansson, and A. Sandberg. 2014. 'Preschool Teacher's View on Learning in Preschool in Sweden and Denmark.' European Early Childhood Educational Research Journal 22 (5): 590-603.

Brunton, P., and L. Thornton. 2012. Science in the Early Years: Building Firm Foundations from Birth to Five. Los Angeles: Sage.

Conezio, K., and L. French. 2002. 'Science in the Preschool Classroom: Capitalizing on Children's Fascination with the Everyday World to Foster Language and Literacy Development.' Young Children 57 (5): 12-18.

Doğan, Y., and A. Simsar. 2018. 'Preschool Teachers' Views on Science Education, the Methods They Use, Science Activities, and the Problems They Face.' International Journal of Progressive Education 14 (5), 57-76.

Driver, R., E. Guesne, and A. Tiberghien. 1985. 'Some Features of Children's Ideas 
and Their Implications for Teaching.' In Children's Ideas in Science, edited by R. Driver, E. Guesne, and A. Tiberghien, 193-201. Philadelphia: Open University Press.

Duit, R., and D. F. Treagust. 1995. 'Students' Conceptions and Constructivist Teaching Approaches.' In Improving Science Education, edited by B. J. Fraser and H. J. Walberg, 46-69. Chicago: The University of Chicago Press.

Eshach, H., and M. N. Fried. 2005. 'Should Science be Taught in Early Childhood?' Journal of Science Education and Technology 14 (3): 315-336.

Garbett, D. 2003. 'Science Education in Early childhood Teacher Education: Putting forward a Case to Enhance Student Teachers' Confidence and Competence.' Research in Science Education 33:467-481.

Gil-Pérez, D., J. Guisasola, A. Moreno, A. Cachapuz, A. M. Pessoa De Carvalho, J. Martínez Torregrosa, J. Salinas et al. 2002. 'Defending Constructivism in Science Education.' Science \& Education 11:557-571.

Hadzigeorgiou, Y. 2002. 'A Study of the Development of the Concept of Mechanical Stability in Preschool Children.' Research in Science Education 32 (3): 373-391.

Harlen, W., and A. Qualter. 2009. The Teaching of Science in Primary Schools. 5th ed. London: Routledge.

Ivanuš Grmek, M., B. Čagran, and L. Sadek. 2009. Didaktični pristopi pri poučevanju predmeta Spoznavanje okolja $v$ tretjem razredu osnovne šole. Znanstvena poročila Pedagoškega inštituta. Ljubljana: Pedagoški inštitut.

Kavalari, P., D. M. Kakana, and V. Christidou. 2012. 'Contemporary Teaching Methods and Science Content Knowledge in Preschool Education: Searching for Connections.' Procedia: Social and Behavioural Sciences 4:3649-3654.

Krnel, D. 2008. 'Narava.' In Otrok v vrtcu: priročnik h kurikulumu za vrtce, edited by L. Marjanovič Umek, 157-175. Maribor: Obzorja.

Kuhn, D., and S. Pearsall, S. 2000. 'Developmental Origins of Scientific Thinking.' Journal of Cognition and Development 1:113-129.

Loxley, P., L. Dawes, L. Nicholls, and B. Dore. 2010. Teaching Primary Science: Promoting Enjoyment and Developing Understanding. Harlow: Pearson Education.

Marentič Požarnik, B. 2000. Psihologija učenja in pouka. Ljubljana: DZS.

Martin, R., C. Sexton, and J. Gerlovich. 2014. Teaching Science for All Children. Harlow: Pearson Education.

Matthews, M. R. 2000. 'Editorial of the Monographic Issue on Constructivism, Epistemology and the Learning of Science.' Science and Education 9:491505.

Mirzaie, A. R., F. Hamidi, and A. Anaraki. 2009: 'A Study on the Effect of Science Activities on Fostering Creativity in Preschool Children.' Journal of Turkish Science Education 6 (3): 81-90.

Morgan, P. L., G. Farkas, M. M. Hillemeier, and S. Maczuga. 2016. 'Science Achieve- 
ment Gaps Begin Very Early, Persist, and Are Largely Explained by Modifiable Factors.' Educational Researcher 45 (1): 18-35.

Mullis, I. V. S., and L. B. Jenkins. 1988. 'The Science Report Card.' Report No. 175-01, Educational Testing Service, Princeton, NJ.

Organization for Economic Cooperation and Development. 2003. The PISA 2003 Assessment Framework. Paris: Organization for Economic Cooperation and Development.

Özbey, S., and F. Alisinanoğlu. 2008: 'Identifying the General Ideas, Attitudes and Expectations Pertaining to Science Activities of the Teachers Employed in Preschool Education.' Journal of Turkish Science Education 5 (2): 82-94.

Petek, D. 2012. 'Zgodnje učenje in poučevanje naravoslovja z raziskovalnim pristopom.' Revija za elementarno izobraževanje 5 (4): 101-114.

Piaget, J. 1972. Child's Conceptions of the World. Lanham, MD: Littlefield Adams.

Saçkes, M., K. C. Trundle, R. Bell, and A. A. O'Connol. 2011. 'The Influence of Early Science Experience in Kindergarten on Children's Immediate and Later Science Achievement: Evidence from the Early Childhood Longitudinal Study.' Journal of Research in Science Teaching 48 (2): 217-235.

Trundle, K. C. 2010: 'Teaching Science During the Early Childhood Years.' http:// ngl.cengage.com/assets/downloads/ngsci_proo000000028/am_trundle _teach_sci_early_child_scl22-0429a.pdf

Trundle, K. C. 2014. 'Teaching Young Children Science.' In Contemporary Perspectives and Research on Early Childhood Education, edited by M. Yasar, O. Ozgun, and J. Galbraith, 126-134. Newcastle: Cambridge Scholars Publishing.

Tu, T. 2006. 'Preschool Science Environment: What Is Available in a Preschool Classroom?' Early Childhood Education Journal 33:245-251.

Worth, K. 2010. 'Science in Early Childhood Classrooms: Content and Process.' http://ecrp.illinois.edu/beyond/seed/worth.html

\section{Pomen konstruktivističnega pristopa poučevanja zgodnjega naravoslovja v vrtcu}

Učenje naravoslovja je zelo pomembno za številne vidike otrokovega razvoja, zato mnogi znanstveniki svetujejo, da bi otroci z njim pričeli že $v$ zgodnjem predšolskem obdobju. Danes je poučevanje zgodnjega naravoslovja v vrtcu zasnovano pretežno na načelu konstruktivizma, po katerem otroci v učnem procesu delujejo kot aktivni udeleženci in svoje znanje gradijo na podlagi izkušenj. To jim omogoča pridobivanje znanstvenih spoznanj in razvoj sposobnosti razmišljanja ter reševanja problemov na logičen način. Pri tem igra bistveno vlogo kompetenten vzgojitelj, ki otrokom pomaga razvijati pozitiven odnos do naravoslovja ter postavlja temelje za nadaljnji razvoj naravoslovnih konceptov in s tem osnovo nadaljnjemu učenju naravoslovja v šoli. Vendar pa številne študije kažejo, da je poučevanje zgodnjega naravoslovja po vsem 
svetu v primerjavi s poučevanjem matematike, jezika, književnosti in umetnosti zapostavljeno, pretežno zaradi nezadostnega naravoslovnega znanja vzgojiteljev. Znanstveniki zato predlagajo rešitve, ki bi k pogostejšemu poučevanju zgodnjega naravoslovja v vrtcu pripomogle s pomočjo dodatnih izobraževanj vzgojiteljev.

Ključne besede: poučevanje zgodnjega naravoslovja, konstruktivizem, kompetentni vzgojitelji, naravoslovni koncepti, naravoslovna pismenost 


\title{
Raziskovanje glasbenega razvoja in pomen glasbenega okolja za dojenčka
}

\author{
Bogdana Borota \\ Univerza na Primorskem \\ bogdana.borota@pef.upr.si
}

Raziskovanje glasbenega razvoja pri dojenčku je poseben izziv, ki so se ga v 20. stoletju lotevali na različne načine. Pogled na pristope k raziskovanju z diahrone perspektive nam pokaže pomemben premik od opazovanja lastnih otrok in testiranja $v$ laboratorijih $\mathrm{k}$ opazovanju glasbenega vedênja $v$ naravnem okolju. Pod vplivom drugih znanosti so se raznovrstni odzivi dojenčka na glasbo interpretirali kot oblike glasbenega vedênja, in ne kot odziv na stimulus iz okolja. S poznavanjem prirojenih glasbenih dispozicij se je védenje o oblikah glasbenega vedênja spremenilo. V prispevku zato zagovarjamo predpostavko, da je dojenček velik poznavalec glasbe. Pri tem poudarimo pomen procesov akulturacije $v$ družinskem okolju in na novo opredelimo nekatere oblike glasbenega vedênja dojenčka v povezavi z njegovimi zaznavnimi sposobnostmi ter razvojem glasbene zavesti. Na podlagi raziskav $v$ ameriškem kulturnem okolju ugotavljamo tudi, da v prvem letu življenja odzivov dojenčka na glasbo in zvoke še ne moremo interpretirati kot oblike melodičnega ali ritmičnega vedênja niti jih ne moremo povezovati s sposobnostjo imitacije glasbe.

Ključne besede: raziskovanje glasbenega razvoja, glasbeni razvoj dojenčka, glasbene dispozicije, oblike glasbene zavesti pri dojenčku

\section{Uvod}

Tako kot ni otroka brez vsaj nekaj inteligentnosti, ga tudi ni brez vsaj nekaj glasbenih dispozicij (Gordon 1995). ${ }^{1}$ Edwin Gordon s to ugotovitvijo usmeri našo pozornost na iskanje povezav med glasbenim okoljem in razvojem glasbenih dispozicij. Prirojene dispozicije za glasbo so podobne kot za govor. $\checkmark$ obeh primerih gre za slušno-govorno modaliteto, saj jezik in glasbo zaznavamo in izvajamo kot zaporedje govorjenih, zapetih ali preko gibanja v času izvedenih zvočnih vzorcev (Sloboda 2007). Ameriški psiholog in raziskovalec glasbene kognicije John Sloboda je glasbene dispozicije opredelil na

\footnotetext{
${ }^{1}$ Gordonove raziskave nakazujejo, da ima posameznik najvišjo stopnjo glasbenega potenciala ob rojstvu. Če otroka ne spodbujamo, da glasbene dispozicije uporablja, se v možganih ne tvorijo sinapse. Nevrolog Robert Post ugotavlja, da sinapse, ki niso uporabljene za glasbo, začnejo podpirati druge zaznave, kot je npr. vidna (Gordon 1995).
} 
naslednjih področjih: reagiranje na zvok in ugotavljanje smeri zvoka, razlikovanje med glasbenimi in neglasbenimi zvoki, glasbeno čebljanje, težnja po usklajevanju gibanja z glasbo in pomnjenje glasbenih vzorcev (Sloboda 2007). Prirojenih dispozicij ne smemo zamenjevati z dednostjo. Ni dokazov, da bi otrok talentiranih glasbenikov podedoval tudi glasbene sposobnosti (Motte-Haber 1990; Gordon 1995). Učitelj tako mora biti pozoren na individualne potrebe in glasbeni potencial vsakega otroka posebej.

$Z$ učenjem $v$ spodbudnem okolju in lastno aktivnostjo dispozicije razvijemo $v$ glasbene sposobnosti. ${ }^{2}$ Sposobnosti lahko izrazimo, če imamo razvite spretnosti. ${ }^{3}$ Pri tem vemo, da otrokove sposobnosti prehitevajo motorično izvedbo. Otrok v glasbi veliko več zazna, doživi, si zapomni in razume, kot lahko izrazi (Motte-Haber 1990). Tudi tu najdemo vzporednice z govornim razvojem. Otrok razume pomen povedi, ki je oblikovana po določenih pravilih sintakse, še preden jo zna po teh pravilih tvoriti. Tudi v glasbi otrok zazna glasbeno celoto in se odzove nanjo, še preden zna po pravilih glasbene sintakse ustvariti novo (Sloboda 2007). Razliko med glasbenimi sposobnostmi in dosežki otroka ugotavlja tudi Gordon (1995) in dodaja, da povezave med njimi niso vedno premo sorazmerne. Raven glasbenih sposobnosti se vse do 9. leta starosti spreminja $v$ odvisnosti od kakovosti glasbenega okolja, v katerem otrok živi. Po tem obdobju se otrokov glasbeni potencial ustali in okolje nima več vpliva na raven razvitosti glasbenih sposobnosti (Gordon 1995).

Otrok nosi v sebi ustvarjalne potenciale. Nestrpno čaka na priložnosti, da jih bo izrazil in da ga bomo mi, odrasli, opazili (Rinaldi 2006). Če njegovim glasbenim dosežkom pozorno prisluhnemo, zagledamo podobo »velikega glasbenika« in poznavalca glasbe. Izgrajevanje te podobe je odvisno od našega védenja o otroku in naših pričakovanj, ki jih gojimo do njega (Borota 2009).

V prispevku želimo razpravljati o glasbenem razvoju otroka. Posebno pozornost namenjamo dojenčku - otroku v prvem letu življenja. Pogled na nje-

\footnotetext{
${ }^{2}$ Izraz se najpogosteje uporablja za elementarne glasbene sposobnosti, ki se razvijejo iz glasbenih dispozicij. To so melodične in ritmične sposobnosti pa tudi sposobnost harmonskega občutenja, ki se razvije na podlagi melodičnih sposobnosti. V preteklosti smo te sposobnosti poimenovali z izrazom posluh (melodični, ritmični, harmonski posluh) (Oblak 2001). Elementarne glasbene sposobnosti so odvisne od sposobnosti za posploševanje, ki otroku omogoča npr. nadaljevati začeto glasbeno misel, odgovoriti na glasbeno vprašanje, predvideti potek melodije (Gordon 1995).

${ }^{3}$ Pri glasbi gre za spretnost rabe dveh temeljnih izraznih sredstev: (pevskega) glasu in rokovanja z glasbili (Borota 2013). Omenja se tudi spretnost poslušanja glasbe, predvsem na področju preusmerjanja pozornosti med elementi in izraznimi sredstvi glasbe, kot so motivi in oblikovni deli, ritem, melodija, zvočna barva, tempo ... (Bamberger 2000).
} 
gove zmožnosti se je skozi čas spreminjal. $V$ ta namen bomo raziskovanje glasbenega razvoja in védenje o glasbenih sposobnosti pri otroku osvetlili skozi diahrono perspektivo. Predpostavljamo, da je dojenček velik poznavalec glasbe. Pri utemeljevanju predpostavke se opiramo na teorije razvoja glasbenih sposobnosti, ki izpostavljajo pomen kritičnih razvojnih obdobij za glasbo in bogatega glasbenega okolja v socialno-kulturnem kontekstu. Ugotovitve so lahko $v$ pomoč pri razumevanju pomena procesov inkulturalizacije in posebnosti zgodnjega glasbenega razvoja pa tudi razumevanja otrokovega doživljanja in izražanja doživetij.

\section{Pogled na raziskovanje in razumevanje glasbenega razvoja z diahrone perspektive}

Začetki znanstvenega preučevanja glasbenega razvoja segajo $v$ začetek 20. stoletja. Raziskovalci so z opazovanjem lastnih otrok prepoznavali in opisovali značilna glasbena vedênja $v$ povezavi z glasbenim spominom ter sposobnosti prepoznavanja melodičnih in ritmičnih prvin (Motte-Haber 1990). Po zgledu razvojne psihologije so bila raziskovanja usmerjena $v$ opredeljevanje glasbenih razvojnih stopenj in iskanje praoblik glasbenega izražanja. Iz tega obdobja je znana raziskava nemškega psihologa Heinza Wernerja (1890-1964). ${ }^{4}$ Menil je, da je odkril ontogenetično melodično praobliko. Praoblika otrokovih pevskih začetkov naj bi bil ton, ki pada v glissandu, ki ga triletni otrok že more razločiti kot motiv male terce (str. 326). Mala terca naj bi bila tako izhodišče za otroške pesmi in glasbeno opismenjevanje otrok. Tej raziskavi je bilo očitano, da je bila zanemarjena predpostavka, da je lahko mala terca $v$ določenem glasbenem okolju priučljiva.

Vrsto let so strokovnjaki iskali odgovor na vprašanje, ali obstaja enovita glasbena sposobnost ali gre za raznovrstne glasbene sposobnosti, ki delujejo navzven usklajeno in vzajemno (Radoš 2010). Tovrstno raziskovanje se je osredinilo predvsem na populacijo otrok $v$ srednjem in poznem otroštvu ${ }^{5}$ ter mladostnike. Pogosto je šlo za primerjavo glasbenih sposobnosti otrok, ki niso ali so bili deležni glasbenega izobraževanja.

Prvi psihološki test glasbenih sposobnosti je leta 1880 razvil Carl Stumpf (1848-1936). Meril je reprodukcijo tona, izvedenega na klavirju, sposobnost razlikovanja tonskih višin in oceno stopnje konsonance (Radoš 2010). Prvi

\footnotetext{
${ }^{4} \mathrm{~V}$ raziskavi je sodelovalo 45 otrok iz družin nižjega ekomskega statusa na Dunaju. Raziskovalec je bil mnenja, da je tako izločil vpliv okolja in možnosti vpliva glasbenega šolanja, saj otroci iz revnih družin niso deležni glasbenega šolanja (Motte-Haber 1990).

${ }^{5}$ Otroci, stari med 6 in 11 let.
} 
standardizirani test, zasnovan na teoretičnih osnovah, je razvil Carl Emil Seashore (1866-1949). Bil je zagovornik eksaktnega merjenja in natančne analize dobljenih podatkov.

Zanimivo je, da so raziskovanje glasbenega razvoja vse do 80 . let 20. stoletja izvajali psihologi. Ni naključje, da gre za obdobje intenzivnega razvoja testnih baterij in drugih inštrumentov za merjenje glasbenih sposobnosti. Raziskave so potekale v laboratorijih. Zvok in glasba sta bila izvedena na generatorjih. Merski inštrumenti so bili zasnovani na tedanjih teorijah glasbenega razvoja. Unitaristična smer teorije glasbenih sposobnosti je zagovarjala enovito glasbeno sposobnost, ki so jo pogosto poimenovali kot muzikaličnost. Zagovorniki te teorije so bili predvsem angleški raziskovalci. Očitalo se jim je, da so pri testiranju merili posamezne komponente muzikalnosti, na koncu pa rezultate preprosto sešteli (Rojko 2010). Druga smer je atomistična. Zagovarja stališče, da je muzikaličnost skupek raznovrstnih glasbenih sposobnosti. To smer so razvijali ameriški psihologi.

Glavni zagovornik enovite glasbene sposobnosti je angleški psiholog Henry Wing. ${ }^{6} \mathrm{Z}$ raziskavami in faktorsko analizo je izluščil splošni faktor glasbenih sposobnosti. Glasbeno inteligentnost je opredelil kot splošno sposobnost zaznavanja in vrednotenja glasbe, ki se navzven kaže kot sposobnost percepcije, recepcije in produkcije glasbe ter sposobnost estetske presoje glasbe (Radoš 2010, 100). Skupaj z Arnoldom Bentleyjem (1913-2001) sta, pod vplivom teorije o splošnem inteligenčnem količniku, računala količnik muzikalnosti.

Danes je teorija o inteligenčnem količniku Charlesa Spearmana presežena. Gordon je mnenja, da je povezav med glasbenimi sposobnostmi in testi inteligentnosti le za od 5 do 10 odstotkov (Gordon 1967). Bentley se je kasneje od ekstremističnih pogledov na razvoj glasbenih sposobnosti oddaljil. $\mathrm{Na}$ predpostavkah o obstoju treh elementarnih glasbenih sposobnosti ${ }^{7}$ je razvil enega najbolj znanih testov, mere glasbenih sposobnosti (angl. Measures of Musical Ability) (Smolej-Fritz 200o). Test je bil uporabljen v raziskavi Bar-

\footnotetext{
${ }^{6}$ Pred njim je bil poznan raziskovalec enovite glasbene sposobnosti madžarski psiholog Geza Révész, ki je imel za takratne razmere ogromen lasten laboratorij $s$ kar 40 sobami za testiranje glasbenih sposobnosti (Radoš 2010). Štejemo ga za pionirja eksperimentalnega ugotavljanja muzikalnosti pri otrocih (Rojko 1981). Opredelil je osem slušno-glasbenih sposobnosti: smisel za ritem, regionalni sluh, analizo dvoglasja in večglasja, relativni posluh, smisel za harmonijo, glasbeno dojemanje in ponavljanje melodije ter igranje po posluhu z improvizacijo (Révész 2001).

${ }^{7}$ Te so: sposobnost razlikovanja tonskih višin, sposobnost pomnjenja melodije in sposobnost pomnjenja ritma, ki se jim doda sposobnost analize akordov (Radoš 2010).
} 
bare Smolej-Fritz na populaciji otrok v Sloveniji med 7. in 14. letom starosti, na vzorcu 436 otrok. Namen raziskave je bil ugotoviti razvoj sposobnosti razlikovanja višin, pomnjenja melodije, pomnjenja ritma in analize sozvočij glede na obiskovanje ali neobiskovanje glasbene šole. Rezultati so pokazali, da se pri učencih, ki obiskujejo glasbeno šolo, omenjene sposobnosti razvijejo prej. Pri otrocih, ki obiskujejo glasbeno šolo, in pri tistih, ki je ne obiskujejo, povprečni dosežki postopno naraščajo s starostjo do približno 12. leta in pol. Kaže, da se razvoj te sposobnosti zaključuje nekje okoli te starosti pri obeh skupinah otrok, s tem da pri otrocih, ki obiskujejo glasbeno šolo, na višjem nivoju kot pri otrocih, ki glasbene šole ne obiskujejo (Smolej-Fritz 2000, 103).

Eden vidnejših predstavnikov atomistične smeri teorije glasbenih sposobnosti je Carl Emil Seashore (1866-1949). Muzikalnost je opredelil kot skupek glasbenih sposobnosti, ki se združujejo v glasbeno zavest (Seashore 1969; Radoš 2010). Zagovarja stališče, da muzikalnost ni enostaven seštevek posameznih sposobnosti, ampak je integrirana celota, ki jo bolje spoznamo, če raziščemo posamezne komponente. Baterija testov, ki jo je razvil posebej za glasbene amaterje in za glasbeno izobražene, vključuje teste za tonsko višino, jakost, ritem, tonska trajanja, zvočno barvo, konsonanco in glasbeni spomin (Rojko 1981; Radoš 2010). Zanimivo je, da je pozornost usmeril na senzorne sposobnosti. Pri tem je izhajal iz predpostavke, da je zvok osrednji medij za glasbo. Njegove fizikalne lastnosti zaznavamo in spoznavamo preko čutil (Seashore 1969).

Obdobje testiranj $\vee$ glasbi je zaokrožil ameriški psiholog Edwin Gordon (1927-2015), ki je teste osnovne mere glasbene avdiacije (angl. The Primary Measures of Music Audiation) prilagodil tudi za mlajše otroke, stare od pet let in pol do osem let. S testi merimo melodične in ritmične sposobnosti glede na razlikovanje enakih in različnih glasbenih motivov (Gordon 1986). Vsak test vsebuje 40 nalog. Teste je za populacijo slovenskih otrok prilagodila Barbara Sicherl-Kafol, tako, da je upoštevala značilno motiviko slovenske glasbe. Zmanjšala je tudi število nalog na devet za vsak preizkus. V eksperimentalni raziskavi o učinkih celostne glasbene vzgoje na uravnotežen razvoj otroka na afektivno-socialnem, psihomotoričnem in kognitivnem področju je merila sposobnosti ritmične in melodične avdiacije otrok $v$ prvem razredu osemletke. Otroci, ki so bili deležni celostne glasbene vzgoje, so dosegli višje rezultate na področjih melodične in ritmične avdiacije kot otroci kontrolne skupine, ki so imeli klasičen pouk glasbene vzgoje (Sicherl-Kafol 2001).

Edwin Gordon je glasbeni razvoj raziskoval v povezavi z avdiacijo. Opredeljuje jo kot sposobnost predvidevanja glasbenih dogodkov brez predhodne 
fizične prezentacije zvoka. ${ }^{8}$ Pravi, da je avdiacija za glasbo to, kar je mišljenje za jezik. Je osnova glasbenim sposobnostim in dosežkom. Povezuje jo s »čistim « zvokom, in ne s sposobnostmi branja ter pisanja glasbe (Gordon 1967; 1984; 1995). Avdiacijo lahko razvijamo za vse glasbene parametre, kot so zvočna barva, ritem, melodija, dinamika, artikulacija, agogika, metrum in tempo (Gordon 1997).

Ker je avdiacija pogojena z glasbenim spominom, se je polje raziskovanja razširilo na glasbeno kognicijo in načine »skladiščenja " glasbenih informacij. Raziskovanje se je iz laboratorijev preselilo v naravno okolje. Osrednja tehnika raziskovanja niso testi, pač pa opazovanje z udeležbo ali brez nje v problemsko zasnovanih situacijah. Predmet raziskav so glasbeno vedênje, procesi učenja in ustvarjanja ter glasbeni dosežki otrok. Pomembna predstavnica te generacije raziskovalcev je glasbenica in razvojna psihologinja Jeanne Bamberger (1925-). Sprva se je naslanjala na teorijo konstruktivizma. Glasbeni razvoj je želela razčleniti po etapah logičnega mišljenja, kot jih je opredelil Jeanne Piaget. Ugotovila je, da ima glasbeno mišljenje svoja pravila in omejitve in zato ga ni mogoče vključiti v jezikovno ali logično-matematično mišljenje. Glasbeno mišljenje tudi nima enovitega razvoja. $V$ fazi figuralnega mišljenja, ki je značilna za otroka v zgodnjem obdobju, imata pomembno vlogo glasbena intuicija in sposobnost predvidevanja glasbenih dogodkov. Ta vrsta mišljenja se pod vplivom učenja nadgradi $v$ formalni način mišljenja, ki je podprt z znanjem o glasbi kot simbolnem sistemu (Gardner 1995; Bamberger 2000). Tu najdemo stičišče s teorijo simbolnih sistemov Howarda Gardnerja, po kateri glasbeno inteligentnost opredeli kot eno od sedmih samostojnih inteligentnosti (Gardner 1995). Pripisuje ji lasten simbolni sistem, $v$ katerem poteka glasbena komunikacija. Razumemo jo kot zmožnost posameznika za glasbeno percepcijo, recepcijo in produkcijo. Nas zanimajo prve oblike te glasbene zavesti in glasbenega vedênja pri dojenčku. Pri tem se bomo oprli na ugotovitve danes delujočih raziskovalcev, kot so Hanuš in Mechthild Papoušek, Sandra E. Trebuh, E. Glenn Schellenberg in John Sloboda.

\section{Dojenček je dober poznavalec glasbe}

Pogosto citirani stavek, da se med vsemi nadarjenostmi, s katerimi je obdarjen človek, najprej pokaže glasbena (Gardner 1995, 135), je primerno izhodišče za predpostavko, da je dojenček velik poznavalec glasbe. Poznavalca v tem kontekstu razumemo kot pozornega poslušalca, ki ima velike zaznavne

\footnotetext{
${ }^{8}$ Audiacije ne smemo zamenjevati s slušno zaznavo, notranjim slišanjem, imitacijo, glasbenim spominom ali slušnim razlikovanjem (Gordon 1995).
} 
sposobnosti in zna razlikovati glasbene izvedbe. Ta sposobnost zahteva poznavanje glasbe določenega kulturnega okolja. Tovrstno znanje ni dano neizkušenim poslušalcem. Sprašujemo se, kako lahko to sposobnost pripisujemo dojenčku. Mnenje ugledne ameriške raziskovalke zgodnjega glasbenega razvoja Sandre E. Trebuh je, da je to povezano z njegovimi glasbenimi dispozicijami, odličnim spominom za glasbo, bogatim glasbenim okoljem, radovednostjo in velikim zanimanjem za ekspresivno glasbo (Trebuh 2006).

Razvojni psihologi ugotavljajo, da ima dojenček v primerjavi z zelo omejeno gibalno kompetentnostjo izjemno dobro razvite vse temeljne čute, ki, z izjemo vida, dosežejo primerljivo učinkovitost s čuti odraslega že v prvih nekaj mesecih po rojstvu (Zupančič 2004, 186). Dojenček se uči in spoznava svet s čutili. Čutila so primarni vzvodi tudi za občutenja. Pri otroku jih razvijamo na treh ravneh: (1) na ravni senzornega stika s stvarmi in z dogodki (veččutno učenje); (2) razpoznavanja lastnega razpoloženja in občutenja na telesu (mišična napetost, neudobje, ugodje, čustva); (3) občutenj, ki gredo preko realnosti, v območje domišljije, ki vključuje tudi sanje, spomine in predvidevanja (Mayesky 2009).

Prvo obsežno presečno študijo je leta 1976 opravil nemški filozof in pedagog Helmut Moog na vzorcu 500 otrok, starih od treh mesecev do petih let. $\mathrm{Na}$ magnetofonske trakove je posnel šest testov. ${ }^{9}$ Natančno je opazoval in popisoval kakršnekoli odzive otrok na predvajane zvočne posnetke. Ugotovil je, da 6-mesečni dojenčki prenehajo z dejavnostjo (tudi s hranjenjem) in se obrnejo proti izvoru zvoka z izrazi začudenja. Prepoznal je njihovo selekcionirano pozornost v povezavi s kakovostjo zvoka. Pozornost dojenčka v večji meri pritegnejo glasbeni vzorci kot neglasbeni. Ta opažanja označi kot preferenco dojenčka do čutno lepega zvoka (angl. sensuously beautiful sound) (Moog 1976 v Sloboda 2007).

John Sloboda je kritičen do raziskovalnih pristopov, ki temeljijo na subjektivnih ocenah opazovalca o odzivanju dojenčka na glasbene stimuluse. Stališče utemelji na ugotovitvah razvojne psihologije. Znano je, da se dojenček odziva na spremembe v okolju (Zupančič 2004). Glasbeni dražljaj je lahko le ena od teh sprememb. Zato osredotočenosti dojenčka na zvok ali njegove odzive na glasbene dražljaje še ne moremo razumeti kot obliko glasbenega

\footnotetext{
${ }^{9}$ 1. test je vseboval posnetke treh otroških pesmi, ki so jih zapeli otroci, 2 . test je bil posnetek ritmičnega izrekanja besednih zvez, 3. test je vseboval ritmične vzorce, zaigrane na različna rimtična glasbila, 4 . test so bili posnetki instrumentalne glasbe, 5 . test je vseboval tonalni motiv glasbe iz 4. testa, ki mu je dodal različne disonantne harmonije, 6 . test je bil sestavljen iz neglasbenih zvokov, kot sta zvok sesalca, prometa...
} 
vedênja (Sloboda 2007). ${ }^{10}$ Ključna pri tem je glasbena zavest, ki se kaže v zmožnosti diferenciacije tonskih višin, značilnih samo za glasbene zvoke (Sloboda 2007, 198).

Nadaljnja raziskovanja zgodnjega glasbenega razvoja so zato temeljila na novih tehnikah opazovanja, ki so zmanjševale potencialno subjektivnost opazovalca. Kot primer učinkovitega pristopa se je uveljavilo opazovanje dojenčka med gledanjem lutkovne predstave $v$ živo, $v$ kateri v ozadju potekajo ponavljajoči se glasbeni vzorci, sestavljeni z od 5 do 10 toni. Dojenček med gledanjem predstave reagira na majhne, subtilne spremembe $v$ glasbi. Melodične ali ritmične spremembe navadno povzročijo, da se obrne proti zvočniku, kot da bi preverjal razlog za spremembo. Obrat, ki sledi takoj po predvajani spremembi, se za nekaj sekund nagradi z izbranim vizualnim prikazom, primernim starosti otroka. Obračanje pozornosti izven navedenega konteksta se ne nagrajuje. Dojenček med šestim in desetim mesecem se teh pravil nauči v nekaj minutah. Na tej osnovi raziskovalci ugotavljajo odzive dojenčka na spremembe $v$ glasbenih vzorcih (Trebuh 2006).

Prelomnico v razumevanju glasbenega razvoja dojenčka pomeni raziskava Hsing-Wu Changa in Sandre E. Trebuh (1977a), ki sta pri 5-mesečnih dojenčkih ugotavljala zmožnost zaznavanja razmerij med tonskimi višinami v glasbenem vzorcu. Pri tem sta se naslonila na paradigmo habituacije ${ }^{11}$ in merjenja srčnega utripa. Dojenček je poslušal ponavljanje 6-tonskega atonalnega glasbenega vzorca. Ko se je navadil na prvi glasbeni vzorec, so mu predvajali drugega. Drugi vzorec se je začel ali na enaki tonski višini s spremenjenimi tonskimi razmerji v nadaljevanju ali pa je bil izveden kot transpozicija prvega. Opazili so, da se je srčni utrip dojenčka spremenil pri spremembah razmerij med toni (nova melodija), ne pa tudi pri transpozicijah. Prav tako sta ugotovila, da je dojenček občutljiv na ritmične spremembe v zaporedno predvajanih ritmičnih vzorcih (Chang in Trebuh 1977b). Zanimiva je tudi ugotovitev, da dojenčki te subtilne razlike $v$ melodičnih in ritmičnih vzorcih zaznavajo $\checkmark$ glasbi ne glede na to, ali izvira iz njihovega kulturnega okolja ali od drugod (Trebuh in Hannon 2006). Sposobnost zaznave dojenčka za odzivanje na spremembe $v$ tonskih in ritmičnih razmerjih $v$ zaporednih zvočnih vzorcih Sloboda označuje kot prvo obliko glasbenega vedênja (Sloboda 2007). Ti principi so $v$ obdobju zgodnjega glasbenega razvoja univerzalni glede na

\footnotetext{
${ }^{10}$ Nakazuje se potreba po redefiniranju glasbenih mejnikov, kot sta jih prvič objavila Rosamund Shuter-Dyson in Clive Gabriel v knjigi The Psychology of Musical Ability (1981). Prvi mejnik v glasbenem razvoju opišeta kot odziv dojenčka na zvok (Hargreaves 2001, 61).

${ }^{11}$ Do habituacije pride pri ponavljanju istega stimulusa. Ko se dojenček na stimulus privadi, se mu srčni utrip umiri in ustali.
} 
starost in spol, zato se sklepa, da temeljijo na bioloških predispozicijah (Deliège in Sloboda 1996).

Odziv dojenčka na glasbo je običajno gibalni. Helmut Moog je v svoji raziskavi opazil, da se dojenčki, ki so med poslušanjem sedeli, zibajo levo-desno, tisti, ki so stali, pa so klecali v kolenih gor-dol. Enake gibalne odzive je opazil pri poslušanju petja ali instrumentalne glasbe. Sloboda ugotavlja, da v prvem letu starosti teh gibalnih odzivov še ne moremo razumeti kot ritmično vedênje, čeprav pri dojenčku opazimo še druge z ritmom povezane aktivnosti, kot sta enakomerno ponavljanje zloga ali besede ter enakomerno udarjanje $\mathrm{s}$ predmetom ob podlago (Deliège in Sloboda 1996). Da lahko neko vedenje opredelimo kot ritmično, je treba $v$ gibalnih odzivih prepoznati naslednje: podelitev glasbenega utripa ${ }^{12}$ vsaj $v$ zaporedju dveh ali več glasbenih utripov; ohranjanje glasbenega utripa med pavzo in nadaljevanje $z$ njim po pavzi; posnemanje ritmičnih motivov ter gibanje v ritmu glasbe ali izvajanje metruma (Deliège in Sloboda 1996). Nobena od navedenih oblik glasbenega vedênja se ne pojavi pred prvim letom (Sloboda 2007).

Z rezultati temeljnih raziskav lahko potrdimo predpostavko, da je dojenček poznavalec glasbe. Raven razvitosti glasbene zavesti prepoznavamo z njegovim odzivom na spremembe $v$ melodični in ritmični strukturi ponavljajočih se glasbenih vzorcev. Slednje strokovnjaki opredeljujejo kot prvo obliko glasbene zavesti. Opredelimo jo lahko kot mejnik v glasbenem razvoju. Ključni dejavniki pri doseganju tega mejnika so interakcije $v$ glasbenem okolju in $z$ njim povezani procesi akulturacije.

\section{Pomen akulturacije v domačem okolju za glasbeni razvoj dojenčka}

Akulturacija (angl. enculturation) je del procesov socializacije, ki potekajo v interakciji z okoljem. Gre za sprejemanje, učenje in usklajevanje posameznika $s$ kulturo okolja. $V$ tem prispevku jo obravnavamo $v$ povezavi z interakcijami $v$ družinskem okolju, v katerem se otrok privaja na glasbo in glasbene navade. Povezava med družinskim okoljem in glasbenim razvojem dolgo časa ni pritegnilo pozornosti raziskovalcev (Papoušek 1996). Raziskave o pomenu akulturacije za govorni in glasbeni razvoj dojenčka so bile narejene konec 20. stoletja. V ameriškem kulturnem okolju so preučevali značilnosti govorne in glasbene komunikacije matere $z$ dojenčkom. Ugotovili so, da se govor, ki je usmerjen na dojenčka, razlikuje od običajnega govora po višini glasovne

${ }^{12} \mathrm{Z}$ izrazom poimenujemo splošno občutenje glasbenega časa, ki ga odrasli navzven spontano izražamo s tleskanjem, z zibanjem, udarjanjem z nogo ob tla, ki je usklajeno z glasbenim potekom. 
lege, podaljševanju samoglasnikov, ponavljajočih se besednih zvezah in modulaciji glasu (Papoušek, Papoušek in Symmes 1991). Opažene modulacije in konture glasu v kontekstu nasprotnih si situacij, kot sta vznemirjenost - pomirjenost, odobravanje - neodobravanje, predstavljajo univerzalno predverbalno komunikacijo matere $z$ dojenčkom ne glede na kulturno okolje (Papoušek, Papoušek in Symmes 1991). Komunikacija, v kateri ima mati priložnost za izražanje lastnih čustev do otroka, ima tudi močen doživljajski naboj (Schubert in McPherson 2006).

Vsa kulturna okolja poznajo glasbo, ki jo mati izvaja med negovanjem dojenčka ali drugimi vsakodnevnimi opravili (Trebuh in Trainor 1998). Strokovnjaki ugotavljajo, da večina dojenčkov prvo glasbeno izkušnjo $v$ živo doživi ob materinem petju ali petju skrbnika. Na populaciji ameriških mater je bilo ugotovljeno, da severnoameriške matere, usmerjene $\mathrm{k}$ sodobnejšemu življenjskemu slogu, pojejo živahne pesmi, ob katerih se gibajo in igrajo. Matere iz tradicionalnejših okolij pa pojejo uspavanke (Trebuh, Hill in Kamenetsky 1997). Matere s sodobnejšim življenjskim slogom izvajajo glasbo z namenom spodbujanja otrokovega razvoja. Pričakujejo, da se bodo dojenčki odzvali s smehom in željo po interakciji. V tradicionalnih kulturnih okoljih matere glasbo izvajajo za umirjanje in uspavanje dojenčka. Zadovoljne so, če se dojenček ob petju umiri in zaspi (Toda 1990 v Sloboda 2007). Skupaj z Arnoldom Bentleyjem (1913-2001) sta pod vplivom teorije o splošnem inteligenčnem kvocientu računala kvocient muzikalnosti. Strokovnjaki ugotavljajo, da so prve glasbene izkušnje večine dojenčkov povezane s poslušanjem žive glasbe doma. Dom in starši so pomembni učitelji glasbe v kritičnem obdobju glasbenega razvoja do 18. meseca starosti (Gordon 1997). Neformalno glasbeno učenje ob petju in gibanju ob glasbi sta zadostna pogoja za otrokov nadaljnji glasbeni razvoj. Ob tem dobi še eno izkušnjo več - da sta življenje in umetnost medsebojno povezana (Gordon 1997).

Edwin Gordon je obdobje privajanja otroka na glasbo v okolju raziskoval z vidika razvoja avdiacije kot oblike glasbenega mišljenja. Prvo fazo razvoja, ki traja od rojstva do drugega oziroma četrtega leta starosti, poimenuje inkulturacija (angl. acculturation). $V$ tem obdobju otrok doseže tri razvojne stopnje: (1) vsrkavanje (angl. absorption) glasbe iz okolja, ki mu omogoča izgrajevanje poslušalskega besednjaka za nadaljnje izvajanje in ustvarjanje glasbe; (2) nenamerne (angl. random response) odzive na glasbo, tako imenovano glasbeno bebljanje in (3) namerne odzive na glasbeno izvajanje drugega (angl. purposeful response) (Bluestin 2000).

Najzgodnejša oblika namernega glasbenega vedênja je sposobnost dojenčka za posnemanje posameznih tonskih višin. Vendar pa ni dokazov, da 
bi dojenčki posnemali melodične vzorce, tudi če bi bili sestavljeni le iz dveh tonov (Schellenberg in Trebuh 1996; Kessen Levine in Wedrich 1979 v Sloboda 2007; Hargreaves 2001). Pogosteje prepoznamo drugo obliko glasbenega oz. govornega vedenja - vokalizo ali bebljanje. ${ }^{13}$ Glasbeno bebljanje opredeljujemo kot obliko ekspresivnega odziva dojenčka na glasbo in zvoke iz okolja, pa tudi kot težnjo po vzpostavljanju interakcij z okoljem (Hargreaves 2001). Tovrstne glasovne odzive dojenčka je prvi raziskoval Helmut Moog. Glasovne odzive v obliki tonskih gibanj navzdol na enem vokalu je opazil že pri nekaterih tri mesece starih dojenčkih, pogosteje pa pri šest in $v$ večini pri devet mesecev starih dojenčkih. Tovrstno predverbalno komunikacijo med starši in dojenčkom sta raziskovala tudi M. Papoušek in H. Papoušek. Ugotovila sta, da se med starši in dojenčki vzpostavi svojsko sporazumevanje kot neke vrste predjezikovni kod, ki vsebuje glasbene prvine, skupne govornemu in glasbenemu bebljanju, npr. višino in modulacijo glasu, glasnost, barvo glasu in poudarke. Pomembna je tudi ugotovitev, da pri tem starši uporabljajo tudi neverbalne oblike komunikacije, kot so dotik, gestikuliranje in izraz na obrazu. Integracija neverbalne komunikacije in glasbenega izvajanja je za dojenčka pomembna spodbuda za nadaljnje razvijanje sposobnosti zaznavanja (Papoušek 1996).

$\checkmark$ glasbenem bebljanju še ne prepoznamo zametkov glasbene sintakse, značilne za glasbo $v$ določenem kulturnem okolju. Zato pri dojenčku še ne moremo govoriti o imitaciji kot značilni obliki glasbenega vedênja, ki se običajno pojavi po 18. mesecu starosti (Gordon 1995). Kljub temu lahko dosežke glasbene akulturacije dojenčka strnemo v naslednje tri ugotovitve: (1) dojenček ob koncu 1. leta razlikuje glasbene in neglasbene zvoke, kar pokaže s posebno pozornostjo na zvok, z gibanjem in vokalizo; (2) izraža preference do glasbenih zvokov, še posebej do petja in instrumentalne glasbe; (3) posnema posamezne tonske višine; (4) zaznava ritmične in melodične spremembe $v$ zaporednih ponovitvah glasbenih vzorcev, če prej sliši večkratno ponovitev prvega glasbenega vzorca (Sloboda 2007).

Ugotavljamo, da rezultati raziskav potrjujejo pomen procesov inkulturacije $v$ družinskem okolju za glasbeni razvoj dojenčka, še posebej v povezavi s petjem matere oz. skrbnika.

\section{Sklepne ugotovitve}

Novejši pristopi k raziskovanju glasbenega razvoja v zgodnjem obdobju so razširili in poglobili razumevanje odzivov otroka na glasbene spodbude. Pre-

\footnotetext{
${ }^{13}$ Raziskovalci ločijo govorno in glasbeno bebljanje.
} 
lomnico predstavljajo raziskave o glasbeni zavesti dojenčka. Dojenček je zmožen zaznavati razmerja med tonskimi višinami in trajanji v zaporedno izvedenih melodičnih ter ritmičnih vzorcih. Sloboda (2007) te odzive opredeli kot prvo obliko glasbenega vedênja. Te sposobnosti dojenčka se povezujejo z njegovimi glasbenimi dispozicijami, odličnim spominom za glasbo, radovednostjo in bogatim glasbenim okoljem. Dojenček je lahko dober poznavalec glasbe, če je deležen raznovrstnih glasbenih izkušenj. Tako procesi akulturacije dobijo pomen $v$ družinskem okolju. Dosežki tovrstne socializacije otroka z glasbo se ob koncu prvega leta kažejo $v$ zmožnostih razlikovanja glasbenih in neglasbenih zvokov, izražanja preferenc do petja in instrumentalne glasbe, glasbenega bebljanja, posnemanja tonskih višin in zaznavanja sprememb v zaporedno izvedenih melodičnih ter ritmičnih vzorcih. Edwin Gordon je te procese preučeval z vidika razvoja avdiacije kot oblike glasbenega mišljenja; pri tem izpostavi potrebo po neposrednem stiku dojenčka z glasbo $v$ živo, še posebej petju. Ugotovitve so pomembna iztočnica za nadaljnje razvijanje pristopov k zgodnjemu učenju glasbe. Vzor nekateri strokovnjaki vidijo $v$ naravnem didaktičnem modelu verbalne, neverbalne in glasbene komunikacije matere $z$ dojenčkom. Intimen odnos med njima, ki se vzpostavi med izvajanjem glasbe $v$ živo, ima tudi močen doživljajski naboj.

\section{Literatura}

Bamberger, J. 2000. Developing Musical Intuitions: A Project-Based Introduction to Making and Understanding Music. Oxford: Oxford University Press.

Bluestine, E. 2000. The Ways Children Learn Music: An Introduction and Practical Guide to Music Learning Theory. Chicago: GIA Publications.

Borota, B. 2009. »Podoba velikega glasbenika skozi očala Reggio Emilia.« V Izzivi pedagoškega koncepta Reggio Emilia, ur. T. Devjak in D. Skubic, 135-150. Ljubljana: Pedagoška fakulteta.

- 2013. Glasbene dejavnosti in vsebine. Koper: Annales.

Chang, H. W., in S. E. Trebuh. 1997a. »Auditory Processing of Relational Information by Young Infants." Journal of Experimental Child Psychology 24:324331.

- 1997b. »Infants' Perception of Temporal Grouping in Auditory Patterns." Child Development 48 (4): 1666-1670.

Deliège, I. in Sloboda, J. 1996. Musical Beginnigs: Origins and development of Musical Competence. Oxford: Oxford University Press.

Gardner, H. 1995. Razsežnosti uma. Ljubljana: Tangram.

Gordon, E. E. 1967. »The Musical Aptitude Profile.« Music Educators Journal 53 (6): 52-54.

. 1984. Study Guide for Learnig Sequences in Music: Skill, Content, and Patterns. Chicago: GIA Publications. 
. 1986. The Nature, Description, Measurement and Evaluation of Music Aptitude. Chicago: GIA Publications.

—. 1995. »The Role of Music Aptitude in Early Childhood Music.« Early Childhood Conections 1 (1-2): 14-21.

_ 1997. A Music Learning Theory for Newborn and Young Children. Chicago: GIA Publications.

Hargreaves, D. J. 2001. The Developmental Psychology of Music. Cambridge: Cambridge University Press.

Kessen, W., J. Levine in K. Wendrick. 1979. »The Imitation of Pitch in Infants." Infant Behavior and Development 2:93-100.

Mayesky, M. 2009. Creative Activities for Young Children. Clifton Park, NY: Delmar Cengage Learning.

Moog, H. 1976. The Musical Experience of the Pre-School Child. London: Schott.

Motte-Haber, H. 1990. Psihologija glasbe. Ljubljana: Državna založba Slovenije.

Oblak, B. 2001. Glasbena slikanica 3: priročnik za učitelje. Ljubljana: DZS.

Papoušek, M. 1996. »Intuitive Parenting: A Hidden Source of Musical Stimulation in Infancy.« V Musical Beginnings: Origins and Development of Musical Competence, ur. I. Deliège in J. Sloboda, 88-114. Oxford: Oxford University Press.

Papoušek, M., H. Papoušek in D. Symmes. 1991. »The Meanings of Melodies in Motherese in Tone and Stress Languages."Infant Behavior and Development 14 (4): 415-440.

Radoš, K. 2010. Psihologija muzike. Beograd: Zavod za udžbenike.

Révész, G. 2001. Introduction to the Psychology of Music. Mineola, NY: Dover.

Rinaldi, C. 2006. In Dialogue with Reggio Emilia. London: Routledge.

Rojko, P. 1981. Testiranje u muzici. Zagreb: Muzikološki zavod Muzičke akademije u Zagrebu.

Schellenberg, E. G., in S. E. Trebuh. 1996. »Natural Musical Intervals: Evidence From Infant Listenars. Psychological Science 7 (5): 272-277.

Schubert, E., in G. E. McPherson. 2006. »The Perception of Emotion in Music. \V The Child as Musician, ur. G. McPherson, 193-212. Oxford: Oxford University Press.

Seashore, C. E. 1969. Psychology of Music. New York: Dover.

Shuter-Dyson, R., in C. Gabriel. 1981. The Psychology of Musical Ability. London: Methuen.

Sicherl-Kafol, B. 2001. Celostna glasbena vzgoja: srce, um, telo. Ljubljana: Debora. Sloboda, J. 2007. The Musical Mind. Oxford: Oxford University Press.

Smolej-Fritz, B. 2000. »Razvoj vidikov glasbenih sposobnosti, ki jih meri Bentleyev test. «Psihološka obzorja 9 (1): 91-106.

Toda, S., A. Fogel in M. Kawai. 1990. »Maternal Speech to Three-Month-Old Infants in the United States and Japan." Journal of Child Language 17:279294. 
Trebuh, S. E. 2006. »Infants as Musical Connoisseurs."V The Child as Musician, ur. G. McPherson, 33-50. Oxford: Oxford University Press.

Trebuh, S. E., in E. E. Hannon. 2006. »Infant Music Perception: Domain-General or Domain-Specific Mechanisms?« Cognition 100:7399.

Trebuh, S. E., in L. J. Trainor. 1998. "Singing to Infants: Lullabies and Play Songs." Advances in Infancy Research 12:43-77.

Trebuh, S. E., D. S. Hill in S. B. Kamenetsky. 1997. »Parents' Sung Performances for Infants." Canadian Journal of Experimental Psychology 51 (4): 385-396.

Zupančič, M. 2004. »Zaznavni in spoznavni razvoj dojenčka in malčka. "V Razvojna psihologija, ur. L. Marjanovič Umek in M. Zupančič, 186-214. Ljubljana: Filozofska fakulteta.

\section{Researching Musical Development and the Significance of Musical Environment for Babies}

Researching musical development in babies is a special challenge, which in the 2oth century was addressed in various ways. The look at the approaches to research from a diachronic perspective reveals a significant shift from observing one's own children and testing in laboratories to observing musical behaviour in natural environment. Under the influence of other sciences diverse responses of babies to music were interpreted as forms of musical behaviour rather than as response to a stimulus from the environment. Based on the knowledge of inborn musical dispositions the knowledge about the forms of musical behaviour changed. In the paper we therefore defend the assumption that babies are great connoisseurs of music. Here we emphasize the importance of the processes of acculturation in the family environment and redefine some of the forms of musical behaviour of babies in relation to their perceptual abilities and the development of musical awareness. Based on studies in American cultural environment we also conclude that in the first year of life the baby's responses to music and sounds cannot already be interpreted as forms of melodic or rhythmical behaviour or linked to the ability of imitating music.

Keywords: research of musical development, musical development of babies, musical dispositions, forms of musical awareness in babies 


\title{
Značilno vedenje otrok prvega starostnega obdobja v igralnicah z različno glasbo
}

\author{
Barbara Kopačin \\ Univerza na Primorskem \\ barbara.kopacin@pef.upr.si
}

Danes je glasba kot psihološki pojav v vsakdanjem življenju razširjena in vsem dostopna kot še nikoli prej. Poslušamo jo lahko v avtu, preko pametnih telefonov skozi slušalke, preko radijskih ali televizijskih sprejemnikov ... Glasbo, ki jo poslušamo, si lahko izberemo tudi sami. Ali si jo otroci prve starostne skupine v vrtcu lahko tudi sami izberejo? Tam glasbo izbirajo vzgojitelji. Od njih pričakujemo, da imajo razvite glasbene sposobnosti, spretnosti, glasbeno ustvarjalnost in znanje, torej vse tiste glasbene sposobnosti, ki so pomembne za uspešen otrokov glasbeni razvoj. V katerih igralnicah z raznovrstno glasbo v ozadju se otroci najdlje zadržujejo, smo ugotavljali z raziskavo, ki je potekala v petih primorskih vrtcih. $V$ raziskavi je sodelovalo 66 otrok prve starostne skupine. $\mathrm{Na}$ izbiro smo jim dali tri glasbene zvrsti. V treh igralnicah, kjer smo izvajali glasbo, so bile otrokom na razpolago različne namizne igre. Ugotovili smo, da so se otroci najraje zadrževali v igralnici, kjer so lahko poslušali otroške pesmi.

Ključne besede: otrokov celostni razvoj do tretjega leta starosti, otrokov glasbeni razvoj do tretjega leta starosti, glasbena vzgoja v vrtcih, poslušanje glasbe

\section{Uvod}

Otrok že v materinem telesu dobiva sporočila iz okolja preko zvoka in nanje tudi reagira. Ta spoznanja moramo upoštevati pri pripravi in vodenju glasbenih dejavnosti v vrtcu. Otroku bi morali vzgojitelji v vrtcu omogočati, da skozi umetnost izraža svoj intimni svet in z okoljem komunicira spontano, neposredno in individualno.

Glasbena dejavnost poslušanje glasbe v vrtcu zahteva specifične učne metode in oblike dela. Poslušamo vse glasbene zvrsti, od ljudske do umetne glasbe vseh stilnih obdobij in v različnih vokalnih, vokalno-instrumentalnih ali instrumentalnih zasedbah. Sposobnost zaznavanja glasbe pa nam ni dana sama po sebi, ampak se je moramo naučiti.

\section{Teoretična izhodišča}

Prvi zvoki, s katerimi se otrok sreča, so enakomeren utrip krvi, ki teče po materinem telesu, dviganje in upadanje pri njenem dihanju, globoko basovsko 
bobnenje trebuha, premiki tekočine $v$ maternici in $v$ ozadju vsega tega materin srčni utrip.

Prvo čutilo, ki se razvije pri zarodku, je uho. Slušni živec, ki prenaša informacije iz ušesa v možgane, je prvi telesni čutni živec, ki začne delovati. V plodovem slušnem sistemu so približno v petem mesecu povezave toliko dozorele, da možganom omogočajo celovito obdelavo zvoka. Ko je plod v maternici sposoben slišati, ne le aktivno posluša, ampak se od tistega, kar sliši, tudi uči. Še nerojeni otrok je že sposoben sprejemati zvočne informacije, si jih zapomniti in jih priklicati iz spomina tudi po rojstvu (Clinic 2001; Campbell 2004).

$S$ poslušanjem glasbe vplivamo na otrokov emocionalni razvoj, razvoj estetske kulture in glasbenih sposobnosti (Denac 2002). Otrok že v predšolskem obdobju raziskuje zvoke. Ob ustvarjanju na improvizirane in lastne instrumente raziskuje različne barve, glasnosti, trajanja in višine zvokov. Na ta način pridobiva prve izkušnje s poslušanjem glasbe. Otrok lahko posluša vokalno, instrumentalno ali vokalno-instrumentalno glasbo. Ponudimo pa mu lahko tudi glasbene pravljice ter zvoke iz narave in okolja (Borota 2013).

Glasbo lahko poslušamo na različne načine: (i) doživljajsko poslušanje; (ii) doživljajsko-analitično poslušanje in (iii) analitično poslušanje. $V$ predšolskem obdobju je osrednji način poslušanja glasbe doživljajski, saj otroku omogoča doživeto in poglobljeno poslušanje; predvsem pa mu spodbudi različna razpoloženja in čustvene odzive (Borota 2013). Hkrati s poslušanjem otroku lahko omogočimo tudi izražanje teh doživetij preko gibanja, slikanja ali izražanja $z$ besedo. Mlajši predšolski otroci doživetja in predstave glasbenih del najpogosteje izražajo gibalno (Denac 2010).

\section{Celostni razvoj otrok do tretjega leta starosti}

Razvoj otroka poteka celostno in usklajeno na gibalnem, telesnem, miselnem, čustvenem in socialnem področju. Poteka približno v enakih obdobjih, za katera je značilno tipično vedenje otrok (Gallahue in Ozmun 2006 v Videmšek in Pišot 2007).

M. Videmšek, P. Berdajs in Karpljuk (2003) otrokov razvoj opredeljujejo kot dinamičen proces, ki ga $v$ medsebojni povezanosti opredeljujeta dednost in okolje. Avtorji menijo, da se na vse dejavnosti otrokovega razvoja ne da vplivati enako.

Otrok je ob rojstvu popolnoma odvisen od odraslega človeka in okolja, $v$ katerem se je znašel. Najprej je to njegova družina, $v$ kateri se nauči prvih medsebojnih odnosov. Naslednje je okolje, v katerem se gibljejo njegovi starši v razširjeni družini in med prijatelji. Tik pred dopolnjenim prvim letom pa otrok navadno vstopi v vrtec, kjer se sreča z vzgojitelji in s svojimi vrstniki, 
s čimer se njegov socialni krog razširi. Oblikujejo se nove povezave, nov način življenja in reševanja težav (Kranjc 2011).

Med pomembnejše otrokove razvoje uvrščamo ravno socialni in čustveni razvoj, saj pripomoreta k razvoju v odraslo osebo, ki je pripravljena na spoznavanje in razumevanje sveta. Pomembno pa je, da pri otroku vsi, ki smo vključeni v njegovo vzgojo, razvijamo pozitivna čustva, kot so veselje, ljubezen, občutek varnost ... S poznavanjem in sprejetjem teh čustev lahko razvijamo socialna čustva, kot so prijaznost, dobrota, obzirnost ... (Benkovič 2011).

Poznamo veliko različnih teorij o razlagi čustev. Vsem je skupno to, da slednja razumejo kot skupek zaporednih dražljajev in odzivov, ki si sledijo v določenem vrstnem redu. Na čustva otrok vpliva tudi odnos med starši in zgled, ki ga posredujejo svojemu otroku (Kožman 2011).

Otroci, ki kažejo v večji meri pozitivna čustva, bolj sodelujejo v vsakdanjih situacijah. Nasprotno je otroke, ki so potrti in večinoma slabe volje, težje motivirati za dejavnosti. Socialno kompetentni otroci sodelujejo v vsakodnevnih dejavnostih in se radi igrajo s svojimi vrstniki. Take otroke si tudi vrstniki izbirajo v svoj ožji krog. L. Marjanovič Umek in M. Zupančič (2009) prepoznavata, da so deklice odprtejše in komunikativnejše in zaradi tega tudi socialno kompetentnejše kot dečki.

Gibalni razvoj vsakega otroka poteka po nekem določenem zaporedju. Najprej sedi, nato stoji in šele nato hodi. Hitrost gibalnega razvoja je individualna. Otrok najprej usvaja osnovne oblike gibanja, ki jih počasi avtomatizira, in zaključi z gibanjem, ki ga otrok obvlada v različnih okoliščinah in situacijah. M. Videmšek in Pišot (2007) gibalni razvoj opredeljujeta kot proces, s pomočjo katerega otrok pridobiva gibalne spretnosti in vzorce, kar je rezultat medsebojne povezanosti dednosti in okolja. Dani vplivi so pomembni za mišično zorenje, med okoljskimi dejavniki pa imajo najpomembnejši vpliv predhodne gibalne izkušnje, tudi iz predporodnega obdobja. Otrok skozi vsakodnevne dejavnosti in igro pridobiva gibalne spretnosti in uri svoje gibalne sposobnosti. Najraje se igra na prostem in s svojimi vrstniki. Ves čas aktivno raziskuje svoje zmožnosti in okolico. Človekov gibalni razvoj se torej začne že $\checkmark$ predrojstvenem obdobju in se neprestano izpopolnjuje $v$ nadaljnjem razvoju. Še posebno izrazit je v prvih treh letih življenja. Starejši kot je otrok, kompleksnejša gibanja uporablja. Na rast in telesni razvoj v veliki meri vpliva gibanje (Videmšek in Pišot 2007).

V prvem starostnem obdobju govor otroka nekoliko sunkovito napreduje. Najprej šele spoznavajo besede, ki jih povezujejo s predmeti in dejanji. Do tretjega leta starosti pa otroci že sestavljajo enostavčne povedi in besede povezujejo med seboj (Marjanovič Umek in Zupančič 2001). 


\section{Glasbeni razvoj otrok do tretjega leta starosti}

Znanstveno je dokazano tudi, da se vsak otrok rodi z nagnjenji do glasbe, ki se lahko $v$ prvem letu življenja $v$ ugodnih razmerah razvijejo $v$ elementarne sposobnosti, v neugodnih pa zakrnijo. To je odvisno od treh dejavnikov: prvi je otroški svet s svojimi razvojnimi periodami in duševnimi sprejemljivostmi, drugi sta okolje in družba s svojimi načeli vzgojnega usmerjevanja, tretji pa je glasba s svojimi tonskimi fenomeni (Šivic 1975).

Glasbeni razvoj je zapleten in kompleksen proces, ki ga je težko do potankosti spoznati in razložiti. Prav v njem so med ljudmi največje individualne razlike. Je pomembno odvisen od številnih dejavnikov, ki ga podpirajo ali zavirajo, podobno kot razvoj otrokovega mišljenja, saj je z njim tesno povezan. Poglavitne značilnosti in zakonitosti psihičnega razvoja veljajo tudi za glasbeni razvoj, zato ga lahko razložimo tudi z nekaterimi razvojnimi teorijami in njihovimi znanstvenimi izsledki. Nekatere raziskovalne metode preučevanja psihičnega razvoja otroka so psihologi aplicirali tudi na preučevanje glasbenega razvoja (Wing 1961; Lundin 1967).

Največji vpliv na glasbeni razvoj v obdobju dojenčka in malčka ima tako družinsko kot širše socialno okolje. Kritično obdobje za razvoj občutljivosti za glasbo traja od rojstva do drugega leta, zato ga moramo podpreti z ustreznimi spodbudami iz okolja in dojenčkom ter malčkom omogočiti čim pogostejši stik z glasbo (Starc in Markočić 2004).

Opisati splošne stopnje otrokovega glasbenega razvoja po bioloških starostnih obdobjih je zelo težko ali skoraj nemogoče, saj so glasbene lastnosti kompleksne in večdimenzionalne, sestavljene iz različnih glasbenih sposobnosti. Pri mnogih otrocih se določene glasbene sposobnosti pokažejo prej, pri drugih pa lahko kasneje. Zato ni mogoče povsem natančno predvideti, kdaj se določena glasbena sposobnost lahko razvije in kdaj ne. Napredovanje otrok iz enega stadija v drugi poteka individualno.

Glasbene sposobnosti delimo na elementarne glasbene sposobnosti (melodični in ritmični posluh) in sposobnosti višjega reda (harmonski posluh, analitično poslušanje in sposobnosti estetskega oblikovanja in vrednotenja). Za otrokov razvoj je pomemben razvoj melodičnega in ritmičnega posluha, saj je to osnova za razvoj sposobnosti višjega reda (Sicherl Kafol 2001).

Vidimo, da strnjen pregled glasbenega razvoja po starostnih obdobjih predstavlja le ogrodje. To velja tudi za podatke o stopnji razvoja glasbenih sposobnosti po starostnih obdobjih le do četrtega leta starosti, ki sta ga podala R. Shuter-Dyson in Gabriel (1981 v Slosar 1995) (preglednica 1).

Danes je veliko govora o glasbenem razvoju že v predrojstvenem obdobju, 
Preglednica 1 Pregled glasbenega razvoja otrok do četrtega leta starosti

\begin{tabular}{ll}
\hline Starost v letih & Stopnje razvoja \\
\hline $0-1$ & Reakcije na zvok \\
$1-2$ & Spontano ustvarjanje glasbe \\
$2-3$ & Pričetek produciranja pesmi, ki jih otrok sliši \\
$3-4$ & Ustvarjanje splošnega načrta melodije \\
& razvoj absolutnega posluha, če se otrok uči igranja na instrument \\
\hline
\end{tabular}

Opombe Povzeto po Shuter-Dyson in Gabriel (1981 v Slosar 1995, 29).

ko se nerojeni otrok odziva na zvok in glasbene spodbude. Odzive na glasbo opažamo pri novorojenčku, ko se v prvih dneh življenja vidno obrača za zvočilom. Na fiziološki ravni so spremembe vidne v intenziteti dihanja in pospešenem bitju srca. Od tretjega meseca se otrok aktivno odziva na glasbo, ko se začne obračati k izvoru zvoka in premikati v ritmu glasbe (Smolej 1996).

Otroci okrog šestega meseca starosti začno že aktivno reagirati na glasbo. Obračajo se proti zvočilu in kažejo zadovoljstvo ali čudenje. Kmalu po šestem mesecu starosti se začnejo ob glasbi gibati - zibati. Po šestem mesecu se začnejo pojavljati poskusi ponavljanja zunanjih zvočnih vtisov - najprej z grobo imitacijo posameznih zlogov, nato njihovo podvajanje in ponavljanje, v katerem opazimo že spremembe v višini in ritmu. Ostwald (1973 v Slosar 1995) meni, da otroci z »vokalno igro« raziskujejo rang višin tonov glede na svoj glasovni obseg. Revesz (1954 v Slosar 1995) pa je prepričan, da otroci poskušajo imitirati tone, ki so jih slišali.

Hargreavesova (1990 v Slosar 1995) študija razvoja spontanega petja govori o tem, da je v začetni fazi sestavljeno iz kratkih melodičnih fraz, brez fiksiranih tonskih višin v malih nenatančnih intervalih, ki se ponavljajo $v$ nedogled. Melodičen in ritmičen obris motiva v grobem ostaja nespremenjen, spreminjajo se tonska višine. Sposobnost natančnega razlikovanja tonov po višini se razvija postopno. Triletni in štiriletni otroci imajo še težave pri razlikovanju tonov po višini.

Velik napredek v glasbenem razvoju poleg gibnega pomeni še zvočno odzivanje na glasbene dražljaje. To se zgodi v prvem letu starosti. Te zvočne reakcije otroka na glasbo Moog (1976 v Slosar 1995) imenuje glasbeno čebljanje. Sestavljeno je iz tonov različnih višin, izvedenih na enem vokalu ali na manjšem številu zlogov. Nadalje ugotavlja, da melodije glasbenega čebljanja ne kažejo podobnosti s poslušano glasbo in nimajo še jasne melodične in ne ritmične organizacije, pavze so npr. tam, kjer se je pojavila potreba po vdihu.

$V$ drugem letu starosti se močno povečata količina in raznovrstnost gib- 
nega reagiranja na glasbo. Oblike gibanja so različne (nihanje stopala, dviganje in spuščanje pet, premikanje kolen itd.). Med tretjim in četrtim letom prevzame dominirajočo vlogo nad gibom petje, čeprav je gibanje še vedno pomembna oblika odzivanja na glasbo. Petje $v$ tem obdobju namreč postane del domišljijskih iger (Piaget 1952 v Slosar 1995). Čeprav se količina gibanja, povezanega z glasbo, s starostjo zmanjšuje, se njegova pestrost povečuje; izboljšuje se koordinacija gib - glasba in gib - gib, ki prerašča v prepoznavne plesne korake. Proti koncu drugega leta starosti začno otroci v svoje »spontane pesmi« vključevati $z$ učenjem pridobljene ritmične in melodične vzorce (iz »učenih« otroških pesmi). McKernon (1979 v Slosar 1995) ugotavlja, da otrok pri triindvajsetem mesecu starosti povzame že ritmični vzorec, pri katerem sledi dvema kratkima tonoma en daljši ton.

Proces razvoja "spontane pesmi « lahko razložimo s Piagetovo teorijo asimilacije in akomodacije (Piaget 1952 v Slosar 1995). Otrok glasbene elemente iz okolja asimilira v svojo shemo »spontane pesmi«. Če otrok teh glasbenih vzorcev ne more asimilirati v svoje že obstoječe sheme, ustvari nove sheme - proces akomodacije. Na ta način se obris otrokove spontane pesmi vedno bolj približuje oblikam naučenih pesmi. Tako otrok ustvarja nove pesmi, ki jih Moog (1976 v Slosar 1995) imenuje pesmi »pot-pourri«. To so pesmi, ki imajo izposojen ali ritem ali melodijo ali pa tudi dele besedila; to so nekakšna zlitja in kombinacije spontanih in naučenih pesmi. Vendar spontanega ustvarjanja pesmi otroci ne opustijo kljub temu, da znajo zapeti že nekaj naučenih otroških pesmi. Gojijo ga dalje in vanj vnašajo vedno več $z$ učenjem pridobljenih glasbenih elementov. McKernon (1979 v Slosar 1995) ugotavlja, da spontane pesmi ostanejo melodično neorganizirane tudi pri štiriletnih otrocih kljub vplivom glasbenega učenja. Dokaj hitro pa se naučijo "standardno« otroško pesem. Približno polovica triletnih otrok je sposobnih bolj ali manj natančnega imitiranja vseh treh elementov pesmi: besedila, ritma in melodije. Dominantno vlogo ima sicer besedilo, ritem in melodija sta še nekaj bolj »abstraktnega«.

Pri otrocih v predšolskem obdobju harmonski posluh še ni razvit, zato je pomembno, da otrok sliši tudi večglasno petje, na osnovi katerega se razvijajo tudi dispozicije za nadaljnji razvoj harmonskega posluha (Denac 2002).

\section{Glasbena vzgoja v vrtcu}

Dnevne programe $v$ javnih vrtcih vzgojitelji in pomočniki vzgojiteljev oblikujejo po Kurikulumu za vrtce (Ministrstvo za šolstvo in šport 1999), ki je nacionalni dokument in ima svojo osnovo $\mathrm{v}$ analizah, predlogih ter rešitvah, $\mathrm{ki}$ so uokvirile koncept in sistem predšolske vzgoje $v$ vrtcih. $V$ njem so prepo- 
znavna tako temeljna načela in cilji predšolske vzgoje kot tudi spoznanja, da otrok svet dojema in razume celostno, da se razvija in uči v aktivni povezavi s svojim socialnim in fizičnim okoljem ter da v vrtcu v povezavi z vrstniki in odraslimi razvija lastno družbenost in individualnost. Glasba je zajeta v poglavju Umetnost, ki zajema tudi likovne, plesne in dramske dejavnosti. Kurikulum navaja, da se otrokovi potenciali kažejo v igrivem raziskovanju in spoznavanju sveta, saj v umetnosti izumlja in ustvarja, ko odkriva jezikovne strukture, artikulira vsebine, si zamišlja in oblikuje sliko, pesem, igro, ples in predmet. Otroška umetniška dela nastajajo, ko ima otrok pri delu svobodo in se od njega pričakujejo neposrednost, drugačnost, izvirnost.

V Kurikulumu za vrtce (Ministrstvo za šolstvo in šport 1999) so predstavljeni primeri glasbenih dejavnosti v vrtcih, ki naj bi jih otroci delali v prvi starostni skupini: (i) s petjem, z igranjem, s poslušanjem in z izmišljanjem glasbe glasbo doživlja, poustvarja, ustvarja, se z njo izraža in komunicira; (ii) ritmično izreka enostavne ljudske in otroške izštevanke in šaljivke; (iii) petje in ritmično izreko spremlja z glasbili in gibanjem; (iv) posluša, posnema in razlikuje zvoke iz narave in okolja; (v) posluša izvedbe in posnetke izbranih del glasbene literature; (vi) poje otroške, ljudske in umetne pesmi v obsegu svojega glasu; (vii) izvaja ritmične vzorce s ploskanjem, topotanjem, tleskanjem, udarjanjem ... in igranjem na mala glasbila; (viii) spontano si izmišlja ritmično-melodične vzorce; (ix) doživlja in opazuje igranje ter petje odraslega in starejših otrok; $(x)$ posluša glasbene pravljice in sodeluje $v$ njih.

Na področju umetnosti bi morali pri izvajanju dejavnosti vsi, ki jim je zaupano vzgojno delo v vrtcu, upoštevati razvojne zakonitosti otroka in značilnosti otroka na posameznih umetniških področjih, ki se pri posamezniku odražajo na individualen način. Prav bi bilo, da se v vrtčevski skupni, kjer prebijejo otroci kar nekaj ur dnevno, oblikuje bogato in raznovrstno umetniško (glasbeno, likovno, gledališko, plesno) okolje z različnimi spodbudami, ki otroku omogočajo doživljanje sebe in drugih, okolice in umetnosti. Kakovostno estetsko in umetniško okolje tudi sooblikuje otrokov razvoj estetskega vrednotenja ter osebnega okusa.

Glede na pestrost odzivov na glasbo in reagiranja otrok do tretjega leta starosti s področja petja, igranja na glasbila za otroke, poslušanja in ustvarjanja nas je $v$ naši raziskavi zanimalo področje poslušanja glasbe.

\section{Empirični del}

\section{Opredelitev problema, namen in cilji raziskave}

Danes nas, bolj kot kdajkoli prej, na vsakem koraku obdajajo zvoki in glasba različnih zvrsti. Doma si lahko sami izberemo glasbo, ki jo želimo poslušati, v 
avtu tudi; na avtobusu, $v$ trgovini, na sprehodu po mestu ... pa nam glasbo izberejo drugi. Največkrat te zvočne kulise ne poslušamo zavedno. Ob tem se nam zastavlja vprašanje, kako je s poslušanjem glasbe v vrtcu oz. kaj je značilno za glasbo $v$ ozadju v igralnicah za otroke prvega starostnega obdobja.

Z raziskavo, ki smo jo izvedli, smo želeli ugotoviti, koliko časa se otrok zadržuje ob igri v igralnicah z različno glasbo kot zvočno kuliso in kaj je za otrokovo vedenje $v$ igralnicah $z$ različno glasbo značilno. Glede na namen raziskave smo oblikovali dva cilja:

1. Opazovati in beležiti vedenja otrok v igralnici s stalno prisotnostjo namiznih iger ob glasbi kot zvočni kulisi.

2. Beležiti čas zadrževanja otrok v posamezni igralnici, kjer so se predvajale različne zvrsti glasbe.

\section{Raziskovalni vprašanji}

Na podlagi oblikovanih ciljev raziskave smo si postavili raziskovalni vprašanji:

1. Katere so značilnosti otrokovega vedenja v igralnicah z različnimi zvrstmi glasbe $v$ ozadju?

2. V katerih igralnicah z glasbo v ozadju se otroci najdlje zadržujejo?

\section{Metodologija}

V okviru kvalitativnega pristopa se lahko posvetimo posameznemu primeru (skupina, družina, razred ...), ki ga raziščemo in opišemo v obliki študije primera. Študija primera je celovit opis posameznega primera in njegova analiza, opis značilnosti in dogajanja ter opis procesa odkrivanja teh značilnosti (Mesec 1998). V naši študiji primera obravnavamo, kako so se otroci prve starostne skupine vedli v igralnicah, kjer se je predvajala različna glasba. Vzgojiteljice so merile in si zapisovale čas zadrževanja vsakega otroka v posamezni igralnici, kolikokrat so se vračali v posamezno igralnico, kaj so otroci ob poslušanju zvočne kulise počeli ter reakcije otrok ob slišani glasbi (petje pesmic, gibanje, ples z drugimi otroki ...).

Raziskavo, v kateri je sodelovalo 66 otrok prve starostne skupine, smo izvajali v petih vrtcih na Primorskem. Med otroki, ki so sodelovali v raziskavi, so bili le trije $v$ raziskavo vkljčeni otroci (4,55-odstotni delež) mlajši od enega leta. Do enega leta in pol starih otrok, sodelujočih v raziskavi, je bilo 16 ali 24,24-odstotni delež vzorca. Otrok, starih med enim letom in pol ter dvema letoma, je v raziskavi sodelovalo 18 ali 27,27-odstotni delež vzorca. 14 otrok (21,21-odstotni delež vzorca), ki so sodelovali v raziskavi, je bilo starih med 
Preglednica 2 Starost sodelujočih otrok v raziskavi

\begin{tabular}{lrr}
\hline Starost otrok & Število otrok & Delež otrok \\
\hline Do 11,5 mesecev & 3 & $4,55 \%$ \\
Od 12 do 18 mesecev & 16 & $24,24 \%$ \\
Od 18 do 24 mesecev & 18 & $27,27 \%$ \\
Od 24 do 30 mesecev & 14 & $21,21 \%$ \\
Od 30 do 36 mesecev & 15 & $22,73 \%$ \\
\hline Skupaj & 66 & $100,00 \%$ \\
\hline
\end{tabular}

dvema letoma in dvema letoma in pol. Najstarejših otrok, starih med dvema letoma in pol in tremi leti, je bilo 15 (22,73-odstotni delež vzorca).

$\checkmark$ raziskavi je sodelovalo 31 deklic ali 47-odstotni odstotni delež vzorca in 35 dečkov ali 53-odstotni delež vzorca.

\section{Potek raziskave}

Raziskavo smo izvajali v marcu 2014. Najprej smo se o njenem poteku pogovorili z vzgojiteljicami predšolskih otrok, ki so nam pomagale izvesti raziskavo, saj so otroke poznale in tako lažje zapisovale njihova opažanja ob poslušanju izbrane glasbe in prosti igri.

Pripravili smo soglasja za starše oz. skrbnike otrok. V raziskavi so sodelovali vsi otroci, za katere smo prejeli podpisana soglasja. Vsi podatki, ki smo jih z raziskavo pridobili, so tajni in uporabljeni zgolj v raziskovalne namene.

$\mathrm{V}$ raziskavi je sodelovalo 66 otrok prve starostne skupine. Otroci so se v dopoldanskem času, po dopoldanski malici, 20 minut ob poljubni igri lahko prosto gibali med tremi različnimi igralnicami, med katerimi so imeli prost prehod. Igralnice so bile zvočno izolirane. $V$ vsaki igralnici se je predvajala glasba in so bile na mizicah enake namizne igre, s čimer smo želeli zadostiti pogoju, da bi se otroci iz igralnice v igralnico sprehajali zaradi všečnosti predvajane glasbe, in ne namiznih iger.

V prvi igralnici smo predvajali izbrane aktualne popevke, ki jih trenutno poslušamo po radijskih postajah. Popularna glasba, katere besedila navadno otroci niti ne razumejo, lahko vključuje elemente rocka, hip hopa, reggaeja, plesne glasbe, jazza, elektronske glasbe in drugih zvrsti. Ker si popularna glasba predvsem prizadeva biti priljubljena množicam in posledično dobro prodajan tržni predmet, je po našem mnenju vsebinsko nezahtevna, večinoma neizvirna ter šablonsko oblikovana. Ritmični, harmonski in melodični vzorci popevk so večinoma preprosti, besedila pogosto obravnavajo ljubezensko tematiko, ki otrokom niti ni blizu, njihova kitična zgradba največkrat vsebuje tudi refren. 
V drugi igralnici smo predvajali posnetke klasične glasbe - izbrane skladbe z zgoščenke Mozart in Motion (Campbell 1983), ki vsebuje odlomke Mozartovih skladb. Skladbe smo izbrali zato, ker so različne študije pokazale, da ima Mozartova glasba pozitiven vpliv na intelektualni in ustvarjalni razvoj otroka (Campbell 2004).

$V$ tretji igralnici so otroci lahko poslušali otroške pesmice $z$ instrumentalno spremljavo in brez nje, ki jih poje Otroški pevski zbor RTVS. Izbrali smo otroške pesmi Janeza Bitenca. Otroci so poslušali skladbe, posnete na prvi zgoščenki Mavrica (Bitenc 2008). Te pesmice smo izbrali, saj smo mnenja, da je avtor besedil in skladatelj znal poiskati idealno sozvočje med besedo in melodijo. Iz besedil pesmic lahko vidimo, da je avtor izhajal predvsem iz bogastva otroškega doživljanja in to domišljijo, nežnost in lepoto znal prenesti v glasbeno sporočilo, ki se nas vedno dotakne. Preproste Bitenčeve melodije upoštevajo tudi obseg otroškega glasu.

Vse tri igralnice je bile preprosto opremljene $z$ nekaj omarami ob steni ter $s$ štirimi mizami na sredini, na katerih so bile zložene namizne igre: puzzle, vstavljanke, nizanke, kocke, kocke za razvrščanje, urejanje, vstavljanje, nizanje. Iger je bilo v igralnici dovolj za vse otroke, ki so se hkrati sprehajali iz igralnice $v$ igralnico in se igrali ob zvočni kulisi.

Vzgojiteljice so za vsakega otroka merile in si zapisovale čas njegovega zadrževanja $v$ posamezni igralnici, kjer se je predvajala različna glasba. Zapisovale so si, kolikokrat so se otroci vračali v posamezno igralnico, kašne so bile njihove reakcije ob slišani glasbi (petje pesmic, gibanje, ples $z$ drugimi otroki ...) ter kaj so ob poslušanju zvočne kulise počeli.

\section{Rezultati in interpretacija}

Otroci so se 20 minut sprehajali iz ene igralnice $v$ drugo in se ob igrah na mizi in v različnih kotičkih različne igre igrali sami, v dvojicah ali največ $v$ skupini po tri. Na mizah so imeli v vseh treh igralnicah enake otroške namizne igre. Otrokom smo pred pričetkom raziskave povedali, da se lahko prosto sprehajajo po igralnicah. Preden smo začeli predvajati glasbo, smo si z otroki ogledali vse igre v vseh igralnicah in jim razložili pravila pri posameznih igrah.

\section{Otrokovo vedenje ob zvočni kulisi v posamezni igralnici ter sodelovanje $z$ drugimi}

Otroci so bili najprej v igralnici, kjer se je poslušalo aktualne popevke, torej glasbo, ki jo lahko slišijo vsak dan na različnih radijskih postajah. $V$ tej igralnici so bili zelo razigrani, glasni in pri igrah je prišlo do kreganja in izločevanja. Nekateri otroci so bili agresivni do drugih in so jemali igrače drugim otrokom 
iz rok. Otroci so se ob poslušanju te glasbe gibali z intenzivnimi in veliki gibi. Ko so se v glasbi ponavljali zvočni vzorci, so otroci to prikazali s ponovljenimi gibalnimi vzorci. Podobno ugotavlja tudi Borota (2013). M. Videmšek in Pišot (2007) govorita o ustvarjalnem gibu, s katerim otrok izrazi doživetja ob glasbi, spremlja glasbeni potek ali z njim vizualizira glasbene predstave o elementih glasbe (krajši, daljši, višji in nižji toni, hitro, počasi ter glasno in tiho).

Otroci v drugi igralnici, kjer so poslušali klasično glasbo, so se ob vstopu $v$ prostor zelo umirili. $V$ največjih primerih so se mirno usedli za mizo k prostim igračam in se igrali samostojno. Ob glasbi so se vidno umirjeno gibali. Nekateri so od igre vstali in po igralnici zaplesali. Opazili smo, da so se otroci, ko so bili v skladbi slišati nizki toni, gibali predvsem z oponašanjem gibanja baletk z nogami. Visoke tonske lege in slišane svetle barve zvoka violine pa so pri otrocih spodbudili gibanje $z$ rokami. Podobno ugotavlja tudi Borota (2013), ki je opazila nekatere ustaljene vzorce gibanja v povezavi z njihovim doživljanjem glasbe.

Otroci v tretji igralnici so bili ob različnih skladbah z instrumentalno spremljavo ali brez nje pri igri zelo sproščeni in razigrani. Ne moremo sicer trditi, da so otroci pesmi poznali, saj on njih niso vsi prepevali, so se pa ob glasbi gibali in si pripevali na nevtralne zloge. Nekaj deklic je tudi zaplesalo v paru. Zelo nazorno so ob plesu prikazali tudi čustva, ki jih je v njih spodbudilo poslušanje te glasbe. Ob plesu so $z$ dvignjenimi rokami nad glavo in z obrazno mimiko pokazali občutek veselja in zadovoljstva. Otroci so se ob namiznih igrah mirno pogovarjali in se pri igri pridruževali drugim otrokom - največ $v$ dvojicah, nekaj otrok se je igralo tudi v skupini po tri. M. Zagorc (1997) ugotavlja, da otroci veliko bolj izražajo svoje duševno počutje s telesnim izražanjem kot odrasli. Trdi, da imata gibanje in čustvovanje veliko skupnega, saj se vsa čustva kažejo v ekspresivni govorici telesa. Predvsem otroci in mladostniki najdejo posebno zadovoljstvo v plesu, »kajti mnogi med njimi odkrijejo $\checkmark$ njem pot za osvoboditev svojih čustev in občutij, ki bi jih s pomočjo besed težko izrazili« (Zagorc 1997, 18). Nadalje ugotavlja, da plesno gibanje izjemno prispeva k samozavedanju, občutenju uspeha in zadovoljstva, saj omogoča oblikovanje ustrezne telesne slike in vliva samozadovoljstvo, vpliva na vedenje, odnos do drugih in oblikovanje stališč (Zagorc 1997, 18).

Tudi A. Pesek (1997) ugotavlja, da otroci z gibanjem izražajo različne glasbene značilnosti, kot so razpoloženja $v$ glasbi (veselo - žalostno), tempo in spremembe tempa s spreminjanjem hitrosti gibanja, dinamiko ter dinamične spremembe $z$ različno količino energije $v$ gibih, s hojo po prstih pri tihi glasbi ter stopanjem po celem podplatu pri glasni, tonsko višino $z$ gibanjem v visokih položajih pri visokih tonih in nizkih položajih pri nizkih tonih, ritem z 
Preglednica 3 Povprečne vrednosti in delež časa, preživetega v posamezni igralnici

\begin{tabular}{lrr}
\hline Igralnica z glasbo ... & Povprečen čas & Delež časa \\
\hline Aktualne popevke & 4,60 minute & $23,0 \%$ \\
Klasična glasba (Campbell 1983) & 7,08 minute & $35,4 \%$ \\
Otroške pesmice (Bitenc 2008) & 8,32 minute & $41,6 \%$ \\
\hline Skupaj & 20,00 minut & $100,0 \%$ \\
\hline
\end{tabular}

zadrževanjem gibov pri dolgih tonih in s kratkimi, odsekanimi potezami pri kratkih tonih, akcent $z$ uporabo poudarjenih gibov, dobo s stalnim gibanjem na glasbeni pulz, repeticijo in kontrast s ponavljanjem ali spreminjanjem določenih telesnih gibov ter katerekoli spremembe $v$ glasbi s spreminjanjem sloga, smeri ali stopnje intenzivnosti gibanja.

\section{Čas, preživet $v$ posameznih igralnicah, in prehajanje med igralnicami}

V spodnji preglednici so predstavljene povprečne vrednosti časa, ki so ga otroci preživeli v posamezni igralnici. Vzgojiteljice so si za vsakega otroka zapisovale čas, ki ga je preživel v posamezni igralnic; izračunali smo povprečne vrednosti (preglednica 3).

V prvi igralnici, kjer so lahko otroci poslušali aktualne popevke, so se zadrževali v povprečju najmanj časa: 4,60 minute ali $23 \%$ časa, ki so ga imeli na razpolago za prosto igro. Največ časa, v povprečju za 15 sekund dlje, so se $v$ tej skupini zadrževali najstarejši otroci, torej otroci, stari med dvema letoma in pol ter tremi leti. Predvidevamo, da se pri teh otrocih lahko že občuti vpliv vsakodnevnih glasbenih sporedov radia, televizije in poslušanja glasbe njihovih staršev, starejših sorojencev. Skoraj vsi otroci, ki so to igralnico zapustili in se šli igrat $z$ igračami $v$ drugih dveh igralnicah, se $v$ to skupino niso vrnili, z izjemo dveh najstarejših dečkov, ki se tja nista vrnila hkrati.

$V$ drugi igralnici so otroci preživeli v povprečju 7,08 minute ali 35,4\% časa, ki so ga imeli na razpolago za prosto igro. $V$ to igralnico so se otroci, ko so skupino zapustili, še vračali - v glavnem iz igralnice s predvajano otroško glasbo in nazaj.

Otroci, so se ob igri v povprečju največ časa zadrževali v igralnici, kjer so lahko poslušali otroške pesmice Janeza Bitenca. $V$ tej igralnici so preživeli $v$ povprečju 8,32 minute ali $41,6 \%$ časa, ki so ga imeli na razpolago za prosto igro.

Otroci so bili najprej v igralnici, kjer so se izvajale aktualne popevke. Po določenem času so odšli v drugo ali tretjo igralnico. Iz igralnice, kjer smo predvajali otroške pesmice, so se otroci vrnili še v igralnico, kjer so lahko slišali 
klasično glasbo. $V$ igralnico s popevkami pa sta se vrnila samo dva najstarejša dečka (3,03-odstotni delež vzorca). Ko so otroci enkrat prišli v igralnico $s$ predvajanimi otroškimi pesmicami, $v$ večini te niso več zapustili. $V$ igralnico $s$ klasično glasbo je iz igralnice $z$ otroškimi pesmicami ponovno šlo le sedem otrok ali 10,61-odstotni delež vzorca.

\section{Sklepne ugotovitve}

V študiji primera, ki smo jo izvedli v marcu 2014, nas je zanimalo, kako so se otroci prve starostne skupine vedli v igralnicah, kjer se je predvajala različna glasba. Vzgojiteljice otrok so merile in si zapisovale čas zadrževanja vsakega otroka v posamezni igralnici, kolikokrat so se v posamezno igralnico vrnili in kaj so ob poslušanju zvočne kulise počeli. Zapisovale so si tudi reakcije otrok ob slišani glasbi (petje pesmic, gibanje, ples z drugimi otroki ...). Otroci, ki so sodelovali v raziskavi, so večino, kar $41,60 \%$ časa, ki so ga imeli na razpolago ob prosti igri, preživeli v igralnici, kjer so se vrtele umetne otroške pesmice. Ob tej glasbi so se otroci mirno igrali in se $v$ igri povezovali tudi $z$ drugimi otroci. Predvidevamo, da so se $v$ tej igralnici zadrževali ravno zaradi tega, ker so glasbo razumeli, jo podoživeli, se z njo poistovetili in jo ponotranjili. Menimo, da so bili otrokom bližja predvsem preprostost melodije, ritma in harmonije ter besedila, ko so jih razumeli.

Nekomercialno umetno glasbo običajno poimenujemo klasična glasba, ne glede na čas, v katerem je nastala. Poslušanje klasične glasbe pa v primerjavi s komercialno zahteva mir, čas, zbranost, usmerjeno pozornost, ustvarjalnost, razvite glasbene sposobnosti in znanje. Tudi otroci so se, ko so vstopili v igralnico, kjer se je vrtela klasična glasba, umirili in mirno igrali z igračo, ki so si jo izbrali. V povprečju so se $v$ tej igralnici zadrževali $35,40 \%$ časa, ki so ga imeli namenjenega prosti igri ob zvočni kulisi. $V$ tej igralnici se otroci $v$ igri niso povezovali v dvojice, so se pa tisti, ki so igralnico zapustili, vanjo še vrnili.

Pojem komercialna glasba združuje vse zvrsti umetne glasbe, od narodno zabavne do popa in drugih zvrsti, ki jih ponuja komercialna glasbena industrija, ta vrsta glasbe pa je namenjena predvsem sproščanju, zabavi in ustvarjanju različnih razpoloženj. Njen namen je, da deluje na poslušalca predvsem $z$ všečnimi, ponavljajočimi se glasbenimi motivi v minimalnem glasovnem obsegu. V igralnici, kjer so se vrtele aktualne popevke, take, ki jih otroci slišijo po radijskih in televizijskih sprejemnikih, so se zadrževali najmanj, le 23,00\% časa, ki so ga imeli na razpolago za prosto igro. Ob taki glasbi, ki je niti ne razumejo, so postali agresivni in $v$ nekaj primerih je morala $v$ kreganje za isto igračo poseči tudi vzgojiteljica. $Z$ izjemo dveh najstarejših dečkov se $v$ to igralnico, ko so jo zapustili, ni vrnil nihče več. 
Umetniške dejavnosti, tudi poslušanje glasbe, so pomemben in spodbuden del učenja tudi na drugih področjih. Zato se moramo tisti, ki otrokom glasbene dejavnosti izbiramo, zavedati, da vse, kar je dobro za odrasle, ni vedno dobro tudi za otroke.

\section{Zahvala}

Rada bi se zahvalila dr. Mirku Slosarju za usmerjanje, napotke, zaupanje in pomoč, ne samo pri nastajanju tega članka, ampak pri moji rasti od pisanja diplomskega dela naprej. Zato ta članek posvečam njemu.

\section{Literatura}

Bitenc, J. (2008). Mavrica: 100 najlepših otroških pesmic. CD. Ljubljana: RTV Slovenija.

Benkovič, B. 2011. »Socialni in čustven razvoj predšolskega otroka.« V Socialni in čustveni razvoj predšolskega otroka: 4. mednarodna strokovna konferenca vzgojiteljev v vrtcih, ur. M. Željeznov Seničar in E. Šelih, 7-14. Ljubljana: MiB

Borota, B. 2013. Glasbene dejavnosti in vsebine. Koper: Annales.

Campbell, D. G. (1983). The Mozart Effect: Music for children. Zv. 3, Mozart in Motion. CD. B. k.: Magnamusic Baton.

Campbell, D. G. 2004. Mozart za otroke: prebujanje otrokove ustvarjalnosti in mišljenja s pomočjo glasbe. Ljubljana: Tangram.

Clinic, M. 2001. Vse o nosečnosti in otrokovem prvem letu. Ljubljana: Educy.

Denac, O. 2002. Glasba pri celostnem razvoju otrokove osebnosti: priročnik za vzgojitelje, razredne učitelje, učitelje glasbe in glasbenih predmetov $v$ splošnem šolstvu in glasbenih šolah. Ljubljana: Zavod Republike Slovenije za šolstvo.

Gallahue, D. L., in J. C. Ozmun. 2006. »Motor Development in Early Childhood Education." V Handbook of Research on the Education of Young Children, ur. B. Spodek in O. Saracho, 105-120. Mahwah, NJ: Lawrence Erlbaum.

Hargreaves, D. (1990). The Developement Psychology of Music. Cambridge: Cambridge University Press.

Kožman, P. 2011. »Spoznavanje čustev v oddelku eno do dvoletnih in v oddelku dve do triletnih otrok. « V Socialni in čustveni razvoj predšolskega otroka: 4. mednarodna strokovna konferenca vzgojiteljev $v$ vrtcih, ur. M. Željeznov Seničar, M. in E. Šelih, 144-150. Ljubljana: MiB.

Kranjc, M. 2011. „Socialni in čustveni razvoj predšolskega otroka v starostno kombiniranih skupinah." V Socialni in čustveni razvoj predšolskega otroka: 4. mednarodna strokovna konferenca vzgojiteljev $v$ vrtcih, ur. M. Željeznov Seničar, M. in E. Šelih, 151-158. Ljubljana: MiB.

Ministrstvo za šolstvo in šport. 1999. Kurikulum za vrtce: predšolska vzgoja v vrtcih. Ljubljana: Ministrstvo za šolstvo in šport.

Lundin, R. W. 1967. An Objective Psychology of Music. New York: Ronald. 
Marjanovič Umek, L., in M. Zupančič. 2009. Razvojna psihologija: izbrane teme. Ljubljana: Znanstvena založba Filozofske fakultete Univerze v Ljubljani.

McKernon, P. E. 1979. »The Development of First Songs in Young Children. « New Directions for Child and Adolescent Development, št. 3: 43-58.

Mesec, B. 1998. Uvod v kvalitativno raziskovanje $v$ socialnem delu. Ljubljana: Visoka šola za socialno delo.

Moog, H. 1976. »The Development of Musical Experience in Children of PreSchool Age.« Psychology of Music 4 (2): 38-45.

Ostwald, P. F. 1973. »Musical Behavior in Early Childhood." Developmental Medicine \& Child Neurology 15 (3): 367-375.

Piaget, J. 1952. The Origins of Intelligence in Children. New York: International Universities Press.

Pesek, A. 1997. Otroci v svetu glasbe: izbrana poglavja iz glasbene psihologije in pedagogike. Ljubljana: Založba mladinska knjiga.

Revesz, G. 1954. Introduction to the Psychology of Music. Norman, OK: University of Oklahoma Press.

Shuter-Dyson, R., in C. Gabriel. (1981). The Psychology of Musical Ability. London: Methuen.

Sicherl Kafol, B. 2001. Celostna glasbena vzgoja. Ljubljana: Debora.

Slosar, M. 1995. »Dejavniki uspešnosti razrednih učiteljev pri glasbeni vzgoji na razredni stopnji osnovne šole.« Doktorska disertacija, Univerza v Ljubljani.

Smolej, B. 1996. »Razvoj glasbenih sposobnosti.« Psihološka obzorja 5 (1): 77-88.

Starc, B., in M. Markočić. 2004. Osobine i psihološki uvjeti razvoja djeteta predškolske dobi: priručnikza odgojitelje, roditelje i sve koji odgajaju djecu predškolske dobi. Zagreb: Golden marketing.

Šivic, P. 1975. »K zbirki Pojem - plešem. « Grlica, revija za glasbeno vzgojo 18 (1-2): 1-2.

Videmšek, M., P. Berdajs in D. Karpljuk. 2003. Mali športnik. Ljubljana: Fakulteta za šport.

Videmšek, M., in R. Pišot. 2007. Šport za najmlajše. Ljubljana: Fakulteta za šport Wing, H. D. 1961. Standardized Test of Musical Intelligence. Upton Park: Taylor \& Francis.

Zagorc, M. 1997. »Ples - ustvarjanje z gibom.« Ljubljana: Fakulteta za šport.

\section{Typical Behaviour of the Children of First Age Group in Playrooms with Different Music Genres}

Today, music as a psychological phenomenon in everyday life is widespread and accessible to everyone as never before. We can listen to music in the car, through our smartphones on the headphones, through radio or television sets ... We can choose the music we listen to ourselves. Can children of the first age group in kindergarten choose it for themselves? In kindergarten mu- 
sic is chosen by nursery teachers. We expect them to have developed musical abilities and skills, musical creativity and possess knowledge, namely, all those musical abilities that are important for a child's successful musical development. Which playrooms with different music genres children chose by themselves to stay for longest amount of time was determined by a study that took place in five kindergartens in the Primorska Region of Slovenia. The study included 66 children of the first age group. We offered the children to choose three music genres. In three playrooms, where we played the music, various table games were available to children. We concluded that children preferred staying in the playroom where nursery rhymes were played.

Keywords: children's integrated development in the first age group, children's musical development in the first age group, musical art in kindergartens, listening to music, musical culture 


\title{
Stališča do pomena uspavanke $v$ zgodnjem otroštvu nekoč in danes
}

\author{
Bogdana Borota \\ Univerza na Primorskem \\ bogdana.borota@pef.upr.si \\ Bojana Kralj \\ Univerza na Primorskem \\ bojana.kralj@pef.upr.si
}

Uspavanka je neločljivo povezana z otroštvom nekoč in danes. Z etnomuzikološke perspektive predstavlja eno najstarejših oblik otroške ljudske pesmi. V novejših raziskavah se njen pomen odkriva v povezavi z inkulturalizacijo, obdobjem, ko se dojenček in malček navajata na zvoke in glasbo iz okolja. Ker je poslušanje petja (uspavanke) ena prvih izkušenj otroka z glasbo, so pomembna stališča odraslih do obravnavane tematike. $S$ tem namenom smo v raziskavo vključili vzgojiteljice in študentke, ki se izobražujejo za poklic vzgojiteljice. Zanimalo nas je, kakšna stališča imajo do uspavanke kot dela kulturne dediščine in kakšen pomen ji pripisujejo za otrokov zgodnji glasbeni razvoj. Rezultati kažejo, da imajo anketiranke pozitivna stališča do pomena uspavank za otrokov zgodnji glasbeni razvoj. Zelo se strinjajo, da so uspavanke živo izročilo, ki ga je treba ohranjati in negovati za prihodnje rodove, še posebej v današnjem času, ko so starši preobremenjeni in je okolje nasičeno s tehnologijo. Strinjajo se, da so danes uspavanke za otroka pomembna glasbena izkušnja, v kateri se vzpostavlja (glasbena) komunikacija med otrokom in odraslim. Ker se uspavanke pogosteje pojejo doma kot v vrtcu, se nakazujejo možnosti za tesnejše sodelovanje vzgojiteljic s starši pri vzpostavljanju glasbeno bogatega, varnega in zaupljivega učnega okolja v vrtcu.

Ključne besede: glasbena kulturna dediščina, glasbeni razvoj do 3. leta, uspavanka, stališča vzgojiteljic do uspavanke

\section{Uvod}

V prispevku obravnavamo uspavanko kot pesem, ki se poje. Zanima nas ljudska uspavanka, ki jo po navadi pojemo otroku pred spanjem ali v situacijah, ko ga želimo potolažiti in umiriti. Pri tem izhajamo iz stališča, da je uspavanka neločljivi del otroštva nekoč in danes, še posebej v obdobju dojenčka in malčka. ${ }^{1} \vee$ ta namen $v$ teoretičnem delu analiziramo bistvene značilnosti

\footnotetext{
${ }^{1} \mathrm{~V}$ razvojni psihologiji se otroka $v$ prvem letu starosti imenuje dojenček, $v$ drugem in tretjem
} pa malček. Ko v prispevku govorimo o otroku do tretjega leta oziroma šestega leta starosti,

Čotar Konrad, S., B. Borota, S. Rutar, K. Drljić in G. Jelovčan, ur. 2022. Vzgoja in izobraževanje predšolskih otrok prvega starostnega obdobja. Koper: Založba Univerze na Primorskem. 
uspavanke pa tudi njen pomen za otrokov celostni in glasbeni razvoj. Ker se uspavanka poje otroku $v$ različnih okoljih, so nas $v$ raziskavi zanimala stališča in izkušnje vzgojiteljic in študentk, bodočih vzgojiteljic, tudi o prisotnosti uspavanke $v$ domačem in vrtčevskem okolju.

\section{Uspavanka kot del slovenske kulturne dediščine}

Glasbena kulturna dediščina vključuje ljudske pesmi, ljudske plese, ljudska glasbila in godce (Kumer 1983; Kunaver 1984). Je sestavni del slovenske kulturne dediščine. Njen glasbeni del preučujejo etnomuzikologi pa tudi folkloristi. Ena pomembnejših etnomuzikologinj in folkloristk pri nas je Zmaga Kumer (1927-2008). Na osnovi etnografskega dokumentacijskega gradiva, zbranega na terenu, je opredelila področja glasbene kulturne dediščine in jih podrobno analizirala v sociokulturnem kontekstu njihovega nastajanja in ohranjanja skozi živo izročilo. Zanimale so jo predvsem povezave kulturne dediščine z življenjem in delom človeka. Na njeno teorijo se opiramo, ko obravnavamo vlogo uspavanke $v$ življenju otroka in odraslega ter analiziramo njene oblikovne značilnosti.

Osrednji del glasbene kulturne dediščine so ljudske pesmi, ki so še danes del narodove kulturne dediščine (Kumer 2002). V naši zavesti jih ohranjamo kot pesmi, ki se pojejo (Terseglav 1984). Njihov nastanek je tesno povezan z vsakdanjim življenjem, delom, s praznovanji, z običaji in obredi (Omerzel Terlep 1984). Pravimo, da je ljudska pesem človekova spremljevalka od rojstva do smrti (Kunaver 1987; Klemenčič 2008). Z. Kumer (1996) jih obravnava kot pesmi življenjskega kroga. S študijo ljudske glasbene zapuščine je opredelila njihove značilnosti (Kumer 2002 v Borota 2015, 23):

- ljudsko pesem z melodijo se vedno poje, med besedilom in melodijo je neločljiva povezanost;

- po vsebini, jeziku, čustvovanju, razmišljanju ustreza narodu, iz katerega je izšla; ${ }^{2}$

- zaradi skladnosti verznega in glasbenega ritma isto besedilo pojemo na različne melodije oz. isto melodijo uporabimo za vsebinsko različna besedila;

uporabljamo izraz otrok. Ko želimo poudariti značilnosti v prvem letu življenja, uporabimo izraz dojenček, $v$ drugem in tretjem letu pa malček. Izraz zgodnje otroštvo pa uporabimo, ko obravnavamo značilnosti otroka do šestega leta starosti.

${ }^{2}$ Današnjemu otroku je oddaljena prav zaradi povezave z življenjem nekoč. V besedilu ljudskih pesmi je veliko narečnih besed in poimenovanj, ki jih danes redkeje uporabljamo. Priporočamo, da otroško ljudsko pesem, če je le-ta vključena v vzgojno-izobraževalni proces, poučujemo v kontekstu običajev oz. dogodkov iz preteklosti. 
- ljudska pesem nima inštrumentalne spremljave in je navadno večglasna, enoglasne pesmi niso solistične, pojejo se v skupini.

Med ljudske pesmi življenjskega kroga uvrščamo tudi otroške ljudske pesmi. To so tiste pesmi, ki so jih ustvarili in peli otroci, najpogosteje med igro. Terseglav v spremni besedi v knjigi Slovenske ljudske pesmi 1 (Terseglav in Čater 2004,5$)$ opozarja na posebnosti uvrščanja ljudske pesmi med otroške, ko ugotavlja, da velik del otroških pesmi, kot jih pojmujemo danes, ne nastane med otroki, ampak jih ustvarjajo odrasli, ki pesmi tudi prenašajo na otroke. ${ }^{3}$ Ob nastanku so te pesmi imele drugačno funkcijo in namen. ${ }^{4}$ Te opise najdemo v zbirki Štrekljevih slovenskih ljudskih pesmi in v dveh knjigah Nika Kureta Praznično leto Slovencev.

Večina zbiralcev glasbene kulturne dediščine uspavanko uvršča med otroško ljudsko pesem (Štrekelj 1980; Kumer 1975; Merkú 1976). ${ }^{5}$ Pri tem je zanimivo, da folkloristi uspavanko imenujejo zazibalka oziroma zazibavka, ker jo povezujejo z gibanjem. Ob petju mati zaziba otroka v sen (Stanonik 1999). Prvi zapisi o zazibalki na Slovenskem segajo v leto $1620 .{ }^{6}$ Zato ni naključje, da etnomuzikologi uspavanko opredeljujejo kot eno najstarejših oblik otroške ljudske pesmi (Kumer 1983).

\section{Oblikovne značilnosti uspavanke in njen pomen}

Ljudska uspavanka nastaja in se ohranja neodvisno od umetne pesmi. Ravna se po lastnih zakonitostih. Njene oblikovne značilnosti prepoznavamo po vsebini, refrenu in melodiji. Zanjo so značilni ponavljajoči se motivi in tipični refren. Besedilo je napisano v verzih. Lahko gre tudi za izštevanko ali krajši opis dogodka. V starejših uspavankah je pogost motiv angela varuha, ki otroka varuje in zaziba v spanec. Pogosto nastaja sproti, iz pragmatičnega razloga, ko želimo otroka uspavati, umiriti, potolažiti ali mu dati občutek sprejetosti in varnosti.

\footnotetext{
${ }^{3}$ Primerjaj uvod k pesmarici Slovenske ljudske pesmi (Terseglav in Čater 2004).

${ }^{4}$ Tak zgovoren primer so ljudske pesmi Marko skače, Čuk se je oženil, Abraham 'ma sedem sinov, ki so danes vključene $v$ skoraj vsak pevski repertoar $v$ vrtcu. Te pesmi so odrasli peli na svatbah.

${ }^{5}$ Merhar (1956) uspavanke ločuje od otroških pesmi, kar utemeljuje z dejstvom, da je v uspavankah otrok predmet pesmi, pri otroških ljudskih pesmi pa nosilec izvedbe pesmi.

${ }^{6}$ Zazibalke so bile omenjene v jezuitski kroniki v Ljubljani. Zapis je bil del opisa božičnih kolednic. Koledniki so prevzeli gibalni element zibanja iz cerkvenega obreda zibanja Jezusa. Ob zibanju so otroku peli in z lesenimi palicami, na katerih so bili pritrjeni viseči kovinski obročki ali zvončki, udarjali ob tla. Enakomeren ritem cingljanja in petja je podpiral enakomerno zibanje otroka (Kuret 1986).
} 
Prepoznavni element uspavanke je refren. Sestavljen je iz besednih zvez aja-aja, aja-tutaja, nina-nana, nine-nane, tana-nine ali huha-ha, ki dajejo uspavanki značilen zven. Melodija, ki je po večini malotonska ali povzeta po motivih otroške pesmi, je grajena na ponavljajočem se motivu. Tovrstna gradnja melodije omogoča, da tisti, ki otroka uspava, besedilo sproti improvizira in glede na situacijo dolžino pesmi skrajša ali podaljša. Ritem izhaja iz besednega ritma. Cvetko (2005) meni, da glasbeni ritem otroku daje občutek strukture sveta, melodija pa občutek oblike sveta.

Uspavanke pojemo tiho, počasi in vezano. Če pojemo otroku v naročju, petje združujemo z enakomernim zibanjem. Gibalne spodbude ob petju otroku pomagajo razviti sposobnost občutenja enakomernega glasbenega utripa (Trebuh 2006), ki je osnova za nadaljnji razvoj ritmičnih sposobnosti (Sloboda 2007).

Zanimivo je, da Hargraves (2001) primarno kulturno okolje opredeljuje prav z okoljem, v katerem otroka obkrožajo uspavanke, rajalne pesmi in ljudska glasba, ki temeljijo na skupnih glasbenih izhodiščih, kot so zmeren tempo, ponavljajoči se melodika, tonalni vzorci in harmonija (Dowling 1982 v Hargreaves 2001) ugotavlja, da je razvoj tonalnega občutenja povezan z zaznavanjem teh značilnih glasbenih vzorcev iz okolja.

Uspavanka je del bogatega glasbenega okolja, ki je za otroka do tretjega oziroma šestega leta ključnega pomena za razvoj avdiacije - oblike glasbenega mišljenja, ki omogoča razmišljanje, poustvarjanje in ustvarjanje $v$ glasbenem jeziku (Gordon 1997). Ti procesi se odvijajo v obdobju, ko je otrok še neobremenjen z glasbenim okusom in odprt za sprejemanje raznovrstne glasbe iz različnih kulturnih okolij (Gordon 1997; Trebuh 2006).

Uspavanka je eden prvih stikov otroka z glasbo in glasom odraslega (Trebuh 2004; Cvetko 2005; Juvančič 2009). Petje odraslega otroku omogoča, da usmeri pozornost na odraslo osebo in z njo vzpostavi čustveno komunikacijo, ki spodbudno vpliva na pomnjenje in učenje glasbenih vzorcev (Trainer 1996 v Verdelj 2006). Tako se med odraslim in otrokom vzpostavita posebno intimno glasbeno doživetje in glasbena komunikacija, $v$ kateri otrok pridobiva glasbene izkušnje, odrasli pa dobi priložnost za izražanje čustev (Trebuh 2006).

Ugotavljamo, da je uspavanka kot oblika otroške ljudske pesmi pomemben del glasbene kulturne dediščine, petje uspavanke pa spodbudno vpliva na otrokov celostni in glasbeni razvoj; ob tem nas preseneča dejstvo, da se iz glasbene ustvarjalnosti za otroke vedno bolj izgublja (Terseglav 2006). Z našo raziskavo smo želeli spodbuditi strokovno javnost, da temu izzivu nameni več pozornosti. 


\section{Raziskava o stališčih vzgojiteljic in študentk, bodočih vzgojiteljic, do uspavanke}

Petje je naravna oblika (glasbene) komunikacije, ki v odnosu med materjo in otrokom prerašča v intimno doživetje. Matere pogosto pojejo otrokom, da jih potolažijo, umirijo in pospremijo k spanju (Trebuh 2004). Uspavanka je za dojenčka tako rekoč prvi stik z živo glasbo. Ta povezava je še posebej pomembna $v$ obdobju inkulturalizacije, ki traja do drugega oziroma četrtega leta, ko se otrok navaja na zvoke in glasbo iz okolja (Gordon 1997), po drugi strani pa ugotavljamo, da se iz glasbene ustvarjalnosti izgublja (Terseglav 2006). To potrjuje tudi 10-letna longitudinalna študija o pevskem repertoarju v slovenskih vrtcih: med prvimi desetimi najpogosteje petimi pesmimi v skupini otrok prvega starostnega obdobja ni uspavank (Borota 2010).

$\checkmark$ raziskavi smo želeli ugotoviti, kakšno stališče imajo vzgojiteljice in študentke - bodoče vzgojiteljice do uspavanke kot dela kulturne dediščine in kakšno stališče imajo do pomena uspavank za otrokov celostni in glasbeni razvoj. Pri tem nas je zanimalo, kdo otroku najpogosteje poje uspavanke in katere so značilnosti petja uspavank v domačem in vrtčevskem okolju.

\section{Metodologija}

$\checkmark$ raziskavi smo uporabili deskriptivno in kavzalno-neeksperimentalno metodo pedagoškega raziskovanja. Podatke smo zbirali s spletnim vprašalnikom v januarju 2019. Vprašalnik je bil poslan na skupne elektronske naslove študentov in diplomantov visokošolskega študijskega programa prve stopnje Predšolska vzgoja na Pedagoški fakulteti Univerze na Primorskem, ki so V študijskih letih 2017/18 in 2018/19 obiskovali 3. letnik študija. Zabeleženih je bilo 155 klikov na anketo, od tega je bilo veljavnih 99 vprašalnikov $(63,8 \%$ vseh evidentiranih), kar predstavlja tudi število sodelujočih $v$ raziskavi. $\mathrm{Na}$ vprašanje o statusu anketirank je bilo možnih več odgovorov. Večina so bili študenti (77; $77,8 \%)$, slaba tretjina se je opredelila kot zaposleni v vrtcu (29; $29,3 \%$ ), nekaj tudi kot starši, brezposelni ali zaposleni drugje.

Vprašalnik smo oblikovali glede na namen naše raziskave. Zanesljivost smo preverjali z metodo notranje konsistentnosti. Cronbachov koeficient $\alpha$ je pokazal sprejemljivo stopnjo zanesljivosti $(\alpha=0,579)$ za sklop vprašanj o uspavanki kot kulturni dediščini ter dobro stopnjo zanesljivosti $(\alpha=0,772)$ za sklop vprašanj o pomenu uspavanke za otrokov razvoj. Objektivnost smo zagotovili z uporabo pretežno zaprtih vprašanj ter petstopenjske številčne ocenjevalne lestvice. Podatke smo obdelali na ravni opisne in inferenčne statistike. Za ugotavljanje razlik in povezanosti med domačim in vrtčevskim okoljem smo uporabili $t$-preizkus za odvisne vzorce. 
Preglednica 1 Stališča anketirank do uspavanke kot kulturne dediščine in tradicije

\begin{tabular}{|c|c|c|c|c|c|c|c|c|c|}
\hline \multirow[t]{2}{*}{ Trditev } & & \multicolumn{5}{|c|}{ Ocena strinjanja } & \multirow[t]{2}{*}{$N$} & \multirow[t]{2}{*}{$M$} & \multirow[t]{2}{*}{$S D$} \\
\hline & & (1) & (2) & (3) & (4) & (5) & & & \\
\hline \multirow{2}{*}{$\begin{array}{l}\text { Uspavanke so pomemben del } \\
\text { kulturne dediščine. }\end{array}$} & $f$ & 0 & 0 & 2 & 33 & 64 & \multirow[t]{2}{*}{99} & \multirow[t]{2}{*}{4,63} & \multirow[t]{2}{*}{0,527} \\
\hline & $\%$ & 0,0 & 0,0 & 2,0 & 33,3 & 64,6 & & & \\
\hline \multirow{2}{*}{$\begin{array}{l}\text { Uspavanke poznajo povsod po } \\
\text { svetu. }\end{array}$} & $f$ & 0 & 2 & 9 & 50 & 37 & \multirow[t]{2}{*}{98} & \multirow[t]{2}{*}{4,24} & \multirow[t]{2}{*}{0,704} \\
\hline & $\%$ & 0,0 & 2,0 & 9,2 & 51,0 & 37,8 & & & \\
\hline \multirow{2}{*}{$\begin{array}{l}\text { Uspavanke so del ljudskega } \\
\text { izročila, ki ga je treba negovati in } \\
\text { ohranjati za prihodnje rodove. }\end{array}$} & $f$ & 0 & 0 & 1 & 32 & 64 & \multirow[t]{2}{*}{97} & \multirow[t]{2}{*}{4,65} & \multirow[t]{2}{*}{0,501} \\
\hline & $\%$ & 0,0 & 0,0 & 1,0 & 33,0 & 66,0 & & & \\
\hline \multirow{2}{*}{$\begin{array}{l}\text { Uspavanke so najstarejša oblika } \\
\text { otroške pesmi. }\end{array}$} & $f$ & 0 & 2 & 23 & 46 & 26 & \multirow[t]{2}{*}{97} & \multirow[t]{2}{*}{3,99} & \multirow[t]{2}{*}{0,770} \\
\hline & $\%$ & 0,0 & 2,0 & 23,2 & 46,5 & 26,3 & & & \\
\hline \multirow{2}{*}{$\begin{array}{l}\text { Nekoč so bile uspavanke } \\
\text { neločljiv del otroštva. }\end{array}$} & $f$ & 0 & 1 & 5 & 31 & 60 & \multirow[t]{2}{*}{97} & \multirow[t]{2}{*}{4,55} & \multirow[t]{2}{*}{0,646} \\
\hline & $\%$ & 0,0 & 1,0 & 5,2 & 32,0 & 61,9 & & & \\
\hline \multirow{2}{*}{$\begin{array}{l}\text { V preteklosti se je otrokom pelo } \\
\text { uspavanke pogosteje kot danes. }\end{array}$} & $f$ & 0 & 0 & 3 & 34 & 60 & \multirow[t]{2}{*}{97} & \multirow[t]{2}{*}{4,59} & \multirow[t]{2}{*}{0,554} \\
\hline & $\%$ & 0,0 & 0,0 & 3,1 & 35,1 & 61,9 & & & \\
\hline
\end{tabular}

Opombe Naslovi stolpcev: (1) sploh se ne strinjam, (2) ne strinjam se, (3) ne morem se odločiti, (4) strinjam se, (5) zelo se strinjam.

\section{Rezultati in interpretacija}

Rezultate bomo predstavili v dveh sklopih. Najprej bomo obravnavali uspavanko kot del kulturne dediščine, nato pa njen pomen danes.

\section{Uspavanka kot del kulturne dediščine in tradicije}

Etnomuzikološki zapisi, ki jih hranijo na ZRC SAZU, kažejo, da je uspavanka ena od najstarejših oblik otroške pesmi in sestavni del otroštva, kot so ga živeli nekoč. Zanimala so nas stališča anketirank oz. njihovo strinjanje s trditvami, ki se nanašajo na pomen uspavanke kot kulturne dediščine.

Anketiranke uspavanko pojmujejo kot pomemben del kulturne dediščine in tradicije, povezane $z$ otroštvom. Zelo se strinjajo $s$ trditvami, da je uspavanka pomemben del kulturne dediščine $(M=4,63)$, ki jo je treba negovati in ohranjati za prihodnje rodove $(M=4,65)$. Prav tako se zelo strinjajo, da so bile nekoč uspavanke neločljivi del otroštva $(M=4,55)$ in da so se pele pogosteje kot danes $(M=4,59)$. Uspavanko pojmujejo kot eno najstarejših oblik otroške pesmi $(M=3,99)$, ki jo poznajo povsod po svetu $(M=4,24)$. Močna zavest anketirank o uspavanki kot delu tradicije, ki jo je treba negovati in ohranjati, nakazuje obenem uresničevanje smernic vzgoje in izobraževanja za trajnostni razvoj, še posebej v povezavi z uresničevanjem načela medkulturnega dialoga (Lepičnik Vodopivec in Tominc 2011). Predloga anketirank to potrjujeta: 
Preglednica 2 Stališča anketirank do pomena uspavanke danes

\begin{tabular}{|c|c|c|c|c|c|c|c|c|c|}
\hline \multirow[t]{2}{*}{ Trditev } & & \multicolumn{5}{|c|}{ Ocena strinjanja } & \multirow[t]{2}{*}{$N$} & \multirow[t]{2}{*}{$M$} & \multirow[t]{2}{*}{$S D$} \\
\hline & & (1) & (2) & (3) & (4) & (5) & & & \\
\hline \multirow{2}{*}{$\begin{array}{l}\text { Danes so uspavanke neločljiv } \\
\text { del otroštva. }\end{array}$} & $f$ & 2 & 18 & 30 & 35 & 11 & \multirow[t]{2}{*}{96} & \multirow[t]{2}{*}{3,36} & \multirow[t]{2}{*}{0,985} \\
\hline & $\%$ & 2,1 & 18,8 & 31,3 & 36,5 & 11,5 & & & \\
\hline \multirow{2}{*}{$\begin{array}{l}\text { Uspavanke so za današnji čas } \\
\text { zastarele. }\end{array}$} & $f$ & 13 & 44 & 15 & 23 & 2 & \multirow[t]{2}{*}{97} & \multirow[t]{2}{*}{2,56} & \multirow[t]{2}{*}{1,060} \\
\hline & $\%$ & 13,4 & 45,4 & 15,5 & 23,7 & 2,1 & & & \\
\hline \multirow{2}{*}{$\begin{array}{l}\text { Danes ni tolikšne potrebe po } \\
\text { petju uspavank kot nekoč. }\end{array}$} & $f$ & 16 & 34 & 14 & 25 & 7 & \multirow[t]{2}{*}{96} & \multirow[t]{2}{*}{2,72} & \multirow[t]{2}{*}{1,229} \\
\hline & $\%$ & 16,7 & 35,4 & 14,6 & 26,0 & 7,3 & & & \\
\hline
\end{tabular}

Opombe Naslovi stolpcev: (1) sploh se ne strinjam, (2) ne strinjam se, (3) ne morem se odločiti, (4) strinjam se, (5) zelo se strinjam.

»Predlagam, da naj starši, vzgojitelji, stari starši, sestre, brati in vsi, ki so v stiku z majhnim otrokom, prepevajo uspavanke otroku, da se bodo le-te ohranile in prenašale iz roda v rod.«»Želim, da bi mladim staršem, vzgojiteljicam, odraslim in vsem, ki živijo in delajo z otroki, uspelo ohraniti to lepo pesem - uspavanko. Kjer je volja, je tudi pot.« Da so uspavanke v zavesti anketirank živo izročilo, razberemo iz naslednje izkušnje: »Nama s sestro je mami vsak večer po pravljici prišla zapet pesem, ki nama jo je pela že od majhnega.Zjutraj naju je $z$ enako pesmijo zbudila. Ko se je rodila najmlajša sestrica, sem enako delala jaz zanjo.« Negovanje tradicije potrjujeta tudi ta dva zapisa: »Rada pojem sestrici uspavanke odkar se je rodila in tudi sedaj, ko je stara 11 let. Vedno me prosi pred spanjem, naj ji zapojem pesem, ki nama jo je pela mama.«»Uspavanke pojem nečaku pred spanjem. Ko je potrebno iti spat, vsakič začne jokati. Ko začnem peti, se popolnoma umiri in mirno zaspi.«

Pozitivne izkušnje anketirank so primerno izhodišče za ugotavljanje stališč do pomena, ki ga ima uspavanka danes.

Ocene strinjanja o tem, da so danes uspavanke neločljivo povezane $z$ otroštvom, so nižje $(M=3,36)$ od ocen povezanosti nekoč $(M=4,55)$. Po drugi strani pa se več kot polovica anketirank ne strinja (58,5\%), da bi bile uspavanke za današnji čas zastarele in da danes ni tolikšne potrebe po njihovem petju $(52,1 \%)$. Vzroke, da se $v$ današnjem času uspavanka izgublja, anketiranke vidijo $v$ pogostejši rabi sodobne tehnologije, kot so tablice, telefoni, zvočne igrače in računalniki, ter pogostem gledanju risank, poslušanju predvajane glasbe in gledanju videoposnetkov na YouTubu. Kot drugi najpogostejši vzrok navajajo pomanjkanje časa in prezaposlenost staršev. Anketiranki sta zapisali: »Starši nimajo časa. So preutrujeni ali pa se jim ne zdi smiselno peti otroku uspavanke.« »Starši so preobremenjeni. Lažje jim je, da otrokom prižgejo televizijo ali predvajajo glasbo preko računalnika.« 
Preglednica 3 Stališča anketirank do pomena uspavanke za otrokov razvoj

\begin{tabular}{|c|c|c|c|c|c|c|c|c|c|}
\hline \multirow[t]{2}{*}{ Trditev } & & \multicolumn{5}{|c|}{ Ocena strinjanja } & \multirow[t]{2}{*}{$N$} & \multirow[t]{2}{*}{$M$} & \multirow[t]{2}{*}{$S D$} \\
\hline & & (1) & (2) & (3) & (4) & (5) & & & \\
\hline \multirow{2}{*}{$\begin{array}{l}\text { Uspavanka je prvi stik otroka } \\
\text { z glasbo. }\end{array}$} & $f$ & 1 & 6 & 8 & 45 & 25 & \multirow[t]{2}{*}{85} & \multirow[t]{2}{*}{4,02} & \multirow[t]{2}{*}{0,886} \\
\hline & $\%$ & 1,2 & 7,1 & 9,4 & 52,9 & 29,4 & & & \\
\hline \multirow{2}{*}{$\begin{array}{l}\text { Petje uspavanke je intimno } \\
\text { glasbeno doživetje med } \\
\text { otrokom in odraslim. }\end{array}$} & $f$ & 0 & 0 & 3 & 44 & 38 & \multirow[t]{2}{*}{85} & \multirow[t]{2}{*}{4,41} & \multirow[t]{2}{*}{0,563} \\
\hline & $\%$ & 0,0 & 0,0 & 3,5 & 51,8 & 44,7 & & & \\
\hline \multirow{2}{*}{$\begin{array}{l}\text { Petje uspavank je način komu- } \\
\text { nikacije odraslega z otrokom. }\end{array}$} & $f$ & o & 0 & 4 & 45 & 36 & \multirow[t]{2}{*}{85} & \multirow[t]{2}{*}{4,38} & \multirow[t]{2}{*}{0,577} \\
\hline & $\%$ & 0,0 & 0,0 & 4,7 & 52,9 & 42,4 & & & \\
\hline \multirow{2}{*}{$\begin{array}{l}\text { Uspavanka spodbudno vpliva } \\
\text { na otrokov celostni razvoj. }\end{array}$} & $f$ & o & 0 & 13 & 40 & 31 & \multirow[t]{2}{*}{84} & \multirow[t]{2}{*}{4,21} & \multirow[t]{2}{*}{0,695} \\
\hline & $\%$ & 0,0 & 0,0 & 15,5 & 47,6 & 36,9 & & & \\
\hline \multirow{2}{*}{$\begin{array}{l}\text { Uspavanka spodbudno vpliva } \\
\text { na otrokov glasbeni razvoj. }\end{array}$} & $f$ & 0 & 0 & 5 & 39 & 40 & \multirow[t]{2}{*}{84} & \multirow[t]{2}{*}{4,42} & \multirow[t]{2}{*}{0,605} \\
\hline & $\%$ & 0,0 & 0,0 & 6,0 & 46,4 & 47,6 & & & \\
\hline
\end{tabular}

Opombe Naslovi stolpcev: (1) sploh se ne strinjam, (2) ne strinjam se, (3) ne morem se odločiti, (4) strinjam se, (5) zelo se strinjam.

Anketiranke izražajo skrb, da bodo uspavanke šle v pozabo, da se bodo vedno manj pele in da se ne bodo več poznale. Navajajo tudi siromašenje otrokovega doživljanja in izgubljanje stika z otrokom. Primer zapisa: "Skrbi me, da bi uspavanke šle v pozabo, saj jih bodo najverjetneje zasenčili predvajana glasba in posnetki z YouTuba. Tako se bo zgubila možnost, da se med odraslim in otrokom ustvari neka posebna vez.« Iz odgovorov razberemo tudi empatičnost anketirank, na primer: "Skrbi me, da otroci ne bodo imeli izkušenj, kako je lepo zaspati, če ti nekdo zraven poje lepo umirjeno uspavanko. Otroci se bodo navadili zaspati z risankami in elektroniko.« Ugotavljamo, da anketiranke poleg želje po ohranjanju uspavanke v ospredje postavljajo skrb za otroka in njegov razvoj.

\section{Pomen uspavanke za otrokov razvoj}

Uspavanka je vez med otrokom, odraslim in glasbo (Borota 2015). Zanimajo nas stališča anketirank do pomena, ki ga ima uspavanka za otrokov razvoj.

Anketiranke se strinjajo, da uspavanka spodbudno vpliva na otrokov celostni razvoj $(M=4,21)$. Percepcija uspavanke odraslega je povezana s situacijami, ko mati poje otroku $v$ naročju ali pred spanjem. Tudi zato je strinjanje anketirank s trditvami, da je petje uspavank intimno glasbeno doživetje med otrokom in odraslim ( $M=4.41)$ in način komunikacije odraslega $z$ otrokom $(M=4,38)$, pričakovano. Zanimive bi bile nadaljnje raziskave o povezanosti petja uspavank z razvojem navezanosti kot dejavnega, medsebojno močno 
naklonjenega recipročnega odnosa med dvema osebama (Zupančič 2004), $\checkmark$ našem primeru med dojenčkom in materjo, ter $s$ socialnim in čustvenim razvojem dojenčka. Smiselnost raziskave je podkrepljena z izkušnjami anketirank, ki jih razberemo iz naslednjih zapisov. »Ko sem svojim otrokom prepevala uspavanke, se je poglabljala čustvena vez med mano in otrokom.«»Ko sem dojenčku pela uspavanko, sem se počutila kot mama.«»Počutila sem se kot mama, ki ima svojega otroka.« »Med petjem uspavanke sem čutila sproščenost in še večjo povezanost z otrokom. « »Rada se spominjam otrokovega stiska k meni, ko sem mu pela uspavanke."

Na področju glasbenega razvoja sta spodbudni oceni strinjanja $s$ trditvama, da je uspavanka prvi stik otroka z glasbo $(M=4,02)$ in da uspavanka pozitivno vpliva na otrokov glasbeni razvoj $(M=4,42)$. Pri interpretaciji teh rezultatov bomo uspavanko obravnavali kot sestavni del bogatega glasbenega okolja, v katerem se dojenček in malček navajata na glasbo iz okolja ter razvijata prirojene glasbene sposobnosti (Gordon 1997). Raziskave so pokazale, da si dojenček s poslušanjem ekspresivnega petja izgrajuje glasbeni spomin, ki je potreben za kasnejše vzpostavljanje glasbene komunikacije (Trebuh 2004). Dojenček izkazuje veliko zanimanje za glasbo. $V$ neposrednem stiku $z$ odraslim odkriva subtilne razlike $v$ melodični in ritmični strukturi glasbe iz svojega glasbenega okolja ali drugih glasbenih kultur (Lynch idr. 1990 v Trebuh 2006). Zvoke, ki jih sliši, povezuje z gibi, kar vpliva na njegovo dojemanje glasbenega ritma (Phillips-Silver in Trainor 2005 v Trebuh 2006). Čeprav se matere ne zavedajo glasbenih sposobnosti dojenčkov, jim intuitivno zagotavljajo intimno glasbeno doživetje $z$ raznovrstnimi glasbenimi spodbudami in ekspresivnim petjem. Dojenček se na te spodbude odzove s pozornostjo, kar je eden od pogojev za nadaljnji razvoj glasbenih dispozicij (Trebuh 2006).

Rezultati naše raziskave so pokazali, da uspavanke najpogosteje pojejo matere doma ( $91,8 \%$ anketirank) in vzgojiteljice v vrtcu ( $49 \%$ anketirank). Rezultati nakazujejo, da je uspavanka aktualna v domačem in vrtčevskem okolju. Zanimalo nas je, s katerim namenom se pojejo uspavanke doma in vrtcu in ali je med domačim ter vrtčevskim okoljem povezanost oz. ali med njima obstajajo razlike.

Rezultati korelacije kažejo na statistično značilno povezanost petja uspavanke $v$ domačem in vrtčevskem okolju. Razlike se kažejo $v$ pogostosti petja uspavank pred spanjem doma in v vrtcu $(t=2,196, g=91,2 p=0,031)$, pri hranjenju $(t=3,588, g=80,2 p=0,001)$, na sprehodu $(t=2,831, g=81,2 p=0,006)$ in v situaciji, ko je otrok bolan $(t=3,307, g=81,2 p=0,001)$. V navedenih primerih se uspavanke pogosteje pojejo $v$ domačem kot vrtčevskem okolju. Vzroke bi lahko iskali v tesnejšem stiku z otrokom doma, pa tudi v večji čustveni na- 
Preglednica 4 Rezultati $t$-preizkusa glede pogostosti petja uspavanke doma in v vrtcu

\begin{tabular}{|c|c|c|c|c|c|c|c|c|c|}
\hline \multirow[t]{2}{*}{ Trditev } & & \multirow[t]{2}{*}{$M$} & \multirow[t]{2}{*}{$N$} & \multirow[t]{2}{*}{$S D$} & \multicolumn{2}{|c|}{ Korelacija } & \multicolumn{3}{|c|}{$t$-preizkus } \\
\hline & & & & & $r$ & $p$ & $t$ & $g$ & $2 p$ \\
\hline \multirow[t]{2}{*}{ Pred spanjem } & Doma & 3,83 & 92 & 1,164 & 0,441 & 0,000 & 2,196 & 91 & 0,031 \\
\hline & V vrtcu & 3,54 & 92 & 1,171 & & & & & \\
\hline \multirow[t]{2}{*}{ Kot tolažba } & Doma & 3,33 & 84 & 1,293 & 0,482 & 0,000 & $-0,179$ & 83 & 0,859 \\
\hline & V vrtcu & 3,36 & 84 & 1,83 & & & & & \\
\hline \multirow[t]{2}{*}{ Med pripoved. } & Doma & 2,51 & 81 & 1,026 & 0,230 & 0,039 & 0,920 & 80 & 0,360 \\
\hline & V vrtcu & 2,38 & 81 & 0,916 & & & & & \\
\hline \multirow[t]{2}{*}{ Pri hranjenju } & Doma & 1,90 & 81 & 0,995 & 0,346 & 0,002 & 3,588 & 80 & 0,001 \\
\hline & V vrtcu & 1,49 & 81 & 0,760 & & & & & \\
\hline \multirow[t]{2}{*}{ Na sprehodu } & Doma & 2,02 & 82 & 0,994 & 0,492 & 0,000 & 2,831 & 81 & 0,006 \\
\hline & V vrtcu & 1,73 & 82 & 0,847 & & & & & \\
\hline \multirow[t]{2}{*}{ Na praznovanjih } & Doma & 2,12 & 82 & 1,261 & 0,745 & 0,000 & $-0,253$ & 81 & 0,801 \\
\hline & V vrtcu & 2,15 & 82 & 1,177 & & & & & \\
\hline \multirow[t]{2}{*}{ Na mojo željo } & Doma & 3,54 & 80 & 0,993 & 0,192 & 0,087 & 1,792 & 79 & 0,071 \\
\hline & V vrtcu & 3,29 & 80 & 0,970 & & & & & \\
\hline \multirow[t]{2}{*}{ Ko sem bil/-a bolna } & Doma & 3,54 & 82 & 1,178 & 0,374 & 0,001 & 3,307 & 81 & 0,001 \\
\hline & V vrtcu & 3,07 & 82 & 1,086 & & & & & \\
\hline
\end{tabular}

vezanosti med odraslim in otrokom doma, kar se pogosto izraža s petjem kot obliko komunikacije med njima (Trebuh 2006). Anketiranke so zapisale predloge, ki bi pripomogli k pogostejšemu petju uspavank v vrtcu. Izpostavljajo potrebo po osveščenosti odraslih o pomenu uspavanke, organizirala naj bi se izobraževanja, pogosteje naj bi se pelo tudi v dejavnostih dnevne rutine. Anketiranka je zapisala: »Predlagam še več petja uspavank v vrtcu. O njihovem pomenu je treba seznaniti odrasle (starše), jih poučiti o pomenu uspavank za otroka in odraslega, jih spodbuditi za pogostejšo rabo in tako poskrbeti tudi za našo kulturno dediščino."

Ugotavljamo, da je uspavanka prisotna v domačem in vrtčevskem okolju. Otroku lahko predstavlja vez med domom in vrtcem. Smiseln je razmislek o tesnejšem sodelovanju vzgojiteljic s starši pri oblikovanju glasbeno bogatega, varnega in zaupljivega vrtčevskega okolja, v katerem otrok preživi veliko časa.

\section{Sklepne ugotovitve}

Uspavanka je tesno povezana zživljenjem otroka v prvih letih nekoč in danes. Petje uspavanke je za otroka eden prvih stikov z živo glasbo. Gre za intimno doživetje med materjo in otrokom. Če predpostavljamo, da so stališča vzgo- 
jiteljic pomemben dejavnik subjektivnih teorij, ki vplivajo na njihova ravnanja in delovanje, moramo ugotoviti, da so pozitivna stališča do uspavanke za otrokov celostni in glasbeni razvoj pomembna. Rezultati raziskave so pokazali, da se anketiranke zelo strinjajo, da je uspavanka tisti del kulturne dediščine in ljudskega izročila, ki ga je treba negovati in ohranjati za prihodnje rodove. Strinjajo se, da gre za neločljivi del otroštva nekoč in danes. Ob tem pa izražajo skrb, da bi v prihodnje utonila v pozabo zaradi vpliva tehnologije, pomanjkanja časa in preobremenjenosti staršev. Na osnovi ocen strinjanja s trditvami o pomenu uspavanke za otrokov celostni in glasbeni razvoj sklepamo o osveščenosti anketirank glede potrebe po stiku otroka z živo glasbo, še posebej ekspresivnim petjem odraslega.

Naša raziskava je potrdila, da uspavanke najpogosteje pojejo matere doma in vzgojiteljice v vrtcu. Ugotavljamo, da je uspavanka pomembna vez med domačim in vrtčevskim okoljem. Razlike se kažejo v pogostejšem petju uspavank doma, in sicer pred spanjem, pri hranjenju, na sprehodih in ko je otrok bolan. Vzroke bi lahko iskali v tesnejšem stiku in večji čustveni povezanosti odraslega z otrokom doma. Slednje se pogosto izraža v petju kot obliki komunikacije med otrokom in odraslim (Trebuh 2006).

Ugotavljamo, da imajo vzgojiteljice in študentke - bodoče vzgojiteljice pozitivna stališča do uspavanke nekoč in danes. Strinjajo se, da je petje uspavanke spodbudno za otrokov celostni in glasbeni razvoj. Obenem pa izkazujejo potrebo po večji osveščenosti o pomenu petja v prvih letih otrokovega življenja zaradi vse večjega vpliva sodobne tehnologije in poslušanja predvsem predvajane glasbe.

\section{Literatura}

Borota, B. 2010. »Raziskava o pevskem repertoarju v vrtcu, $v$ oddelkih otrok prvega starostnega obdobja.« Glasba v šoli in vrtcu 15 (2): 6-14.

- 2015. Glasbene dejavnosti in vsebine. Koper: Annales.

Cvetko, I. 2005. Aja tutaja: slovenske ljudske uspavanke. Ljubljana: DZS.

Dowling, W. J. 1982. »Melodic Information Processing and Its Development.« V The Psychology of Music, ur. D. Dutsch, 413-429. New York: Academic Press.

Gordon, E. 1997. A Music Learning Theory for Newborn and Young Children. Chicago: GIA Publications.

Hargreaves, D. 2001. The Developmental Psychology of Music. Cambridge: Cambridge University Press.

Juvančič, K. 2009. »Ko se prebudijo »nine nane in saje tutajes: etnomuzikološke raziskave uspavank." Traditiones 38 (1): 275-286.

Klemenčič, I. 2008. Slovenske ljudske pesmi. Maribor: Obzorja.

Kumer, Z. 1975. Pesem slovenske dežele. Maribor: Obzorja. 
_. 1983. Ljudska glasbila in godci na Slovenskem. Ljubljana: Slovenska matica Ljubljana.

_. 1996. Vloga, zgradba, slog slovenske ljudske pesmi. Ljubljana: Slovenska matica.

- 2002. Slovenska ljudska pesem. Ljubljana: Slovenska matica.

Kunaver, D. 1984. Slovenska pesem v besedi in glasbi. Ljubljana: Državna založba Slovenije.

- 1987. Pesmi in šege moje dežele. Ljubljana: Državna založba Slovenije.

Kuret, N. 1986. Slovenska koledniška dramatika. Ljubljana: Slovenska matica.

Lepičnik Vodopivec, J., in J. Tominc. 2011. »Vzgoja za trajnostni razvoj v praksi vrtcev.«Revija za elementarno izobraževanje 4 (4): 5-22.

Lynch, M. P., R. E. Eilers, D. K. Oller in R. C. Urbano. 1990. »Innateness, Experience and Music Perception. «Psychological Science 1 (4): 272-276.

Merhar, B. 1956. »Otroške pesmi.« V Zgodovina slovenskega slovstva, 88-92. Ljubljana: Slovenska matica.

Merkú, P. 1976. Ljudsko izročilo Slovencev, zbrano v letih 1965-1976. Trst: Založništvo tržaškega tiska.

Omerzel Terlep, M. 1984. »Slovenska ljudska glasba.« V Glasbena mladina Slovenija 14 (8): 7-9.

Phillips-Silver, J., in L. J. Trainor. 2005. »Feeling the Beat: Movement Influences Infant Rhythm Perception. «Science 308 (5727): 1430.

Sloboda, J. 2007. The Musical Mind. Oxford: Oxford University Press.

Stanonik, M. 1999. Slovenska slovstvena folklora. Ljubljana: Državna založba Slovenije.

Štrekelj, K. 1980. Slovenske narodne pesmi. Ljubljana: Cankarjeva založba.

Terseglav, M. 1984. Ljudsko pesništvo. Ljubljana: Državna založba Slovenije.

- 2006. Otroška pesmarica 2. Ljubljana: Mladinska knjiga.

Terseglav, M., in D. Čater, ur. 2004. Slovenske ljudske pesmi. Ljubljana: Karantanija.

Trainer, L. J. 1996. »Infant Preferences for Infant-Directed Versus NonifantDirected Playsongs and Lullabies." Infant Behavior and Development 19: 83-92.

Trebuh, S. 2004. »Foundation: Music perception in infancy.« V The Musical Lives of Young Children, ur. J. Flohr, 24-29. Upper Saddle River, NY: Prentice-Hall.

_. 2006. »Infants as Musical Connoisseurs. «V The Child as Musician: A Handbook of Musical Development, ur. G. McPherson, 33-51. Oxford: Oxford Universiy Press.

Verdelj, K. 2006. »Uspavanje otroka - komuniciranje ali zgolj spodbuda za lažje spanje?« Šegavec 2005/2006: 55-57.

Zupančič, M. 2004. »Socialni razvoj dojenčka in malčka.« V Razvojna psihologija, ur. L. Marjanovič Umek in M. Zupančič, 255-278. Ljubljana: Filozofska fakulteta. 


\section{Attitudes toward the Relevance of the Lullaby in Early Childhood in the Past and Today}

The lullaby was inseparably linked to childhood in the past and has also been a part of it in the present time. From the viewpoint of ethnomusicology, it represents one of the most ancient forms of children's folk song. Recent research has investigated its relevance in relation to inculturation, the period when the baby and the toddler are getting used to sounds and music from the environment. As listening to singing (a lullaby) is a first time the child gets experience with music, the attitudes of adults to the discussed topic are extremely relevant. With the purpose in view to gather information on their attitudes toward the lullaby as a part of cultural heritage and on what relevance they ascribe to it for child's early musical development, preschool teachers and students training for the job of preschool teachers were included in the research. The results indicate the surveyees (all of them feminine) have a positive attitude toward the relevance of the lullaby for child's early musical development. They agree to a very large extent that lullabies represent living heritage that needs to be preserved and cultivated for future generations, especially in modern times, when parents are overburdened and the environment is saturated with technology. They agree to a very large extent that today for children lullabies represent relevant musical experience in the framework of which (musical) communication gets established between the child and the adult. As at home lullabies are sung more often than at preschool, potential seems to be present for closer cooperation between teachers and parents in establishing musically rich as well as safe and trusting learning environment in preschool.

Keywords: musical cultural heritage, musical development at the age up to three years, lullaby, attitudes of preschool children toward the lullaby 



\title{
Z merilnikom pospeška izmerjena gibalna aktivnost in gibalna neaktivnost otrok med prvim in tretjim letom starosti
}

\author{
Tadeja Volmut \\ Univerza na Primorskem \\ tadeja.volmut@pef.upr.si
}

Cilj prispevka je preučiti gibalno aktivnost in neaktivnost otrok med prvim in tretjim letom starosti, primerjati med vrtčevskim in izvenvrtčevskim časom, med tednom in koncem tedna ter preučiti povezanost znotrajdnevne in mednevne variabilnosti gibalne aktivnosti. Štiriindvajset otrok je merilnik pospeška nosilo pet zaporednih dni. Primerjali smo fenotipe intenzivnosti gibalne aktivnosti $v$ času vrtca in po njem ter med tednom in koncem tedna. Otroci so v povprečju dosegli $571 \pm 200$ sunkov na minuto, od tega so bili gibalno neaktivni $389 \pm 43$ minut, $v$ srednji in visoki intenzivnosti gibalne aktivnosti $71 \pm 25$ minut. Med tednom so deležni $4 \%$ več gibalne neaktivnosti $(p=0,017 ; E S=$ $0,57)$ in $3 \%$ manj nizke intenzivnosti $(p=0,002 ; E S=0,75)$ kot med koncem tedna. $V$ času po vrtcu dosegajo $41 \%$ večjo celotno gibalno aktivnost $(p=0,026$; $E S=1,16)$, za $8 \%$ manj gibalne neaktivnosti $(p<0,001 ; E S=1,00)$, za $6 \%$ več nizke intenzivnosti $(p<0,001 ; E S=1,20)$ ter za $2 \%$ več srednje in visoke intenzivnosti gibalne aktivnosti ( $p=0,024 ; E S=0,50)$. Obstaja povezanost celotne gibalne aktivnosti med tednom in koncem tedna $(r=0,688 ; p<0,001)$ ter med vrtčevskim in izvenvrtčevskim časom $(r=0,448 ; p=0,028)$. Študija prinaša pomembne podatke o gibalni aktivnosti najmlajših vrtčevskih otrok, ki nakazujejo povezave gibalne aktivnosti v različnih obdobjih dneva in med dnevi, kar je potrebno upoštevati pri zasnovi gibalnih programov otrok.

Ključne besede: merilnik pospeška, vrtec, teden, konec tedna, dopodne, popoldne

\begin{abstract}
Uvod
Predšolsko obdobje je eno izmed pomembnih obdobji, v katerem se oblikujejo gibalne in sedentarne navade (Janz, Burns in Levy 2005; Certain in Kahn 2002). Redna gibalna aktivnost ugodno vpliva na gibalni, mišično-skeletni in psiho-socialni razvoj predšolskih otrok (Timmons, Naylor in Pfeiffer 2007), poleg tega zmanjša tveganje za številne bolezni, kot so srčno-žilne bolezni (Vale idr. 2015), debelost (Reilly 2008), sladkorna bolezen tipa 2, osteoporoza, debelost ter nekatere oblike raka (Blair, Cheng in Holder 2001; Kriska idr. 2003). Redna gibalna aktivnost $v$ različnih oblikah je pomembna tudi za razvoj in
\end{abstract}


ohranjanje potrebne ravni gibalnih sposobnosti in oblikovanje takšnih navad ter vedenjskih vzorcev, ki zagotavljajo redno gibalno/športno aktivnost v vseh življenjskih obdobjih (Riddoch idr. 2004; Pišot in Planinšec 2005). Na drugi strani pa je povečana količina sedentarnih navad povezana $z$ neugodnimi psihosocialnim zdravjem, kognitivnim in gibalnim razvojem ter debelostjo predšolskih otrok (LeBlanc idr. 2012).

Strokovnjaki iz različnih držav (Tremblay idr. 2012; Department of Health and Aging 2010; National Association of Sport and Physical Education 2009) so oblikovali okvirna priporočila gibalne aktivnosti otrok do petega leta starosti. Večina teh priporoča, da naj bodo predšolski otroci dnevno gibalno aktivni najmanj 90 do 180 minut $v$ različnih fenotipih intenzivnosti gibalne aktivnosti. Ameriško združenje za šport in športno vzgojo (National Association of Sport and Physical Education 2009), za otroke med prvim in tretjim letom starosti, priporoča, da so gibalno aktivni najmanj 30 minut na dan v organizirani vadbi ter 60 minut in več $v$ neorganizirani. Poudarjajo tudi, da naj mlajši predšolski otroci ne preživijo sedentarno več kot 60 minut strnjeno, razen takrat, ko spijo. Kanadske smernice za omejevanje gibalne neaktivnosti (Canadian Society of Exercise Physiology 2015) celo priporočajo, da naj otroci do drugega leta starosti ne preživljajo svojega prostega časa pred televizijskimi ekrani, medtem ko naj ga otroci med drugim in četrtim letom največ eno uro dnevno.

V zadnjem desetletju raziskovalci veliko pozornost posvečajo objektivnemu merjenju in preučevanju gibalne aktivnosti in gibalne neaktivnosti predšolskih otrok, vendar moramo poudariti, da so študije, ki preučujejo gibalno aktivnost in gibalno neaktivnost otrok med prvim in tretjim letom, zelo redke (Cardon, Van Cauwenberghe in De Bourdeaudhuij 2011). Rezultati študij kažejo, da so vsi predšolski otroci čez dan deležni predvsem nizke intenzivnosti, ${ }^{1}$ velike količine gibalne neaktivnosti ${ }^{2}$ in nizke količine srednje ${ }^{3}$ ter visoke ${ }^{4}$ intenzivnosti gibalne aktivnosti (Aadland in Johannessen 2015; Van Cauwenberghe idr. 2012; Reilly 2008; Tucker 2008; Kuzik idr. 2015; Johanssson idr. 2015; Carson idr. 2019). P. Tucker (2008) v svoji pregledni študiji navaja, da je le polovica otrok med drugim in šestim letom starosti deležna vsaj 60minutne gibalne aktivnosti na dan ter da le četrtina predšolskih otrok dosega priporočila Ameriškega združenja za šport in športno vzgojo (National Asso-

\footnotetext{
${ }^{1}$ Nizka intenzivnost - gimnastične vaje, hoja pri o,4 m/s.

${ }^{2}$ Gibalna neaktivnost: ležanje s poslušanjem, ležanje, risanja, branje.

${ }^{3}$ Srednja intenzivnost: Hitra hoja pri o,8 m/s, lahkoten tek pri 1,2 m/s.

${ }^{4}$ Visoka intenzivnost: Tek pri 2-2,4 m/s, skiping, žabji poskoki.
} 
ciation of Sport and Physical Education 2009). Študije, ki preučujejo gibalno neaktivnost otrok med prvim in tretjim letom, kažejo, da otroci večji del budnega časa preživijo gibalno neaktivno (Vale idr. 2010; Johanssson idr. 2015; Carson idr. 2019) in pred ekrani (Vandewater idr. 2007; Zimmerman, Christakis in Meltzoff 2007), zato jih ogrožajo razvojne zamude in slabše splošno zdravstveno stanje (Kipling Webster, Martin in Staiano 2019). E. Johansson idr. (2015) navajajo, da dve leti stari otroci preživijo le $11 \%$ dnevnega časa v srednji in visoki intenzivnosti ter kar $55 \%$ časa gibalno neaktivno.

Predšolski otroci lahko dnevno v vrtcu preživijo od štiri pa vse do devet ur; prav zato ima vrtec pomembno vlogo pri oblikovanju otrokovih zdravih življenjskih navad, med katere vključujemo tudi gibalno aktivnost (Benjamin idr. 2008). Vsakodnevno vključevanje gibalne aktivnosti v obstoječi kurikulum vrtcev je učinkovita strategija za povečanje količine in intenzivnosti gibalne aktivnosti otrok v času vrtca (Trost idr. 2002). Pred samo izvedbo intervencijskega programa je nujno celovito poznavanje vzorcev gibalne aktivnosti posamezne starostne skupine otrok, saj le tako lahko zasnujemo učinkovit program za povečanje gibalne aktivnosti in zmanjšanje gibalne neaktivnosti otrok.

V zadnjem času je objavljenih kar nekaj študij, $v$ katerih so merili gibalno aktivnost z merilnikom pospeška in preučevali znotrajdnevne (Verbestel 2011; Van Cauwenberghe idr. 2012; Grønholt Olesen idr. 2014; Hesketh, Griffin in van Sluijs 2015; Brasholt idr. 2013) ter meddnevne (Verbestel idr. 2011; Van Cauwenberghe idr. 2012; Andersen idr. 2017; Grønholt Olesen idr. 2014; Hesketh idr. 2015; Brasholt idr. 2013; Vanderloo in Tucker 2015; Volmut 2014; Metcalf idr. 2002; Trost idr. 2000; Bringolf-Isler idr. 2009; Riddoch idr. 2007; Hardman, Horne in Rowlands 2009; Trayers idr. 2006; Treuth idr. 2005) razlike $v$ količini in intenzivnosti gibalne aktivnosti predšolskih otrok. Ugotovitve teh študij niso enotne, saj rezultati nekaterih kažejo, da so predšolski otroci gibalno aktivnejši med koncem tedna (Metcalf idr. 2002; Trost idr. 2000), druge kažejo na večjo aktivnost med tednom (Bringolf-Isler idr. 2009; Riddoch idr. 2007; Hardman, Horne in Rowlands 2009; Brasholt idr. 2013; Grønholt Olesen idr. 2014; Verbestel idr. 2011) Oz. da med tednom in koncem tedna razlik v gibalni aktivnosti ni (Trayers idr. 2006; Treuth idr. 2005). Primerjavo med dopoldanskim in popoldanskim časom je opravila T. Volmut (2014) na slovenskih predšolskih otrocih, starih pet let, in ugotovila, da imajo nižjo količino gibalne aktivnosti $v$ dopoldanskem času kot $v$ popoldanskem, ki ga preživijo $v$ domačem okolju. Njene ugotovitve so potrdili tudi L. Grønholt Olesen idr. (2014), in sicer da imajo danski predšolski otroci, stari pet in šest let, večjo količino gibalne aktivnosti v dopoldanskem času, ki ga preživijo v vrtcu. Večina 
študij se nanaša na pet- in šestletne predšolske otroke, medtem ko nismo zasledili podatkov za mlajše otroke, tj. med prvim in tretjim letom starosti.

Cilj naše raziskave je preučiti gibalno aktivnost in neaktivnost otrok med prvim in tretjim letom starosti ter povezanost znotrajdnevne (dopoldne in popoldne) in mednevne (teden in konec tedna) variabilnosti gibalne aktivnosti.

\section{Metode dela}

\section{Vzorec}

V raziskavo so bili vključeni predšolski otroci od prvega do tretjega leta starosti iz treh različnih slovenskih vrtcev. Skupno število sodelujočih otrok je bilo 26 , vendar smo dva otroka iz raziskave izključili, saj merilnika pospeška nista nosila zadostno količino časa in tako njunih podatkov nimamo za veljavne. $\checkmark$ nadaljnjo obdelavo smo vzeli podatke 24 otrok (11 dečkov, 13 deklic), povprečno starih 2,0 $\pm 0,6$ let. Vzorec je bil neslučajnosten in namensko izbran. Pred raziskavo so starši otrok podpisali pisno soglasje za sodelovanje $v$ raziskavi.

\section{Potek raziskave}

Raziskava je potekala aprila in maja 2015. Pred pričetkom smo vodstvo vrtcev prosili za sodelovanje pri raziskavi. Po odobritvi vodstva smo staršem razložili cilje in metode raziskave ter pridobili pisna soglasja. Meritve smo izvedli enkrat, presečno. Po predhodnem dogovoru s starši smo otrokom v vtrcu namestili merilnik pospeška. Staršem otrok smo izročili navodila ter jim na kratko razložili, kako z napravo ravnamo. Starši so otrokom nameščali (zjutraj) in odstranjevali (zvečer) merilnik pospeška skozi vseh pet dni merjenja.

\section{Pripomočki}

Gibalno aktivnost vsakega otroka smo zajemali z merilnikom pospeška (enoosni merilnik pospeška Actigraph GT1M, Actigraph LLC, ZDA) pet zaporednih dni, in sicer tri dni med tednom in dva dni med koncem tedna (od srede do nedelje). Merilnik pospeška, s katerim smo izmerili količino in intenzivnost gibalne aktivnosti, so otroci nosili okoli pasu na desnem boku - $v$ višini popka. Med spanjem, tuširanjem in kopanjem merilnika otroci niso nosili. Merilniki so merili v 15-sekundni časovni epohi, to je časovni interval, v katerem merilnik pospeška zbira in shranjuje podatke (Rowlands 2007). Upoštevali smo le podatke med osmo uro zjutraj in osmo uro zvečer. Pred nadaljnjo obdelavo smo vse zaporedne ničle, ki so bile daljše od 20 minut, izločili (Cain idr. 2013; Esliger idr. 2005). Za veljavno smo dnevno merjenje šteli le $v$ primeru vsaj 
šesturnega ( $50 \%$ ) posnetka gibanja, kar je več kot priporočajo T. Hinkley idr. (2012). Za veljaven posnetek je moral otrok imeti vsaj tri veljavne dni merjenja oz. dva dni med tednom in en dan med koncem tedna (Cliff, Reilly in Okelly 2009). Upoštevali smo naslednje meje med posameznimi intenzivnostmi: gibalna neaktivnost: <192 sunkov na minuto (cpm); nizka intenzivnost gibalne aktivnosti: 193-1673 cpm, srednja in visoka intenzivnost gibalne aktivnosti: $>1673 \mathrm{cpm}$ (Trost idr. 2012).

\section{Obdelava podatkov}

Vse statistične analize smo opravili s programom SPSS. Podatki so v preglednicah prikazani s povprečno vrednostjo in standardnim odklonom. S $t$ testom za odvisne vzorce smo preučili, ali obstajajo razlike med količino in vsemi fenotipi intenzivnosti gibalne aktivnosti v času vrtca (od 8.00 do 16.00) in po njem (od 16.00 do 20.00) ter med tednom in koncem tedna. S pomočjo Pearsonove korelacije smo preverili, ali obstaja povezava med posameznimi fenotipi intenzivnosti in celotno gibalno aktivnostjo med tednom ter med koncem tedna in ali obstaja povezava med dopoldanskim in popoldanskim časom (le podatki od srede do petka). Vse odločitve smo sprejemali pri stopnji tveganja $p<0,05 . V$ primeru značilnih razlik povprečnih vrednosti smo poročali še o velikosti efekta teh razlik (ES) in v primeru značilnih povezav še o determinacijskem koeficientu $\left(r^{2}\right)$. Velikost efekta smo opredelili kot majhno $(>0,2)$, srednjo $(0,2-0,8)$ in veliko $(<0,8)$.

\section{Rezultati}

Otroci, ki so dosegali kriterije (minimalno nošenje merilnika pospeška dva dni med tednom in en dan med koncem tedna ter vsaj $50 \%$ dnevnega opazovanega časa) in bili vključeni v nadalnjo analizo, so merilnik pospeška $v$ povprečju nosili $78 \%$ dnevnega časa. Le 13 otrok $(54,2 \%)$ je v povprečju doseglo vsaj 60 minut srednje in visoke intenzivnosti. Le 5 otrok (21\%) pa je doseglo omenjena priporočila $v$ vsakem dnevu nošenja merilnika pospeška.

Preglednica 1 prikazuje skupno količino in čas posameznega fenotipa intenzivnosti tedenske (od srede do vključno nedelje) gibalne aktivnosti, ki je prikazana v sunkih na minuto. Prikazana sta tudi količina in odstotek časa gibalne aktivnosti posameznega fenotipa intenzivnosti med tednom (od srede do petka) in med koncem tedna (od sobote do nedelje). Otroci med petdnevnim nošenjem merilnika pospeška preživijo v povprečju $54 \%$ dnevnega časa gibalno neaktivno, $36 \%$ dnevnega časa so deležni nizke intenzivnosti ter le 9,9\% časa so deležni srednje in visoke intenzivnosti gibalne aktivnosti. Rezultati kažejo, da ni razlik med količino ter odstotkom časa srednje in visoko 
Preglednica 1 Skupna tedenska gibalna aktivnost in primerjava gibalne aktivnosti ter posameznih intenzivnosti med tednom in koncem tedna

\begin{tabular}{lrrrr}
\hline Postavka & Skupna GA & $\begin{array}{r}\text { GA med } \\
\text { tednom }\end{array}$ & $\begin{array}{r}\text { GA med } \\
\text { koncem tedna }\end{array}$ & $\begin{array}{r}p \text { (teden/konec } \\
\text { tedna) (ES) }\end{array}$ \\
\hline Skupna količina GA & $571 \pm 200$ & $558 \pm 231$ & $584 \pm 184$ & 0,542 \\
Gibalna neaktivnost & $389 \pm 43$ & $55 \pm 7$ & $51 \pm 9$ & $0,017(0,57)$ \\
Nizka intenzivnost GA & $260 \pm 28$ & $35 \pm 4$ & $38 \pm 5$ & $0,002(0,75)$ \\
Srednja in visoka & $71 \pm 25$ & $10 \pm 4$ & $9 \pm 3$ & 0,895 \\
intenzivnost GA & & & & \\
\hline
\end{tabular}

Opombe ES-velikost efekta.

Preglednica 2 Skupne gibalne aktivnosti in intenzivnosti posameznih gibalnih aktivnosti med časom vrtca in časom po vrtcu

\begin{tabular}{lrrr}
\hline Postavka & GA v času vrtca & GA po vrtcu & $p(E S)$ \\
\hline Skupna količina GA & $491 \pm 172$ & $692 \pm 461$ & $0,026(1,16)$ \\
Gibalna neaktivnost & $58 \pm 8$ & $50 \pm 8$ & $<0,001(1,00)$ \\
Nizka intenzivnost GA & $33 \pm 5$ & $39 \pm 5$ & $<0,001(1,20)$ \\
Srednja in visoka intenzivnost GA & $9 \pm 4$ & $11 \pm 6$ & $0,024(0,50)$ \\
\hline
\end{tabular}

Opombe ES - velikost efekta. V analizo so zajeti le podatki od srede do petka.

intenzivne gibalne aktivnosti med tednom in koncem tedna. Otroci so med tednom deležni $4 \%$ več gibalne neaktivnosti kot $(p=0,017 ; E S=0,57)$ med koncem tedna, medtem ko so med koncem tedna deležni $3 \%$ več časa nizke intenzivnosti gibalne aktivnosti kot med tednom $(p=0,002 ; E S=0,75)$. Kot vidimo, je velikost efekta na gibalno neaktivnost in nizko intenzivnost gibanja srednja.

$\checkmark$ preglednici 2 so prikazani rezultati količine in posameznega fenotipa intenzivnosti gibalne aktivnosti otrok v času, ki ga preživijo v vrtcu (od 8. do 16. ure), in v času, ki ga preživijo v domačem okolju (od 16. do 20. ure). Rezultati kažejo, da otroci v času, ki ga preživijo v domačem okolju, dosežejo za $41 \%$ večjo količino gibalne aktivnosti $(p=0,026 ; E S=1,16)$, za $8 \%$ manj gibalne neaktivnosti $(p<0,001 ; E S=1,00)$, za $6 \%$ več nizke intenzivnosti gibalne aktivnosti ( $p<0,001 ; E S=1,20)$ in za $2 \%$ več srednje in visoke intenzivnosti gibalne aktivnosti $(p=0,024 ; E S=0,50)$ kot v času, ki ga preživijo v vrtcu. Kot vidimo, je velikost efekta na vse fenotipe gibalne aktivnosti srednja do velika.

Preglednica 3 prikazuje povezanost gibalne aktivnosti med tednom in koncem tedna. Rezultati kažejo srednjo moč pozitivne povezanosti celotne količine gibalne aktivnosti otrok $(r=0,688 ; p<0,001)$, časa gibalne neaktivnosti $(r=0,433 ; p>0,039)$ in časa nizke intenzivnosti $(r=0,500 ; p=0,015)$ gibalne aktivnosti. In sicer čas med tednom razloži med 19 in $47 \%$ variance povezano- 
Preglednica 3 Pearsonova povezanost $(r)$ fenotipov gibalne aktivnosti med tednom in koncem tedna

\begin{tabular}{lrr}
\hline Postavka & Pearsonova $r\left(r^{2}\right)$ & $p$ \\
\hline Skupna količina GA & $0,688(47 \%)$ & $<0,001$ \\
Gibalna neaktivnost & $0,433(19 \%)$ & 0,039 \\
Nizka intenzivnost GA & $0,500(25 \%)$ & 0,015 \\
Srednja in visoka intenzivnost GA & 0,262 & 0,227 \\
\hline
\end{tabular}

Preglednica 4 Pearsonova povezanost $(r$ ) fenotipov gibalne aktivnosti med dopoldanskim in popoldanskim časom.

\begin{tabular}{lrr}
\hline Postavka & Pearsonova $r\left(r^{2}\right)$ & $p$ \\
\hline Skupna količina GA & $0,448(20 \%)$ & 0,028 \\
Gibalna neaktivnost & 0,395 & 0,056 \\
Nizka intenzivnost GA & 0,208 & 0,330 \\
Srednja in visoka intenzivnost GA & $0,543(29 \%)$ & 0,006 \\
\hline
\end{tabular}

sti. V primerjavi časa srednje in visoke intenzivnosti gibalne aktivnosti nismo ugotovili povezanosti.

Preglednica 4 prikazuje povezanost gibalne aktivnosti med časom, ki so ga otroci preživeli v vrtcu, in časom, ki so ga preživeli v domačem okolju, in sicer le za obdobje od srede do petka. Rezultati kažejo srednjo moč pozitivne povezanosti celotne gibalne aktivnosti $(r=0,448 ; p=0,028)$ in časa srednje ter visoke intenzivnosti gibalne aktivnosti $(r=0,543 ; p=0,006)$. In sicer dnevni čas razloži med $20 \%$ in $29 \%$ variance povezanosti. V času nizke gibalne intenzivnosti nismo ugotovili povezanosti. Pravo tako smo ugotovili zgolj trend povezanosti časa gibalne neaktivnosti $(r=0,395 ; p=0,056)$.

\section{Razprava}

Cilj našega prispevka je bil z merilnikom pospeška izmeriti gibalno aktivnost in gibalno neaktivnost otrok med prvim in tretjim letom starosti ter preučiti znotrajdnevno in mednevno variabilnost gibalne aktivnosti. Ugotovili smo, da so otroci $46 \%$ dnevnega časa gibalno aktivni, tako $v$ nizki kot tudi $v$ srednji in visoki intenzivnosti gibalne aktivnosti. Žal pa kar $54 \%$ dnevnega časa preživijo gibalno neaktivno. V skladu z našimi rezultati je tudi raziskava E. Johansson idr. (2015), ki navajajo, da dve leti stari norveški otroci več kot $50 \%$ dnevnega časa preživijo gibalno aktivno.

Rezultate študij, ki preučujejo gibalno atkivnost šolskih otrok, velikokrat primerjamo s priporočili Svetovne zdravstvene organizacije (World Health Organization 2010). Slednja pravijo, naj bodo otroci in mladostniki med 5. 
in 17. letom deležni vsaj 60 minut srednje in visoke intenzivnosti na dan. Strokovnjaki iz različnih držav (Tremblay idr. 2012; Department of Health and Aging 2010; National Association of Sport and Physical Education 2009) so razvili priporočila gibalne aktivnosti za otroke, mlajše od pet let. Slednja pravijo, naj bodo predšolski otroci najmanj 90 minut dnevno gibalno aktivni, tako v nizki kot v visoki intenzivnosti. Priporočila gibalne aktivnosti za vrtčevske otroke ne omenjajo, koliko časa na dan naj bodo deležni posameznega fenotipa intenzivnosti, kot to omenjajo priporočila gibalne/športne aktivnosti za otroke, starejše od pet let, in mladostnike. Prav zato je nemogoče primerjati naše rezutlate $s$ priporočili gibalne aktivnosti za vrtčevske otroke, saj smo naše rezultate primerjali s priporočili Svetovne zdravstvene organizacije (World Health Organization 2010), ki priporoča, naj bodo otroci deležni vsaj 60 minut srednje in visoke intenzivnosti gibalne aktivnosti na dan. Večina študij, ki prečuje gibalno aktivnost predšolskih otrok, poroča, da znaten delež otrok ne izpolnjuje splošnih priporočil World Health Organization (2010; Hnatiuk idr. 2014), ampak da večji del dneva preživijo gibalno neaktivno (Aadland in Johannessen 2015; Van Cauwenberghe idr. 2012; Reilly 2008; Trucker 2008; Kuzik idr. 2015; Johanssson idr. 2015; Carson idr., 2019). Ugotovili smo, da so otroci deležni 36,4 do 128,3 minut dnevne srednje in visoke intenzivnosti gibalne aktivnosti, medtem pa kar 314,2 do 460,3 minut dnevne gibalne neaktivnosti. Do poodobnih ugotovitev so prišli tudi Andersen idr. (2017), ki poročajo, da so norveški predšolski otroci, stari tri in štiri leta, deležni od 16 do 116 dnevnih minut v srednji in visoki gibalni intenzivnosti, gibalno neaktivni pa so od 150 do 390 minut. Glede na te podatke lahko zaključimo, da je le 13 (54\%) naših otrok doseglo priporočila Svetovne zdravstvene organizacije, ki so sicer priporočena za pet- in večletne otroke. Poudariti pa gre tudi, da le pet otrok (21\%) sistematično vsakodnevno dosega ta priporočila. Vsa priporočila (Tremblay idr. 2012; Department of Health and Aging 2010; National Association of Sport and Physical Education 2009) za predšolske otroke poudarjajo večurno dnevno gibalno aktivnost, ki je razporejena skozi cel dan ter vključuje različne gibalne naloge in pripomočke, saj lahko otroci le tako razvijajo svoje gibalne sposobnosti in spretnosti.

T. Volmut (2014) v svoji študiji, v katero so bili vključeni slovenski otroci med petim in osmim letom starosti, navaja, da ni razlik med tednom in koncem tedna v celotni gibalni aktivnosti, gibalni neaktivnosti ter srednji in visoki intenzivnosti gibalne aktivnosti. Gibalna aktivnost otrok našega vzroca je bila med tednom in koncem tedna skoraj enaka, saj smo ugotovili, da ni razlik v količini gibalne aktivnosti ter deležom časa srednje in visoke intenzivnosti gibalne aktivnosti. Medtem pa lahko opazimo, da imajo otroci med tednom večjo gi- 
balno neaktivnost in manjši delež časa nizke intenzivnosti gibalne aktivnosti kot med koncem tedna. Ugotovili smo tudi povezanost količine gibalne aktivnosti, gibalne neaktivnosti in nizke intenzivnosti gibalne aktivnosti mlajših predšolskih otrok med tednom in koncem tedna, vendar ne moremo postavljati trditev o vplivu.

Splošni podatki Statističnega urada Republike Slovenije navajajo, da $64 \%$ otrok med prvim in drugim letom starosti med tednom obiskuje vrtce. Vsakdanji vrtčevski urnik omogoča, da so otroci v dopoldanskem času prosto ali organizirano gibalno aktivni na prostem ali v zaprtih prostorih. S. E. Benjamin idr. (2008) poudarjajo, da imajo vrtci pomembno vlogo pri vzpostavljanju vsakodnevnih gibalnih navad in zmanjševanju sedentarnih navad. Kljub temu pa rezultati študij kažejo, da temu ni tako, saj navajajo, da so otroci v času, ki ga preživijo v vrtcih, deležni preveč gibalne neaktivnosti ter malo časa srednje in visoke intenzivnosti (Vanderloo idr. 2014; Byun idr. 2013; Reilly 2010). Rezultati naše študije se ujemajo z ugotovitvami predhodno objavljenih študij (Vanderloo idr. 2014; Byun idr. 2013; Reilly 2010), saj kažejo, da imajo otroci večji delež časa gibalne neaktivnosti nižjo celotno količino gibalne aktivnosti, nižji delež časa nizke ter srednje in visoke intenzivnosti gibalne aktivnosti v času vrtca kot po njem. Ugotovili smo tudi povezanost količine gibalne aktivnosti, gibalne neaktivnosti ter srednje in visoke intenzivnosti gibalne aktivnosti mlajših predšolskih otrok v času, ki ga preživijo v vrtcu, in času, ki ga preživijo v domačem okolju, vendar ne moremo postavljati trditev o vplivu.

Zavedati se moramo, da je vključevanje gibalne aktivnosti v obstoječi kurikulum vrtcev učinkovita strategija za povečanje količine gibanja (Trost idr. 2002) in zmanjšanje gibalne neaktivnosti. Gibalna aktivnost otrok v času vrtca je odvisna od interesa, motivacije in strokovnega znanja vzgojiteljic glede izvajanja gibalnih aktivnosti. Ne smemo zanemariti tudi dobrih materialnih in prostorskih dejavnikov, ki so poleg dobrega in usposobljenega kadra pomembni pri uresničevanju kakovostnih gibalnih aktivnosti v vrtcu, katerih cilj je celosten razvoj otroka (Zajec 2009). J. Zajec (2009) v svoji doktorski disertaciji ugotavlja, da imajo le redki vrtci ustrezne posebne prostore in športne pripomočke za izvajanje gibalnih aktivnosti. Vzgojitelji najpogosteje izvajajo gibalne aktivnosti ravno $v$ manj primernih prostorih, in sicer vigralnicah, nato $\checkmark$ večnamenskih prostorih, na hodnikih, $v$ športni igralnici in drugje.

Nižjo gibalno aktivnost otrok med prvim in tretim letom starosti $v$ času vrtca lahko pripisujemo tudi dolžini dnevnega spanja. Več kot $90 \%$ otrok (Blair idr. 2012) te starosti čez dan še vedno povprečno spi od ene do treh ur (Pantley 2003; Blair idr. 2012). Zato menimo, da bi bilo potrebno v prihodnjih študijah izključiti čas dnevnega spanja, saj bi le tako dobili realnejše podatke 
o gibalni aktivnosti v času, ki ga otroci preživijo v vrtcu. Menimo, da lahko razlog za nižjo gibalno aktivnost mlajših predšolskih otrok $v$ času, ki ga preživijo $v$ vrtcu, pripisujemo tudi mnenju vzgojiteljic, da otroci v tej starosti ne zmorejo daljših in zahtevnejših aktivnosti. $V$ našo raziskavo je zajet le majhen delež mlajših predšolskih otrok, zato rezultatov ne moremo posplošiti, predlagamo pa, da se v prihodnje naredi obširnejša študija, katere namen bo preučiti gibalne navade otrok med prvim in tretjim letom starosti.

Dobljeni rezultati zagotavljajo boljše razumevanje vzorcev gibalne aktivnosti in gibalne neaktivnosti najmlajših predšolskih otrok. Le $z$ dobrim poznavanjem vzorcev gibalne aktivnosti in neaktivnosti lahko načrtujemo ter izvajamo gibalne intervencije, katerih namen je povečati gibalno aktivnost otrok in zmanjšati gibalno neaktivnost najmlajših predšolskih otrok.

\section{Literatura}

Aadland, E., in K. Johannessen. 2015. »Agreement of Objectively Measured Physical Activity and Sedentary Time in Preschool Children."Preventive Medicine Reports 21 (2): 635-639.

Andersen, E., J. Borch-Jenssen, S. Øvreås, H. Ellingsen, K. A. Jørgensen in T. Moser. 2017. »Objectively Measured Physical Activity Level and Sedentary Behavior in Norwegian Children during a Week in Preschool.» Preventive Medicine Reports 7:130-135.

Benjamin, S. E., A. Cradock, E. M. Walker, M. Slining in M. W. Gillman. 2008. »Obesity Prevention in Child Care: A Review of U.S. State Regulations."BMC Public Health 30 (8): 188.

Blair, S. N., Y. Cheng in S. J. Holder. 2001. »/s Physical Activity or Physical Fitness More Important in Defining Healt Benefits? « Medicine and Science in Sports and Exercise 33 (6): 379-399.

Blair, P. S., J. S. Humphreys, P. Gringras, S. Taheri, N. Scott, A. Emond, J. Henderson in P. J. Fleming. 2012. "Childhood Sleep Duration and Associated Demographic Characteristics in an English Cohort." SLEEP 35 (3): 353-360.

Brasholt, M., B. Chawes, E. Kreiner-Møller, S. Vahlkvist, M. Sinding in H. Bisgaard. 2013. »Objective Assessment of Levels and Patterns of Physical Activity in Preschool Children.«Pediatric Research 74 (3): 333-338.

Bringolf-Isler, B., L. Grize, U. Mäder, N. Ruch, F. H. Sennhauser in C. BraunFahrländer. 2009. "Assessment of Intensity, Prevalence and Duration of Everyday Activities in Swiss School Children: A Cross-Sectional Analysis of Accelerometer and Diary Data.« International Journal of Behavioral Nutrition and Physical Activity 6 (50). https://www.doi.org/10.1186/1479-5868-6 $-50$

Byun, W., S. Blair in R. Pate. 2013. „Objectively Measured Sedentary Behavior in Preschool Children: Comparison between Montessori and Traditional Pre- 
schools. International Journal of Behavioral Nutrition and Physical Activity 10:2-7.

Cain, K. L., J. F. Sallis, T. L. Conway, D. Van Dyck in L. Calhoon. 2013. »Using Accelerometers in Youth Physical Activity Studies: A Review of Methods. "Journal of Physical Activity and Health 10 (3): 437-450.

Canadian Society of Exercise Physiology. 2015. »Canadian Sedentary Behaviour Guidelines for the Early Years (o-4 Years).« http://www.csep.ca/CMFiles/ Guidelines/CSEP_SBGuidelines_early-years_en.pdf

Cardon, G., E. Van Cauwenberghe in I. De Bourdeaudhuij. 2011. »What Do We Know about Physical Activity in Infancy and Toddlers: A Review of the Literature and Future Research Directions." Science and Sports 26:127-130.

Carson, V., E.-Y. Lee, K. D. Hesketh, S. Hunter, N. Kuzik, M. Predy, R. E. Rhodes, C. M. Rinaldi, J. C. Spence in T. Hinkley. 2019. »Physical Activity and Sedentary Behavior Across Three Time-Points and Associations with Social Skills in Early Childhood."BMC Public Health 19 (1): 27.

Certain, L. K., in R. S. Kahn. 2002. »Prevalence Correlates and Trajectory of Television Viewing among Infants and Toddlers.« Pediatrics 109 (4): 634-642.

Cliff, D. P., J. J. Reilly in A. D. Okely. 2009. »Methodological Considerations in Using Accelerometers to Assess Habitual Physical Activity in Children Aged 0-5 Years." Journal of Science and Medicine in Sport 12 (5): 557-567.

Department of Health and Aging. 2010. Get up and Grow: Healthy Eating and Physical Activity for Early Childhood. Canberra: Australian Government.

Esliger, D. W., J. L. Copeland, J. D. Barnes in M. S. Tremblay. 2005. "Standardizing and Optimizing the Use of Accelerometer Data for Free-Living Physical Activity Monitoring. " Journal of Physical Activity and Health 2 (3): 366-383.

Grønholt Olesen, L., P. Lund Kristensen, M. Ried-Larsen, A. Grøntved in K. Froberg. K. 2014. »Physical Activity and Motor Skills in Children Attending 43 Preschools: A Cross-Sectional Study.« BMC Pediatrics 14:229. https://www .doi.org/10.1186/1471-2431-14-229

Hardman, C. A., P. J. Horne in A. V. Rowlands. 2009. „Children's PedometerDetermined Physical Activity During School-Time and Leisure-Time.« Journal of Exercise Science \& Fitness 7 (2): 129-134.

Hesketh, K. R., S. J. Griffin in E. M. F. van Sluijs 2015. »UK Preschool-Aged Children's Physical Activity Levels in Childcare and at Home: A Cross-Sectional Exploration. « International Journal of Behavioral Nutrition and Physical Activity 12:123.

Hinkley, T., E. O'Connell, A. D. Okely, D. Crawford, K. Hesketh in J. Salmon. 2012. »Assessing Volume of Accelerometry Data for Reliability in Preschool Children.« Medicine and Science in Sports and Exercise 44 (12): 2436-2441.

Hnatiuk, J. A., J. Salmon, T. Hinkley, A. D. Okely in S. Trost. 2014. »A Review of Preschool Children's Physical Activity and Sedentary Time Using Objective Measures."American Journal of Preventive Medicine 47 (4): 487-497. 
Janz, K. F., T. L. Burns in S. M. Levy. 2005. »Tracking of Activity and Sedentary Behaviors in Childhood: The lowa Bone Development Study.«American Joural of Preventive Medicine 29 (3): 171-178.

Johansson, E., M. Hagströmer, V. Svensson, A. Ek, M. Forssén, H. Nero in C. Marcus. 2015. »Objectively Measured Physical Activity in Two-Year-Old Children: Levels, Patterns and Correlates. International Journal of Behavioral Nutrition and Physical Activity 12:3. https://www.doi.org/10.1186/s12966 -015-0161-0

Kipling Webster, E., C. K. Martin in A. E. Staiano. 2019. »Fundamental Motor Skills, Screen-Time, and Physical Activity in Preschoolers." Journal of Sport and Health Science 8 (2): 114-121.

Kriska, A. M., A. Saremi, R. L. Hanson, P. H. Bennett, S. Kobes, D. E. Williams in W. C. Knowler. 2003. »Physical Activity, Obesity, and the Incidence of Type 2 Diabetes in a High-Risk Population. « American Journal of Epiodemiology 158 (7): 669-675.

Kuzik, N., D. Clark, N. Ogden, V. Harber in V. Carson. 2015. »Physical Activity and Sedentary Behaviour of Toddlers and Preschoolers in Child Care Centres in Alberta, Canada."Canadian Journal of Public Health 106 (4): e178-e183.

LeBlanc, A. G., J. C. Spence, V. Carson, S. Connor Gorber, C. Dillman, I. Janssen, M. E. Kho, J. A. Stearns, B. W. Timmons in M. S. Tremblay. 2012. "Systematic Review of Sedentary Behaviour and Health Indicators in the Early Years (Aged o-4 Years).«Applied Physiology, Nutrition, and Metabolism 37 (4): 753772.

Metcalf, B. S., J. S. H. Curnow, C. Evans, L. D. Voss in T. J. Wilkin. 2002. »Technical Reliability of the CSA Activity Monitor: The Early Bird Study." Medicine and Science of Sports and Exercise 34 (9): 1533-1537.

National Association for Sport and Physical Education. 2009. Active Start: A Statement of Physical Activity Guidelines for Children from Birth to Age 5. 2. izd. Sewickley, PA: American Alliance for Health, Physical Education, Recreation, and Dance.

Pantley, E. 2003. Otroško spanje - brez joka v sanje. Radovljica: Didakta.

Pišot, R., in J. Planinšec. 2005. Struktura motorike v zgodnjem otroštvu: motorične sposobnosti v zgodnjem otroštvu v interakciji z ostalimi dimenzijami psihosomatičnega statusa otroka. Koper: Annales.

Reilly, J. J. 2008. »Physical Activity, Sedentary Behaviour and Energy Balance in the Preschool Child: Opportunities for Early Obesity Prevention. "The Proccedings of the Nutrition Society 67 (3): 317-325.

- 2010. "Low Levels of Objectively Measured Physical Activity in Preschoolers in Child Care.« Medicine and Science in Sports and Exercise 42 (3): 502-507.

Riddoch, C. J., L. Bo Andersen, N. Wedderkopp, M. Harro, L. Klasson-Heggebø, L. B. Sardinha in A. B. Cooper. 2004. »Physical Activity Levels and Patterns 
of 9- and 15-Yr-Old European Children. «Medicine and Science in Sports and Exercise 36 (1): 86-92.

Riddoch, C. J., C. Mattocks, K. Deere, J. Saunders, J. Kirkby, K. Tilling, S. D. Leary, S. N. Blair in A. R. Ness. 2007. "Objective Measurement of Levels and Patterns of Physical Activity." Archives of Disease in Childhood 92 (11): 963-969.

Rowlands, A. V. 2007. »Accelerometer Assessment of Physical Activity in Children: An Update.« Pediatric Exercise Science 19 (3): 252-266.

Timmons, B. W., P. J. Naylor in K. A. Pfeiffer. 2007. »Physical Activity for Preschool Children: How Much and How? «Canadian Journal of Pubblic Health 98 (S2): 122-134.

Trayers, T., A. R. Cooper, C. J. Riddoch, A. R. Ness, K. R. Fox, R. Deem in D. A. Lawlor. 2006. „Do Children from an Inner City British School Meet the Recommended Levels of Physical Activity?« Archives of Disease in Childhood 91 (2): 175-176.

Treuth, M. S., N. Hou, D. R. Young in M. Maynard. 2005. »Accelerometry-Measured Activity or Sedentary Time and Overweight in Rural Boys and Girls." Obesity Research 13 (9): 1606-1614.

Tremblay, M. S., A. G. Leblanc, V. Carson, L. Choquette, S. Connor Gorber, C. Dillman, M. Duggan idr. 2012. „Canadian Physical Activity Guidelines for the Early Years (Aged o-4 Years).« Applied Physiology, Nutrition, and Metabolism 37 (2): 345-356.

Trost, S. G., R. R. Pate, P. S. Freedson, J. F. Sallis in W. C. Taylor. 2000. »Using Objective Physical Activity Measures with Youth: How Many Days of Monitoring are Needed?« Medicine and Science in Sports and Exercise 32 (2): 426-431.

Trost, S. G., R. R. Pate, J. F. Salis, P. S. Freedson, W. C. Taylor, M. Dowda in J. Sirard. 2002. "Age and Gender Differences in Objectively Measured Physical Activity in Youth." Medicine and Science in Sports and Exercise 34 (2): 350-355.

Trost, S. G., B. S. Fees, S. J. Haar, A. D. Murray in L. K. Crowe. 2012. »Identification and Validity of Accelerometer Cut Points for Toddlers. «Obesity 20 (11): 23172319.

Tucker, P. 2008. „The Physical Activity Levels of Preschool-Aged Children: A Systematic Review.«Early Childhood Research Quarterly 23:547-558.

Vale, S., P. Silva, R. Santos, L. Soares-Miranda in J. Mota. 2010. „Compliance with Physical Activity Guidelines in Preschool Children. « Journal of Sports Science 28 (6): 603-608.

Vale, S., S. G. Trost, C. Rêgo, S. Abreu in J. Mota. 2015. »Physical Activity, Obesity Status, and Blood Pressure in Preschool Children. «The Journal of Pediatrics 167 (1): 98-102.

Van Cauwenberghe, E., R. A. Jones, T. Hinkley, D. Crawford in A. D. Okely. 2012. »Patterns of Physical Activity and Sedentary Behaviour in Preschool Children. «The International Journal of Behavioral Nutrition and Physical Activity 9:138. https://www.doi.org/10.1186/1479-5868-9-138 
Vanderloo, L. M., in P. Tucker. 2015. »An Objective Assessment of Toddlers' Physical Activity and Sedentary Levels: A Cross-Sectional Study.«BMC Public Health 15:969. https://www.doi.org/10.1186/s12889-015-2335-8

Vanderloo, L. M., P. Tucker, A. M. Johnson, M. M. van Zandvoort, S. M. Burke in J. D. Irwin. 2014. „The Influence of Centre-Based Childcare on Preschoolers' Physical Activity Levels: A Crosssectional Study.« International Journal of Environmental Research and Public Health 11:1794-1802.

Vandewater, E. A., V. J. Rideout, E. A. Wartella, X. Huang, J. H. Lee in M. S. Shim. 2007. »Digital Childhood: Electronic Media and Technology Use among Infants, Toddlers, and Preschoolers.«Pediatrics 119 (5): e1006-e6015.

Verbestel, V., E. Van Cauwenberghe, V. De Coen, L. Maes, I. De Bourdeaudhuij in G. Cardon. 2011. »Within- and Between-Day Variability of Objectively Measured Physical Activity in Preschoolers. « Pediatric Exercise Science 23 (3): 366-378.

Volmut, T. 2014. »Z merilnikom pospeška izmerjena gibalna/športna aktivnost mlajših otrok in analiza izbranih intervencij.» Doktorska disertacija, Univerza na Primorskem.

Zajec, J. 2009. »Povezanost športne dejavnosti predšolskih otrok in njihovih staršev z izbranimi dejavniki zdravega načina življenja.« Doktorska disertacija, Univerza v Ljubljani.

Zimmerman, F., D. A. Christakis in A. N. Meltzoff. 2007. »Television and DVD/Video Viewing in Children Younger than 2 Years." Archives of Pediatrics and Adolescent Medicine 161 (5): 473-479.

World Health Organization. 2010. Global Recommendations on Physical Activity for Health. Geneva: World Health Organization.

\section{Accelerometer Assessed Physical Activity and Inactivity of Children between the First and Third Years of Age}

Objective: The aim of our study is to examine the physical activity and inactivity of children between the first and third year of age, and to study the correlation of the intra-day and inter-day variability of physical activity phenotypes. Methods: Twenty-four children, between the first and third year of age, from three Slovenian kindergartens, wore an accelerometer for five consecutive days. We compared the phenotypes of the intensity of the physical activity during the time of the kindergarten ( $9 \mathrm{am}-4 \mathrm{pm}$ ) and after (16-20 pm), and between the week (Wednesday-Friday) and the end of the week (Saturday-Sunday). Results: On average, children reached $571 \pm 200$ counts per minute, of which 389 \pm 43 minutes were inactive, with a moderate and vigorous physical activity of $71 \pm 25$ minutes. During the week, they were $4 \%$ more physically inactive ( $p=$ $0.017 ; E S=0.57)$ and $3 \%$ less time in low intensity physical activity $(p=0.002$; $E S=0.75)$ as during the weekend. After the kindergarten they were $41 \%$ more physically active $(p=0.026, E S=1.16), 8 \%$ less inactive $(p<0.001, E S=1.00), 6 \%$ 
less time in low intensity of physical activity $(p<0.001, E S=1.20)$ and for $2 \%$ more in modetate to vigorous physical activity $(p=0.024, E S=0.50)$. We found also a correlation between the total physical activity during the week and the weekend $(r=0.688, p<0.001)$, as well as during the kindergarten time and afterwards $(r=0.448, p=0.028)$. Conclusion: The study provides important physical activity data of the youngest, one to three year olds, children who indicate the correlations of physical activity at different times of the day and between days, which should be taken into account when designing children's physical programs.

Keywords: accelerometer, kindergarten, week, weekend, morning, afternoon 



\title{
Gibalna/športna (ne)aktivnost vzgojiteljic in njihova kompetentnost za razvoj gibanja predšolskih otrok v prvem starostnem obdobju
}

\author{
Matej Plevnik \\ Univerza na Primorskem \\ matej.plevnik@fvz.upr.si \\ Tanja Peternelj \\ Univerza na Primorskem \\ peternelj.tanja@gmail.com
}

\begin{abstract}
Potreba po gibanju je otrokova primarna potreba. Zato ima razvoj gibanja, kot enega od področij dejavnosti v vrtcu, še poseben pomen. Otrok je v zgodnjem otroštvu izredno dojemljiv za impulze okolja, vpliv v tem obdobju pridobljenih gibalnih izkušenj je za njegov nadaljnji razvoj izredno pomemben. Vrtec je poleg staršev v obdobju otroštva izredno pomembno okolje, saj otroci v njem preživijo večino svojega dneva. Otroci naj bi bili v okolju vrtca deležni mnogoterih gibalnih izkušenj, kar pa je povezano z ustreznim načrtovanjem, organiziranjem, izvajanjem in vrednotenjem izvedbe gibalnih/športnih aktivnosti s strani vzgojiteljice, na kar ima vpliv tudi njena kompetentnost za vodenje omenjenih vsebin. V študiji je sodelovalo 65 vzgojiteljic, ki poučujejo predšolske otroke $v$ prvem starostnem obdobju. Zanimala nas je razvitost njihovih kompetenc za razvoj vsebin gibanja, tudi v povezavi z njihovo lastno redno gibalno/športno aktivnostjo. Ugotovili smo, da gibalno/športno aktivnejše vzgojiteljice svoje kompetence za razvoj gibanja predšolskih otrok ocenjujejo višje. Ključne besede: razvoj, gibalna/športna aktivnost, kompetentnost, otrok, okolje
\end{abstract}

\section{Uvod}

Posamezna področja razvoja otroka so še posebej v predšolskem obdobju izrazito povezana in prepletena. Razvoj telesnega, gibalnega, senzornega, spoznavnega, čustvenega ali socialnega področja ima hkraten vpliv tudi na druga omenjena področja razvoja. $\vee$ predšolskem obdobju je pomemben cilj programov vzgoje in izobraževanja, v katere je otrok vključen, tudi izpostavljenost otroka bogatemu izkušenjskemu okolju, v katerem bo lahko razvijal svoje potenciale in si pridobival pestro ter široko paleto raznovrstnih izkušenj na vseh področjih razvoja, ki jih bo v prihodnosti bogatil in nadgrajeval (Gallahue, Ozmun in Goodway 2012, 186; Pišot in Jelovčan 2012, 28). Okolje otroka 
v predšolskem obdobju, vsaj v času vključenosti v redne programe vzgoje in izobraževanja, lahko delimo na vsaj dva pomembna vidika. Prvi je vidik fizičnega okolja, v katerega je vključen otrok. Tega predstavlja vrtec sam kot objekt, s tem povezana pa umestitev objekta $v$ širši prostor (npr. bližina narave, velikost zunanjih površin ...), značilnosti samega objekta (svetlost prostorov, velikost igralnic/učilnic, možnost izhoda na teraso ...), opremljenost objekta z igrali, s pripomočki in z drugo opremo ter druge značilnosti, vezane na vrtec kot objekt. Drugi, za razvoj predšolskega otroka pomembnejši, pa je vidik socialnega okolja. Tega predstavljajo drugi otroci, vključeni v oddelek, in vzgojitelj/-ica predšolskih otrok ter pomočnik/pomočnica vzgojitelja (ter drugi vključeni v oddelek), ki delo v oddelku načrtujeta, organizirata, izvajata in vrednotita. Kompetentnost vzgojiteljice za razvoj posameznih področij razvoja otroka v predšolskem obdobju je tesno povezana z vsebino in kvaliteto izvedenih aktivnosti.

Družbene, politične in gospodarske razmere družbe znanja so danes turbulentne in se odražajo tudi v vzgojno-izobraževalnem prostoru. Zato je pomembno, da se še posebej vzgojitelji in učitelji, ki delajo $z$ otroki v najranljivejših in najdločilnejših razvojnih obdobjih otroštva, zavedajo pomena vseživljenjskega učenja, ki temelji na poglabljanju in razvijanju ključnih kompetenc, na podlagi katerih načrtujejo, izvajajo in usmerjajo dejavnosti otrok $v$ predšolskem obdobju. Pouk $v$ družbi znanja se spreminja in $z$ njim vloga učitelja, ki ni več le prenašalec znanja, temveč moderator, animator, organizator spodbudnega učnega okolja, mentor in spodbujevalec samostojnega učenja (Retar in Lepičnik Vodopivec 2017, 2). Dokument o ustvarjalnih in inovativnih učnih okoljih med možnosti, s katerimi vzgojno-izobraževalne ustanove bogatijo obstoječe pristope poučevanja in vzgoje, umešča raznolikost in prepletanje pedagoških prijemov, ki učence pritegnejo k udejstvovanju in uresničujejo prilagajanje posamezniku, kar se nanaša tudi na krepitev skupinskega dela ob hkratni individualizaciji (Organisation for Economic CoOperation and Development 2013, 14). Prilagajanje družbenim razmeram in smernicam različnih organizacij je odločujoče povezano $z$ vsaj tremi procesi, v katere je vključen vzgojitelj, to so učenje in motiviranost, kompetentnost za načrtovanje ter organiziranje, izvajanje in vrednotenje vsebine $v$ okviru programov predšolske vzgoje. Učenje UNESCO (2011) opredeljuje kot vsako spremembo v vedenju, informiranosti, znanju, razumevanju, stališčih, spretnostih ali zmožnostih, ki je trajna in je ne moremo pripisati fizični rasti ali razvoju podedovanih vedenjskih vzorcev (Maretič Požarnik 2012, 10). Motivacija povzroča in usmerja delovanje posameznika in obsega vsa gibala vedenja: potrebe, nagone, motive, želje, cilje, vrednote, ideale, interese in voljo 
(Kohont 2005, 36). Kompetentnost Retar, Plevnik in Kolar $(2013,5)$ opisujejo kot zmožnost uporabe znanja, spretnosti, izkušenj, veščin, odnosov, osebnostnih lastnosti in motivacije, da posameznik na sebi lasten način uspešno opravi pričakovano delo. Rezultat vzgojiteljeve kompetentnosti na določenem področju so torej načini načrtovanja, organizacije, izvedbe in vrednotenja vsebin predšolske vzgoje, $v$ katero je vključen otrok. Zato je zavedanje svoje kompetentnosti, ki vključuje tako prepoznavo strokovno močnih kot šibkejših področij, izredno pomembno za strokovno nadgrajevanje in bogatitev kompetenc vzgojitelja v procesu vseživljenjskega razvoja in učenja.

Gibalna/športna aktivnost ima v razvoju otroka izredno pomemben prispevek (Malina, Bouchard in Bar-Or 2004, 480; Weiler idr. 2013). Za njegov normalen razvoj in oblikovanje zrele osebnosti predstavlja nenadomestljiv vir izkušenj. Jasne smernice in priporočila glede količine in intenzivnosti gibalnih/športnih aktivnosti predšolskih otrok v prvem starostnem obdobju ne obstajajo, zgolj vsebinska priporočila (Timmons, Naylor in Pfeiffer 2007). Mednarodna in po njih povzeta nacionalna poročila o priporočljivi količini in intenzivnosti gibalne/športne aktivnosti se za otroke začnejo s petimi leti starosti (World Health Organization 2010). T. Volmut, P. Dolenc in Šimunič (2010, 25-26) to aktivnost opisujejo kot kompleksen proces, s tem povezano pa je tudi njeno merjenje in spremljanje. Narava gibalnih/športnih aktivnosti mlajših otrok se v marsičem razlikuje od gibalnih/športnih aktivnosti, ki so značilna za druge starostne skupine. Gibalna/športna aktivnost predšolskih otrok $v$ prvem starostnem obdobju je usmerjenja predvsem $v$ učenje komunikacije $z$ okoljem z usvajanjem lokomotornega gibanja (naravnih oblik gibanja), ki omogoča gibanje po prostoru, ter z izvedbo spretnostnih gibalnih veščin, ki omogočajo samostojno opravljanje nalog (npr. hranjenje z žlico, listanje knjig ...). V vsebino gibalnih/športnih aktivnosti so lahko vključene tudi nekatere lažje veščine in elementi posameznih športov, v kolikor so ustrezno osmišljeni. Obdobje prvega starostnega obdobja predšolskega otroka je obdobje razvoja temeljnih gibalnih vzorcev in spretnosti, med katere so vključene tudi nekatere športne veščine. Zato je področje gibanja $\checkmark$ predšolskem obdobju pogosto vsebinsko opredeljeno tudi kot področje gibalnih/športnih aktivnosti. Gibalne izkušnje predšolskega otroka ob zaključku prvega starostnega obdobja predstavljajo temelj prehoda v obdobje zgodnjega otroštva, ki je odločilno za razvoj kvalitete elementarnih gibalnih vzorcev in struktur (Plevnik in Pišot 2016, 31). Če otrok ne usvoji ustreznih gibalnih vzorcev, obstaja velika verjetnost, da bo imel v nadaljnjem gibalnem razvoju težave (Gallahue, Ozmun in Goodway 2012). Cilji za področje dejavnosti gibanja, ki so opredeljeni v Kurikulumu za vrtce (Ministrstvo za šolstvo 
in šport 1999), za otroke v prvem starostnem obdobju predvidevajo predvsem mnogotero in raznovrstno izpostavljenost različnim dražljajem okolja in nalog, ki spodbujajo pridobivanje bogatih gibalnih izkušenj in opravljanje različnih gibalnih izzivov $z$ namenom razvoja zavedanja lastnega telesa $v$ prostoru in doživljanja pozitivnih občutkov $v$ gibanju ter usvajanje najrazličnejših osnovnih gibalnih struktur (Videmšek in Pišot 2007, 112; Lemos, Avigo in Barela 2012).

Otrok je v zgodnjem otroštvu izredno dojemljiv za dražljaje okolja, vpliv gibalnih izkušenj je $v$ tem obdobju največji. Poznavanje osnovnih zakonitosti rasti in razvoja ter razvojnih značilnosti otrok je predpogoj za smiselno načrtovanje dela in izbiro primernih vsebin gibalnih/športnih aktivnosti. Vzgojitelj mora poznati biološke dejavnike razvoja otroka, teorijo gibalne/športne vzgoje in pedagoškega dela. Poznati mora tudi najrazličnejše otrokove lastnosti in sposobnosti, da proces usvajanja gibalnih vsebin primerno zastavi in ga po potrebi tudi individualno prilagodi (Pišot in Jelovčan 2012, 7). Tu pa prihaja $v$ ospredje vzgojiteljeva kompetentnost za načrtovanje, organiziranje, izvajanje in vrednotenje vsebin gibalnih/športnih aktivnosti za otroke v predšolskem obdobju.

\section{Metode}

\section{Postopek zbiranja podatkov}

Za namen izvedbe študije smo oblikovali vprašalnik, ki smo ga vnesli v portal 1ka.si. Povezavo do vprašalnika smo poslali na več skupin, $v$ katere se združujejo vzgojiteljice predšolskih otrok na portalu facebook.si. Povezava je bila dostopna med 11. marcem in 1. junijem 2014. Vprašanja so se nanašala na več vsebinsko zaokroženih sklopov, in sicer: (i) osebne značilnosti vzgojiteljice (spol, starost, delovno mesto, delovna doba, delo s starostno skupino, zaposlitveni status, formalna izobrazba, kraj dela) (ii) značilnosti gibalnih navad vzgojiteljice (odnos do gibalne/športne aktivnosti, zgodovina gibalnega/športnega udejstvovanja), (iii) značilnosti vrtca (velikost vrtca, mnenje o opremljenosti z ustrezno infrastrukturo), (iv) kompetence za izvajanje različnih področij vsebin in (v) kompetence za izvajanje gibalne/športne aktivnosti.

Oceno kompetentnosti so preiskovanke ocenjevale na lestvici od 1 (izredno slaba ocena kompetentnosti) do 6 (odlično razvita kompetenca). Dosegli smo 503 klike na povezavo, pri čemer pa je bilo za nadaljnjo analizo ustrezno izpolnjenih 167 vprašalnikov. Vprašalnik je ustrezno izpolnilo 39 \% vzgojiteljic $(N=65)$, ki v vrtcu delajo $z$ otroki prve starostne skupine ter $61 \%$ vzgojiteljic $(N=102)$, ki v vrtcu delajo $z$ otroki druge starostne skupine. 


\section{Vzorec}

V nadaljnjo analizo smo skladno s cilji znanstvenega sestanka vključili odgovore vzgojiteljic, ki so v času izpolnjevanja vprašalnika v vrtcu delale $z$ otroki prve starostne skupine. Podvzorec preiskovancev, ki smo ga tako vključili v analize za potrebe prispevka, je predstavljal 65 enot.

Preiskovanci so bili v 64 primerih ženskega spola ${ }^{1}$ ter 1 primeru moškega spola, njihova povprečna starost je bila 37,1 $\pm 10,7$ let. Značilnosti njihovega zaposlitvenega statusa so bile naslednje: $80 \%$ preiskovank je imelo pogodbo o zaposlitvi za nedoločen čas, $18,5 \%$ preiskovank pogodbo za določen čas, $1,5 \%$ preiskovank pa jo bilo v delo vključenih kot pripravnice. $V$ povprečju so bile zaposlene 13,1 $\pm 12,02$ let (najmanj 1, največ 36 ).

Glede zgodovine ukvarjanja z gibalno/športno aktivnostjo je 52,3\% preiskovank navedlo, da so se $v$ preteklosti aktivno ukvarjale s športom (pomeni, da so bile vključene $v$ reden proces športne vadbe), medtem ko $47,7 \%$ preiskovank nima zgodovine rednega ukvarjanja s športom. Glede trenutnega statusa ukvarjanja z gibalno/športno aktivnostjo (kar pomeni redno izvajanje gibalne/športne aktivnosti, vsaj 2-krat tedensko) je 64,4\% preiskovank odgovorilo, da so redno gibalno/športno aktivne, in $35,6 \%$, da niso.

\section{Obdelava podatkov}

Podatke smo analizirali $z$ računalniškim programom za statistične analize SPSS 23.0, in sicer z metodami opisne statistike. Rezultati so prikazani kot aritmetična sredina \pm standardni odklon ( $\mathrm{AS} \pm \mathrm{SO}$ ). Po testiranju predpostavk statističnih testov smo statistično značilnost razlik $v$ oceni kompetentnosti med skupinama redno gibalno/športno aktivnih in neaktivnih vzgojiteljic izračunali z neparametričnim Mann-Whitneyevim U-testom. Stopnjo tveganja smo določili pri $p<0.05$.

\section{Rezultati in razprava}

Preiskovanke so navedle, da so zaposlene $v$ vrtcu, v katerega je po njihovi oceni vključenih $247,2 \pm 237,11$ otrok (najmanj 19, največ 750 ). Glede opremljenosti vrtca z opremo za izvajanje gibalnih/športnih aktivnosti $20 \%$ preiskovank ocenjuje, da je opremljenost vrtca odlična (imajo na voljo več opreme, kot jo običajno uporabljajo); $58,5 \%$, da je zadovoljiva (imajo na voljo toliko opreme, kot jo redno tudi uporabljajo), ter 21,5\% preiskovank, da je opremljenost slaba (opreme in pripomočkov za delo jim primanjkuje).

\footnotetext{
'Zaradi prevladujočega števila preiskovancev ženskega spola bomo v nadaljevanju za oba spola uporabljali žensko slovnično obliko.
} 
Preglednica 1 Ocena kompetentnosti za izvajanje vsebin področij dejavnosti v predšolski vzgoji

\begin{tabular}{lrr}
\hline Področje dejavnosti & AS \pm SO & $p$ \\
\hline Gibanje & $4,9 \pm 0,85$ & $U=196, p=0,022$ \\
Umetnost & $4,9 \pm 0,84$ & \\
Jezik & $4,9 \pm 0,82$ & \\
Družba & $4,8 \pm 0,81$ & \\
Narava & $4,8 \pm 0,82$ & \\
Matematika & $4,6 \pm 0,74$ & \\
\hline
\end{tabular}

Opombe AS - aritmetična sredina, SO - standardni odklon, $p$ - statistično značilna razlika v oceni kompetentnosti med gibalno/športno aktivnimi in neaktivnimi vzgojiteljicami.

Z vidika izvajanja posameznih področij dejavnosti smo vzgojiteljice najprej povprašali o njihovi oceni kompetentnosti za izvajanje posamezne vsebine (preglednica 1).

Skupina gibalno/športno (G/Š) aktivnih vzgojiteljic statistično značilno višje ocenjuje svojo kompetentnost za izvajanje vsebin področja gibanja (G/Š aktivne $5,12 \pm 0,69 ; G / S ̌$ neaktivne $4,5 \pm 0,99 ; U=196, p=0,022)$. Ocena kompetentnosti za izvajanje drugih področij se med omenjenima skupinama statistično značilno ne razlikuje. Vzgojiteljice, ki delajo z otroki v prvem starostnem obdobju, najvišje ocenjujejo svojo kompetentnost za izvajanje dejavnosti s področij gibanja, umetnosti in jezika, slabše pa ocenjujejo kompetence za izvajanje vsebin matematike.

Skupina gibalno/športno aktivnih vzgojiteljic statistično značilno višje ocenjuje naslednje kompetence izvajanja gibalnih/športnih aktivnosti z vidika načrtovanja (preglednica 2): znam pripraviti letni program gibalnih/ športnih aktivnosti (G/Š aktivne 4,61 \pm 0,83; G/Š neaktivne $3,78 \pm 1,11 ; U=$ 173; $p=0,010)$, znam prepoznati otroke $s$ posebnostmi $v$ gibalnem razvoju in prilagajati delo njihovim posebnostim (G/Š aktivne $4,71 \pm 1,0$; $G / S ̌$ neaktivne $4,11 \pm 1,0 ; U=207 ; p=0,048)$, znam načrtovati program gibalnih/športnih aktivnosti z organizacijskega vidika (G/Š aktivne $4,82 \pm 0,83 ; \mathrm{G} / \mathrm{S}$ neaktivne 4,11 $\pm 1,02 ; U=187,5 ; p=0,016$ ), znam načrtovati program gibalnih/športnih aktivnosti s količinskega vidika (G/Š aktivne 4,82 $\pm 0,80$; G/Š neaktivne 4,06 $\pm 1,0$; $U=184,5 ; p=0,013)$, znam načrtovati program gibalnih/športnih aktivnosti z didaktičnega vidika (G/Š aktivne 5,00 $\pm 0,78 ; \mathrm{G} / S ̌$ neaktivne 4,22 $\pm 0,94 ; U=$ $178 ; p=0,009$ ) ter znam načrtovati svoj strokovni razvoj in vseživljenjsko uče-

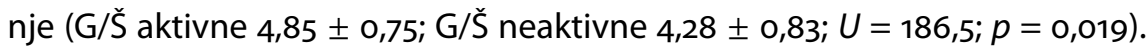
Vzgojiteljice, ki delajo z otroki v prvem starostnem obdobju, pri izvajanju gibalnih/športnih aktivnosti v vrtcu z vidika načrtovanja najvišje ocenjujejo 
Preglednica 2 Ocena kompetentnosti za izvajanje gibalnih/športnih aktivnosti v vrtcu z vidika načrtovanja

\begin{tabular}{lrr}
\hline Trditev & $\mathrm{AS} \pm \mathrm{SO}$ & $p$ \\
\hline $\begin{array}{l}\text { Znam oblikovati učno pripravo za uro gibalnih/športnih } \\
\text { aktivnosti }\end{array}$ & $5,2 \pm 0,87$ & \\
$\begin{array}{l}\text { Znam načrtovati program gibalnih/športnih aktivnosti z } \\
\text { didaktičnega vidika }\end{array}$ & $4,7 \pm 0,91$ & $U=178 ; p=0,009$ \\
$\begin{array}{l}\text { Znam načrtovati svoj strokovni razvoj in vseživljenjsko } \\
\text { učenje }\end{array}$ & $4,6 \pm 0,82$ & $U=186,5 ; p=0,019$ \\
$\begin{array}{l}\text { Znam načrtovati program gibalnih/športnih aktivnosti s } \\
\text { količinskega vidika }\end{array}$ & $4,6 \pm 0,94 \quad U=184,5 ; p=0,013$ \\
$\begin{array}{l}\text { Znam načrtovati program gibalnih/športnih aktivnosti z } \\
\text { organizacijskega vidika }\end{array}$ & $4,6 \pm 0,96 \quad U=187,5 ; p=0,016$ \\
$\begin{array}{l}\text { Znam prepoznati gibalno nadarjene otroke ter } \\
\text { prilagajati delo njihovim posebnostim }\end{array}$ & $4,6 \pm 0,98$ & \\
$\begin{array}{l}\text { Znam prepoznati otroke s posebnostmi v gibalnem } \\
\text { razvoju in prilagajati delo njihovim posebnostim }\end{array}$ & $4,5 \pm 1,04$ & $U=207 ; p=0,048$ \\
$\begin{array}{l}\text { Znam pripraviti letni program gibalnih/športnih } \\
\text { aktivnosti }\end{array}$ & $4,3 \pm 1,01$ & $U=173 ; p=0,010$ \\
\hline
\end{tabular}

Opombe AS - aritmetična sredina, SO - standardni odklon, $p$ - statistično značilna razlika v oceni kompetentnosti med gibalno/športno aktivnimi in neaktivnimi vzgojiteljicami.

kompetenco znanja oblikovanja učne priprave za uro gibalnih/športnih aktivnosti $(A S=5,2)$, najnižje pa kompetenco znanja priprave letnega programa gibalnih/športnih aktivnosti za otroke $(A S=4,3)$.

Skupina gibalno/športno aktivnih vzgojiteljic statistično značilno višje ocenjuje naslednje kompetence izvajanja gibalnih/športnih aktivnosti z vidika organiziranja (preglednica 3): sposobna sem organizirati izvajanje gibalnih/športnih aktivnosti (G/Š aktivne $5,15 \pm 0,74 ; \mathrm{G} / S$ s neaktivne 4,44 $\pm 0,98$; $U=183 ; p=0,011)$, znam organizirati didaktične gibalne igre $(\mathrm{G} / \zeta$ aktivne $5,15 \pm 0,61 ; \mathrm{G} / S$ neaktivne $4,61 \pm 0,98 ; U=212 ; p=0,040$ ), znam organizirati gibalne/športne aktivnosti v naravi (G/Š aktivne $5,3 \pm 0,56 ; G / S ̌$ neaktivne $4,65 \pm 0,86 ; U=168 ; p=0,007)$ ter sposobna sem načrtovati in izvajati gibalne/športne aktivnosti otrok s posebnostmi v gibalnem razvoju (G/Š aktivne 4,29 $\pm 0,91 ; \mathrm{G} / S ̌$ neaktivne 3,67 $\pm 1,0 ; U=205 ; p=0,041$ ).

Vzgojiteljice, ki delajo z otroki v prvem starostnem obdobju, pri izvajanje gibalnih/športnih aktivnosti v vrtcu z vidika organiziranja najvišje ocenjujejo kompetenco znanja organizacije gibalnih/športnih aktivnosti v naravi $(A S=$ $5,1)$, najnižje pa kompetenco načrtovanja in izvajanja gibalnih/športnih aktivnosti otrok s posebnostmi v gibalnem razvoju $(A S=4,1)$.

Skupina gibalno/športno aktivnih vzgojiteljic statistično značilno višje 
Preglednica 3 Ocena kompetentnosti za izvajanje gibalnih/športnih aktivnosti v vrtcu z vidika organiziranja

\begin{tabular}{lrr}
\hline Trditev & AS \pm SO & $p$ \\
\hline Znam organizirati gibalne/športne aktivnosti v naravi & $5,1 \pm 0,74$ & $U=168 ; p=0,007$ \\
Znam organizirati didaktične gibalne/športne igre & $5,0 \pm 0,79$ & $U=212 ; p=0,040$ \\
Sposobna sem organizirati sodelovanje s starši & $5,0 \pm 0,84$ & \\
$\begin{array}{l}\text { Sposobna sem organizirati sodelovanje s svojim } \\
\text { delovnim okoljem }\end{array}$ & $5,0 \pm 0,78$ & \\
$\begin{array}{l}\text { Sposobna sem organizirati izvajanje gibalnih/športnih } \\
\text { aktivnosti }\end{array}$ & $4,9 \pm 0,89$ & $U=183 ; p=0,011$ \\
$\begin{array}{l}\text { Znam izbrati primernost gibalnih nalog glede na } \\
\text { materialne pogoje dela }\end{array}$ & $4,9 \pm 0,85$ & \\
$\begin{array}{l}\text { Znam izbrati zahtevnost gibalnih nalog, ki so primerne } \\
\text { otrokovemu individualnemu razvoju }\end{array}$ & $4,8 \pm 0,87$ & \\
$\begin{array}{l}\text { Sposobna sem organizirati sodelovanje z zunanjim } \\
\text { okoljem }\end{array}$ & $4,6 \pm 0,95$ & \\
$\begin{array}{l}\text { Sposobna sem načrtovati in izvajati gibalne/športne } \\
\text { aktivnosti otrok s posebnostmi v gibalnem razvoju }\end{array}$ & $4,1 \pm 0,99$ & $U=205 ; p=0,041$ \\
\hline
\end{tabular}

Opombe AS - aritmetična sredina, SO - standardni odklon, $p$ - statistično značilna razlika $v$ oceni kompetentnosti med gibalno/športno aktivnimi in neaktivnimi vzgojiteljicami.

Preglednica 4 Ocena kompetentnosti za izvajanje gibalnih/športnih aktivnosti v vrtcu z vidika izvajanja

\begin{tabular}{lrr}
\hline Trditev & AS \pm SO & $p$ \\
\hline Sposobna sem zagotoviti varnost otrok & $5,2 \pm 0,78$ & $5,2 \pm 0,69$ \\
Znam spodbujati otrokov napredek & $5,2 \pm 0,71$ & \\
Zmorem vzpostaviti varno, prijetno in zaupljivo vzdušje & $5,0 \pm 0,79 \quad$ U $=208 ; p=0,041$ \\
Sposobna sem ustvariti dobro sodelovalno ozračje & $5,0 \pm 0,79$ & \\
Znam motivirati otroka s primernimi učnimi športnimi & & \\
pripomočki & $5,0 \pm 0,91$ & \\
Zmorem izvesti gibalne/športne aktivnosti, ki razvijajo & & \\
gibalne sposobnosti otroka & $4,8 \pm 0,80$ & \\
Znam prenesti v prakso teoretična didaktična znanja & $4,8 \pm 0,90$ & \\
Obvladam demonstracijo gibalnih/športnih aktivnosti & $4,8 \pm 0,78$ & \\
Znam poskrbeti za obvladovanje zmage in poraza pri & & \\
otrocih & $4,7 \pm 0,89$ & \\
Znam uporabljati inovativne učno-vzgojne pristope & &
\end{tabular}

Opombe AS - aritmetična sredina, SO - standardni odklon, $p$ - statistično značilna razlika v oceni kompetentnosti med gibalno/športno aktivnimi in neaktivnimi vzgojiteljicami.

ocenjuje naslednjo kompetenco izvajanja gibalnih/športnih aktivnosti z vidika izvajanja: sposobna sem ustvariti dobro sodelovalno ozračje (G/Š ak- 
Preglednica 5 Ocena kompetentnosti za izvajanje gibalnih/športnih aktivnosti v vrtcu z vidika vrednotenja

\begin{tabular}{lrr}
\hline Trditev & AS \pm SO & $p$ \\
\hline Znam prepoznati otrokov gibalni napredek & $4,9 \pm 0,75$ & $U=214 ; p=0,042$ \\
Znam ustrezno nagraditi otrokov gibalni napredek & $4,7 \pm 0,89$ & $U=191 ; p=0,018$ \\
Zmorem samokritično oceniti svoje delo & $4,7 \pm 0,87$ & \\
Usposobljena sem za izmeritev otrokovega gibalnega & $4,0 \pm 1,18$ & $U=207,5 ; p=0,050$ \\
napredka & & \\
\hline
\end{tabular}

Opombe AS - aritmetična sredina, SO - standardni odklon, $p$ - statistično značilna razlika v oceni kompetentnosti med gibalno/športno aktivnimi in neaktivnimi vzgojiteljicami.

tivne $5,18 \pm 0,72 ; \mathrm{G} /$ Š neaktivne $4,67 \pm 0,84 ; U=208 ; p=0,041)$. Vzgojiteljice, ki delajo $z$ otroki v prvem starostnem obdobju, pri izvajanju gibalnih/športnih aktivnosti $v$ vrtcu $z$ vidika izvajanja najvišje ocenjujejo kompetenco zagotavljanja varnosti otrok $(A S=5,2)$, najnižje pa kompetenco uporabe inovativnih učno-vzgojnih pristopov $(A S=4,7)$.

Skupina gibalno/športno aktivnih vzgojiteljic statistično značilno višje ocenjuje naslednje kompetence izvajanja gibalnih/športnih aktivnosti z vidika vrednotenja: znam prepoznati otrokov gibalni napredek ( $G / S ̌$ aktivne $5,06 \pm 0,65 ; \mathrm{G} / S ̌$ neaktivne 4,61 $\pm 0,85 ; U=214 ; p=0,042)$, usposobljena sem za izmeritev otrokovega gibalnega napredka (G/Š aktivne 4,26 $\pm 1,1 ; \mathrm{G} / \mathrm{S}$ neaktivne 3,56 $\pm 1,19 ; U=207,5 ; p=0,050$ ) in znam ustrezno nagraditi otrokov gibalni napredek (G/Š aktivne 4,94 $\pm 0,74 ; \mathrm{G} / S \breve{~ n e a k t i v n e ~ 4,28 ~} \pm 1,09 ; U=191$; $p=0,018)$. Vzgojiteljice, ki delajo z otroki v prvem starostnem obdobju, pri izvajanju gibalnih/športnih aktivnosti v vrtcu z vidika vrednotenja najvišje ocenjujejo kompetenco prepoznavanja otrokovega gibalnega napredka (AS $=4,9$ ), najnižje pa kompetenco merjenja otrokovega gibalnega napredka ( $A S$ $=4,0$ ), kar je bilo pričakovano glede na zahtevnost vrednotenja gibalnega razvoja otrok v tej starosti (Volmut, Dolenc in Šimunič 2010, 25-26).

Redna gibalna/športna aktivnost pomembno vpliva na telesno, duševno in socialno zdravje. A. Prašnikar $(2011,30)$ v svoji raziskavi ugotavlja, da je skladno s priporočili Svetovne zdravstvene organizacije (2010) dovolj gibalno/športno aktivnih le $37,5 \%$ vzgojiteljic. Tiste vzgojiteljice, ki imajo pozitivnejši odnos do gibalnih/športnih aktivnosti, vanje pogosteje vključujejo tudi otroke, s katerimi delajo v vrtcu (Zajec 2009). Vzgojiteljice prenašajo svoj odnos do gibanja na otroke in s tem, ko so premalo gibalno/športno aktivne, še posebej, če se tega ne zavedajo, to razvado prenašajo tudi na mlajše generacije. Poklic vzgojitelja je eden od poklicev, ki zahteva strokovnost na vseh področjih otrokovega razvoja, spretnost dobrega opazovanja, odgovornost, 
dobro psihofizično pripravljenost ter razvitost gibalnih in ročnih spretnosti. Uspešnost v vzgojiteljskem poklicu je odvisna tudi od dobre telesne pripravljenosti, saj se vzgojitelji vsakodnevno srečujejo s številnimi obremenitvami (Gregorc idr. 2010). M. Jeram $(2016,26)$ poroča, da vzgojiteljice, ki se s športom ukvarjajo več kot dvakrat tedensko, bolje komunicirajo $z$ otroki na področju gibanja kot tiste, ki se s športom ukvarjajo enkrat tedensko ali se z njim sploh ne ukvarjajo. M. Sajevic (2016) je v svoji raziskavi ugotovila, da se na splošno vzgojitelji sicer zavedajo pomena in pomembnosti gibalnih/športnih aktivnosti za otrokov celostni razvoj; navade in vzorci gibalnih/športnih aktivnosti, pridobljeni v obdobju otroštva in mladostništva, se namreč $v$ veliki večini ohranijo tudi v kasnejših obdobjih življenja.

\section{Sklep}

Vzgojiteljeva primarna naloga je oblikovati pogoje in možnosti, da se bo otrok lahko celostno razvijal. Gibalna/športna aktivnost ima za celosten razvoj otroka izreden pomen. Glede na to, da predšolski otroci v veliki večini med tednom v programih predšolske vzgoje preživijo pretežni del dneva, je pomembno, $v$ kakšne aktivnosti so vključeni, predvsem pa tudi, na kakšen način so te načrtovane, organizirane, izvajane in vrednotene. Rezultati raziskave so pokazali, da vzgojitelji svojo kompetentnost za razvoj področja gibanja otrok v primerjavi z ostalimi področji na splošno ocenjujejo kot dobro. $Z$ različnih vidikov vodenja gibalnih/športnih aktivnosti pa se je izkazalo, da v kompetencah za izvajanje gibalnih/športnih aktivnosti med gibalno/športno aktivnimi in neaktivnimi vzgojiteljicami ni bistvenih razlik. So pa te opazne na ostalih področjih kompetentnosti, torej pri načrtovanju, organiziranju in vrednotenju gibalnih/športnih aktivnosti otrok. Iz tega lahko sklepamo, da vzgojiteljice, ki se redno, tudi v svojem prostem času, ukvarjajo $z$ gibalno/športno aktivnostjo, te vzorce in znanja prenašajo na otroke v skupini, s katero delajo. Rezultati, ki smo jih pridobili v okviru predstavljene študije, predstavljajo prikaz pomena tematike gibalno/športno aktivnih in neaktivnih vzgojiteljic, ki podajajo oceno svoje kompetentnosti za razvoj področja gibanja pri predšolskih otrocih prvega starostnega obdobja. Z rezultati lahko prikažemo pomen skrbi vzgojiteljic predšolskih otrok za lastno gibalno aktivnost in zdravje, saj posledično izražajo tudi večjo kompetentnost za razvoj področja gibanja otrok, ki so jim zaupani. Prav gotovo bi bilo v prihodnosti smiselno tudi objektivno, $z$ uporabo primerne merilne opreme, preveriti povezavo med gibalno/športno aktivnostjo vzgojiteljic in njihovo kompetentnostjo za razvoj področja gibanja otrok, pri tem pa upoštevati tudi velikost vzorca preiskovancev. Izredno zanimiva pa bi bila tudi zahtevnejša študija, 
kjer bi objektivno preverjali gibalno/športno aktivnost vzgojiteljic in gibalno kompetentnost otrok, vključenih v njihove skupine.

Literatura

Gallahue, D. L., J. C. Ozmun in J. Goodway. 2012. Understanding Motor Development: Infants, Children, Adolescents, Adults. New York: McGraw-Hill.

Gregorc, J., J. Štihec, M. Videmšek, A. Cemič in M. Meško. 2012. »The Quality of Kindergarten Care As an Important Element of the Subjective Theories." Acta Universitatis Palackianae Olomucensis: Gymnica 42 (1): 17-25.

Jeram, M. 2016. »Inovativni pristopi poučevanja gibalnih/športnih aktivnosti v zgodnjem otroštvu. "Diplomska naloga, Univerza na Primorskem.

Kohont, A. 2005. »Kompetenčni profili slovenskih strokovnjakov za upravljanje človeških virov." Magistrsko delo, Univerza v Ljubljani.

Lemos, A. G., E. L. Avigo in J. A. Barela. 2012. »Physical Education in Kindergarten Promotes Fundamental Motor Skill Development.« Advances in Physical Education 2 (1): 17-21.

Malina, R., C. Bouchard in O. Bar-Or. 2004. Growth, Maturation, and Physical Activity. Champaign, IL: Human Kinetics.

Maretič Požarnik, B. 2012. Psihologija učenja in pouka. Ljubljana: DZS.

Ministrstvo za šolstvo in šport. 1999. Kurikulum za vrtce: predšolska vzgoja v vrtcih. Ljubljana: Ministrstvo za šolstvo in šport.

Organisation for Economic Co-Operation and Development. 2013. Innovative Learning Environments. Pariz: Organisation for Economic Co-Operation and Development.

Pišot, R., in G. Jelovčan. 2012. Vsebine gibalne/športne vzgoje v predšolskem obdobju. Koper: Annales.

Plevnik, M., in R. Pišot, ur. 2016. Razvoj elementarnih gibalnih vzorcev v zgodnjem otroštvu. Koper: Annales.

Prašnikar, A. 2011. »Povezanost gibalnih/športnih aktivnosti vzgojiteljic v povezavi z izbranimi dejavniki zdravega načina življenja.« Diplomska naloga, Univerza v Ljubljani.

Retar, I., in J. Lepičnik-Vodopivec. 2017. »Kompetentnost vzgojiteljev za inovativno gibalno poučevanje.« Pedagoška obzorja: časopis za didaktiko in metodiko 32(1): 17-32.

Retar, I., M. Plevnik in E. Kolar. 2013. »Key Competences of Slovenian Sport Managers."Annales kinesiologiae 4 (2): 81-94.

Sajevic, M. 2016. „Zavedanje vzgojiteljev o pomenu gibalnih/športnih aktivnosti za otrokov celostni razvoj.« Diplomska naloga, Univerza na Primorskem.

Timmons, B. W., P. J. Naylor in K. A. Pfeiffer. 2007. »Physical Activity for Preschool Children: How Much and How?« Applied Physiology, Nutrition, and Metabolism 32 (S2E): S122-S134. 
UNESCO. 2011. International Standard Classification of Education ISCED 2011. Quebec: UNESCO.

Videmšek, M., in R. Pišot. 2007. Šport za najmlajše. Ljubljana: Fakulteta za šport. Volmut, T., P. Dolenc in B. Šimunič. 2010. »Metode spremljanja in merjenja gibalne/športne aktivnosti otrok.«V Otroci potrebujemo gibanje, ur. B. Šimunič, T. Volmut in R. Pišot, 25-32. Koper: Annales.

Weiler, R., S. Allardyce, G. P. Whyte in E. Stamatakis. 2013. »ls the Lack of Physical Activity Strategy for Children Complicit Mass Child Neglect?« British Journal of Sports Medicine 48 (13): 1010-1013.

World Health Organization. 2010. Global Recommendations on Physical Activity for Health. Geneva: World Health Organization.

Zajec, J. 2009. »Povezanost športne dejavnosti predšolskih otrok in njihovih staršev z izbranimi dejavniki zdravega načina življenja.« Doktorska disertacija, Univerza v Ljubljani.

\section{Physical (In)activity of Preschool Teachers and Their Competence for Development of Movement among First Age Group of Preschool Children}

The need for movement is a child's primary need. Therefore, the development of the movement, as one of the fields of activity in preschool, has a special importance. In the early childhood, the child is extremely perceptible for the impulses of the environment, and the influence of the acquired experiential experiences in this period is of great importance for his further development. Kindergarten is, in addition to parents, an extremely important environment during childhood, as children spend most of their day in it. Children should adopt many motor skills in the environment of the kindergarten, which is connected with the appropriate planning, organization, implementation and evaluation of the physical activities guided by the preschool teacher, which is also influenced by its competence. Sixty-five preschool teachers, who work with first age group of preschool children, cooperated in the study. We were interested in the development of their competences for developing the content of the movement and physical activity also in connection with their own level of physical activity. We found that more physical active teachers assess their competences for the development of pre-school children's movements higher.

Keywords: development, physical activity, competency, environment, child 


\title{
Delež prostega gibanja in spontane igre otrok v prvem starostnem obdobju
}

\author{
Maja Cerar \\ Vrtec pri Osnovni Šoli Janka Modra \\ maja.cerar2@guest.arnes.si
}

\begin{abstract}
Življenjski slog danajšnjih otrok je vedno bolj sedentaren ter odvisen od elektronskih medijev. Priložnosti za prosto gibanje ter spontano igro v senzorno stimulativnem okolju, ki sta temeljna za celostni razvoj otroka, je vse manj. Posledično se spreminjajo sposobnosti in potrebe otrok. Ob zavednju pomena najzgodnejšega obdobja, ki ga v vzgojo prinašajo spoznanja nevroznanosti, je ključno vprašnje, v kakšni meri se zmorejo vrtci odzvati na nova spoznanja stroke ter potrebe otrok 21. stoletja. $V$ ta namen smo izvedli raziskavo o deležih gibalnih dejavnosti in proste igre, ki jih trije izbrani vrtci omogočajo otrokom prve starostne skupine tekom dopoldneva. Ugotavljamo, da so gibalne in statične dejavnosti v vrtcih enakovredno zastopane. Prosti igri je namenjeno $30 \%$ časa. Količina časa, namenjena prosti gibalni dejavnosti ter vodenim in statičnim dejavnostim $v$ vrtcih, ne dosega standardov in priporočil strokovnjakov. Med vrtci obstajajo pomembne razlike $v$ zagotavljanju časa za prosto igro in gibanje izven rutine.
\end{abstract}

Ključne besede: prosto gibanje, spontana igra, sedeč življenjski slog, prvo starostno obdobje, vrtec

\section{Uvod}

$\checkmark$ zadnjem desetletju se izrazito povečuje zanimanje za organizirano predšolsko vzgojo vzgojo v prvih treh letih življenja (Vonta 2009; Juriševič, Rajović in Drgan 2010; Jakovljević 2016). Poudarja se pomen zagotavljanja kvalitetnih pogojev, ki omogočajo kakovostno spodbujanje otrokovih potencialov v najzgodnejšem obdobju. Razlogov za to je več. Na eni strani se je v zadnjem desetletju delež otrok, starih od 1 do 3 let, ki obiskujejo vrtec, povečal s 45 na $65 \%$ (Kozomelj 2018), na drugi strani nevroznanost prihaja do novih ugotovitev na področju delovanja in razvoja možganov, ki v ospredje kot temeljna za celosten kasnejši razvoj posameznika postavljajo prav prva leta otrokovega življenja. Poleg tega je predšolsko obdobje v središču zanimanja stroke, tudi zaradi hitrega spreminjanja življenjskega sloga najmlajših otrok, ki postaja vedno bolj sedentaren (Elkind 2008; Miller in Almon 2009; Kuzik idr. 2015) ter vezan na preživljanje prostega časa pred ekrani elektronskih medijev ali v organiziranih prostočasnih dejavnostih namesto ob spontani igri z vrstniki in 
prostem gibanju v naravi. Posledično se spreminjajo sposobnosti današnjih otrok ter njihove potrebe (Juriševič, Rajović in Drgan 2010; Jakovljević 2016; Hosta 2018), ki se izražajo kot vedenske težave in v predšolsko vzgojo vnašajo nove izzive.

Bistveno vprašanje, ki si ga zastavljamo v pričujočem prispevku, je, kako uspešni so vrtci pri zagotavljanju pogojev za razvoj potencialov najmlajših otrok z vidika vključevanja gibalnih dejavnosti in spontane nestrukturirane igre $v$ izvedbeni kurikulum. Gibanje in spontana igra $v$ senzorno stimulativnem okolju sta v skladu z novimi spoznanji stroke (Juriševič, Rajović in Drgan 2010; Bregant 2012; Jakovljević 2016; Hosta 2018) namreč opredeljena kot temeljni potrebi in osnova za nadaljni razvoj možganov ter kognitivnih sposobnosti otrok.

\section{Pregled ugotovitev na področju gibanja in proste igre otrok}

Nova spoznanja o delovanju možganov, skupaj z drugimi spoznanji, vedno bolj spreminjajo pogled na to, kakšna naj bi bila organizirana predšolska vzgoja in kaj naj bi bilo njeno poslanstvo. Predšolska vzgoja tako ni več prvenstveno namenjena pripravi na šolo, temveč »temeljnemu razvoju otroških možganov, ki bo omogočal implementacijo vzgoje in procesov učenja v kasnejšem osnovnošolskem obdobju« (Jakovljević 2016, 2).

Slednje na ravni predšolske vzgoje predstavlja vedno večji izziv, saj se je, po besedah T. Jakovljević (2016), v zadnjih desetletjih potek otroštva »obrnil na glavo", tako v domačem okolju kot v vrtcih, in s tem tudi razvoj otrokovih možganov. Ob tem opozarja, da je bilo otrokom odvzeto mnogo priložnosti spontanega gibanja, spontane igre ter nebesednega stika s socialnim okoljem, čeprav so ti za njihov razvoj bistvenega pomena. Meni, da so namesto tega otroci deležni pretežno vodenih dejavnosti in izpostavljanja elektronskim medijem (TV, računalniki, tablice, mobiteli), "potrošniškim sredstvom« ter »treniranju višjih miselnih funkcij«, življenjski slog malčkov pa ob tem postaja pretežno sedentaren.

Gray (2011), eden vodilnih raziskovalcev otroške igre, izpostavlja, da od začetka druge polovice prejšnjega stoletja obseg proste igre otrok močno upada. Največji upad opaža pri igri otrok z vrstniki na prostem. Igra izginja tudi v dopoldanskem času, ko so otroci v formalnih ustanovah (vrtcih, šolah). Elkind (2008) ugotavlja, da so $v$ zadnjih dveh desetletjih otroci izgubili kar osem ur svobodne, nestrukturirane in spontane igre na teden, čas otrok, preživet v zunanjih prostorih oz. v naravi, pa je upadel za $50 \%$. Najbolj se je $v$ tem času zmanjšal delež gibalne aktivnosti ter bistveno povečal čas, ki ga otroci namenjajo pasivnim dejavnostim, in sicer s 30 minut leta 1997 na več kot 3 ure dnevno v letu 2003. 
V raziskovalnem poročilu Crisis in the Kindergarden: Why Children Need to Play in School (Miller in Almon 2009), ki je nastalo na temeljih devetih različnih raziskav $v$ ZDA, ugotavljajo, da imajo otroci drugega starostnega obdobja $\checkmark$ povprečnem vrtčevskem dnevu za prosto igro le še 30 minut časa. Preostali čas je večinoma zapolnjen s poučevanjem predmatematičnih in predopismenjevalnih veščin. Dvome o učinkovitosti takšnega pristopa je v 90 . letih prejšnjega stoletja zbudila longitudinalna raziskava (Darling-Hammond in Snyder 1992 v Miller in Almon 2009, 7), izvedena v 50 nemških vrtcih, ki je pokazala, da otroci, ki so bili že od prvega starostnega obdobja dalje spodbujani $k$ razvoju višjih miselnih funkcij in kognitivnih dosežkov, pri starosti 10 let niso dosegali boljših učnih rezultatov v primerjavi z otroki, ki so bili v predšolskem obdobju vključeni v programe, temelječe na prosti spontani igri in gibalnih dejavnostih. Slednji so otroke iz prve skupine prekašali na področju branja in matematike ter v socialni in čustveni zrelosti. Izstopali so tudi v kreativnosti, inteligenci ter govornem izražanju. Ugotovitve omenjene raziskave se skladajo tudi $z$ današnjim prevladujočim stališčem stroke, da je najučinkovitejše tisto učenje, ki je skladno $s$ t.i. kritičnimi oz. občutljivimi obdobji v otrokovem razvoju (Juriševič, Rajovič in Drgan 2010; Bregant 2012; Montessori 2011).

Kuzik idr. (2015) so preučevali gibalne in sedentarne vedenjske vzorce današnjih malčkov v vrtcu in ugotavili, da otroci, stari v povprečju 3 leta, $60 \%$ časa preživijo $v$ statičnih dejavnostih, preostanek časa, ki ga preživijo $v$ gibalnih dejavnostih, pa zaznamuje predvsem nizko intenzivna gibalna dejavnost (počasna hoja, krajši umirjeni premiki v prostoru ipd.). Otroci so sicer v statičnih položajih vztrajali v povprečju manj kot 5 minut naenkrat, večina otrok nikoli ni ostala gibalno neaktivna več kot 15 minut naenkrat. Ugotovili so še, da so se otroci v času 5,5 ur, preživetih v vrtcu, manj kot 60 minut gibali vsaj srednje intenzivno.

Zaradi alarmantnih ugotovitev o zmanjševanju prostega gibanja in spontane igre otrok $v$ vseh razvitih tehnoloških družbah po svetu so nekatera združenja in nacionalne organizacije, kot npr. Ameriško združenje za šport in športno vzgojo ter Kanadsko združenje za telesno vadbo, pripravili smernice o priporočenih minimalnih količinah gibanja in spontane igre otrok ter dopustnem času izpostavljenosti elektronskim medijem.

\section{Priporočila za gibalno aktivnost in prosto igro otrok prvega starostnega obdobja}

Ameriško združenje za šport in športno vzgojo (National Association for Sport and Physical Education 2006) tako priporoča, da naj bi bili malčki (starosti od 12 do 36 mesecev) deležni vsaj 30 minut strukturirane gibalne aktiv- 
nosti dnevno in od 60 minut do več ur nestrukturirane gibalne aktivnosti ter ne bi smeli biti neaktivni več kot 60 minut skupaj, razen med spanjem. Kot najustreznejšo priporočajo prosto igro $\mathrm{v}$ senzorno stimulativnem okolju oz. na prostem, ki otroku omogoča raziskovanje, preizkušanje in posnemanje. Priporočeno je vključevanje $v 2$ ali več strukturiranih ali vodenih dejavnosti dnevno (minimalno 30 minut). V obdobju 8 ur dnevno svetujejo 60 do 90 minut intenzivne gibalne dejavnosti, ki vključuje tek ali hojo $v$ hrib ipd.

Kanadsko združenje za telesno vadbo (Canadian Society for Exercise Physiology) (Tremblay idr. 2012) poleg navedenih smernic dodaja še priporočila glede sedentarnih dejavnosti. Svetujejo, da se otroke, mlajše od dveh let, ne izpostavlja ekranom elektronskih naprav (TV, mobitel, tablica, računalnik), otrokom od dveh let starosti dalje pa naj bodo ekrani na voljo največ 1 uro dnevno. Tudi Ščuka (2007) opozarja, naj statična dejavnost otrok ne traja več kot 10 minut naenkrat, če čas statične dejavnosti doseže 30 minut, pa ji mora obvezno slediti intenzivna gibalna aktivnost.

Ker smernice omenjenih nacionalnih združenj predvidevajo standarde, $\mathrm{ki}$ veljajo za celoten dan, so M. Driediger idr. (2018) razvili smernice, ki veljajo za celodnevne programe predšolskega varstva. Priporočajo, da od priporočenih 60 minut dnevne intenzivne gibalne aktivnosti najmanj 40 minut poteka $v$ vrtcu, 20 minut pa v domačem okolju. Otroci naj bi dnevno zunaj preživeli od 90 do 120 minut, razdeljenih na 2 do 3 sklope, ki naj bi se izmenjevali z dejavnostmi v notranjih prostorih.

Ob spoznanju, da imajo današnji otroci zaradi širših družbenih vplivov vse manj možnosti za razvoj zdravih temeljev možganov, postaja eno ključnih vprašanj za stroko, ki se ukvarja s predšolsko vzgojo, kako umestiti spontano, možgansko stimulativno igro in spontano gibanje $v$ izvedbeni kurikulum vrtca. Najpomembnejša vloga in odgovornost v procesu prilagajanja izvedbenega kurikuluma današnjim družbenih razmeram in potrebam otrok je prav gotovo na strani vzgojiteljic.

\section{Vloga vzgojitelja pri vključevanju gibanja in proste igre otrok v izvedbeni kurikulum}

Na vsebine in kakovost izkušenj, ki jih otrok dobi v vrtcu, bolj kot formalni kurikulum vplivajo stališča, vrednote, znanja in izkušnje vzgojiteljic - njihove subjektivne teorije, ki zajemajo tako implicitna (nereflektirana, rutinska ter pretežno nezavedna) ravnanja kot tudi eksplicitno izražena stališča in vrednote (Batistič Zorec 2005, 22). Deloma pa se te teorije prekrivajo tudi s prikritim kurikulumom, in sicer $v$ preučevanju nenamernih in nenačrtovanih ravnanj in učinkov vzgoje (Hozjan 2018). 
Odprt koncept predšolske vzgoje, ki vzgojiteljem dopušča strokovno avtonomijo (Ministrstvo za šolstvo in šport 1999), ter na drugi strani subjektivne teorije in različna opremljenost strokovnih delavcev z znanji imajo močan vpliv na izvedbeni kurikulum v posameznem oddelku, posledično pa lahko prihaja do precejšnjih razlik v procesni kakovosti tako med vrtci kot tudi znotraj njih, med oddelki (Marjanovič Umek in Fekonja Peklaj 2008; Batistič Zorec 2013). Subjektivnemu prepričanju v lastni »prav« o tem, kaj je »dobro za otroka« in kaj je "prav v vrtcu«, se lahko vzgojitelji, po mnenju N. Turnšek (2008) izognejo le s povečevanjem ključnih elementov profesionalizma: s samoevalvacijskim povezovanjem v vrtcu, med vrtci in s strokovnjaki.

Ob koncu pregleda nekaterih ugotovitev raziskav ter smernic na področju gibanja in spontane igre otrok vidimo, da je bistveno $v$ okviru predšolske vzgoje današnjim otrokom omogočiti več možnosti prostega gibanja in spontane, nestrukturirane igre. Gibanje in igra sta izrednega pomena za zdrav celostni razvoj otroka, obenem pa sta v tehnološko naprednih družbah tudi njegovi najbolj zapostavljeni področji. V nadaljevanju bomo predstavili izsledke raziskave o količini gibanja in proste igre otrok prvega starostnega obdobja v treh izbranih slovenskih vrtcih ter preverili, v kolikšni meri v svojem izvedbenem kurikulumu zagotavljajo čas za gibalne dejavnosti in prosto igro otrok.

\section{Empirični del}

\section{Namen in cilji raziskave}

Namen raziskave je bil ugotoviti delež časa, ki ga vzgojiteljice v tipičnem dopoldnevu namenijo gibalni dejavnosti in prosti igri otrok.

Naš cilj je bil ugotoviti delež časa, ki se v vrtcih namenja gibalni dejavnosti in prosti igri otrok, delež gibanja izven in znotraj rutinskih dejavnosti, delež gibalnih in statičnih vodenih dejavnosti, dolžino intervalov sedentarnih dejavnosti ter morebitne razlike med vrtci v količini proste igre in gibanja otrok izven rutine.

V okviru empirične raziskave smo si zastavili nasledje hipoteze:

1. Otroci preživijo tekom dopoldneva več časa v gibalnih dejavnostih kot v statičnih dejavnostih.

2. Otroci preživijo tekom dopoldneva več časa v prostih dejavnostih kot $\checkmark$ vodenih dejavnostih.

3. Otroci preživijo tekom dopoldneva več časa v prostih gibalnih dejavnostih kot v vodenih gibalnih dejavnostih. 
4. Obstajajo razlike med vrtci v zagotavljanju časa za gibanje otrok izven rutinskih dejavnosti.

5. Obstajajo razlike med vrtci $v$ zagotavljanju časa za prosto dejavnost otrok.

\section{Metoda}

Pri delu je bila uporabljena metoda opazovanja z udeležbo.

\section{Vzorec}

V raziskavo smo vključili 5 skupin otrok iz 3 različnih vrtcev, in sicer:

1. skupino 10 otrok, starih 1-3 leta (vrtec VAMK),

2. skupino 14 otrok, starih 2-6 let (vrtec VOSJM),

3. tri skupine po 12 otrok, starih 2-3 leta (vrtca VTR in VOSJM).

\section{Postopek zbiranja podatkov}

Podatki so bili zbrani v oktobru 2018, zbrale pa so jih svetovalne delavke posameznega vrtca. Z vzgojiteljicami v posamezni skupini je bilo nekaj dni prej dogovorjeno, da bo $v$ skupini potekalo opazovanje in pisno beleženje izvajanih dejavnosti, ki bodo tudi časovno merjene. Opazovanje je potekalo na dan, ki je po presoji strokovnih delavk predstavljal povprečen oz. tipičen dan v skupini. Vnaprej je bil pripravljen opazovalni list z natančnimi navodili za izpolnjevanje, $v$ katerega se je s poimenovanjem ali kratkim opisom na podlagi opazovanja beležilo posamezne dejavnosti, ki so $v$ skupini potekale tekom dopoldneva. Beležilo se je tudi trajanje posamezne dejavnosti v minutah. Opazovane dejavnosti se je nato kategoriziralo na podlagi naslednjih odvisnih spremenljivk:

- okolje, v katerem je dejavnost potekala: igralnica, telovadnica, igrišče, narava, drugo,

- prosta, vodena ali rutinska dejavnost, ${ }^{1}$

- gibalna ali statična dejavnost. ${ }^{2}$

\footnotetext{
${ }^{1}$ Prosta dejavnost - čas otrokove spontane igre, gibanja; vodena dejavnost - čas, ko vzgojiteljica ali pomočnica vzgojiteljice načrtujeta in izvedeta eno ali več vzporednih dejavnosti za celotno skupino otrok oz. večino otrok v skupini; rutinska dejavnost - čas, ko otroci izvajajo dejavnosti, ki se ponavljajo vsak dan in niso del spontane igre/gibanja ali vodene dejavnosti (npr. hranjenje, garderoba, higiena, počitek, prehajanja iz notranjih v zunanje prostore in obratno). Izbrani strokovni izrazi povzeti po Marjanovič Umek in Fekonja Peklaj (2008).

${ }^{2}$ Kot gibalna dejavnost otrok je bila v raziskavi opredeljena vsaka dejavnost, kjer je šlo pretežno za premike telesa v prostoru, kot statična dejavnost pa tista, kjer je otrok pretežno stal ali se-
} 
Opazovanje z udeležbo je v vsaki od skupin potekalo strnjeno eno dopoldne, in sicer $v$ času od 7.45 do začetka počitka otrok. Počitek se je $v$ različnih skupinah pričel ob različnem času, zato so se opazovanja zaključevala med 12.20 in 12.45 uro. Odločitev za pričetek opazovanja ob 7.45 temelji na dejstvu, da je to čas, ko je večina otrok že prisotnih v vrtcu, otroci pa so v tem času že razporejeni v svoje matične skupine in ob prisotnosti matične vzgojiteljice. Opazovanje je potekalo do začetka počitka, z namenom, da se zajame celoten aktivni del dopoldneva večine otrok v vrtcu.

\section{Postopek obdelave podatkov}

Podatke smo statistično obdelali s programsko opremo IBM SPSS Statistic, preglednice pa oblikovali s programsko opremo Microsoft Excel. Podatki so bili obdelani kvantitativno. Za to smo uporabili frekvenčno porazdelitev in $t$-preizkus za neodvisne vzorce. $Z$ njim smo preučili razliko med časom, namenjenim gibalnim nasproti statičnim, prostim nasproti vodenim in prostimgibalnim nasproti vodenenim-gibalnim dejavnostim. Med vrtci smo preučili tudi razliko $v$ času, ki ga namenjajo prostim dejavnostim (prosti igri) ter gibalni dejavnosti otrok izven rutinskih dejavnosti. Predstavitev rezultatov $v$ nadaljevanju temelji na deskriptivni in inferenčni statistiki.

\section{Rezultati}

V okviru rezultatov so prikazani rezultati preverjanja predhodno navedenih hipotez. Pri prvi hipotezi nas je zanimalo, ali otroci tekom dopoldneva preživijo več časa $v$ gibalnih dejavnostih kot $v$ statičnih dejavnostih. Povprečne vrednosti porabljenega časa $v$ gibalnih dejavnostih $(M=134,40)$ so višje od povprečne vrednosti porabljenega časa za statične dejavnosti $(M=121,80)$. Vendar razlika $v$ porabljenem času $v$ gibalnih dejavnostih in statičnih dejavnostih ni statistično pomembna $(2 p=0,759)$, kar pomeni, da ni statistično pomembnih razlik med porabljenim časom za gibalne in statične dejavnosti. Razpršenost pri gibalni dejavnosti je manjša $(S=38,49)$ kot pri statičnih dejavnostih $(S=49,51)$. Koleracijski koeficient $(r=-0,89)$ je negativen in kaže na pomembno povezanost med obema vrstama dejavnosti (preglednica 1).

Druga hipoteza je temeljila na tezi, da otroci tekom dopoldneva preživijo več časa v prostih dejavnostih kot v vodenih dejavnostih. Za proste dejavnosti je bilo porabljenega več časa $(M=80,40)$ kot za vodene dejavnosti $(M=$ $52,20)$. $V$ tem primeru so razlike statistično pomembne $(2 p=0,097)$, in sicer pri

del, pri čemer je bila zgornja polovica trupa v mirovanju ali gibanju. Izbrana strokovna izraza povzeta po Jakovljević (2016). 
Preglednica 1 Inferenčna statistika o preživelem času v okviru gibalnih in statičnih dejavnosti otrok v vrtcih

\begin{tabular}{|c|c|c|c|c|c|c|c|c|}
\hline \multirow[t]{2}{*}{ Postavka } & \multirow[t]{2}{*}{$M$} & \multirow[t]{2}{*}{$n$} & \multirow[t]{2}{*}{$S$} & \multicolumn{2}{|c|}{ Korelacija } & \multicolumn{3}{|c|}{$t$-preizkus } \\
\hline & & & & $r$ & $2 p$ & $T$ & $g$ & $2 p$ \\
\hline Gibalne dejavnosti & 134,4 & 5 & 38,49 & $-0,89$ & 0,04 & 0,33 & 4 & 0,759 \\
\hline Statične dejavnost & 121,8 & 5 & 49,51 & & & & & \\
\hline
\end{tabular}

Preglednica 2 Inferenčna statistika o preživelem času v okviru prostih in vodenih dejavnosti otrok v vrtcih

\begin{tabular}{|c|c|c|c|c|c|c|c|c|}
\hline \multirow[t]{2}{*}{ Postavka } & \multirow[t]{2}{*}{$M$} & \multirow[t]{2}{*}{$n$} & \multirow[t]{2}{*}{$S$} & \multicolumn{2}{|c|}{ Korelacija } & \multicolumn{3}{|c|}{$t$-preizkus } \\
\hline & & & & $r$ & $2 p$ & $T$ & $g$ & $2 p$ \\
\hline Proste dejavnosti & 80,4 & 5 & 23,86 & $-0,09$ & 0,88 & 2,16 & 4 & 0,097 \\
\hline Vodene dejavnosti & 52,2 & 5 & 14,74 & & & & & \\
\hline
\end{tabular}

Preglednica 3 Inferenčna statistika o preživelem času v okviru prostih gibalnih in vodenih gibalnih dejavnosti otrok $v$ vrtcih

\begin{tabular}{|c|c|c|c|c|c|c|c|c|}
\hline \multirow[t]{2}{*}{ Postavka } & \multirow[t]{2}{*}{$M$} & \multirow[t]{2}{*}{$n$} & \multirow[t]{2}{*}{$S$} & \multicolumn{2}{|c|}{ Korelacija } & \multicolumn{3}{|c|}{$t$-preizkus } \\
\hline & & & & $r$ & $2 p$ & $T$ & $g$ & $2 p$ \\
\hline Proste gibalne dejavnosti & 49,8 & 5 & 19,97 & $-0,54$ & 0,35 & 1,48 & 4 & 0,212 \\
\hline Vodene gibalne dejavnosti & 27,4 & 5 & 18,51 & & & & & \\
\hline
\end{tabular}

10-odstotni stopnji značilnosti, kar pomeni, da drži hipoteza, da otroci tekom dopoldneva več časa namenijo za proste kot za vodene dejavnosti.

Razpršenost je v obeh primerih dokaj velika. Pri prostih dejavnostih je večja $(S=23,86)$ kot pri vodenih $(S=14,74)$. Korelacijski koeficient $(r=-0,09)$ je prav tako negativen in kaže zelo nizko povezanost med rezultati proste dejavnosti in vodene dejavnosti (preglednica 2).

$\checkmark$ nadaljevanju nas je zanimalo, ali otroci tekom dopoldneva več časa preživijo $v$ prostih gibalnih dejavnostih kot $v$ vodenih gibalnih dejavnostih. Prostim gibalnim dejavnostim je bilo namenjenega več časa $(M=49,80)$ kot vodenim gibalnim dejavnostim $(M=27,40)$. Vrednost $t$-preizkusa kaže, da razlike niso statistično pomembne $(2 p=0,212)$. To pomeni, da ni statistično pomembnih razlik med časom, namenjenim prostim gibalnim dejavnostim in vodenim gibalnim dejavnostim. Razpršenost je $v$ primeru proste gibalne dejavnosti $(S=19,97)$ podobna kot pri vodeni gibalni dejavnosti $(S=18,51)$. Tudi $v$ tem primeru je korelacijski kofecient negativen $(r=-0,54)$, vendar kaže pomembno povezanost med rezultati (preglednica 3 ).

Četrta hipoteza temelji na tezi, da obstajajo razlike med vrtci v zagotavljanju časa za gibanje otrok izven rutinskih dejavnosti. V povprečju je bilo giba- 
Preglednica 4 Inferenčna statistika o gibanju otrok izven rutine v izbranih vrtcih

\begin{tabular}{llrrrrrr}
\hline Postavka & $M$ & $n$ & $S$ & \multicolumn{4}{c}{ t-preizkus } \\
\cline { 5 - 8 } & & & & $T$ & $g$ & $2 p$ \\
\hline Gibanje izven rutine & 77,6 & 5 & 18,16 & 9,55 & 4 & 0,001 \\
\hline
\end{tabular}

Preglednica 5 Inferenčna statistika o prostih dejavnostih otrok v izbranih vrtcih

\begin{tabular}{lrrrrrrr}
\hline Postavka & $M$ & $n$ & $S$ & \multicolumn{4}{c}{ t-preizkus } \\
\cline { 5 - 8 } & & & & $T$ & $g$ & $2 p$ \\
\hline Prosta dejavnost & 80,4 & 5 & 23,86 & 7,53 & 4 & 0,002 \\
\hline
\end{tabular}

nju izven rutine namenjeno 77,60 minut, pri čemer je vrednost standardnega odklona 18,16. 2p-vrednost enostranskega $t$-preizkusa je enaka 0,001, kar pomeni, da hipotezo potrjujemo. Pregled porabljenega časa za gibanje izven rutinskih dejavnosti kaže, da največ časa za gibanje izven rutinskih dejavnosti nameni VAMK $(M=95,00)$. Sledi mu VOSJM $(M=80,00)$. Najmanj časa namenjajo gibanju izven rutinskih dejavnosti v VTR $(M=52)$ (preglednica 4).

Pri zadnji hipotezi smo raziskovali, ali obstajajo razlike med vrtci v zagotavljanju časa za prosto dejavnost otrok. Prostim dejavnostim je bilo $v$ povprečju namenjeno 80,40 minut, pri standradnem odklonu 23,86. 2p-vrednost enostranskega $t$-preizkusa je enaka 0,002. Zastavljeno hipotezo lahko potrdimo, kar pomeni, da obstajajo razike med vrtci v zagotavljanju časa za prosto dejavnost otrok. Podatki o porabljenem času kažejo, da največ časa za prosto dejavnost namenij v OSJM $(M=93,00)$, sledi VTR $(M=78,00)$ in najmanj $\vee$ VAMK $(M=45,00)$ (preglednica 5$)$.

Dodatna analiza podatkov, pridobljenih $v$ času aktivnega dopoldneva $v$ vrtcu, ki je znašal v povprečju 4,3 ure na oddelek, je pokazala, da največji del dopoldneva zavzemajo rutinske dejavnosti ( $48 \%$ oz. 2 uri), sledijo jim proste dejavnosti (31\% oz. 1,3 ure), najmanj pa je vodenih dejavnosti ( $20 \%$ oz. 0,9 ure). Otroci v gibalnih dejavnostih v povprečju preživijo $52 \%$ časa oz. 2,2 uri, v statičnih pa $48 \%$ časa oz. 2 uri dopoldneva. Od celotnega časa gibanja $(2,2$ uri) se $42 \%$ časa oz. 1,3 ure otroci gibajo znotraj rutinskih opravil, $58 \%$ časa oz. 1,2 uri pa v prostih in vodenih dejavnostih. $V$ času vodenih dejavnosti, ki trajajo v povprečju 52 minut, vzgojiteljice $52 \%$ oz. 27 minut namenijo gibalnim dejavnostim ter $48 \%$ časa oz. 25 minut statičnim dejavnostim.

\section{Razprava}

Na podlagi rezultatov ugotavljamo, da so gibalne in statične dejavnosti v analiziranih vrtcih enakovredno zastopane. Otroci v analiziranih vrtcih tako pri 
statičnih dejavnostih preživijo skoraj polovico dopoldneva, kar je z vidika novih dognanj nevroznanosti ter zavedanja o pomenu gibanja za otrokov razvoj (Juriševič, Rajovič in Drgan 2010; Bregant 2012; Montessori 2011; Jakovljević 2016) veliko. Če izmerjen čas gibalnih in statičnih dejavnosti primerjamo še $s$ smernicami CSEP (Tremblay idr. 2012), ki priporočajo 3 ure gibalne dejavnosti in največ 1 uro statičnih dejavnosti dnevno, pa vidimo, da vrtci komaj ali pa ne dosegajo priporočil. To velja še posebej pri deležu statičnih dejavnosti, saj je dnevna količina presežena že v vrtcu za 1 uro. 2,3 ure, preživete $v$ gibalnih dejavnostih $v$ vrtcu, pa se nehajajo $v$ okviru priporočil le, če predvidevamo, da se otrok giba tudi v domačem okolju in tam pridobi manjkajoči čas gibanja, tj. do minimalnih treh ur dnevno.

Ob podrobnejši analizi gibanja še ugotavljamo, da od celotnega časa gibanja otroka v vrtcu skoraj 1 ura gibanja poteka znotraj rutinskih dejavnosti. Spremenljivki "gibanje med rutino« in "gibanje izven rutine« smo dodatno analizirali, ker menimo, da gre $v$ teh primerih za različno kvaliteto gibanja. Pri "gibanju med rutino" gre pretežno za dejavnosti, kot so odhod na stranišče, $v$ umivalnico, po kosilo, $v$ garderobo ipd. Ta gibanja so $v$ veliki večini nizko intenzivna in možgansko nestimulativna. Relevantnejši podatek o otrokovem kvalitetnejšem gibanju je torej podatek o »gibanju izven rutine«. Ugotavljamo, da je tovrstnega gibanja v povprečju le z 1,3 ure dnevno. V primerjavi s smernicami CSEP (Tremblay idr. 2012), ki priporočajo 3 ure gibanja dnevno, vidimo, da skupna količina prostega in vodenega gibanja v vrtcu ne dosega niti $50 \%$ priporočene dnevne količine.

Posebej smo analizirali tudi čas, ki je namenjen prostim gibalnim dejavnostim. To so dejavnosti, ki so v prvem starostnem obdobju med najbolj možgansko stimulativnimi in zato nujno potrebne za zdrav otrokov razvoj (Jakovljević 2016). V analizi ugotavljamo, da zavzamejo le $15 \%$ oz. okoli $40 \mathrm{mi}$ nut dopoldanskega časa. Čas, namenjen prostim gibalnim dejavnostim, pa ne dosega niti priporočil CSEP (Tremblay idr. 2012) niti priporočil National Association for Sport and Physical Education (2006), ki predvidevajo vsaj $60 \mathrm{mi}-$ nut prostega gibanja otrok dnevno.

Na področju trajanja posameznih statičnih dejavnosti ugotavljamo, da njihov čas v povprečju za 2 minuti presega priporočila Ščuke (2007), ki priporoča največ 10 minut sedenja naenkrat. Zgornja meja 30 minut strnjene statične dejavnosti pa je bila $v$ vrtcih presežena 4 -krat. Tudi ob primerjavi z ugotovitvami Kuzika idr. (2005) vidimo, da je trajanje posameznih statičnih dejavnosti v naših vrtcih za 7 minut daljše, prav tako je bila mnogokrat presežena maksimalna meja 15 minut trajanja statične dejavnosti, ki jo navajajo v svojih ugotovitvah. 
Ugotavljamo, da v času vodenih dejavnosti vzgojiteljice podoben delež namenijo tako gibalni kot statični izvedbi dejavnosti, kar se le delno sklada s potrebami malčkov v procesu učenja, ki je mnogo učinkovitejše, kadar "poteka v stanju otrokove miselne in telesne aktivnosti« (Juriševič, Rajovič in Drgan 2010, 9). Vodenim dejavnostim sicer vzgojiteljice $v$ povprečju namenijo 52 minut dnevno, kar krepko presega minimalni priporočeni čas, ki je $30 \mathrm{mi}-$ nut (National Association for Sport and Physical Education 2006; Tremblay idr. 2012).

V vrtcu namenijo 1,3 ure oz. $31 \%$ časa za prosto igro otrok (oz. t. i. proste dejavnosti). Ker je spontana igra poleg prostega gibanja temeljna dejavnost v prvem starostnem obdobju, menimo, da je njen delež, glede na današnje poznavanje razvojnih potreb otrok, premajhen.

V primerjavi analiziranih vrtcev smo ugotovili, da med njimi obstajajo statistično pomembne razlike $v$ zagotavljanju časa, namenjenega prostim dejavnostim ter gibanju otrok izven rutine. $S$ tem se je potrdila domneva, da je čas, namenjen prosti igri in gibanju kot temeljnima gradnikoma otrokovega razvoja ter temeljnima potrebama otrok prve starostne skupine, zelo odvisen od posameznega izvedbenega kurikuluma vrtca. Na obeh analiziranih področjih so bile razlike med vrtci občutne. Pri zagotavljanju časa za proste dejavnosti je bila razlika med najvišjo in najnižjo povprečno vrednostjo skoraj $50 \%$. Podobna, sicer nekoliko manjša razlika med vrtci se je pokazala tudi pri zagotavljanju časa za gibanje otrok izven rutinskih dejavnosti.

\section{Sklep}

$Z$ raziskavo o deležu gibalnih dejavnosti in proste igre, ki ga trije vrtci v osrednjeslovenski regiji omogočajo otrokom prve starostne skupine tekom tipičnega dopoldneva, smo želeli preveriti, kako uspešni so vrtci pri zagotavljanju pogojev za razvoj potencialov najmlajših otrok z vidika vključevanje gibalnih dejavnosti in spontane nestrukturirane igre v izvedbeni kurikulum.

Na podlagi analize rezultatov ugotavljamo, da v vrtcih, vključenih $v$ raziskavo, na ravni izvedbenega kurikuluma prevladuje načelo uravnoteženosti različnih vrst dejavnosti, razen v primeru prostih in vodenih dejavnosti, kjer nekoliko prevladujejo proste dejavnosti. Načelo uravnoteženosti in s tem zagotavljanja raznolikosti na različnih ravneh izvedbenega kurikula je ustrezno, kadar je z raznolikimi vrstami dejavnostmi obogateno tudi vsakdanje življenje malčkov izven časa, preživetega $v$ vrtcu. Vendar, kot smo ugotavljali v uvodnem delu prispevka, danes temu ni tako. Po eni strani nas ugotovitve o razvoju in delovanju možganov $v$ najzgodnejšem obdobju učijo, da sta za razvoj zdravih temeljev možganov bistvenega pomena prosto gibanje in 
spontana igra, po drugi strani se bistveno spreminjajo okoliščine in družbeni okviri, v katerih odraščajo današnji otroci. Spreminjajo se življenjski slogi malčkov, ki danes ne temeljijo več na pretežno zdravem, gibalnem vedenju niti na uravnoteženem vkljčevanju raznolikih aktivnosti, temveč na vedno bolj sedentarnem življenjskem slogu. Gray $(2011,7)$ še opozarja, da sta "zaradi želje odraslih po vedno večjem nadzoru nad otroki in njihovim življenjem izredno zmanjašana tudi prosto gibanje in spontana igra otrok«. Upoštevanje navedenih dejstev nas tako pripelje do sklepa, da je, kot posledico novih spoznanj stroke ter spremenjenih življenjskih slogov otrok, potrebno prilagoditi tudi izvedbeni kurikulum vrtcev $v$ prvem starostnem obdobju. Prilagoditve so smiselne predvsem $v$ smeri prilagajanja načina izvedbe vseh glavnih dejavnosti v Kurikulumu za vrtce (Ministrstvo za šolstvo in šport 1999). Namesto npr. vodenih dejavnosti, ki predpostavljajo sedeče zaposlitve malčkov ter frontalno podajanje vsebin, lahko enako vsebino predstavimo preko gibalno zasnovanih aktivnosti v senzorno stimulativnem in obogatenem okolju, ki omogoča učenje otrok preko lastne aktivnosti in spontanega raziskovanja pripravljenega okolja. Spontana igra in gibanje sta, zaradi poudarjanja miselnih dejavnosti in pospeševanja kognitivnega razvoja, $v$ veliki meri izgubila svojo pedagoško vrednost, vendar danes spoznavamo, da je takšno razumevanje razvoja napačno, saj razvoj kognitivnih sposobnosti poteka prvenstveno preko gibalne aktivnosti otroka in spontane igre $v$ obogatenem in senzorno stimulativnem okolju. Na podlagi ugotovitev raziskave lahko zaključimo, da so vrtci v povprečju manj uspešni pri zagotavljanju pogojev za vsestranski razvoj potencialov najmlajših otrok z vidika količinsko zadostnega vključevanja gibalnih dejavnosti in spontane igre $v$ izvedbeni kurikulum. $V$ primerjavi s priporočili nekaterih nacionalnih združenj v tujini naši vrtci ne dosegajo priporočenega minimalnega časa, ki bi ga morali zagotavljati otrokom na področju prostih gibalnih dejavnosti. Prav tako po količini krepko presegajo priporočen čas vodene dejavnosti ter statične dejavnosti v vrtcu. Pri statičnih dejavnostih je presežen tudi čas trajanja posamezne statične dejavnosti naenkrat.

Menimo, da spoznanja, izpostavljena v teoretičnem in empiričnem delu raziskave, nakazujejo potrebo po določenih prilagoditvah izvedbenih kurikulumov vrtcev ter večjem poenotenju slednjih, saj je iz raziskave razvidno, da se izvedbeni kurikulumi med posameznimi vrtci precej razlikujejo. Menimo, da bi bilo $v$ nadaljevanju smiselno raziskati razloge $v$ ozadju tovrstnih razlik in preveriti, ali gre morda za pomanjkanje znanja in posledično subjektivnih teorij vzgojiteljic o tem, kaj je »dobro za otroke« (Marjanovič Umek 2008; Batistič Zorec 2013). 


\section{Literatura}

Batistič Zorec, M. 2005. »Evalvacija vzgojnega dela.« Vzgojiteljica: revija za dobro prakso 7 (3): 16-20.

—. 2013. »Predšolski otrok svet razume in dojema celostno.« Vzgojiteljica: revija za dobro prakso 15 (5): 15-18.

Bregant, T. 2012. »Razvoj, rast in zorenje možganov.« Psihološka obzorja 21 (2): 51-60.

Darling-Hammond, L., in J. Snyder. 1992. »Curriculum Studies and the Traditions of Inquiry: The Scientific Tradition. "V Handbook of Research on Curriculum, ur. P. W. Jackson, 41-78. New York: MacMillan.

Driediger, M., L. Vanderloo, S. Truelove, B. Bruijns in P. Tuckera. 2018. »Encouraging Kids to Hop, Skip, and Jump: Emphasizing the Need for HigherIntensity Physical Activity in Childcare. « Journal of Sport and Health Science 7 (3): 333-336.

Elkind, D. 2008. »Can we play?« Greater Good Magazine, 1. marec. https:// greatergood.berkeley.edu/article/item/can_we_play

Gray, P. 2013. Free to Learn: Why Unleashing the Instinct to Play Will Make Our Children Happier, More Self Reliant, and Better Sudents for Life. New York: Basic Books.

Hosta, M. 2018. Playness pedagogika za razigrano in razmigano učenje. Notranje Gorice: Playness, izobraževanje in razvoj.

Hozjan, D. 2018. »A Theoretical Conceptualization of the Hidden Curriculum in the Second Half of the Twentieth Century. «In Implicit Pedagogy for Optimized Learning in Contemporary Education, ur. J. Lepičnik-Vodopivec, L. Jančec in T. Štemberger, 23-40. Hershey, PA: Information Science Reference.

Jakovljević, T. 2016. »Zakaj možgani današnjih otrok onemogočajo implementacijo vzgoje in procesov učenja v vzgojno izobraževalnem obdobju.« Interno gradivo, Zgodnja obravnava, izobraževanje in usposabljanje na področju otrok s posebnimi potrebami, Kamnik.

Juriševič, M., R. Rajović in L. Drgan. 2010. »NTC učenje: spodbujanje razvoja učnih potencialov otrok v predšolskem obdobju. Gradivo za strokovni seminar, Pedagoška fakulteta, Ljubljana.

Kozomelj, A. 2018. »Udeleženci predterciarnega izobraževanja in tisti, ki so izobraževanje na teh ravneh končali, Slovenija, šolsko leto 2017/2018 in 2016/ 2017.« https://www.stat.si/StatWeb/News/Index/7398

Kuzik, N., D. Clark, N. Ogden, V. Harber in V. Carson. 2015. »Physical Activity and Sedentary Behaviour of Todders and Preeschoolers in Child Care Centres in Alberta, Canada." Canadian Journal of Public Health 106 (4): 178-183.

Marjanovič Umek, L., in U. Fekonja Peklaj. 2008. Sodoben vrtec: možnosti za otrokov razvoj in zgodnje učenje. Ljubljana: Filozofska fakulteta.

Miller, E., in J. Almon. 2009. Crisis in the Kindergarten: Why Children Need to Play in School. College Park, MD: Alliance for Childhood. 
Ministrstvo za šolstvo in šport. 1999. Kurikulum za vrtce: predšolska vzgoja v vrtcih. Ljubljana: Ministrstvo za šolstvo in šport.

Montessori, M. 2011. Srkajoči um. Ljubljana: Uršulinski zavod za vzgojo, izobraževanje in kulturo.

National Association for Sport and Physical Education. 2006. »Active Start Physical Activity Guidelines for Children Birth to Five Years.« http:// cecpdonline.org/wp-content/uploads/2016/05/08-NAPSE-Guidelines.pdf Ščuka, V. 2007. Šolar na poti do sebe. Radovljica: Didakta.

Tremblay, M. S., A. G. LeBlanc, V. Carson, L. Choquette, S. Connor Gorber, C. Dillman, M. Duggan idr. (2012). »Canadian Physical Activity Guidelines for the Early Years (Aged o-4 Years).«Applied Physiology, Nutrition and Metabolism 37 (2): 345-356.

Turnšek, N. 2008. Subjektivne teorije o otroštvu in vzgoji. Ljubljana: Pedagoška fakulteta.

Vonta, T. 2009. Organizirana predšolska vzgoja v izzivih družbenih sprememb. Ljubljana: Pedagoški inštitut.

Vrbovšek, B. 2014. »|zvedbeni kurikul v sodobnem vrtcu. Vzgojiteljica: revija za dobro prakso v vrtcih, 15 (izr. št.): 5-8.

\section{Amount of Physical Activity and Free Play of the First Age Group in Kindergarten}

Children's lifestyle is more and more sedentary and depends on electronic media. There is a substantial decrease in the number as well as variety of opportunities available for the children to be physically active and play freely in an sensory rich environment. Due to the lack of such opportunities, a shift in children's abilities as well as needs can also be observed. The key issue here is to what extent can pre-school institutions deal with needs of the children of 21th century? In order to address these issue, a research was carried out on how much time a particular pre-school institution actually spent on physical activities and free play during a typical day. We find that physical and sedentary activities in child care are equally represented. Free play represents $30 \%$ of time. The amount of time for free physical activities, adult-led and sedentary activities does not meet the standards and recommendations of the experts guidelines. There are important differences between pre-school institutions in providing time for free play and physical activity.

Keywords: physical activity, sedentary behaviour, free play, child care, first age agroup 

